Historic, Archive Document

Do not assume content reflects current scientific knowledge, policies, or practices. 



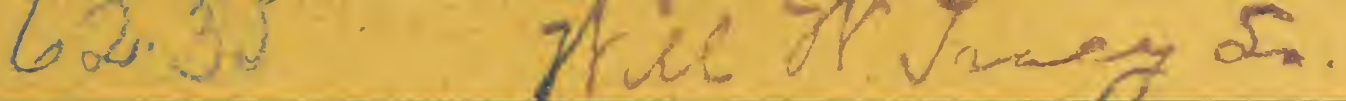

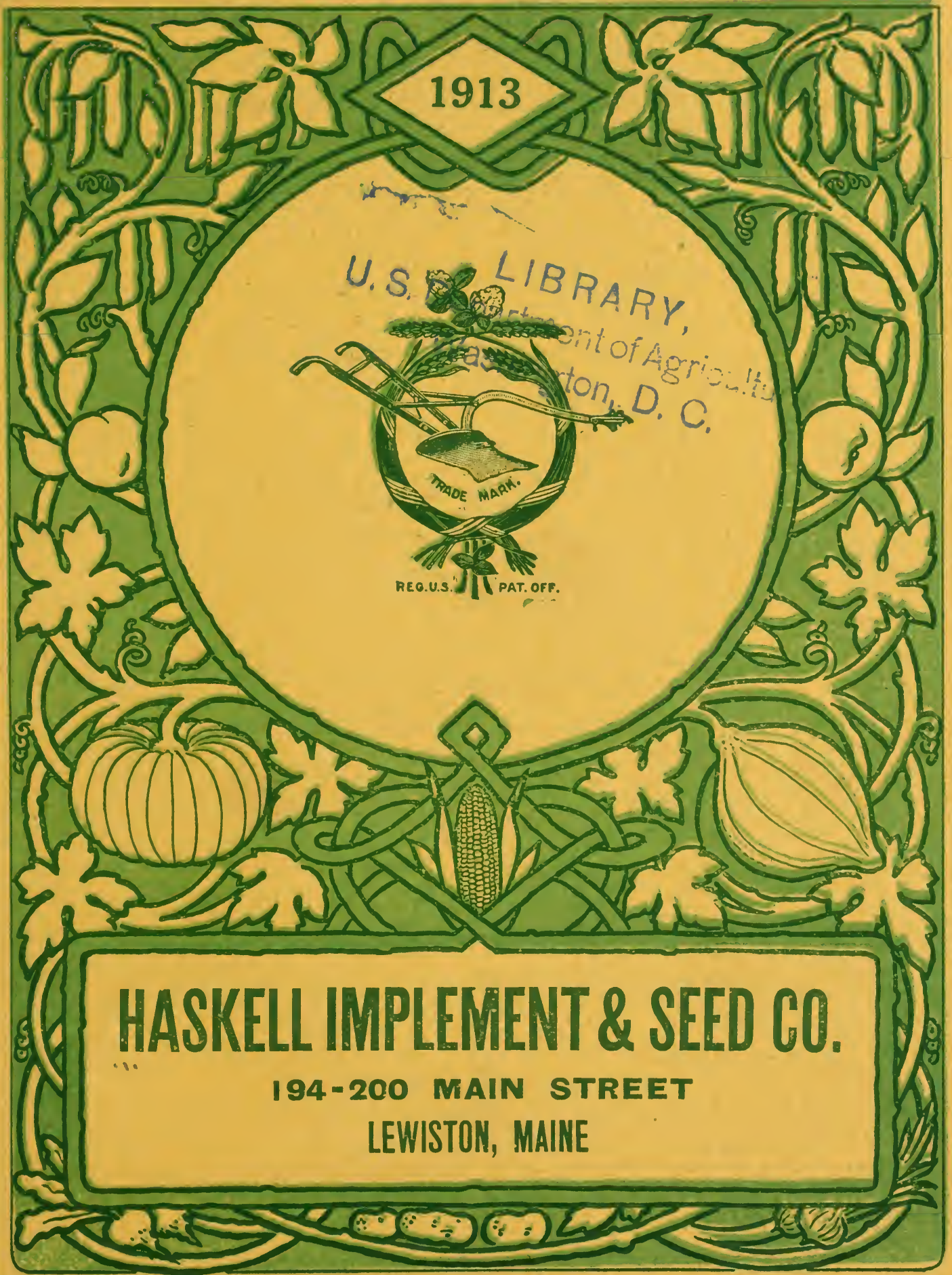




\section{HASKELL IMPLEMENT \& SEED CO.}

Formerly THE GEO. B. HASKELL CO.

194-200 Main Street

LEWISTON, MAINE

\section{IMPORTANT.}

Price and Terms. All prices stated in this catalogue are based on the present market and are subject to change without notice. We have purposely omitted prices on Grains and Grass Sceds because of the market fluctuations, as we believe it to be to the advantage of the purchaser, and we will gladly submit samples and lowest quotations on application.

Our Terms of payment are net cash.

Remittances. All moneys should be sent either by P. O. Money Order, Bank Draft, Registered Letter or Express Money Order.

We Deliver all Vegetable and Flower Seeds when bought at the packet, ounce, $\frac{1}{4}$-pound, $\frac{1}{2}$-pound and I-pound prices, but when seeds ordered are listed in pints and quarts, postage should be added at the rate of 8 cents per pint and I 5 cents per quart. In all other cases goods will be SHIPPED_F.0.B. LEWISTON, with no charge for packing.

Bags will be charged as follows :- 2 -bushel bags 22 cents, $\frac{1}{2}$-bushel bags 10 cents, peck bags 8 cents.

Non-Warranty. While we do not give any warranty, either expressed or implied, as to the productiveness of our seeds, we buy only the best and purest, and we carefully test all seeds before putting them on the market. If goods are not accepted on these terms they must be returned at once with all charges paid. 


\section{3

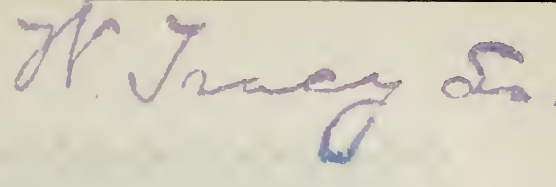

\section{Haskell Implement \& Seed Co.}

\section{CATALOG \\ OF}

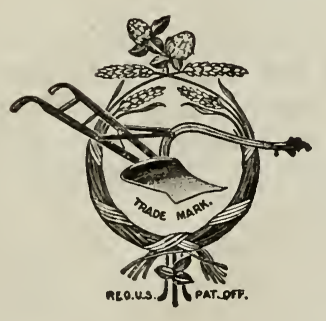

\section{Farm, Garden and Flower \\ SEEDS}

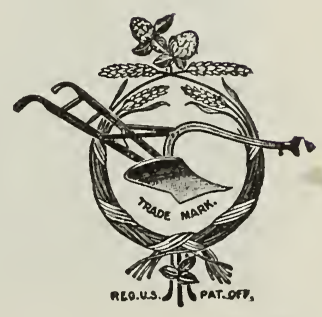

also

Dairy and Poultry Supplies, Wooden Ware, Hardware, Galvanized Ware, Brooms

Brushes, Fencing, Garden Seeders and Cultivators, Pumps and

Suburban Water Systems, Spraying Outfits, Fer-

tilizers, Chemicals, etc., etc.

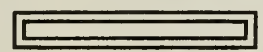

\section{"THE FURROW"}

If you will send us your name and address we will send you FREE for one year The Furrow. This is a paper published in the interest of better farming and contains much. useful information on farming and soil culture, also valuable Household Hints for the housewife, and a lot of entertaining reading for the younger members of the family.

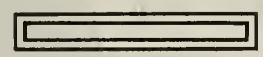

\section{HASKELL IMPLEMENT \& SEED CO., 194-200 MAIN STREET}




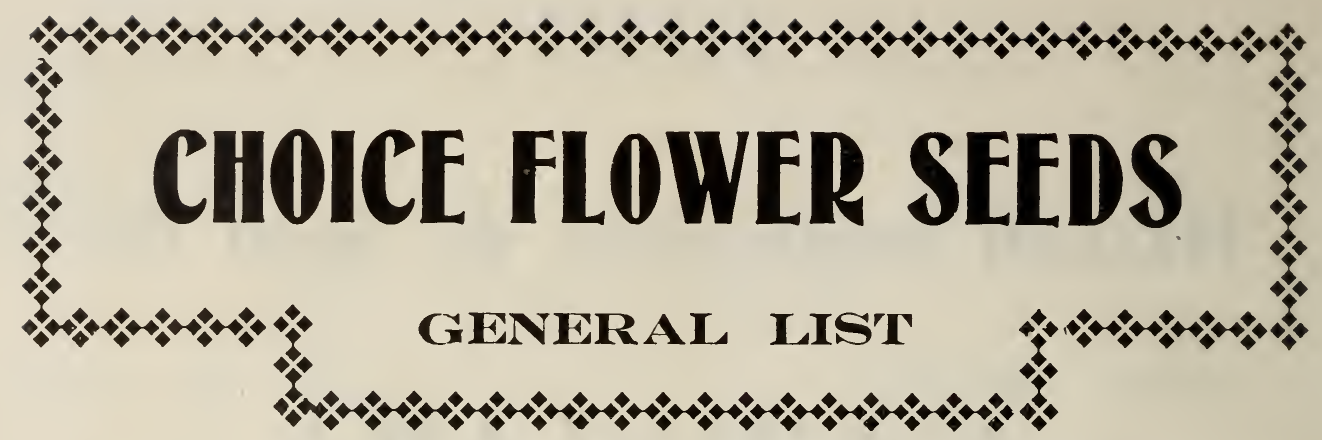

Postage Prepaid on all Flower Seeds in Packets at Prices Quoted

\section{SPECIAL INDUCEMENTS}

When the money accompanies the order, purchasers of Seeds in packets at catalogue prices may select 25 cents' worth extra packets for each $\$ 1.00$ sent. Thus anyone enclosing $\$ 1.00$ may order seeds in packets amounting to $\$ 1.25$. Two dollars sent to us with the order will pay for seeds in packets amounting to $\$ 2.50$, and so on. This offer does not include seeds in collections, by weight or measure, bulbs, plants or anything excepting seeds in packets.

Plants are generally known and described as Annuals, Biennials, and Perennials. The term annual is applied to plants which flower and ripen their seeds the same season. Hardy annuals are those which may be sown in the open ground. Half hardy annuals are those which should be started in the house and transplanted to the garden. The term biennial is applied to plants which flower the second season after planting and then perish. The term perennial is applied to plants which flower the second season after planting, and continue to flower year after year.

ACROCLINTUM. (Everlasting) hhA Pretty Everlasting Flower, fine for winter bouquets. The flowers should be gathered when young. Double White..... Pkt., .05c.

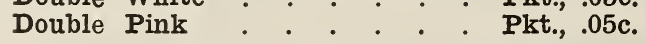

ADONIS. Showy, popular border flowers, remaining a long time in bloom.

Aestivalis. "Flos Adonis." Flowers scarlet. Hardy annual. $1 \mathrm{ft}$. Pkt., .05c.

AGERATUM. (Floss-Flower.) hA. Blossom continuously throughout the summer. Highly prized for bedding out, and valuable for winter blooming indoors.

Imperial Dwarf. Dark blue. 9 in; good for edging. Pkt. .05c.

ALYSSUM. Very hardy, free blooming dwarf plants, all the varieties growing freely in common soil. The pretty, fragrant flowers are much prized for bouquets; excellent for the summer garden.

Saxatile Compactum. Yellow flowers; fine for borders. Perennial. Pkt., .05c.

Little Gem. White. They grow but three or four inches in height, very compact, of spreading growth, each plant often forming a circle a foot in diameter. Pkt., .05c.

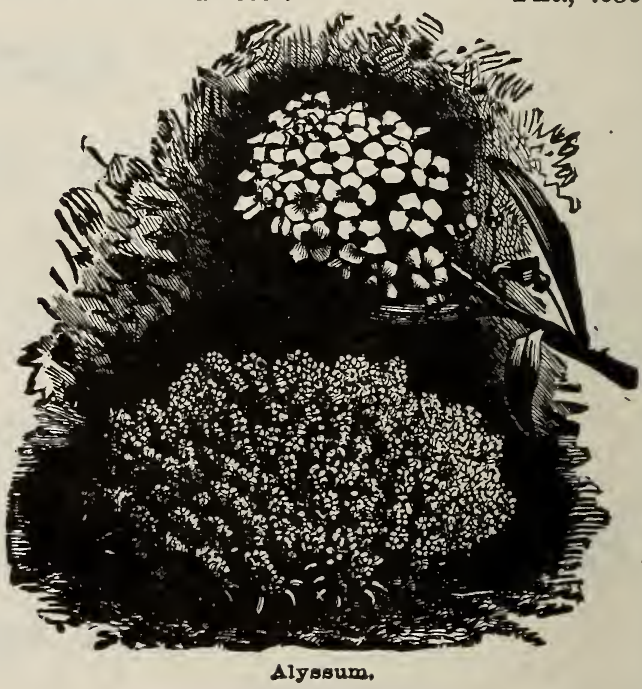




\section{CHOICE FLOWER SEEDS-Continued}

AMARANTHUS. Ornamental foliage. Very striking and effective decorative plants. Sow early and set out young plants early in June. Annual.

Tricolor. Mixed.-Carmine scarlet, splendid variety. 4 to $5 \mathrm{ft}$ Pkt., .05c

ANTIRRHINUM. (Snapdragon.) Beautiful, hardy, free blooming plants for summer and fall. Flowers the first year from seed as annuals and should be treated as such. Average height, $1 \frac{1 / 2}{2}$ feet.

Crimson

White

Finest Mixed

Pkt., .05c Pkt., .05c Pkt., .05c.

\section{ASTERS}

(Half Hardy Annuals)

Tall Varieties

American Branching. A free growing Aster of robust, erect habit, producing large, feathery blossoms resembling Japanese Chrysanthemums; one of the finest for cutting. Height $3 \mathrm{ft}$.

Crimson

Pkt., .05c

Dark Blue

Pkt., .05c

Lavender

Rose

White

Pkt., .05c

Pkt., .05c

Finest Mixed Pkt., .05c

Semples Branching. A superior and free flowering class. The flowers are large with graceful wavy petals on long stem. Excellent for cutting. Height, $3 \mathrm{ft}$.

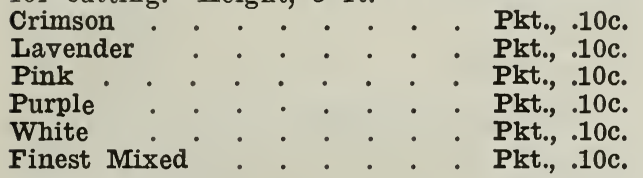

Giant Comet. Splendid class of pyramidal habit, with very large flowers.

Crimson

Pkt., .10c.

Lavender . . . . . . . Pkt., .10c.

Rose Pink . . . . Pkt., .10c.

Purple + . + . . . . Pkt., 10c.

White . . . . . . . Pkt., .10c.

Finest Mixed . . . . . . Pkt.,.10c.

Peony Flowered Perfection.. The finest form of incurved Aster, splendid for exhibition and popular for both florists' and private use. The plants are about two feet in height, with flowers usually four inches across, very double, and of fine globular form.

Dark Blue

Lilac

Pkt., .10c.

Blood Red

Rose Pink

White

Finest Mixed

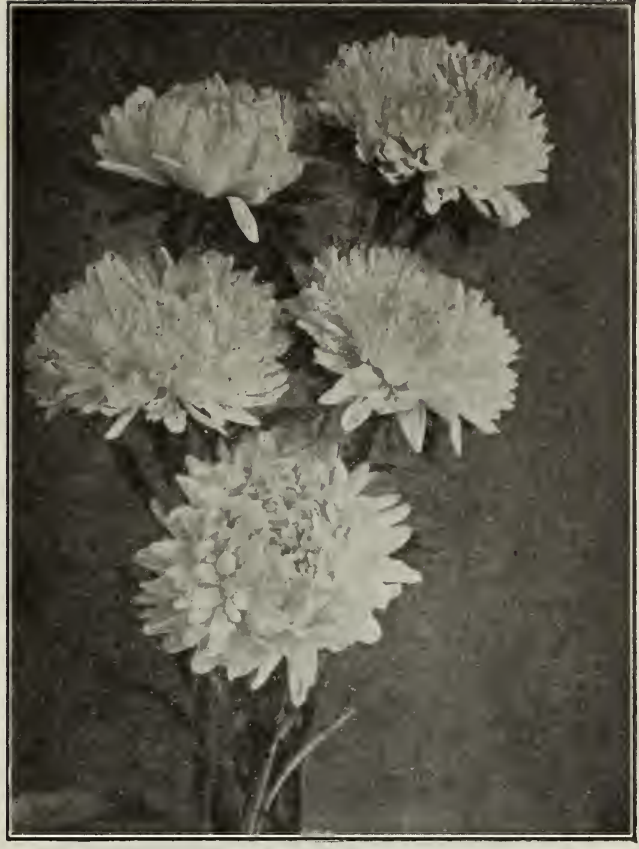

White Branching Asters

\section{ASTERS-Dwarf Varieties}

\section{Chrysanthemum}

Snow White

$.05 \mathrm{c}$

Dark Crimson

Finest Mixed

$.05 \mathrm{c}$

Queen of the Market. Early flowering aster, of branching habit, producing its flowers on long stalks; fine class for cutting and bunching.

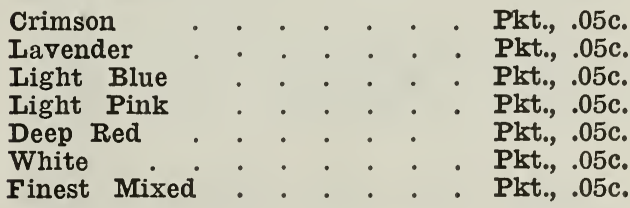

Victoria. Flowers large, very double, with the petals beautifully incurved. Cannot to be excelled for bedding or exhibition. $2 \mathrm{ft}$.

Crimson . . . . . . . Pkt., .10c.

Dark Blue . . . . . . Pkt., .10c.

Rose Pink . . . Pkt., .10c

White Pkt., 10c.

Finest Mixed . . . . . Pkt., .10c.

China Finest Mixed . . . Pkt., .05c.

ALL SORTS MIXED. Pkt., .05c. \& .10c. 


\section{CHOICE FLOWER SEEDS-Continued}

BALSAM. Beautiful plants for the summer garden. Of fine pyramidal form, thickly studded with large flowers of rich shades. They should be started early in heat and transplanted. We offer the finest strains in cultivation. Annuals.

Double Dwarf Mixed

Pkt., .05c.

BELLIS Perennis flore pleno. Double Daisy. A favorite spring-flowering perennial, producing charming effects when planted with Pansies, Forget-Me-Nots or Silene. They are easily raised from seed, flowering in autumn if sown in spring, although it is better to sow in July or August in cold frames and plant them out the following April.

Longfellow-Dark Rose . . . Pkt., .05c. Snowball-White . . . . Pkt., .05c. Mixed . . . . . . . Pkt, .05c. Califormia Daisy . . . . Pkt., .05c.

BROWAILIA. Elegant, free flowering, half-hardy annuals for house or garden; growing about eighteen inches in height, with Verbena-like flowers; excellent for cutting. Seeds started in July will give fine plants for winter blooming in the greenhouse for which they are valuable. For summer blooming they may be sown under glass in March, or in the open ground in May. Finest mixed.

Pkt., .05c.

CALENDULA. Vigorous, hardy, free-flowering annuals, with large, flat, double, flowers; valuable for growing in light soils, or dry situations. They are useful as cut flowers, and are frequently grown under glass during winter for cutting. $1 \mathrm{ft}$.

Meteor. Double orange yellow striped with primrose.

Prince of Orange . . . . Pkt., .05c. Double Mixed . . . . . Pkt., .05c.

CALLIOPSIS or Coreopsis, Perennial Virieties. These frequently bloom the first year from seed sown in the spring; it is most satisfactory, however, to sow in July or August, protecting the plants with coarse straw or pine boughs during winter. They will flower profusely the following summer. Height, $2 \mathrm{ft.}$ Mixed.

Pkt., .05c.

CANDYTUFT. Showy hardy annuals, growing about a foot in height. Excellent for bouquets.

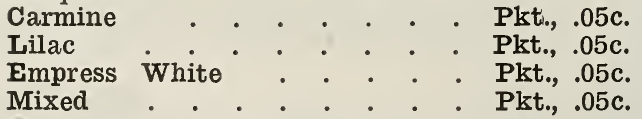

CANNA. Indian Shot. The luxuriant foliage and superb flower of the Cannas, especially of the new French and Italian races, easily places them foremost among our subtropical bedding plants.

Crozy's Newest Mixture . . . Pkt., .05c. Nigricans-Dark red foliage : Pkt., .05c.

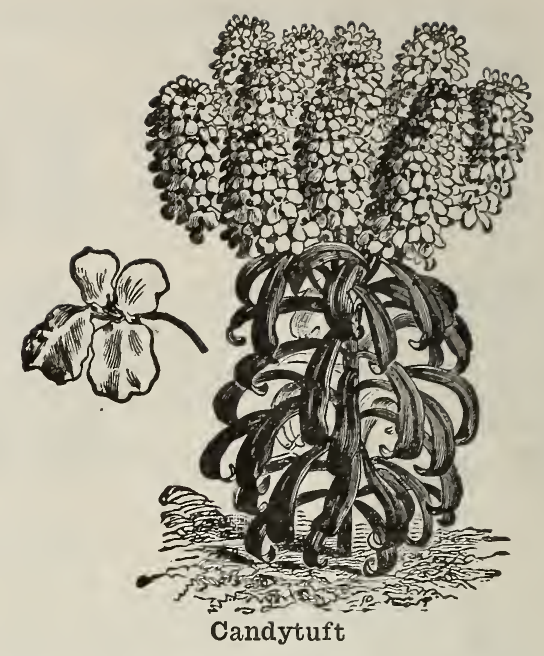

CARNATIONS-Marguerite-The earliest of all Carnations, blooming in July or August if sown in spring and continuing till frost. Being half-hardy perennials, a slight protection of coarse straw or pine boughs will preserve them during winter and they will flower profusely the next summer, or they may be potted to bloom during winter in the house. The flowers are large, about eighty per cent. usually coming double; beautifully fringed, and clover scented.

\section{Carnations Marguerite}

\begin{tabular}{|c|c|c|c|}
\hline Giant & White & & \\
\hline Giant & Rose & & \\
\hline Giant & Red & • & • \\
\hline Giant & Yellow & • & - \\
\hline Giant & Mixed & • & . \\
\hline
\end{tabular}

CELOSIA, or Coxcomb. Showy annuals of easy cultivation; producing large, brilliant, comb-like flower heads. They prefer a light soil, and should not be allowed to become crowded if a dwarf habit is desired.

Tall Mixed . . . . . . . Pkt., .05c.

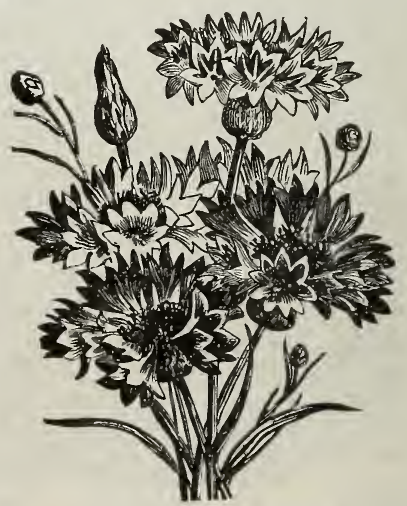

Centaurea Cyanus 


\section{CHOICE FLOWER SEEDS-Continued}

CENTAUREA. Flowering Annuals. Imperialis-Giant Corn Flower. The flowers are of enormous size; fragrant, and of the most charming colors, including white, pink, lilac, rose and purple. They are among our best summer flowers for cutting.

Marguerite-White . . . Pkt., .05c. Cyanus-Bachelor's Button, mixed. Pkt., .05c.

CHRYSANTHEMUM (Annual Varieties.)

Showy, hardy annuals of easiest cultivation and blooming early in summer. They are most desirable for seashore and mountain gardéns. Height, $2 \mathrm{ft}$.

Double Yellow

Double White

Double Mixed

Pkt., .05c. Pkt., .05c. Pkt., .05c.

COBOEA SCANDENS. A fine, rapid growing climber with handsome foliage and large, bell-shaped flowers, green at first, but rapidly changing to a beautiful, deep violet-blue. A well established plant will run about thirty feet in a season, covering a large veranda with handsome foliage and beautiful flowers. Tender perennial.

Pkt., .05c.

COLEUS. Splendid bedding plants, with beautifully colored and handsomely marked foliage. They are easily raised from seed if kept in a warm temperature. Tender perennials.

Hybrida Mixed

Pkt., .25c.

CONVOLVULUS MAJOR-Tall Morning Glory.

Finest Mixed . . . . . . Pkt., .05c.

CONVOLVULUS MINOR-Dwarf Morning Glory.

Finest Mixed

Pkt., .05c.

Japanese Morning Glory - . Pkt., .05c.

COSMOS. This is one of our most useful and beautiful autumn flowers. To get it in bloom early, the seed should be sown in May in the open ground where the plants are desired to bloom, and the seedlings allowed to grow and flower without being transplanted.

Finest Mixed

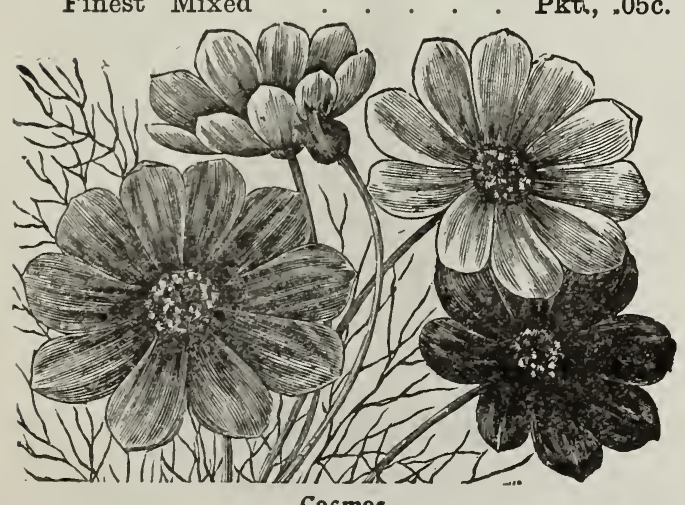

CYPRESS VINE. Ipomoea Quamoclit. Very graceful twining annuals with feathery dark green foliage and star like flowers. Twenty feet.

Scarlet

Pkt., .05c.

DAHLIA. This popular flower can be easily raised from seed and flowered the same season. The roots should be placed in dry sand and kept in a cellar where there is no frost during the winter.

Hybrida Pleno Fine Double Mixed Pkt., .10c. Single Mixed . . . . . Pkt., .05c.

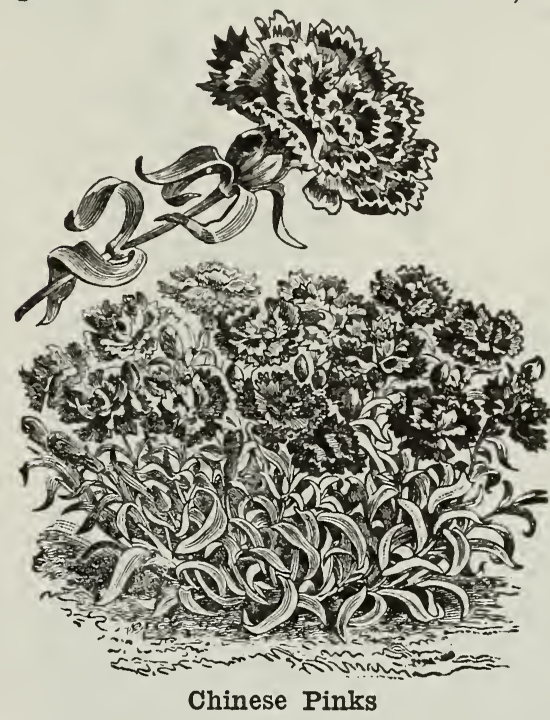

DIANTHUS. Chinensis fl. pl. hP. Double Chinese Pinks. Finest mixed. Pkt., .05c.

Heddewigii. (Japan Pinks.) hB. Single. First-class, selected. Mixed. Pkt., .05c.

DOLICHOS LABLAB. (Hyacinth Bean.) Purple. 10 feet. Plst., .05c.

ESCHSCHOLTzIA. California Poppy. The bright colors, long duration and dwarf habit of these free-blooming hardy annuals, admirably adapt them for massing and border planting. Height, $1 \mathrm{ft}$.

Califormia-Yellow, orange center Pkt., .05c. Califormia Alba-White, . . Pkt., .05c. Mixed . . . . . . . Pkt., .05c.

GOURDS. Luxuriant, climbing annuals, useful in covering arbors, fences or slopes, and bearing gourds which are of interesting forms and colors, 10 to $15 \mathrm{ft}$. Mixed

Pkt., .05c.

GYPSOPHILA. Infant's Breath. Free flow. ering, hardy plants; extremely light and graceful, easy of cultivation, and most useful for bouquet and cut-flower work. Height 18 inches.

Mixed

Plct., .05c. 


\section{CHOICE FLOWER SEEDS-Continued}

HELIANTHUS. Sunflower. The large varieties are useful in forming backgrounds of large beds or borders and for distant effects, while the smaller sorts may be planted with scarlet Salvia, Cannas and other tall bedding plants, besides being excellent for cutting. Hardy annuals.

Diadem (New). Flowers beautiful light lemon with black center; of the greatest value for cut flowers.

Pkt., .05c. Double Mixed

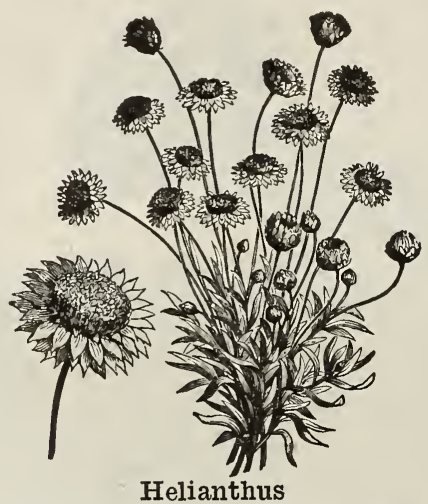

Pkt., .05c.

Helianthus

HELICHRYSUM. Everlasting. Flower. Showy annuals for beds or borders; useful as dried flowers for winter bouquets, for which use the blooms should be cut before they are fully open, and hung up to dry with the flowers downward if stiff stems are desired. Height $2 \mathrm{ft}$.

Double Mixed . . . . . .Pkt., .05c.

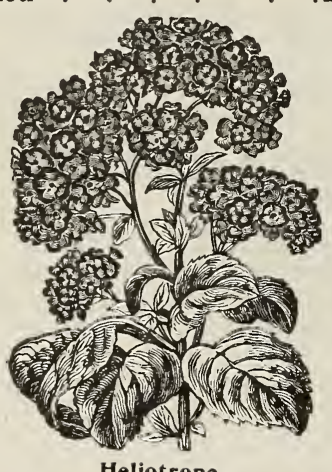
HELIOTROPE. Delightfully fragrant
reenhouse perennial; excellent for bedding or indoor cultivation and particularly useful for cutting.

Giant. Newest large flowering varieties mixed.

Pkt., .10c.

HOLLYHOCK. This ever popular hardy favorite of our gardens has few rivals in majestic grandeur. Hollyhocks succeed best in rich, well-drained soil. They should be lightly protected during winter with pine boughs, coarse straw or other mulch not liable to rot.
Seeds sown in July produce fine plants for blooming the following summer. Hardy biennials; 6 to $8 \mathrm{ft}$.

Chaters Strain. Double finest mixed. Pkt., .10c

HUMULUS JAPONICA. Japanese Hop. Splendid annual climber of fast growth and very ornamental. $12 \mathrm{ft}$. Pkt., .05c.

KOCHIA TRICHOPHILA. (Standing or Summer Cypress.) Splendid ornamental annual of unusual quick growth, forming regu. ular pyramids of about $3 \mathrm{ft}$. in height. The slender-leaved plants are of a cypress-like appearance during summer, changing their lightgreen foliage to carmine and blood-red colorings towards autumn; flowers small, scarlet. The plant also called "Burning Bush," is of great value when planted singly or in groups, as well as for pot culture. $3 \mathrm{ft}$. Pkt., .10c.

LARKSPUR. Splendid hardy annuals with showy flowers borne on long spikes; white, lilac, and all shades of blue; excellent for cut. ting. Height, 18 inches.

Double Tall. Branching or stock flower mixed. Pkt., .05c.

LAVENDER. Ornamental hardy perennial. bearing long spikes of very fragrant blue flowers. 18 inches. Pkt., .05c.

IOBELIA. The Erinus varieties are most valuable for edgings, hanging baskets and vases, blooming profusely from June till frost. Lobelia Cardinalis and its varieties are among our most brilliant autumn flowering perennials.

Crystal Palace Compacta. The darkest blue. Pkt., .05c. Finest Mixed . . . . . .Pkt., .05c.

MARIGOLD. Tagetes. These handsome half-hardy annuals when well grown cannot be surpassed either in mixed borders or when grouped together. They succeed best in moderatey rich soil and in open situations, and are strongly recommended where a gorgeous display in the autumn is an essential feature. African-Double tall yellow . . Pkt., .05c. African-Double tall mixed . . Pkt., .05c. French-Double tall mixed . . Pkt., .05c.

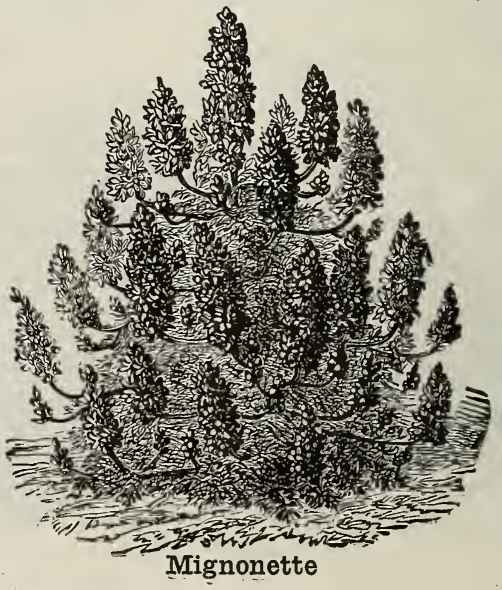




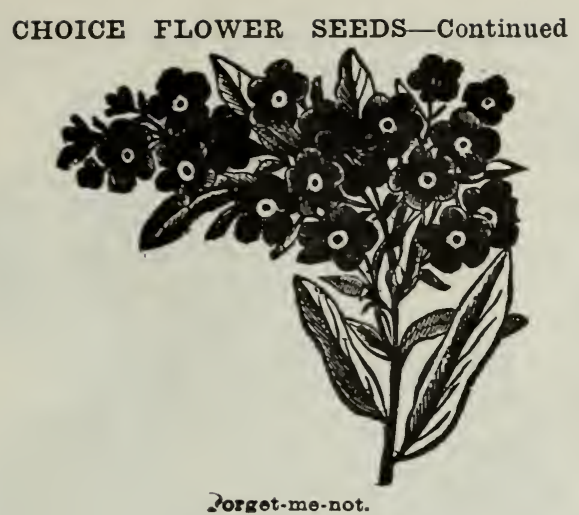

MYOSOTIS-Forget-Me-Not. Dwarf, halfhardy perennials, bearing a profusion of little, star-shaped flowers. They thrive best in rather moist, shady situations. Most of them will bloom the first year from seed if sown early. If sown in July or August in shaded frames, fine plants will be obtained for spring blooming. They are very beautiful when planted in combination with late spring bulbs, Daisies Arabis or Golden Alyssum.

Palustris-True Forget-Ne-Not. Dark blue, very beautiful; profuse flowering. Pkt., .05c.

MIGNONETTE. Reseda Odorata. The most fragrant anunal, prized as much for forcing in winter as for the summer garden. The seed should be sown early and the plants as they grow, thinned sufficiently to allow them to branch. The beds should be liberally watered during dry weather.

Parson's White

Machet, Red

Pkt., .05c.

Pkt., .05c.

Bird's, Mammoth Mixed . . . Pkt., .05c.

\section{NICOTIANA Affinis-Ammual.}

Colossea-Magnificent foliage plant, the young leaves at first tinted with red. It soon attains a height of five or six feet, with leaves often two feet in length, and a foot in width. Excellent for foliage beds. Pkt., .10c

Sylvestris. A splendid new variety with glaucous leaves and large pendants, pure white, tube-shaped flowers; a very stately plant.

Pkt., .05c.

PAPAVER, or Poppy. Annual varieties. showy hardy annual of easiest cultivation and embracing many rich and beautiful colors. The seed should be sown early in spring where intended to bloom.

Shirley-Finest mixed. A most charming race of single Poppies with shining flowers of silky texture, varying in color from pure white and delicate pink to rosy carmine and deep crimson; many of them being beautifully striped and edged with white. The blooms if eut when young will keep in water for two or three days. Height, $2 \mathrm{ft}$. Pkt., .05c. Double Carmation Mixed . . . Pkt., .05c. Oriental Deep Crimson . . . Pkt., .05c. White Swan . . . . Pkt., .05c.

NASTURTIUMS-Dwarf varieties.

Tom Thumb, or Dwarf. These hardy annuals are of easiest cultivation; succeeding best in rather light soil, withstanding heat and drought and flowering profusely from June or July until cut down by severe frost usually well into November. The dark leaved varieties are particularly adapted for ribbon beds and borders, the brilliant flowers contrasting admirably with the bronzy red foliage. Height, $1 \mathrm{ft}$.

Finest Mixed. Our special mixture of the finest sorts, in great variety of color.

Pkg., .05c; 0z., .10c; 1/4 1b. .30c.

NASTURTIUMS-Tall or Climbing. Pkg., .05c. 0z., .10c; 1/4 1b., .30c.

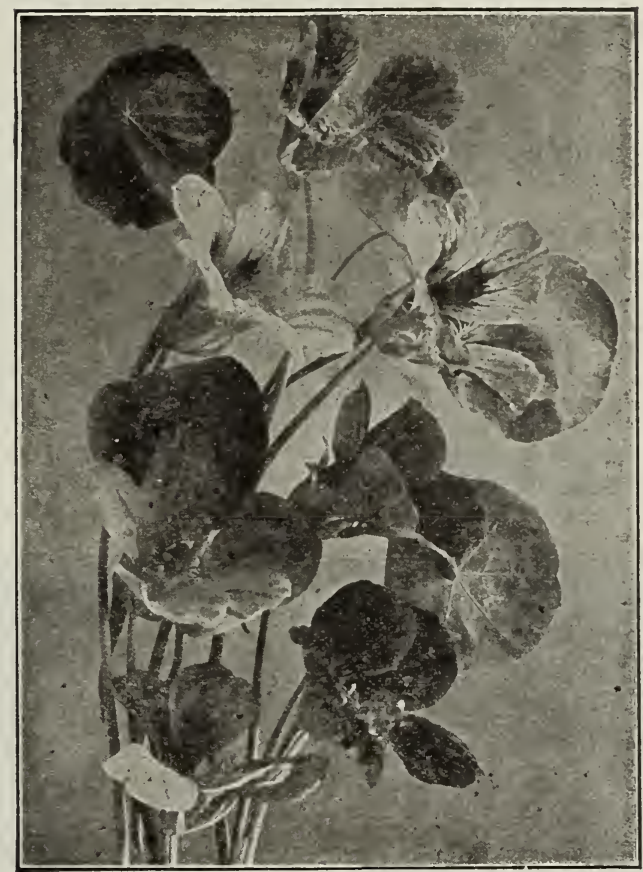

\section{Nasturtium}

PHLOX DRUMIMNDI. This is one of the finest annuals, being hardy, easy of cultivation and making as a summer bedding plant, an effective and brilliant display. The flowers are of long duration and of most gorgeous and varied colors. Height, $1 \mathrm{ft}$.

Finest Mixed-Splendid colors Pkt., .05c.

Grandiflora Finest Mixed. The flowers are of large size, finely rounded form, and with well defined eyes. The colors are superb.

Pkt., .10c. 
CHOICE FLOWER SEEDS-Continued

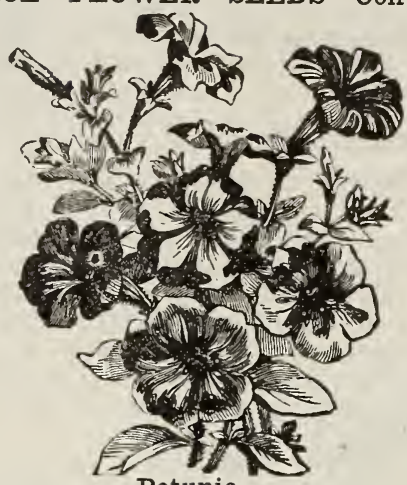

Petunia

PETUNIA. The petunia is popular because it is of easiest cultivation, blooms from early summer continuously until frost and is one of the most showy and free-growing annuals. Height, 12 to 15 inches.

Single Flowering Petunias.

Hybrida-Finest Mixed . . . Pkt., .10c. Double Flowering Petunias.

Fimbriata-Fringed. Single Mixed Pkt., 15c. Double Fringed-Extra Large Pkt., .20c.
PORTULACA. Charming dwarf annuals for sunny situations or light soils, producing flowers of most brilliant colors in great profusion. Height 6 inches.

Grandiflora Plenissima-Double Mixed

Grandiflora-Fine Single Mixed Pkt., .05c.

RHCDANTHE. Half-hardy annuals with "Everlasting" flowers. They are beautiful for the open garden, or grown in pots for the conservatory. If required for winter use, as dried flowers, they should be cut before they are fully expanded. Height, $1 \mathrm{ft}$.

White $\cdot \cdot \cdot \cdot \cdot \cdot \cdot \cdot$ Pkt., $05 \mathrm{c}$.

RICINUS. Castor Oil Plant. Tender annuals of rapid and gigantic growth, producing enormous dark green or bronze-colored palmate leaves; excellent for sub-tropical beds, or for massive foliage effects on lawns or backgrounds.

Zanzibariensis. Mixed. A new and distinct race from East Africa, producing leaves of enormous size, varying in color from light green to purplish red. Height, $15 \mathrm{ft}$.

Pkt., .05c.

\section{PANSIES}

PANSY, or Heartsease. Too much importance cannot be attached to the culture of these beautiful plants, flowering as they do in great abundance for several months. When sown in the early spring a good display in most cases can be had in the following fall, but the best results are not obtained by so doing. To obtain fine blooms it is better to sow during summer and transplant the seedlings into cold frames in September, protecting during the winter with mats or shutters. Pansies delight in a cool, moist, well-drained soil, enriched with decomposed barnyard manure. They should never be allowed to suffer for want of water.

Giant Blue . . . . . . Pkt., .10c. Giant White . . . . . . Pkt., .10c.

Giant Black . . . . . . Pkt., .10c. Giant Mixed . . . . . Pkt., .10c.

Giant Purple . . . . . Pkt., .10c. Mixed . . . . . . . Pkt., .05c.

Giant Yellow . . . . . Pkt., .10c. Giant Fringed Mixed . . . Pkt., .15c.

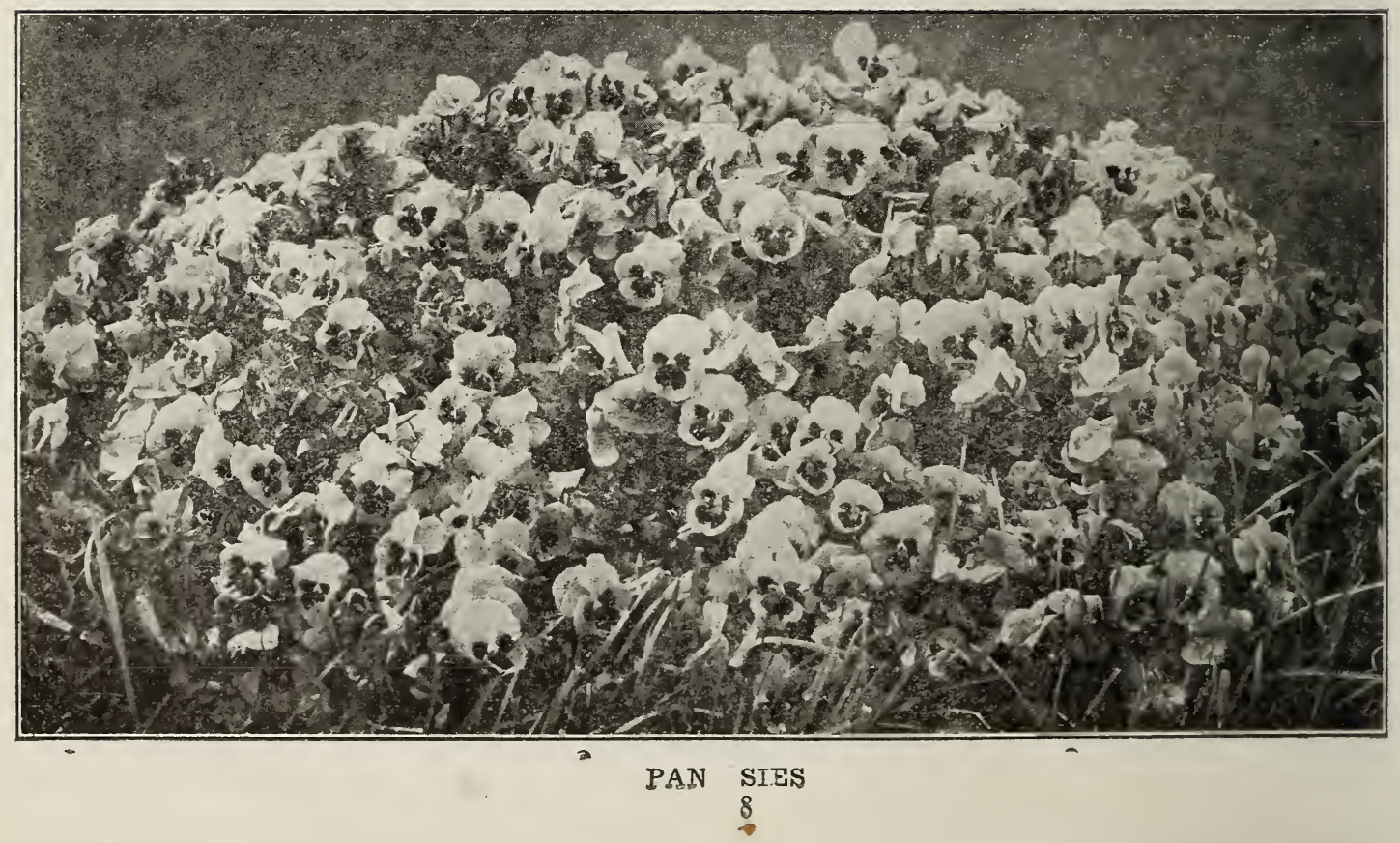




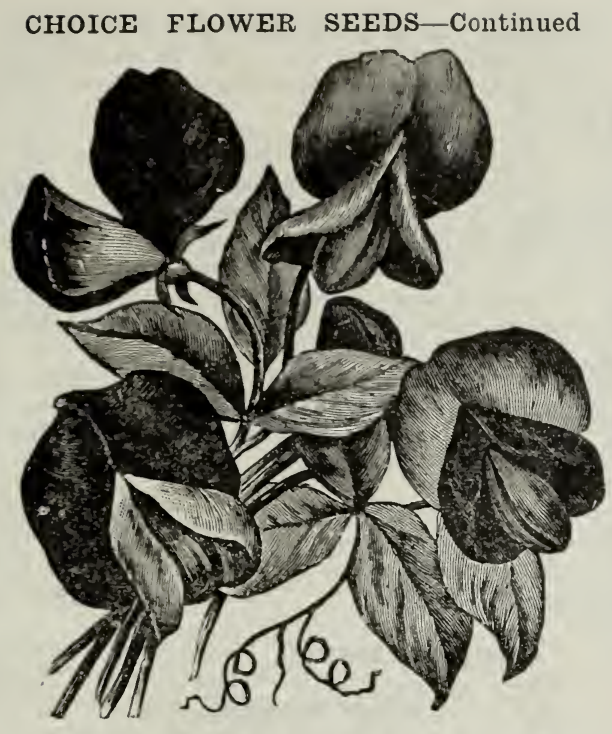

Sweet Peas

\section{SWEET PEAS}

Our Sweet Peas are unsurpassed in selection. purity and vitality. Seed should be sown in new ground as early as it can be worked in spring. The vines should be thoroughly established before the hot weather sets in. White-seeded sorts sliould be sown a little later, when the ground is warm.

Haskell's Peerless Mixture. The invite com parison of our mixture with any and all others, no matter under wlat name or at how high a price offered, and are certain a trial will demonstrate the superiority of our Peerless Mixture.

Prices on Haskell's Peerless Mixture,

Pkt., .05c.; 0z., .10c.; 1/4 1b., .30c.; 1/. 1b., .50c.; lb., $.90 \mathrm{c}$.

Price on all Separate Colors,

Pkt., .05c.; 0z., .15c.; 1/4 lb., .45c.; 1/2 lb., .80c.; 1b., $\$ 1.50$.

\section{Blue and Purple.}

Captain of the Blues. Standard light maroom; wings light purple.

Navy Blue. Deep violet blue.

\section{Variegated.}

Aurora. Flaked orange salmon; largest striped.

America. The brightest blood red striped.

Daybreak. Crimson scarlet on white ground.

Gray Friar. Beautiful watered purple on white ground.

Helen Pierce. Blue mottled on pure white.
Mrs. Joseph Chamberlain. Rose and white stripert.

Princess of Wales. Striped maure on whitc ground.

\section{Lavender and Mauve.}

Countess of Radnor. Pale manve stand daris, wings pale lilac, very fine.

Dorothy Tennant. Deep rosy mauve; beau tiful.

Emily Eckford. Standard reddish mauve. wings blue.

\section{White.}

Blanch Burpee. P'ure white of superior sub, stance, flowers large and fincly formed.

Emily Henderson. A new pure white, larg est of all and an excellent sort.

Sadie Burpee. White seed. Tery large. Pure white.

Dorothy Eckford. Pure white.

Light Yellow.

Mrs. Eckford. Delicate shade of primrose yellow

Primrose. Color pale primrose approaching yellow.

\section{Shades of Pink.}

Lovely. Large pink standari, delicate rose wings.

Hon. F. Bouverie. Stantari flesh-pink, wings rosy huff.

Sybil Eckford. Pink and buff.

Prima Donna. Lovely pale pink. One of the finest.

Katherine Tracy. Soft lut brilliant piuk.

Gladys Unwin. Large, light pink.

Blanche Ferry. Tlie popular pink and white.

Her Majesty. Beautiful rose color.

Painted Lady. Old popular pink and white. fiery sluade.

\section{Shades of Red.}

Red Riding Hood. Rosy pink, very fragrant.

Brilliant. Bright searlet, fine form.

Firefly. Deep brilliant scarlet; truly a fiery shade.

\section{White and Blue.}

Maid of Honor. White edged with blue.

Lottie Eckford. White, suffused with lavender.

\section{Claret and Maroon.}

Boreatton. Tery dark maroon self-colored.

Captivation. Beautiful claret color.

Waverly. Standards rosy claret, wings shaded blue. 


\section{CHOICE FLOWER SEEDS-Continued}

SALPIGLOSSIS. Half-hardy annuals; elegant late summer flowering plants of great diversity in color; beautifully penciled in rich tints of yellow, purple, and brownish red. Of easy culture.

Grandiflora-Finest mixed . . Pkt., .05c.

SALVIA. Flowering Sage. Very ornamental; flowers borne in spikes of fiery red, crimson or blue, and continue in bloom in open ground until after severe frosts. Start in heat and transplant into light soil one to t.wo feet apart. Tender perennials, but bloom the first season. Height $2 \mathrm{ft}$. to $3 \mathrm{ft}$. Splendens-Brilliant scarlet . Pkt., .10c. Cocinea-Mixed . . . . Pkt., .05c.

STOCK-Gilliflower. The charming colors, delightful fragrance and free-blooming character of the Stocks have made them favorite plants for both summer and winter cultivation. They are very effective for beds and borders, and their handsome spikes are invaluable for bouquets and floral decorations.

Large-Flowering Double Ten-Week Varieties. Highest grade, pot-grown seed. The best variety for early summer blooming, producing massive, pyramidal flower spikes of brilliant colors and delightful fragrance. Height $1 \mathrm{ft}$.

Lavender . . . . . . . Pkt., .10c. Pink . . . . . . . . . Pkt., .10c. White . . . . . . . Pkt., .10c. Finest Mixed . . . . . Pkt., .10c.

SWEET WILLIAM. Dianthus Barbatus. Showy hardy biennials of easiest culture; admirable for clumps among shrubs or borders. Height, 18 inches.

Hunt's Perfection Mixed . . . Pkt., .05c.

VIRGINIA CREEPER. (or American Woodbine). Though a common native climb- er this is one of the best plants for covering unsightly objects, or it may be easily trained into festoons of exceeding grace and beauty. $.05 \mathrm{c}$.

VERBENA. The Verbena is one of the most decorative and easily grown bedding plants. If started in heat in March the seedlings begin to bloom in June and continue until frost. Plants raised from seeds are stronger and flower more freely than those grown from cuttings. Half-hardy perennials. Height, $1 \mathrm{ft}$.

Hybrida-Fine mixed . . Pkt., .05c. Hybrida-Mammoth mixed : Pkt., .10c. Hybrida-Extra selected; dark blue. Pkt., .10c Hybrida-Candissama. White . Pkt,, .10c.

WILD CUCUMBER. Hardy. vigorous climber, with very pretty seed-pods, large seeds; to be sown in the open ground in autumn. $20 \mathrm{ft}$.

Pkt., .05c.

XERANTHEMUM. Profuse blooming, hardy annuals with "Everlasting" flowers; useful for winter bouquets; colors pure white and deep purple. Height, 18 inches.

Finest Double Mixed. . . . Pkt., .05c.

ZINNIA. The double flowering Zinnias, Zinnia elegans fl. pl., are among the finest annuals, blooming from July till frost. The flowers are large, handsome, and in a variety of colors. Of easy cultivation in common garden soil. Seed should be started in heat and transplanted. Our seed of these beautiful flowers is saved from the finest collection in Germany.

Single Mixed . . . . . . . . .05c. Double Mixed . . . . . . . . .05c

MIXED FLOWER SEEDS FOR WILD GARDENS. A splendid mixture of more than one hundred kinds of flower seeds at a low price.

Pkt., .05c.

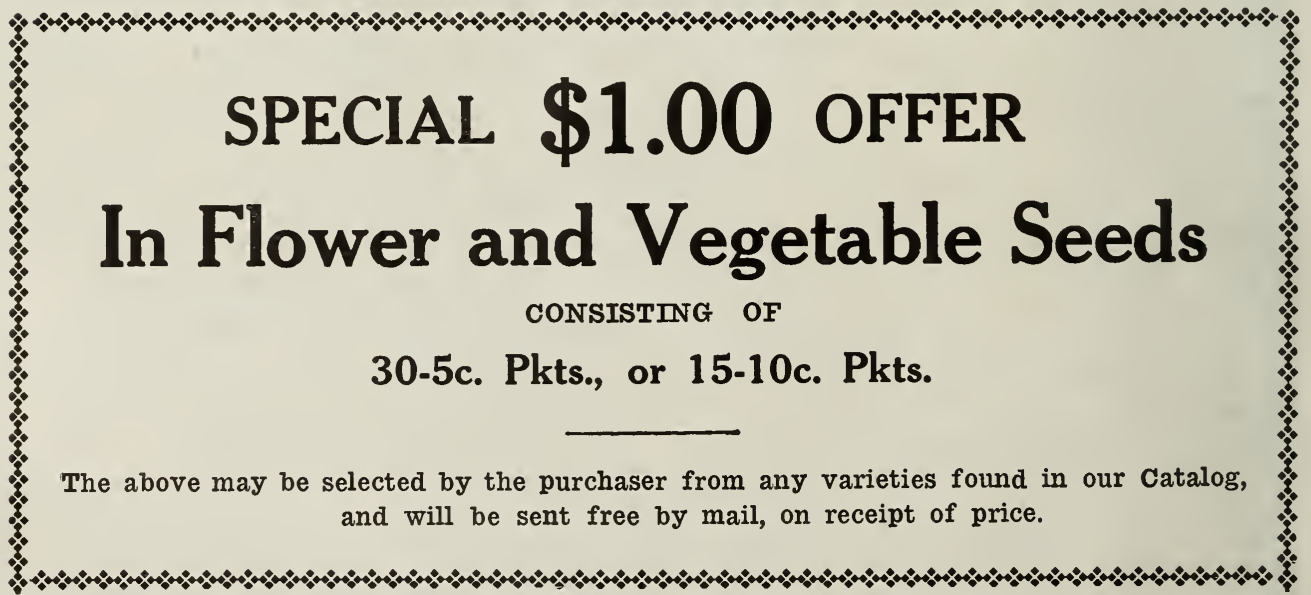




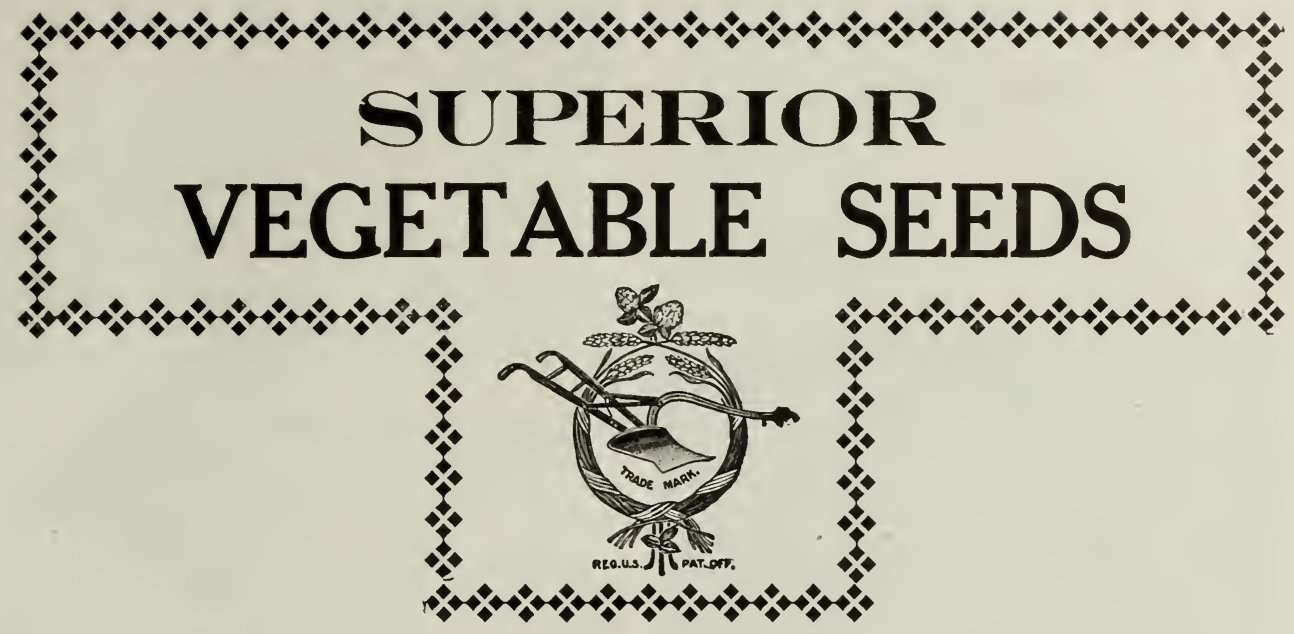

\section{ASPARAGUS}

German,-Gpargel. Spanish,-Esparragos.

One ounce for 60 feet of drill.

A convenient bed is about six feet wide, with a path two feet wide on each side. This will require six rows one foot apart, and a bed of that width 50 feet long will be ample for an ordinary family, requiring about one pound of seed. It will require about three years from the time of sowing until the bed is in full bearing, but once established, it is good for twenty years. It should be sown in drills one foot apart, and when the plants

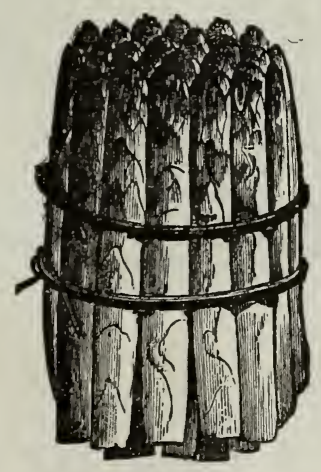

are four or five inches high they should be thinned out so that the plants will be nine inches apart from each other in all the rows. Great care must be taken for the first year to keep down all weeds as soon as they appear, else they will choke up and destroy the young seedling Asparagus. The deeper the soil and the more manure used, the greater will be the crop.
Conover's Colossal. The best known, and one of the most desirable sorts. Pkt., .05c.; oz., .10c; 1/4 lb., .20c; 1b., .50c.

Palmetto. Shoots are very large and light green, also tender and very desirable for the market and home garden. Very quick in growth, with close, round-topped shoots.

Pkt., .05c; oz., .10c; 1/t lb., .25c; 1b., .75c.

\section{ASPARAGUS ROOTS}

A saring of one to two years is effected by planting roots. Those offered below are strong, two-year-old roots, and the proper size for testing. These roots are not carried in stock but will be shipped direct from the growers. Prices on the following varieties will be quoted on application:

Columbia, Mammoth White, Conover's Colossal, Barr's Mammoth and Palmetto.

When in the city make our store your headquarters. Always glad to have strangers and others call and examine our Farm Implements. We carry the largest and most complete stock of any concern in New England.

We give no warranty, expressed or implied, but we buy our Seeds from reputable Seedsmen and we carefully test them before putting on the market. Goods not accepted on these terms must be returned at once, prepaid. 


\section{BEANS}

\section{Dwarf or Bush}

German,-Bohnen.

French,-Haricot.

Spanish,-Frijole nano.

One quart to 100 feet in drills or 150 hills; two bushels to the acre, in drills.

A succession of sowing can be made from the first week in May until August. Plant in drills about two inches deep, and from eighteen inches to two feet apart, according to the richness of the soil; the poorer the soil the closer they can be planted. The seeds should be dropped about two inches apart.

Add. .03c per pkg.; .08c per pt.; .16c per qt., if to be sent by mail.

Packets of all varieties, 5c each.
Black German Wax. (Black seed.) Very early; round, yellow pods; a well-known standard sort. Pt., .15c.; qt., .25c.; pk., \$1.50.

Currie's Rust-proof Wax. Pods long, flat and straight, very productive and rust-proof; black seed. Pt., .15c.; qt., .25c.; pk., \$1.50.

Wardwell's Dwarf Kidney Wax Bean. Hardy and productive, pods long, broad, flat and of a delicate waxy yellow, brittle and entirely stringless. The yield considerably exceeds that of the Common Golden Wax and is equally early. Pt., .15c.; qt., .25c.; pk., $\$ 1.50$.

Improved Golden Wax. Rust proof. An improvement on the old Golden Wax. The pod is somewhat round, meaty and entirely rust proof. Pt., .15c.; qt., .25c.; pk., \$1.50.

Refugee Wax. A perfect Refugee with long, round, yellow, wax pods. Suitable for early or late planting, and an immense yielder. $\quad$ Pt., .15c.; qt., .25c.; pk., \$1.50.

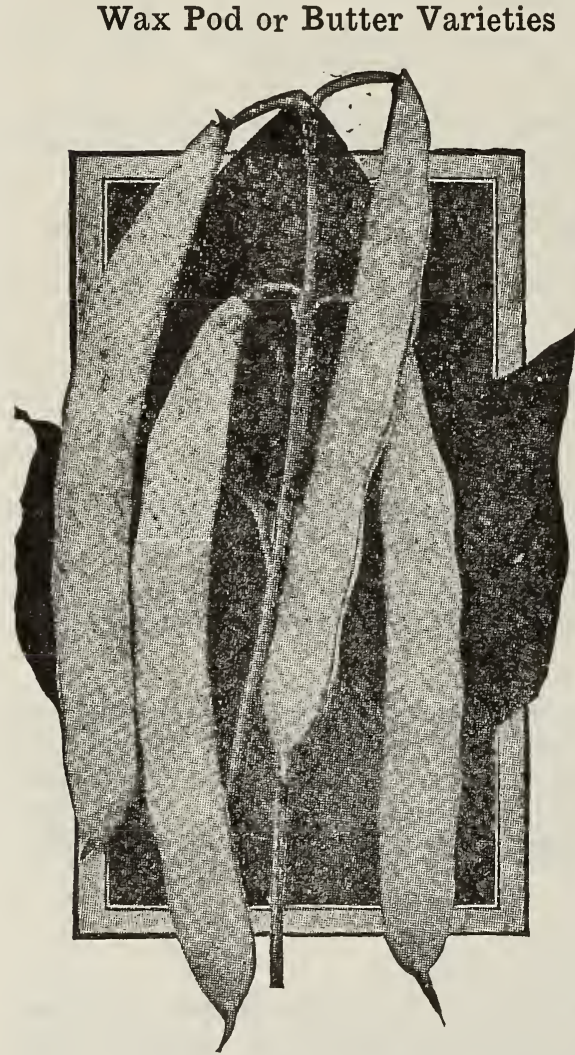

Davis White Kidney Wax. Pods remarkably long, straight, and handsome, waxy white color; enormously productive; seed white. $\quad$ Pt., .15c; qt., .25c; pk., $\$ 1.50$.

\section{Green Pod Varieties}

Rave

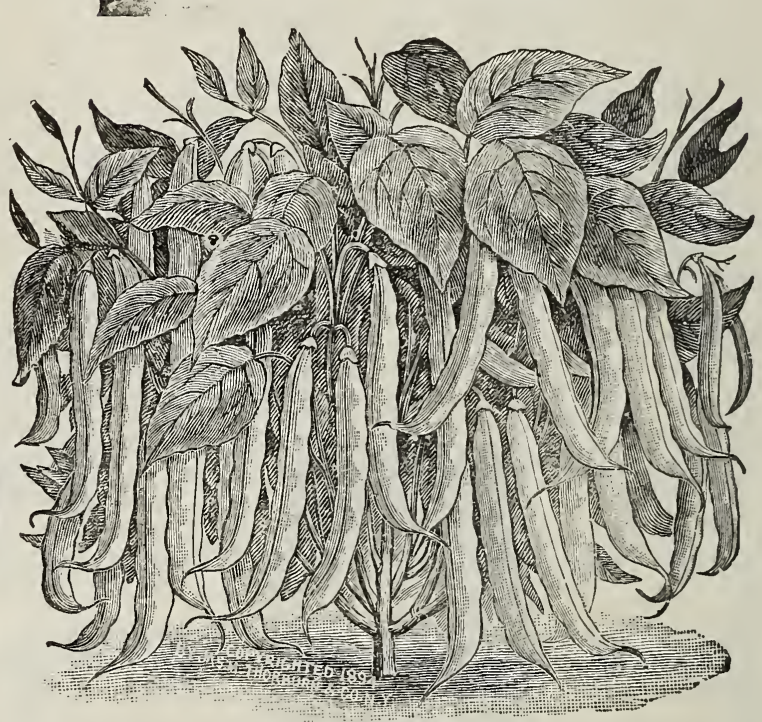

Stringless Green Pod. The pods are green, not quite so round as Valentine and less curved. The pods are stringless-absolutely -this quality at once placing the variety at the tol' of the list among table beans.

Pt., .15c.; qt., .25c.; pk., $\$ 1.50$.

Long Yellow Six Weeks. Pods are long, flat, straight, green. Pt., .15c.; qt., .25c.; pk. $\$ 1.50$.

The greatest help to the gardener is a good Garden Seeder and Cultivator. We have them in several different makes. Call and see them 


\section{BEANS-Continued}

Low's Champion. Very productive, with stringless, large green flat pods. Excellent either as a string or shell bean. Pt., .15c.; qt., 25c.; pk., $\$ 1.50$.

Dwarf Horticultural. The best shell bean for fine quality. Pt., .15c.; qt., .25c.; pk., $\$ 1.50$.

Old-fashioned Yellow-eye Bean. An excellent field bean and much preferred to the Improved Yellow Eye as a bahing beall.

Pt., .15c.; qt., .25c.; pk., $\$ 1.25$.

Improved Yellow-eye Bean. In excellent ficld bean and very productive. Pt., .10c.; qt., .20c.; pk., $\$ 1.25$.

Red Kidney Bean. An easily raised bean and very productive. Also greatly prized by many for baking. Pt., .10c.; qt., .20c.; ps., $\$ 1.25$.

\section{LIMA}

Burpee's Bush Lima. The only Bush form of the true large Lima. Bushes grow to eighteen inches in height and always erect.

Pt., .20c.; qt., .35c.; pk., $\$ 2.00$.

\section{Pole or Running}

German,-Stangen Bohnen,
Spanish,-Judias.
French,-Haricot a Rames.

One quart to 150 hills; 10 to 12 quarts to the acre in drills.

These are more tender and require rather more care in culture than the Bush Beans, and should be sown two weeks later. They suceeed best in sand loam, which should be liberally enriched with short manure in the hills, which are formed, according to the variety, from three to four feet apart. From five to six seeds are planted in each hill, about two inches deep. As the matured bean is used mostly, the season is too short for succession of crops in the North, though it is advantageous to plant succession crops in the southern states, where the season of growth is often from March to November. Rough cedar or similar poles about seven or eight feet long should be used for Lima Beans to climb on. They should be set in the ground at least eighteen inches, so as to prevent being blown over.

Add .08c per pt.; 16c per qt., if to be sent by mail.

German Black Wax, or Indian Chief. A superb snap bean; pods yellow and stringless. Pt., 15c.; qt., .25c.; pk., \$1.75.

We supply all of our BEANS IN PACKETS at 5c each. Postage .03c extra.
Our Implements are worth looking over. We extend a cordial invitation to call and examine them. Be sure and ask to see the New Columbia Garden Seeder.

Horticultural or Cranberry. Showy and excellent, either as a snap or shell bean, or for cooking when dry. Pt., .15c.; qt., .25c; pk., $\$ 1.50$.

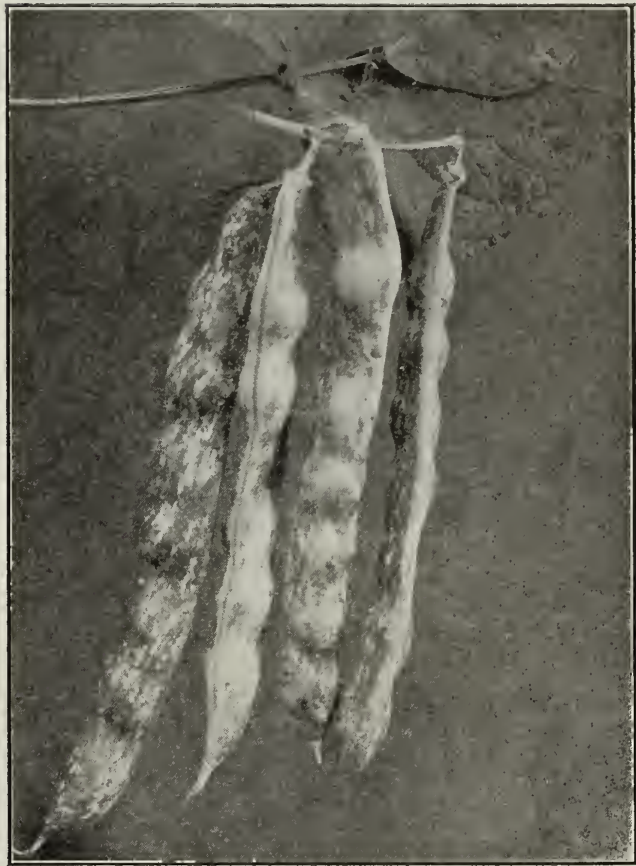

King Horticultural. Pods bright carmine color; both beans and pods are much larger than the common kind. Pt., .15c.; qt., .25c; pk., $\$ 1.75$.

Kentucky Wonder. An excellent green podded variety; enormously productive, the long pods hanging in great clusters along the entire vine. Seed dark brown; entirely stringless. $\quad$ Pt., .15c.; qt., .25c.; pk., \$1.75.

Lazy Wife. One of the best of the later green-podded pole beans for snaps. The pods, borne in large clusters, are five to seven inches long, broad, thick, fleshy and entirely stringless. When young they have a rich, buttery flavor, which is retained until they are nearly ripe. The dry beans are excellent for winter use. Seed white. Pt., .15c.; qt., .30c.; pk., $\$ 1.75$.

Red Cranberry Pole. A popular string or snap bean; very productive with large and tender pod. Pt., .20c.; qt., .35c.; pk., $\$ 2.00$.

Lima, Early Jersey. One of the earliest. Pt., .20c.; qt., .35c.; pk., \$2.25. 


\section{BEET}

German,-Runtel Rube.

French,-Betterave.

Spanish,-Beteraga.

A rather light soil, well enriched, is best suited to the cultivation of the various beets. The mangels and sugar beets in particular require very liberal manuring. For an early crop of table beets, sow the seed as early as the ground is in condition to work; light frosts will not injure the young plants. For a main crop sow the first of May; and for winter beets, the last of June. Sow in drills, 12 to 15 inches apart, and about one inch deep, pressing the earth firmly upon the seed,-a very important matter. Use about six pounds of seed per acre. Thin out when the plants are large enough. The varieties for table use should be left three or four inches apart.

Crosby's Egyptian. This variety is as early as the original Egyptian, but by careful selection has been made thicker and of better quality. Pkt., .05c.; 0z., .10c.; 1/4 1b., 35c.; lb. $\$ 1.25$.

Detroit Dark Red Turmip. An excellent beet for bunching for market; tops exceptionally small and upright; roots turnip shaped with small tap root. Color of skin dark blood red; flesh bright red. Quality is of the best; sweet and tender. One of the best varieties for the market gardener and the home garden. Pkt., .05c.; 0z., .10c.; 1/4 lb., .30c.; 1b., $\$ 1.10$.

Dewing's Early Of deep red color, smooth and of fine form. One of the leading varieties both for market and for family use. Pkt., .05c.; 0z., .10c; 1/4 lb., .30c.; 1b., \$1.00.

Early Eclipse. Very early; dark-red color, small top, and free from fibrous roots. Pkt., .05c.; 0z., .10c.; 1/4 lb., .30c.; 1b., \$1.10.

Edmand's. This variety is thoroughly fixed and uniform in type. The flesh is deep blood red in color, and exceedingly sweet and tender. It is round, smooth, of good market size, and does not grow over-large. Pkt.. .05c.; 0z., .10c.; 1/4 lb., .30c.; 1b., \$1.10.

Long Smooth Blood. A prolific variety; very dark in color; stands drought better than the turnip varieties. Pkt., .05c.; 0z., $.10 c . ; 1 / 4$ lb., .25c.; 1b., \$1.00.

Dirigo Extra Early. A rich, blood-red beet of fine grain and flavor and is earlier than either the Egyptian or the Eclipse. Pkt., .05c.; 0z., .10c.; 1/4 lb., .35c.; lb., \$1.20.

Haskell's Special Blood Turnip. We have a very fine strain of Blood Turnip Beet, of the Edmand's type. Very deep red fleshed so much in demand in all markets. Pkt., .05c.; oz., .10c.; 1/4 lb., .35c.; lb., \$1.20.

Swiss Chard, or Silver Sea Kale. Used as greens, and the ribs of leaves cooked and served as asparagus. Pkt., .05c.; 0z., .10c.; $1 / 4$ lb., .35c.; 1b., $\$ 1.25$.

\section{MANGEL-WURZEL AND SUGAR BEETS}

Sow in April or May, using eight to twelve pounds to the acre.

Price of all varieties except the Sludstrup and Eckendorf: Oz., .10c.; 1/4 lb., .15c.; 1b., .40c.

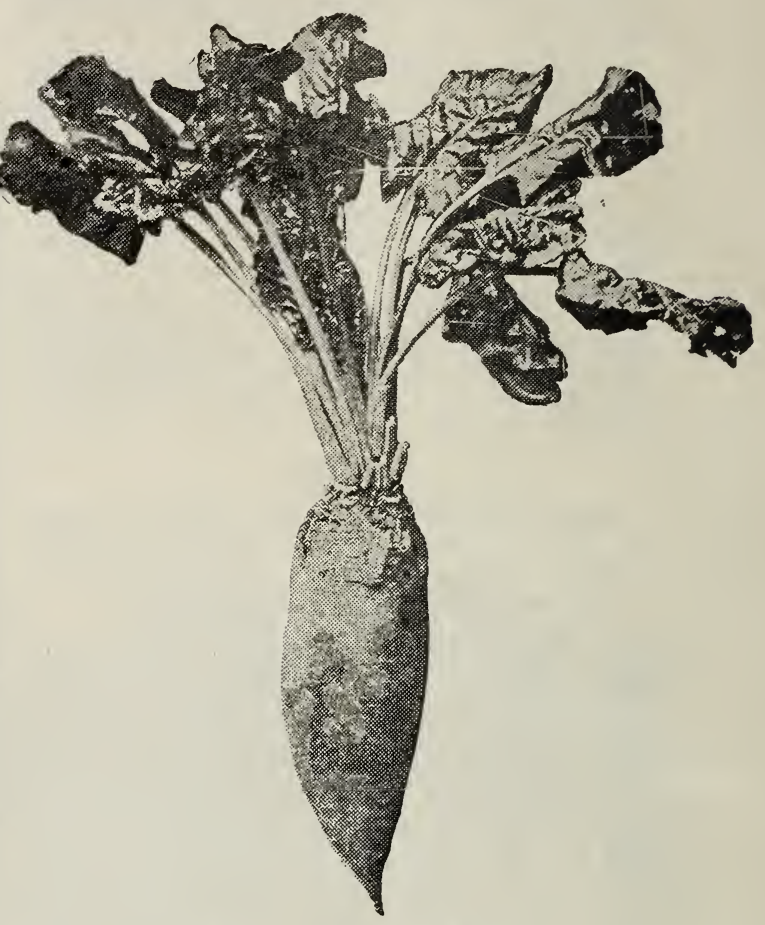

\section{Mangel Danish Sludstrup}

Mangel Danish Sludstrup. Long Reddish Yellow. Grows well above the ground and easy to pull. More percentage of dry matter than in any known Mangel. Very heavy cropper. Considered by the Danish People the best Mangel in the world.

Price, Ounce, .10c.; Quarter lb., .20c.; Pound, .60c.

Red Giant Eckendorf. Of cylindrical form and grows mostly above the surface. Has been known to yield as high as 58 tons to the acre.

Price, Ounce, .10c.; quarter pound, .20c.; pound, .50c.

Lane's White Sugar. One of the best for feeding stock. Very sweet.

Vilmorin's Improved White Sugar. Very sweet, and keeps well. Much relished by stock.

Mangel-Wurzel, Norbiton Giant. A mammoth long-red variety, enormously productive, and keeps well; good for deep soils.

Mangel-Wurzel, Yellow Globe. Does better on shallow soils than the long varieties. An excellent keeper. 


\section{BEETS-Continued}

Mangel-Wurzel, Golden Tankard. F'lesh a deep, rich yellow; very sweet and nutritious. Half long in shape. A very heavy cropper.

Improved Mammoth Long Red. An improvement on the old variety. The roots are very large, uniformly straight and well formed; proportionately thicker, and are deeper colored than the common sort, and with smaller tops.

\section{BRUSSELS SPROUTS}

(Species of Cabbage; cultivation the same)

German,-Rofen-Kohl.

French,-Chou de Bruxelles.

Spanish,-Berza de Brusels.

One ounce will sow a bed of forty square feet, and produce about 3,000 plants.

This is a delicious vegetable, superior to either borecole or spinach. The small, cabbage-like heads which grow upon the stem are much improved by a moderate frost. Sow in hotbeds in March or April, and in the open ground in May; cultivate same as broccoli.

Dwarf Improved. Produces excellent, compact sprouts; very sure cropper. Pkt., $.05 c . ; 0 z ., .20 c . ; 1 / 4$ lb., .60c.

\section{CABBAGE}

German,-Kopf-Kohl. French,-Chou Pomme. Spanish,-Berza.

One ounce of seed produces about 3,000 plants

Early varieties are grown from seed sown in hotbeds in February or March, only moderate bottom heat being required. Transplant into other frames without much, if any, bottom heat, as soon as the plants show the fourth leaf. In April, or as soon as the ground can be easily worked, set out in rows three feet apart, and about eighteen inches between the plants. The ground should be thoroughly stirred with cultivator and hoed every week till the plants cover the ground. For a fall crop, sow in the open ground in May, in hills the proper distance apart, using a liberal quantity of manure in the hill, beside that which is plowed in; thin out to one good plant in each hill. In the same way crops may be grown to lay in for the winter use, planting seed as late as July 1. Seeds can also be sown in shallow drills and, when the plants are large enough, can be transplanted, setting the plants in rows three feet apart and two feet apart in the row. If the young plants are troubled with the cabbage fly, sprinkle them with tobacco dust, air-slaked lime, slugshot or wood ashes, while the dew is on them. T'o keep off the cabbage worm, sprinkle with Dalmatian insect powder or slugshot.

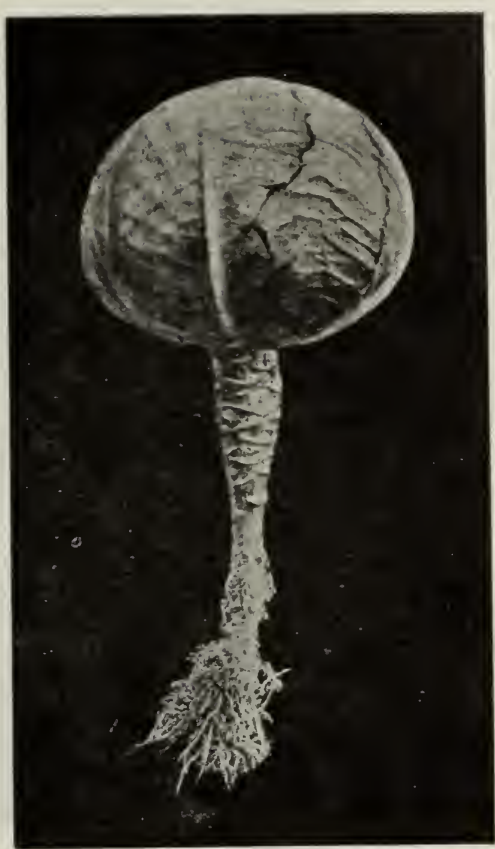

Danish Ball Head.

The wide and unfailing popularity of the Danish Ball Head cabbage is simply wonderful. It seems to adapt itself to all soils and conditions.

The leading characteristics of Danish Ball Head cabbage are: First, that it is a sure header; second, that it is of unapproachable solidity and weight; third, that it is an extra good keeper; and fourth, that it is a good seller.

It is a medium to late cabbage, but is generally grown as a late crop. It is sure to head, the heads being round, hard and extremely heavy, though not extra large. It can be grown in close quarters, on account of its compact habit. Pkt., .05c.; 0z., .25c.; 1/4 lb., .75c.; lb., $\$ 2.50$.

All Seasons An early Drumhead, sure heading, solid variety. Desirable for early or fall use. Pkt., .05c.; oz., .20c.; 1/4 1b., .60c.; lb., $\$ 2.00$.

Charleston Wakefield Grows to a much larger size than the Jersey Wakefield Very productive and a good shipping variety.

Pkt., .05c.; 0z., .25c.; 1/4 lb., .75c.; lb., $\$ 2.50$.

Mammoth Rock Red. The largest heading of any of the red sorts, of deep rich color, and excellent quality. Pkt., .05c.; 0z., .25c.; 1/4 lb., .75c.; lb., .\$2.50.

Sure Head. A fine variety for main crop. A good shipper and sure header. Pkt., .05c.; oz., .20c.; 1/4 lb., .60c.; 1b., $\$ 2.00$

Marblehead Mammoth The largest heading cabbage of them all. Pkt., .05c.; 0z., $.20 c . ; 1 / 4$ lb., .60c.; lb., $\$ 2.00$. 


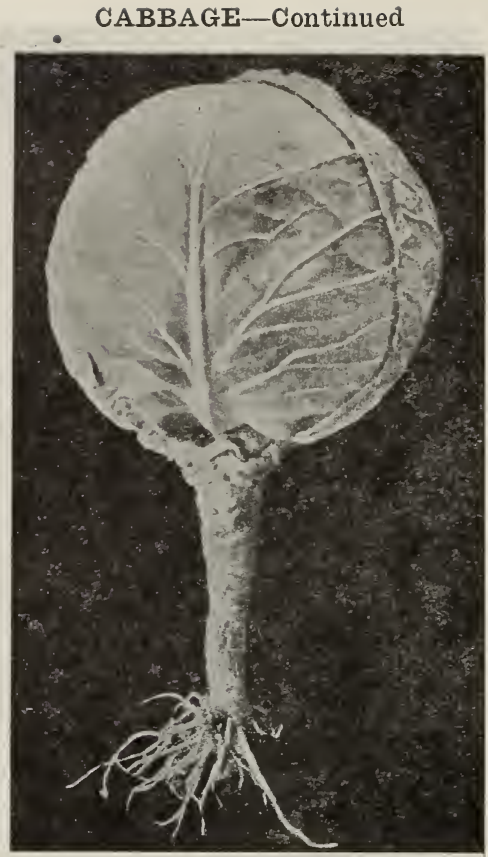

Danisi summer ball head

Danish Summer Ballhead, extra. The heads of this cabbage are of a splendid shape and ready early in the season. It is very early, very large, very firm and heavy.

Pkt., .05c.; 0z., .30c.; 1/t lb., .90c.; 1 lb., $\$ 3.00$.

Danish Roundhead Short-stemmed. This cabbage is recommended as the best ever offered. It embodies all the good qualities which grower's ever worked up in cabbage, is large, hardy and splendid keeper.

Pkt., .05c.; 0z., .25c.; 1/t lb., .75c.; 1 lb., $\$ 2.50$.

Warren's Stone Mason. An improvement on the Stone Mason Drumhead; heads rounder, firmer and earlier; is an extra good keeper. Pkt., .05c.; 0z., .25c.; 1/4 lb., .75c.; lb., $\$ 2.50$.

Savoy Improved American. The finest flavored of all the cabbage family, large and solid. Pkt., .05c.; 0z., .20c.; 1/4 1b., .60c.; 1b., $\$ 2.00$.

Early Winningstadt An early variety of excellent quality, not as early as the Wakefield. Pkt., .05c.; 0z., .20c.; 1/4 1b., .60c.; 1b., $\$ 2.00$.

Henderson's Early Summer. A standard summer variety. We have the true stock. Pkt., .05c.; 0z., .20c.; 1/4 lb., .60c.; lb., $\$ 2.00$.

Fottler's Early Brunswick. An early fall variety well known and popular Pkt., .05c.; oz., .20c.; 1/4 lb., .60c.; 1b., \$2.00.

Early Jersey Wakefield. A standard early variety for home use or market. Pkt., .05c.; oz., .25c.; 1/t 1b., .75c.; 1b., \$2.50.

Red Dutch. For pickling or for salads. Pkt., .05c.; 0z., .25c.; 1/4 lb., .75c.; lb., \$2.50.

Succession. A sure-headed, long-keeping variety, very similar to All Seasons but maturing a little later. Heads deep and very firm. Pkt., .05c.; 0z., .20c.; 1/1 1b., .60c.

Enkhuizen Glory. A new Holland cabbage which originated at a large seed farm at Enkhuizen. Holland. It is an early cabbage, but still of large size; solid and of the best quality. It is one of the largest early cabbages we have seen, and may be set out as late as the last of July or first of August in this latitude, and will make large, fine heads for late fall or winter use. The great merit of this cabbage lies in the perfect uniformity of its growth. The plants are compact, and have few outside leaves, and can be planted close together, and will produce very large crops. Pkt., .05c; 0z., .25c; 1/4 lb., .90c.

\section{CARROT}

German,-Rohre. French,-C'arotte. Spanish,-Zanahoria.

One ounce will sow 100 feet of drill; 3 pounds required for an acre.

('arrots require a very finely pulverized soil to grow them to perfection. A good, light and well-enriched sandy loam is the best for this crop). For field culture, sow in drills $21 \%$ feet apart, so as to cultivate by horse. Market gardeners sow in drills about 15 inches apart. and cultivate by liand. For early crops cover $1 / 2$ inch deep, and thin to 6 inches apart in the rows; for late, cover $3 / 4$ inch deep, and thin to 4 inches.

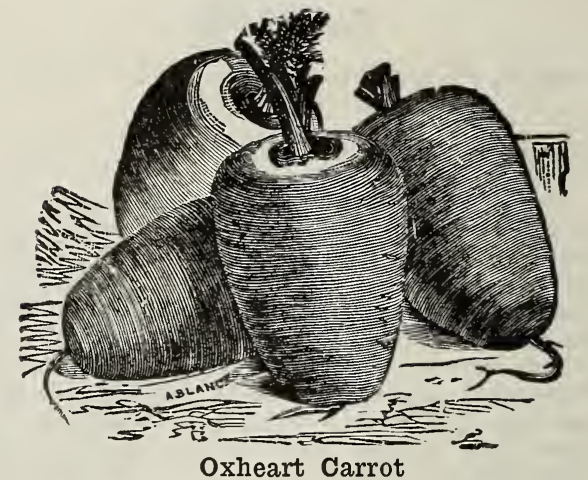

Danvers Half-Long. One of the heaviest croppers; roots dark orange color 8 to 10 inches in length, thick, and ending in a somewhat abrupt point; first class for all soils.

Pkt., .05c; oz., .15c; $1 / 4$ lb., .50c.

Oxheart, or Guerande. Roots short and very thick, and intermediate between Scarlet Horn and Chantenay; color deep orange; fine grained. Pkt., .05c; 0z., .15c; 1/4 Ib., .50c.

Large White Belgian Roots very large and smooth; grown exclusively for stock feeding. Grained.

Pkt., 05c; 0z., .15c; 1/4 lb., .50c.

Improved Long Orange. The best known and most largely cultivated of any Carrot; excellent for stock or table use; roots deep orange, 12 to 15 inches long.

Pkt., .05c; 0z., .15c; $1 / 1 / \pm$ lb., .50c. 


\section{CAULIFLOWER}

German,-Blumenkohl. Spanish,-Coliflor. French,-Chou-fleur.

One ounce of seed will produce 1,500 to 2,000 plants if sown in open ground, or about 3,000 in frames.

To raise good Cauliflower there is nothing so essential to success as good seed. The best Cauliflower seed is very expensive, but it is worth to the grower ten times as much as cheap and carelessly grown seeds. The best results are obtained from using Snowball for main late crop, as well as for early use.

Early Cauliflowers are difficult to raise and are not of the best quality but when the plants are set out in July and the heads form in October there is no difficulty in getting fine, large heads of first-class quality. The seed should be sown in open ground or cold frames about the middle of May or first of June, on good soil. When plants are large enough, transplant to rich, moist soil: These remarks refer to Snowball or other early kinds. The late kinds must be sown and transplanted earlier.

Henderson's Early Snowball. This is undoubtedly the finest ever introduced; it is the earliest, and produces beautiful snow-white heads of the most delicious flavor. The seed we offer is pure and genuine, and sure to prove satisfactory. Pkt. .20c.; oz., \$2.50.

Extra Selected Dwarf Eearly Erfurt. The finest strain of the Erfurt Cauliflower; almost as early as the Snowball; grows about 15 inches high producing very solid, pure white heads of the very finest quality; seldom fails to form a good-sized head. Pkt., .15c.; oz., $\$ 2.00$.

\section{DANISH GIANT (Dry Weather)}

This superior strain originated in Denmark. It is about two weeks later than our Snowball; makes a larger head and is very resisting against unfavorable season and dry weather. We would suggest to our customers who have had trouble in raising other kinds of Cauliflower to give this variety a trial, as to our minds the chances of success with this Cauliflower is increased many fold over any other strain.

Pkt., .20c; oz., \$2.50.

All kinds of Insecticides, Spray Pumps, Power Sprayers, etc., always on hand. Call and examine or write for catalogue and prices.

\section{CELERY}

German-Sellerie.

Spanish-Apio.

French-Celeri.

One ounce of seed produces about 3,000 plants.

Sow seed the first of second week in April in hotbed or cold frame. As soon as the plants have attained a height of three inches, transplant, setting them four inches apart. In order to secure "stocky" plants cut off the tops once or twice before again transplanting into richly manured soil, in rows four or five feet apart, with plants eight inches apart. As fall approaches draw earth up to the plants, keeping the stalks well together. When well blanched it is ready for use. Some of the varieties, such as Golden Self-Blanching and White Plume, may be blanched by simply placing a board 12 to 15 inches wide on edge on each side of the row.

Boston Market. The best and most popular sort in cultivation.

Pkt., .05c.; oz., .30c.; $1 / 4$ lb., .75c.

Giant Pascal. A strong grower and wonderful keeper, quality very fine.

Pkt., .05c.; 0z., .20c.; 1/4 lb., .50c.

Golden Self-Blanching. A self-blanching early golden-colored variety that is very popular. Crop failed.

White Plume. A variety that can be more easily grown than any other as it does not require high banking to blanch the stalks. Simply earthing up enough to keep the stalks together or by passing a string around each plant is sufficient.

Pkt., .05c.; oz., .25c.; 1/4 lb., .75c.

Celeriac, or Turnip-rooted. The turnipshaped roots of this variety are cooked and sliced and used with vinegar, making a most excellent salad.

Pkt., .05c.; oz., .15c.; 1/4 lb., .50c.

\section{CHICORY}

One ounce is sufficient for a bed of four square yards.

Large-Rooted or Coffee. Leaves when blanched make an excellent salad.

Pkt., .05c.; oz., .10c.; 1/4 lb. 30c.

\section{CORN-Sugar} German,-Welfehkorn.
Spanish,-Maiz. French,-Mais.

One quart will plant 200 hills; 1 peck will plant 1 acre in hills.

Corn requires a good soil and a warm situation. Commence for first early by planting the early varieties about May 1 , and if a continuous supply is wanted all summer, make plantings about two weeks apart from May 1 until the last of July, first planting early varities then later ones. Plant in rows 3 feet apart, and make the hills about the same distance apart in the rows. Five kernels in the hills are plenty. Cover about 1 inch deep for early and a little deeper for late. Thin to 3 plants in a hill. Add .05e per pt.; .10e per 


\section{CORN-Continued}

Early Red Cory. This variety is the favorite for first early.

Pk., \$1.50; qt., .25c; pt., .15c; pkt., .05c.

White Cob Cory. This is an improvement over the Early Cory as the cob is white which gives it a finer appearance. It is as early as the Early Cory, and of excellent quality.

Pk., $\$ 1.50$; qt., .25c; pt., .15c; pkt., .05c.

Crosby's Early. An early corn of large size and choice quality. It has long been a standard variety.

Pk., \$1.75; qt., .25c; pt., .15c; pkt., .05c.

Stowell's Evergreen. The best late corn for all purposes. It has been a leader for many years as a main crop variety and is unexcelled as a market corn.

Pk., \$1.75; qt., .25c; pt., .15c.; pkt., .05c.

Country Gentleman. This is the finest of the medium late varieties. The rows are zigzag with long slender kernel of delicious flavor.

Pk., \$1.75; qt., .25c; pt., .15c; pkt., .05c.

Black Mexican. This corn when in condition for the table cooks remarkably white; but the ripe grain is black or bluish-black. It is surpassed by none in tenderness.

Pk., \$1.75; qt., .25c; pt., .15c; pkt. .05c.

Golden Bantam. The fact that the grains of this variety are yellow is an indication of hardiness and its value for early planting and early maturity. It is a rapid grower, and produces ears measuring about 5 inches, but the smallness of ears is fully made up by the deliciuosly sweet flavor and tender quality of

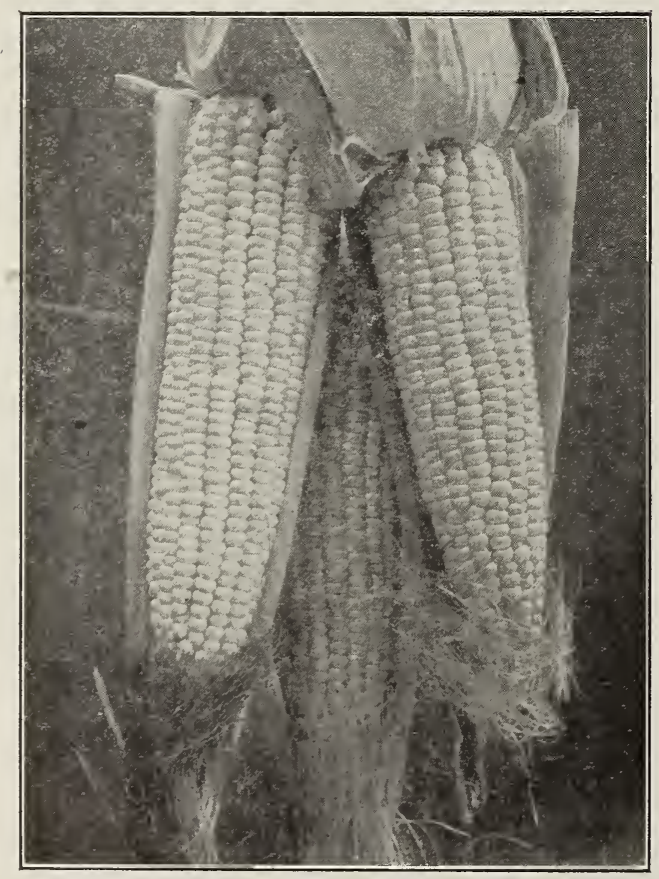

Stowell's Evergreen. the corn when cooked. It is a fine variety for the home garden.

Pk., \$1.75; qt., .25c; pt., .15c.; pkt., .05c.

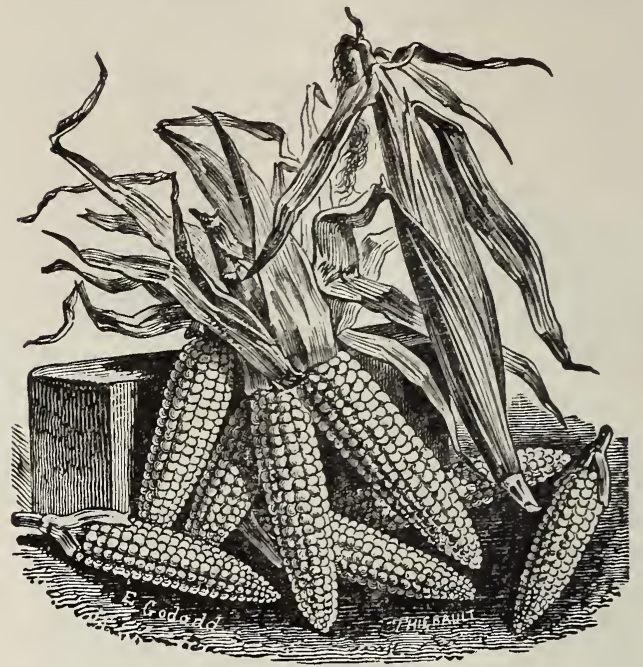

FIELD AND FODDER CORN

Prices will be quoted on application on the following corns. Please give the amount desired as well as the kind in all cases.

Southern White. A white variety that no silo owner or dairy farmer should overlook. It grows 12 to 16 feet high; has broad foliage and tender stocks. There is no better fodder to keep up the flow of milk during hot weather when the grass is burned up. Heavy cropper.

Leaming. An early very heavy long-eared corn. Grows to medium height with large amount of foliage. One of the best ensilage corns, very much relished by stock. Cob red; grain yellow.

Red Cob. A very large-growing white dent corn, with red cob. Fodder sweet, juicy and tender. Very popular in northern dairy districts.

Sanford. A well-known variety, adapted to the whole of New England. Kernels silvery white flint color; large and broad. An excellent fodder and ensilage corn.

Early Canada. An eight-rowed, yellow flint variety with small cob and deep grain. This is one of the earliest and best and seldom fails to produce a crop. The Early Canada seed we have to offer was grown in this State by the same party who has grown it for us for several years. From the fact that this corn matured in good shape last season it is sufficient evidence that it is Early and well adapted to this climate. The yield is also of the best having a record of 103 bus. shelled corn to the acre.

Longfellow. An eight-rowed, yellow flint sort; ears average 10 to 15 inches. Large kernels and small cob. Particularly adapted to New England, 


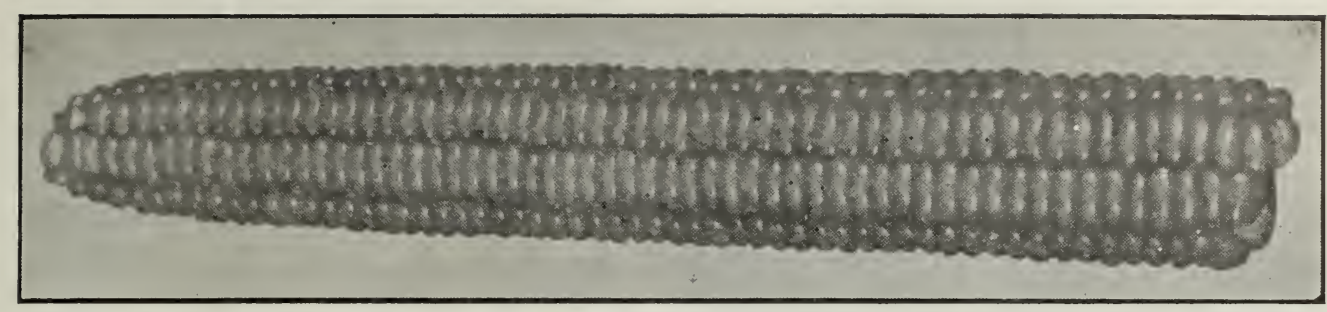

Haskell's Prizetaker Corn.

CORN-Continued.

\section{HASKELL'S PRIZETAKER CORN.}

This corn has fully maintained its past record as being the very best flint corn grown.

This corn showed a test of 12.2 per cent. protein, 5.51-fat, and 78.56 carbo-hydrates, which makes it the highest test corn from a food value of any of the known flints or dents. The germinating test of this will show fully 100 per cent.

On a recent test of this corn 70 pounds of ears made 63 pounds of shelled corn.

This also makes an exceptionally fine corn for an ensilage corn as it grows when planted for ensilage very rank, being 10 to 12 feet tall, and the stalks are very fine grain, making a much more profitable corn for ensilage than any of the dent varieties.

\section{CHERVIL}

One ounce will sow about 300 feet of drill. Cultivated like parsley. Sow thickly in May, in drills half an inch deep, one foot apart. Use while the leaves are young and tender.

Curled Chervil. The young leaves are used for garnishing, and flavoring soups. Pkt., .05c; 0z., .10c.; 1/4 lb., .25c.

\section{CORN SALAD OR FETTICUS} German,-Uckerfalat.
Spanish,-Macha Valerianilla.

One ounce will sow 150 feet of drill.

Sow in September, in drills eight inches apart, covering the seeds lightly, and protect from frost by a light covering of hay or litter. The seed may also be sown in spring.

Large Green Cabbaging. A small, hardy salad; used also as a substitute for lettuce; can be sown in September, and wintered over same as spinach.

Pkt., .05c; 0z., .10c; 1/4 lb., .30c.

\section{CRESS OR PEPPERGRASS}

German,-Areffe. Spanish,-Masuerzo.

French,-Cresson.

One ounce will sow 16 square feet, or 150 feet of drill.

A popular salad. which should be sown early in the spring-very thickly in shallow drillsand at short intervals, for success, as it soon runs to seed.

Extra Curled. A small plant, having a fine, pungent flavor, and used as a salad; may be cut two or three times.

Pkt., .05c; 0z., .10c; 1/t 1b., .20c; lb., .50c.

True Water Cress. Grows along the banks of ponds and streams, and is easily introduced; wholly unlike Extra Curled; leaves are quite large and thick; a fine salad, sold in immense quantities in the large markets in spring.

Pkt., .10c; oz., .40c; 1/t lb., $\$ 1.25$.

\section{CUCUMBER}

German,-Gurfe. French,-Concombre. Spanish,-Pepino.

One ounce wil plant 50 hills; 2 pounds will plant an acre.

Culture-For earliest use, sow the seed in the hotbed or greenhouse in February or March, in warm loam, where the temperature is about 90 degrees; cover half an inch deep, and when the plants are of fair size, transplant into hills (made in the greenhouse), four plants in a hill, so that when the weather permits the whole hill can be moved to the open ground by means of tins made for that purpose. Plant for general use in the open ground about June 1, in hills 6 feet apart each way, and thin to three plants in a hill. Fine old manure (about six cords per acre) is sufficient; or, better still, plant on land from which a crop has been taken, and which was heavily manured for that crop. 


\section{CUCUMBER-Continued}

Davis Perfect. As now selected, this popular new variety is well worthy of praise. The long, even fruits are of fine form, with an intensely dark rich green skin. With very few seeds the solid white flesh is of superb quality for slicing. So handsome and regular are the fruits that they bring an extra price on market.-often being taken for "hot-house grown.', The vines are of strong growth and quite prolific.

Pkt., .05c; 0z., .10c; 1/4 lb.,. 50c.

Extra Early Russian. Earliest variety known, hardy and productive, fruit very small and quality fine for pickling or slicing.

Pkt., .05c; oz., .10c; 1/4 lb., .35c.

Early Cluster. Fruit borne in pairs; light green, a great bearer.

Pkt., .05c; 0z., .10c; 1/4 lb., .35.

Early Frame or Short Green. An excellent sort, both for table use and for pickling. Plants very vigorous and productive. Fruit straight, a little smaller at the ends, bright green, lighter at the blossom end. Comes into use at little later than the Early Cluster and keeps green a long time. Our stock is evry superior.

Pkt., .05c; oz., .10c; 1/4 lb., .35c.

Boston Pickling. Fruit short, smooth and pointed at each end, bright green and a great vielder, one of the best pickling.

Pkt., .05c; 0z., .10c; 1/4 lb., .35c.
White Spine Improved. The most popular strain of White Spine, and for general outdoor culture the best.

Pkt., .05c; 0z., .10c; 1/4 lb., 35c.

Long Green Improved. Fine for pickling when small, good for table use when about half grown.

Pkt., .05c; oz., .10c; 1/t lb., .35c.

Japanese Climbing. Villes are extra strong and foliage much more vigorous than other kinds, and being a climbing sort, can be grown on trellises, etc., saving much valuable space in small gardens. It is very prolific, from forty to fifty cucumbers having been counted on single plants. Fruit cylindrical, about ten inches long, thick and of fine flavor.

Pkt., .05c; oz., .15c; 1/4 1b., .50c.

\section{DANDELION}

German,-Lowenzahn. French,-Pissenlit. Spanish,-Amargon.

One ounce will sow 100 feet of drill.

The Dandelion resembles endive, and affords one of the earliest as well as one of the most heathful of spring greens. Sow as early as the weather will permit, in good, well-enriched soil, in rows 12 inches apart, covering seed $1 / 4$ of an inch deep, and firming the soil well over them. Thin to two or three inches apart in the rows; by so doing the roots will be larger and a great amount of time will be saved the

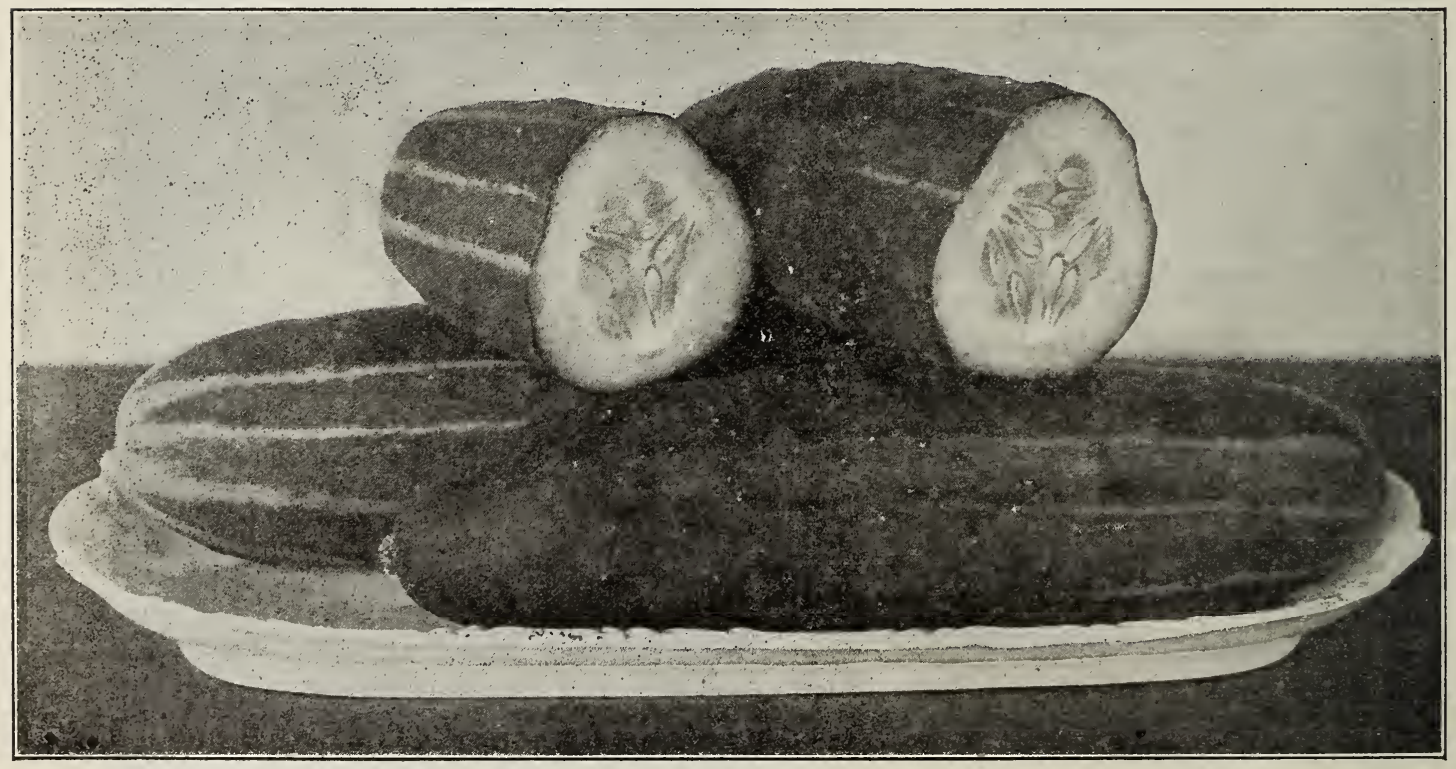

White Spine Cucumber. 
next spring in trimming or gathering the crop. One pound per acre is sufficient.

Improved Thick-Leaved. Cultivated for spring greens; an immense improvement on the common Dandelion, both in size and thickness of its leaves and fine flavor, being far less hitter.

Pkt., .05c; 0z., .50c; 1/4 1b., $\$ 1.75$.

\section{EGGPLANT}

(ierman,-Gierpanze. French,-Aubergine.
Sipanish-Berengena.

The Eggulant will thrive well in any good garden soil, but will repay good treatment. The seeds should be sown in hotbed or warm greenhouse in March or April, and when about an inch high potted in two-inch pots. Plant ont about June 1 , two and one-half feet apart.

New York Improved Purple. The leading market variety, and undoubtedly the best for si\%e, quality and productiveness.

Pkt., .05c; 0z., .50c; 1/4 lb; $\$ 1.50$.

\section{ENDIVE}

German,-Gendive.

Spanish,-Endivia.

One of the most refreshing and attractive of all autumn and winter salads. Sow seed from the middle of June until the end of August.

Green Curled. Beautifully curled, tender, and erisp.

Pkt., .05c; oz., .15c; $1 / 4$ lb., .50c.

Moss Curled. More finely curled, and a heavier and more dense plant than Green curled.

$$
\text { Pkt., .05c; 0z., .15c; 1/4 1b., .50c. }
$$

Broad-leaved Batavian (Escarolle). This variety is chiefly used in soups and stews; requires to be tied up in blanching. Pkt., .05c; 0z., .15c; 1/4 lb., .50c.

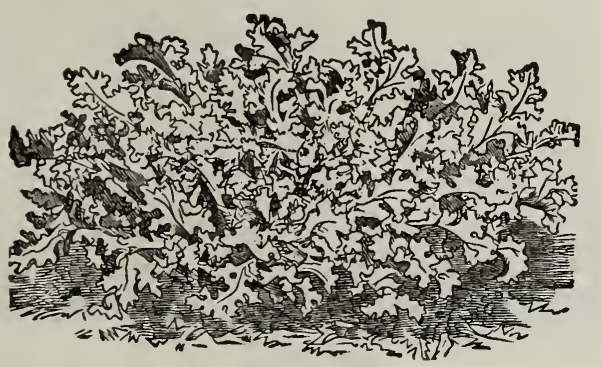

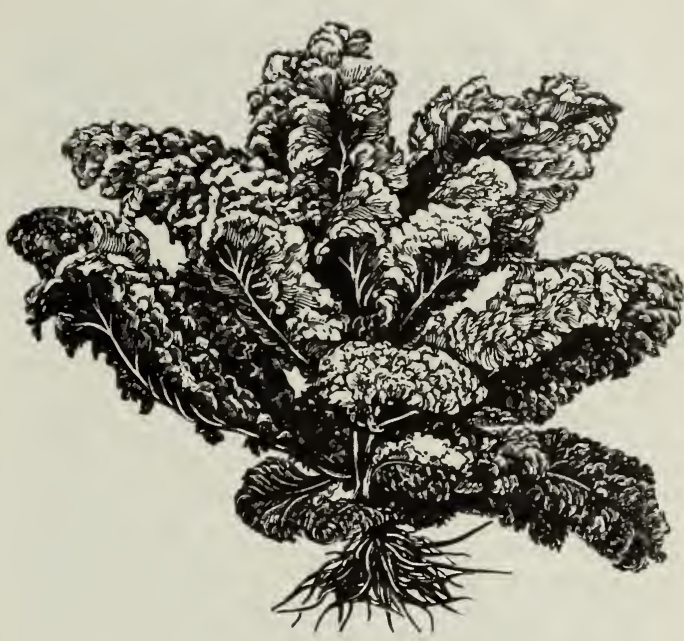

Kale.

\section{KALE OR BORECOLE}

German,-Blatter-Kohl. French,-Chou Vert Spanish,-Breton.

One ounce will produce 3,000 plants.

Sow from the middle of April to the beginning of May in prepared beds; transplant in June, and treat in the same manner as for cabbage. Of all the cabbage tribe this is the most tender and delicate. The varieties are all extremely hardy, and are best when touched by frost.

Dwarf German Purple, or Brown Curled. Esteemed by Germans; very hardy and of fine quality; so handsome that it is frequently grown for ornament.

$$
\text { Pkt., .05c; 0z., .10c; 1/t 1b., .30c. }
$$

Dwarf Green Curled Scotch. Rarely exceeding 18 inches in height, but spreading out under good cultivation to 3 feet in diameter; leaves beautifully curled and bright green. Pkt., .05c; 0z., .10c; $1 / 4$ 1b., .30c.

Tall Green Curled Scotch. Grows about two feet high; leaves dark green, curled and wrinkled; very hardy, and is improved by a light frost.

$$
\text { Pkt., .05c; 0z., .10c; 1/4 1b., .30c. }
$$

\section{KOHL RABI} German,-Rohl-Rab. French,-Chou-Rave.
Spanish,-Col de nabo.

One ounce will sow 200 feet of drill.

This vegetable, the popularity of which is rapidly increasing, combines the virtues of the turnip and cabbage, but excels both in nutri. tive, hardy and productive qualities. The seed may be sown in June in rows 18 inches apart, and the plants thinned out to eight or ten inches in the rows. 
KOHI RABI-Continued

Early White Vienna. Best for general table use; flesh tender and white.

Pkt., .05c; 0z., .25c; 1/4 lb., .60c.

Purple Vienna. A little later than the White; color bluish purple.

Pkt., .05c; 0z., .25c; 1/4 lb., .60c.

Large Green or White. Good for table and also for feeding stock.

Pkt., .05c; 0z., .25c; 1/4 lb., .60c. LEEK

German,-Lanch. $\quad$ French,-Poireau. Spanish,-Puerro.

One ounce will plant 200 feet of drill.

The leek is very hardy and-easily cultivated; it succeeds best in a light but wellenriched soil. Sow as early in the spring as praticable in drills one inch deep and one foot apart. When six or eight inches high they may be transplanted in rows ten inches apart each way, as deep as possible, that the neck, being covered, may be blanched.

London Flag. Very popular with market gardeners.

Pkt., .05c; 0z., .15c; 1/4 lb., .50c.

Broad American Flag. Large and superior to London Flag; popular with gardeners.

Pkt., .05c; 0z., .10c; 1/4 lb., .50c.

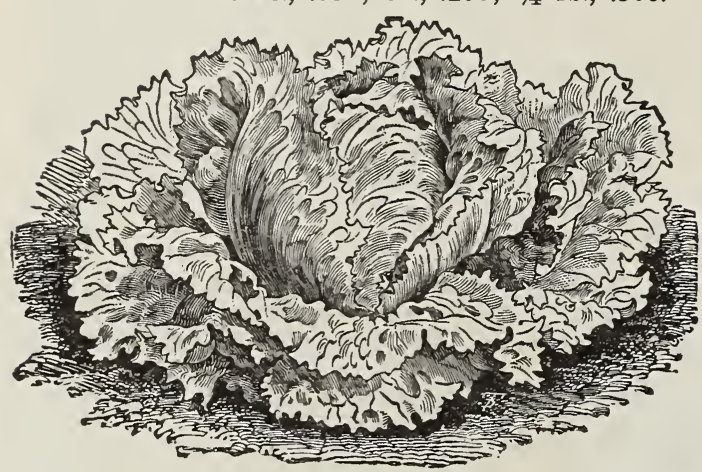

\section{LETTUCE}

German,-Lattich. French,-Laitue. Spanish,-Lechuga.

One ounce will sow 100 square feet, or 120 feet of drill.

Requires a rich, moist soil, and to be crisp and tender needs to be grown in cool weather. For winter use, sow in hotbeds every two weeks, at the rate of one ounce of seed to four sashes (a sash is three feet long by six feet wide); cover very lightly, and transplant, first to three inches apart each way, afterward to eight inches. For garden or field, sow in rows, and cover, one-fourth of an inch deep, and thin out to twelve inches apart in the rows. For New England the White Seeded Tennisball for cultivation under glass, and the Black Seeded Tennisball for outdoor use, are the standard variety.

May King. Probably the finest all-seasons lettuce yet introduced. It is very early and hardy, and will stand cold, damp weather better than many varieties. Planted out of doors or under glass it will produce fine solid heads much sooner than any other variety. Outer leaves are yellowish green, tinged with brown, while the inside is a rich yellow.

Pkt., .05c; 0z., .25c; 1/4 lb., .75c; lb., $\$ 2.00$.

Big Boston. A most desirable variety, either for forcing in cold frames or openground planting; always produces large, solid, saleable heads. Pkt., .05c; 0z., .20c; $1 / 4$ lb., .60c

Boston Curled. Of ordinary quality but great beauty; highly ornamental in growth, with its frilled leaves.

Pkt., .05c; 0z., .20c; 1/4 lb., .50c.

Prize-Head Early. Leaves green and red, very thin, erisp and tender; one of the best for private use.

Pkt., .05c; 0z., .20c; 1/4 lb., .50c.

Tennisball, Black-Seeded. A very popular sort for open-ground culture; forms a handsome head, and is crisp and tender.

Pkt., .05c; 0z., .20c; 1/4 lb., .50c.

Tennisball, White Seeded. Extensively grown for forcing and heading under glass; heads firm and good size, very white and crisp. $\quad$ Pkt., .05c; 0z., .15c; $1 / 4$ lb., .40c.

Simpson Black-Seeded. Nearly double the size of the Early Curled Simpson; leaves delicate golden yellow; superior variety for forcing or sowing out of doors.

Pkt., .05c; 0z., .15c; 1/4 lb., .30c.

Simpson Early Curled (White Seed.) A leading early sort for forcing or open ground. Pkt., .05c; 0z., .15c; 1/4 lb., .30c.

Tomhannock. A variety with upright leaves, beautifully wrinkled; edges of outer leaves have reddish tinge; one of the best.

Pkt., .05c; 0z., .15c; 1/4 1b., .30c.

Boston Market. One of the best for forcing under glass, as well as for outside use; forms fair-sized heads, edge of leaves slightly tinged with red.

Pkt., .05c; oz., .20c; 1/4 1b., .50c.

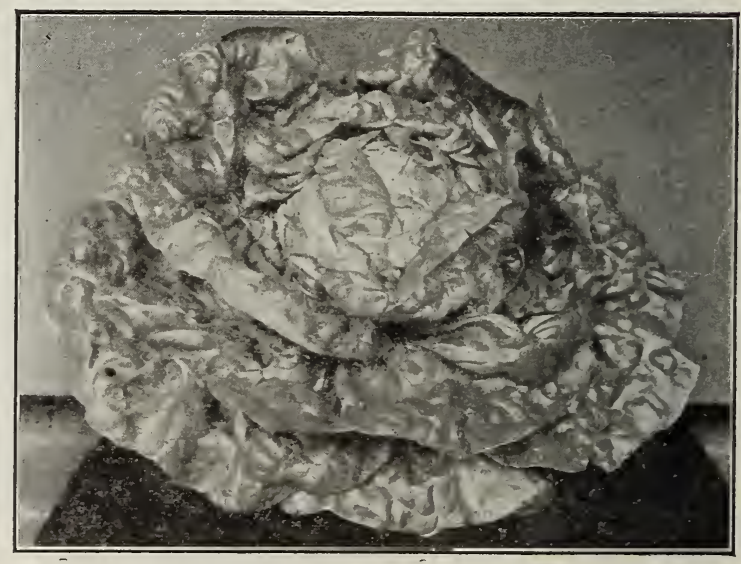

May King 
There is a breezy farm paper named the "Furrow" which we want in your home. Send your name for our mailing list and four times a year it will be sent you FREE.

\section{LETTUCE-Continued}

Grand Rapids. An excellent forcing variety with loose heads and of good size and form. Pkt., .05c; 0z., .15c; 1/t lb., .40c

Brown Dutch. Leaves large, thick, green, tinged with brown; forms large, solid heads; exceedingly hardy.

Pkt., .05c; 0z., .15c; 1/4 lb., .50c.

Hanson. Large, solid heads; tender, crisp, and of fine flavor.

Pkt., .05c; 0z., .15c; 1/t lb., .40c.

White Paris Cos. Has long, narrow, upright leaves; does not head, but when tied uj blanches very nicely.

Pkt., .05c; 0z., .15c; 1/t 1b., .40c.

\section{MELON, MUSK}

German,-Melone. Spanish,-Melon.

French,-Melon.

One ounce will plant about 50 hills; 2 to $3 \mathrm{lbs}$. in hills per acre.

Melons thrive best in a light, rich soil. Plant early in May, when the ground has become warm and dry, in hills six feet apart each way for Muskmelons, eight feet for Watermelons. Previous to sowing the seed, mix a few shovelfuls of well-rotted manure in each hill, and plant in each twelve to fifteen seeds; after all danger of bugs is over, thin out to three plants per hill. When about one foot long, pinch off the tips to make them branch, as it strengthens the growth of the vines and makes the fruit mature earlier. Give plenty of water, and feed liquid manure occasionally. A few hills for early use may be had by sowing on pieces of sod in a hotbed, and when warm enough transplant to open ground.

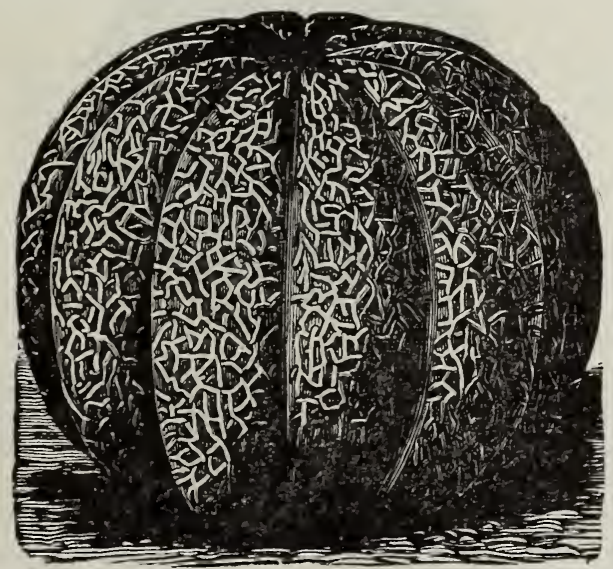

Emerald Gem Melon. The Emerald Gem is entirely unlike any other muskmelon yet introduced. The melons are about the size of the Netted Gem, but unlike that variety, the skin, while ribbed, is perfectly smooth, and of a very deep emerald green color. The flesh, which is thicker than any other native melon of the same size, is of a suffused salmon color, and ripens thoroughly to the thin green rind, which is distinctly defined. The flesh is peculiarly crystalline in appearance, and so very juicy, sweet and rich that is almost drops to pieces. It natures very early, and is quite productive.

Pkt., .05c; 0z., .10c; 1/4 1b., ..50c; 1b., \$1.50.

Rocky Ford. This new Muskmelon is similar to the oval strain of Netted Gem. The strain here offered originated with the melon growers in the vicinity of Rocky Ford, Col., who have shipped this melon from that distant IVestern point to Eastern markets. The melons grown by them are so fine in quality as to outsell all others, and the demand for such melons has been far beyond the supply.

Pkt., .05c; 0z., .10c; 1/4 1b., .40c; 1b., \$1.25.

Long Yellow Musk. A long, large melon of peculiar musky flavor; a rich, yellow color both inside and out.

Pkt., .05c; oz., .10c; 1/1/1 lb., .40c; 1b., \$1.25.

Early Hackensack. An improvement over the old Hackensack, producing melons of as good quality and ten days earlier. Large fruit, with thick, green flesh of the finest flavor.

Pkt., .05c; 0z., .10c; 1/4 1b., .40c; lb., $\$ \$ 1.25$.

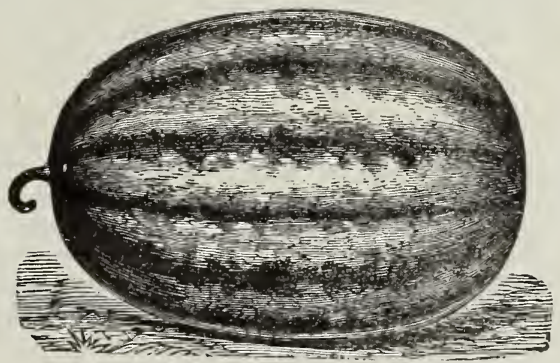

\section{MELON, WATER}

German,-Waffermelone. French,-Melon d'Eau. Spanish,-Zandia.

One ounce will plant 50 hills.

Prices on all varieties of Watermelons as follows: .05c per pkt.; .10c per 0z.; 1/4 lb., $.25 \mathrm{c}$; $1 \mathrm{lb} ., .75 \mathrm{c}$.

Citron for Preserves. The old and well known Preserving Citron; seeds red.

New Florida Favorite. An improvement on the old Florida Favorite, growing to double the size and more prolific. Its perfect shape bright red crisp flesh, and delicious flavor, 


\section{MELONS-Continued}

Phinney's Early. This is another very early melon, earlier than the preceding; it is hardy and a sure cropper and extensively cultivated in the North.

Peerless or Ice Cream. Very early, flesh firm and sugary.

Cuban Queen. Very productive; flesh bright red, very solid, crispy and sugary.

\section{MUSTARD}

German,-Senf. French,-Moutarde. Spanish,-Mostaza.

One ounce will sow 75 feet of drill.

As an ingredient, the green Mustard imparts a delightfully pungent flavor to the various forms of prepared salads. For early crops the seed may be sown in a hotbed in March, and for general crop at frequent intervals through the spring, in drills from eight to twelve inches apart.

White London. Considered the best for salads and spinach; leaves light green. It is best when about four inches high.

Pkt., .05c; 0z., .10c; 1/4 1b., .15c.

Brown or Black. Pkt., .05c; 0z., .10c; 1/4 lb., .15c.

\section{OKRA OR GUMBO}

German,-Ocher. Spanish,-Cebolla.

French,-Gombo.

One ounce will plant 100 hills.

This is an annual from the West Indies, cultivated from its green seed-pods, which are used in soups or stewed and served like asparagus. It is highly esteemed in the South for making gumbo soup. 'The pods when young and tender should be sliced in sections, strung on a thread and hung up in the shade to cure like dried apples; can be used for soup at any time.

Culture. Sow the seed thinly in dry, warm soil, in shallow drills two feet apart. After the plants are up, thin them out to nine inches apart; hoe frequently and draw a little earth to the stems as they grow. Gather the pods when quite green and about one and one-half inches long.

Long Green. Pods long, green and ribbed, and a heavy bearer. Pkt., .05c; 0z., .10c; $1 / 4$ lb., .25c.

White Velvet. Great improvement over the older varieties; pods larger, white, smooth, and a more abundant bearer; of superior quality. Pkt., .05c; oz., .10c; 1/4 1b., 30c.
Weeders, Seeders and Garden Tools for the Market Gardeners are Specialties with us. Call and examine same.

\section{ONION}

Select the clean, richest land on the farm for the Onion crop. If Onions were grown on the land the previous year, so much the better, but any good corn or potato land will do. Broadcast fifteen to twenty cords of fine wellrotted manure to the acre and plow not deeper than six inches; harrow thoroughly, cross plow, and harrow again, after which, hand rake with wood rake and remove stones and rubbish. Sow four to five pounds of seed per acre in drills twelve to fourteen inches apart and about one-half inch deep. See that the Seed Drill is equipped with a good roller, that will press the earth firmly upon the seed. Sow as early in the spring as the ground can be properly worked. There is seldom necessity for thinning Onions if the land has been properly manured and seeded. After the Onions are three to four inches high, an application of about five hundred pounds to the acre of fertilizer, rich in available nitrogen, strewn between the rows, will be very beneficial. Keep the Onions growing by never allowing the weeds to get ahead and the acre should produce, in a good average season, five hundred to seven hundred bushels. When the tops are down, the Onions may be pulled and left on the ground, and should be frequently turned with a wooden rake, until tops are dried.

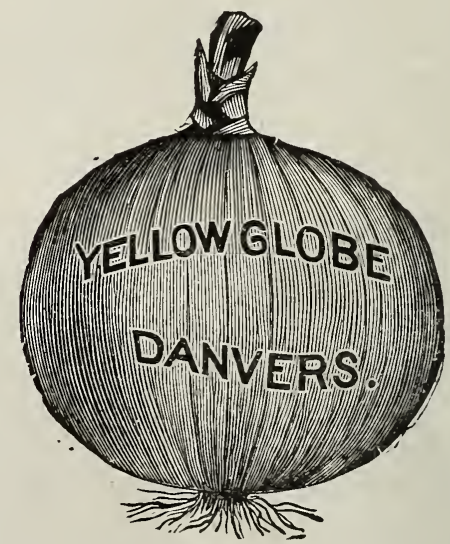

Yellow Globe Danvers. Undoubtedly the best known and most popular of all onions; the earliest yellow variety; is entirely free from stiff necks. Globular in shape; has a small top. It is the most productive, producing as high as one thousand bushels per acre, 
We buy our ONION SETS from the largest grower in the country and know that we have as fine a lot as can be obtained.

\section{ONION-Continued}

culture five to seven hundred bushels.

Pkt., .05c; 0z., .20c; 1/t lb., .60c; 1b., \$2.00.

Yellow Globe Danvers, our Finest Strain. This is the product of years of careful selection, and is the most perfect type of the Yellow Globe Danvers Onion which intelligent, painstaking care can produce. It is immeasurably superior to the average seed offered, not only in shape and color, but in producttiveness. Pkt., .10c; 0z., .25c; 1/. 1b., .75c; 1b., $\$ 2.50$.

Large Red Wethersfield. We have a very fine and select strain of this sort. Color is deep purplish red, flesh white, moderately grained and very firm. Yields enormously and is one of the best winter keeping onions.

Pkt., .05c; oz., .25c; 1/4 1b., .75c; lb., $\$ 2.50$.

White Portugal, or Silverskin. A large flat, white onion of mild and pleasant flavor; hard and fine-grained, and a good keeper. Extensively sown for sets, and is also largely grown for pickling. Pkt., .05c; oz., .25c; $1 / 4$ lb., $.75 \mathrm{c} ; 1 \mathrm{~b} ., \$ 2.50$.

Southport Red Globe. The onions from Southport, Conn., generally command an extra price in New York markets, because of their beautiful shape and color, due partly to the variety grown and partly to the favorable soil and the extra care taken in handling the crop. Pkt., .05c; 0z., .25c; 1/t lb., .75c; lb., $\$ 2.50$.

Prize-Taker. A globe-shaped variety of delicate straw color, growing to a very large size. It ripens up hard and firm, the flesh being pure white, fine grained and of mild, delicate flavor. Pkt., .05c; oz., .25c; 1/1 1b., .75c; 1b., $\$ 2.50$.

\section{ONION SETS}

Potato Onion Sets
Red Bottom Sets
White Bottom Sets
Yellow Bottom Sets
Top Sets

qt. $.20 \mathrm{c} ; \mathrm{pk} . \$ 1.25$ qt. .25c; pk. $\$ 1.25$ qt. $.25 \mathrm{c} ;$ pk. $\$ 1.25$ qt. $.25 \mathrm{c} ; \mathrm{pk}$. $\$ 1.25$ qt. $.20 \mathrm{c} ; \mathrm{pk} . \$ 1.00$

Onion Sets should be planted as early in the spring as convenient to obtain early green onions, but they may be set at any time up to June 1. Set in rows a foot apart, and three to four inches between them in the row. Any good soil will suit them. Then grown in quantity, high cultivation is given in order to forward the crop for an early market. They are ready for use as soon as the bulbs begin to be of fair size. Those not used in green condition will ripen early in July and make nice onions. Potato and Top Onions are grown from bulbs only.

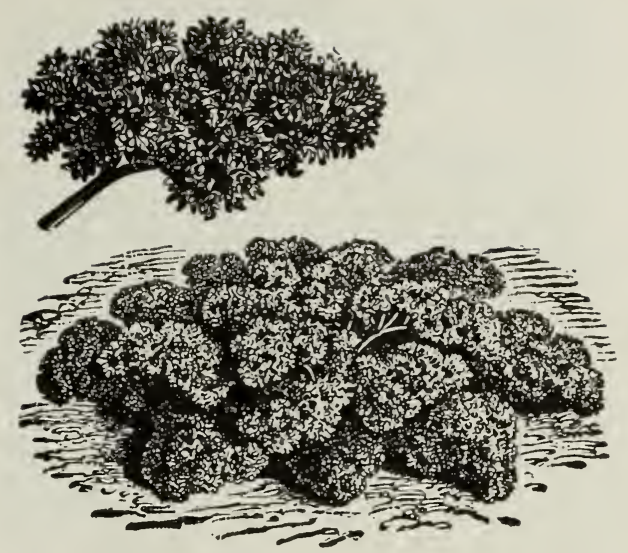

\section{PARSLEY}

German,-Peterfile. French,-Persil. Spanish,-Perejil.

One ounce for 150 feet of drills.

Parsley succeeds best in rich, mellow soil. As the seed germinates very slowly, it should be sown early in spring, previously soaking the seed for a few hours in tepid water. Sow thickly in rows a foot apart and half an inch deep.

Champion Moss Curled. The standard variety. Pkt., .05c; 0z., .10c; 1/4 1b. .25c; 1b., .75c.

Extra Curled Dwarf. Leaves finely cut, very early and bright green; desirable for either the home or market garden. Pkt., .05c; oz. $.10 c ; 1 / 4$ lb. .25c; lb., .75c.

\section{PARSNIP}

German,-Pastinake. French,_-Panais.
Spanish,-Pastinaca.

One quart for 75 feet of drill; one to two bushels in drills for an acre.

Sow as early in spring as the weather will admit, drills fifteen inches apart, covering half an inch deep. When well up thin out to five or six inches apart in the rows. Unlike carrots, they are improved by frost, and it is usual to take up in fall a certain quantity for winter use, leaving the rest in the ground till spring, to be dug as required.

Irices on all varieties of parsnips as follows:

Pkt., .05c; 0z., .10c; 1/4 1b., .20c; prices in quantity on application.

Abott's Improved. Hollow Crown. Smootl and quite large; fine sort.

Guernsey. Roots not quite so long as Hollow Crown, but of greater diameter and more 


\section{PEAS}

German,-Erbren.

Spanish,-Guizante.

One quart for 75 feet of drill; one to two bushels in drills for an acre.

Peas come earliest to maturity in light, rich soil. For general crop, a deep loam or a soil strongly inclining to clay is best. For early crops decomposed leaves or leaf-mold should be used; or, if the soil is very poor, strong manure may be used. For general crops a good dressing should be applied, and for the dwarf-growing kinds the soil can hardly be too rich. When grown as a market crop, peas are never staked; for private use, they are generally sown in double rows, and the tall varieties stalied up by brush. For an early crop sow as soon as the ground can be worked, and make repeated sowings every two weeks for succession. After the first of Jume sowing should be discontinued until the middle of August, when a good crop may sometimes be secured by sowing an extraearly sort for fall use.

If sent by mail add .08c per pt.; .16c per qt. extra.

All marked thus (*) indicate wrinkled varieties.

\section{Extra Early Dwarf Varieties}

*Bliss American Wonder. An old variety, but still highly prized for its flavor and quality. Of dwarf, robust habit, growing twelve to fifteen inches in height, and bearing an abundance of good-sized, well-filled pods.

Pt., .15c; qt., .30c; pk., \$2.00.

*Sutton's Excelsior. Ripens early on vines fourteen to sixteen inches high, covered with a great abundance of long, straight, broad pods of a pale-green color. Price: Pt., .15c; qt., .30c; pk. $\$ 2.25$.

*Premium Gem. A fine-flavored dwarf, wrinkled variety; height, eighteen inches.

Pt., .15c; qt., .25c; pk., \$1.75.

*Nott's Excelsior. This. is the earliest dwarf wrinkled pea. The plant is dwarf and needs no support. The pods are of good size and well filled with large peas of the finest quality. It is as early as the American Wonder, while the vines are much more productive and the pods of larger size. There is no better early dwarf pea. Fifteen inches. Pt., .15c; qt., .30c.; pk., $\$ \$ 2.00$.

Every person planting peas should have one of our Garden Seeders. Send for description circular and prices, or if possible call at our store and examine them.

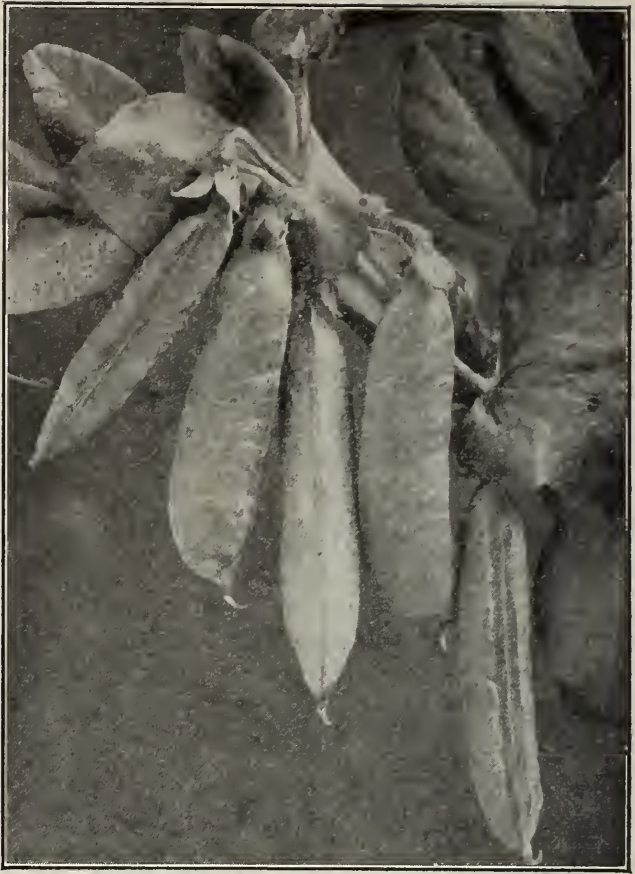

Sutton's Excelsior.

\section{Extra Early Varieties Not Dwarf}

Alaska. An extra early round pea bearing pods of a dark green color; two feet.

Pt., .15c; qt., .25c; pk., $\$ 1.75$.

*Gradus, or Prosperity. No new variety of peas has ever met with the favor and sale as the "Gradus" has since its introduction in America several years ago. It combines the finest quality with extreme earliness, and is also productive, bearing pods fully as large as Telephone. The color of the shelled peas is a beautiful light green, which color they retain after being cooked; the quality and flavor are delicious, and the peas remain tender and sweet for a long time. Pt., .20c; qt., .40 c; pk., $\$ 2.75$.

*Thomas Laxton. One of the very best of the tall growing large pod early peas. The plant is a very hardy and strong grower, producing extra large size pods in abundance. The quality is delicious, and cannot be surpassed by any other variety. The "Thomas Laxton" will mature nearly as early as any of the extra early smooth peas, and being a wrinkled sort is much sweeter. Pt., .20c; qt., .40c.; pk., $\$ 2.75$. 


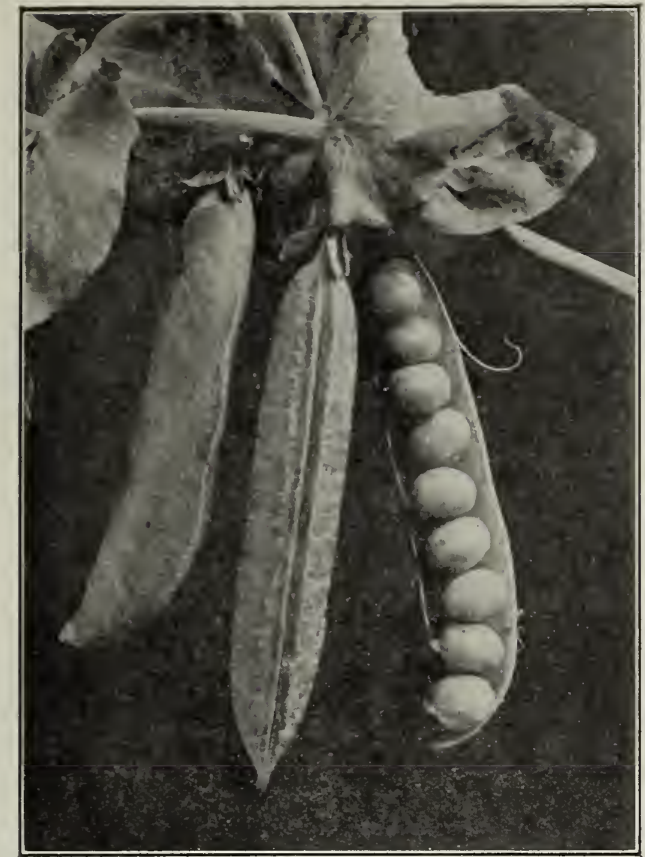

Thomas Laxton

\section{PEAS-Continued}

\section{Second Early Varieties}

*Heroine. One of the very best late kinds. Very long pods well filled with deliciously sweet dark green peas. Two feet. Pt., .15c; qt., .30c; pk., $\$ 2.00$.

*Telephone. A pea of the finest quality, sweet and delicious. Medium late, growing four feet tall with pods of the largest size.

Pt., .15c; qt., .30c; pk., \$1.75.

*Yorkshire Hero. Bears large, well filled pods on stocky, vigorous vines. A first-class late pea. Two feet. Pt., .15c; qt., .30c; pk., $\$ 1.75$.

*Bliss Everbearing. Medium late and very productive two feet tall. Pt., .15c; qt., .30c; pk., $\$ 1.75$.

*Haskell's Dark Green Pod Pea. Immense pods of the style of the Telephone. A very superior wrinkled pea of quick and robust habit of growth. Pods are very deep green, averaging five to six inches in length and are borne in great abundance. The peas have a peculiarly pleasing flavor sure to satisfy all lovers of this most delicious vegetable. Haskell's Dark Green Pod is a medium late variety growing from three and one-half to four feet in height. Pt., .15c; qt., .30c; pk., $\$ 1.75$.
*Duke of Albany or American Champion. Very fine, large pods and peas of finest quality. Medium late three feet. Pt., .15c; qt., $.30 \mathrm{c} ;$ pk., $\$ 2.00$.

*Dwarf Champion. Possesses all the merits of the reliable Champion of England. A hardy robust grower producing dark green pods of good size and in great abundance. Quality excellent. Pt., .15c; qt., .30c; pk., $\$ 1.75$.

*Dwarf Telephone. (Carter's Daisy). Similar to the Tall Telephone except in the height of the vine, which is only about two feet.

Pt., .15c; qt., .30c; pk. \$1.75.

*Admiral Dewey. An enormous eropper; peas very large and sweet. Pt., .15c; qt., 30c; pk., $\$ 2.00$.

\section{Late Varieties for General Crop}

*Champion of England. The standard for quality. Grows four feet tall, very prolific, and still one of the best late peas. Pt., .15c; qt., .30c.; pk., $\$ 1.75$.

*Improved Stratagem. A very large, fine pea growing about twenty inches tall, strong and stocky. Late. Pt., .15c; qt., .30c; pk., $\$ 2.00$.

Mammoth Melting Sugar. (Edible pods.) Large broad pods, very brittle and entirely stringless Height four feet. Pt., .25c; qt., $.50 \mathrm{c}$.

White Marrowfat. A good late sort. Cultivated very extensively for the summer crop. Pt., .15c; qt., .25c; pk., \$1.25.

Black-Eyed Marrowfat. An old and standard late variety for garden or field use. Pt. $.15 \mathrm{c}$; qt., .25c; pk., \$1.25.

Canada Field. Seeds small, white; for field culture only; largely used for sowing among oats. Bu., $\$ 2.60$.

\section{PEPPER}

German,-Pfeffer French,-Piment. Spanish,-Pimiento.

One ounce will produce 2,000 plants.

Grown largely for pickles. Sow in hotbeds early in April, and transplant to the open ground when the weather is favorable. They should be planted in warm mellow soil in rows 18 inches apart. They may also be sown in the open ground when danger of frost is past.

Large Bell, or Bull Nose. A favorite and well-known pickling sort; is early, large, mild and thick-skinned. Pkt., .05c; 0z., .25c.

Long Red Cayenne. A small, long, bright red sort, very productive; extremely strong and pungent. Pkt., .05c; 0z., .35c. 
We will have a fine assortment of

\section{SEED POTATOES}

in many of the common sorts and all are from selected stock. Ask for quotations.

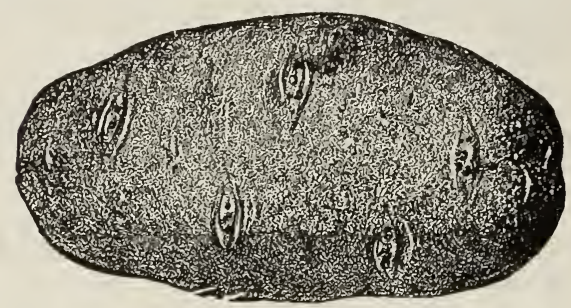

\section{POTATOES}

While there are many varieties of potatoes which claim the public favor, we have included in our stock only a few and these we know to be the best in cultivation. All our potatoes are grown from selected stock in Maine and being of a uniform size are calculated to give the best results when used in a planter. Write for prices and descriptions on

Green Mountain,
Irish Cobbler,
Gold Coin,
Early Harvest,

Norcross,
Early Rose and
Early Six Weeks
New Queen.

\section{PUIMIPKIN}

German,-Kurbis. French,-Poitron. Spanish,-Calabaza.

One ounce will plant 20 hills.

Pumpkins are grown chiefly as food for stock. The usual method of planting is to scatter a few seeds at intervals in the hills when planting Indian corn; in this way good

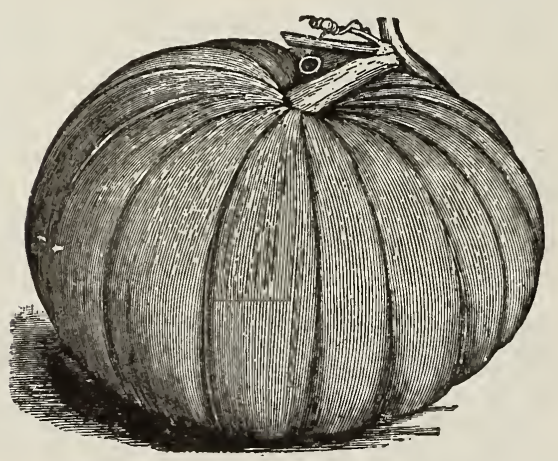

crops of Pumpkins are secured with slight labor and expense, and make a valuable addition to the season's crops.

Connecticut Field. The common yellow pumpkin, grown chiefly for feeding stock. Oz., .05c; 1/t Ib., .15c; 1b., .40c.

Large Cheese or Kentucky Field. A most popular variety Fruit flattened, the diameter being two or three times more than the length. Oz., .05c; 1/t lb., .10c; lb., .40c.

Sweet, or Sugar. A small variety, finegrained and sweet; the best for table use. Oz., .05c; 1/4 lb., .20c; lb., 60c.

\section{RADISH}

German,-Rettig, Rabies. Spanish,-Rabano.

French,-Radis, Rave, Petite Rave.

One ounce will sow 100 feet of drill.

Culture. The soll for Radishes should be very rich, light and mellow, well broken by digging as their tender and mild qualities depend much upon their rapid growth. For very eariy use sow in hotbeds in February and March and in the open air as soon as the ground can be worked, at intervals of ten or twelve days for a succession as long as they may be wanted. The winter varieties should be sown in August, lifted before severe frost, and stored in the cellar.

Vick's Scarlet Globe Radish. A leader among bright round Red Radishes. Quick maturing, extremely attractive, short tops, solid and tine flavor. Pkt., .05c; 0z., .10c; $1 / 4$ lb., $.25 \mathrm{c} ; 1 \mathrm{lb} ., .75 \mathrm{c}$

Early Scarlet Turnip, White Tipped. One of the handsomest of the turnip radishes and a great favorite in many large markets for early planting outdoors. It is but little later than the White Tipped Forcing, and will give entire satisfaction where extreme earliness is not the primary object. Roots slightly flattened on the under side; color, very deep scarlet with a white tip; flesh white and of the best quality. Pkt., .05c; 0z., .10c; 1/4 lb., $.25 \mathrm{c}$; lb., .75c.

Long Scarlet. Short top. The standard variety of the long sorts, used either for forcing or open culture; six or seven inches long. Pkt., .05c; 0z., .10c; 1/t lb., .20c; lb., $.50 \mathrm{c}$.

Chartier. Decidedly distinct in appearance from any radish in cultivation. The color at the top being crimson, running into pink about the middle, and from thence downward it is a pure waxy white. It will attain a very large size before it becomes unfit for the table. Pkt., .05c; 0z., .10c; 1/4 lb., .25c; lb., $.75 \mathrm{c}$. 


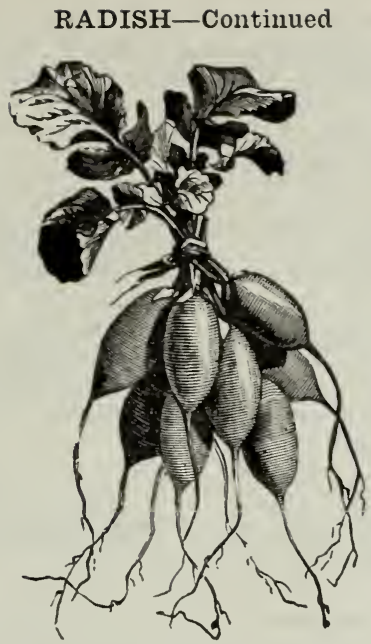

French Breakfast. Olive-shaped scarlet, with white tip; crisp and tender. Very earl.y A general favorite. Pkt., .05c; oz., $.10 \mathrm{c} ; 1 / 41 \mathrm{db} ., .25 \mathrm{c} ; 1 \mathrm{lb} ., .75 \mathrm{c}$

Early Scarlet Turnip. A well known and popnlar variety. Small top of quick growtl, mild and erisp. Pkt., .05c; 0z., .10c; $1 / \pm$ lb., $.25 \mathrm{c} ; 1 \mathrm{~b} ., .75 \mathrm{c}$.

Non Plus Ultra. One of the earliest foreing radishes, being ready for the table in three weeks from planting Roots round and bright scarlet, crisp and delicate. Pkt., .05c; oz., .10c; 1/t lb., .25c; lb., .75c.

China Rose. Bright rose-colored skin; flesh white and quality excellent; one of the best for fall and winter use. Pkt., .05c; oz., .10c; $1 / 4$ lb., .25c; lb., .75c.

Long White Vienna. Of rapid growth and beantiful shape; skin and flesh snow-white. The finest of long white rarlishes. Pkt., .05c; cz., .10c; 1/1 lb., .25c; lb., .75c.

Long Black Spanish. Long, black; flesh, white and slightly pungent; one of the latest and hardiest. Pkt., .05c.; 0z., .10c; $1 / 4$ lb. $.25 \mathrm{c} ; 1 \mathrm{~b} ., .75 \mathrm{c}$.

Round Black Spanish. Skin black; white fleshed and piquant flavor. Pkt., .05e; oz. $.10 \mathrm{c} ; 1 / \mathrm{l} \mathrm{lb} ., .25 \mathrm{c} ; \mathrm{lb} ., .75 \mathrm{c}$.

\section{SAISIFY OR OYSTER PLANT}

\author{
(ierman,-Bocksbart. French,-Salsifis. \\ S Janish, -Ostra regetal.
}

One ounee will sow 50 feet of drill.

Culture. Sow the seed in light deep soil, early in the spring, in drills twelve inches apart and one inch deep, thinning out the young plants to four or five inches. The roots will be ready for use in October, when a smply should be taken up and stored, like carrots. Those remaining will suffer no injury by being left in the ground till spring hut should be $\mathrm{lug}$ up before commencing their growtl.

Mammoth Sandwich Island. We consider this the largest and most profitable sal sify in cultivation; roots are two to three times the size of the ordinary salsify and of more agreeable flavor. It is pure white in color and invaluable to market gardeners. Pkt., .05c; 0z., .20c; 1/1 lb., .50c.

\section{SPINACH}

German,-Spinat. French,-Espinard. Spanish,-Espinaca.

One ounce for 100 feet of drill; 10 to 12 pounds in drills for an acre.

This is a very important crop in our market gardens, and is one of the most easily man aged of all regetables requiring but little cul ture, and may be had fit for use the entire season. The main crop is sown in Septemher. It is sometimes covered up in exposed places with straw or salt hay during winter, which prevent it from being cut with frost; but in sheltered fields there is no necessity for covering. For summer use it may be sown at intervals of two or tliree weeks from April to August. Spinach is best developed and most tender when grown in rich soil.

Prices on all varieties as follows: Pkt., $.05 c ; 0 z ., .10 c ; 1 / 1$ lb., .15c; lb., .35c.

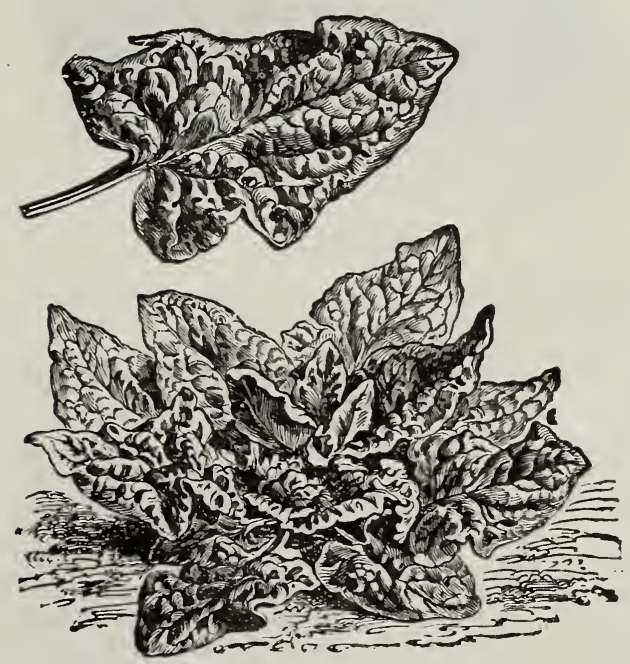

Giant Thick Leaf. This rariety gives the best results. The leaves are large, thick and somewhat crmmpled, and it is equally good 


\section{SIMPLEX SEPARATOR}

Cannot be beaten. The easiest running, cleanest skimming, simplest in construction and less work to clean of any machine on the market.

Send for Special Catalogue if interested in the best machine to be had.

\section{SPINACH-Continued}

Bloomsdale Savoy-Leaved. A heavy cropper of fine quality and very hardy; succulent leaves, curled and wrinkled like a Savoy cabbage; hardiest and most productive sort.

Victoria. A variety with heavy, broad, dark green leaves. Valuable for spring sowing.

New Zealand. A valuable variety for the garden as it produces the thick, tender leaves throughout the summer. Grows very large and luxuriantly-in warm, rich soil.

Long Standing Thick Leaved. Stands longest before running to seed; dark green.

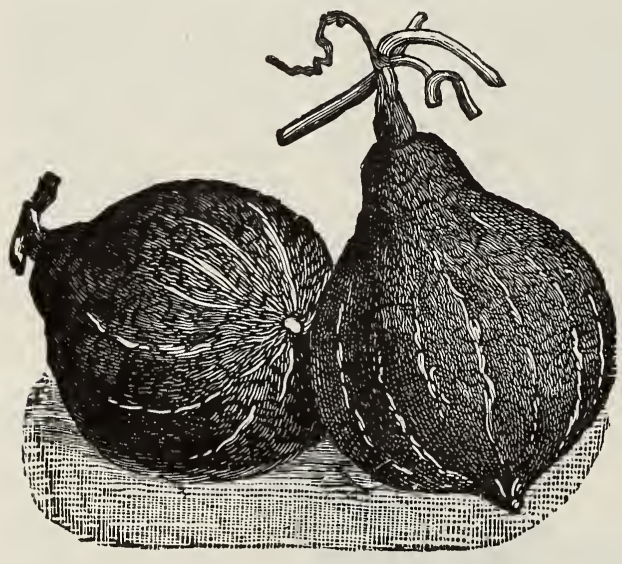

SQUASH

German,-Kurbiss. Spanish,-Calabaza.

French,-Courge.

One ounce Early will plant 50 hills; one ounce Marrow, 25 hills.

Culture-The plants are very tender and sensitive to cold, and planting must be delayed until settled warm weather. The general principles of culture are the same as those given for cucumbers and melons, but the plants are less particular as to soil. The summer varieties should be planted four feet apart each way, and the winter sorts eight feet. Three plants are sufficient for a hill. Care should be taken not to break the stems from the squashes intended for winter use, as the slightest injury will increase the liability to decay.
Delicious. We have found this squash all that the originator elaims for it. It is the driest, sweetest and finest flavored squash we have ever tasted; a fall and winter squash and is a good keeper. Pkg., .05c; 0z., .10c; $1 / 4$ lb., .30c; 1b., $\$ 1.00$.

Metcalf. Similar to Boston Marrow, but is much earlier. It is of a deep orange color, and is empletely covered with fine, warty excrescences. For forty years the Metcalf Squash has had a local reputation in sections of Maine as being the most prolific, finestgrained and earliest Marrow squash in cultivation. Our seed is Maine grown and is absolutely pure. Crop failed.

Bay State. Has a hard green shell; good for fall and winter use. Pkg., .05c; 0z.,. 10c; $1 / 1$ lb., .25c; lb., .75c.

Boston Marrow. Fine fall variety; oval, bright orange; flesh yellow and firm; best for pies, and also for canning. Pkg., .05c; oz., $.10 \mathrm{c} ; 1 / 4 \mathrm{lb} ., .25 \mathrm{c} ; \mathrm{lb} ., .75 \mathrm{c}$.

Improved Marblehead. Resembles the Hubbard but is earlier; has a gray, hard shell; a very popular winter sort. Pkt., .05c; oz., $.10 \mathrm{c} ; 1 / 4 \mathrm{lb} ., .25 \mathrm{c} ; 1 \mathrm{~b} ., .75 \mathrm{c}$.

Early White Bush Scalloped. A standard summer variety; good either for home or market garden. Pkg., .05c; 0z., .10c; $1 / 4$ lb., $.25 \mathrm{c} ; 1 \mathrm{~b} ., .75 \mathrm{c}$.

Essex Hybrid, or Hard-Shelled Turban. A standard winter sort; flesh a trifle darker than the Hubbard; an excellent keeper. Pkg., $.05 \mathrm{c} ; 0 \mathrm{z} ., .10 \mathrm{c} ; 1 / 4$ lb., .30c; lb., $\$ 1.00$.

Giant Summer Crookneck. Double the size of the ordinary Crookneck and very warty but similar in other respects. Their handsome appearance commands an extra price in the market. Pkg., .05c; 0z., .10c; 1/4 lb., .30c; lb., $\$ 1.00$.

Winter Crookneck. An excellent-keeping Crookneck variety, lasting several months, Yellow skin and a well-known squash. Pkg., $.05 c$; 0z., .10c; 1/4 lb., .30c; lb., $\$ 1.00$.

Improved Hubbard. The well-known and standard late variety; our strain is excellent. Pkg., .05c; 0z., .10c; 1/4 lb., .30c; lb., $\$ 1.00$.

Golden Hubbard. A genuine Hubbard Squash except in color, which is a bright red; quality excellent. Oz., .10c; 1/4 1b., .30c; lb., $\$ 1.00$.

Warted Hubbard. A superior strain of mainmoth size, and entirely covered with warty excrescences. Rich dark-green color. and of very best quality. Pkg., .05c; oz., $.10 \mathrm{c} ; 1 / 4 \mathrm{lb}$., .30c; lb., $\$ 1.00$. 


\section{GASOLINE ENGINES, WINDMILLS AND PUMPS}

Will surely interest you. By the use of a windmill, or gasoline engine, at a very small expense, every Farmer can having running water in his buildings. Write us in regard to same or better still, call and examine our line.

Special catalogues on water systems can be had for the asking.

\section{SUNFLOWER}

Mammoth Russian. The standard largegrowing variety, which is used largely for feeding poultry. Pkt., .05c; 1/4 lb., .10c; 1b., $.20 \mathrm{c}$.

\section{TOMATO}

German, Liebsapfel. Spanish,-Tomate.

French,-Tomate.

In this latitude to produce extra early tomatoes the seed should be planted in the hotbed about the middle of February, in drills five inches apart, and not over one-half inch deep. When the plants are two inches high they should be transplanted three to four inches apart, and when abut four inches high should again be transplanted; this time about

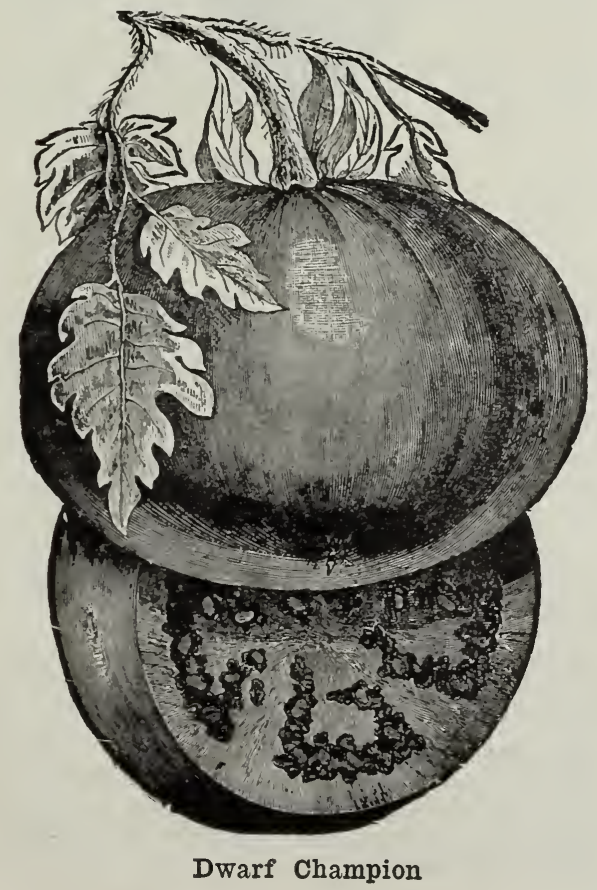

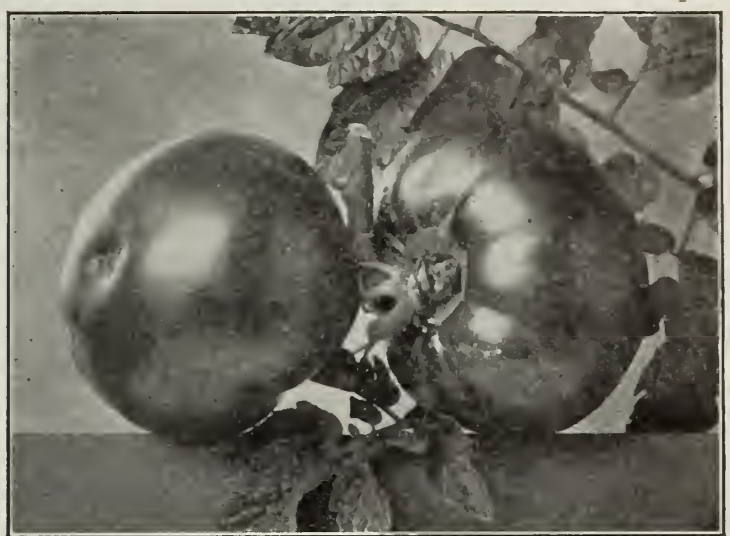

Stone Tomato

five inches apart. Again they should be transplanted about the middle of April into moderately warm beds or frames, and should not be nearer than eight inches. The final transplanting to the open ground may be made the last of May, when the plants should be fine, large and stocky, and if sufficient soil is taken up with each plant they will keep right on growing with no setback.

For ordinary plants, sow the seed early in March, and transplant, once in the hotbed and from hotbed into cold frames about four inches apart. The last of May they will be ready for the open ground where the Dwarf varieties should be planted $3 \frac{1}{2}$ feet apart and the spreading varieties 4 to $41 / 2$ feet apart.

Dwarf Champion. Dwarf and strong hahit of growth; very solid and of extra quality. Pkt., .05c; 0z., .25c; 1/4 1b., .85c.

Earliana. Jt is remarkable for its earliness, very large size, handsome shape and bright red color. Its solidity and fine qualities are equal to the best medium and late sorts.

Pkt., .05c; 0z., .30c; 1/4 lb., \$1.00.

Livingston's Favorite. Smoother than the Paragon is a darker red than the Perfection: ripens evenly, and is as early as any good variety. Pkt., .05c; 0z., .25c; 1/4 lb., .75c.

Livingston's Beauty. Very glossy, crimson in color, slight tinge of purple; early, free from rot: skin tough, bears handlng remarkably well. Pkt., .05c; 0z., .25c; 1/4 lb., .75c.

Ponderosa. Very large, solid and of a good flavor. Specimens have been grown to weigh four pounds. Bright red. Very few seeds. Pkt., .05c; 0z., .25c; 1/4 lb., .75c.

Stone. Fruit very large and deep; bright scarlet, smooth, ripening evenly to the stem, without a crack; exceedingly solid and firmfleshed, of the finest quality; one of the best for family use and for canneries. Late. 


\section{TOMATO-Continued}

Acme. (Early). Well-known and generally cultivated. Smooth, and ripens evenly; color purplish red. Pkt., .05c; 0z., .25c; $1 / 4$ lb., $.75 \mathrm{c}$.

Matchless. Very large smooth, solid and fine flavor. Cardinal red. Pkt., .05c; oz., $.25 \mathrm{c} ; 1 / 1 \mathrm{lb} ., .75 \mathrm{c}$.

Essex Hybrid. A very early sort, color bright pink; large size, solid, rich flavored; very productive; fine market variety. Pkt., $.05 c ; 0 z ., .25 c ; 1 / 4$ lb., .75c.

June Pink. An early variety, similar in habit to the famous Earliana, differing only in its color, which is pink instead of red. Early, blight resisting, long and heavy yielding. An excellent shipper on account of its reasonably tough skin. Pkt., .05c; oz., .25c; $1 / 4$ lb., .75c.

Chalk's Early Jewel. This is a very productive variety, ripens nearly as early as Spark's Earliana, but is more desirable for home use as the fruits are thicker through and more solid; borne in large clusters. Color bright searlet and quality good. Pkt., $.05 c ; 0 z ., .25 c ; 1 / 4$ lb., .75c.

\section{TOBACCO}

Connecticut Seed-Leaf. Best adapted for the climate of the Northern and Middle States. Pkt., .05c; 0z., .30c.

\section{TURNIP}

German,-Steckrube. French,-Navet. Spanish,-Nabo Comun.

Turnips may be sown at all seasons from April to August in our climate, although those will be the best wihch are sown very early in spring for summer crops, and early in August for a fall and winter crop. A light soil, well manured the previous year, is the best, a few hundred pounds per acre of quick-acting fertilizer will have a tendency to make the roots smooth, and to make the rapid growth so essential in producing sweet and palatable Turnips.

Ruta Bagas, or Swedes should be planted from the last of June to about July 10, as they require more time in which to mature than the Early or Strap Leaf varieties. Newly-turned sod will produce the sweetest and smoothest turnips.

Extra Early Purple Top Milan. (Flat.) The earliest turnip in cultivation and a splendid variety; favorite with gardeners who want first turnips in market. Bulb white, flat, of medium size, with a bright purple top; one of the sweetest and finest flavored of summer sorts. Pkt., .05c; oz., .10c; 1/4 lb., .20c; lb., $.65 \mathrm{c}$.

Extra Early White Milan. This is one of our most popular turnips for spring sowing; it is a splendid extra early turnip in which the extreme earliness, small top and taproot of the Purple Top Milan is united with clear white skin and flesh. Pkt., .05c; 0z., .10c; $1 / 4$ lb., .25c; lb., .75c.

Purple Top Strap Leaf. Rapid grower and mild flavor. The most popular variety for early use, either for the table or stock. Pkt., $.05 \mathrm{c} ;$ oz., .10c; $1 / 4 \mathrm{lb}$., .20c lb., .50c.

Yellow Stone. A very popular yellowfleshed variety; fine for table use. Flesh very firm, tender, sweet and fine flavored; an excellent keeper. Pkt., .05c; 0z., .10c; 1/4 1b., .20c; lb., .50c.

White Egg. Belongs to the class of quickgrowing fall turnips, and for this purpose should be sown in this latitude between $\mathrm{Au}$ gust 10 and 2.5 Its shape is nearly oval or egg, as its name would indicate. Pkt., .05c; oz., .10c; $1 / \mathrm{t}$ lb., .20c; lb., .50c.

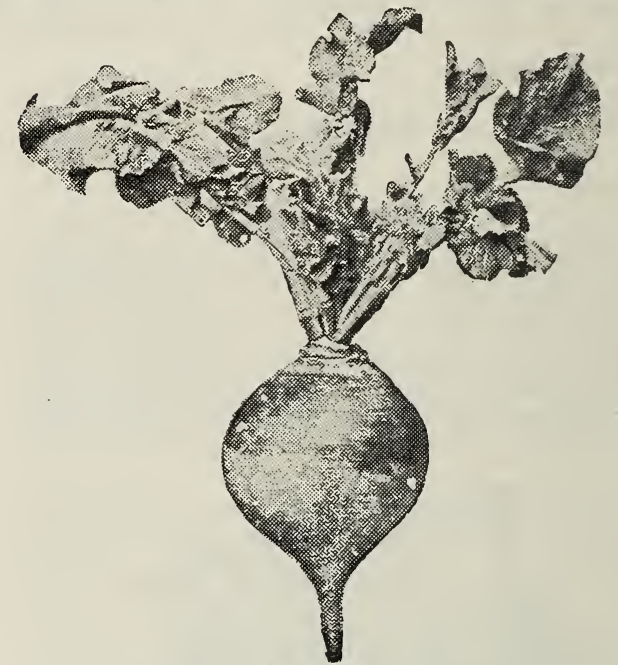

\section{RUTA BAGA OR SWEDISH TURNIP}

Rutabaga Bangholm. Oblong, globular shaped, with very small neck, yellow flesh, very dark purple top, superior to all other Swedes. One of the very heaviest croppers. Oz., .05c; $1 / 4$ lb., ..15c; lb., .45c.

Long Island Purple (Skirving's). Undoubtedly the finest variety of purple-top Ruta Baga. Leaves few and small; bulbs fine shaped with very short, small necks; purple crown, skin and flesh bright yellow, solid, sweet and mild flavor. Oz., .05c; 1/1 lb., $.15 c$; 1b., $40 \mathrm{c}$.

White Sweet German. Sweet, and fine flavor. (rood keeper. Oz., .05c; $1 / 1 \mathrm{lb} ., .15 \mathrm{c}$; lb., $.40 \mathrm{c}$.

Imperial Hardy Swede. Claimed by many to be the best Swede turnip grown. Bulb of large size with purple crown; flesh yellow; very smooth and a heavy cropper. Oz., .05c; $1 / 1$ lb., .15c; lb., .40c, 


\section{MEDICINAL HERBS}

These are of easy cultivation. As a rule it is best to cut herbs when in flower, wilt in the sun and thoroughly dry in the shade.

Anise. Haldy annual Pkt. .05c; 0z..10c.

Balm. ITardy, herbaceous. jerenuial

Pkt. .05c; 0z. .25c.

Caraway. Ilardy bi-annual Pkt. .05c; oz. .10c.

Coriander. IIardy annual Pkt. .05c; 0z. .10c.

Catnip. Perennial Pkt. .05c; oz. .25c.

Dill. Biennial

Pkt. .05c; 0z. .10c.

Horehound. Perennial Pkt..05c; oz. .20c.

Marjoram. Sweet, annual Pkt. .05c; 0z. .15c.

Rosemary. Perennial Pkt. 05c; 0z. .25c.

Rue. Perennial

Sage. Hardy perennial

Saffron. Annual

Summer Savory. Ilardy an nual

Pkt. .05c; 0z. .15c.

Pkt. .05c; 0z. .15c.

Pkt. .05c; 0z. .15c.

Winter Savory. Perennial Pkt. .05c; 0z..15c.

Thyme. Hardy Perennial Pkt..05c; oz. .25c.

Wormwood. Perennial Pkt. .05c; 0z. .25c.

\section{VEGETABLE AND}

\section{FLOWER PLANTS}

We have in their season a choice assortment of both regetable and flower plants.

Tomato PLANTS. Essex Hybrid, Dwarf ('hampion, Chalk's Jewel, Earliana, etc.

CABBAGE PLANTS. All Seasons, Stone Mason, Drumbead, Danish Ball Head, Early Summer, etc.

CAULIFLOWER. Snowball.

CELERY. Giant Pascal, Boston Market, White Plume.

FLOWER PLANTS. Pansies, Geraniums, Verbenas, Stocks, Salvia, Asters.

Our Plants are all grown for us locally and are hardy and vigorous. Prices as low as can be made and furnish good strong, healthy plants.

\section{BIRD SEED}

Add $.08 \mathrm{c}$ per $1 \mathrm{~b}$. for postage. Prices subject to variations of the Market.

Canary. Sicily. Selected. Lb., .08c.

Hemp. Russian. First quality. Lb., .08c.

Rape. German. Lb., .08c.

Sunflower. Russian. Lb., .08c.

Millet. Lb., .06c.

Cuttlefish. Lb., .40c.

Unhulled Rice. Lb., .08c.
Showing Weight per Bushel, also Quantities sown per acre of Grass, Grain and

Vegetable Seeds

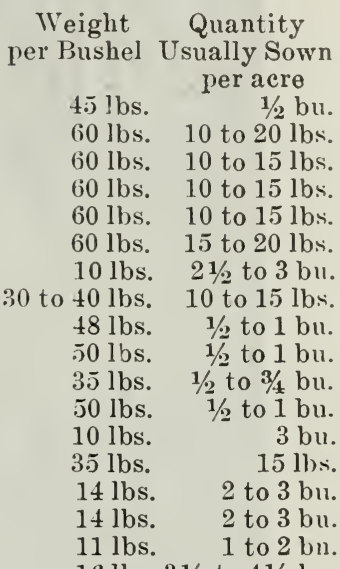

Timothy,

Clover, Red,

Clover, Alsyke,

Clover, White,

Clover,Crimson,

Clover, Alfalfa,

Red top, unhulled,

Red Top, cleaned, . 30 to $40 \mathrm{lbs}$

Millet, Hungarian,

Millet, German,

Millet, Japanese,

Millet, Siberian,

Bent, R. I.

Bent, Fancy,

Orchard Grass,

Blue Grass,

Fowl Meadow,

Lawn Seed,

Lawn Seed, Special,

Perennial Rye Grass,

Italian Rye Grass,

Tall Oat Grass,

Yellow Oat Grass,

Meadow Fescue,

Tall Fescue,

Sheep Fescue,

Hard Fescue,

Meadow Foxtail,

$8 \mathrm{lbs}$. for pastures.

Rough Stalked Meadow, 14 lbs. /grain lands.

Wood Meadow,

Crested Dog's Tail,

Sweet Vernal,

Seed Barley,

Seed Wheat,

Seed Rye,

Seed Oats,

Seed Buckwheat,

Flax,

Canary,

Hemp,

Rape, German,

Rape, Dwarf Essex, 50 lbs.

Corn, Field,

Corn, Fodder,

Corn, Sweet, measured bushel 8 to $10 \mathrm{qts}$.

Beans, White, $60 \mathrm{lbs}$. $11 / 2 \mathrm{bu}$

Beans, Red Kidney, $60 \mathrm{lbs}$. $\quad 11 \frac{1}{2} \mathrm{bu}$.

Beans, Fancy, $60 \mathrm{lbs}$. $11 \frac{1}{2} \mathrm{bu}$.

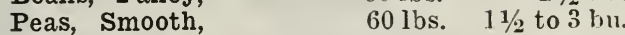

Peas, Wrinkled, measured bushel $1 \frac{1}{4}$ to $2 \mathrm{bu}$.

We are general agents for the OHIO CUTTER for Ensilage and Dry Fodder, and shall carry in stock a line equipped with elevators, enclosed steel carriers and blowers. Send for Special Catalog. 


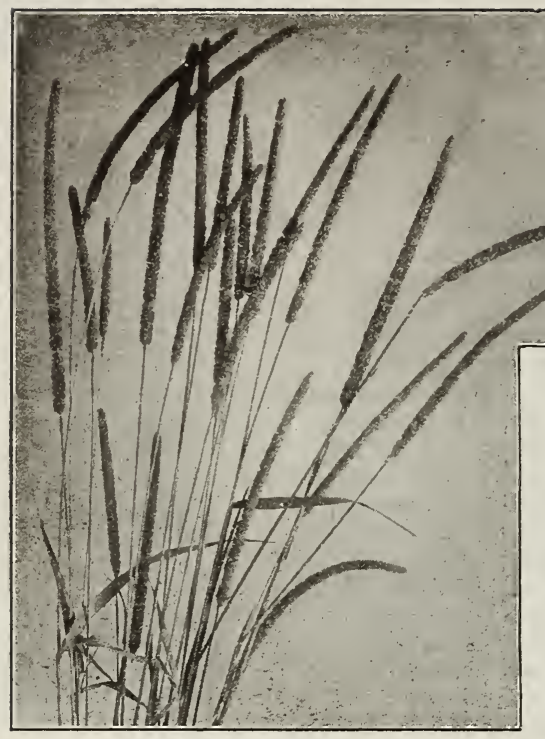

\section{GRASSES and GRAINS}

NOTE-Owing to the frequent changes in price of Grains and Grasses, we have refrained from inserting prices of them in this catalogue. The lowest market price will be quoted on application.

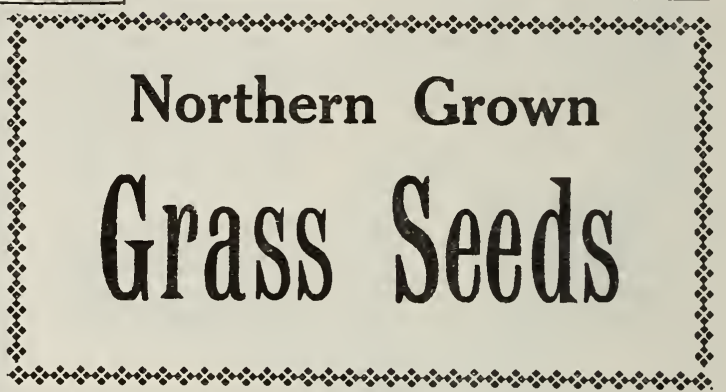

\section{SPECIAL ATTENTION}

Though we trust you will give your careful attention to the vegetable section of our seed catalog, we do not want to overlook that part treating on Northern Grown Grass Seeds.

While we carry several grades of the different varieties of seeds, we recommend our Purity Brand as the very best the market affords. These seeds are strictly Northern grown, and are selected by us because they possess the two essential qualities of purity and vitality. It is well known that there have been large quantities of Grass and Clover Seed sold as pure, which official analysis have shown to contain large percentages of adulteration. This not only defrauds the planter by selling him a worse than useless article, but inflicts injury also by filling his land with noxious weeds. We list Grass and Clover Seeds according to their quality, grading down from our Purity Brand, which is always the best.

Again we call your attention to the following pages, hoping that our grass-seed business may be of mutual advantage to us both.

\section{TIMOTHY, CLOVERS, MILLETS, RED TOP \\ in several grades}

\section{IAWN SEEDS}

Our own mixture, from the purest seeds obtainable

We make a specialty of GRASS SEEDS, and while we carry several grades from PURITY BRAND down we always recommend the best, our

\section{PURITY BRAND}

We can surely please you on this brand

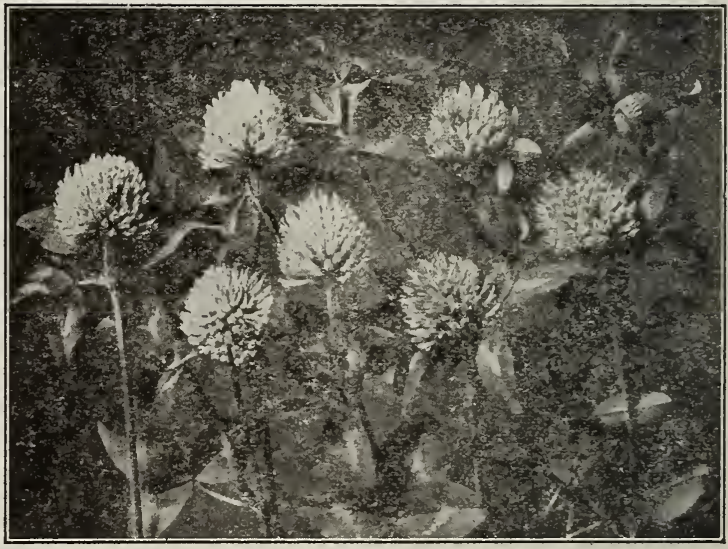




\section{HINTS ON MAKING HAY}

\section{About Cutting, Value of Hay Crop}

The value of the hay crop to the farmer and especially to the stock feeder is not expressed by what it will bring on the market.

Aside from the market value there is the feeding value and the manureal value both of which cannot be computed in dollars and cents.

Growing grasses supply humus to the land and some supply nitrogen, a valuable fertilizing element.

The feeding value is the one most influenced by the method of harvesting. Too early or too late eutting, too much exposure to sun and rain, destroys more or less of the value as a feed.

To save this loss is the object of careful methods of making hay.

When to Cut.

The first thing is to know when to cut the different varieties of hay. If cut too early, there is a loss of weight and nutrients. If cut too late, there is a loss in digestible nutrients and palatability.

In the case of clover and alfalfa, any delay in cutting produces a shrinkage in the succeeding crop. Alfalfa produces from two to four crops each season and when each crop is

\section{Curing and Storing}

ready it should be harvested without delay.

It is best to eut alfalfa when the blossoms are about one-third out. At this time the plant possesses the greatest amount of digestible nutrients and if properly cured has no equal as a forage.

Clover should be cut when coming into full bloom, at which time a few of the heads are beginning to turn brown.

If cut before this time, the clover will be hard to cure. If cut later, many of the leaves will fall off and much of the feeding value be lost.

The whole crop of either clover or alfalfa should be handled within a few days. Where large quantities are grown, it is advisable to use machines of large capacity in order to rush the work.

Timothy makes the best hay if cut when going out of bloom. If cut in full bloom, the blossoms will tend to make the hay dusty.

Cow peas make good hay when cut about the time the pods begin to appear.

Grains like wheat and oats should be cut for hay when the stalks first begin to turn yellow near the ground.

The time for cutting mixed crops like timothy and clover should be determined by the condition of the one which predominates.

\section{CHOICE GRASS SEEDS FOR LAWN AND FARM}

\section{MISCELLANEOUS GRASSES}

Orchard Grass. Grown in shady places for hay, and in wooded upland pastures. Sow thirty to thirty-eight pounds to the acre.

Kentucky Blue Grass. For lawns and pastures. Sow thirty to forty pounds per acre.

English Blue Grass, Meadow Fescue. For wet or shaded. Sow thirty to forty pounds per acre.

English Rye Grass. For pastures and lawns, wet or shaded. Sow thirty to forty pounds per acre.

Wood Meadow. For pastures and lawns, wet lawns, wet or shaded. Sow thirty to forty pounds per acre.

Rhode Island Bent. For pastures and lawns of light, loamy soil. Sow thirty to forty pounds per acre.

Meadow Oat Grass. For hay or upland pastures. Sow forty to fifty pounds per acre.

Sheep's Fescue. For sheep pastures. Sow thirty to forty pounds per acre.

Crested Dog's Tail. A strong, heady grass for dry upland playgrounds, lawns or golf links. Sow thirty to forty pounds per acre.

Sweet Vermal. Annual. Used in lawn mixtures.

\section{LAWN SEEDS}

We can confidently recommend our Lawn Grass Seed as being unexcelled for the purpose of making a new and permanent lawn, which will retain its rich green color and velvety appearance throughout the entire summer and fall.

In making a new lawn, primary expense should be deemed secondary to ultimate effect. We offer strictly high-grade mixture of the purest seed obtainable, entirely free from weeds and foreign seeds, at reasonable prices.

To obtain satisfactory results we recommend sowing at the rate of eighty pounds per acre.

Purity Brand. Lb., 35c.

Prime Brand. A very good mixture for lawns composed of high-grade seeds. Ib., $.25 c . ; 100$ lbs., $\$ 20.00$.

\section{TIMOTHY}

Purity Brand. The average farmer when he seeds down his grassland buys the Timothy his country dealer has to sell, which is usually anything from a third to a tenth grade, and may be very good or very poor. Our Purity Brand of Timothy, like our Purity Brand of Red Top, is the very best obtainable, and was found to be 99.8 per cent. pure by the last official analysis.

Fancy. A very fine grade but does not analyze quite as pure as our Purity Brand.

Best Prime. Much better than Prime commonly sold.

\section{RED TOP}

Purity Brand. This is the very best grade of Red Top to be found at any price. A recent State analysis of same pronounces it 98 per cent. pure.

Choice. This is a very close second to our Purity Brand.

Prime. This is a clean and handsome seed showing a high percentage of purity. 


\section{CLOVERS}

\section{RED CLOVER}

Our Purity Brand of Red Clover is a Northern-grown seed, very large, well colored, and the purest obtainable. Frequent analyses of this brand pronounce it about 100 per cent. pure. Lower grades at lower prices.

Mammoth Pea-Vine Clover. Similar to Red Clover, but makes a larger growth with heavier stock. Sow eight to ten pounds per acre.

\section{WHITE CLOVER}

Purity Brand. Selected especially for Lawns.

Prime. For lawns and pastures.

\section{ALSIKE}

It is usually sown with other seeds for hay; a valuable fertilizer if plowed under when in full bloom. Productive and sweet. An excellent honey plant for bees. Sow eight to ten pounds per acre.

Purity Brand. This is in the same class with our Purity Brand Red Clover, and analyzes nearly as high.

Prime. High grade but not as pure as Purity Brand.

\section{ALFALFA CLOVER}

Alfalfa or Lucerne Clover yields a very heavy crop; it is grown successfully in the West and Middle West, and by liming properly drained soil is yielding most satisfactory results in New England, and when well started will endure most severe droughts.

Purity Brand. This is a pure Alfalfa seed which has been developed in Montana, and without doubt is the most hardy of any yet offered in the United States.

\section{CRIMSON CLOVER}

Crimson. (Scarlet or Italian.) Grown in pastures and for turning under. Very deep rooting. Sow ten to fifteen pounds per acre.

\section{MILLETS}

Hungarian. Used for hay and forage. Sow forty to fifty pounds per acre between the first and middle of June. Yields heavily and when well cured is excellent hay for cattle, increasing the flow of milk.

Japanese. This grows very tall, yielding heavily, and the demand for it is increasing rapidly. Sow thirty-five to fifty pounds per acre. Excellent for silo.

Siberian. Very similar to the Hungarian, maturing about the same time, but leaves are unusually wide and tender, starting close to the ground, continuing nearly to the top of the stem, yielding more heavily, making it in many respects preferable to other millets. Sow twenty to twenty-five pounds per acre.

German or Golden. (Southern Grown.) It has become an established fact that seed of German Millet grown in the Southern States will produce a much larger yield of forage or hay than will seed grown in the North or Northwest, and we advise our customers to buy the Southern-grown seed, although the cost is, as a rule, a little higher.

\section{GRAINS}

\section{Prices subject to Market Changes.}

Barley, Fancy No. 1, Montana Two-Rowed. Barley, Beardless.

Seed Oats, No. 1, Montana choice.

Spring Rye. Best Northern grown.

Winter Rye. New England grown.

Spring Wheat. Northern grown.

Winter Wheat. Northern grown.

Buckwheat.

\section{MISCELLANEOUS SEEDS}

\section{Prices subject to Market Changes}

For growing Fodder and Fertilizing Crops.

Canada Field Peas. The old standard variety for sowing with Oats for green fodder. Very valuable also as pigeon feed.

Dwarf Essex Rape. Excellent for pasturing for sheep or hogs, also for soiling,.

Vetches or Tares. Sand, Hairy or Winter.

A very hardy plant, growing well on the poorest of sandy soil. When mature it reaches a height of about 3 feet and if cut for forage as soon as full grown and before setting seed, it will start up again and grow a second crop as large as the first.

Sunflower, Mammoth Russian. Used to some extent for ensilage. Plant with ensilage corn 3 or 4 pounds to the acre.

\section{IMONTANA OATS}

OUR PURITY BRAND of Montana White Oats is the heaviest cropper we have ever known and yields from 10 to 20 per cent. more oat and straw than any other seed oat we have seen.

\section{MONTANA BARLEY}

THE PURITY BRAND of Montana Barley which we carry produces large nearly white berries and is a very heavy yielder. This Barley has been growing rapidly in popularity the past few years and we have the highest quality of seed to be found. Samples and prices will be sent on application. 


\section{HUBBARD'S}

\section{Bone and Blood Fertilizers.}

\section{The Great Crop Producers}

There are so many goods being manufactured today in the cheapest possible way, that we can demonstrate to your satisfaction the superiority of this brand. They cost more to make than others because the ammonia is derived from blood, fish, sulphate of ammonia, nitrate of soda and tankage, and not from ground leather, scrap, hoof meal, hair and similar insoluble forms of ammonia. The Phosphoric Acid used in IIubbard's Fertilizer is derived from dissolved bone instead of dissolved rock, and in consequence is more valuable. The rotash is derived from High Grade Muriate and Sulphate.

\section{HUBBARD'S ESTABLISHED BRANDS}

We enumerate herewith a list of the brands carried by us, showing their guaranteed analysis. The actual analysis has exceeded these figures.

\section{HUBBARD'S SPECIAL POTATO}

For Irish and Sweet Potatoes, Cabbage, Onions, etc.

\section{GUARANTEED ANALYSIS}

Nitrogen . ............. 3.28 per cent. Equivalent to Ammonia .... 4.00 per cent. Available Phosphoric Acid ...6 6.00 per cent. Potash (Soluble in Water) ..10.00 per cent.

Ammonia derived from fish, bone tankage, blood, nitrate of soda and sulphate of ammonia.

Phosphoric Acid from dissolved bone.

Potash from high grade muriate and sulphate.

B. B. AND P. BLOOD, BONE and POTASH

Manufactured especially for the growing of potatoes in New England, and which has given the best of satisfaction. Equally good for cabbage, peas, beans, onions, melons and other vegetables. Also used as a top dressing for grass land.

\section{ANALYSIS.}

Nitrogen .............. 3.28 per cent. Ammonia ............. 4.00 per cent. Available Phosphoric Acid .. 8.00 per cent. Available Phosphoric Acid .. 6.00 per cent. Potash (Soluble in Water)...7.00 per cent. Ammonia derived from bone tankage, blood, nitrate of soda and fish.

Phosphoric acid from dissolved bone.

Potash from muriate of potash and highgrade sulphate.

\section{HUBBARD'S 10 PER CENT. POTASH GUANO}

An especially good seller for potatoes in this section of the state.

Nitrogen Analysis ........ 2.45 per cent. Ammonia ............. 3.00 per cent. Available Phosphoric Acid . . 8 8.00 per cent. Potash (Soluble in Water)...10.00 per cent.

Ammonia derived from fish, bone tankage, blood, nitrate of soda and sulphate of ammonia.

Phosphoric acid from dissolved bone.

Potash from high grade muriate and sulphate.

\section{ROYAL ENSIGN}

A high-grade fertilizer especially for the growing of sweet corn. Also excellent for cabbage, peas, beans, tomatoes, tobacco, wheat, oats, barley and grass.

\section{ANALYSIS.}

Nitrogen .............2.46 per cent. Ammonia .............. 3.00 per cent. Available Phosphoric Acid .. 8.00 per cent. Potash (Soluble in Water) ... 4.00 per cent.

Ammonia derived from bone tankage, blood, fish and nitrate of soda.

Phosphoric acid from dissolved bone.

Potash from high grade muriate and sulphate.

\section{FARMER'S I. X. L.}

For tomatoes, cabbage, corn, potatoes and other vegetables. One of the best for seeding down.

\section{ANALYSIS.}

Nitrogen $\ldots \ldots \ldots \ldots \ldots \ldots \ldots 1.64$ per cent. Ammonia ............. 2.00 per cent. Available Phosphoric Acid .. 8.00 per cent. Potash (Soluble in Water) ... 2.00 per cent.

Ammonia derived from bone tankage, blood, fish and nitrate of soda.

Phosphoric acid from dissolved bone.

Potash from high-grade sulphate.

\section{SOLUBLE BONE AND POTASH}

For corn, wheat, rye, oats, barley and grass

\section{ANALYSIS.}

Available Phosphoric Acid ...10.00 per cent.

Potash (Soluble in Water) ...2.00 per cent. Phosphoric acid derived from high grade Tennessee and Florida pebble rock.

Potash from high grade muriate and sulphate. 
Fertilizers and Chemicals

(Continued)

\section{AGRICULTURAI LIME}

Is your land sour; Does it yield poorly? Is it worn out? Then apply $\mathbf{R}-\mathbf{R}$ Agricultural Lime, manufactured by Rockland-Rockport Lime Co., Rockland, Me.

Prepared especially for farmer's use, put up in jute sacks. It is ready for immediate use, no slacking being required. It will keep indefinitely in a dry place, and is fine and uniform, so that it can be applied with a spread. er if desired. Lime neutralizes the acid, causes clay soils to become more pliable, and sandy soil to become more compact. Lime by itself will not sustain fertility, but increases the efficiency of fertilizers which may be applied. Price: Per ton $\$ 8.50$. Per 100 lbs., .50c.

\section{PREPARED BORDEAUX LIME}

It is exactly right for the purpose, and is ready for immediate use, and there is no waste. Requires no slacking or preparation of any sort, hence a great saving of time and labor. Will keep any length of time without deterioration. Per ton $\$ 14.00$. Per bg, 40 lbs. .35c.

\section{BEST OF GROUND PLASTER.}

Price 100 lb. Bgs., .65 hd., \$10.50 Ton. Price $200 \mathrm{lb}$. Bgs., $.62 \frac{1}{2} \mathrm{~h}$ hd., $\$ 10.00$ Ton.

\section{BOWKER'S AMMONIATED FOOD FOR FLOWERS}

A dressing made especially

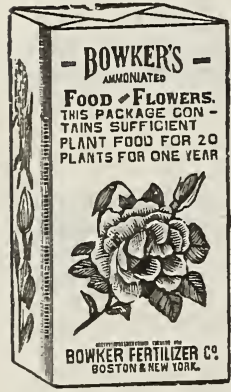
for plants grown in the home, garden or conservatory. Clean, odorless and producing early and abundint blossoms of rich and brilliant color, and healthy, luxuriant plants, free from vermin.

No. 1 package, sufficient for thirty ordinary-sized plants for three months., .15c No. 2 package, sufficient for thirty ordinary-sized plants for one year .25c.

\section{HIGH GRADE CHEMICALS}

Chloride of Lime

Sulphate of Copper

Sulphur

Pine Tar

Lye or Potash

Coal Tar

Tobacco Stems
Sulphate of Iron
Nitrate of Soda

Muriate of Potash

Sulphate of Ammonia

Kainit

Dissoived Bone Black

Plain Superphosphate

Tankage

Fine-Ground Bone

\section{Sulphate of Potash}

To persons desirous of mixing their own fertilizers we are able to quote very favorable prices in either bag, ton or car lots. We also guarantee our chemicals to be true to analy. sis and to be none better on the market.

\section{STERLINGWORTH LAWN COIMPOUND}

Kills the Weeds but not the Grass, and Makes the Lawn Green and Velvety

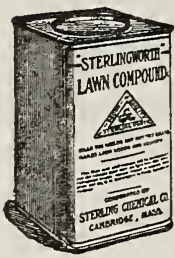

It is a dry powder to be sprinkled over the lawn and weeds when they are dry. It adheres to the rough, broad surfaces of such weeds as plantain, dandelions, chickweed, and all other weeds having a broad, hairy surface and soon destroys them. It does not stick or lodge on the grass owing to its upright position and smooth surface.

One pound will dress 100 to 200 square feet, depending on the condition of the lawns. Each package gives full particulars for use.

Price: 5-1b. cans, .60c; 10-1b. cans, $\$ 1.00$; 50-lb. kegs, $\$ 4.00 ; 100-1 b$. kegs, $\$ 7.50$.

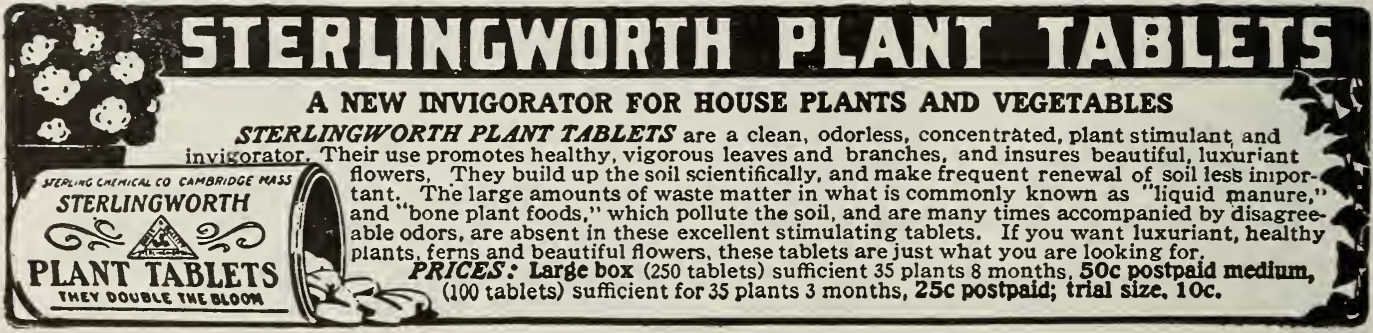




\section{INSECTICIDES and FUNGICIDES}

\section{SPRAY CALENDAR}

APPLE-Scab-Use Formula No. 5 before the flower buds open, repeat just after the flow. ers fall. If the oreliard is badly infected, repeat at intervals of three weeks with two more sprayings.

Bitter Rot-Use Formula No. 5 about the middle of June, or if it has not previously been serious, spray when the disease appears. Give two or three other sprayings at intervals of about three weeks.

Canker Worm, Codling Moth, ('urenlic, and other Biting Insect-Use Formula No. 2.

Leaf ('url-Use Formula No. 5 or No. 8 when the trees are dormant.

San Jose Scale-Use Formula No. 8 when the trees are dormant.

PEARS - Seab and Leaf Spot-See under Apple.

RASPBERRY, BLACKBERRY and DEWBERRY-Anthracnose-Cut out all infected canes in the Spring and use Formula No. 5 before the buds open. Spray again at intervals using the same formula. As the fruit ripens use Formula No. 9.

STRAWBERRY-Mildew-Use Formula No. 5 at first sign of disease.

Rust-Use Formula No. 5 before the buds open. Formula No. 9 before the fruit ripens. After fruiting apply with Formula No. 5 again as may be needed.

POTATO-Blight, Rot and Beetle-Use Formula No. 2 or No. 4 when either appears and again at intervals of ten days as long as either is prevalent. The Bordeaux Mixture is for the Blight and Rot, and the Arsenate of Lead or Paris Green is for the Beetles, but either may be used in combination with the Bordeaux Mixture.

TOMATOES-Blight and Rot-Use Formula No. 5 when first fruit is half grown. Spray again in ten or fifteen days. Formula No. 9 should be used when the fruit is ripening if any spraying is necessary at that time.

DANDELIONS-Use Formula No. 10. Do not spray for two days before or after eutting the lawn. Most effective if it does not rain for 20 hours after spraying. Water the lawn and allow the grass to dry before spraying. Young plants should only require one spraying. Old plants are resistive, so repeat when they grow up again. When dandelions are dead, seed in with grass at once. Sulphate of Iron is not poisonous but will descolor clothing.

WILD MUSTARD-See under Dandelions.

CANADA THISTLES-See under Dandelions.

\section{SPRAY FORMULAS}

1. ARSENATE OF LEAD-Use from 3 to $5 \mathrm{lbs}$. Arsenate of Lead to 50 gallons of water.

2. ARSENATE OF LEAD AND BORDEAUX COMBINED-Use from 3 to 5 lbs. Arsenate of lead to 50 gallons of Bordeaux Mixture. The Arsenate of Lead is used as an insecticide, and the Bordeaux Mixture as a-fungicide especially recommended for preventing blight.

3. PARIS GREEN-Use 1 to 2 lbs. Paris Green to 50 gal. water. Paris Green should not be used on peach, cherries or Japan plums, and only with extreme caution on other stone fruits. In mixing Paris Green solutions add Milk of Lime, which will prevent the burning of foliage.

4. PARIS GREEN AND BORDEAUX COMBIINED-Use 1 to 2 lbs. Paris Green to 50 gals. Bordeaux Mixture.

5. BORDEAUX MIXTURE-Copper sulphate $5 \mathrm{lbs}$; Lime 5 lbs.; Water 50 gallons. In preparing use two one-half barrel tubs. One for Copper Sulphate and the other for the Milk of Lime. The two solutions are now poured into a barrel at the same time. The Lime solution should be kept well stirred. Two men are required to make Bordeaux Mixture, so as to get the two liquids poured into the barrel evenly.

6. KEROSENE EMULSION.-Kerosene, 2 gallons; Whale Oil Soap, 1/2 pound; Soft Water, 1 gallon.

7. TOBACCO DECOCTION-Tobaceo Stems and other refuse tobacco, 1 pound; Water, 2 gallons. Boil tobacco stems and other refuse tobacco thoroughly in the water. This solution is sufficiently strong for aphides and other very delicate insects.

8. LIME SULPHUR WASH-Lime, 15 pounds; Sulphur, 10 pounds; Water 50 gallons. Considerable stirring is necessary to prevent caking on the bottom. After the violent boiling, which accompanies the slaking of the lime is over, the mixture should be diluted ready for spraying, or at least enough cold water added to stop the cooking. The mixture should be strained through a sieve in order to prevent coarse particles of lime, but all the sulphur is to be worked through the strainer.

9. AMMONIACAL COPPER CARBONATE-Copper Carbonate 6 ounces; Strong Ammonia (just enough to dissolve the Carbonate) about 3 pints; Water 50 gallons. This is for use only when the fruit is ripe, or nearly so, and we do not wish to discolor it with Bordeaux Mixture.

10. SULPHATE OF IRON-Dissolve 4 pounds Sulphate of Iron in 2 gallons of water. Strain the liquid carefully through a fine screen of cheesecloth.

We have everything in Spraying Machinery including Hand, Traction and Gasoline Power Outfits. Send for descriptive matter or else call at our store and examine them. 
INSECTICIDES \& FUNGICIDES-Cont'd

PURE PARIS GREEN

ANSBACHER'S

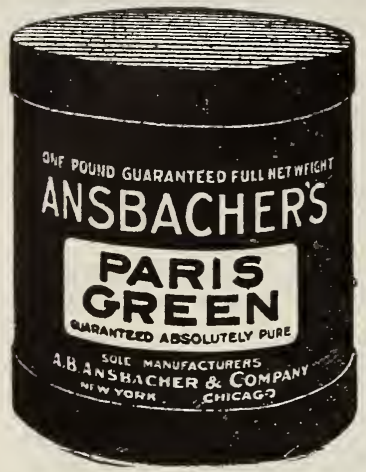

After having tried several of the other kinds of Paris Green we are convinced that Ansbacher's has no superior, consequently are hand. ling this kind $\mathrm{ex}$. clusively.

The price of paris green not being established at the time of going to press, we will be pleased to quote prices on application.

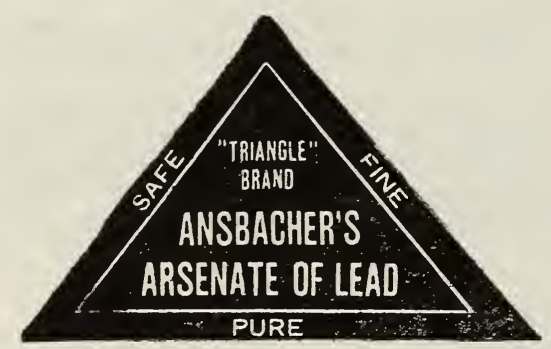

ARSENATE OF LEAD-PASTE

GUARANTEED:

At least $15 \%$ Arsenic Oxid (As 20 $\mathrm{O}^{5}$ ).

Not over $50 \%$ Dry Arsenate of Lead.

Not over $1 / 2$ of $1 \%$ Soluble Arsenates.

Over $99 \%$ pure.

This perfect paste is deserving and winning leadership in all fruit districts; it pleases and pays all who use it, not a single complaint: every one praises it!

It is over $99 \%$ Pure, contains no impurities which will injure Lime-Sulphur or cause spray-injury to fruit or foliage, and has the greatest safety.

Its unequalled Killing-Speed makes it best for all fruit districts where there has been "worm-marked" or " stung" fruit.

Prices on Application.

\section{ARSENATE OF LEAD POWDER}

GUARANTEED:

At least 30\% Arsenic Oxid (As 205).

Not over $1 / 2$ of $1 \%$ Soluble Arsenates.

Over $99 \%$ pure.

To satisfy the many demands upon us, we offer our "Triangle" Brand in an unequalled finely powdered form.

Because we have dried and ground our Colors for over sixty years, it was a simple matter for us to produce a fine powder in the best form for the poison-painting of fruit and foliage.
Ansbacher's "Quick-Death" Powdered Arsenate of Lead has the Greatest Purity and safety; is easiest to mix with water; sticks longest to fruit and foliage; is best for cotton growers, etc.

Easiest to Mix and Spray.

Purity Gives Safety!

Quick Killing Increases Profits.

Prices on Application.

$$
\begin{gathered}
\text { ANSBACHER'S } \\
\text { PYRO-BORDEAUX-LEAD } \\
\text { Two in One. } \\
\text { PASTE }
\end{gathered}
$$

GUARANTEED:

At least $4 \%$ Copper Hydrate

At least $7 \%$ Arsenic Oxid (As $\left.-\mathrm{O}^{5}\right)$.

This is the most convenient Spray that can be made; also is strongest and best.

It is a mixture of Arsenate of Lead Bordeaux Mixture, etc., ready to dilute and spray for control of most of the pests that rob the growers of fruit and vegetables.

Its greatest purity gives it greatest safety! The special methods used in its making give it greatest adhesion to fruit and foliage; also greatest power to prevent blights and fungus diseases.

Potato Growers, Grape Growers and Fruit Growers who must use Bordeaux Mixture to save their crops, will find Ansbacher's PyroBordeaux-Lead superior to all mixtures of similar nature.

\section{GUARANTEED: \\ At least $10 \%$ Copper Hydrate \\ At least $15 \%$ Arsenic Oxid (As $2 \mathrm{O}^{5}$ ).}

In order to produce this powder, the PyroBordeaux-Lead is dried and ground to a powder that will make a perfect poison-paint for control of Fungus Diseases and Chewing Pests.

Prevents Blights and Kills Chewing Pests.

\section{ANSBACHER'S CONCENTRATED LIME AND SULPHUR WASH}

The most widely used and recommended remedy for San Jose Scale

Our Agricultural Experiment Stations have recommended the use of Lime and Sulphur mixture as being generally satisfactory in preference to other mixtures. Ansbacher's Concentrated Lime and Sulphur Wash is offered as a convenient and most effective remedy for this pest. It is ready for use by simply adding water.

Lime and Sulphur is also a preventive of certain fungus diseases, as Peach, Leaf-Curl, Ground and Bitter Rot. Smuts, Seabs, Leaf Spot, etc., and is used as a wash for the bark of the trunks of orchard and shade trees. where it acts as a repellant of many insect pests and prevents their ascending to the branches.

Prices: 1-gallon cans, .75c; 5-gallon jacket cans, $\$ 2.00$. Prices on large quantities on request. 
INSECTICIDES \& FUNGICIDES-Cont'd STERLINGWORTH IIQUID BORDEAUX

A Concentrated Mixture for Use with Water

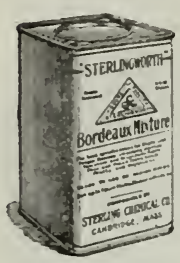

liv far the most important fungicille is Bordeaux Mixture, a chemical compoumd prejared by the action of Milk of lime on a solution of ( $\mathrm{Op}$ per sulphate

"Sterlingworth', Bordeaux Mixture prevents or controls Scab, Leaf Spot and Sooty Mold of the Apple, Anthracnose of the Bean. Blackberry, Raspberry and (irape, Leaf spot of the Beets, and checks the ravages of the flea beetle, the rarious Rusts, Leaf Blights of ('urrant and Gooseberry, ('elery and Pear Blight, Downy Mildew of the ('icumber, Melon and squash, Potato Blight, Plack Knot of the Plum, Peach-Leaf-Curl, Shot-hole Fungus, also Fungus Diseases, Blights and Leaf Spots of Shade Trees.

() gallon makes from 20 to 50 gallons of Bordeaux rearly to use by simply adding water.

Prices: 1-gallon cans, \$.85 each. Prices cn large quantities on request.

\section{STERLINGWORTH DRY BORDEAUX}

We have this with poison (Insecticide and Fungicide) and without poison (Fungicide).

Insecticide and Fungicide kills insects as well as controls Fungi.

Fungicide controls Fungi only.

l'rices: Insecticide and Fungicide, 1-lb. box, .25c; 5-1b. box, \$1.00. Fungicide, 1-lb. box, .20c.

\section{STERLINGWORTH SAN JOSE SCALE KILLER}

A Soluble Oil Concentrated Petroleum Emulsion

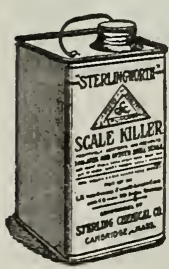

Sterlingworth Scale Killer, properly applied, not only kills the scale, but protects the tree from reinfestation. The form. ula from which this Killer is compounded is recommended by the Counecticut Agricultural Experiment Station, a Station which has had a very extensive experience in fighting San Jose Scale.

We claim that STERLINGWORTH SCALE KILLER will kill every scale covered by it when sprayed according to directions. The work should be done in the fall or winter, or at least before the buds break in the spring. Full directions on every can.

Prices: 1-gallow cans, $\$ 1.00$. Prices on large quantities on request.

\section{STERLINGWORTH \\ KEROSENE EMULSION}

A raluable remedy against Seale and all Soft-bodied and Sucking Insects, such as Plant Lice, Ieaf Aphis, Woolly Aphis, 'Thrip, C'elery Aphis, Squash Bug, Leaf Hopper Mealy Bug, ('abbage Worm, etc., ete.

Price: 1-pint cans, .25c each; 1-qt. can, .40c each.

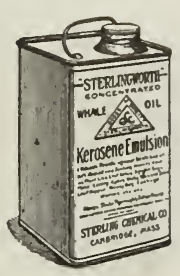

\section{STERLINGWORTH HELLEBORE}

Is an absolutely pure article ground from prime fresh roots. It is stronger than the ordinary IIellebore offered by seedsmen, and is put up in a patent sprinkler-top box, making it easy to use. This patent box is so constructed and the perforations forming the sifter tol can be closed after using so that the strength of the contents remaining unused may be couserved.

No preparation is so satisfactory and generally effective against Rose Slugs, Currant Worms and similar pests as pure Hellebore, but it must be pure and strong, to give good results. You will see a great difference in the strength of this Hellebore and that you have used.

Prices: 1/2 1b. pkg., .15c; 1-1b. pkg., .25c.

\section{STERLINGWORTH WHALE OIL SOAP}

Effective, reliable, simple and cheap for destroying San Jose Scale, Plant Lice and all sucking insects on trees, slirubs, plants, vines, rose bushes, etc. The efficiency of this soap is further increased by the addition of tobacco extractive matter

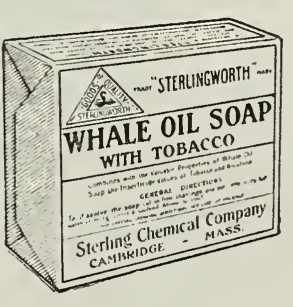
and potasl. The preparation thus compounded possesses all the virtues of Whale Oil Soap, and in addition the valuable insecticide properties of tobacco and potash, making it doubly valuable. Full directions for use on each package.

Prices: 1-1b. box, .15c.

\section{SCALECIDE}

This reliable, simple and economical remedy for all soft-borlierl and sucking insects, such as San .Jose Seale. Pear Psylla, Cottony Maple Scale, Aphis, White Fly, Caterpillars, Lice, ete. Nixes instantly in cold water and stays mixed. Not an emulsion, but may be used with great saving of cost wherever petroleum or kerosene or soap emulsion are advised. Better and eheaper than lime, sulphur aud salt. Price: 1-qut. can, .40c, 


\section{STERLINGWORTH WEED KILLER}

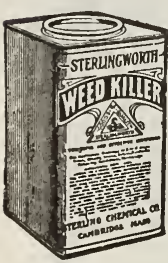

The most satisfactory and powerful, compounded especially for use on walks, drives, tennis courts, golf links, etc. It is a dry powder to be dissolved in water. When applied to vegetation it completely destroys all kinds of weeds, grass (including milkweed and witchgrass), briars, burdock, dandelions, daisies, thistles, poison ivy and other objectionable vegetable growths. One application, kills roots as well as foliage preventing further growth. It may be applied with an ordinary watering can. One pound makes 10 to 15 gallons and one gallon covers three or four square yards. Full directions on each package.

Prices: 1-lb. pkg., .50c.

\section{BUG DEATH}

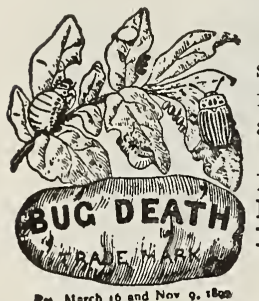

This non-poisonous Insecticide and Plant Food is now too well known to need any detailed description.

Prices: 1-lb. pkg., .15c; $12-\mathrm{lb}$. boxes, $\$ 1.00 ; 100 \mathrm{lb}$. kegs, $\$ 6.00$; Dickey Bug Death Duster, .25c

Acre an Hour Sifter, .75c.

\section{TREE TANGLEFOOT}

For protecting trees against climbing insect pests in a simple, economical and effective way, use Tree Tanglefoot-a sticky substance applied directly to the bark of trees. One application remains sticky on the trees three months fully exposed to the weather. Easily applied with a small wooden paddle. One pound will make a band 7 to 8 feet long.

Price: 1-lb. can, .30c; 5-lb. can, .85c.

\section{FORMALDEHYDE}

For the prevention of Smuts in wheat, oats, barley, all cereal grains, and potato scab. It is also specific for the prevention and cure of hog cholera, and makes a most excellent disinfectant.

Price: .50c. per pound.

\section{STERLINGWORTH SHEEP DIP} dip.

One gallon makes 50 to 60 gallons of strong

Prices: 1/2 gallon cans, .70c.

Larger quantity prices on application.

\section{COOPER'S SHEEP DIP}

25-gal. pkt., each, .50c.

\section{DR. HASS SHEEP DIP}

1-qt. can, .50c.
An Ideal Disinfectant Germicide and Deodorizer

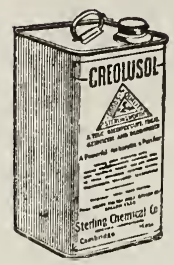

Creolusol is a most powerful antiseptic and purifier, and one of the best disinfectants for private or public sanitation, it being especially adapted for domestic use. It possesses an agreeable, wholesome and refreshing odor. It is nonharmless to animals. It is poisonous and perfectly used by mixing with fresh water as wanted.

For general Disinfecting. For the sick room. For the bath.

For poultry diseases, such as mange, fauns, chicken pox, scabies, roup, cholera, diarrhoea, etc.

For washing out incubator cellars, incubators, broders, brood coops, drinking fountains.

For dressing ulcerating wounds, sores and scratches. For diphtheria, roup, sore eyes and canker.

Full directions for use on every package. Put up in 1 quart cans, sufficient for making 50 quarts of disinfectant. Price: .50c.

\section{CREONOID}

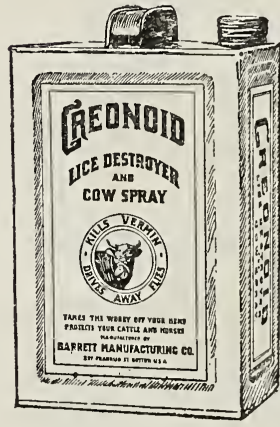

Barrett's Creonoid is an up-to-date preparation from coal tar, of invaulable service to the poultrymen, stock raisers and farmers. It eliminates flies and mosquitoes, and insures sanitary conditions in stables, stock sheds, around barnyards, etc.

Prices as follows: Gallon cans, $\$ 1.00$. Prices on large quantities are quoted on application.

\section{CARBONOL}

Barrett's Carbonol combines all the good properties of carbolic acid, yet has none of its bad features. It is a preparation of coal tar of wonderful healing, cleansing and antiseptic properties, adapted to a wide range of uses. Carbonol is non-poisonous, non-corrosive, and mixes with water in any proportion, and in its full strength can be used with perfect safety. Send for special booklet.

Prices: 4 oz. bottles, .25c each; pint bottles, .05c each; quart bottles, $.75 \mathrm{c}$ each; 1 gal. cans, $\$ 1.75$ each. 
WILI-KILL-FLIES

Formerly Known as Rough-on-Flies

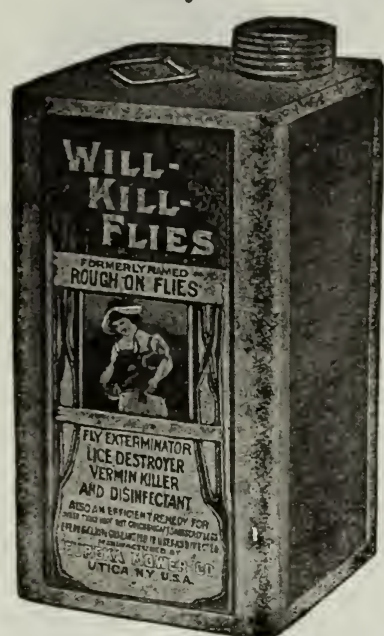

Kills flies, vermin, and lice. Increases the yield of milk. I n s u res more eggs and better poultry. Cures chicken gapes, scaly legs, etc. Kills lice on cat tle and sheep ticks. Heals scab and hoof rot. It is an excellent disinfectant. Is an antiseptic and very healing. Used for cuts, burns or sores on man and beast. Thoroughly high grads. Every gallon guaranteed.

One-galion calls, price per. gal., $\$ 1.50$.

\section{COW'S FAVORITE FLY OIL}

Protects the stock, drives the flies away, means money in the farmer's pocket. Just the preparation for the dairyman or farmer. Cow's Favorite Fly Oil, in bbls., per gal., .50c ('ow's Favorite Fly Oil gal. cans, per gal., .60c

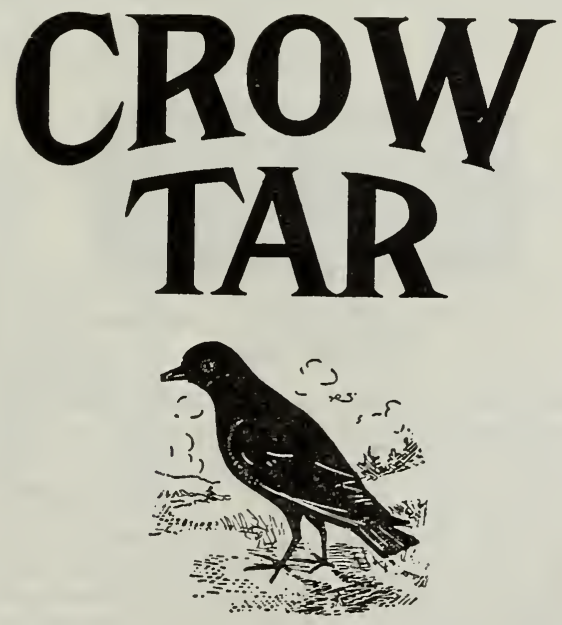

A thoroughly reliable tar made especially for using on corn as prevention against crows. Gives the corn a thin coating which quickly drys so that there is no trouble in putting through planter as is the case with tar preparation not made especially for that use. Write us for prices on whatever quantity you might desire.

\section{HASKELL'S HOMEOPATHIC POULTRY REMEDIES}

IIaskell's Homeopathic Poultry Remedies are put up 10 tablets to a vial, each vial being labeled with complete directions and showing dosage and the disease which the remedy will prevent or cure. The vials are encased in strong, wooden serew-capped mailing tubes, to prevent breakage. They are administered in the fowl's drinking water.

No. 1, for Indigestion and Constipation.

No. 2, for Rheumatism and Cramps.

No. 3, for Colds.

No. 4, for Bronchitis and Croup.

No. 5, for Cholera.

No. 6, for Vent, Gleet and Canker

No. 7, for Chronic Catarrhal Colds.

No. 8, for Disorder of Egg Organs.

No. 9, for Eye Diseases.

No. 10, for Worms.

When ordering specify number required. Price: Per vial, postpaid, 40c each.

STERLINGWORTH DIARRHOEA REMEDY

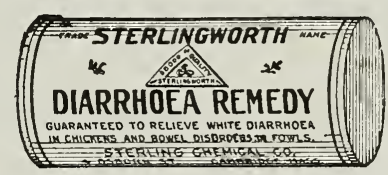

Millions of chickens die yearly from diarrhoea which could be saved if Sterlingworth Diarrhoea Remedy was used. Whenever bowel trouble appears, use this remedy and you will have practically no loss. It is not a cure-all, but a reliable remedy only for Diarrhoea,Dysentery and other kindred bowel troubles in young chickens, full-grown fowls and pigeons. It is a powder for use in the drinking water.

Price: Per box, sufficient for several flocks, $.50 \mathrm{c}$, postpaid.

\section{STERLINGWORTH SULPHUR FUMIGAT- ING CANDLES}

Easy to Light. Safe to Use. Sure in Effect.

Sterlingworth Sulphur Fumigating Candles produce more vapor than any other candle sold at the same price. The candle has a circular wick, which is easy to light and when once lighted stays lighted.

Board of Health officials recommend sulphur fumes for destroying typhoid, diphtheria, smallpox, and other disease germs.

Price: Each, .15c; postpaid, .25c. One dozen, by express, $\$ 1.00$. 


\section{WATER GLASS (Silicate of Soda)}

When your hens are laying well and eggs are plenty then is the time to put some away where you can have them when they are scarce and high. The simplest and best preservative known is Water Glass. 1 gal. of this with 15 gal. water will keep your eggs perfectly fresh almost indefinitely. It is clean, easy to prepare, gives universal satisfaction and price is reasonable.

Price: Qt., .25c; gal., .65c.

\section{STERLINGWORTH'S LICE POWDER}

The Strongest and Cheapest Lice Remedy Known.

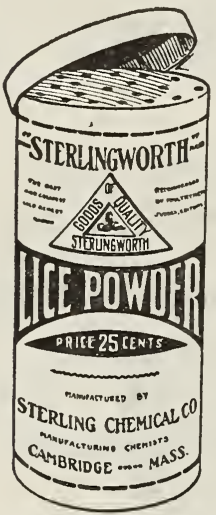

The 5 and 15 ounce sizes of Sterlingworth's Lice Powder are put up in patent sifter-top box, the perforations of which can be closed after the box has once been opened. Few other Lice Powder boxes possess this advantage. After the boxed used for other Lice Powders are once opened there is no way of closing them, and the strength of the powder is lost by evaporation.

Prices: 5 oz. pkg., .10c, postpaid, .15c; 15 oz. plsg., .25c, postpaid, .40c; 48 oz. pkg., $50 \mathrm{c}$, not mailable.

Agents wanted where we have none already located.

\section{DR. HESS INSTANT LOUSE KILLER}

Destroys lice on poultry, stock of all kinds, and ticks on sheep. It is a powder put up in round cans with perforated top, and sold on a written guarantee. Price per pkg., .25c.

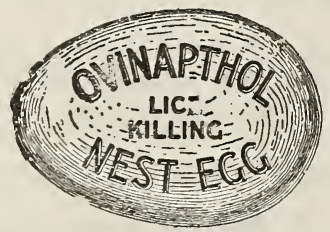

\section{OVINAPTHOL NEST EGGS}

These are the standard combined nest egg and lice killer. Are used in the nest in the same manner as the ordinary nest egg. Rids laying hens of lice and mites, keeping the nest sweet and clean. The genuine bear embossed on each egg the words "Orinapthol Nest Egg.',

Prices: Each, .10c; per doz., .75c.
Every Can Guaranteed to Do as Represented

Sterlingworth Liquid Lice Paint is a wholesale lice and vermin destroyer. It saves time, labor and expense; no dipping; no dusting, no greasing and no handling being necessary.

Sterlingworth Liquid Lice Paint is never sold in bulk. It is put up in 1, 2 and 4 quart cans, all bearing our copyrighted label.

Prices: 1 qt. cans, .35c each; $1 / 2$ gal. cans, .60c each; 1 gal. cans, $\$ 1.00$ each.

\section{NUTRINE CHICK SALTS}

ESSEX-MODEL NUTRINE CHICK SALTS fulfill the need of the chick for animal and mineral food which is often lacking in foods fed to chicks when in confinement. It aids digestion and prevents diarrhoea. These salts are not a purgative, but a tissue build. er, and a wonderfully effective food-salt. Costs five cents a week for fifty chicks.

Prices: 2 lb. package, .50c; 5 lb. package, $\$ 1.00$.

\section{CONKEY'S CELEBATED ROUP CURE.}

Conkey's Celebrated Roup Cure is a most excellent roup cure, and is used by administering in the fowl's drinking water.

Price: Small size, .50c

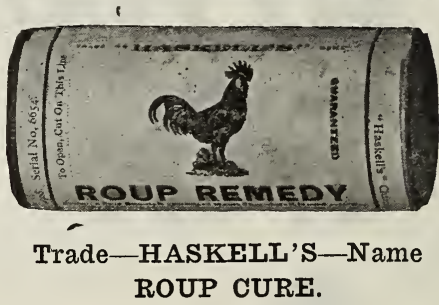

Guaranteed to Relieve or Money Refunded.

Haskell's Roup Cure is put up in one size package only. This package contains sufficient remedy for making 25 full strength gallons of the remedy.

We guarantee Haskell's Roup Cure, when used in accordance with directions on each package, to relieve roup, and will refund ahe purchase price if it fails to cure, except in cases where the fowls have reached the last and incurable stages of the disease.

Price: .50c.

Keep your poultry houses clean and sweet by constant spraying. Call and see our line of Sprayers, Spray Pumps, etc. 


\section{POULTRY FEEDS OF QUALITY \\ Always Ready \\ No Waste \\ No Dirt}

Our trade-mark brands of Poultry, Chick and Pigeon Feeds represent strictly high-grade mixtures,-manufactured from Sweet, Sound, Cracked Grains and Seeds-scientifically proportioned and in sizes best adapted for feeding, earefully sifted and recleaned. No pains are spared to produce Feeds of the greatest value-best quality and uniform grade-the standard of which is maintained at all times.

It is a recognized fact that sound and sweet grain contains a larger pereentage of nutriment, strengthening and fattening properties, naturally producing better and quicker results than uusound, damaged and musty material.

Write for Prices. Liberal Discount on Quantity Lots

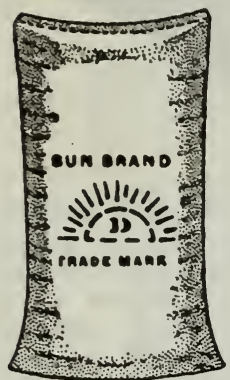

"SUN" CHICK STARTER.

A Primary Grain Feed for Chicks during the first 20 days.

\section{CLEAN SWEET SOUND}

Specially selected for size, and composed of ingredients necessary in promoting healthy and rapid growth. This is the critical period of chick life, and the "Sun Brand" is prepared especially to meet the emergency. In addition to the regular assortment of Grains and Seeds, this mixture contains Steel Cut Oat Meal, fine Granulated Bone and fine Charcoal, which are of utmost importance for proper development and healthy condition.

The factor of feeding must be given the greatest consideration especially during the early stages and the selection of a thoroughly balanced highest quality feed is imperative.

The "Sun Brand" is recommended for this purpose; it is not an experimental Feed, but has proven its superiority by years of test.

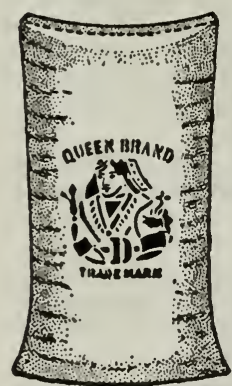

QUEEN POULTRY MASH Contains Alfalfa Meal During Winter.

Proportions changed to meet requirements of different season.

CLEAN SWEET SOUND

A selected mixture of ground feeds manufactured from the choicest sound, sweet and wholesome grains. It is carefully prepared and contalus ingredients in proper proportions essential to the health and growth of the fowl.

Splendid bone builder and especially helpful during the molt. Also contains Beef Seraps and Charcoal, recognized necessities for health and egg production.

This mixture is especially formulated to meet the demands for a high-grade mash feed and is suitable for either the morning, noon or evening meal, whichever method is most convenient.

Mix with warm water during cold weather and feed damp and crumbly.

\section{“CRESCENT", \\ CHICK FEED.}

A Complete Grain Feed for Chicks form 3 to 8 Weeks. CLEAN SOUND SWEET

A standard nixture of re cleaned Cracked Grains and Seeds, Hulled Oats, fine Granulated Bone and fine Charcoal. The proportions are similar to the "Sun

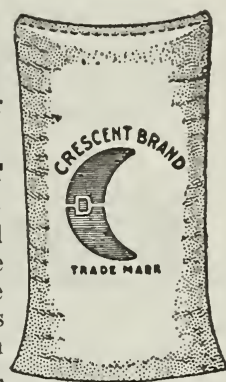
Brand," but a trifle coarser, especially to meet the requirements of the older chicks, although used by many from the beginning.

It produces healthy and rapid growth, and is intended for feeding until the chickens are large enough to be fed the coarse Scratch Feed.

The same high grade standard of quality is maintained in this mixture as the "Sun Brand," and represents the best that can be produced. A trial will demonstrate its feeding ralue.

\section{"GLOBE", \\ SCRATCH FEED.}

A Balanced Grain Ration Poultry Feed for Grown Fowls. Suitable at All Seasons.

\section{CLEAN SWEET SOUND}

Under this brand we offer our standard mixture of Poultry Feed manufactured from selected Cracked and Whole Grains and Seeds, scientifi. cally mixed to furnish a complete valanced ration, with an assortment of material best adapted for rapid growth and egg production. The protein, fat and carbohydrates are so maintained as to form the greatest feeding value and produce best results.

Carefully sifted and recleaned free of dust and chaff, and proportioned so as to meet the requirements of grown fowls throughout the year.

In addition to the regular Grains, it contains Sunflower, Oil Cake, Buckwheat and Charcoal, which are particularly valuable for the general liealth of the fowl and increased egg production.

Feed your fowls "Globe Scratch Feed" and get results. 


\section{POULTRY SUPPLIES}

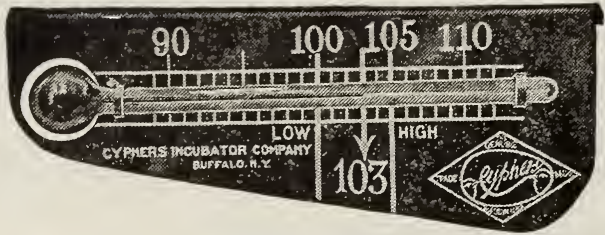

HIGH GRADE TESTED THERMOMETERS. Cyphers Incubator Thermometers, for use in Cyphers Incubators, each, postpaid, .60c. Watertown Incubator Thermometer, .50c.

BROODER THERMOMETERS.

Cyphers unmounted, .50c.

Cyphers Brooder Thermometers mounted on wooden holder, each, $50 \mathrm{c}$.

Watertown Brooder Thermometers, .40c.

\section{LAMP WICKS.}

For incubator lamps, .25c per dozen, postpaid. These wicks come in two sizes; state sizes wanted.

Wicks for Brooder Stoves, .2Uc per doz., postpaid.

\section{WIRE NESTS}

These nests are strongly made from heavy japanned steel wire and will last a lifetime. They are easy to clean and far superior to the ordinary wood boxes

Prices, each, .15c; per doz., $\$ 1.40$.

No. 2 Pedigree Trap Nests, each. $\$ 1.50$.

\section{INCUBATOR LAMPS.}

No. 0, each . . . . . . . . . . $\$ 0.75$

No. 1, 2 or 3 , each. .90

CYPHERS PERFECT POULTRY MARKER.

Cyphers Perfect Marker is made especially for the work of marking chicks, makes a good, clear, clean cut, and does not mutilate the web. Price, each, .50c.

\section{HALLOCK'S FOOD AND WATER HOLDERS.}

Just the thing to prevent chicks or fowls from getting into the pan and soiling food or water; remove all danger of drowning the chicks, save food and prevent disease. These food and water holders are made of heavy galvanized iron, rust-proof pans, protected with heavy wire guards. Made in two sizes; small size, one gallon, each, .75c: medium size, two gallons, each, $\$ 1.00$.

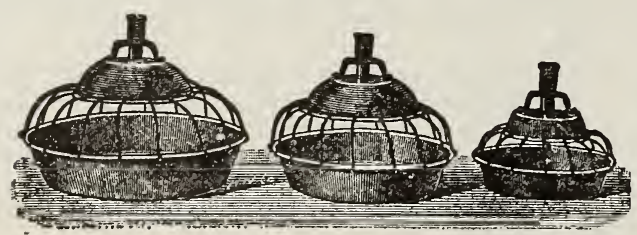

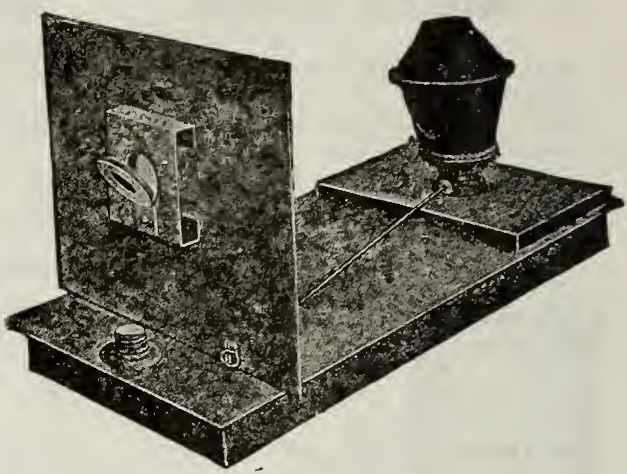

CYPHERS INSULATED BROODER STOVE.

For those desiring to buy brooder lamps, or stoves, we offer the Cyphers Improved Insulated Brooder Stove. This new stove does away with the water jacket or reservoir required on brooder stoves usually sold for the purpose. The Insulating plate of heavy galvanized iron is so placed between the burner and the oil bowl that all heat of the flame is deflected away from the oil reservoir, so that the oil remains cool at all times. The stove has a seamless bottom, hence will not leak. Price, each, $\$ 1.75$.

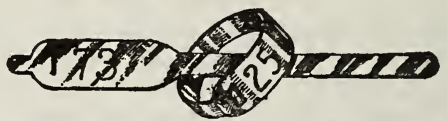

\section{LEADER ADJUSTABLE LEG BANDS. The Best Yet.}

Latest and best adjustable leg band out. Has neat, compact, and smooth fastening with no catching points; easily attached and are absolutely secure. Are made from heavy aluminum and are strong and substantial, and will hold their shape much better than bands made from thin, flimsy stock.

Made in two sizes: No. 1 for Bantams or Mediterraneans; No. 2 for Americans to Asiatics and turkeys. Not made in Pigeon sizes.

Prices, postpaid: $12, .15 \mathrm{c} ; 25, .25 \mathrm{c} ; 50,40 \mathrm{c}$; $100, .65 \mathrm{c} ; 250, \$ 1.50 ; 500, \$ 2.75 ; 1,000, \$ 5.25$.

Initials on bands, $.05 \mathrm{c}$ for 50 or less; $.10 \mathrm{c}$ per 100 extra.

GALVANIZED IRON DRINKING FOUNTAIN.

They are light, non-breakable, easily cleaned and keep the water clean. Small size fountain is just the right size for brooder use.

Prices, small size, each, .18c; medium size, each, .25c; large size, each, .35c.

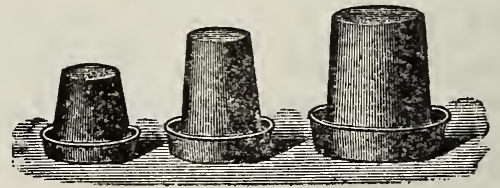




\title{
POULTRY SUPPLIES
}

\author{
(Continued)
}

\section{"THE BOSTON" POULTRY DRY FEEd HOPPER}

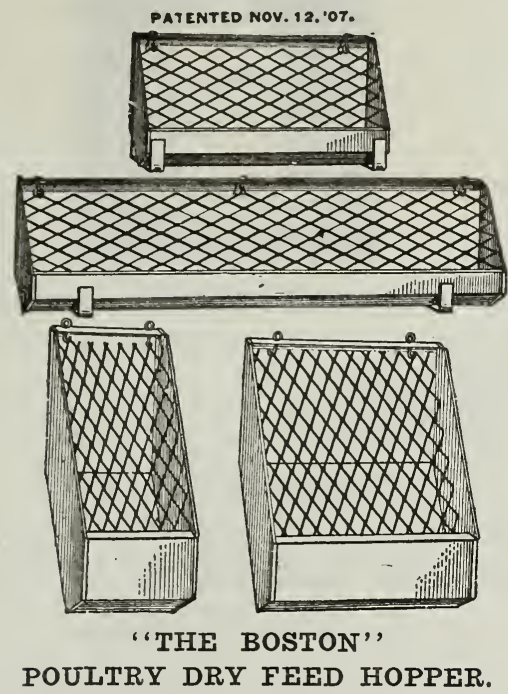

The Dry Feed Hopper System of feeding is endorsed and recommended by practically all the experimental stations and is in use in most of the large practical plants.

Manufactured in Four Sizes.

Chicken Hopper, small size, \$1.00. For use in small brooders.

Chicken Hopper, large size, $\$ 1.90$. For use in brooder houses.

Small Hopper, holds 8 quarts, .90c. For beef scraps, shells, grit or charcoal.

Large Hopper, holds 16 quarts, $\$ 1.00$. For dry feed for hens.

\section{GALVANIZED IRON WALL FOUNTS}

These Founts are very handy, as they may be hung up on the side walls of the poultry house so as to prevent litter getting in the water. They are made of heavy galvanized iron and possess an improvement which enables the user to clean them readily, which cannot be done with the old-fashioned wall fount. They are largely used by pigeon keepers, being especially adapted for that purpose.

Prices: 1 gal. size, .55c each; 2 gal size, $.75 \mathrm{c}$ each.

\section{GRENIER CAPONIZING SET.}

Designed to simplify the operation of caponizing, so that the beginner can easily master it. This set consists of a lancet shaped knife, spring spreader, forceps, hook, ring probe and canula. Price in velvet lined case,

$\$ 3.00$
If You Desire a Most Clean and Wholesome Food for Your Chicks, Try Our

\section{SUN CHICK STARTER} and

\section{CRESCENT CHICK FOOD}

IT WILL PAY YOU

\section{NESCO DRINKING FOUNTAIN}

An extra good quality drinking fountain, which has an especial advantage of the top coming to a point. This prevents chickens or fowls from tipping over the fountain as easily as other styles.

Prices, 1 qt., .20c; 2 qt .25c; 4 qt., .35c; 8 qt., .50c.

\section{PEERLESS DRINKING FOUNT}

Very easy to clean by simply removing the bottom. Can either be hung on the wall or by the bail. A very desirable fount. Price, 5 qt., .60c.
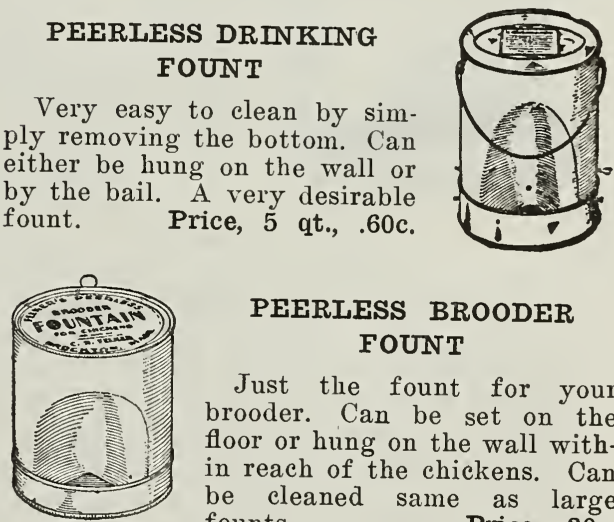

\section{PEERLESS BROODER FOUNT}

Just the fount for your brooder. Can be set on the floor or hung on the wall within reach of the chickens. Can be cleaned same as large founts. Price, .30c.

\section{POULTRY KILING KNIVES}

These knives made of the best steel and of special design.

Price, .50c each.

\section{DRINKING FOUNTS}

Essex-Model Drinking Founts are a popular, low-priced fount for use either in or out of the poultry house. They are easily cleaned. They consist of the fount proper and a removable pan, both of heavy galvanized iron. They will not rust, and are not injured by the water freezing. They are made in four sizes, the smallest for young chicks, the largest for ducks.

Prices: Small chicks size, $.18 \mathrm{c}$ each Medium size for large chicks, .25c each Large size for mature fowls, $.35 \mathrm{c}$ each Extra large size for large flocks or ducks, .50c each. 


\section{POULTRY SUPPLIES}

(Continued)

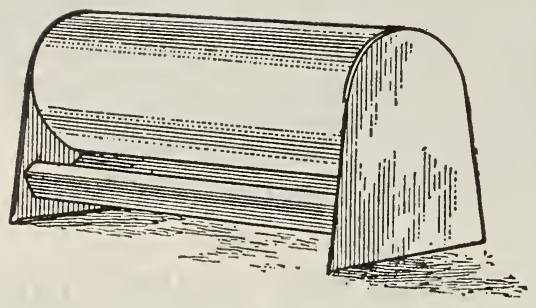

HUB CHICKEN FEEDER

Very sanitary and keeps feed clean and dry. Chickens cannot get into it and will not waste the feed.

Prices, 9-inch, .35c; 15-inch, .50c.

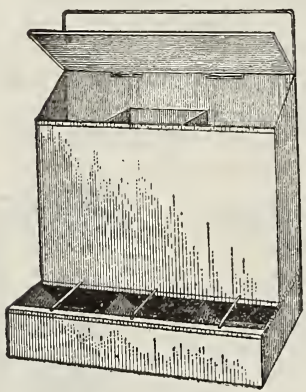

\section{POULTRY FEEDER}

Our popular, 1-2-3 Poultry Feeder can be used as a one, two or three apartment feeder, by simply changing the dividing walls. Perfectly sanitary and clean.

Price, small, .60c. Large, $.75 \mathrm{c}$.

\section{CYPHERS X-RAY EGG TESTER.}

The Cyphers X-Ray Egg Tester is made of the best block tin and consists of a central cylinder or lamp 'flue, 51/4 inches high, with an outside diameter of $25 \%$ inches at the base and $23 / 8$ inches at the top. It is designed for use in an ordinary hand lamp, fits over any style of burner with a diameter approximating that of the tester. In a dark room the light will be found strong enough to penetrate the shell and illuminate the interior of the egg. Price. 25c each; postpaid, .35c.

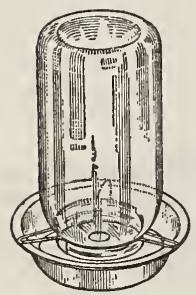

NO-SLOP CHICKEN FOUNT

Can use any size Mason jar thus making a clean, sanitary low price Fount.

Price .15c each; 2 for .25c.

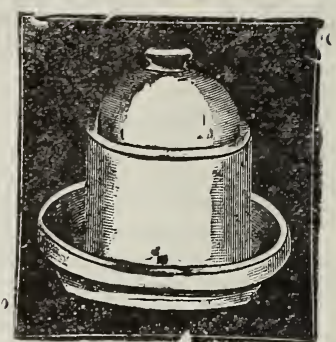

EARTHENWARE DRINKING FOUNTAINS

$1 / 1$ Gal., each . . . . . . . $\$ 0.20$

$1 / 2$ Gal., each . . . . . . . . .25

1 Gal., each : . : . .30

2 Gal., each . . . . . . . .40

\section{PORECIAIN NEST EGGS}

These Eggs are made of first-class Flint Glass. They do not break easily and will last indefinitely. Price, each, .03c; per doz., .25c.

\section{DRY FOOD HOPPERS}

Cyphers Dry Food Hoppers have two compartments, a large one for grain mixtures, holding about six quarts, and a small one for beef scraps, holding about three quarts.

Price, each, .75c.

\section{SANITARY GRIT AND SHELI BOX.}

Is manufactured of the best galvanized iron and contains three apartments for food, shells or grit. It can be hung up against the wall at any height desired and is a thoroughly firstclass article.

By the use of this self-feeding box every particle of grit, shells or food will be properly used and waste prevented, thus increasing the profits.

Price, each, .50c. 


\section{POULTRY SUPPLIES}

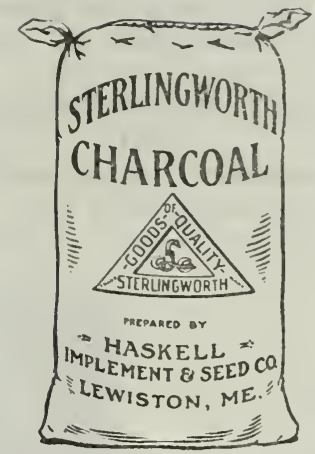

STERIINGWORTH CHARCOAL

Is especially prepared for poultry, carefully screened and is different than other charcoals. Goods are put up in 50-pound burlap bags and in 2-pound paper cartons, in four sizes as follows:

Fine Powdered for Mash Food and Ducks, also Cattle and Hogs.

Fine Granulated for Brooder Chicks and I) $r y$ Chick Food Mixtures.

Medium Granulated for Half Grown Fowls, Pigeons, etc.

Coarse Granulated for Full Grown Fowls, Geese, Turkeys, etc.

Prices: 50-pound bags, .80c each; 2-pound cartons, $.10 \mathrm{c}$ each. Larger quantities a mat. ter for correspondence.

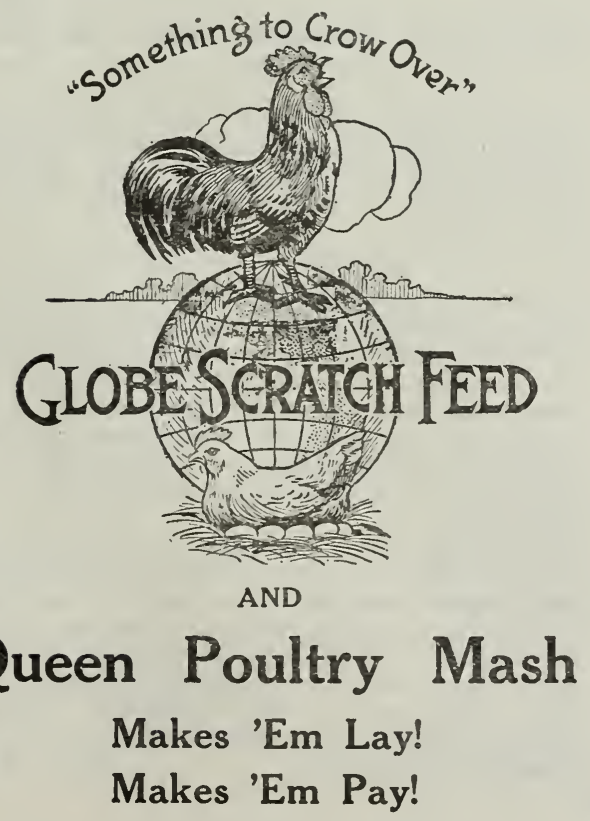

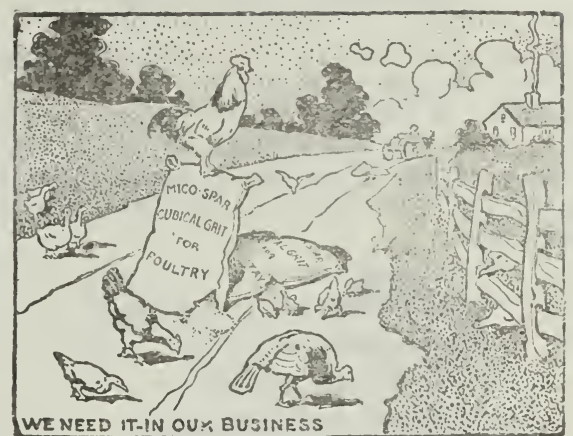

MICO SPAR CUBICAL GRIT

Does not become smooth, but retains its cubical form until entirely worn out.

No. 1. For Turkeys.

No. 2. For Fowls.

No. 3. For growing Chicks, Pigeons anil Ducks.

No. 4. Extra Fine, for Chicken Food.

Price per 100-pound bag, .70c

\section{OYSTER SHELIS}

Crushed and ground to the size which cx pert poultrymen agree to be the best. Every pound of shell we sell is all shell and nii waste. Price in quantities quoted on apl ii cation.

High Grade Beef Scraps.

Fine Cracked Bone for chicks.

Coarse Cracked Bone for fowls.

Feed Grains of all kinds.

\section{PURITY IMEDIUII CUT ALFAIFA}

As an accompaniment to the mash fed hy some, and the dry food by others, a vegetalsie food is indispensable, in fact no mash is co:n plete without it. Among green feeds, Alfal. fa stands at the top, and when used with the mash, Medium Cut Alfalfa is mixed dry with other foods, and sealded or boiled with theis, as the poultryman desires. When fed in connection with dry grains it should be scalderl in a trough or other vessel and left for the fowls to eat at will.

\section{DR HESS' POULTRY PAN-A-CE-A.}

('ontains tonics that aid the digestion; it also coitains iron for the blood and nitrates to expel poisonous material through the skin; it is the only reasonable way to produce exps without stimulants that are injurious.

$11 / 2-1 b .0 k g ., .25 c ; 5-1 b$. pkg., .60c; 12-1b. pkg., $\$ 1.25 ; 25-1 b$. pail, $\$ 2.50$.

Samples and Quantity Prices gladly sent on request on all Poultry Foods. 


\section{POULTRY SUPPLIES}

HASKEIJ TMP. \& SEED CO.'8

\section{SHIPPING EGG CASES}

These are good strong, substantial eases and are complete with fillers.

Prices: 8 dozen, $.70 \mathrm{c}$; 15 dozen, $.90 \mathrm{c} ; 30$ dozen, $\$ 1.10 ; 49$ dozen, $\$ 1.35 ; 56$ dozen, $\$ 1.50$.

Price of fillers per set, 8 dozen, $.15 c ; 15$ dozen, .20c; 30 dozen, .30c; 49 dozen, .45c; 56 dozen, 55c.

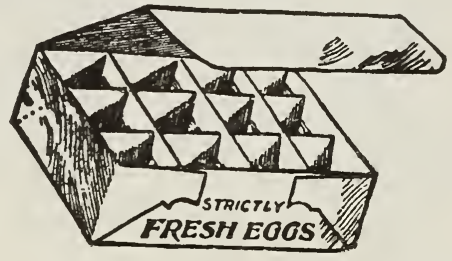

IDEAI EGG BOXES

Just the thing for family egg trade. Shipped knocked down, easily set up.

Prices, 1 dozen size, 10c per dozen; .75c per hundred.

\section{EYRIE SHIPPING BOXES}

A convenient, light and strong pasteboard box with handle for carrying or shipping fancy eggs for settings.

No. 1 for 15 eggs, each, .20c; dozen, $\$ 1.75$

No. 2 for 30 eggs, each, .25c; dozen, 2.50

\section{THE ECONOIMY OATS SPROUTER}

The best device for producing clean sprouted oats. Has five perforated pans each $16 \times 17$ in. and one drip pan at bottom. No Lamp, no Danger, very durable, compact. Green food all winter if you use the Economy Oats Sprouter which means bigger egg yields consequently more protit.

Price, $\$ 5.00$.
If You Desire a Most Clean and Wholesome Food for Your Chicks, Try Our

SUN CHICK STARTER

AND

CRESCENT CHICK FOOD IT WILL PAY YOU

\section{ALI METAI ADAPTABLE HOVER}

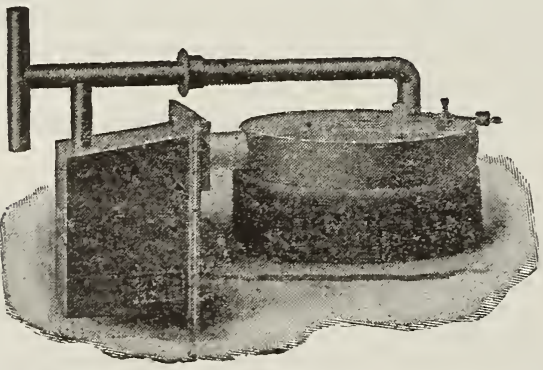

(Nolf-Regulating and bears Insurane Labol as Separate Dovico.)
This machinery-made, all-metal, guaranteed fire-proof heating and brooding device is suitable to be used anywhere that heat is required for brooding chicks or ducklings. It can be used in a roosting coop, colony house, shed, hen house, barn or other building with or without any additional enclosure for the chicks, or in a large goods case or organ or piano box.

Is pronounced by thousands of users to be the best device thus far invented for heating home-made brooders. Recommended especially for use in long brooding houses, one hover for each pen. Adaptable hover is complete in itself, bears insurance label as a separate device, and is safe to use anywhere. Weight, boxed for shipment, only 40 pounds.
Prieo, $\$ 8.80$ 


\section{THE ${ }_{31}$ WORLD-FAMOUS “ESSEX-MODEL” INCUBATORS}

\section{Five Styles-Twelve Sizes}

ESSEX-MODEL "STANDARD," This Company manufactures the Largest Line of IncubaHARDWOOD INCUBATOR tors in America, and our "STANDARDS" Lead the World They are the result of many years' work and hard-earned experience by experts, and represent the latest, down-to-date knowledge of artificial incubation. Year after year they have proven themselves "The W'orld's Best Hatchers" - the rich est appearing Ineubators made.

These Essex-Model "Standards", are the only Incubators made of Hardwood. At first sight, with their rich furniture finish, you will pronounce them SUPERIOR. We built then of high-grade Chestnut because it is the best wood to withstand variations of outside tem perature, dry atmosphere, and damp cellars. Chestnut is of course much more costly than pine or other soft woods which are generally used in the manufacture of incubators, but as it does not swell and shrink like soft cheap woods we prefer to go to this extra expense in making these Superior machines. By being content with a small profit on the large number of machines we nake, we are enabled to sell this Superior machine at no greater cost than other machines that are made of ordinary soft wood, and possess less efficient equipment.

The Essex-Model "Standards", are built with double walls with space between filled with a superior quality of costly insulating material. They possess double glass doors and heavily insulated and packed tops; Heavy Galvanized Iron Asbestos Jacketed Heater; our Latest and Best Self-adjusting Lamp Support, and a Seamless, One-piece, Reinforced Safety Lamp Bowl.

They are Self-Regulating, being equipped with our (Patented) Corrugated Leaf Thermostat, which is the most sensitive and accurate regulator ever placed in an incubator. It cannot be used in any other make.

The Essex-Model "Standards", have for years been the only Self-Ventilating machines made. There are no slides to open and shut. The ventilation is wholly automatic, being controlled by the slatted-bottom principle of construction, the porous diaphragms, and our fresh-air, single-draft heated. By this advanced principle the "Essex-Models" preserve the natural moisture of the air and in the eggs to a greater extent than any other machine, and to the same extent avoid the danger of dead chicks in the shell. They combine, in the highest degree, STRENGTH, DURABILITY, FINISH and HATCHABILITY, being the Highest-Grade Incubators manufactured anywhere, at any price-America's Most Superior Machines.

All these advantages-this Scientific Construction, the use of Superior Material, the use of our Patented Thermostat, etc., etc., all go to build up a machine that is acknowledged to be the Best Hatcher that has ever been built. State Experiment Stations say so! Ex-

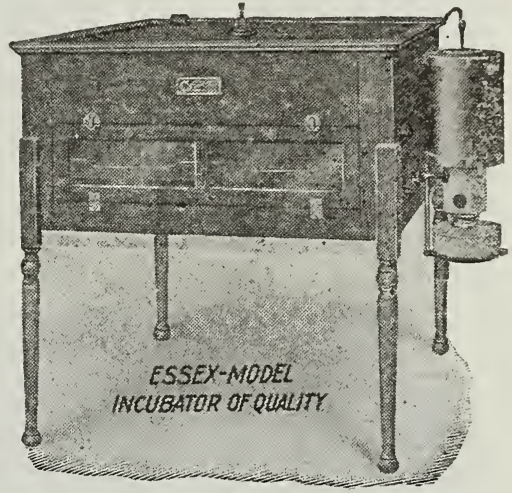

The Famous "Standard" EssexModel Incubator

Complete with Lamp, Thermometer, and Egg Tester-No Extras for you to buy. Case made wholly of Chestnut (the only Hardwood Incubator made); Latest Self-adjusting Lamp Support and Essex-Corrugated Thermostat (Patented).

No. 1175 Egg . . . . \$23.00

No. 2275 Egg . . . . 32.00

No. 3410 Egg : . $\quad . \quad$. 38.00 pert poultrymen say so, and the many unasked-for-letters we have from those who have used them prove that as a Hatcher, the "Essex-Model" stands unequalled. The evidence is given in our Big Catalogue.

The Essex-Models are endorsed and used by State-Experiment Stations and Agricultural Schools in their Poultry Classes.

They hold more eggs than any other High-Grade machine at the price.

Ask your Hardware or Seed Merchant for the Famous "Essex-Models." Don't be satisfied till you've seen them. If your storekeeper does not keep them, write for our Big Free nllustrated Catalogue " $\mathrm{S}$," and please send us his address.

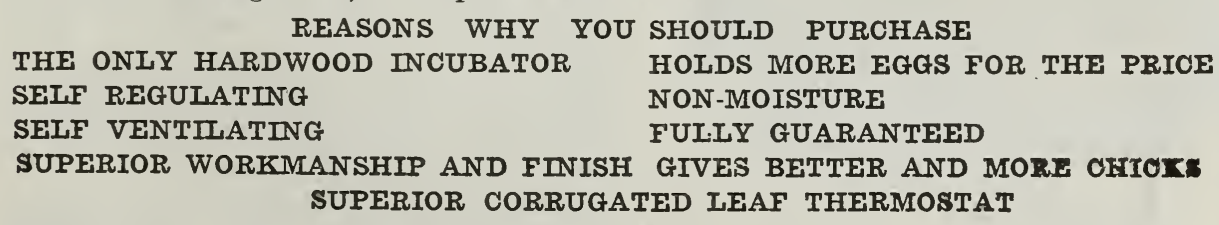




\section{ESSEX-MODEL SUPERIOR BROODERS}

\section{A Line of Brooders Unequalled for their Combination of Light, Heat, Ven- tilation and Floor Space. The Brooders that Raise Most \\ Strong, Healthy Chicks}

America.

Essex-Model Brooders are known wherever poultry is raised by reason of their splendid combination of Light, Heat, Ventilation and Floor Space, so designed as to afford young chicks natural conditions without natural dangers; ventilation without draugiss; heat without oil fumes; light sufficicnt for their needs; but not so much as to allow a great variation in temperature between night and day; and an amount of floor spaee that is not equalled at the prices in any other Iligh-Grade Brooder. 'They Mother the Chicks Better Than a Hen, because they possess the advantages without the dangers and discomforts of natural brooding.

These Brooders are all built on the Essex-Model principle of: "You should see every ehiek every day. Know their condition, and be successful." In the Essex-1Iodel Brooder's (as in no others) the chicks can be readily seen by simply lifting the Hov r without having to unscrew or remove any of the parts. Take a look under the Hover every day. 'That's the way to raise chicks-and the only way.

\section{ESSEX-MODEL A OUTDOOR COLONY BROODER}

Essex-Model A Brooder is a Combination Indoor and Outdoor Brooder. It contains two apartments (Hover and exercise room, separated by the Hover cloth). It is $471 / 2 \times 281 / 4$ incies in size. It contuins a supplementary roof cocer or diaphragm, affording automatic ventilation-the latest improvement in brooders, possesed by no other make. This Brooder possesses in addition a triple roof, including enameled iron exterior and is practically indestructible. Capacity, 75 to 100 chicks, Price, $\$ 12.50$

\section{ESSEX-MODEL C OUTDOOR COLONY BROODER}

This is without doubt the best brooder on the market, and the most popular. It needs to be seen to be fully appreciated. This was the original "Colony" Brooder of Anerica, and our 1912 improvements plaee it further in the lead than eier. No other lamp box is so convenient. The doublehinged combination ventilating door and window, original with our Colony Brooder, is most convenient and useful. (This plan is now imitated in other makes.) The window opening is coveled with fine rat-proof wire on a remorable frame. The roof is of matched boards covered with enameled rolled steel, and doubly insulated with corrugated carpet felt. It is practically imperishable, and is not affected by the action of the sun or rain. Examine other makes oí Brooder's that have been exposed to the weather, and compare the difference..

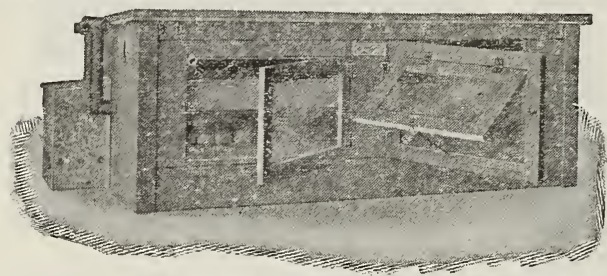

The Famous and Original Lss.sucsuel C' Uutdoor Colony Brooder and Roost Coop

(Size 72x341/2 inches.) The Best Brooder made, regardless of price, showing our original doubble window in exercise compartment and hover full length of nursery compartment.

Capacity, 150 chicks. Price, \$18.50.
The Essex-Model C Brooder has three apartments-the hover and nurs'ry, separated by the hover curtain; and the exercise roon separated by a removable partition having a door and curtain full width of Brooder, so that the chicks never lose their way back to the hover, nor crowd and get chilled in the exercise-room, as they may where the exit is only a small doorway. The nursery apartment is double valled and insulated, making a triple-walled Brooder with five thieknesses of roof. The hover is 15 inches wide by $321 / 2$ inches long, giving more hover space than any other; and the chicks cannot crowd. They hover the full length of the apartment. To be succossful you should be able to see your chicks readily under the hover. This Brooder makes it easy. No other make, at any price, combines these advantages.

\section{ESSEX-MOUEL SINGLE NEW HOMESTEAD BROODER}

The Essex-Model New Homestead Brooder is a low-priced Brooder, substantially constructed, and is considerably in advance of the kind usually sold at the price we ask for it. It can be used either indoor's or outdoor's. It is built of $\pi / 8$-inch dressed, tongued and grooved lumber throughout, including the roof. It is divided into two apartments by the hover cloth. It has ample floor space and light. Its heating equipment is such that it gives astisfaction in all weathers. Its size is $321 / 1 x^{2} 21$ inches. having chick capacity nearly equal to that of some machines that are sold for double the money

Capacity, 100 chicks, Price, $\$ 6.50$

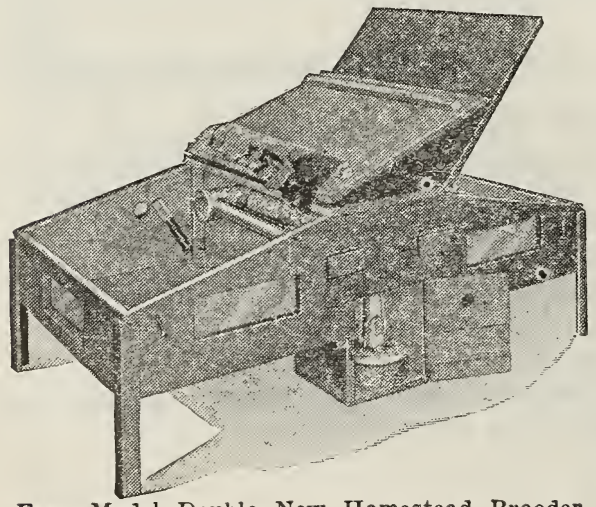

Essex-Model Double New Homestead Brooder

\section{ESSEX-MODEL DOUBLE NEW HOMESTEAD}

The Essex-Model Double New Homestead Brooder is the most economical and convenient Brooder at the price on the market. It is similar in design and construction to the Single New Homestead Brooder, but it provides two separate apartments for two separate focks of chicl-s: n" the partition between the apartments may be removed and the Brooder used for one flock in order to provide more floor space for exercise. It is two brooders in one. It is the most for the money ever offered.

This Brooder is strongly constructed of $7 / 8$ inch. lumber, possesses four windows, two roofs that act independently of each other, and is a wonderfully cheap Brooder considering its size and useful construction. Size $56 \times 30$ inches. It can be used indoors or outdoors in fine weather.

Two Brooders in one. Constructed of $7 / 8$-inch tongued and grooved lumber. Fully equipped witb lamp, chimney, and thermometer. Capacity, 200 chicks. Price $\$ 10.00$. 


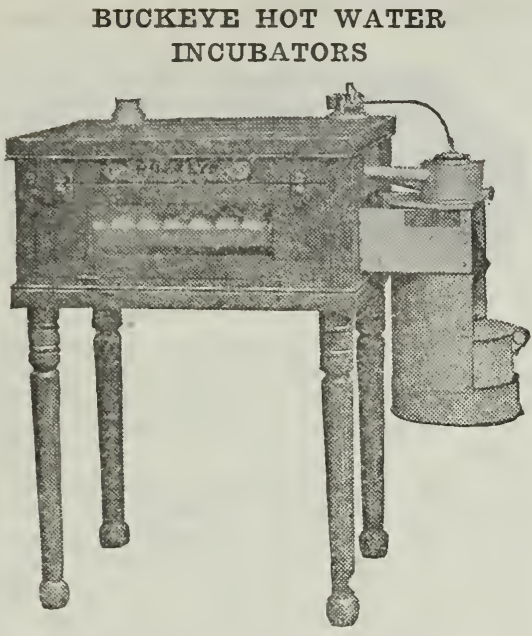

BUCKEYE STANDARD INCUBATOR

The Case. California Redwood is used exclusively in the outside case, because we know it will withstand all kinds of atmospheric ehanges without the slightest danger of warping, splitting or pulling apart. The*inside walls are constructed of seasoned yellow poplar which will also withstand any atmospheric changes regardless of conditions. The sides and top of each incubator consist of two walls of this lumber, which is one inch thick, and a quarter inch thickness of fibre insulation between the two thicknesses of lumber. which produces a case that is absolutely impervious to the changes in the outside temperature. This plan of construetion gives us a case that is two and a quarter inches thick throughout, which not only guards against changes in temperature; but in addition. we have an incubator that will last a lifetime. The doors are made of two thicknesses of one-inch lumber and matched to the case by an expert cabinet maker to insure a perfect fit. The center of each door is equipped with a small window protected by two panes of glass, with a dead air space between, and further protected by a wooden door on the outside. This construction provides the desirable dark egg chamber, and at the same time permits an easy reading of the thermometer, which is placed directly inside the door.

The Heating System. The Buckeye circulating hot water system consists of a tank suspended above the eggs, a boiler outside the case, and two tubes connecting the boiler with the tank. In constructing this heating system, we use extra heavy Pure Copper exclusively, and for the benefit of those not familiar with this metal, it might be well to mention that copper of this kind will not rust or corrode, and its lasting qualities are simply unlimited. The plan of construction used in Buckeye hot water heaters is identical with the most elaborate systems used in

house heating. The water is heated in the boiler and passed into the tubes that are suspended above the eggs. Just so fast as the water is heated and forced out of the boilcr. just that much of returning water goes into the boiler to be heated again and in that way we procure a continuous circulation of hot water through the tank.

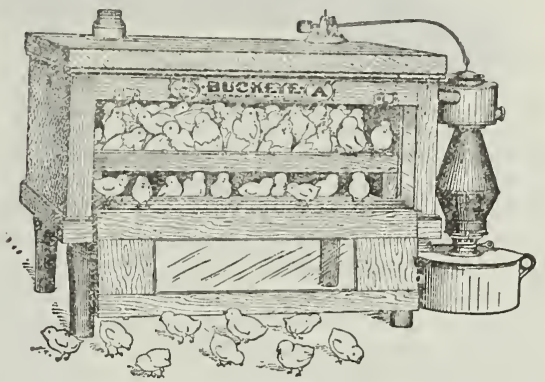

STYLE A BUCKEYE INCUBATOR

Lamp Support and Boiler Jacket. This fix. ture is made of No. 27 gauge steel (Galvanized (in accordance with the requirements of the Insurance Underwriters' Laboratories. In the first place, it provides an absolutely fireproof support for the lamp, and it is so constructed that in case of accident of any kind to the lamp, it would be absolutely impossible for fire to communicate to the incubator. Each fixture is made and inspected under the supervision of the Underwriters' laboratories, and is considered to be absolutely fireproof. Every genuine Buckeye lamp support bears the Underwriters' label of approval and none is genuine without it.

\section{GUARANTEE NO. 327, 194}

This Buckeye incubator is guaranteed to hatch every hatchable egg, to be complete in every detail, and in perfect working order.

We guarantee the efficiency of all its mechanical parts, and the material of which it is constructed is guaranteed against deterioration from wear for a period of five (5) years.

If this incubator, or any part thereof, should fail to fulfill our guarantee, the entire machine or any defective part (excepting thermometers and lamp burners) may be returned to us any time within five (5) years, and we will place the machine in perfect working order, and replace any defective part, without charge.

Thermometers and lamp burners are guaranteed against defect and breakage upon arrival. Should either be defective or broken on arrival, we will replace them without charge.

(Signed) The Buckeye Incubator Co.

Style A

No. 1 Standard

No. 2 Standard

No. 3 Standard

No. 4 Standard

\section{Sizes and Prices}

$60 \mathrm{Egg}$

110 Egg

$175 \mathrm{Egg}$

$230 \mathrm{Egg}$

350 Egg
$\$ 8.00$

16.00

20.00

27.50 35.00 


\section{BUCKAYE TOP HEAT SRLF-RIGULATING BROODERS}

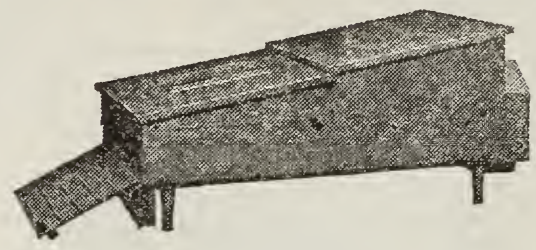

It is a matter of record that poorly constructed brooders are responsible for the leath of more chicks than any other one cause, so we consider it most advisable to eall attention to the importance of using a type of brooder that will properly care for the chicks after they are hatched.

First of all, these brooders are heated by the same system used in Buckeye incubators -Circulating Hot Water.

The Hot Water tank is suspended above the chicks for the same reason that we suspend it above the eggs.

It keeps every corner of the brooder at exactly the same temperature.

We have a heat regulator on Buckeye Brooders that takes care of every condition.

It absolutely controls the heat of that Brooder regardless of conditions.

Sizes and Prices.

No. 2 Outdoor type Capacity 50 Chicks, $\$ 9.00$ No. 4 Outdoor type Capacity 100 Chicks,

\section{BUCKEYE LAMPLESS BROODERS}

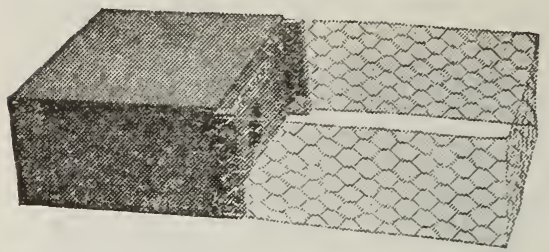

The lampless brooder is no longer an experiment, but on the contrary has proven to be one of the most valuable developments of recent years in connection with the poultry industry.

Artificial Heat is not at all necessary to Successfully rear little chicks, if they are provided with the proper means for keeping themselves warm and comfortable.

If the chicks are supplied with a sufficient amount of covering, they can keep themselves just as comfortable as "a bug in a rug.',

Keeping warm is not the only essential to the welfare of the chicks.

They must have fresh air and crowding must be avoided!

- It is the successful combination of these three features that makes a successful lampless brooder.

\section{Send for Complete Buckeye Catalog.}

Sizes and Prices.

No. 5 Capacity 25 chicks

No. 6 Capacity 50 chicks

\section{ENTERNATIONAI SANITARY HOVERS Eleven Points of Superiority}

Advantages possessed by the International Sanitary Hover and not to be found in any other brooding device.

1. It is warmer at the curtain than near the center. This causes the chicks to distribute themselves just back of the edge of the curtain, where they have a constant supply of fresh air and plenty of room.

2. It is entirely circular and has no corners for the chicks to crowd into.

3. The lamp holder can be lifted out through the top of the hover by a person standing up. This makes it unnecessary for the operator to kneel in dust or mud to tend his lamp.

4. It can be carried around with ease and used anywhere, thus making unnecessary the building of an expensive brooder house.

5. No carpenter work is required in connection with it-no cutting of holes nor building of platforms.

6. It is complete in itself and ready for use whererer it may be dropped.
7. It is metal throughout (except the curtain, of course) and is therefore vermin proof as well as fireproof. Unlike the wooden hover, it will not absorb dirt and hold it.

8. The inch of selected insulating material between the two layers of the dome prevents excessive radiation of heat upward. Plenty of heat is radiated downward upon the backs of the chicks.

9. It cannot be burned nor broken and cannot warp and fall apart. At the worst it can only be kinked or dented through rough usage.

10. Although portable-easy to carry around and usable anywhere-it provides nearly two hundred square inches more hovering space than do other hovers.

11. It gives ample heat under the hover without so heating the surrounding floor space as to cause leg weakness among the chicks.

\section{Send for Full Descriptive Catalog.}

Price, $\$ 8.50$ 


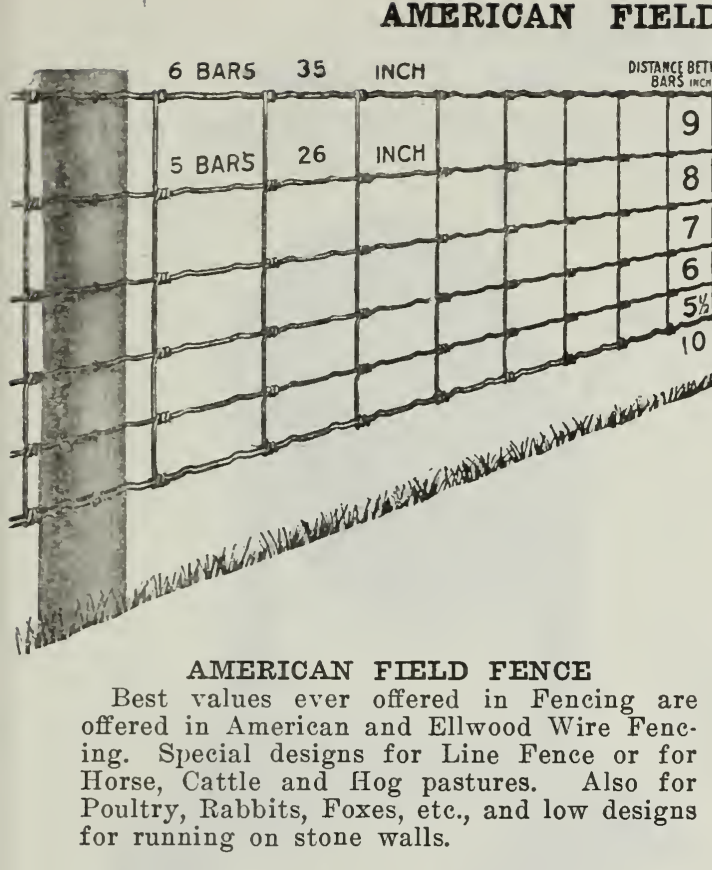

Headquarters for

\section{AMERICAN FIELD AND HOG FENCE.}

Made of large, strong, high-grade steel wires, heavily galvanized. Amply provides for expansion and contraction. Is practically everlasting. Never goes wrong, no matter how great a strain is put on it. Does not mutilate but does, efficiently turn cattle, horses, hogs and pigs.

Every rod of American Fence Guaranteed by the manufacturers. Call and see it. Can show you how it will save you money and fence your fields so they will stay fenced.

\section{Distance List}

Design No. Bars Height between Price

\begin{tabular}{|c|c|c|c|c|}
\hline No. & & ehes & inc & 0 \\
\hline 526 & 5 & 26 & 12 & $\$ .48$ \\
\hline 635 & 6 & 35 & 12 & .59 \\
\hline 845 & 8 & 45 & 12 & .74 \\
\hline 949 & 9 & 49 & 12 & .82 \\
\hline 1149 & 11 & 49 & 12 & .93 \\
\hline 1258 & 12 & 58 & 12 & 1.03 \\
\hline 845 & 8 & 45 & 6 & .96 \\
\hline 832 & 8 & 32 & 6 & .87 \\
\hline 726 & 7 & 26 & 6 & .75 \\
\hline
\end{tabular}

Write for our prices.

American Steel Fence Posts, Galvanized Steel (non Rusting) cheaper than wood and more durable. Send for special catalog and prices.

We also carry full line of plain Wire, Barb Wire, Fence Staples, Poultry Staples, Nails, ote. and POULTRY FrICS

DISTANCE BETWEEN

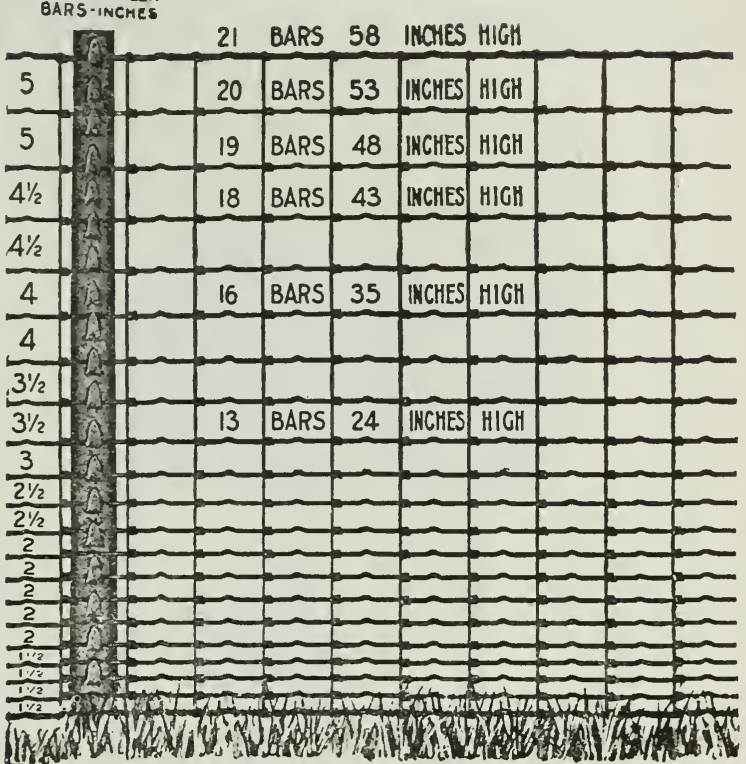

\section{IIST PRICES ON AMIERICAN POULTRY AND RABBIT FENCE.}

Distance Approxi-

Design No. Height between mate wt. List

No. Bars Inches Stays Lbs. per Price

$\begin{array}{rrrcrr} & & & \text { Inches } & \text { rod } & \text { per rod } \\ 2158 & 21 & 28 & 6 & 12.9 & . \$ 1.19 \\ 2053 & 20 & 53 & 6 & 12.2 & 1.13 \\ 1948 & 19 & 48 & 6 & 11.5 & 1.07\end{array}$

Write for our prices.

Our new American Poultry and Rabbit Fence with its close mesh fills a want long felt by dealers handling American Fence.

At the bottom are four spaces of $11 / 2$ inches each, the next five spaces are 2 inches each, the higher spaces graduated to 5 inches as shown in illustration.

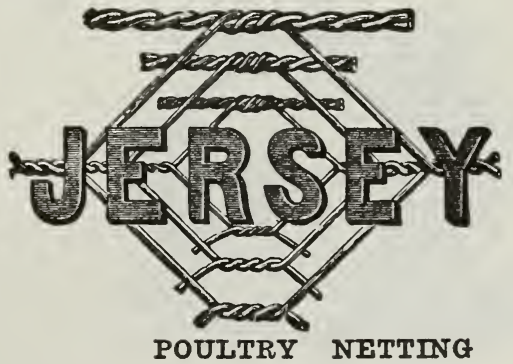

We carry the well-known New Jersey Netting and guarantee it to be the very best. It is galvanized after weaving, has three selvage wires, where other makes have but two. Is coated with pure spelter, or zinc (tin rusts), and is full measure in length and width.

All sizes in both Poultry and Chicken mesh. Writo for pricos. 


\section{DAIFY ELIMER'S PATENT DOUBLE ACTING CHURN}

Unparalleled for quickness, ease, durability and economy. It is a perfect butter worker without making any changes.

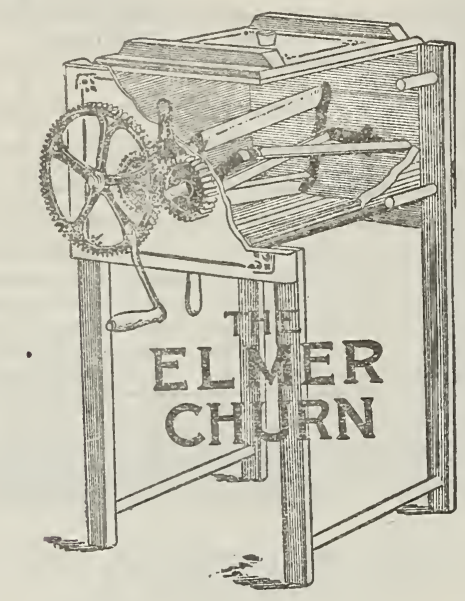

No. 1 will churn 8 quarts cream...

No. 2 will churn 10 quarts cream...

No. 3 will churn 15 quarts cream...

No. 4 will churn 20 quarts cream...

No. 5 will churn 25 quarts cream...

No. 6 will chuin 35 quarts cream...

No. 7 will churn 45 quarts cream...

\section{CYLINDER CHURNS}

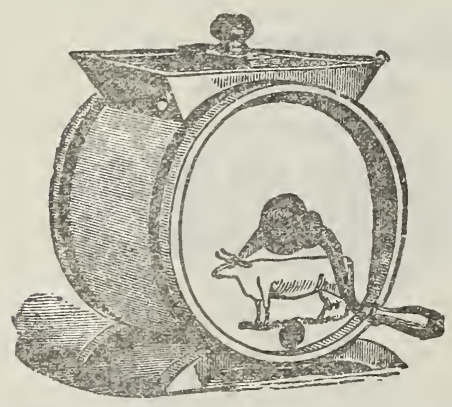

PIRICE

No. 0 will churn 1 gallon....... $\$ 1.60$

N̦o. 1 will chum 2x/4 gallons...... 1.85

ITo. 2 will churn \pm gallons...... 2.15

No. 3 will churn $7 \frac{1}{2}$ gallons...... 2.50

No. 4 will churn 10 $1 / 2$ gallons...... 3.00
PRICE

$\$ 5.00$

5.75

6.50

7.25

8.00

9.00

10.00
Is provided with our new patent Drop Steel Forgeci Cover.

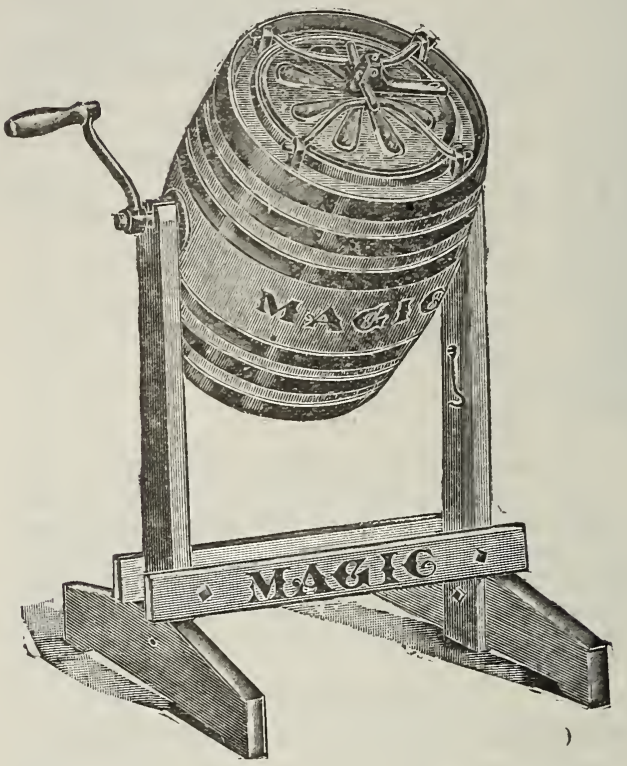

No. 1, capacity 10 gals., will churn 1 to 4 gals., price . . . .

No. 2, capacity 15 gals., will churn 2 to 7 gals., price . . .

No. 3 capacity 20 gals., will churn 3 to 9 gals, price

No. 4, capacity 25 gals., will churu 4 to 12 gals., price . . . . No. 5, capacity 35 gals., will churn 5 to 16 gals., price . . . . No. 51/2, eapacity 45 gals., will churn 5 to 20 gals., price . . . . No. 6, capacity 60 gals., will churn 6 to 28 gals., price . . . . 18.00

\section{HERO BARREL CHURN}

$\$ 8.50$

Similar in construction to the Magic, but has wooden cover in place of metal.

$\begin{array}{lllr}\text { No. } & \text { Capacity } & \text { Will Churn } & \text { Price } \\ 3 . & 20 \text { gals. } & 3 \text { to } 9 \text { gals. } & \$ 5.50 \\ \text { 4. } & 25 \text { gals. } & 4 \text { to } 12 \text { gals. } & 7.00 \\ \text { 5. } & 35 \text { gals. } & 5 \text { to } 16 \text { gals. } & 8.00 \\ 6 . & 60 \text { gals. } & 6 \text { to } 28 \text { gals. } & 11.00\end{array}$


Contrnued

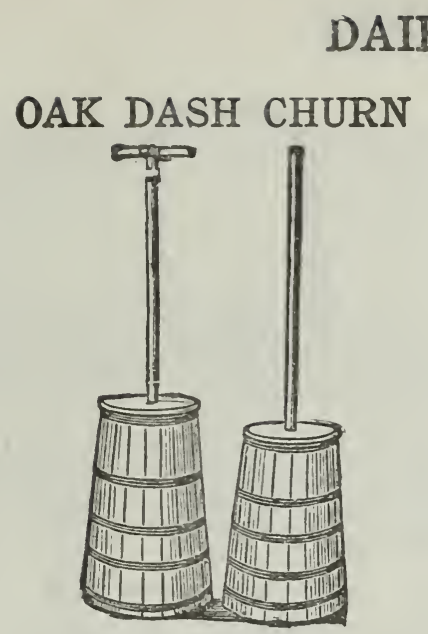

OAK DASH CHURN

No. 0. 3 gallons, witu ueiru. ....... $\$ 1.25$

No. 1. j) gallons, with dasher ....... 1.40

No. 2. T gallons, with dasher ....... 1.50

No. 3. ! gallons, with dasher ........ 1.60

No. 4. 12 gallons, with dasher ....... 1.80

\section{STONE DASH CHURN}

2 gallons, price with dasher .......\$\$ \$ 65

3 gallons, price rith dasher ......... .70

4 gallons, price with dasher........ $\quad .80$

5 gallons, price with dasher. . . . . . . . $\quad .90$

6 gallons, price with dasher........ 1.00

\section{WATERS' BUTTER WORKER}

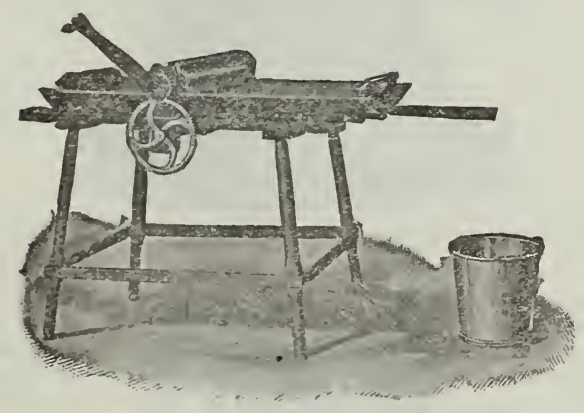

Without doubt the most practical and best known Butter Worker on the market. Guaranteed to handle butter in any condition satisfactorily.

No. 0. Tray, 27 in. long, 14 in. wide; ca. pacity, 1 to $15 \mathrm{lbs}$; price... $\$ 6.00$

No. 1. Tray, 36 in. long, 15 in. wide; capacity, 5 to $30 \mathrm{lbs}$; price... 7.00

No. 2. Tray, 36 in. long, 18 in. wide; capacity, 5 to $40 \mathrm{lbs}$; price... 8.00

No. 3. Tray, 39 in. long, 20 in. wide; capacity, 5 to $50 \mathrm{lbs}$; price. ... 9.00

No. 4. Tray, 48 in. long, 22 in. wide; rapacity, 10 to $75 \mathrm{lbs}$; price... $\quad 11.00$

\section{BLANCHARD BUTTER CARRIERS}

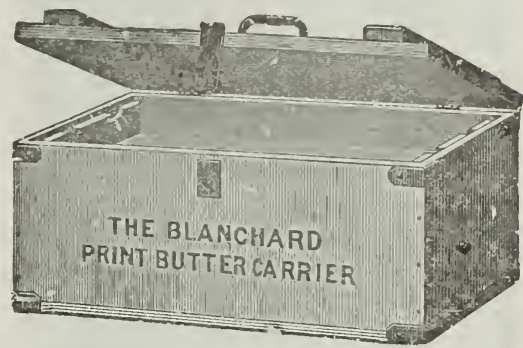

Price

No. $61 / 2 \quad 4$ trays, 12 lbs. capacity ..... \$1.75

No. 7. 4 trays, 16 lbs. capacity ..... 2.10

No. 8. 4 trays, 24 lbs. capacity .... 2.35

No. 9. 4 trays, 32 lbs. capacity .... 2.80

No. 10. 5 trays, 40 lbs. capacity .... 3.00

No. 11.6 trays, 48 lbs. capacity .... 3.60

With or without galranized ice boxes.

Will be shipped without ice boxes, unless they are ordered. Ice boxes separate, 50c each.

\section{GENUINE BLANCHARD BUTTER MOULDS}
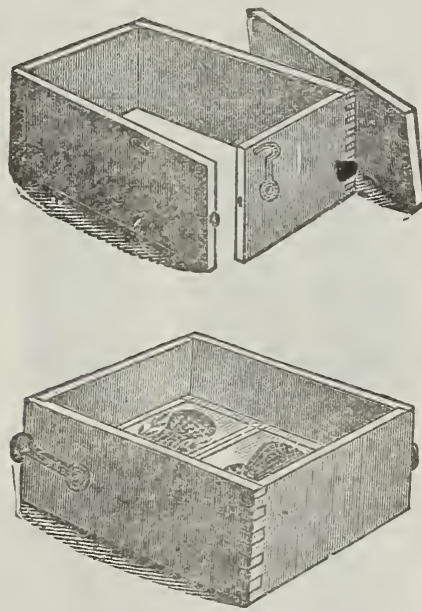

Hand Carved

$1 / 2$ pound $\quad$ PRICE

1 pound..................... 85

Machine Carved

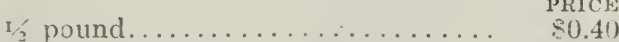

1 Found................ . . 


\section{DAIRY SUPPLIES}

(Continued)

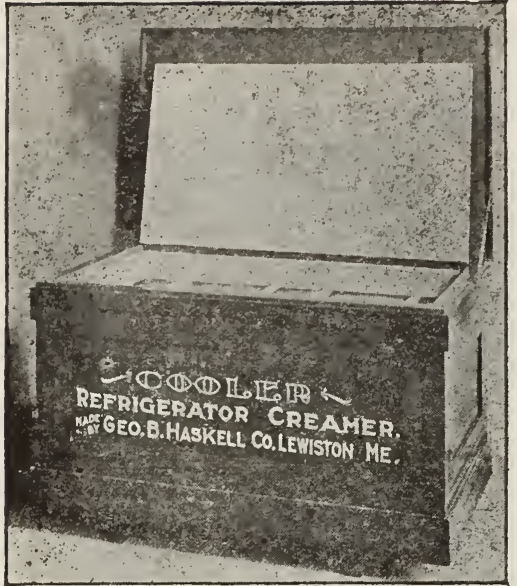

COOLEY CREAMERS.

The Best Gravity Method in the World. Price of Tank Iess Cans.

No. 2. For four cans . . . . $\$ 16.00$

No. 3. For six cans . . . . . 18.00

No. 4. For eight cans . . . . 21.00

No. 5. For ten cans . . . . . 23.50

No. 6. For twelve cans . . . 25.00

No. 7. For fourteen eans . . . . 29.00

No. 8. For sixteen cans . . . 33.00

Strainer frame and thermometer extra.

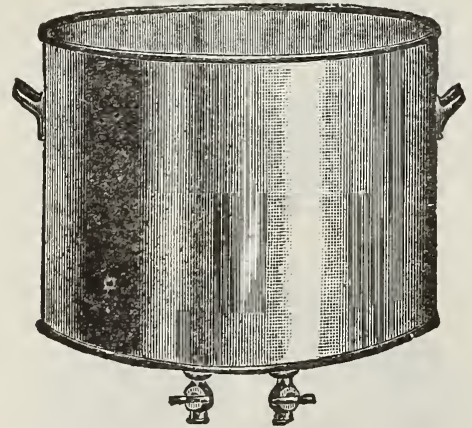

THE SENSIBLE BOTTLE FILLER

This is a small tank, heavily tinned and holding about sixty quarts. It has two straight bore faucets in the bottom near the edge. They are inexpensive and very handy for the small milk dealers who do not feel like paying a large sum for one of the larger machines.

\section{MILK BOTTLE CAPS}

Price each, \$4.

1. Special stock print

Price per Lb.

2. Special stock print

1. Flipper stock print

2. Flipper stock print

Box 5,000 No. 2 Flipper tock print

Bbl. of 50,000 Lip Caps

Bbl. of 50,000 Plain Caps

11.00

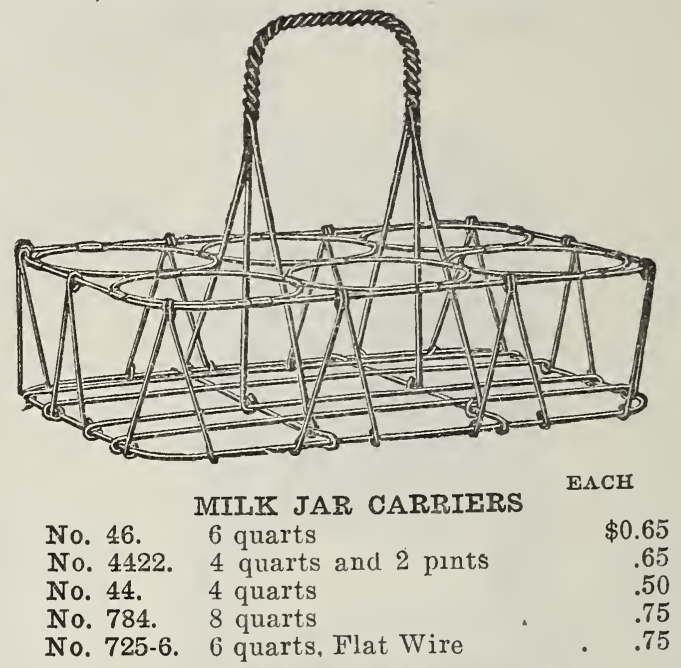

CHAMPION MILK COOLER AERATOR.

A perfect Aerator, removing all flavors arising from excessive cabbage, turnip or silo rations.

A complete deodorizer, removing the animal heat or cowy taste, and all odors arising from the absorption by the milk of stable or other unpleasant gases.

A thorough cooler, reducing the temperature of the milk in one minute nearly to the temperature of the cooling medium.

It is equally well adapted to the use of any cooling medium, either running water, ice water, or, if a very low temperature is not required, ordinary well or spring water.

Is automatic, requiring no attention, while in operation.

Capacity

of Milk Size of Dairy Takes Care of No. Receiver

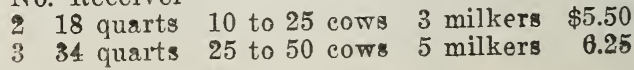
BUTTER COLOR

10.00

Wells, Richardson Co, Thatcher \& Hansen 


\section{DAIRY SUPPLIES \\ (Continued)}

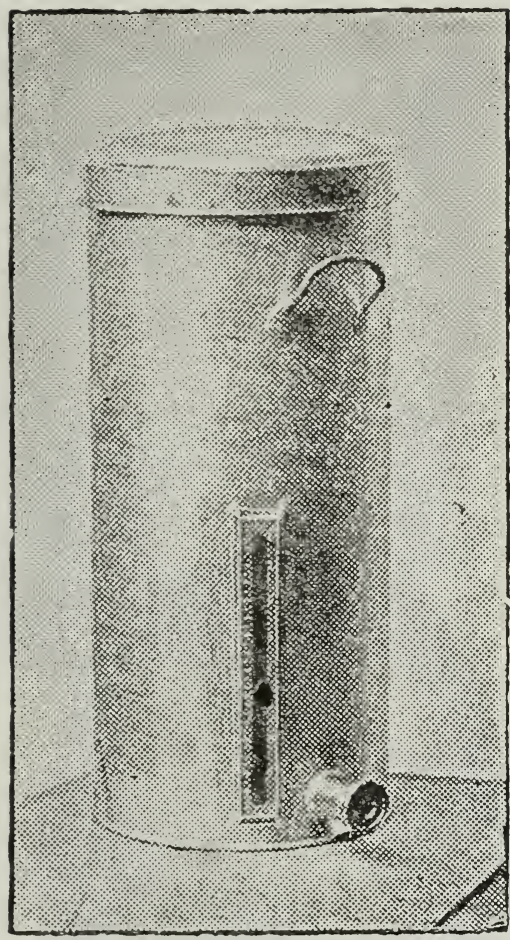

Buffalo Milk Can prick

Butfalo milk cans, each.......... \$1.00 Buffalo cream cans, each......... .75

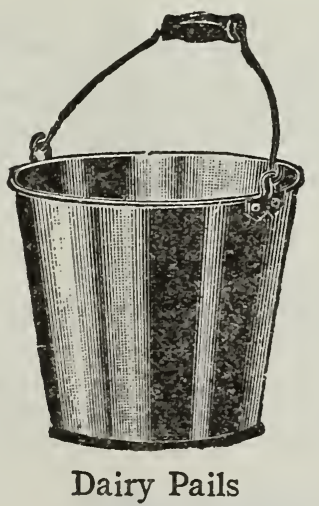

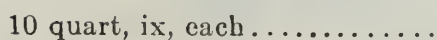

12 quart, ix, oach...............

14 quart, ix, each...........

10 quart, ixx, each...........

12 quart, ixx, each...........

14 quart, ixx, each...........

10 quart, $1 \mathrm{c}$, flaring............

12 quart, ixxxx, extra heavy..

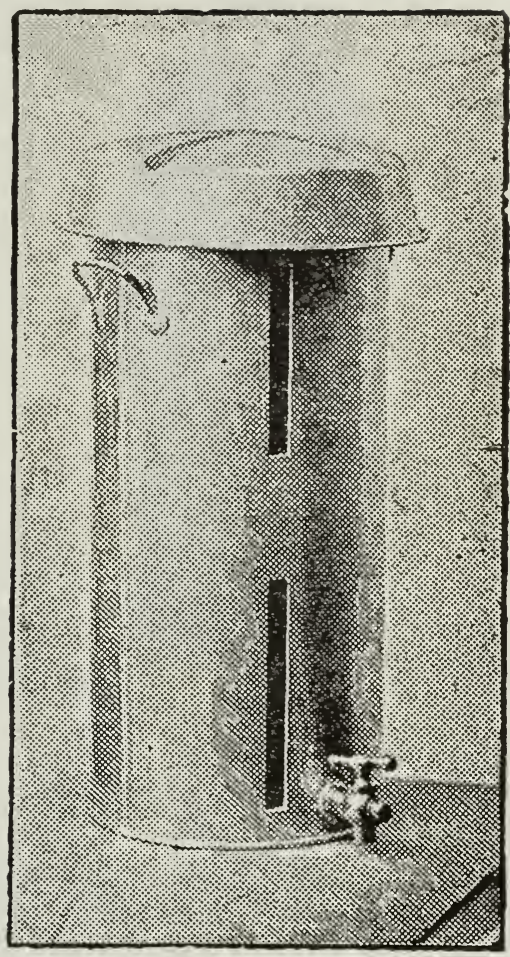

\section{Goss Special Milk Can}

PRICE

$\begin{array}{lr}\text { Goss special milk cans, each....... } & \$ 1.50 \\ \text { Goss cream storage cans, each. .... } & 1.00\end{array}$

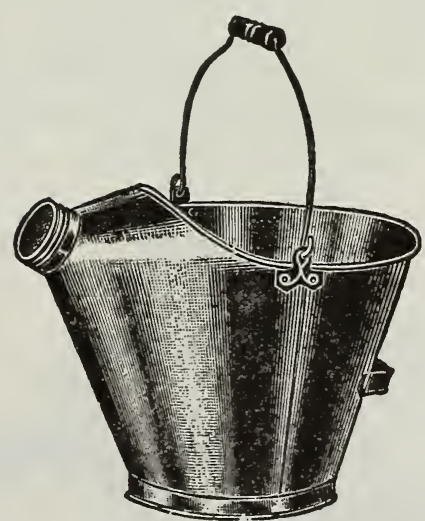

\section{Strainer Pails}

No. 1012. 12 quart, each......

.40

.15

.50
PRIC:

$\$ 1.00$ 


\section{DAIRY SUPPLIES \\ (Continued)}

Milk and Cream Scales

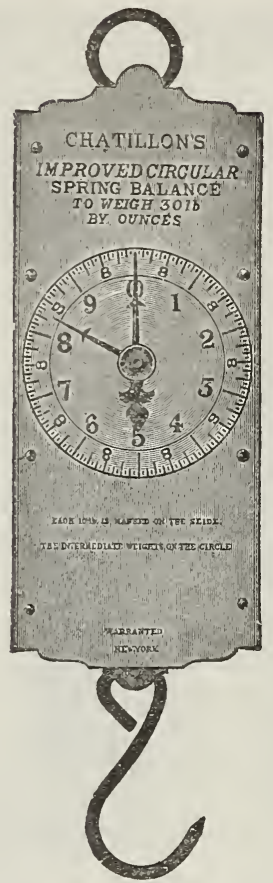

These scales are made with a loose pointer which, by means of a thumbscrew on the center of the pointer, may be set anywhere on the dial, thus taking the tare of the milk pail, etc. They are made with pounds divided in ounces or decimally.

No. 260 M. O. 30 lbs. by 1 oz...... No. 270 M. O. 60 lbs. by 2 oz...... No. 260 M. D. 30 lbs. by $1-20$ lb... No. 270 M. D. 60 lbs. by $1-10$ lb...

PRICE $\$ 3.00$

3.50

3.25 3.70 The "Facile, Jr.," Babcock Milk Tester

An exceedingly simple, light, compact and carefully designed apparatus, especially

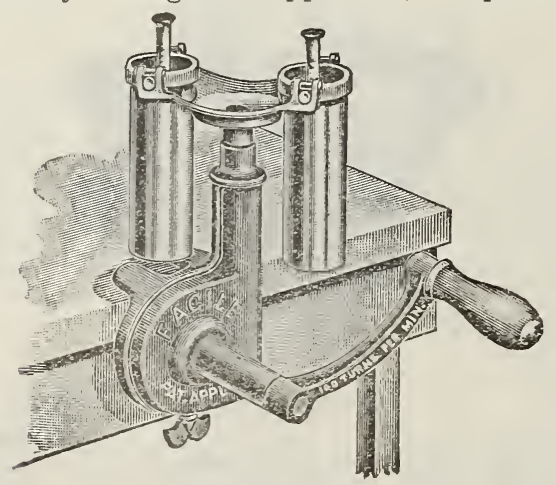

adapted to the use of the dairy, and also, on account of its light weight, to the traveling dairy inspector.

Complete with full set of glassware, consisting of test bottles, pipette and acid measure; also test bottle brush and bottle of acid, with full directions for use.

2-bottle machine complete for testing cream and milk, including two cream test bottles and combined pipette. . \$\$ $\$ .50$ 4-bottle machine complete for testing cream and milk, including two cream test bottles and combined pipette...

\section{The "Facile" Improved Iron Frame Hand Babcock Milk Tester}

\section{Condensed Description}

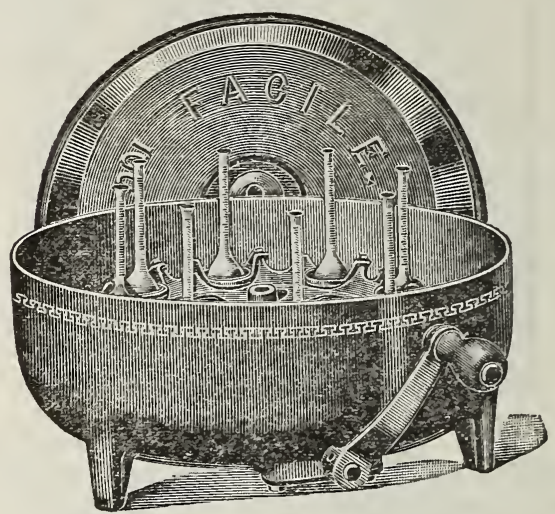

Handsome cast-iron case and cover, cut spur and worm gearing, malleable iron bottle carrier, seamless brass detachable swinging pockets for holding test bottles.

Enclosed gearing, bottles perfectly horizontal when rotating. Turns easily and runs smoothly and noiselessly at a very high speed.

$\ldots \ldots \ldots \ldots . . \ldots \ldots$

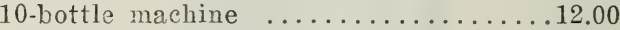

12-bottle machine .............. 14.00

Prices include full set of glassware, comprising test bottles, pipette and acid measure; also test bottle brush and bottle of acid.

\section{Butter Paper}

We handle exclusively the Pinneer Brand of high-grade vegetabie parchment paper and guarantee it to be the rery best obtain able. We solieit corresponderce for large or small quantities in any sizo, plain, or printed with special design. 


\section{DAIRY SUPPLIES}

(Continued)

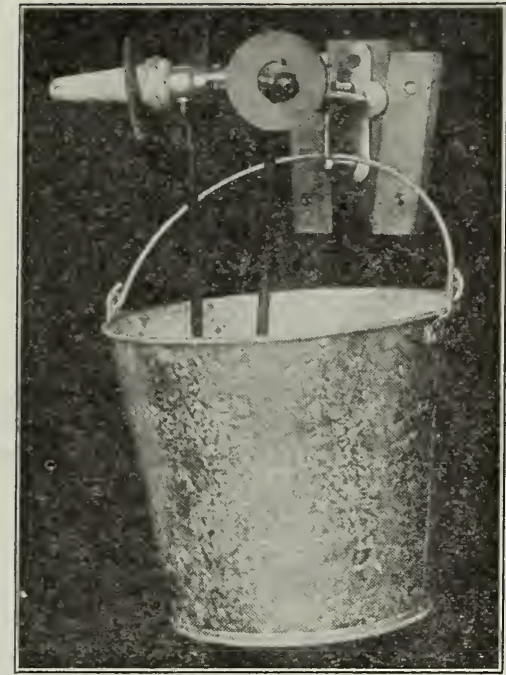

\section{COIMMON SENSE CALF FEEDER}

WHAT IT IS. The Common Sense Calf Feeder is a simple practical device for weaning and feeding calres, so simple and so practical that every calf owner will see the value of it at a glance.

WHAT IT DOES. It enables you to feed the calf out of a bucket in nature's old way. If you could afford to let your calf run with the corv until nature compelled it to seek food elsewhere, there would be no scouring, unhealthy calves.

Follow nature; this feeder not only saves trouble and milk, but it prevents the calf from taking its food in the great gulps that play havoc with the digestive organs.

Price

Extra nipples

$\$ 2.50$

\section{Arabian Scratch and Gall Cure}

It is a scientific remedy for scratches and grease heel. It works as horsemen like to have it. 4-oz. pkg., .25c.; 8-oz. pkg., .50c.

\section{Bag Balm}

Cures chapped, cracked and sore teats, bunches, caked bag, chafing, cuts and inflammation.

Price, per Box, $\$ 0.50$

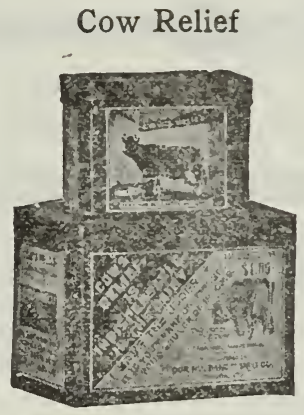

It is used as a local application on cows' bags and teats. It will cure caked bags in 12 to 24 hours, if taken at the start. $1 \frac{1}{2}-\mathrm{lb}$. pkg., $\$ 1.00$.

\section{Calves' Cordial}

Is free if it fails to cure scours in cows and calves. 2-lb. pkg., .50c.

\section{Kow Kure}

\section{The Great Medicine for Cows Only}

It acts upon the digestive, generating and milk-secreting organs, keeping the entire system toned up and in perfect working order. It goes to the roots of trouble, and cures cow diseases by removing the cause.

It prevents abortion, cures barrenness, removes retained afterbirth, prevents tuberculosis, stops the scours, cures milk fever, caked udder, swelling in the bag, bloating, red water, increases the flow of milk, cures cows "off their feed," improves the quality of milk and makes cows pay.

Price, . $50 \mathrm{c}$. and $\$ 1.00$ per can

\section{Grange Garget Romedy}

Positively cures garget without in any way injuring the cow or lessening the flow of milk, and tones and invigorates the affected parts.

\section{Price, .50c. per can}

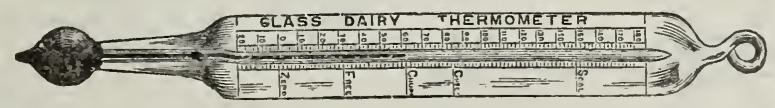

\section{Dairy Thermometers}

PRICE 


\section{DAIRY SUPPLIES}

(Continued)

The "Boston" Aseptir Milking Tube

$21 / 4$ in., self-retaining. Exact size... $\quad \$ 0_{25}$

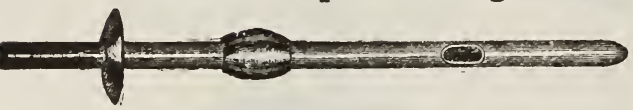

The "Boston" Aseptic Teat Dilator

(Di. Murpby's Modification)

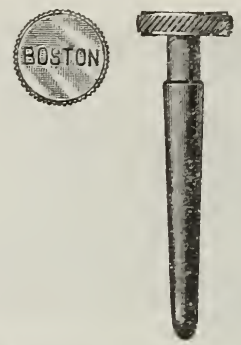

No More Hard Milkers

"Spider" in the teat is easily cured, and sphineter paralysis entirely disappears after a few days' use. Recommended by veter inarians and dairymen.

Price, 25c. each

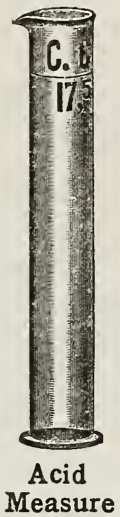

Conn. Style

Cream Test

Measure

$\$ 0.20$

Milk test bottles, 10 per cent, each.

Cream test bottles, 0 to 50 per cent

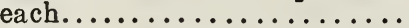

Ohlison's skim milk bottles, each...

Milk and cream pipettes, each......

Acid measure, each.............

Test bottle brush...............

.05

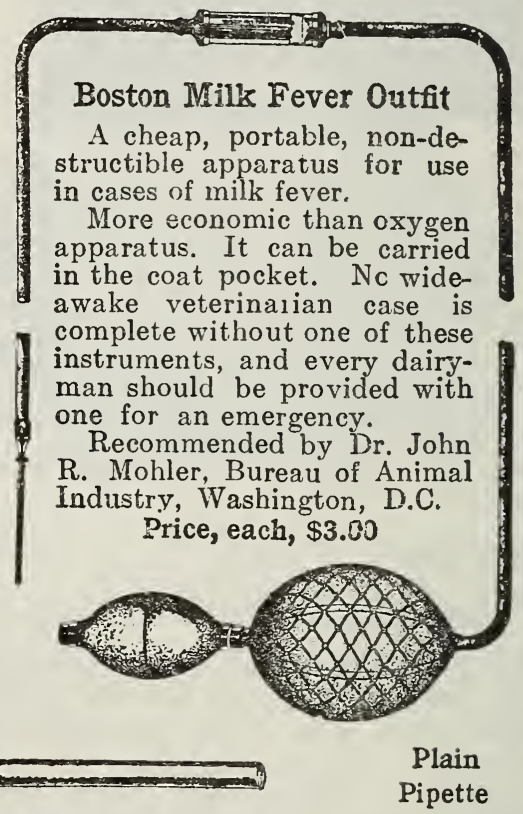

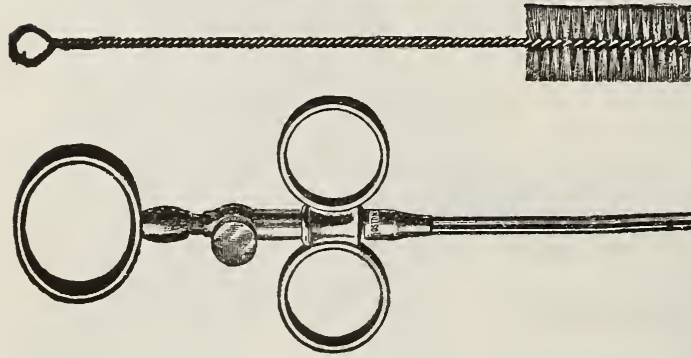

\section{"Boston" Aseptic Stricture Cutter}

An Essential for Every Dairyman

The Boston is modeled on improved lines, and embodies the highest class of workmanship and utility, yet is so simple that professional assistance, while always desirable, is not necessary.

Price, each, $\$ 1.50$ 


\section{STABLE GOODS}

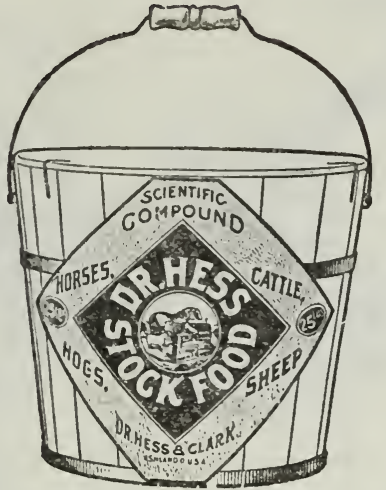

DR. HESS' STOCK FOOD

Is the most paying condiment or medicated food ever given to Horses, Cattle, Hogs or Sheep.

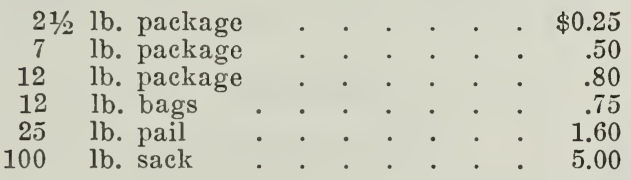

\section{DR. HESS' HEALING POWDER}

Cures Galls, Heals and Prevents Proud Flesh. 4 oz. pkg. .25c.

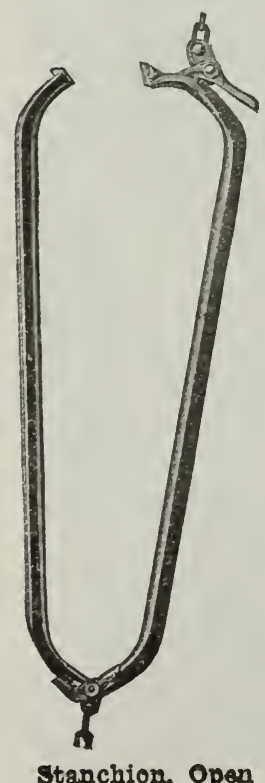

\section{PORTER STEEL STANCHIONS}

Are made of steel and malleable iron and will last a life time. They insure the greatest degree of comfort possible to cattle when in stable. We believe them to be the best cow stanchions on the market.

\section{Price}

Porter's Steel Stanchions, each . . $\$ 1.60$ Doz., . . . . 18.00
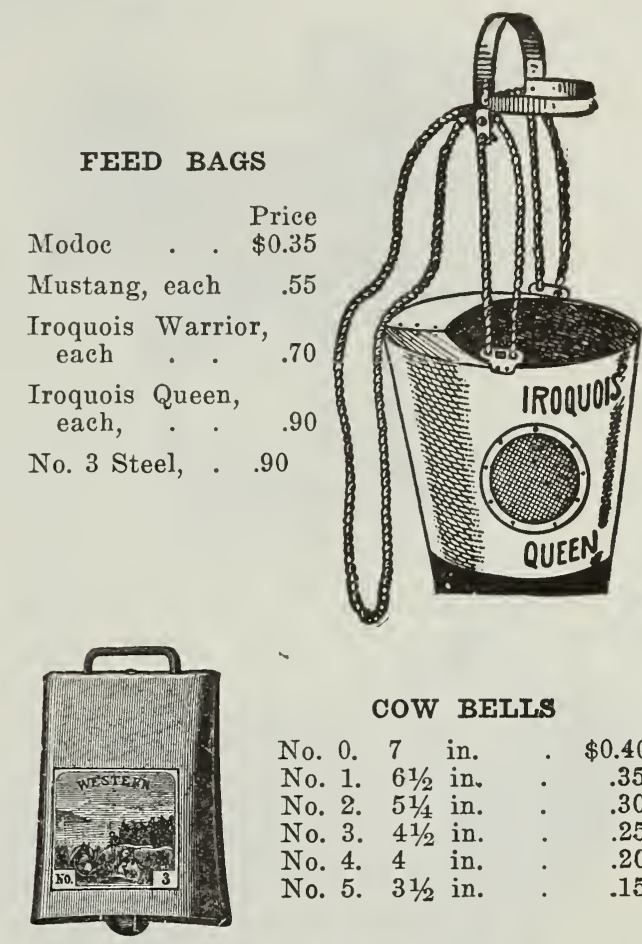

\section{COW BELIS}

No. 0. 7 in. . $\$ 0.40$

No. 1. $61 / 2$ in. . $\quad .35$

No. 2. $51 / 4$ in. . $.30^{\circ}$

No. 3. $41 \%$ in. . $\quad .25$

No. 4. 4 in. . .20

No. 5. $3 \frac{1}{2}$ in. . . .15

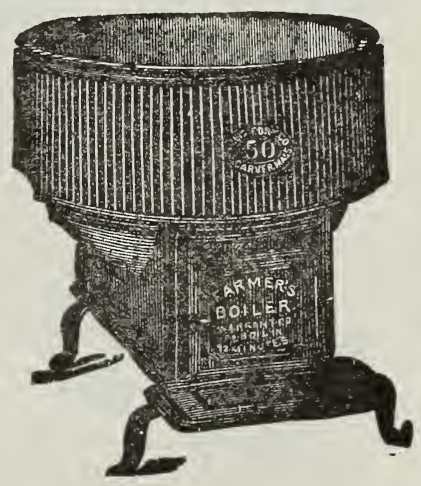

FARIERS' BOILERS

A Low-Priced Farmer's Boiler

Unsurpassed for general farm work.

$$
\begin{gathered}
\text { Net Cash Prices } \\
\text { For Wood }
\end{gathered}
$$

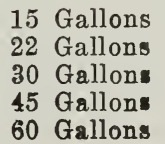




\section{STABLE GOODS}

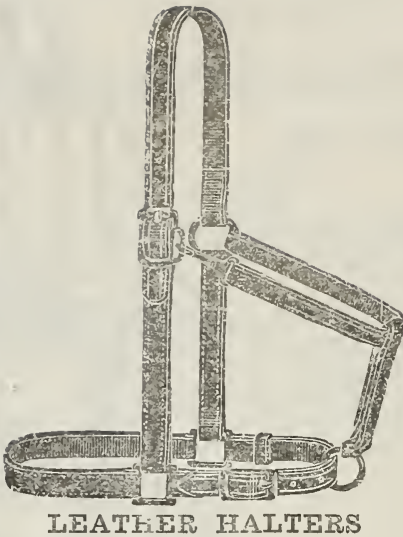

No. 27. Pusset or Black

Russet or Black, Riveter

$\$ 0.90$

Cattle Halters

No. 1 Fawn Web

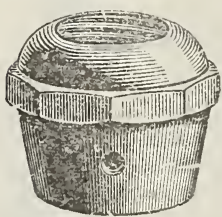

OX BAIIS.

\section{No. 11. Each}

No. 13. Each

No. 14. Each

No. 15. Each

\section{CATTLE CARDS}

No. 04. Leather Board

No. 4. All Leather

No. 3. Leather Bound . . .

No. 2. Leather large size

\section{CURRY COIMBS}

No. 5. Hunter's

No. 550. 6 Bars, close back

No. 500. 6 Bars, open back

No. 234,8 Bars, shingle back

Reform

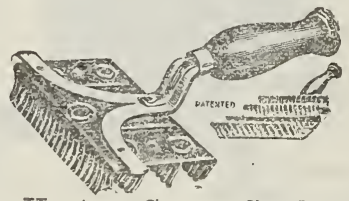

Funter Curry Comb

Ieather Bacis Horse Brushes

From 30 to 75 cents each, according to quality.

No. 0.

\section{Dancy Horso Brushes}

No. 10.

No. 40.

No. 75 .

No. 88.

No.415

London

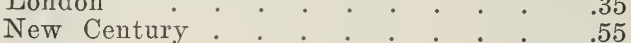

Imperial
(Continued)

\section{ROPE HALTERS}

No. 141. 1 Snap Jute. $\$ 0.15$

No. 132. 2 Snap .Tute. .25

No. 161. 1 Snap Sisal. .15

No. 162. 2 Snap Sisal. .25

No. 81. End Snap Jute. .10

No. 96. End Snap

Manila

.25

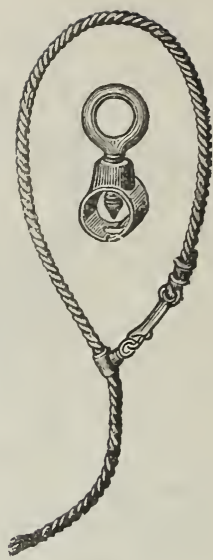

\section{BULI RINGS}

No. 21. 21/2-in. Copper . . . . $\$ 0.20$

No. 11. 21/2-in. Steel . . . . .15

\section{Bull Snaps}

No. 50

$\$ 0.35$

\section{CATTLE LEADS}

No. 52. Each $\$ 0.10$

\section{TRACE CHAINS}

$61 / 2$-Foot Straight

Link with Hooks .45

Half Trace

.35

No. 57. Imperial $1 / 2^{-}$

Trace with snap

and 2 ex. links

Price, .40e Pr.

Girting Chains

.25

\section{HATTER CHATNS}

No. 77. Sargent's

Price
0.077 . Price

$\$ 0.30$

\section{STAKE CHAINS}

$61 / 2$ ft. with Ring $\$ 0.55$

\section{COW CHAINS}

$21 / 2$ Ft. Open Ring $\$ .15$

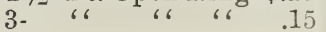

$31 / 2$ ، 6 6 618

4. ، 6 ،

$\begin{array}{lllll}41 / 2 & \text { ، } 6 ~ & 6 & .25\end{array}$

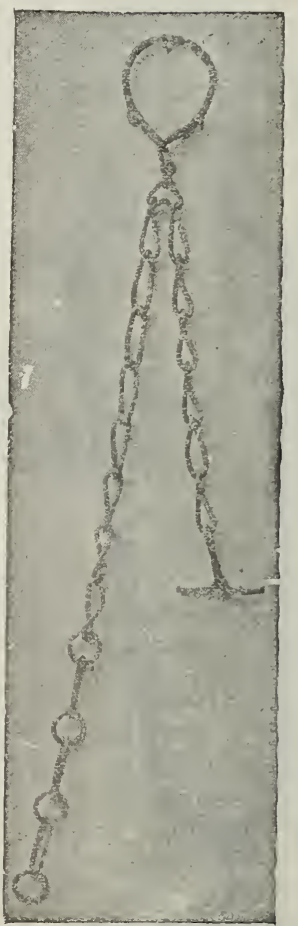




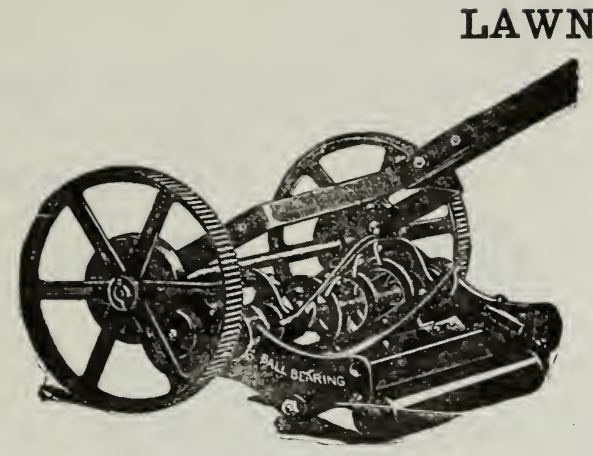

TOWNSEND'S VICTORY

We cannot offer a better mower at any price. It has Ball Bearings of the very highest grade exact to $1 / 4$ of $1-1000$ of an inch, which greatly reduces friction. Double Steel Ratchet, very swift and smooth in action, as well as exceedingly hard for durability. Triple Gear. Entirely enclosed, allowing no dirt or cut grass to find its way into the pinions or cogs.

16-in., $\$ 8.50 ; 18$-in., $\$ 9.00 ; 20$-in., $\$ 9.75$

\section{TOWNSEND'S DERBY}

A first-class, high-grade Mower with closed wheel and frame-two gear principle Ball bearings of the very highest grade. Micrometer adjustment for cones and Ball Cups. One large threaded cone takes up all wear in the reel journals. Double Steel Ratchet. Lower Blade of crucible steel hardened and tempered.

14 in., $\$ 5.75 ; 16$-in., $\$ 6.25 ; 18$-in., $\$ 6.75$

\section{GRAND HIGH WHEEL BALL BEARING}

Look at the only patent reversible blade ever put into a lawn mower.

Made in one piece of channelled crucible steel, this blade is far stiffer and more serviceable than the ordinary old-fashioned flat knife.

The blade will last for years. If it's injured, it takes just twenty seconds to reverse it, by loosening the adjusting screws, and you have a practically new machine-two lawn mowers in one.

\section{Every one of}

\section{COLDWELL'S “GRAND” IAWN MOWERS}

is equipped with this great feature.

The first cost of an ordinary lawn mower may be less, but because a "GRAND" stays out of the repair shop and is always ready for grass-cutting, it's the cheapest in the end.

The name "COLDWELL GRAND" sig. nifies perfection in lawn mower building.

16-in., $\$ 9.25 ; 18$-in., $\$ 10.00 ; 20$-in., $\$ 11.00$

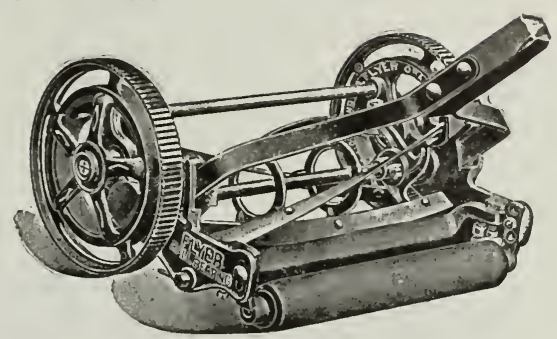

TOWNSEND'S FLYER

A splendid High-Grade Mower at a little lower price than the "Victory." Ball bearings entirely enclosed. Adjustments very simple. Knives very hard and of the best steel.

14-in., $\$ 5.00 ; 16$-in., $\$ 5.50 ; 18$-in., $\$ 6.00$

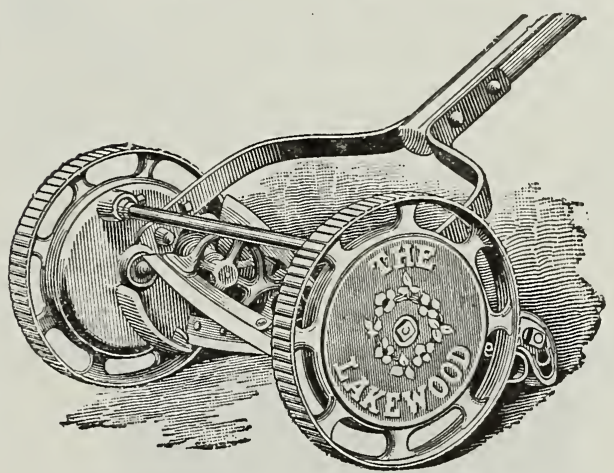

THE IAKEWOOD

Ball Bearing.-(9-inch Wheels.)

The best medium priced Ball Bearing Mower on the market.

The strongest feature of this machine is the simple but positive and reliable adjustment of the bearings.

16-in., $\$ 5.75 ; 18$-inch., $\$ 6.25$

\section{THE NEWPORT}

Similar to the Lakewood, but has Brass Bearings in place of ball bearings. The Revolving Cutter and Bottom Knives of the Newport and Lakewood Mowers are of the same quality and weight as used on many High Grade Mowers of other manufacture.

$$
16 \text { in., } \$ 5.50 ; 18 \text {-in., } \$ 6.00
$$

\section{THE CADET.- (8-inch Wheels.)}

A thoroughly good Mower at a low price. It has large Driving Wheels, Brass Bearings, Patent Flexible Bottom Knife and Ratchets, and Adjustments equal to those used in many makes of High Grade Mowers.

14 and 16-in., \$2.50; 18-in., \$2.75 


\section{LAWN MOWERS}

(Continued)

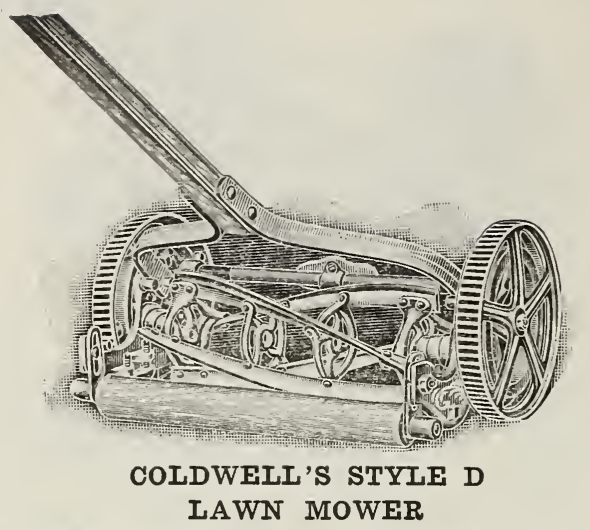

This is the best low priced Ball Bearing Lawn Mower on the market. It is made by the Coldwell Lawn Mower Co., of Newburg, N. Y., who have the reputation of turning out nothing but the best in the Lawn Mower line. This machine has four revolving blades 10 in. drive wheels and Ball Bearings. Handsomely finished in black and gold.

Price 14 in., $\$ 4.60 ; 16$ in., $\$ 4.75 ; 18$ in., $\$ 5.00$
COLDWELL'S STYLE F LAWN MOWER

Same as the Style D except it has 9 in. wheels and 3 revolving blades.

Price 14 in., $\$ 3.75 ; 16$ in., $\$ 4.00 ; 18$ in., $\$ 4.25$

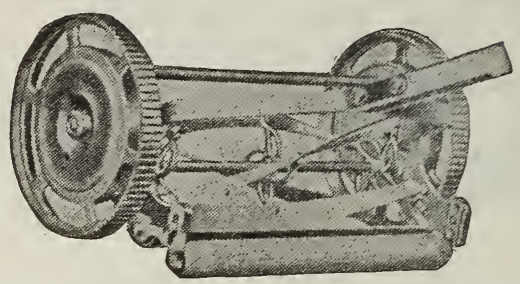

REINDEER BAIL BEARING

10-inch Wheels. Five Revolving Blades. Self-sharpening.

Highest grade ball bearing parts made of solid cone steel thoroughly hardened and ground. Dust proof.

Cutter Bar has patent screw adjustments. Parts machined and fitted. Noiseless in operation. Fully warranted.

Handsomely finished in flat black and gold.

Sizes: 16 and 18 inches. 16 in., $\$ 7.00 ; 18$ in., $\$ 7.25$.

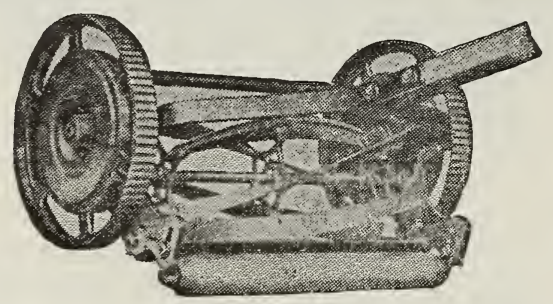

\section{GREYHOUND}

Plain Bearings. 10-inch Wheels, 4 Blades. Self-sharpening.

Built with adjustable brass bushings for taking up wear.

Cutter Bar has serew adjustments.

Noiseless in operation; fully warranted.

Finished in light green and gold. Beautifully decorated.

Sizes: 16 and 18 inches. 16 in., $\$ 5.50 ; 18$ in., $\$ 5.75$.

\section{Townsend's Horse Roller Mower}

The points of advantage are as follows:

Triple Rolls, which keep the blades in motion while turning sharp corners.

Instant change of height of cut, operated by lever close to driver's seat.

Large Rolls, insuring great power and ease of movement.

Instantaneous control of blades, for throwing mower in or out of gear.

Self-aligning jou rn a l boxes and a spacious foot rest.

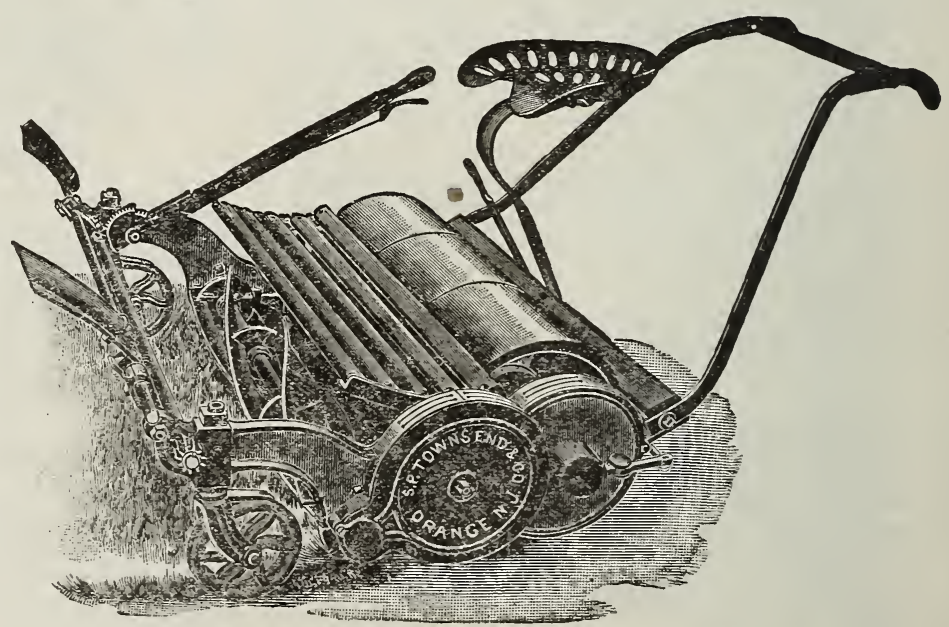

Write for prices and circulars. 


\section{GIFFORD-WOOD CO. ICE TOOLS}

\section{DAIRYMEN'S ICE KING PLOWS}

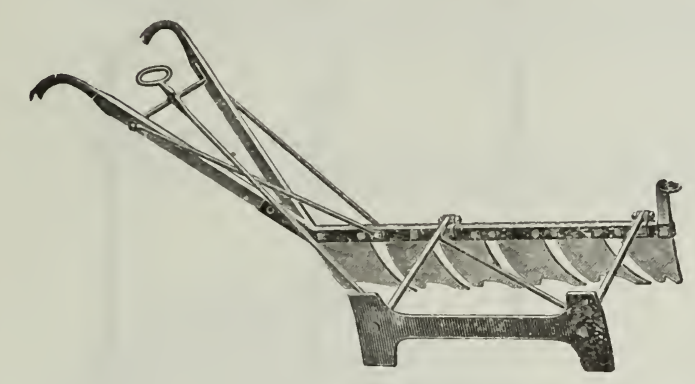

No. $320-8$ in., 5 eutting and 1 Clearing Tooth with 14 to 22 in. Patent Adjustable Swing Guide. Price, $\$ 28.00$

No. 321-10 in., 5 Cutting and 1 Clearing Tooth with 14 to 22 in. Patent Adjustable Swing Guide. Price, $\$ 33.00$. No. 315-8 in. "Ice King's" 5 cutting teeth and clearing tooth with 22-in. Swing Guide.

No. $316-10$ in. "If $\$ 250$ Kings," 5 cutting teeth and clearing tooth, with 22-in.

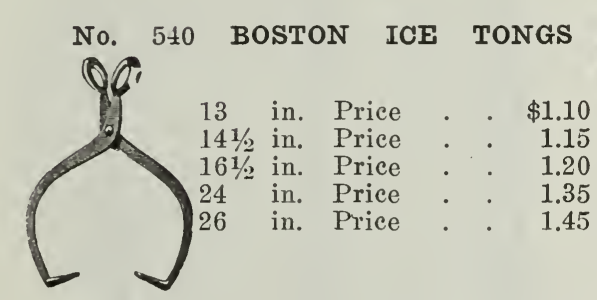

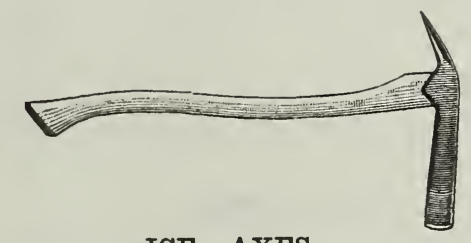

ICE AXES

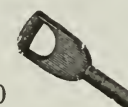

Swing Guide. $\$ 30.00$

No. 604 Boston Ice Axes. Price, \$1.70

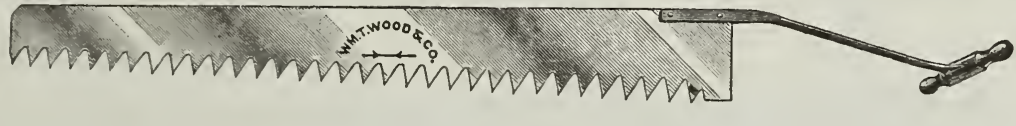

No. $421-4 \frac{1}{2} \mathrm{ft}$. Saw with Case, price

No. 40 WOOD'S HAND PLOW

Useful in marking first line on Ice Field.

Price, $\$ 16.50$

\section{ICE SHAVER}

No. 652 D Handle 4 Point Shaver. Price $\$ 1.75$

No. 667 D Handle 3 Tine Breaker. Priee, 3.00

No. $422-5$ ft. Saw with Case, price . . . . . 5.50

No. $426-41 \frac{1}{2} \mathrm{ft}$. Saw without Case, price . . . . 4.75

No. 427-5 ft. Saw without Case, price . . . . 5.00

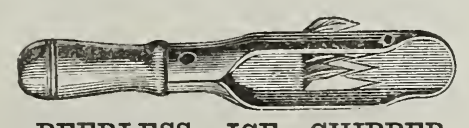

PEERLESS ICE CHIPPER

Ice in a freezer should be chipped fine and uniformly, so that it will mix well with the salt as this insures the best packing. The Peerless Ice Chipper is the best tool for the purpose. 


\section{GIFFORD-WOOD CO. ICE TOOLS}
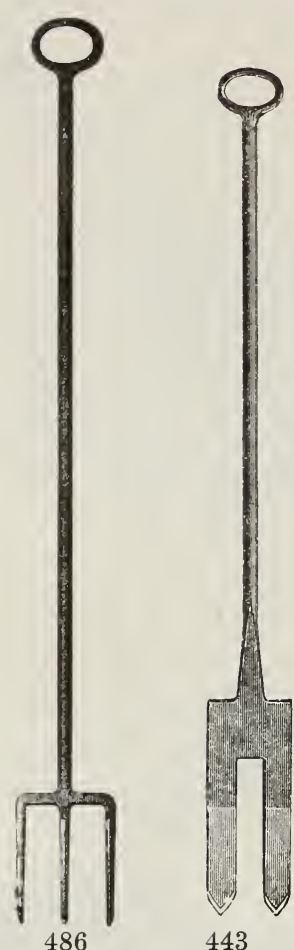

(Continued)
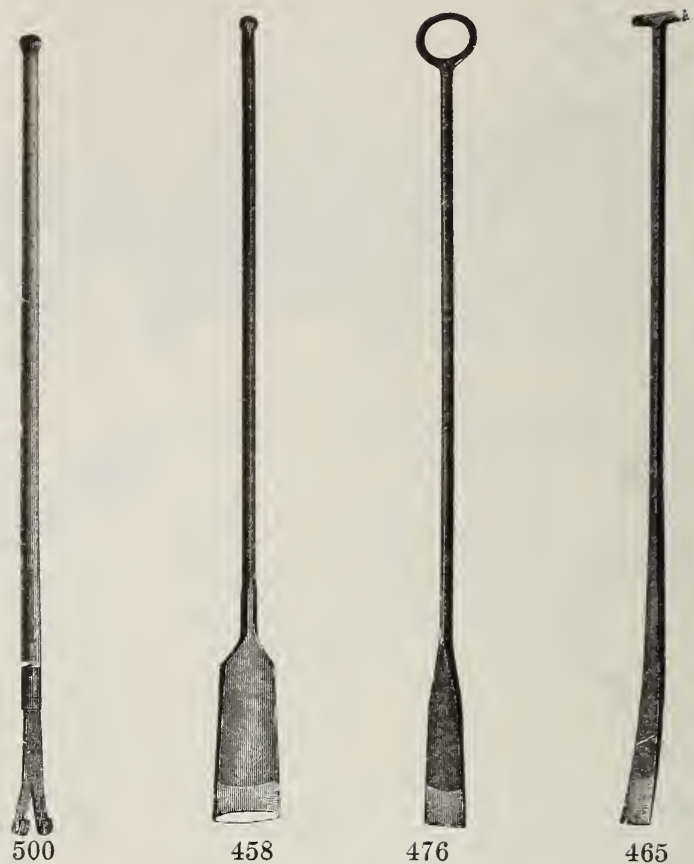

No. 486 Ring Handle 3 tined Needle Bar Price, each

"، 443 Ring Handle Splitting Fork

" 500 Line Marker

" 458 Bar Chisel

“ 476 Ring Handle Splitting Chisel

“ 465 Starting Chisel, regular pattern

No. 454 Breaking Bars . . . . $\$ 3.50$

“ 457 Calking Bars . . . . . 2.50

No. 520 Wood's $3 \mathrm{ft}$. to $18 \mathrm{ft}$. $\$ 0.75$ to 1.70

ICE HOOKS

" 460 Summer Bars . . . 5.00

“ 468 Socket Chisel . . . . $3.50 \quad 3 \mathrm{ft}$. to $14 \mathrm{ft}$.

ICE HOOK HANDLES

We have a very complete line of Ice Tools, cheaper in prices than Wood's

HUBBARD'S FERTHIZER is a leader with us. We are surely in position to quote you attractive prices in either Ton or Car lots

We also have the finest line of GARDEN and FARM IMPLEMENTS to be found east of Boston. See our Implement Catalogue, or better still, call and examine them. 


\section{SIMONDS CELEBRATED SAWS}

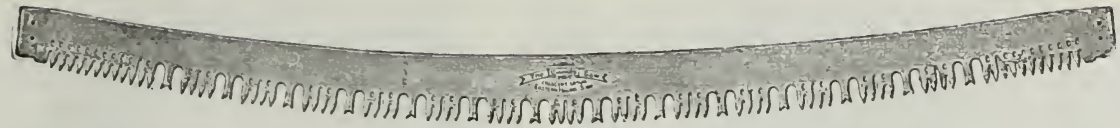

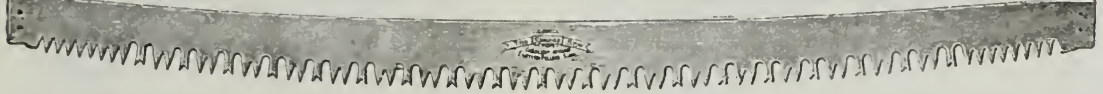

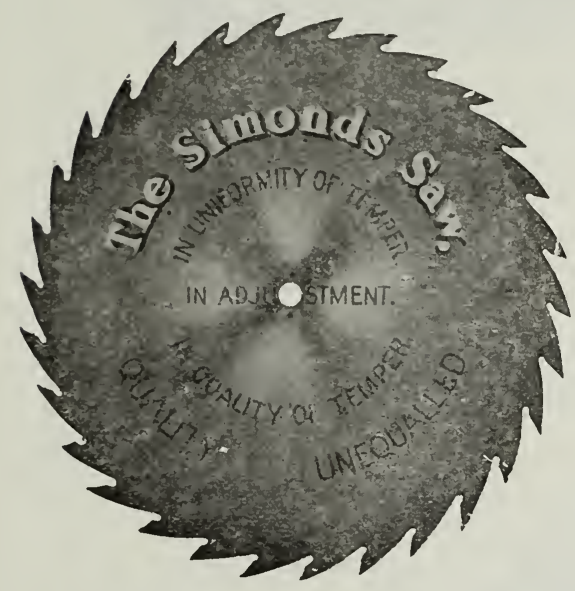

Wood Saw Webs, Wood Saw Rods, C'ross ('ut Saws, any Style Tooth, Cross Cut Saw Handles, Crescent Saw Tools. Simonäs Saw Sets.

Prices on Cross Cut, One Man, Circular, and Wood Saws quoted on application.

\section{CRESCENT GROUND FELLING AND CROSS CUT SAWS}

('ireular Saws, Framed Wood Saws, Ice Saws, One Aan Saws, Hand Saws, Pruning Saws.

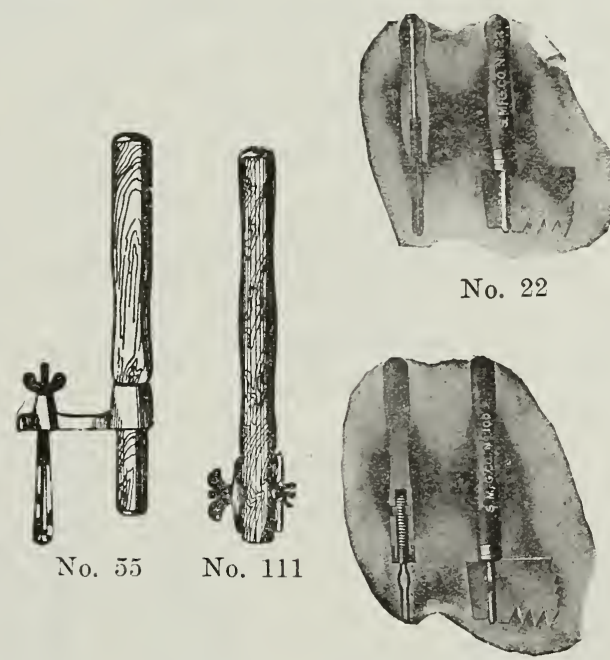

No. 100

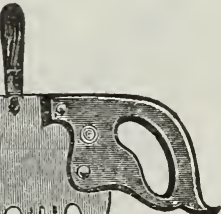

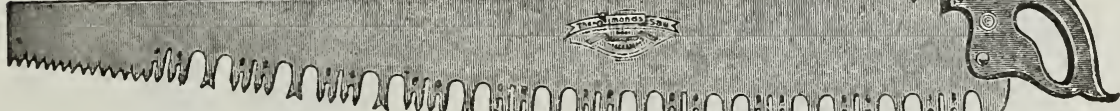

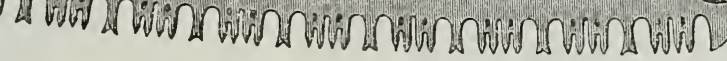

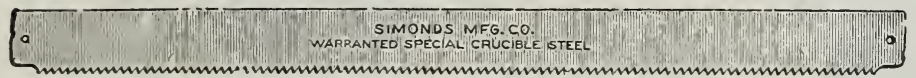

\section{CROSS CUT SAW} HANDLES

No. 22 . . 40c. Pr.

No. 100 . $20 \mathrm{c}$. Pr.

WARAATTEO SPECLAC MEG.CO.

No. $111:$ : 25e. Pr.

One man handle

30c. Each

One man supplementary handle

15c. Each 


\section{GALVANIZED}

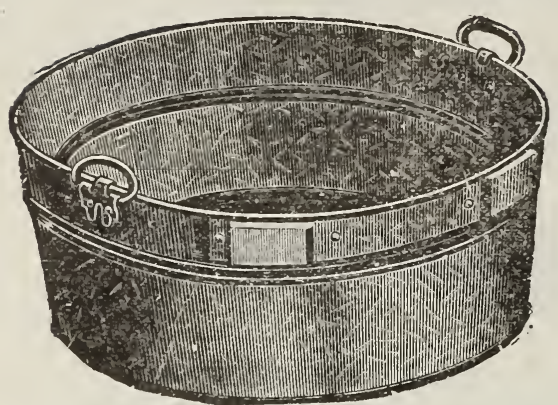

Galvanized Wash Tubs.

No. 11. $201 / 2 \times 173 / 4 \times 101 / 2$

No. 22. $223 / 4 \times 191 / 2 \times 11$

No. 33. $241 \frac{1}{2 \times 21} \times 11$

One Bushel Galvanized Baskets.

Price, each, .60c.

Galvanized Garbage Cans with Cover.

No. 00. 101/1 x12. Price . . . . $\$ 0.60$

No. 3. 14x14. Price . . . . .90

\section{Dust Pans}

No. 4. . . . . . . . . . $\$ 0.10$

No. 90. Steel Edge . . . . $\quad .20$

Galvanized Coal Hods.

No. 516, Price, .30c. No. 517, Price, .35c. No. 518, Price, .40c.

\section{Oil Cans.}

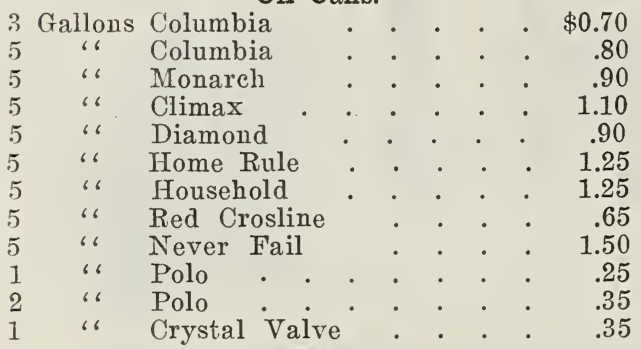

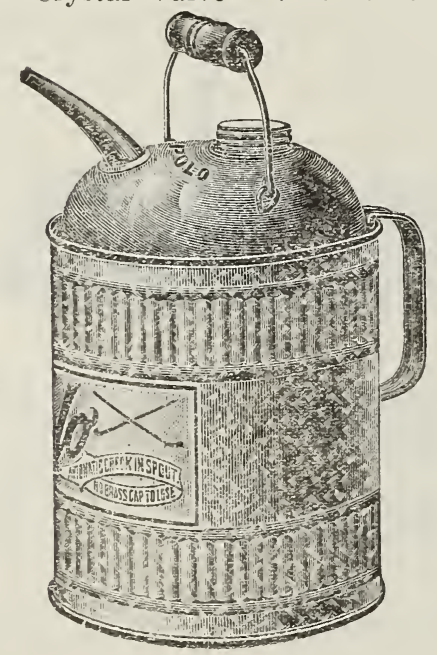

TINWARE

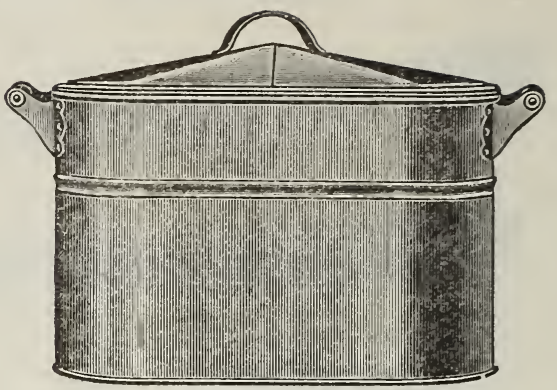

Wash Boilers

No. 8. $1 \mathrm{x}$ Tin Bottom . . . . $\$ 1.00$

No. 9. $1 \mathrm{x}$ Tin Bottom . . . . . 1.05

No. 9. 1xx Tin Bottom . . . . 1.15

No. 8. $1 \mathrm{x}$ Copper Bottom . . . 1.35

No. 9. $1 \mathrm{x}$ Copper Bottom . . . 1.45

No. 9. 14 Ounce, all Copper . . 3.50

\section{Perfection Oil Tanks}

Are made with galvanized top and kalamined bodies and give a steady stream and have detachable pump. Made in three sizes. 30 Gallon capacity . . . . each $\$ 6.00$

60 "، . . each 7.00 106 " 6 . . . each 12.00

Packed with set of 3 measures and one funnel.

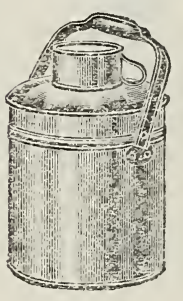

\section{Dinner Pails}

No. 030 . . . Price $\$ 0.45$

No. $040 . \quad$. . . . $\quad .50$

Ladies'. . . . . $\quad .30$

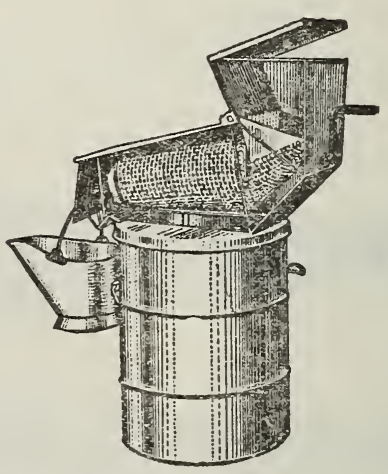

The Perfection Revolving Sifter

Sifts the coal clean without dirt or dust.

Perfection, . . . . Price $\$ 4.00$

Triumph,

Galvanized Chamber Pail

No. $31 / 2$. . . . . . Price, $\$ 0.40$ 
BASKETS

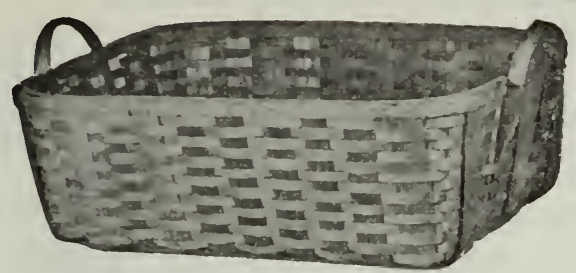

Ash Oblong Clothes Basket

Loop or Hole Handles

Small, .75c; Medium, .90c; Large, \$1.10.

Ash or Oak, Strapped Market Baskets, Hole or Bail Handle.

No. 1, .40c; No. 2, .35c; No. 3, .30c.

Grocers' Counter Baskets.

No. 1, .30c; No. 2, .25c; No. 3, .20c.

Open End Wood Baskets.

Cedar, Ash, Reed and Willow. Prices, .65 to $\$ 3.00$.

\section{Barrel Display Basket.}

Price, .35c.

\section{Ash Lunch Baskets.}

No. 1. $23 \times 13 \times 11$

No. 2. $21 \times 13 \times 9$

. $\cdot 50$

No. 4. $15 \times 9 \times 8$. • . . . . .45

No. 5. $14 \times 9 \times 71 / 2 \quad$. $\quad . \quad . \quad . \quad . \quad . \quad .40$

No. 6. $13 \times 8 \times 61 \%$. . . . . . $\quad .35$

No. 7. $12 \times 7 \times 6$

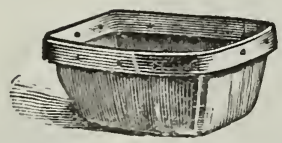

\section{Berry Baskets \\ All styles and sizes. Write for prices.}

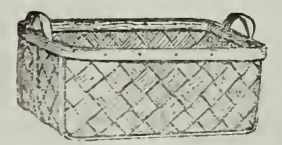

Oxford Clothes Baskets No. 1. Small, Price, .75 No. 2, Medium, $\quad .90$ No. 3, Large, 1.00

\section{Oxford Grocer Baskets}

$1 / 2$ bushel

\section{Round Oak Clothes Basket Price, .35c.}

\section{Laundry Baskets}

4 bushel, each $\$ 1.90 \quad 6$ Bushel, each $\$ 2.85$

\section{Ash Hampers, Covered}

No. 1. $21 \times 21 \times 29$ each $\$ 2.00$ No. 2. $171 / 2 \times 171 / 2 \times 26$

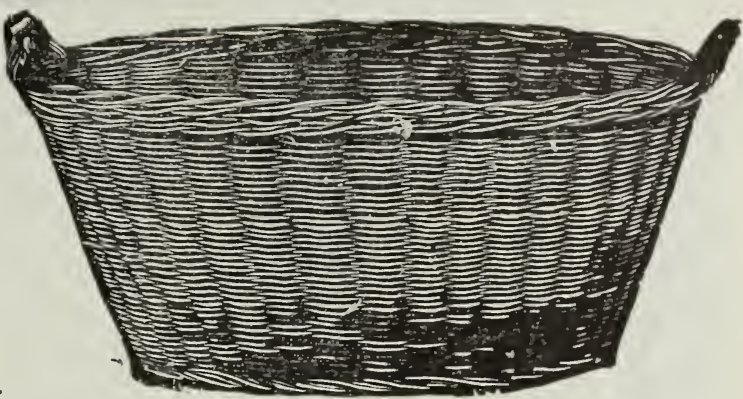

Oval Willow Clothes Baskets

Small . . . . . . . . . $\$ 0.70$

Medium . . . . . . $\quad .80$

Large $: .90$

Extra Large . . . . . . . . 1.00

Office Baskets

Reed, Grass and Willow.

Prices, .50c to $\$ 2.00$ each.

Lane's Canvas Wood and Coal Baskets

\section{Corn Packers' Baskets}

Price, $75 \mathrm{c}$

\section{Oak Baskets}

Round, Strapped and Nailed Rim

No. 1. $1 / 4$ Bushel . . . . each $\$ 0.25$

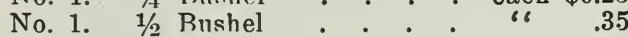

No. 1. 1 Bushel . . . . " 50

No. 1. 2 Bushel $\cdot .0 \%$

No. 2. 1 Bushel $: \dot{D}^{\circ} \cdot$ " $^{.45}$

No. 2. 2 Bushel : . . . “ 75

\section{Oxford Baskets}

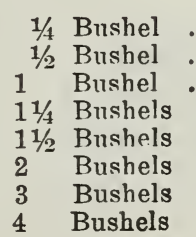

$$
\begin{aligned}
& \text {. . . . . each } \$ 0.25
\end{aligned}
$$

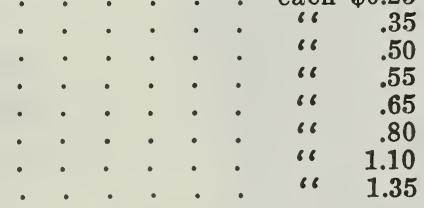

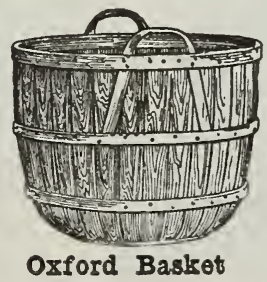




\section{Trellises, Tree Guards, Flower Pots, Etc.}

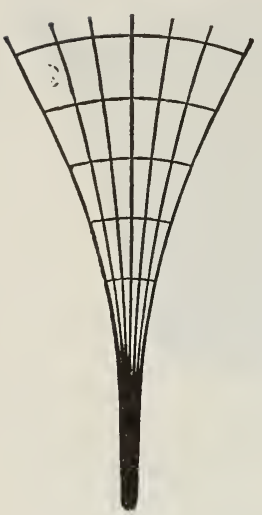

Fan Trellis

\section{Trellises} 2" " " 10 " wide . . . . \$.10

$21 / 2$ " “ 13 " “

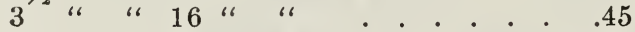

4 “ “ 427 “ “ . . . . . . .65

6 “ " 638 “ " 6 . . . . . . 1.00

8 “ " 86 “ 46 “ . . . . . 1.25

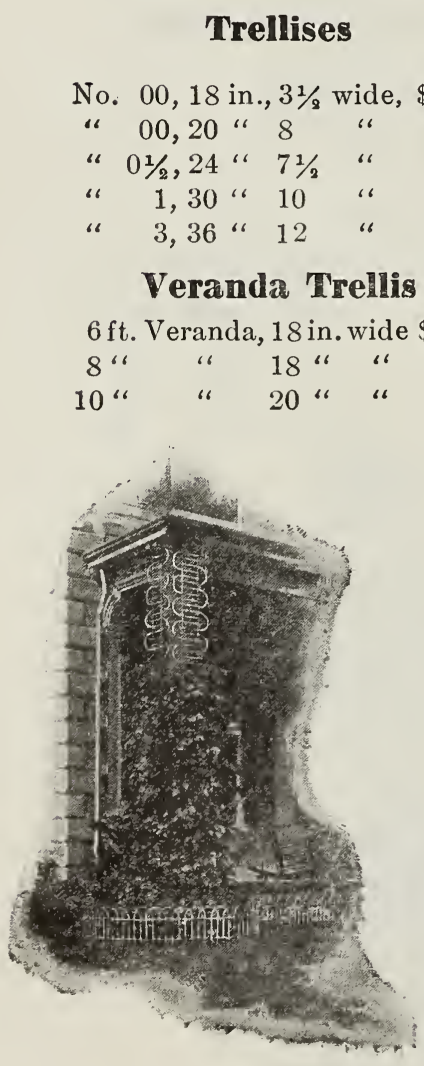

\section{Hartman Tree Guard}

Made from heavy galvanized wire and very ornmental, affording absolute protection to trees. Two or more may be used toget her for trees of large diameter.

No. 1, $6 \mathrm{ft}$., price $\$ 1.00$

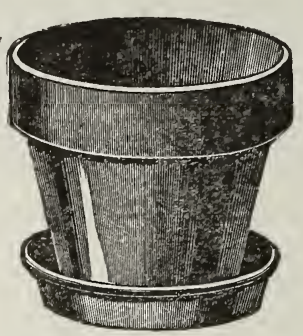

Unglazed Flower Fots

With or without saucers

Sizes 2 in. to 22 in.

Prices on application

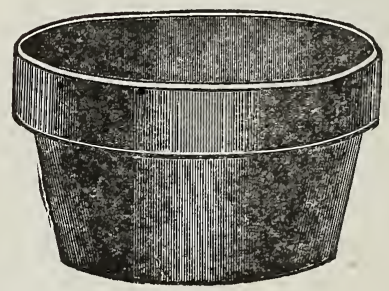

Unglazed Tulb Pans

Sizes 6 in. to

24 in.

Prices

on application

Hot Bed Therm 18 in. wide, ft. $8 \mathrm{c}$.

Fancy

Galvanized Wire Flower Bed Guard

$18 \mathrm{in}$. high, ft. $10 \mathrm{c}$.

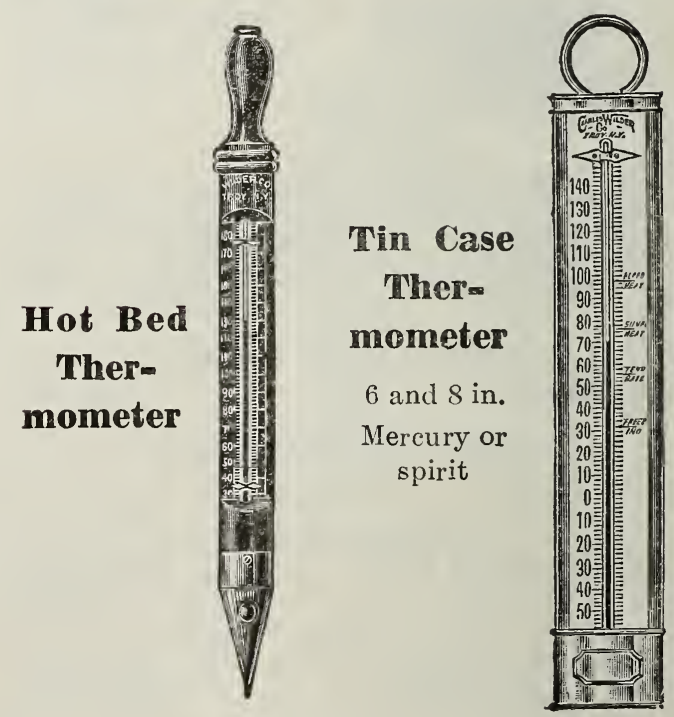




\section{Stoneware}
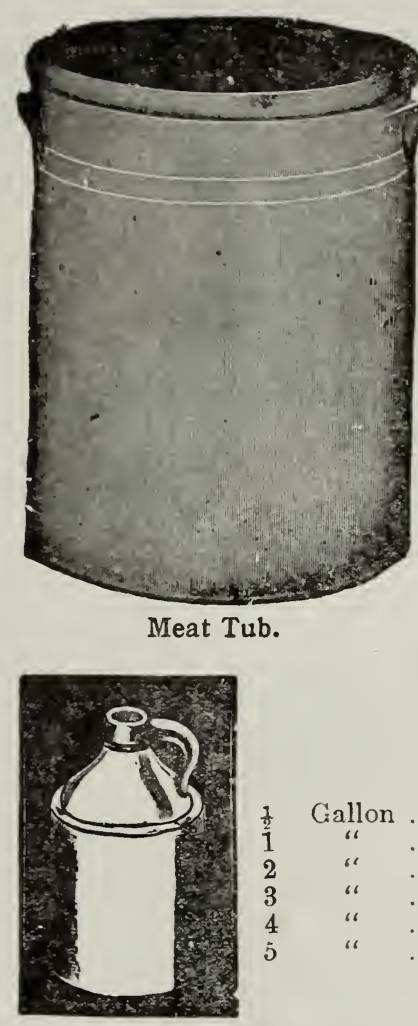

Jugs.

igh Butter Jars and Covers.

$\begin{array}{ll}1 \text { Gallon } \\ 11 / 2 & \text { " } \\ 2 & \text { " } \\ 3 & \text { " } \\ 4 & \text { " } \\ 5 & \\ 6 & \end{array}$

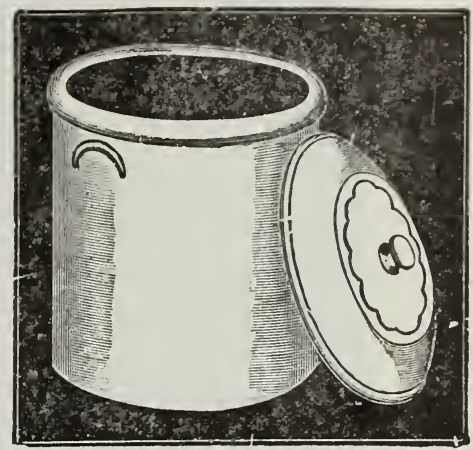

Bean Pots.
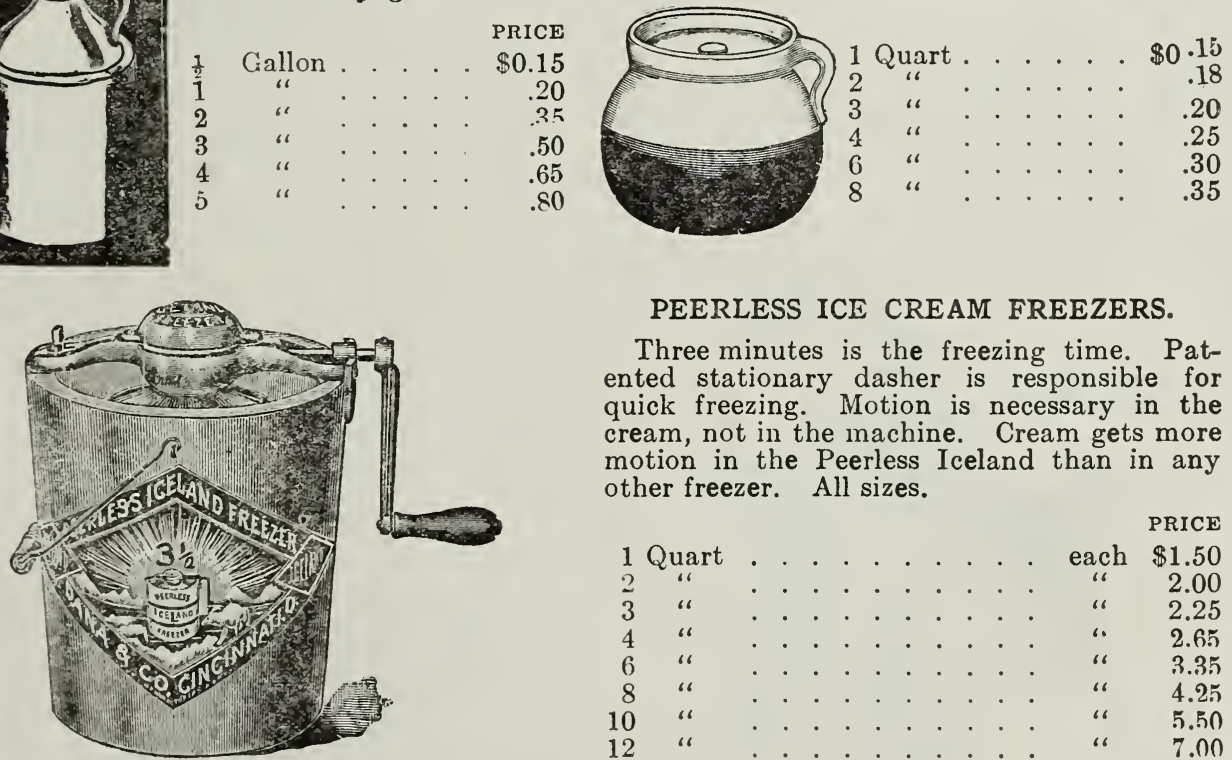

\section{PEERLESS ICE CREAM FREEZERS.}

Three minutes is the freezing time. Patented stationary dasher is responsible for quick freezing. Motion is necessary in the cream, not in the machine. Cream gets more motion in the Peerless Iceland than in any other freezer. All sizes.

\begin{tabular}{|c|c|c|c|c|c|c|c|c|c|c|c|c|}
\hline & & & & & & & & & & & & PRICE \\
\hline 1 Quart & - & & - & & - & & - & . & & & each & $\$ 1.50$ \\
\hline “ & $\cdot$ & . & • & • & ${ }^{\circ}$ & - & ${ }^{\circ}$ & - & . & • & " & 2.00 \\
\hline “ & $\cdot$ & . & . & • & . & . & . & . & $\cdot$ & . & “ & 2.25 \\
\hline “ & . & . & . & $\cdot$ & $\theta^{\circ}$ & . & • & . & . & • & “ & 2.65 \\
\hline “ & $v^{\circ}$ & . & . & - & ${ }^{\circ}$ & • & ${ }^{\circ}$ & . & . & $\cdot$ & $" 1$ & 3.35 \\
\hline “ & $\cdot$ & . & . & . & . & 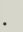 & . & . & . & . & "6 & 4.25 \\
\hline " & & . & . & . & . & . & . & . & . & . & 16 & 5.50 \\
\hline “ & & . & . & . & . & . & . & . & . & . & "6 & 7.00 \\
\hline
\end{tabular}

\section{INDURATED FIBRE WARE.}

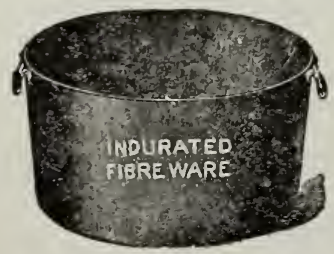

Tubs.

Spittoons.

Measures.

A Full Line of Fibre Ware.
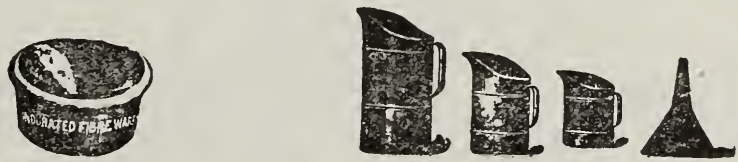
WOODENWARE

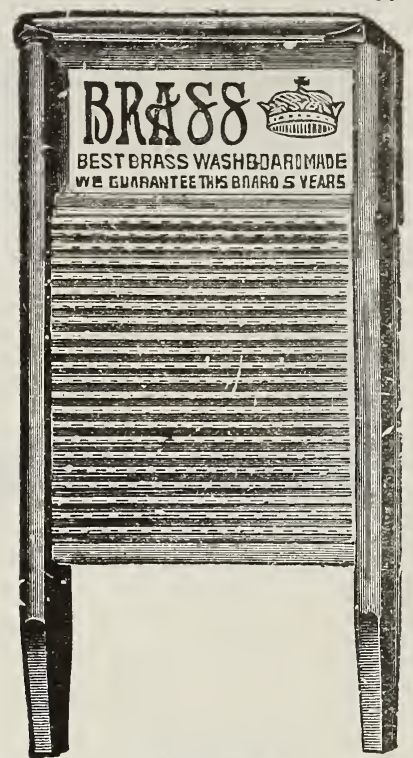

Washboards

No. 126 Ruby $\quad \begin{aligned} & \text { Price } \\ & \$ 0.30\end{aligned}$

No. 100 Northern Queen . . . . .40

No. 101 Tidal Wave . . . . . 30

No. 862 White Hen Glass . . . . .40

No. 800 Brass King . . . . . .45

No. $\mathrm{x}$ Plain Crimp ... .25

No. 130 Little Gem . . . . . . .15

No. 725. Naiad . . . . . . . .30

No. 570 Special Star : . . . $\quad .35$

No. 178 Blue Jay . . . . . . $\quad .40$

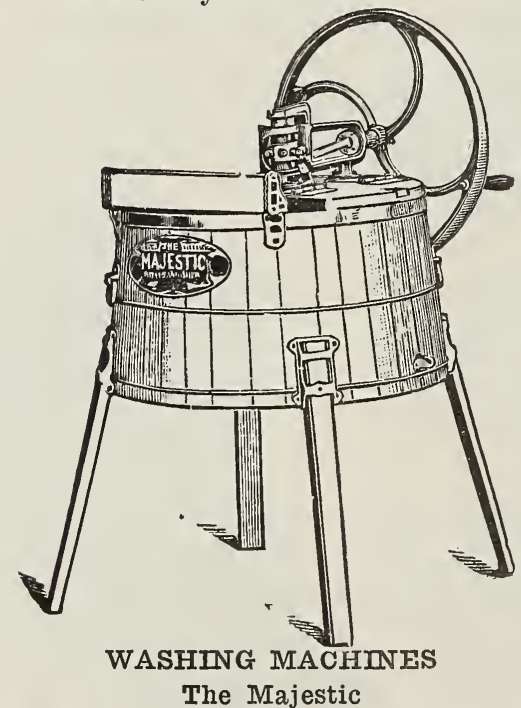

The Majestic has Roller Bearings, Virginia White Cedar Tubs, Electrically Welded Hoops. The best Washer made. Price, $\$ 6.25$
The Lightning Washing Machine

$\Lambda$ good first-class machine made of Virginia White Cedar.

Price, $\$ 3.75$

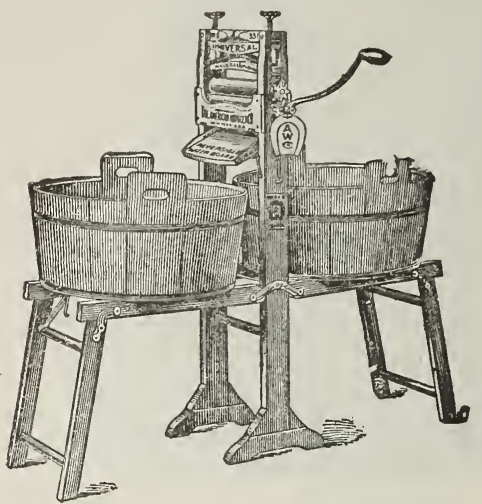

WRINGERS

American Wringer Company's Celebrated Horseshoe Brand.

No. 1050 Chemical, 5 year warrant, 10 in.,

No. 1081 Chemical, 5 year warrant, 11 in., $\mathrm{BB}$

No. 590 Royal, wood frame, 5 year warrant

No. 541 Royal, wood frame, 5 year warrant

No. 330 Universal, iron frame, 3 year warrant

No. 361 Universal reversible board B. B., 11 in. roll

No. 380 Universal, 3 year warrant. BB, 3.70

No. 380E Universal, enclosed gear, BB, 10 in., 3 year warrant

No. 381 Universal, 3 year warrant, BB 4.10

No. B380 Universal, with bench, 3 year warrant, BB,

No. B380E Universal, bench enclosed gear BB 10 in., 3 year warrant 5.10

No. 150 Household, wood frame, 1 year warrant

No. B150 Household, with bench, 1 year warrant

No. 100 Daisy, iron frame, 1 year warrant

Wringer Rolls and Repairs. 


\section{Woodenware}

(Continued)

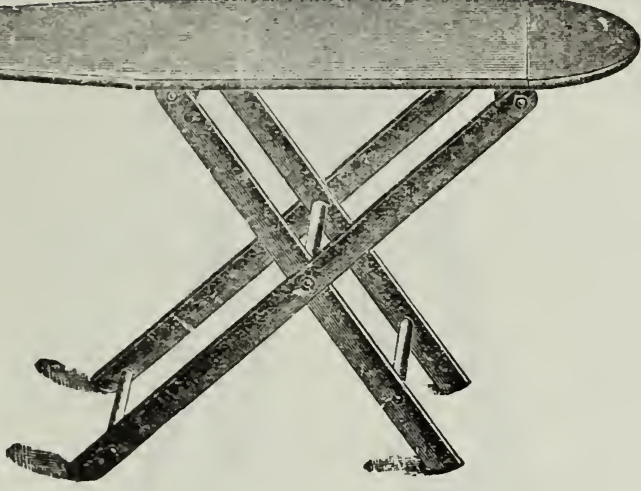

Folding Ironing Table.

Yo. $158 \times 19 \ldots$ each $\$ 200$

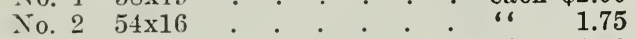

No. $354 \times 16$, Plain Top . . “ “ 1.50

Empire Wall Clothes Dryer Price, .65c.

Wash Benches

Boston

No. 1 Paris

\section{Wood Bowls}

1 in.

13 in.

15 in.

17 in.

19 in.

21 in.

Oak Butter Boxes with Bail

Large, 45c; Small .35c.

Skirt Boards

4 ft., each

$41 / 2 \mathrm{ft}$., each

5 ft., each

Spruce Clothes Horse

No. 3 , .80c; No. $3 \frac{1}{2}, .90 \mathrm{c}$; No. $4, \$ 1.00$.

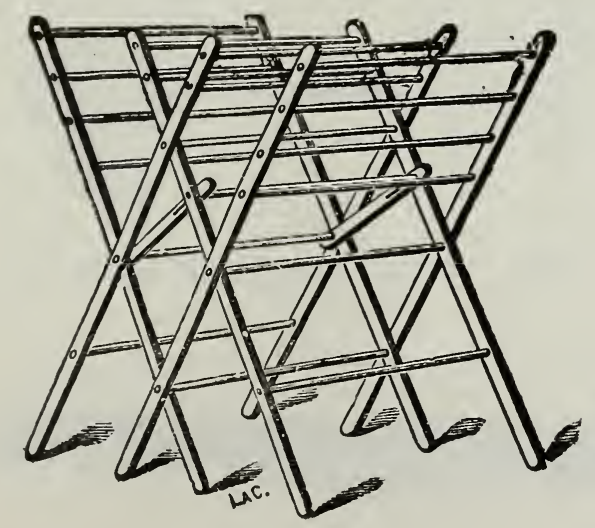

$\$ 0.10$

.20

.30

.50

.75

.90

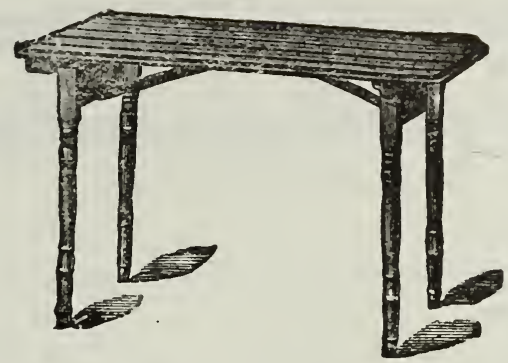

FOLDING SEWING TABLE.

No. 000. $36 \times 19$. . . . . each $\$ 1.00$

No. $\quad 0.36 \times 20$. . . . . . " 1.85

FOLDING CARD TABLES.

No. 21. $24 \times 24$. . . . . . . each $\$ 2.00$

No. $23.27 \times 27$. . . . . " 2.50

Pastry Boards.

$16 \times 22$, each . . . . . . $\$ 0.50$

$18 \times 24$, each . . . . . $\quad .60$

Selected Maple Chopping Trays.

No. $0.18 \times 10$. . . . . . . . $\$ 0.45$

No. 1. $191 / 2 \times 101 / 2$. . . . . . $\quad .50$

No. 2. $21 \times 11$. . . . . . . . . . $\quad .65$

No. 3. $22 \times 12$. . . . . . . . . . 80

No. 4. $231 / 2 \times 13$. . . . . . . . . 1.20

$19 \times 24$, each . . . . . . . . $\$ 0.65$

$22 \frac{1}{2} \times 27$, each . . . . . . 80

Sugar Buckets,

Oil Can $\mathrm{C}_{\mathbf{a}} \mathrm{ps}$,

Saw Bucks,

Barrel Covers,

Well Buckets Pickle Dippers

\section{LAWN SWINGS.}

No. 6. Favorite, two passengers . each $\$ 3.50$

No. 2. Fairfield, two passengers . " 4.25

No. 5. Fairfield, four passengers . " 5.25

No. 2. Paris Manufacturing Co.'s two passenger

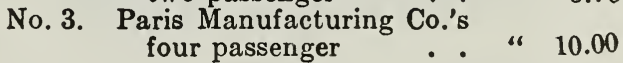

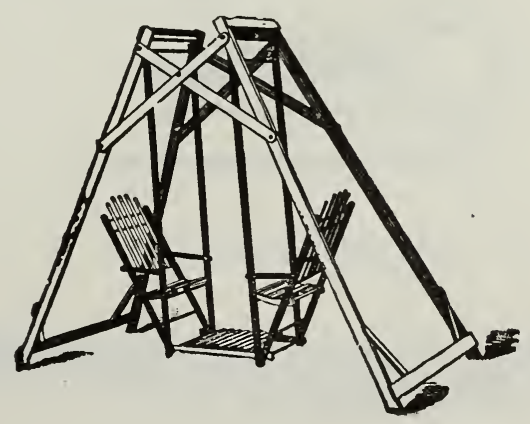




\section{LADDERS, SLEDS, ETC.}

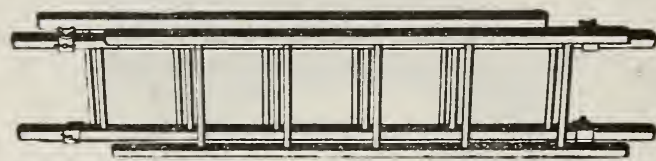

U. S. Extension Ladders

20 Foot

24 Foot

28 Foot

32 Foot

36 Foot

40 Foot

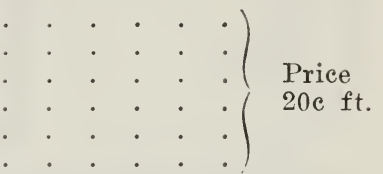

Common Ladders

10 to $18 \mathrm{ft}$

per ft. $\$ 0.12$

Apple Ladders

5 to $15 \mathrm{ft}$.

per ft. $\$ 0.12$

Step Ladders

Paris, 3 to $10 \mathrm{ft}$. . . . . per ft. $\$ 0.30$ Gem, 3 to $10 \mathrm{ft}$. . . . per ft. ${ }^{21}$

PARIS MANUFACTURING COMPANY'S CARTS, WAGONS, WHEEL-

BARROWS, SLEDS,

FRAIME AND CLIPPER

BABY SLEIGH'S AND SLED BOXES
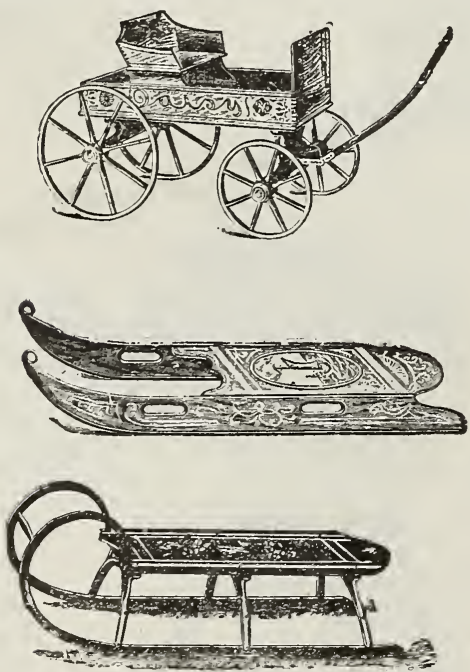
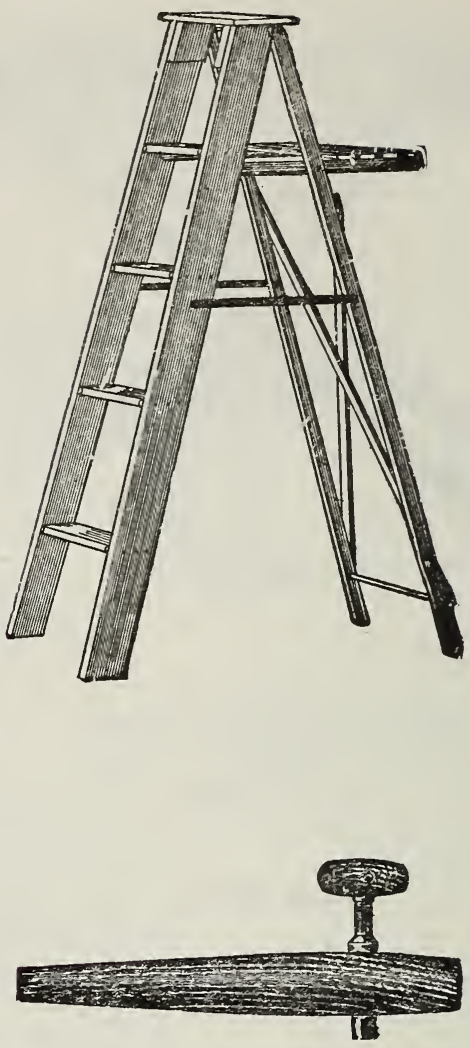

WOOD FAUCETS

6 in. Leather lined . . . . . $\$ 0.07$

7 in. Leather lined . . . . . . . . . . .

8 in. Leather lined . . . . . .10

10 in. Leather lined $\cdot . \cdot \cdot .0 .12$

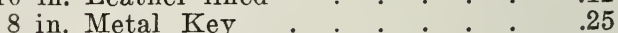

10 in. Metal Key . . . . . . .30

\section{TOBOGGANS}

Quoted on application.

\section{SKI}

All sizes and styles, quoted on application.
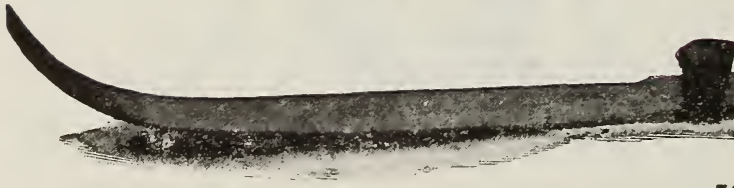


\section{BROOMS, BRUSHES ETC.}

Our line of Brooms is a carefully selected one, especially in the better grades.

\section{Whisk Brooms}

10 to 35 cents each.

Nail and Vegetable Brushes

No. 20, Price

No. T, Price

Handy House, Price

Stove Brushes

No. 31 Price . . . . . . . $\quad .25$

No. 41 Price . . . . . . . .25

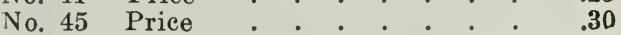

\section{Ostrich Dusters}

Ostrich, 12-in. to 16-in.

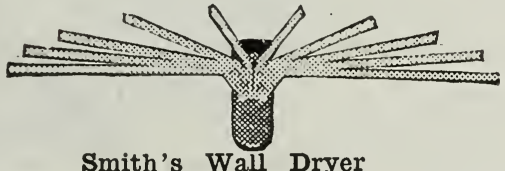

WALI DRYERS

Empire

Smith's

No. 1 Acme

No. 2 Acme

No. 3 Acme

\section{MOP STICKS}

No. 7. Ideal, .10c. No. 8. Ideal, .15c. No. 4 Trojan, 10c. No. 12. Heavy, .20c.
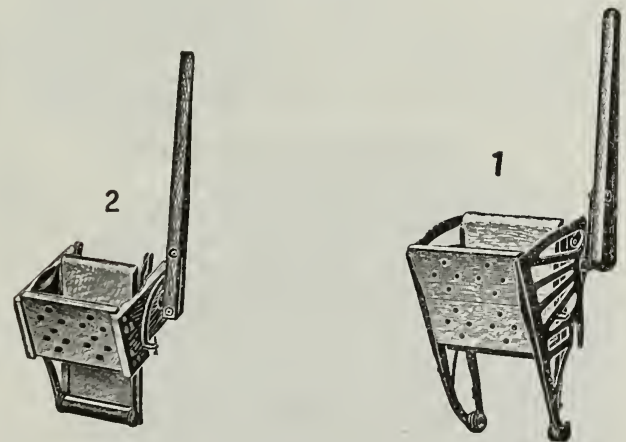

\section{THE WHITE PERFECTION MOP}

\section{WRINGER}

It is the most practical wringer made and will last from two to four times as long as any mop wringer made.

No. 1. Hotel size

$\$ 1.75$

No. 2. Family size

1.25

No. 3. Family size, Steel Frame . $\quad 1.50$
Window Brushes

No. 50 .

No. 60 .

No. 70 .

Shoe Brushes

No. 106.

No. 524 .

Counter or Dust Brushes-Set Bristles

No. 2

$\$ 0.25$

No. 3.

No. 4.

.30

No. 5.

Floor Brushes

No. 6

No. 10

1.25

No. 12 .

No. 14

No. A16.

No. A18.

1.75

2.75

3.00

Scrub Brushes

No. 0 . White

No. 1. White

$\$ 0.10$

No. 80. White

.18

.20

No. 90. Black .25

No. 70. 2 Row Rice Root . . . .08

No. 77. 3 Row Rice Root . . . 10
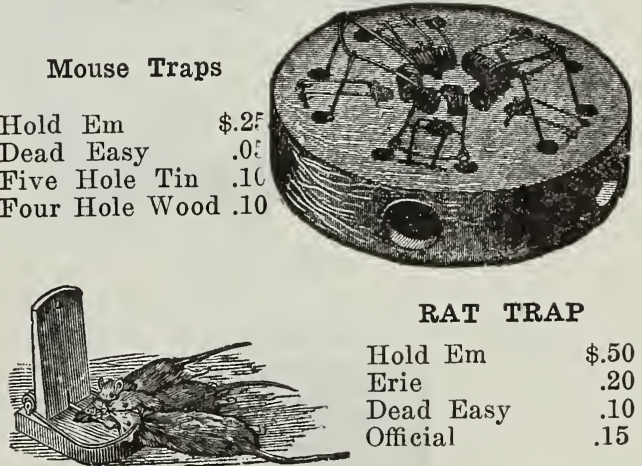

Erie Rat Trap

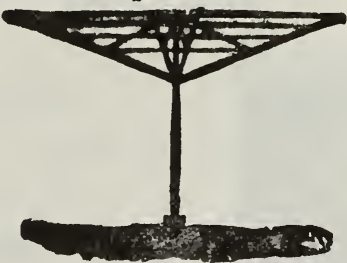

Outdoor Clothes Dryers

Manila or Cotton Line

N.o. 1. $110 \mathrm{ft} .4$ Line

$\$ 3.00$

No. 2. $150 \mathrm{ft}$. 5 Line $\quad$. $\quad$. $\quad 3.25$ 


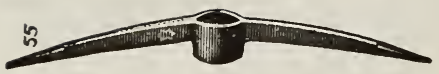

PICKS, MATTOCKS, ETC.

Wood Choppers'

Mauls

6 to $9 \mathrm{lbs}$

Price per lb., 9c.

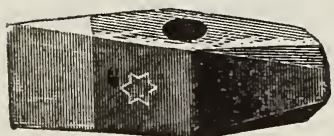

Wood Choppers Wedges

$31 / 2$ to $6 \mathrm{lbs}$.

Price per lb., $\$ .05$ c.

\section{Short Cutter Mattock}

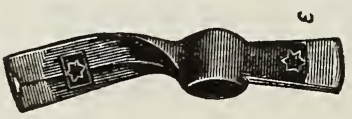

Price, .60c.

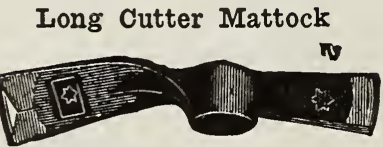

Price, .60c.

Pick Mattock

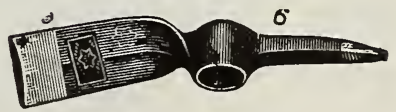

Price, .60c.

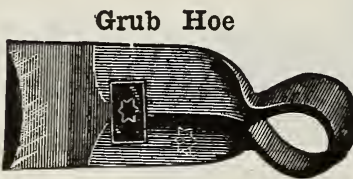

Price, .60c.

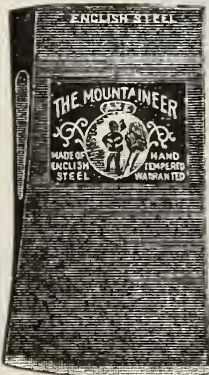

Crowbars

12 to $18 \mathrm{lbs}$

Price per lb., .05e

\section{AXES}

Geo. B. Haskell Co., King and Mountaineer in Maine, Half Wedge and Double Bit Patterns.
TRUCKS, ETC.

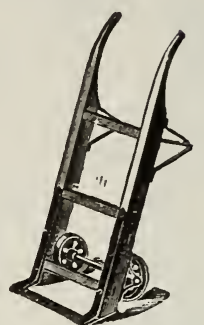

Price, \$2.15

Bag Trucks

Barrel Trucks

One Half and Full Troned.

Prices from $\$ 2.15$ to $\$ 5.50$

Heavy Barrel Trucks

No. 1 ,

No. 4 ,

Eureka 3.75 Price, $\$ 1.50$

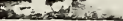

\section{BARREL HEADERS}

A simple contrivance, but indispensable for putting heads in barrels after being filled with apples and other produce.

No. 1. 1-inch Screw

No. 2. 1-inch Screw . . . . 1.40 Reinforced Bail.

\section{AXLE GREASE}

Fraser's Small Tin Boxes . . . \$0.10 Fraser's $31 / 2$ lb. Tin Pails . . . .25 Snow Flake, 1 qt., .25c; 2 qts., .40c; 1 gal., .70

\section{HARNESS COMPOSITION}

1 lb., Small . . . . . . . . $\$ 0.25$

HARNESS DRESSING

Pint Cans

Quart Cans

I. X. L. HARNESS OII

Pint Cans $\$ 0.25$ Quart Cans

\section{UNION COUNTER SCALES}

Ornamented, with tin scoop. $1 / 2$ oz. to $240 \mathrm{lbs}$. No. 210, Price, $\$ 3.75$

\section{EVEN BALANCE TEA SCALES}

Plain japaned, to weigh 4 lbs. No. 161, with Weights, $\$ 1.00$ 


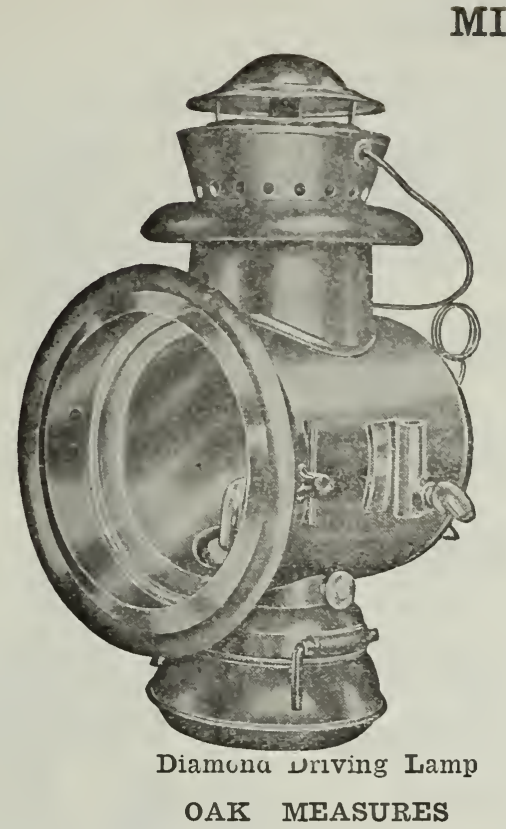

Best varnish and sealed half bushels, iron bound.

Nests

Half Busheis

Pecks

Four Quarts

Two Quarts

One Quart
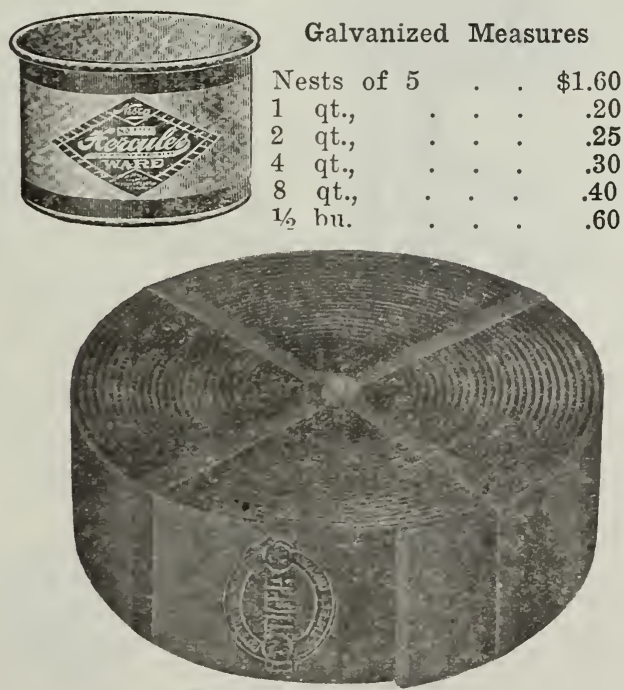

RUBBER BELTING

Prices Right

CUT IACINGS

Different Sizes.

C. T. HAM MFG. CO.'S LANTERNS

No. 0. Clipper . . . $\$ 0.50$

No. 2. Clipper

No. 2. Cold Blast

No. 15. Dash Board

No, 20, Seareh Iight

No. 40. Search Light

Diamond Driving

No. 9. Street

No. 22. Extra Large

fount Cold Blast

frem Cold Blast Side Lamp

Dandy Driving Lamp

Nustyle C-B with Special Globe

$$
\text { and Burner .. . } 1.00
$$

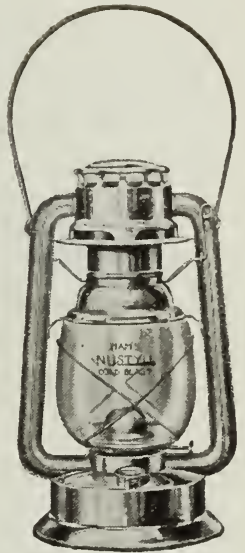

NUSTYLE

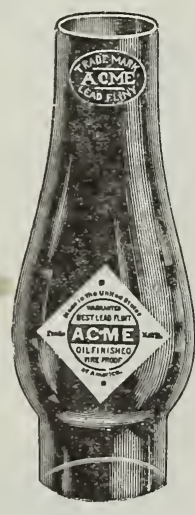

LAMP AND LANTERN BURNERS

All styles.

\section{CAN OPENERS}

\section{Centaur} each $\$ 0.10$

Never Slip

No. 17

IXL

Yankee, with cork screw .15 


\section{MISCELLANEOUS}

Common Corn Poppers

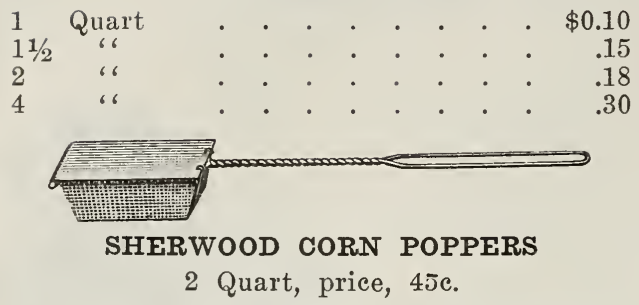

\section{UNTVERSAL STEEL HAND COFFEE MILLS}

Black Enamel Finish, Handsomely ornamented, patent adjusting device. Grinds as fine or coarse as wanted. Grinders warranted equal to steel.

No. 109 Height 6 in. . . . \$.70

No. 110 Height $81 / 2$ in. . . . . .90

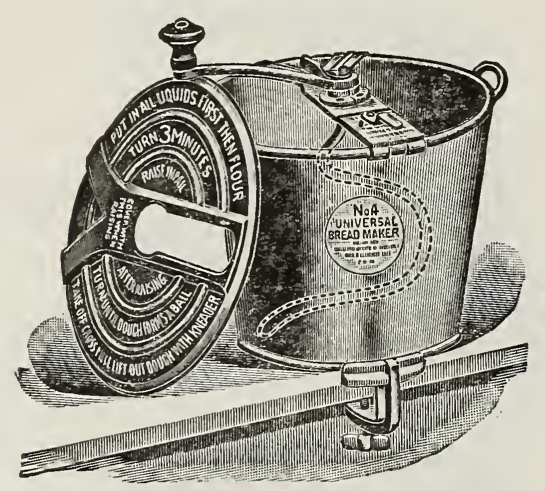

THE UNIVERSAL BREAD MAKER

Three minutes in this easy and pleasant way. Twenty to thirty minutes by the old way. The hands do not touch the dough, which is mixed and kneaded thoroughly in three minutes by this machine.

Price, No. 4, $\$ 2.00$; No. $8, \$ 2.50$

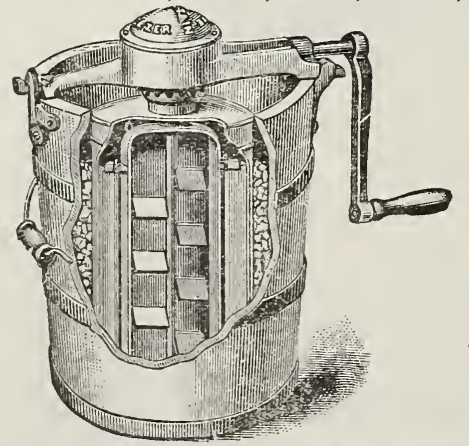

White Mountain Freezer
SCYTHE STONES

Haskell I. \& S. Co.'s Ragg, 10c. Black Diamond, .10c. Willoughby Lake, 10c. Chocolate, 10c. Emery, .10c. Deerlick, .05c. Green Mountain, .05e.

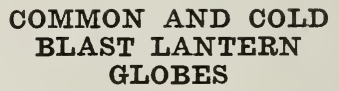

EGG BEATERS

No. 5. Holt's . . .10c

No. A. Holt's . . $.15 \mathrm{c}$

No. B. Holt's . . $.25 \mathrm{c}$

Lyons

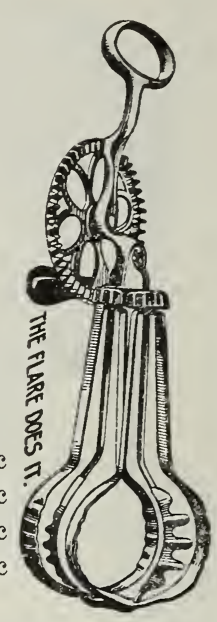

UNTVERSAL FOOD CHOPPER

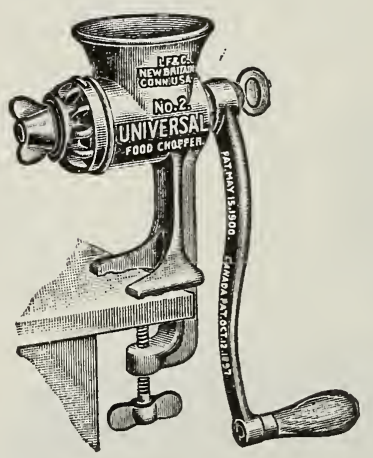

No. $0 \quad \$ 0.85$

No. 11.00

No. $2 \quad 1.40$

No. $3 \quad 1.75$

No. $304 \quad 3.50$

No. $344 . \quad 5.25$

\section{WHITE MOUNTAIN FREEZERS}

The most popular freezer used in this section. Positive triple action.

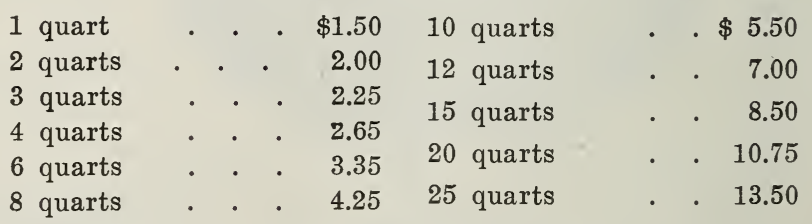

The Arctic Freezer is of cheaper design and made by same factory. 


\section{MISCELLANEOUS}

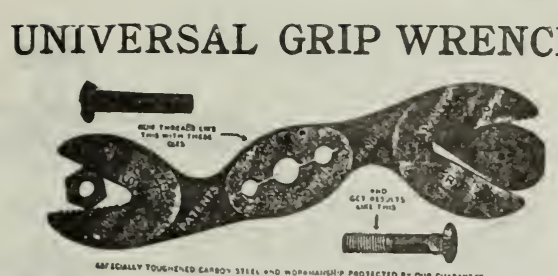

A Wrench and Thread Cutter. Frosted Nickel, Non-Rusting

This tool has more uses than any wrench on the market. A necessity on the farm, in every shop and household.

Price, \$0.50. By Mail, $\$ 0.60$

\section{No. 1900 RUSSELL STAPLE PULLING PLYERS}

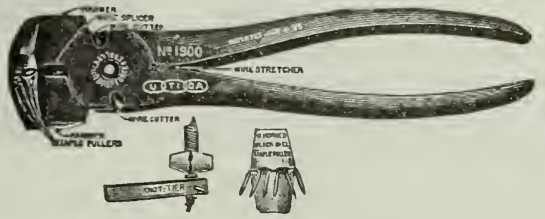

Drives staples, pulls staples, cuts wire, splices wire, stretches wire, straightens wire.

Price, $\$ 0.90$

Little Giant Grass Hook

Folding Handle.

Price $.35 \mathrm{c}$

Brooks Corn Hook

Serrated

$.30 \mathrm{c}$

Yankee Adjustable Corn Hook

Price

$.35 \mathrm{c}$

Bush Hooks

No. 10 Blood's. Price . $.75 \mathrm{c}$

Oxford Wood Hooks

Birch, $1 x^{3} / 8$, steel. Price

Wood, 3/4x5-16, Steel Price

Price $\cdot \cdot .45 \mathrm{c}$

Hay Hooks. Price $\cdot{ }^{\cdot} \cdot \cdot \cdot \cdot \cdot 25 \mathrm{c}$

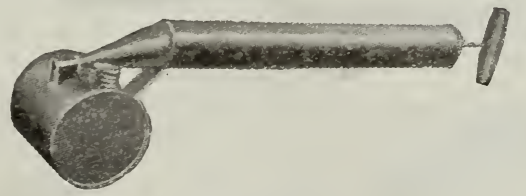

Oil Sprayers

Lowell All Brass. Price . . . . .60

Lowell All Tin. Price $\cdot{ }^{\circ} \cdot 35 \mathrm{c}$

Lowell Continuous. Price $. . \quad . \quad .70 \mathrm{e}$

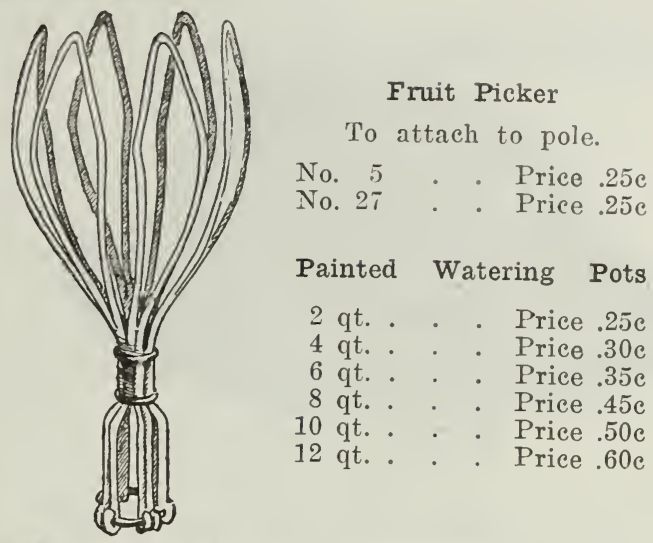

Galvanized

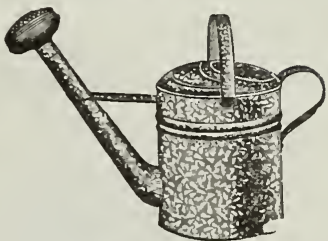

Watering Pots

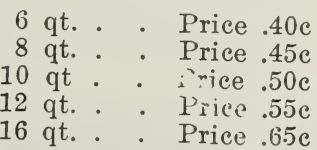

\section{Brownie Dry} Powder Duster

Machine weighs $31 / 2$ lbs., has two 16 in. tubes and one spread nozzle. In other respects similar to the Little Giant.

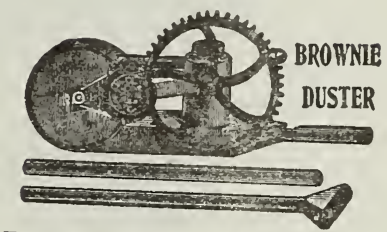

Price.

$\$ 4.00$

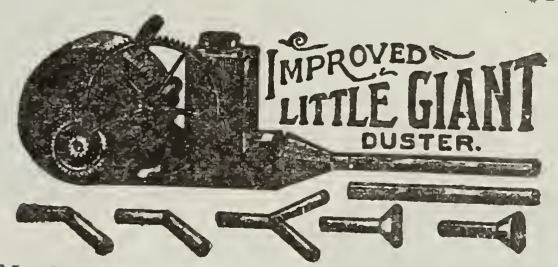

Machine weighs 6 lbs. Furnished with three tubes, 5 nozzles and strap. Distributes any dry powder. Dusts one or two rows. Reservoir holds nearly a quart of Powder.

Price......... $\$ 6.00$

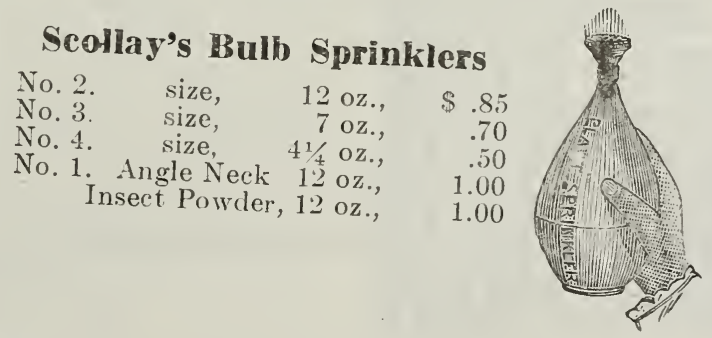




\section{MISCELLANEOUS}

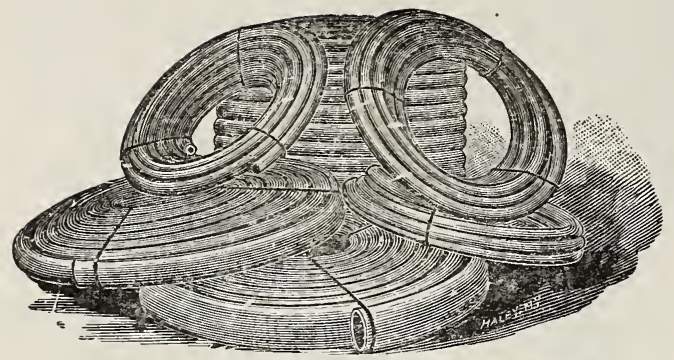

Rubber Garden Hose

All grades $1 / 2$ and $3 / 4$ in.

Price 10 to 15 cents per foot.

\section{Cotton Garden Hose}

10 to $13 \mathrm{c}$ per foot, according to size and quality.

Hose Clamps, Hose Couplings, Hose Menders.

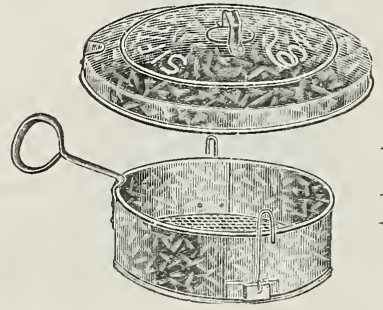

No. 0 Nesco Ash Sifter

An all metal sfter

Price

Without cover $.50 \mathrm{c}$

Favorite Coal Sieves

Wood Rim with wood cover . . . . .50e

Wond Rim without wood cover.$\quad .35$ e

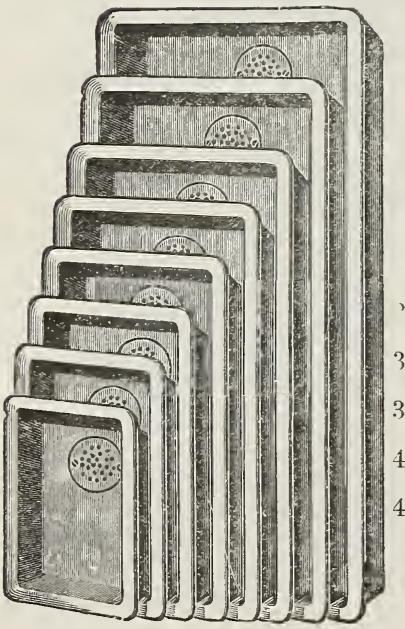

Sinks

We carry the principal izes of cast iron sinks, fit-

d for lead pipe.

$1 / 2$ feet $\times 18$ inches $\$ 2.25$

feet $\times 201 / 2$ inches 2.50

$31 / 2$ feet $\times 22$ inches 3.00

feet $\times 24$ inches 3.75

$41 / 2$ feet $\times 24$ inches 5.00

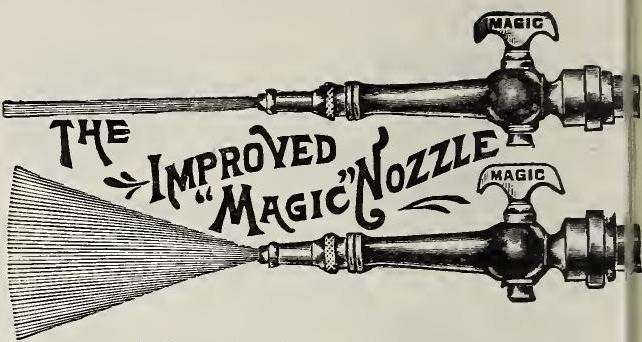

A favorite for years.

Has a removable screw tip which may be removed to produce a heavier stream.

Price . . . . . . . . . . .40c

\section{The "Fountain"}

Lawn Sprinkler

One of the really good things

Made entirely of brass, no moving parts, nothing to get ous of order. More beautiful than a fountain-more efficient than a shower.

Price, $\$ .60$

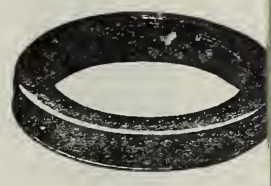

Gibbs' Spray Nozzle

Positive Shut off. Few Parts. i: ice. . . .35c

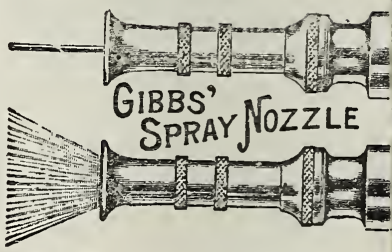

Grass Shears

Price

Common $\$ .25$

Polished, No. 0263 . $. \quad . \quad . \quad . \quad . \quad .30$

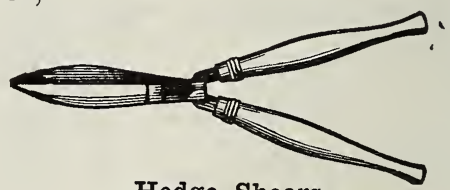

Hedge Shears

$\$ 1.50$

1.75

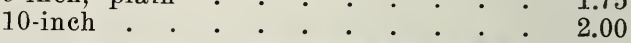

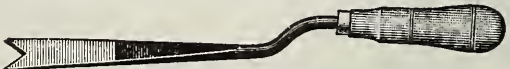

\section{Asparagus Knife}

Drop Forged Blade, excellent not only as an asparagus knife, but the "best ever" for digging Dandelions and other weeds. Price, 50c

\section{Foot Warmers}

More commonly known as soap stones

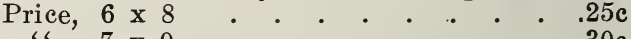

“ $7 \times 9 \times 5 \times 50.30 \mathrm{c}$

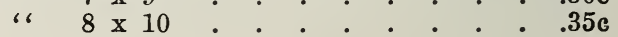




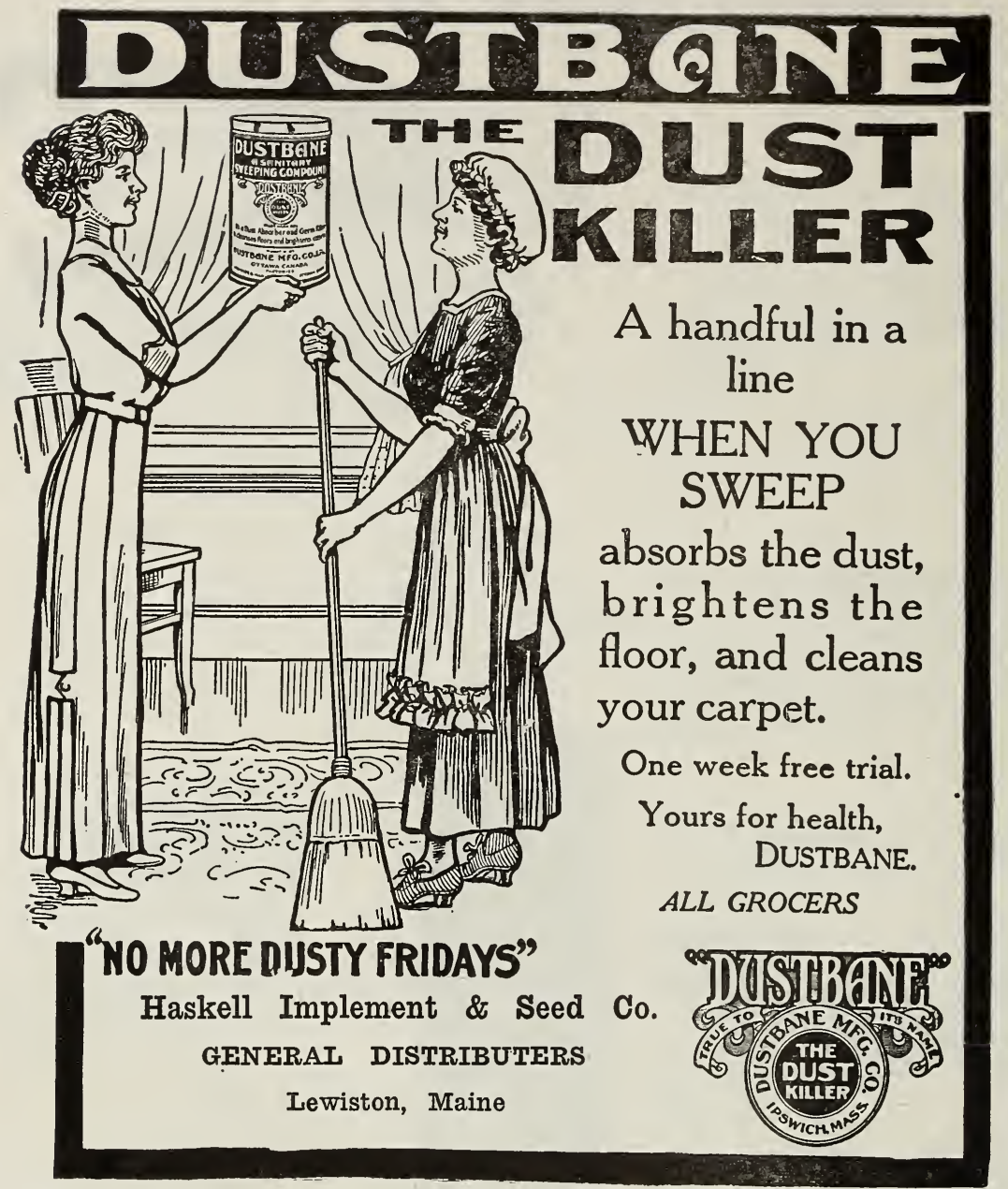

Small Cans $10 \mathrm{c}$

Large Cans $25 \mathrm{c}$

$371 / 2$ lb. bbl. $\$ 1.75$

75 lb. bbl. $\$ 3.00$

150 lb. bbl. $\$ 5.25$

$250 \mathrm{lb}$. bbl. $\$ 8.75$

\section{O-CEDAR MOPS}

\section{A Better and Easier Way to Clean}

No more back-breaking to clean and polish the floors; no more crawling under the bed, or moving of heavy furniture; no more climbing up on chairs to dust the mouldings or tall furniture. The O-Cedar Polish Mop gathers all the dust from everywhere and holds it. Does not stir up the dust but collects it.

It makes easy and pleasant what was hard work. No more getting down on hands and knees to polish hardwood floors. The

\section{O-CEDAR MOP POLISH}

treated with O-Cedar Polish gives a high, hard, durable lustre and finish to all painted, varnished and finished wodwork. It makes linoleum shine like new.

O-Cedar Mops . . . . . . . $\$ 1.50$

O-Cedar Polish, 4-oz. Bottle . . . .25c

\section{BISSELIS CARPET SWEEPERS}

Universal, Jap. Trim., Cyco Bear . . $\$ 2.50$ Grand Rapids, Jap. Trim., Cyco BB : $\quad 2.75$
These Sweepers have been the standard for years and we guarantee their satisfaction. 

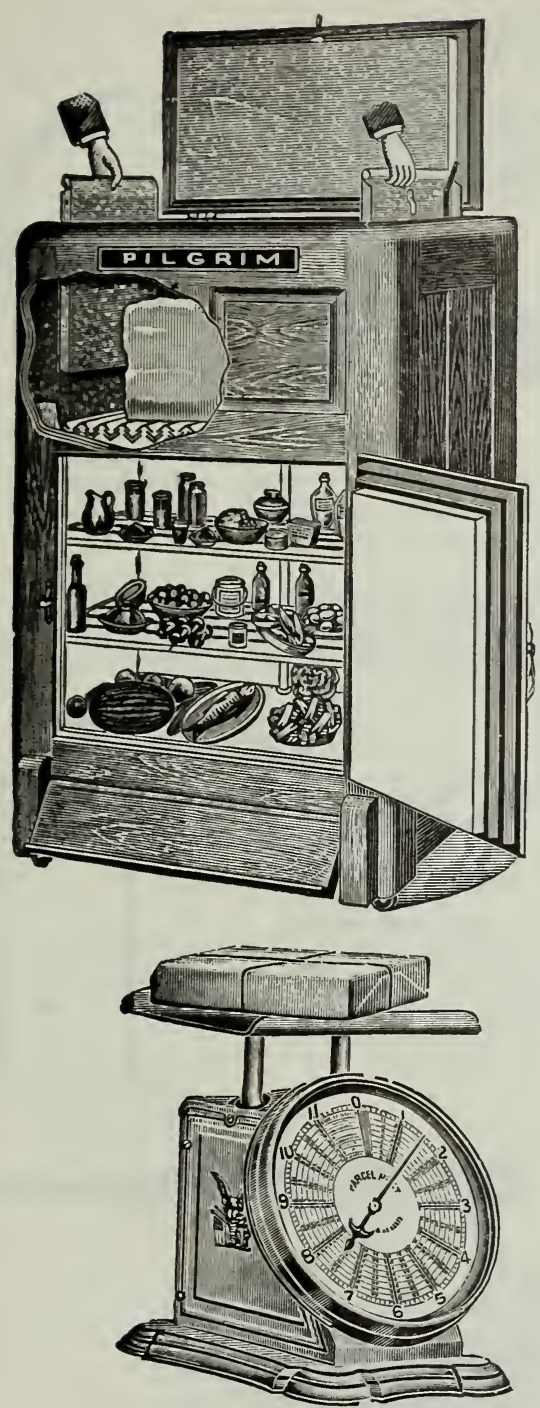

\section{PARCEL POST COUNTER SCALES}

\section{Capacity 11 Pounds By Ounces}

The Parcel Post Scales are made to conform with the new Law, effective January 1st, 1913.

They indicate automatically and accurately in cents the cost of postage on parcels in the United States, according to Zones.

A copy of the law accompanies each scale.

The Dials are very distinct and slanting, making them easy to read.

These scales are invaluable to every business house and every household as they will weigh accurately any article up to eleven pounds.

Price of scale with glass front . . . \$3.65

Price of scale with enameled dial . $\quad 2.15$

\section{REFRIGERATORB}

We handle the unexcelled line of White Mountain and Pilgrim Refrigerators and can recommend these most strongly to any one desiring this article.

If interested let us mail you illustrated catalog giving complete description and sizes of the different styles, also prices.

\section{Buy a Refrigerator that will Satisfy You}

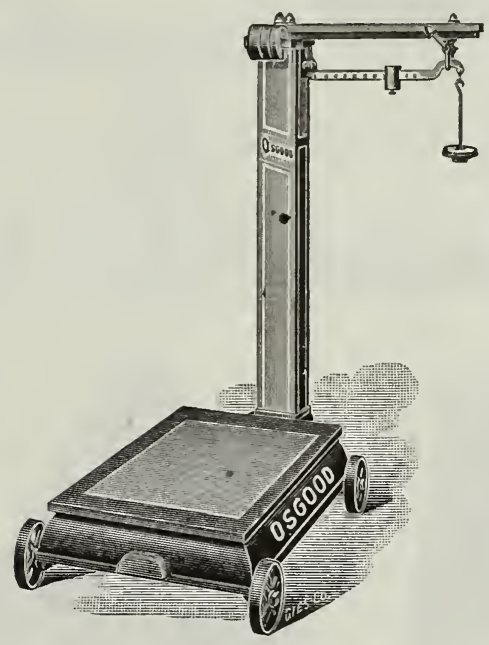

\section{AMERICAN \\ PLATFORM SCALES}

A first-class scale in every way

$800 \mathrm{lbs}$ 66 Price, $\$ 10.75$

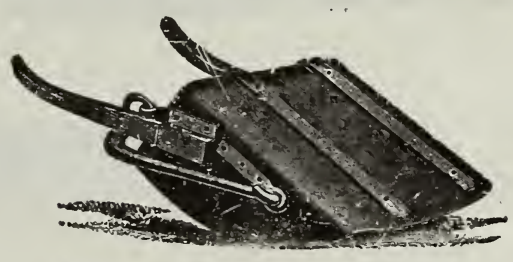

STEEL ROAD SCRAPERS

They are shaped cold from a single piece of steel lapped and riveted at the corners. They are uniform in thickness throughout except at the corners, where they are of double thickness.

No. 0 Capacity 9 cubic feet. . .Price $\$ 8.25$ No. 1. Capacity 7 cubic feet of earth, weight

105 lbs. . . . . . Price $\$ 5.50$ No. 2 Capacity 5 cubic feet of earth, weight

$95 \mathrm{lbs}$. . . . . Price $\$ 5.25$ No. 3 Capacity 3 cubic feet of earth, weight

$85 \mathrm{lbs}$. . . . . . . Price $\$ 5.00$

We have a little lighter made scraper that 85 


\section{REPAIRS AND PARTS}

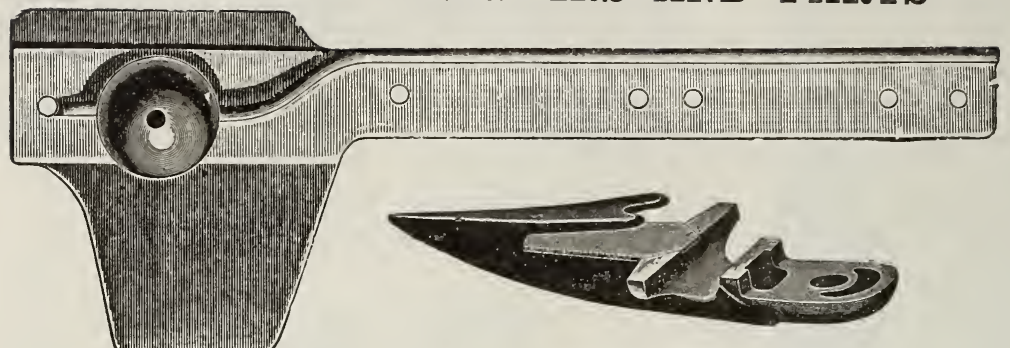

Mower Guard

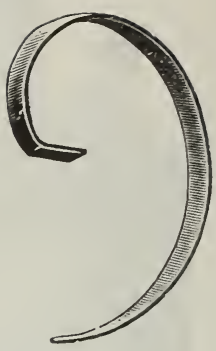

Spring Harrow Tooth

Guard Bolts and Guard Plates for all Guards, Knives, Knife Heads, Sections, Rivets, etc., all guaranteed to fit the machine for which they are intended.

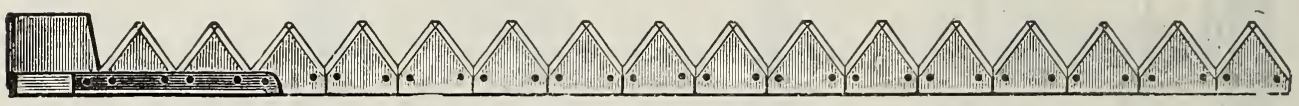

Mower Knife

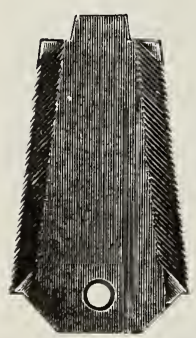

Guard Plate

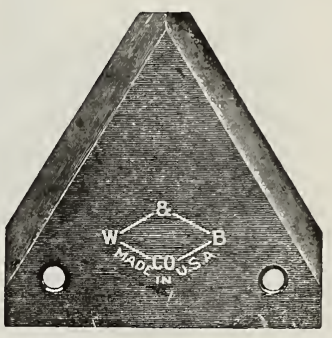

Section

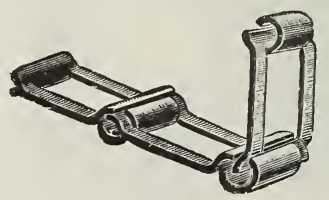

Link Belt Chain

Malleable and Steel. Sizes in siock all the way from No. 25 to No. 62. Prices from $9 \mathrm{c}$ to $22 \mathrm{c}$ per foot.

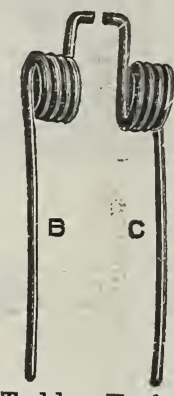

Tedder Fork

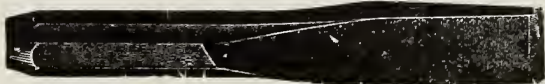

Cold Chisel: Prices, $1 / 2 \times 6 \quad .10$ $5 / 8 \times 61 / 2 \quad .15$

Drive Punch: Price, $1 / 2 \times 6 \quad .10$

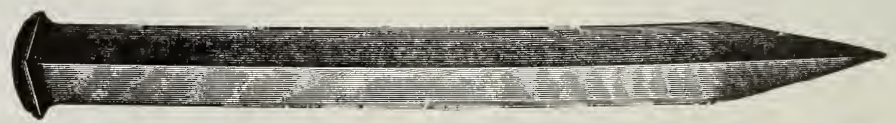

Steel Harrow Tooth: Square $5 / 8$ and 1 inch

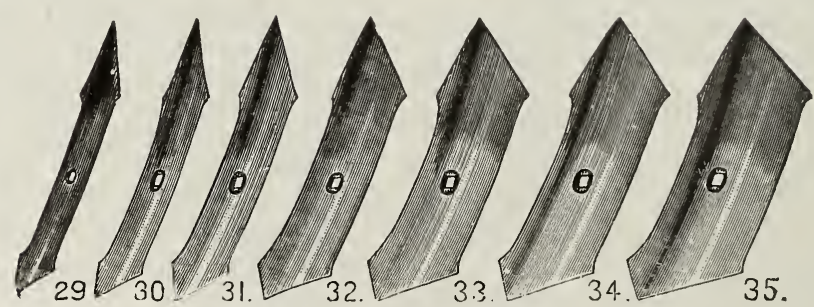

Cultivator Steels

NOTICE.-In ordering repairs always give name of machine and number on old part. When the number or letter cannot be found, it is always best to send, by express prepaid, the old or broken part, thus avoiding mistakes or delays. 


\section{BARN DOOR HANGERS}

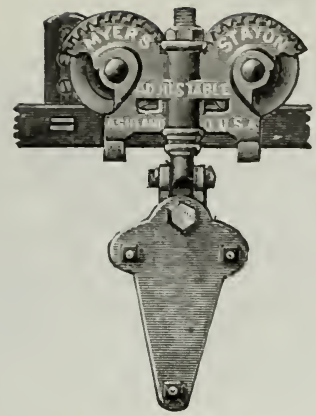

The Myers Adjustable Tandem Stayon Flexible Door Hanger with Steel

\section{Roller Bearings}

This is the only langer on the market that can be adjusted perpendicularly so as to locate the door at any point above the ground desired, or laterally so as to adjust the door to or from the building, and will also adjust itself to any thickness of door. The perpendicular and lateral adjustments are made with an ordinary wrench, and at the will of the user.

The Myers “o. K. Adjustable Stayon" Flexible Covered Door Hanger

Patented

With Hard Steel Roller Bearings. Pushes and pulls easily. It is impossible to throw it off the track or have the door warp sufficient to prevent its operation. The "O. K. Stayon' ' is constructed with a maleable frame extending over and covering the wheel. The frame is reinforced by two heavy ribs extending from a point above the axle to the hasp.

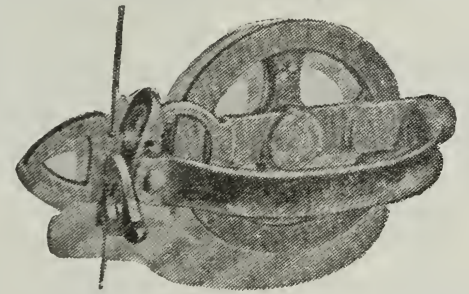

Porter "Slam and Slide", Barm Door Latch

Here is a device that meets with the enthusiastic approval of every farmer. The Porter "Slam and Slide", Barn Door Latch fills a long-felt want.

It is absolutely without equal for simplicity, strength, durability and cleverness of operation.

It works equally well right or left, on either slam or sliding doors.

Can be locked with padlock. The screws are protected. Adapted for any size door. Material is the very best malleable iron. Nicely finished, and packed one dozen in case.

Price. $35 \mathrm{c}$ each
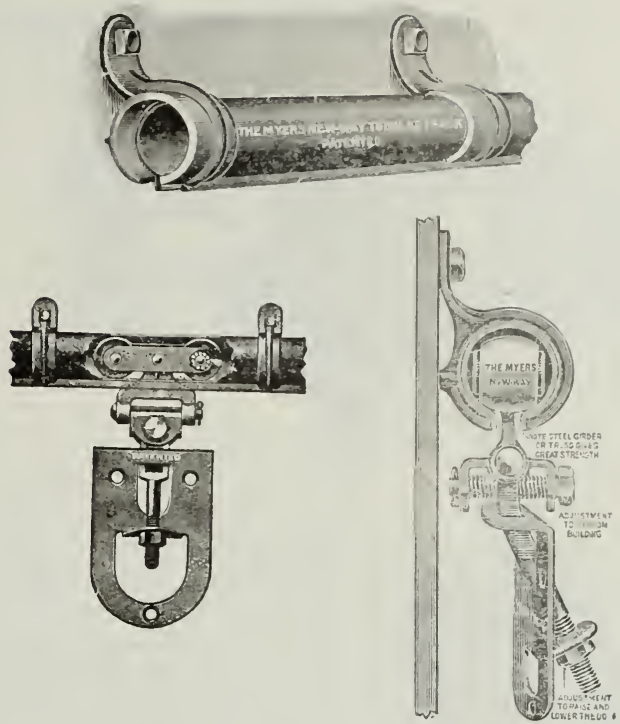

The Myers New-Way Adjustable Tandem Door Hanger

For Tubular Girder Track

Adjustable to and from Building and to Raise and Lower the Door

The track is made of high carbon stiff steel with two flanges turning downward at the lower edge, making the truss or girders which stiffen the track, enabling it to carry a mucl heavier load than any other style tubular track. In addition to this, there is no possible chance for dirt to lodge on the inner side of the track.

The adjustable features of this hanger are very important, as they enable the user to adjust the door to and from the building to prevent snow or rain from blowing in. The pervendicular adjustment permits of the door being raised or lowered, as is necessary, especially in cold weather, as in such cases the ground when frozen will heave up, thus locking the door. Can be used on doors varying in thickness from $1 \frac{1}{2}$ in. to 3 in. or more.

\section{McKenney Door Hanger}

No. 1 . . . . . . . . . . . . c

No. $10 \div \quad \cdot \quad \cdot \quad \cdot \quad \cdot \quad \cdot \quad \cdot \quad \cdot \quad \cdot \quad \cdot 75 \mathrm{c}$

Eagle Door Hanger

No. 1 $.50 \mathrm{c}$

Why not try our Purity Grass and Grain 87

Seeds. "Once Used Always Used." 


\section{HAY CARRIERS}

Swivel and Reversible for Double Steel Track

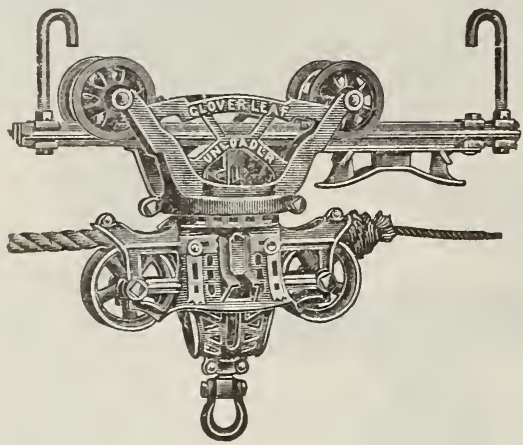

Fig. 1031

Figure 1031 represents the new Clover Leaf Unloader made of malleable iron throughout. Is heavy and substantially made. Is fitted with wide, open mouth to receive the fork pulley when approaching in any direction. Also has swinging fork pulley which relieves the carrier from all strain when drawing hay over a high beam or into a well-filled mow. The track wheels revolve on $7 / 8$-inch turned steel axles. The rope sheaves have longer hub than any other make of carrier. The lock is composed of three parts, and has no springs. The locking device grasps the fork pulley on either side, and permits it to swing free.

Price $\$ 3.75$ each

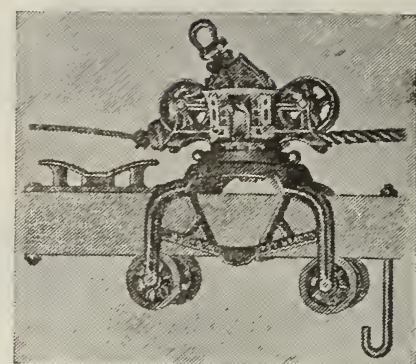

Fig. 1032

Has Swinging Fork Pulley-a Great Advantage in Drawing Hay into a Mow

When Filled Near the Roof

The above illustration represents the Clover Leaf Unloader as made for wood track. This carrier is fitted with a wide, open mouth to receive the fork pulley. The rope sheaves and track wheels are all fitted with large turned bearings. The machine is both swivel and reversible-combined in one machine. By this device the machine can be reversed by reversing the swivel or by drawing the rope through from end to end.

Price $\$ 3.75$ each

\section{HAY CARRIER OUTFITS SPECIAI NOTICE}

When requesting quotations do not fail to give exact length of barn, whether ridge or full rafter, and distance between rafters. Also state whether you expect to hoist from end or center of barn.

\section{ESTIMATES FOR HAY CARRIER OUTFITS}

Estimate of material required for a Steel Track Outfit for different length barns:

For a 40 -foot barn, One Carrier, $36 \mathrm{ft}$. Track, 12 Hanger Hooks, 12 Rafter Brackets, 1 Harpoon, or Grapple Fork, 3 Pulleys, 3 Floor Hooks, 120 feet, 3/4 in. Manila Rope, 50 feet, 3/8 in. Check Rope, 1 Rope Hitel.

Estimated Net Price, $\$ 17.75$

For a 50 -foot barn, One Carrier, $48 \mathrm{ft}$. track, 15 Hanger Hooks, 15 Rafter Brackets, 1 Harpoon or Grapple Fork, 3 Pulleys, 3 Floor Hooks, 160 feet $3 / 4$-in. Manila Rope, 55 feet $3 / 8$ Check Rope, 1 Rope Hitch.

Estimated Net Price, $\$ 20.50$

For a 60 -foot barn, One Carrier, $54 \mathrm{ft}$. Track, 20 Hanger Hooks, 20 Rafter Brackets, 1 Harpoon or Grapple Fork, 3 Pulleys, 3 Floor Hooks, 185 feet 3/4-in. Manila Rope, 65 feet 3/8-in. Check Rope, 1 Rope Hitch.

Estimated Net Price $\$ 23.25$

Above estimates of Rope are for an End Hoist. In hoisting from centre of barn less Rope will be necessary.

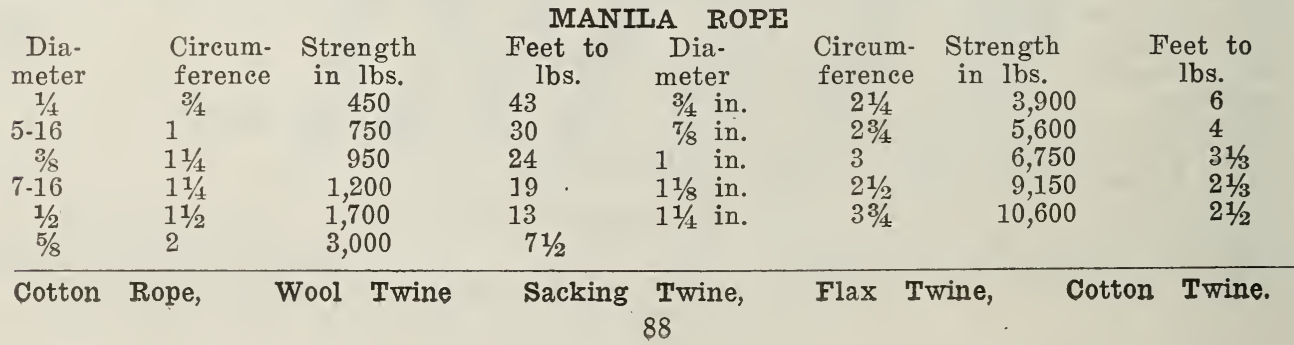




\section{HAY CARRIER FIXTURES}

Descriptions and Prices

PULLEYS

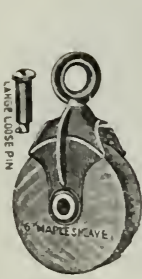

No. 133

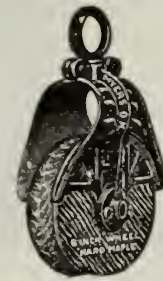

No. 1120

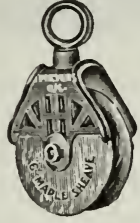

No. 1133

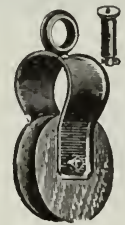

No. 435

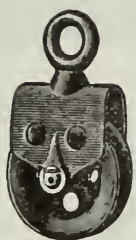

No. $69 \varepsilon$

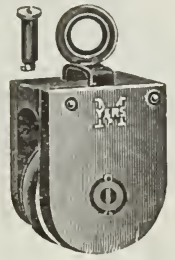

No. 466

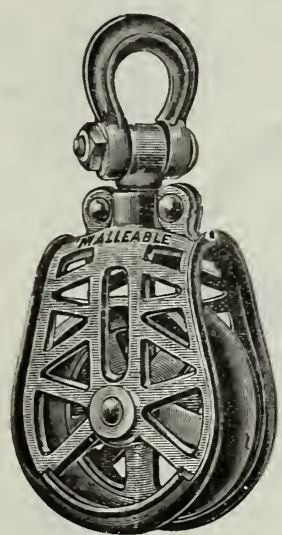

No. 1124

No. 1133. Plain Pulley, 6-inch maple sheave, malleable frame

No. 692. Cast Frame 51/2 inch iron sheaves

No. 486. Floor Pulley with large loose pin

No. 433 C'ast frame, plain, 6-inch maple sheave, 1-inch hollow axle.

No. 435 Cast frame, knot passing, 6-inch maple sheave, 1 -inch hollow axle

To. 1120. Nalleable frame, knot passing, 6inch maple sheave,1-inch axle

Stowell's Malleable Pulley. Malleable frame and sheave, steel axle, roller bearing,

No. 466. O. K. wood pulley with steel yoke, 1-inch hollow axle . . .

No. 434. Ssame as 466, except has wrought hook in place of eye . . .

No. 1124. Special Malleable Frame, extra

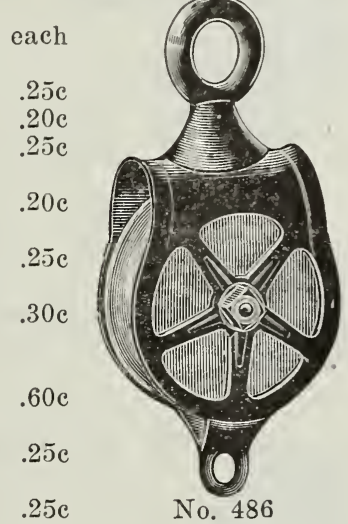

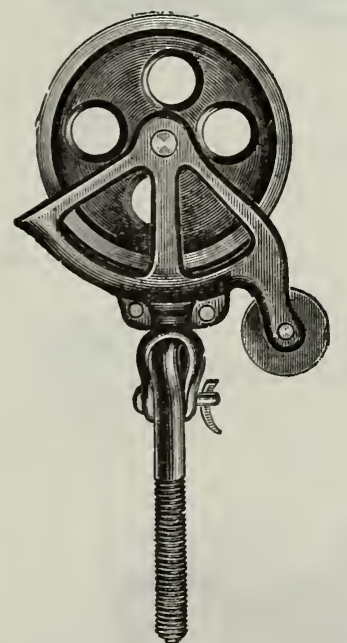

Cross Floor Pulley Malleable throughout, has idler pulley to keep rope in place, and stands erect on floor. Price, each, $\$ 1.25$

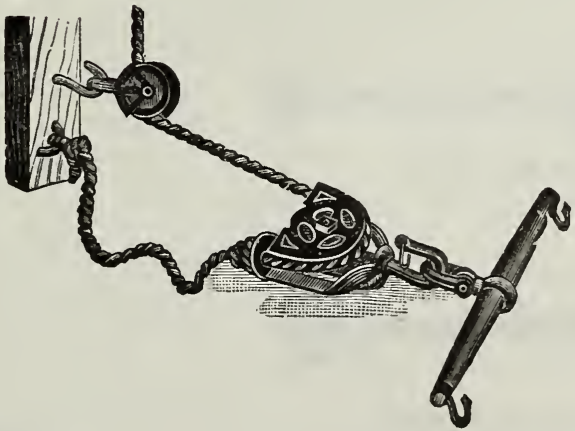

No. 628

Snatch Block Pulleys Price, each, $\$ .55 \mathrm{c}$

Useful in limited space, horse only travels half distance.

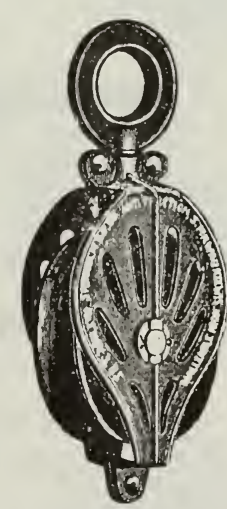

Stowell's

Malleable Pulley 


\section{HAY CARRIER FIXTURES}

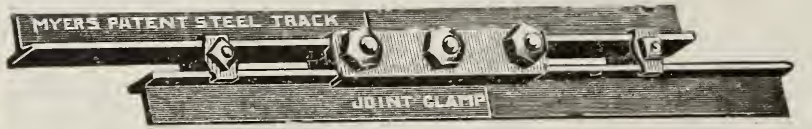

Myers Patent Double

Steel Track

Price per foot, \$.12

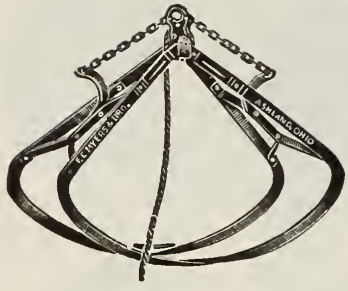

Grapple Fork

Price

4 tined . . $\$ 4.00$

5 tined $: 4.85$

Lock Lever Fork

Price each, $\$ 2.00$

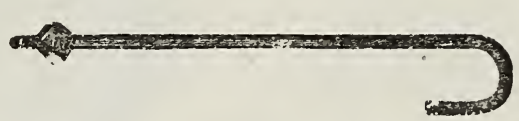

Wood Track Hanger Hooks

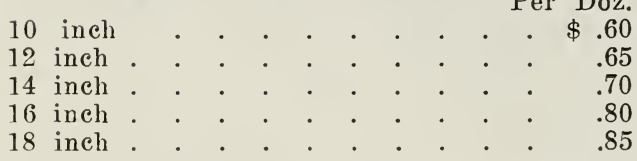

Ridge Pole Hooks

$3 / 8$-inch

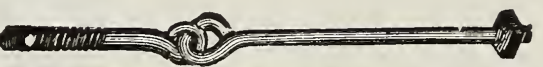

Jointed Hanger Hooks

Per Doz,

12 inch. . . . . . . . . . $\$ 1.20$

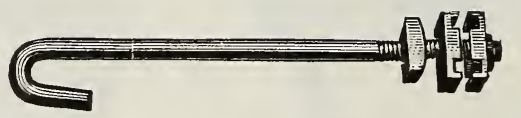

Steel Track Hanger Hooks

Price, per dozen . . . \$ $\$ .85$

Jointed Steel Track Hanger Hooks

Price, per dozen $\$ 1.45$

Knockers, Stops, Wheels, and complete line of Repairs for Myers Clover Leaf Unloaders.

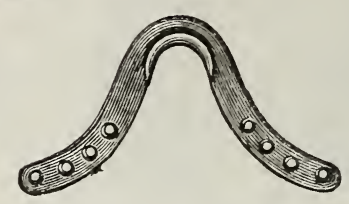

Rafter Brackets

Price

Per dozen . . . . . . . . \$. 40

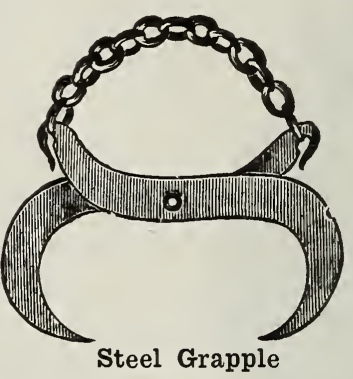

Each . . . . . . . . \$ .50

Floor Hooks

Price

Per Doz.

$3 / 4$-inch

.\$. 95

Drive Screws

Price

Per gross . . . . . . . . . $\$ .60$

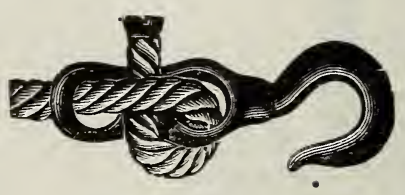

Swivel Rope Hitch 


\section{GALVANIZED PIPE AND FITTINGS}
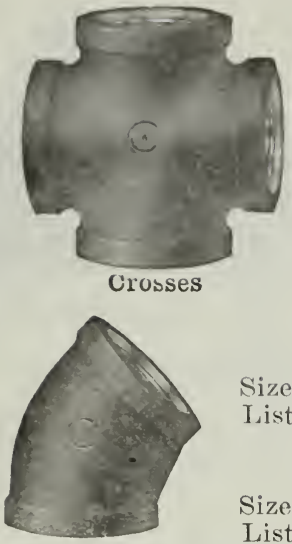

$45^{\circ}$ Ellows

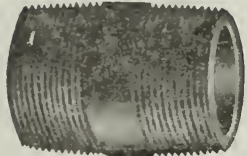

Nipples

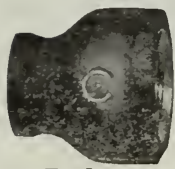

Reducers

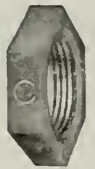

Lock Nuts

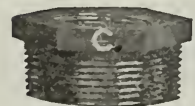

Bushings

Size

List

Size

List

Size

List

Size

List

Size

List

Size

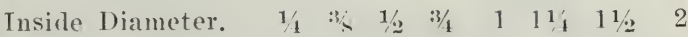

Weight, per Foot., 42. .5) 6 . st 1.12 1.67 2.25 2.68 3.61 Tist per Foot, .06 .06 .081/2.111/2.17.23.271/2.37

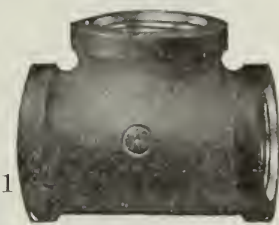

Tees

Size
List

Size List
Galv Elbows, Malleable

$\begin{array}{llllllll}1 / 4 & 3 / 5 & 1 / 2 & 3 / 4 & 1 & 11 / 4 & 11 / 2 & 2\end{array}$

Galv. $45^{\circ}$ Malleable

$\begin{array}{llllllll}1 / 4 & 3 / 8 & 1 / 2 & 3 / 4 & 1 & 11 / 4 & 11 / 2 & 2\end{array}$

$\begin{array}{llllllll}.12 & .15 & .20 & .25 & .40 & .50 & .85 & 1.35\end{array}$

Galv. Drop Elbows, Malleable

Size . . . . . . . . . $3 / 3 \quad 1 / 2 \quad 3 / 4$

List

Galv Tees, Malleable

$\begin{array}{lllllllll}\text { Size . . } & 1 / 4 & 3 / 8 & 1 / 2 & 3 / 4 & 1 & 11 / 4 & 11 / 2 & 2\end{array}$

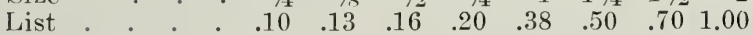

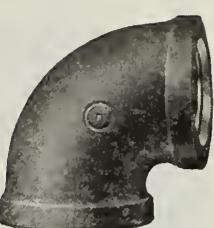

Elbows

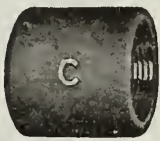

Couplings

Galv. Crosses, Malleable

List
Galv. Plugs, Cast

Galv. Caps, Malleable

Galv. Bushings, Malleable

$\begin{array}{lllllllll}\text {. } & 1 / 4 & 3 / 4 & 1 / 2 & 3 / 4 & 1 & 11 / 4 & 11 / 2 & 2\end{array}$

$1 / 4 \quad 3 / 5 \quad 1 / 2 \quad 3 / 4$

Galv. Reducers, Malleable

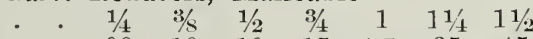

.75

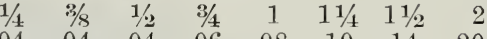
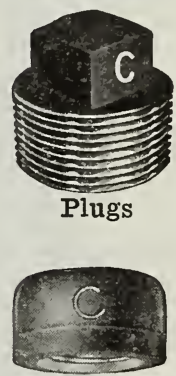

Caps

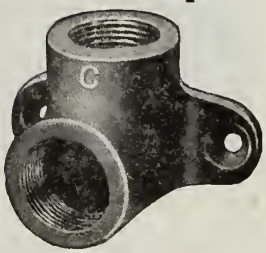

Drop Elbows

Galv. Couplings, Malleable

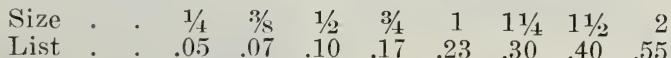

Galv. Unions, Malleable

$\begin{array}{lllllllll}\text { Size . } & 1 / 4 & 3 / 4 & 1 / 2 & 3 / 4 & 1 & 11 / 4 & 11 / 2 & 2\end{array}$ $\begin{array}{lllllllll}\text { Standard } & .27 & .30 & .33 & .40 & .50 & .70 & .90 & 1.15\end{array}$

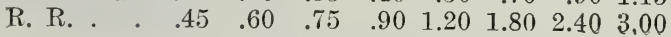

R $\mathbf{R}$ Unions

List Prices subject to discount

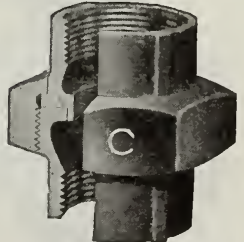

Standard Unions 


\section{BRASS FITTINGS}

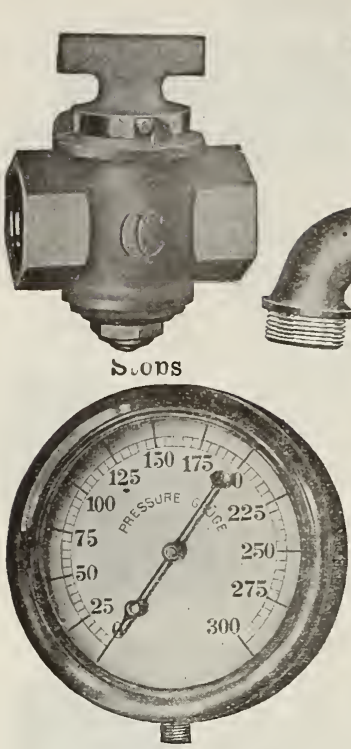

Pressure Gauge

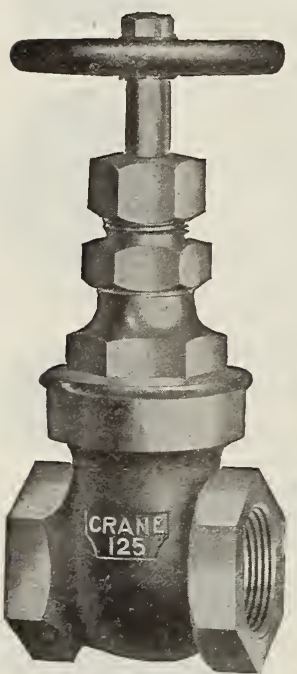

Gate Valve

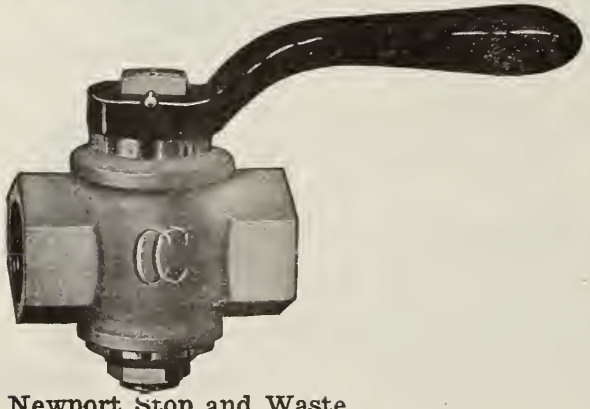

Hose Bibb

Brass Stops

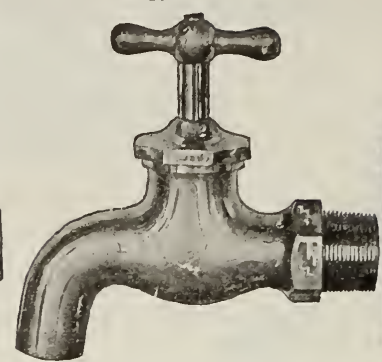

Plain

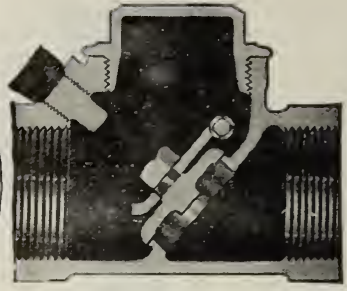

Swing Check Valve

Size . . $\begin{array}{lllllllllll}1 / 2 & 3 / 4 & 1 & 11 / 4 & \text { Size } & 1 / 2 & 3 / 4 & 1 & 11 / 4 & 11 / 2\end{array}$

$\begin{array}{lllllllllll}\text { List . . } & .95 & 1.55 & 2.55 & 4.00 & \text { List } ~ & 1.95 & 3.15 & 5.20 & 8.20 & 12.00\end{array}$

Bibbs, Compression

Plain

For Hose

$\begin{array}{lllllllllllll}\text { Size . . . } & 1 / 2 & 5 / 8 & 3 / 4 & 1 & \text { Size } & \text {. } & \text {. } & 1 / 2 & 5 / 8 & 3 / 4 & 1\end{array}$

Brass, List $.1 .201 .70 \quad 2.20 \quad 4.00$ Brass, List $.1 .401 .90 \quad 2.404 .50$

Nickel, List . $1.45 \quad 2.002 .504 .40 \quad$ Nickel, List . 1.602 .152 .704 .90

\section{No. 35 Swing Check Valves}

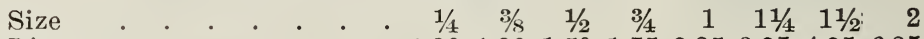

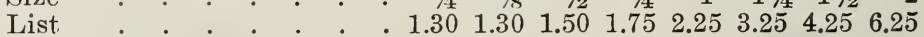

\section{Pressure Gauge}

3 to 5 in., $200 \mathrm{lb}$. pressure, $\$ 1.75 \mathrm{Net}$

No. 32 Horizontal Check Valve

$\begin{array}{llllllllllllll}\text { Size . . . . . . . } & 3 / 4 & 1 & 11 / 4 & 11 / 2 & 2\end{array}$

List . . . . . . . . . . . 2.503 .505 .007 .0011 .00

No. 24 Vertical Check Valve

$\begin{array}{llllllllllllll}\text { Size . . . . . . . . } & 1 / 4 & 1 / 2 & 3 / 4 & 1 & 11 / 4 & 11 / 2 & 2\end{array}$

List . . . . . . . . . . $\begin{array}{lllllll}.72 & 1.00 & 1.26 & 1.80 & 2.52 & 3.50 & 5.30\end{array}$

\section{No. 438 Straight Way Gate Valve}

$\begin{array}{llllllllllll}\text { Size . . . . . . } & 1 / 4 & 3 / 8 & 1 / 2 & 3 / 4 & 1 & 11 / 4 & 11 / 2 & 2\end{array}$

List . . $\quad \begin{array}{lllllllll}1.20 & 1.20 & 1.30 & 1.75 & 2.25 & 3.25 & 4.25 & 6.25\end{array}$

List Prices subject to discount
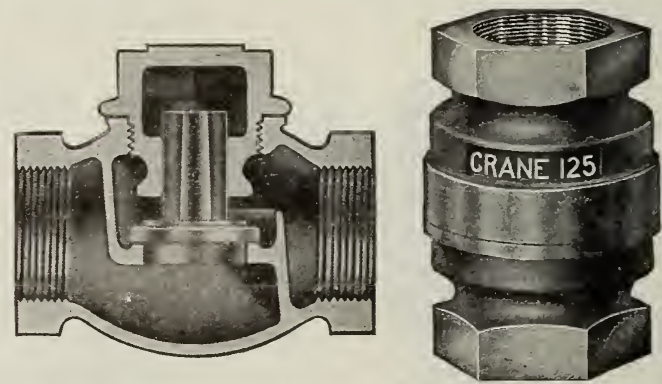

Horizontal Check Valve Vertical Check Valve 


\section{WHEELBARROWS}

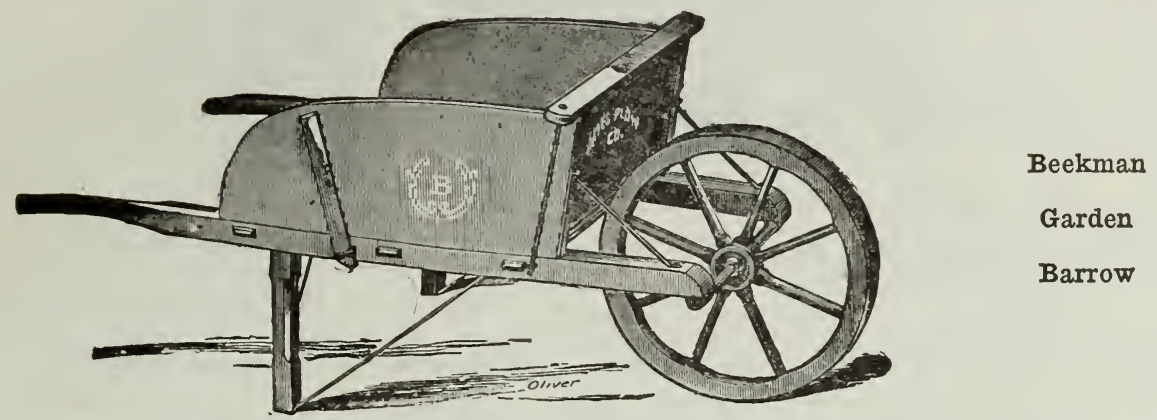

The Beekman is a good looking, well finished barrow and is made in a strong, serviceable way. Has iron hub and axle.

\section{AMERICUS BARROW}

Same as Beekman except built entirely of hard wood and finished in natural wood instead of being painted.

No. 2 Beekman . . . . . . . $\$ 3.00$ No. 4 Americus . . . . . . . $\$ 3.40$

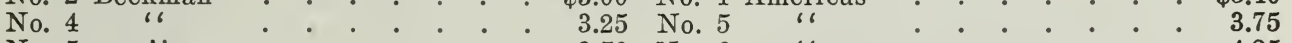

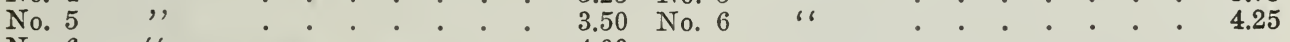

No. 6 " $\quad . \quad . \quad . \quad .5400$

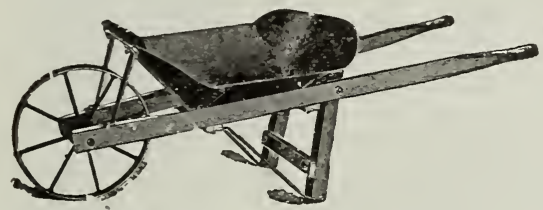

\section{CANAI DUMP BARROW}

A very strong canal barrow which is popular with contractors. Furnished with either wood or steel wheels.

With wood wheel . . . . . . . $\$ 2.25$

With steel wheel . . . . . . 2.40

Special prices in dozen lots.

PIG METAL OR CASTING BARROW

A very strong, well-made barrow. Bottom and front of $1 \frac{1 / 2}{2}$ inch hardwood, dressed and well strapped with No. 10 steel. Painted brown. Weight, 69 pounds each.

With iron-hub wheel.

Price, $\$ 3.50$

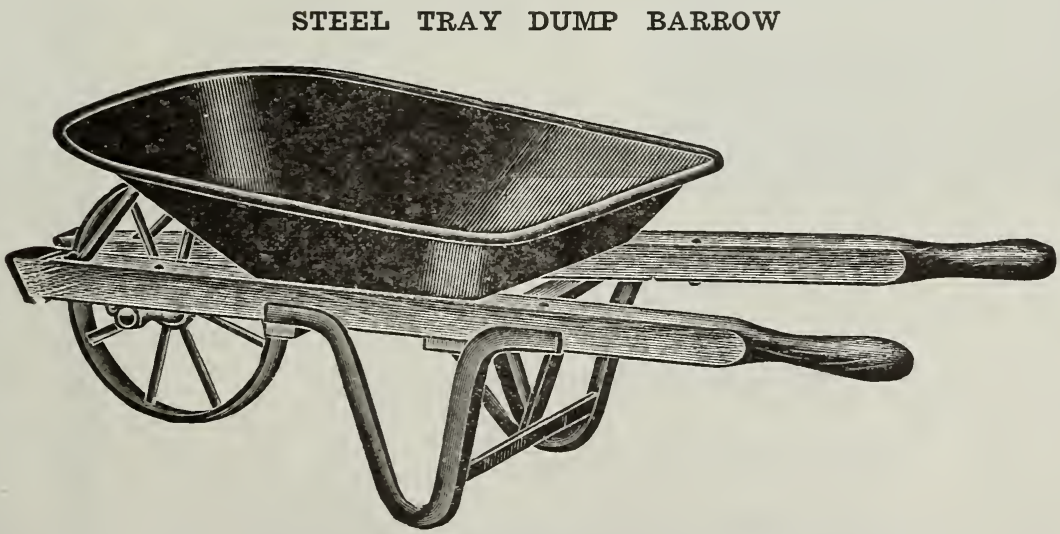

A strong, durable barrow for either dirt or cement work. Also very handy in farm work. Special prices for quantity orders. 


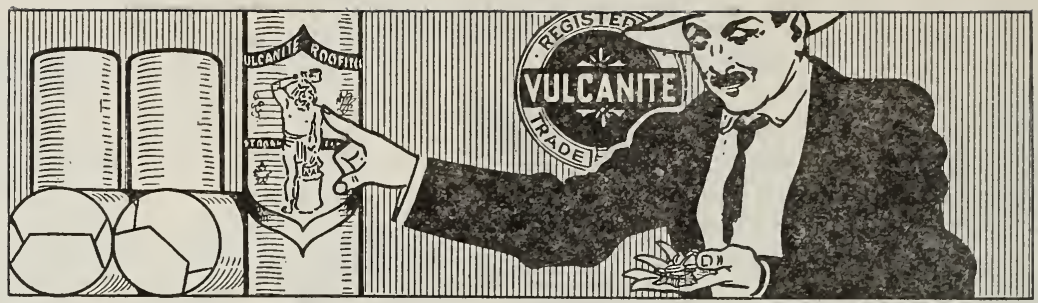

THE SECRET OF GETTING MONEY'S WORTH IN PREPARED ROOFING

The only qualities you really demand in prepared roofing are long wear and freedom from repair expense. All other points are comparatively minor.

In order to get the longest possible wear-in order to roof your buildings with a material which requires no paint and no repair expenses, the roofing must be up to a certain standard of material-must be made with a big slice of "know how" added. Vulcanite Roofing makes good because it is made good.

You'll find lots of roofings that cost more than Vulcanite, but you can't find a roofing that is worth more. Vulcanite Roofing is made in the best possible way out of the best possible material. Any roofing that costs you more money only carries too much profit to someone. It can not be worth more.

Lots of roofings sell for less money than Vulcanite, but they are worth less.

\section{VULCANOID}

\section{THE WEATHER-PROOF ROOFING}

Is made of Heavy Wove Felt, thoroughly saturated with a natural asphalt saturation, which not only gives it a heavy body, but makes it perfectly water-proof, acid-proof and is unaffected by contraction or expansion.

A model roofing for your house, barn, factory, storehouse or outbuildings, with flat or steep roof.

\section{Requires No Annual Painting.}

Handsome in appearance. A pleasing silvery gray color.

Even fire has no terrors for "Vulcanoid" it can't burn from the surface.

It will not freeze and crack in winter, nor crumble in dry weather.

\section{No Expert to Put It On}

Anyone who can drive a nail can lay it.

We furnish the nails and cement.

If you want the best medium priced roofing made, insist on getting "Vulcanoid" Roofing.

1-ply weighs $34 \mathrm{lbs} . \quad . \quad . \quad . \quad$. Price $\$ 2.00$

2-ply weighs $44 \mathrm{lbs} . \quad . \quad . \quad . \quad . \quad$ Price 2.40

3-ply weighs 54 lbs. . . . . . Price 2.75 Per Roll of 108 Square Feet.

Special quantity prices.

\section{HIGH GRADE} finish.

Similar to the Vulcanoid only not quite so fine a

Price 1 ply

Price 2 ply

Price 3 ply

\section{REVERSO}

A lower grade but an excellent roofing for the money.

Price 1 ply

Price 2 ply

Price 3 ply
$\$ 1.75$

2.10

2.50

$\$ 1.25$

1.50

2.00
VULCANITE ASPHALT SHINGLES

Are also heavy sellers to house owners who want a handsome roof. They are cheaper to apply than wood shingles, are permanent, and may be had in four colors.

These are the coming Ornamental Roofings. They'll give a very distinctive effect to any house, and are as suitable for a mansion as for a cottage.

Let us quote you prices and send further information.

"Roofed with Vulcanite Roofed for Good"

\section{WOVEN}

A heavy woven roofing of excellent quality, much used by contractors.

Price, \$3.50

\section{ASPHALT} ing.

A high grade strictly asphalt roof-

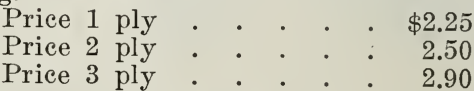

\section{GRAVEL}

If any one desires a gravel roofing ours is as good as any can be found. None better at any price.

Price, $\$ 2.25$

These are all Vulcanite Roofings If interested send for samples and quantity prices.

We also have a full line of Tarred Felt, Rosin Sized Sheathing Paper in different weights, etc. tion.

Prices gladly quoted on applica-

\section{GRAPHILATUMI}

Graphilatum a good-all-round black paint, especially adapted for ready roofings and metal surfaces. It is a bituminous product that is elastic and adhesive. Will not rub, peel, scale or become brittle and crack. Impervions to moisture, resists the action of acids, gases, steam vapors, etc. Graphilatum is put up ready for use in packages of convenient sizes.

Prices:

1 gallon cans . . . . $\$ 1.00$ gal. 5 gal. cans . . . .80 gal. Half barrels (abt. 38 gals.) $\quad .67$ gal. Barrel (abt. 58 gals.) . .65 gal. 


\section{WOOD AND IRON PUMPS}

\section{PUMP DEPARTMENT}

The growth in this part of our business has been extremely large and has necessitated a large development in this line.

We are now prepared to give all orders and inquiries of this nature the attention of experienced men and will gladly quote prices and give detailed information on any outfit desired.

REMEMBER we carry the largest stock of Pumps and fittings in the State, and can handle your orders promptly and satisfactorily. We also wish to call your attention to our suburban water systems following our Pumps. prices.

NOTE-List prices only are given on Myers Pumps. Kindly write for special net

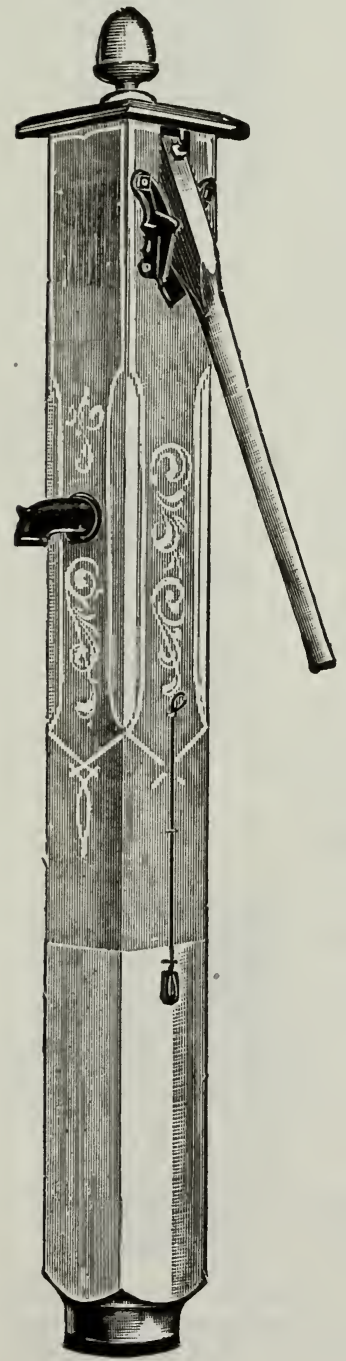

\section{CUCUMBER WOOD PUMPS}

The very best of material is used in our wood pumps. They are superior to any made of Cottonwood and will not taint the water.

\section{PRICES}

$6 \mathrm{ft}$ Plain

$7 \mathrm{ft}$ Plain

$\$ 3.00$

$8 \mathrm{ft}$ Plain

3.50

$10 \mathrm{ft}$ rlain

$7 \mathrm{ft}$ Brass Lined 4.50

$6 \mathrm{ft}$ Porcelain Lined

$7 \mathrm{ft}$ Porcelain Lined 3.75 4.00

$8 \mathrm{ft}$ Porcelain Lined 4.25

$10 \mathrm{ft}$ Porcelain Lined 4.75

12 ft Porcelain Lined

Tubing per ft.

.12

All repairs for Wood Pumps carried in stock

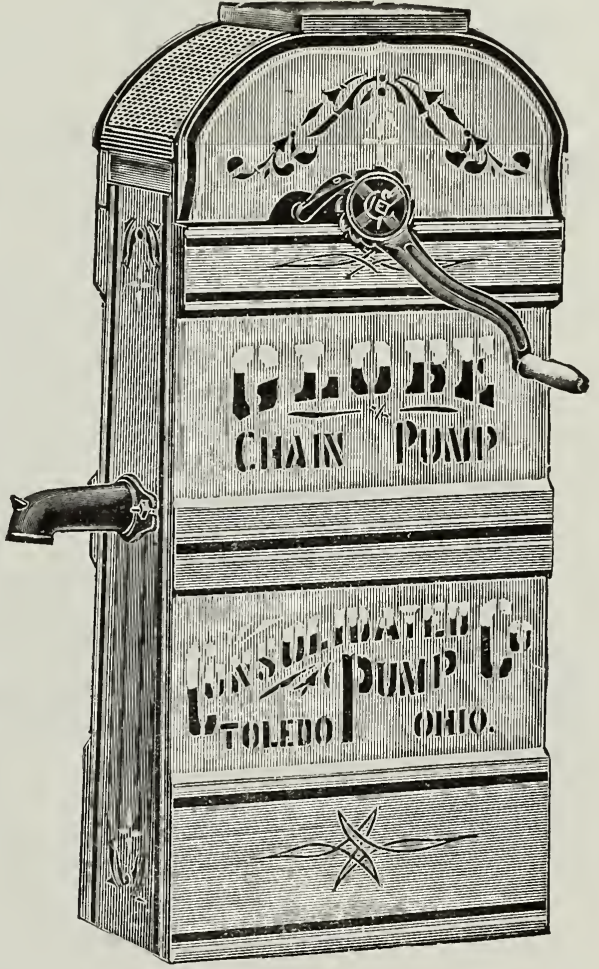

GLOBE CHAIN PUMP

Prices

Globe Pump Curb, $\$ 2.00$

Chain per ft., .06c
Tubing per foot, .06c

Special Buckets, each .10c

\section{DOUGLAS HOUSE PUMPS}

No. $12 \frac{1}{2}$ in. Cylinder Fitted for 1 in. pipe.

No. 23 in. Cylinder Fitted for $11 / 4$ in. pipe.

No. $33 \frac{1}{2}$ in. Cylinder Fitted for $1 \frac{1 / 4}{\text { in. pipe. }}$

Price $\$ 1.75$

Price 2.00

Price 2.25 


\section{Myers House and Cistern Pumps}

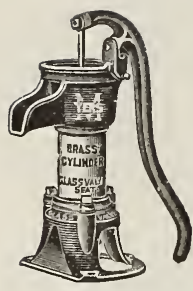

Fig. 788

\section{Myers House Lift Pump}

Fig. 788, No. 220, 3 in. Brass Cylinder.

List, $\$ 5.00$

Fig. 964, No. 245, 3 in. Brass Cylinder, 11/4 in. Suction Pipe.

List, $\$ 5.50$

Fig. 964, No. 247, 31/2 in. Brass Cylinder, $1 \frac{1}{2}$ in. Suction Pipe.

List, $\$ 6.50$

Fig. 1366, No. R 245, Cog Gear, 3 in. Brass Cylinder, Glass Valve Seat, $1 \frac{11}{4}$ in. Suction Pipe.

List, $\$ 5.50$

Fig. 1366, No. R 247, Cog Gear, $3 \frac{1}{2}$ in. Brass Cylinder, Glass Valve Seat, $1 \frac{1 / 2}{2}$ in. Suction Pipe.

List, $\$ 6.50$

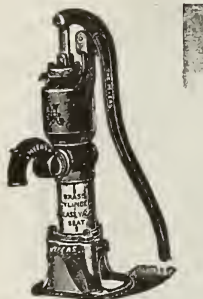

Fig. 964

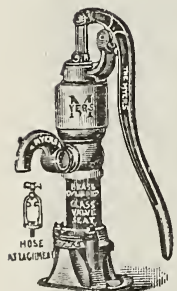

Fig. 922

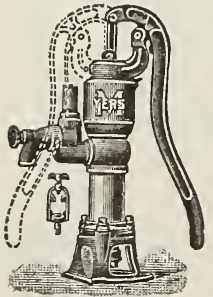

Fig. 902

\section{Myers Double Acting House Force Pump}

Fig. 922, No. 251, 3 in. Brass Cylinder, $11 / 4$ in. Suction Pipe, Siphon Spout.

List, $\$ 8.00$

Fig. 902, No. 251, 3 in. Brass Cylinder, $1 \frac{1}{4}$ in. Suction Pipe, Cock Spout.

List, $\$ 9.50$

Fig. 922, No. 253, $3 \frac{1 / 2}{2}$ in. Brass Cylinder, $1 \frac{1}{2}$ in. Suction Pipe, Siphon Spout.

List, $\$ 9.00$

Fig. 902, No. 253, 31/2 in. Brass Cylinder, $1 \frac{1}{2}$ in. Suction Pipe, Cock Spout.

List, $\$ 10.50$

Fg. 1463, No. R 251, Cog Gear, 3 in. Brass Cylinder, Glass Valve Seat, $1 \frac{1 / 4}{4}$ in. Suction Pipe, Siphon Spout.

List, $\$ 8.00$

Fig. 1384, No. R 251, Cog Gear, 3 in. Brass Cylinder, Glass Valve Seat, $11 / 4$ in. Suction Pipe, Cock Spout,

List, $\$ 9.50$

Fig. 1463, No. R 253, Cog Gear, $31 \frac{1}{2}$ in. Brass Cylinder, Glass Valve Seat, $1 \frac{1}{2}$ in. Suction Pipe, Siphon Spout.

List, $\$ 9.00$

Fig. 1384, No. R 253, Cog Gear, 31/2 in. Brass Cylinder, Glass Valve Seat, $1 \frac{1}{2}$ in. Suction Pipe, Cock Spout.

List, $\$ 10.50$

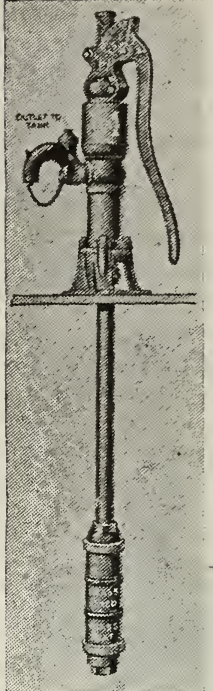

Fig. 1473

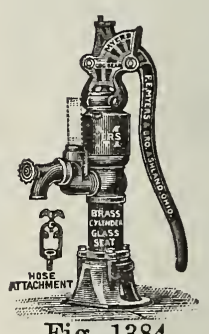

Fig. 1384

Myers Anti-Freezing Cistern and Shallow Well Pump

For House or Outdoor use

Fig. 1217, No. S 245, 3 in. Brass Lined Cylinder Siphon Spout. Plain Lift.

List, $\$ 7.50$

Fig. 1464, No. S 251, 3 in. Brass Lined Cylinder, Double A.ctng Force Siphon Spout.

List, $\$ 8.50$

Fig. 1473, No. RS 5251, Brass Lined Cylinder, Double Acting Force, Glass Valve Seat, Siphon Spout, $1 \frac{1}{4}$ in. pipe.

List, $\$ 8.50$

Fig. 1473, No. RS 251, Brass Lined Cylinder, Double Acting Force, Glass Valve Seat, Cock Spout. List, $\$ 10.00$

\section{All These House Pumps Have}

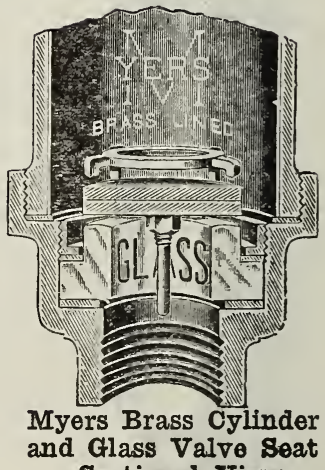




\section{MYERS OUTDOOR LIFT AND FORCE PUMPS}
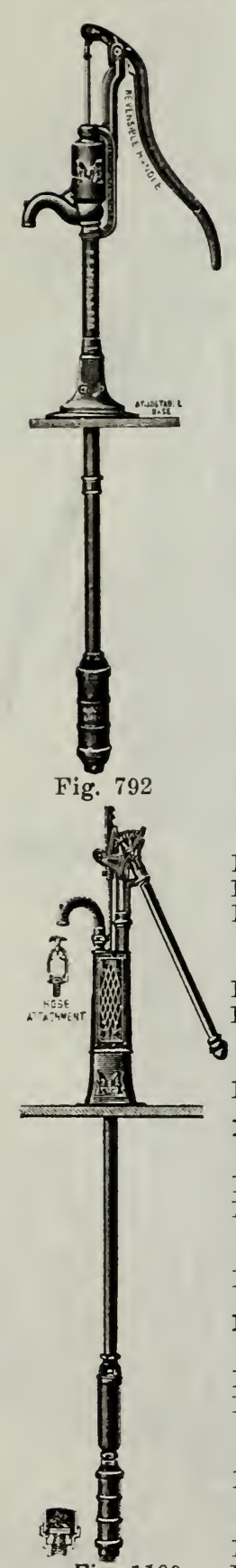

Fig. 1109

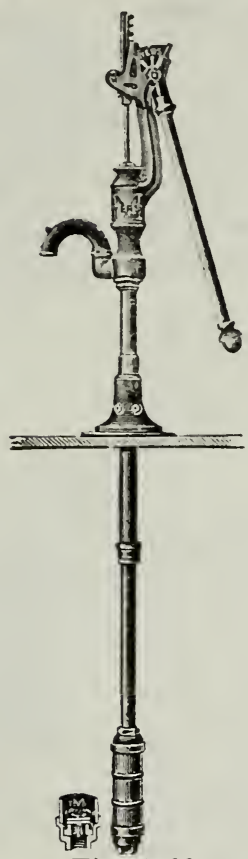

Fig. 1108

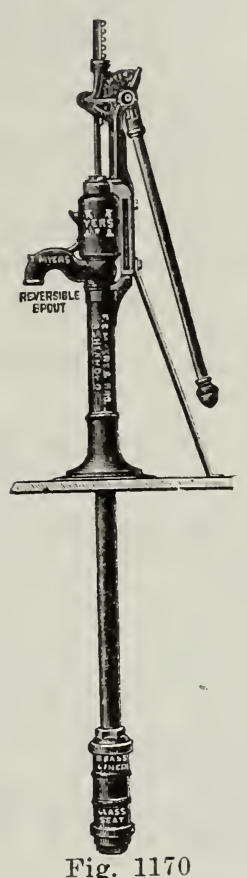

Fig. 1170

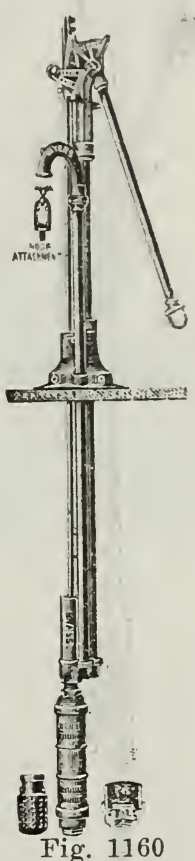

Myers Adjustable Base Lift Pump

Fig. $\quad$ 792-No. $1281 / 2-3$ in. Brass Lined Cylinder, list, \$ 8.00 Fig. $792-$ No. $1301 \frac{1}{2}-3 \frac{1}{2}$ in. Brass Lined Cylinder, list 9.00 Fig. $792-$ No. $125-31 \frac{1}{2}$ in. Iron Cylinder, list, $\quad 7.00$ Myers Ratchet Handle Lift Pump

Fig. 1108-No. R154-31/2 in. Brass Lined Cylinder, list, 9.00 Fig. 1108-No. R152-3 in. Brass Lined Cylinder, list, 8.00

\section{Myers Ratchet Handle Stock Lift Pump}

Fig 1170-No. R104-4 in. Brass Lined Cylinder, list, 13.50 Myers Ratchet Handle Branch Pipe Double Acting Force Pump

Fig. 1160-No. R16-31/2 in. Brass Lined Cylinder, list, 16.00 Fig. 1160-No. R14-3 in. Brass Lined Cylinder, list, 15.00

Myers Combination Shallow and Deep Well Pump

Fig. $522-$ No. $86-3$ in. Brass Lined Cylinder, list, 15.00 Myers Ratchet Handle Combination Shallow or Deep Well Pump

Fig. 1109-No. R186-3 in. Brass Lined Cylinder, list, 15.00 Fig. 1109-No. R188-31/2 in. Brass Lined Cylinder, list, 16.00

\section{Myers Adjustable Base Force Pump}

Fig. $827-N o .135 \frac{1}{1} 2-3$ in. Brass lined Cylinder, list, 9.00

Myers Ratchet Handle Double Acting Force Pump

Fig. 1138-No. R174-31/2 in. Brass Lined Cylinder, list, 10.00 Fig. 1138 -No. R172-3 in. Brass Lined Cylinder, list, 9.00

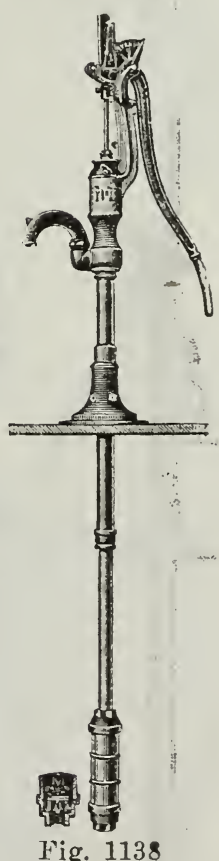

The above are list prices; if interested write us measurements of your well and we wiw gladly quote you net prices on your outfit. 


\section{MYERS WINDMILLS AND POWER PUMPS}
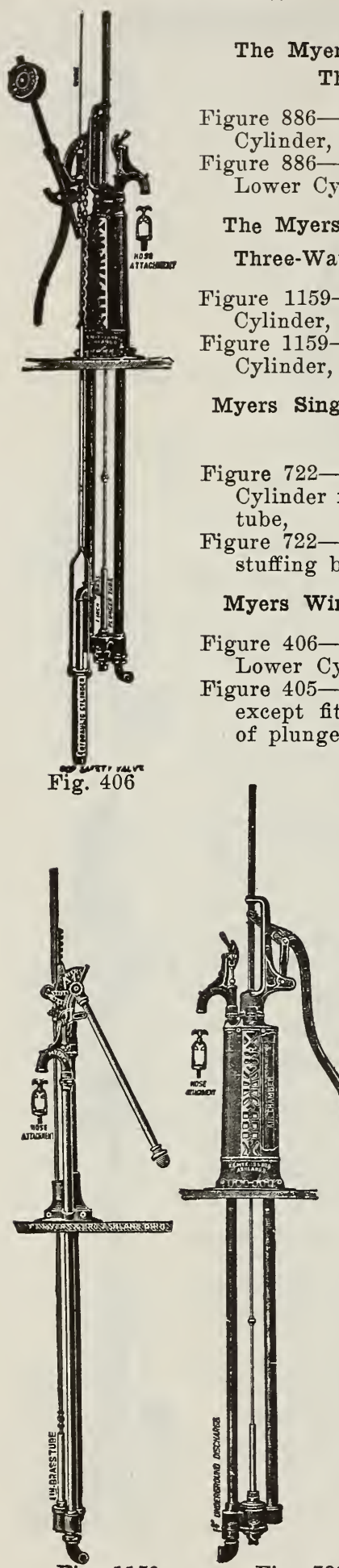

Fig. 1159 Cylinder, Cylinder, Cylinder, tube,

\section{The Myers Branch Pipe Single-Acting Three-Way Force Pump}

Figure 886-No. 22i-Without Lower

List, $\$ 13.50$

Figure 886-No. 228-With $3 \times 14$ Brass

Lower Cylinder,

List, $\$ 19.50$

The Myers Ratchet Handle Branch Pipe

Three-Way Single-Acting Force Pump

Figure 1159-No. R227-Without Lower

List, $\$ 13.50$

Figure 1159 -No. R228-With $3 \times 14$ Brass

List, 19.50

\section{Myers Single-Acting Three-Way Windmill Force Pump}

Figure 722-No. 238A-3-inch Brass-lined Cylinder for $1 \frac{1}{2}$ inch pipe, with plunger

List, $\$ 22.50$

Figure 722-No. 238- Same as above, with stuffing box.

List, $\$ 22.50$

\section{Myers Windmill Regulatior Force Pump}

Figure $406-$ No. $243-21 / 2$ or $3 \times 14$. Brass Lower Cylinder, List, $\$ 31.00$

Figure 405-No. 241-Same as Figure 406 except fitted with stuffing box instead of plunger tube,

List, $\$ 31.00$

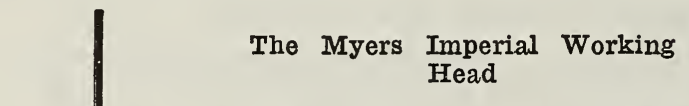

Fig. 1584-No. 389-Illustrates the Myers Imperiall Working Head, which is built on the general plan of the Imperial Underground Three Way Pump, with $11 / 2$ inch air chamber and $11 / 4$ inch discharge. The Three Way is fitted for $1 \frac{1}{2}$ inch pipe; the crosshead carries a 3 inch pipe through which a 3 inch plunger can be removed. It is especially adapted to tubular wells. The jack forms a part of the pump head; is mounted directly on the base of the pump, to which it is securely bolted. The gears are machine cut, back geared 5 to 1 . Has 6 inch and 9 inch stroke. Belt pulley 14 inches in diameter.

NOTE-One special feature of this outfit is that the part forming the jack can be removed from the base of the pump, thus making it easy to handle in placing in the well. In fact, it is just as easy to install this working head as it is to set an ordinary Underground Three Way Pump. List, includng 14 in. Pulley,

Fig. 722

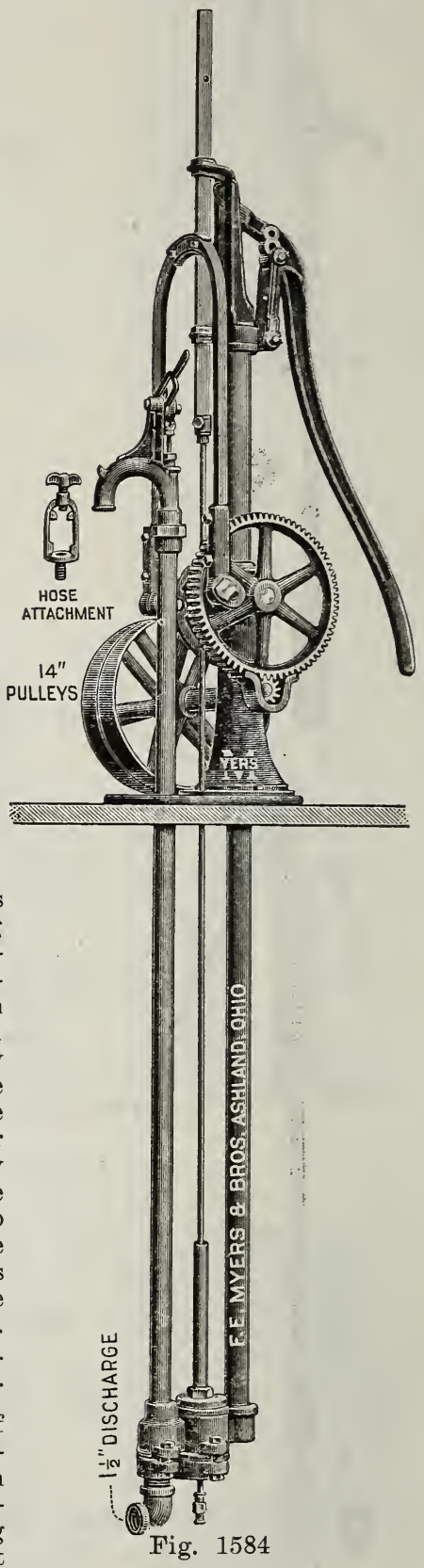

$\$ 30.00$ 
Fig. 1289, No. 470, fitted with hose nipple, hose attachment, hose hand and strainer.

List, $\$ 13.00$

Myers Century Low Down Double Acting Force Pump

Fig. 1263, No. 286, 3 in. Brass Lined Cylinder, 11/4 in. suction and discharge.

List, $\$ 14.00$

Fig. 1371, No. R286 Myers Century Low Down, with cog gear Handle, 3-inch Brass Lined Cylinder List, $\$ 15.00$

The Myers Hydro-Pneumatic Double Acting Century Low

\section{Down Force Pump}

Patented

With Plain or Ratchet Head and Brass end Cylinder. Equipped with brass valve seats, rubber faced valves, and brass covered piston rod, and is especially designed with Hydro-Pneumatic Cylinder for pumping air. Suction attached to either side. Discharge set at an angle, air chamber attached to pumps by union nut.

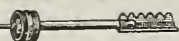

Fig. 1374

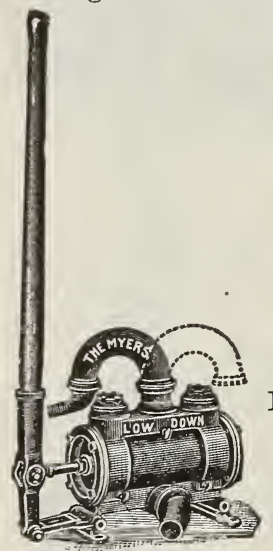

Fig. 1289

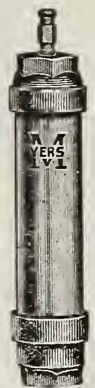

Fig. 215

Myers Brass

Cylinder

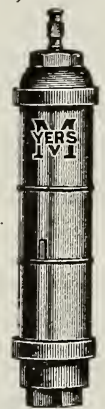

Fig. 976

Myers Iron

Cylinder

Air can be admitted or cut out by a slight turn of the cap on air valve. Forcing the air into tank through the discharge line with the water AERATES the water in the TANK, keeping it pure and sweet.

Fig. 1374. No. R286A. Myers Hydro-Pneumatic Cog Gear Century Low Down Pump, 3-inch brass lined cylinder, suction and Fig. discharge, tapped for $11 / 4$ in. pipe. List, $\$ 18.00$

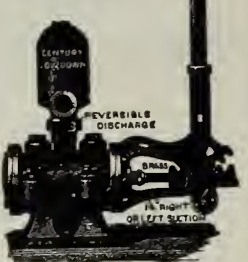

Fig. 1371

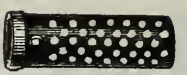

220 Myers Galv. Gauze Covered Strainer

We carry a very complete line of repairs for all Myers House and Outdoor Pumps.

Prices on Myers Pumps subject to discount.

No. $86-1 \frac{1}{4}$ in. $\times 1 \% \mathrm{ft}$. No. $98-1 \frac{1 / 4}{4}$ in. $\mathrm{x} 3$ ft.

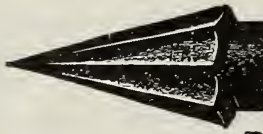

Driver We 11 Points

Price, \$.65 No. $136-11 / 2$ in. $x 2 \mathrm{ft}$.

1.15 No. $144-1 \frac{1}{2}$ in. $x 3 \mathrm{ft}$.

Price, $\$ 1.00$

MYERS POTATO SPRAYER

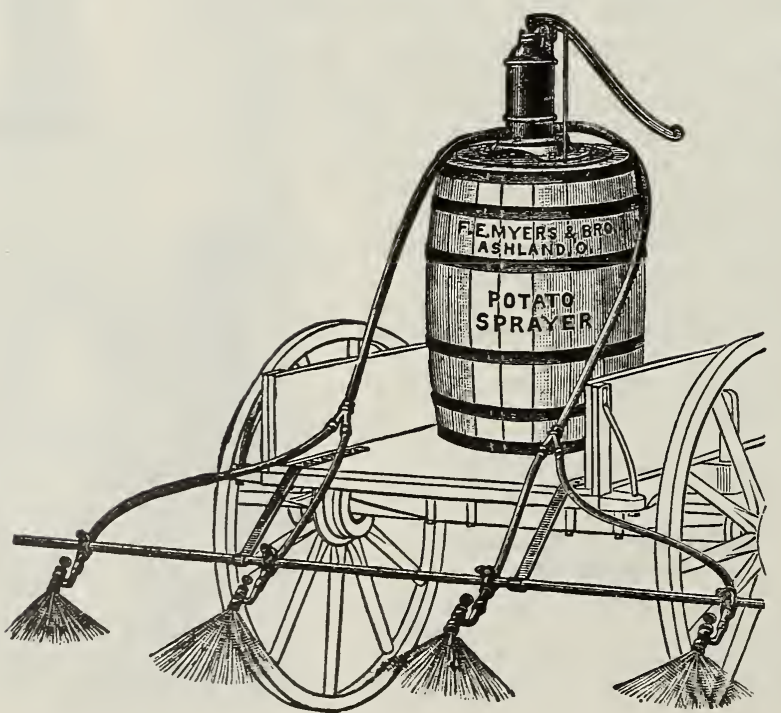

The must practical potato sprayer ever put on the market; it can be attached to any wagon, is very simple in construction and durable, nothing about it to get out of order.

This sprayer was gotten up to meet the denand for a practical and efficient sprayer at a low price. The power sprayers that have been put on the market during the last few sea. sons have proved very unsatisfactory and at a price that is much more than the average farmer is willing to pay.

This sprayer can be readily adjusted to rows any width apart, the liqlid is conducted from the pump by two lines of rubber hose, making the pressure on the nozzles uniform, therehy insuring a perfect spray from all the nozzles at once.

This sprayer is fitted throughout vith brass connections and high pressure rubber hose, the liquid not coming in contact with the iron pipe in any way.

Every sprayer guaranteed to give perfect satisfaction. We do not furnish barrel with sprayer, as they can be obtained nearer home at quite a saving in freight charges. 


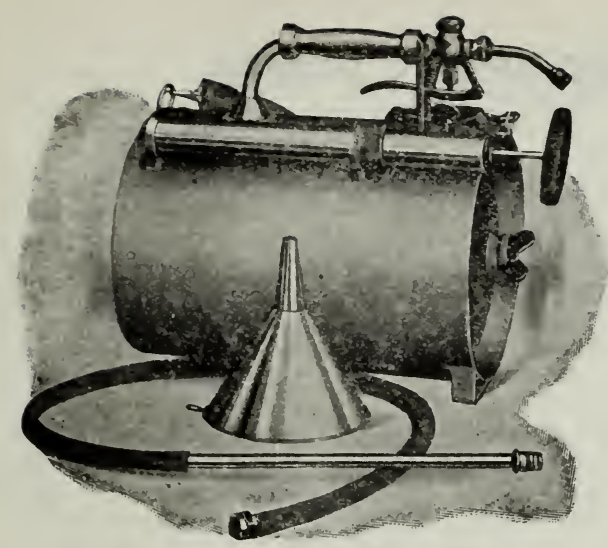

Lowell Compressed Air Sprayer

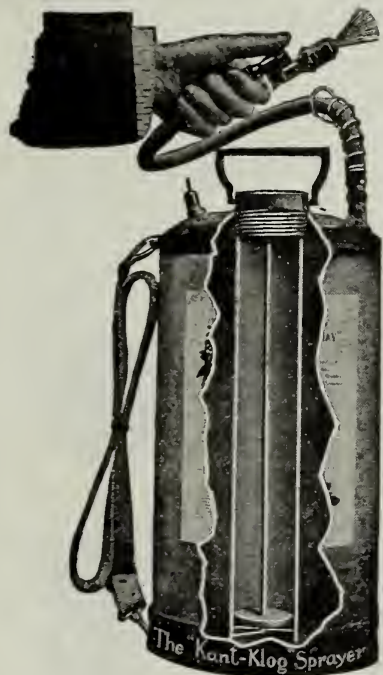

“Kant Klog"'-Style G carrier strap, ments ed.

LOWELL COMPRESSED AIR SPRAYER

Does not require constant pumping.

IIas an automatic thumb lever valve.

Most practical for Orchard, Field and Garden Work.

One pumping will expel entire contents of tank and is sufficient to spray 2,000 plants. Sipraying nozzle may be reversed to spray under side of bushes and plants. The Automatic Thumb Lever Valve is at all tines under complete control of operator-hence none of the solution is wasted. It saves its cost in making a given amount of compound do so much more work. An Adjustable shoul(ler Strap and Tree Attachment with suitable couplings for orchard and tree spraying, furnished with each machine. Aluminum finish. ('apacity 3 gallons.

No. 110 Galvanized Steel No. 111 Prass

"Kant Klog", Sprayer

The tank of this sprayer is made of heavy polished brass or galvanized steel as ordered. Top and bottom are seamed very strongly to sides under heavy pressure making very strong construction.

Price of Style G, with galvanized steel body, brass air pump, hose, escape-valve, "Kant-Klog"' nozzle, spring suut-off and

$\$ 4.00$

Polished Brass Body, with same attach-

3-feet Brass Extension . . . 0.50

Brown's Auto Sprayer

A practical machine for applying Bordeaux and all solutions to Potatoes, Tobacco, Small Fruits, Poultry Houses, etc.

Brass Extension Pipes, Torces and different Nozzles furnished as extras if want-

No. 1 A, Brass Auto Spray wien Stop Cock Nozzle . . . . . . $\$ 6.75$

No. 1 B, Brass Auto Spray with Auto Pop Nozzle . . . . . . $\$ 7.20$

No. 1 C, Galvanized Auto Spray with Stop Cock Nozzle . . . . . $\$ 4.50$

No. 1 D, Galvanized Auto Spray with $\$ 5.00$

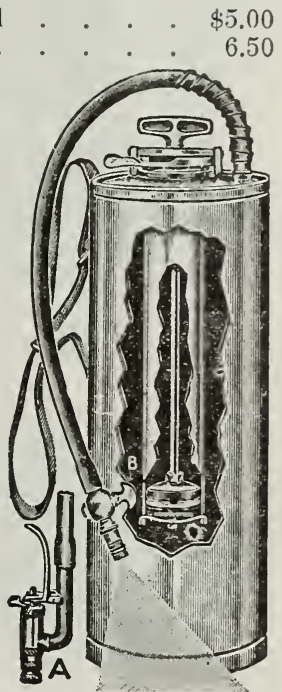

PATENTED.

Brown's Auto Sprayer Auto Pop Nozzle . . . . . . \$4.95

Junior Spray Pump, No. 5

All brass suction, working within a brass cylinder with all brass valves . Price, $\$ 2.75$ Standard Brass Spray Pump

The finest hand pump on the market. Built entirely of Brass. Will throw fine spray to the top of the highest fruit tree.

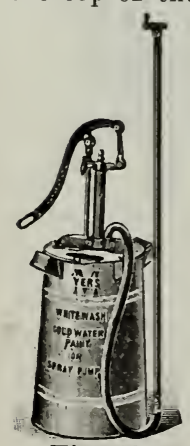

Fig. 1358

\section{The}

\section{Myers}

Whitewash, Cold Water Painting With Patent Double Agitator

Figure 1358 represents the Myers Whitewash, ('old Water Painting Machine and General Purpose Sprayer, with patent Double Agitator; a most complete and serviceable outfit. The tank is made of heary galvanized iron and holds 7 gallons.

\section{Myers Knapsack Spray Pump}

Net Price, $\$ 6.75$ Fig. 547

Trse.

With Patent Agitator, for Orchard or General No. 330, Galvanized Tank No. 331, Copper Tank
Price $\$ 6.00$ Price $\quad 9.50$

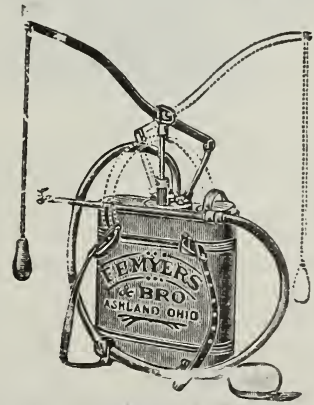

Fig. 547 


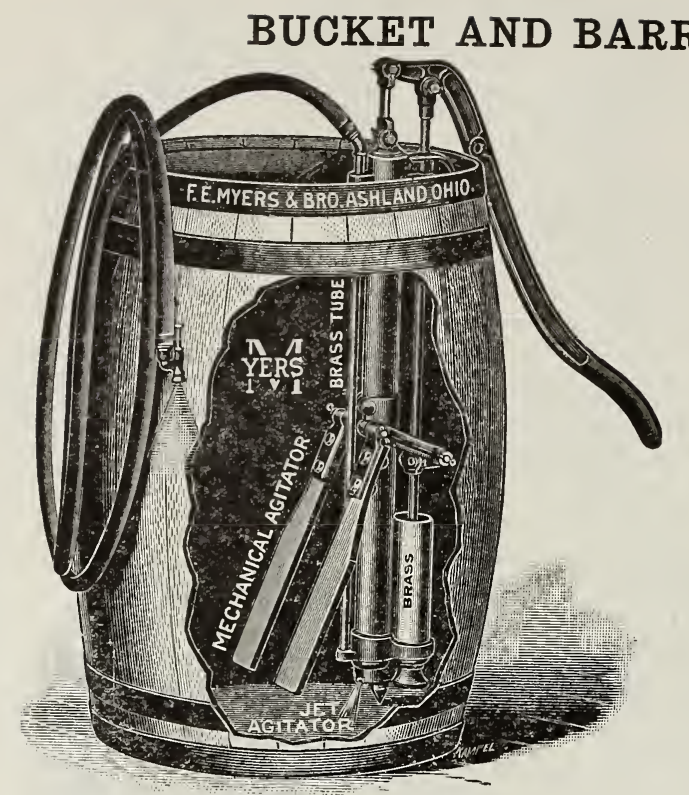

Fig. 1456

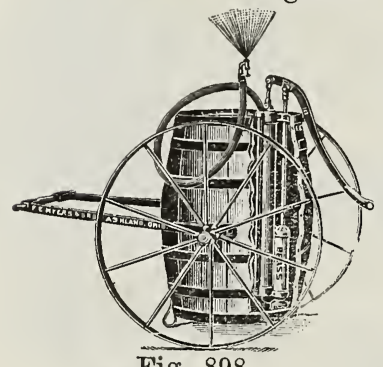

Fig. 898

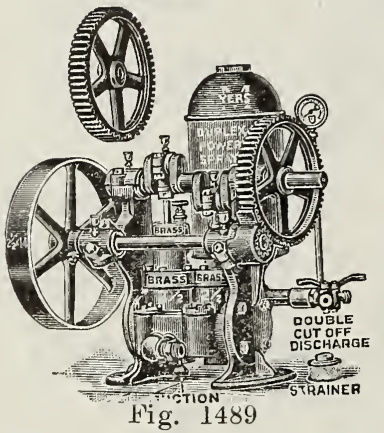

No. 445, Fig. 1489, with 21\% inch cylinder, Belt Pulley and Belt Tightener, Relief Valve, Pressure Gauge and Strainer. List, $\$ 75.00$

No. $445 \mathrm{~A}$, same as above but with $6 \mathrm{ft}$. wire bound suction hose, 2-8 ft. pipe extensions, 2 nozzles.

List, $\$ 80.00$

Above pumps can be furnished with gear wheel and pinion instead of belt pulley at same price.

Above pumps can be furnished with 2 inch instead of $2 \frac{1}{2}$ inch cylinder at deduction of $\$ 10.00$ from list prices.

Large Discount from List prices for Belt or Gear Drive.

\section{MYERS IMPROVED BARREL SPRAY PUMP}

The Myers Improved Brass Barrel Spray Pump was designed to meet the requirements where a good pump at a moderate price was required.

It is a thoroughly serviceable pump, well made and simple in construction; is recommended to the farmer with an ordinary sized orchard.

No. 304-Fig. 1456 Myers Improved Brass Barrel Spray Pump with both jet and mechanical agitator but without hose or nozzle.

List Price, $\$ 9.50$

No. 305B-Same as No. 304 but with one lead of 15 feet of $1 / 2$ inch 5-ply discharge hose, graduating Vermorel nozzle.

List Price, $\$ 13.00$

$8 \mathrm{ft}$. Pipe Extension . . . $\$ .60$

$8 \mathrm{ft}$. Bamboo Pipe Extension with shut off Cock . . . . . $\$ 4.50$

$10 \mathrm{ft}$. Bamboo Pipe Extension with shut off Cock . . . . . . . 5.00

5 ply Hose, per foot . . . $\quad .20$

Figure 632-No. 324 complete with agitator, hose and graduating Vermorel List Price, $\$ 6.00$ Giant Bucket Spray Punp. Figure 639-No. 3271/2 with agitator, hose and Imperial Nozzle. Has List Price, $\$ 4.00$

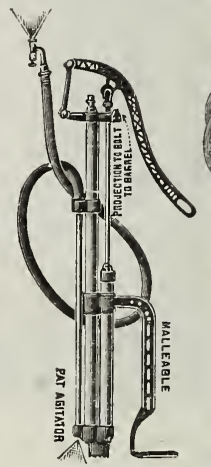

Fig. 632

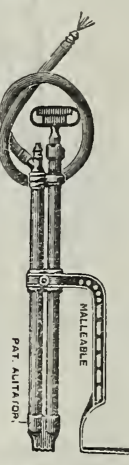

Fig. 639

\section{Myers Duplex Pow er fitted with $\mathrm{machine}$ cut Gear, Back \\ MYERS \\ PERFECT DOUBLE ACT- ING SPRAY PUIMP Fig. 653}

Barrel Cart attached to barrel, has 36 inch steel wheels with $11 / 4$ inch tire. ers Barrel Spray Pump can be Steel Cart only, ready to attach to List, $\$ 8.00$

Has Brass Upper and Brass Lined Lower ('ylinders, all Brass Plunger, Brass Check Valve, Brass Valve Seat, 1 inch Suction Fipe, Strainer, fitted with Canvas Packed Plunger and will handle hot or cold mixture.

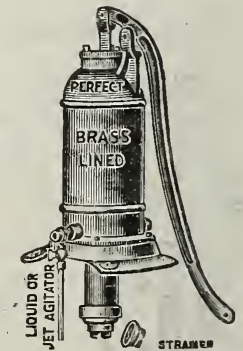

Fig. 653
No. 310, with Strainer, suction pipe and Mechanical Agitator, list $\$ 13.10$. No. 311B same as No. 310 but with $15 \mathrm{ft} .1 / 2$ in. hose and Vermorel Nozzle, list, $\$ 17.00$. No. $312 \mathrm{C}$, same as No. 310 but with two leads of $15 \mathrm{ft}$. hose and Vermorel Nozzle, list, \$21.00.

We carry a very complete line of repairs for all Myers House and Outdoor Pumps.

Prices on Myers Pumps subject to discount. 


\section{SPRAY PUMPS}

The cog gear increases the leverage $25 \%$ over the ordinary plain handle. The special features are the cog gear, the malleable iron base, which is adjustable and is made for end or side of barrel; base for end of barrel is furnished regularly. If pump is wanted for side of barrel, must be stated on order. The plunger is a solid brass tube with closed end, is outside packed, with hemp packing. The packing gland is adjusted by two bolts. The valve and seat are hard brass. The air chamber is $21 / 2$ inch. This in connection with the cog gear enables the operator to carry a pressure of 200 or more pounds, if necessary.

PRICE LIST Represented by Fig. 1542.

\section{List Price}

No. R30S. Myers O. K. Spray Pump, as shown without barrel and fittings. Price, each . . . . . . . . . $\$ 18.00$

No. R308B. Outfit same as shown in figure 1542 with one lead of $15 \mathrm{ft}$. of 7 -ply, $1 / 2 \mathrm{in}$. discharge hose and one Fembro (Fig. 1290) nozzle. Price, each

22.75

No. R308C. Same outfit with two leads of $15 \mathrm{ft}$., 7 -ply, $1 / 2$ in. hose and two Fembro (Fig. 1290) nozzles.

Price, €ach

7 -ply superior hose, our brand.

Price per $\mathrm{ft}$.

Barrel not included in above prices.

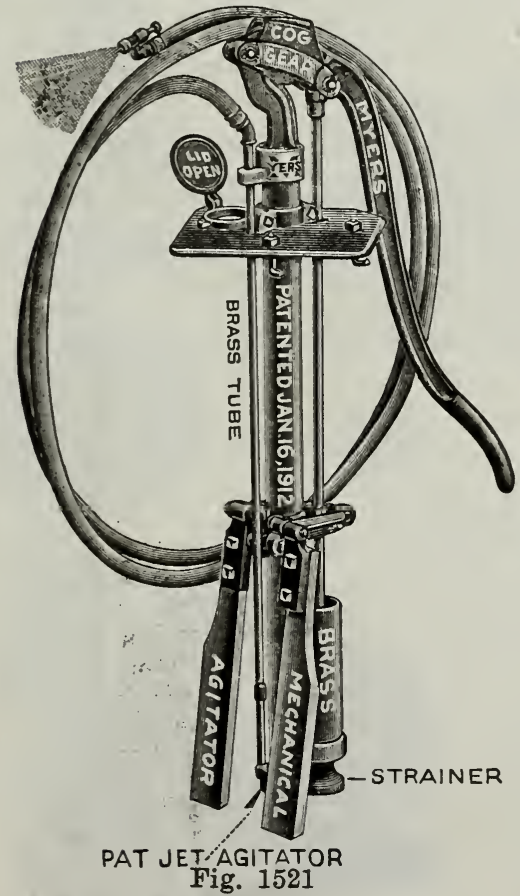

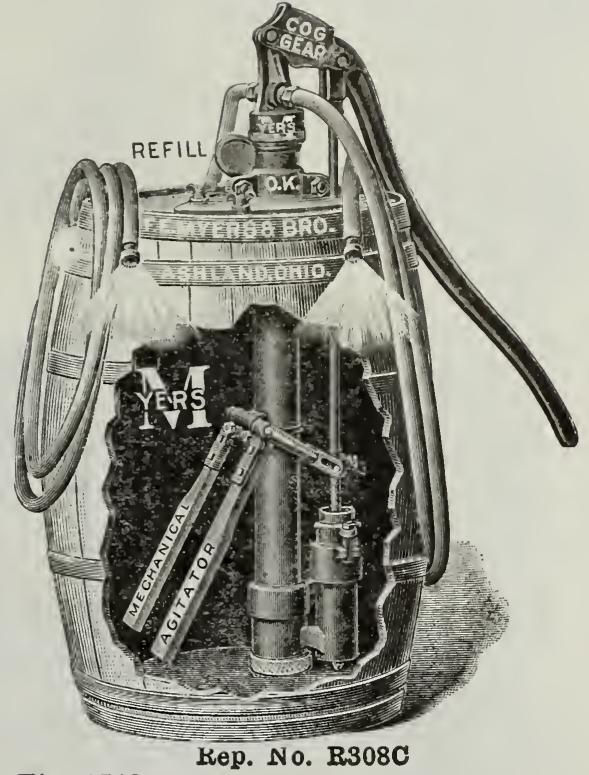

Fig. 1542

\section{THE MYERS COG GEAR SPRAY PUMP}

With Malleable Iron Base Cylinder, Valves, Valve-Seats and Discharge, all Brass.

No. R318, Fig. 1521, Myers Cog Gear Spray, Pump only with both jet and mechanical agitator but without hose or nozzle.

List Price, $\$ 10.50$

No. 318B, Fig. 1521, Complete Myers Cog Gear Barrel Spray Pump with one lead of 15 feet of $1 / 2$ inch 5 ply discharge hose, graduating Vermorel Nozzle both Jet and Mechanical Agitator.

List Price, $\$ 14.00$

5-ply Hose per foot

\section{Large Discount from List Prices}




\section{SPRAY PUMPS}

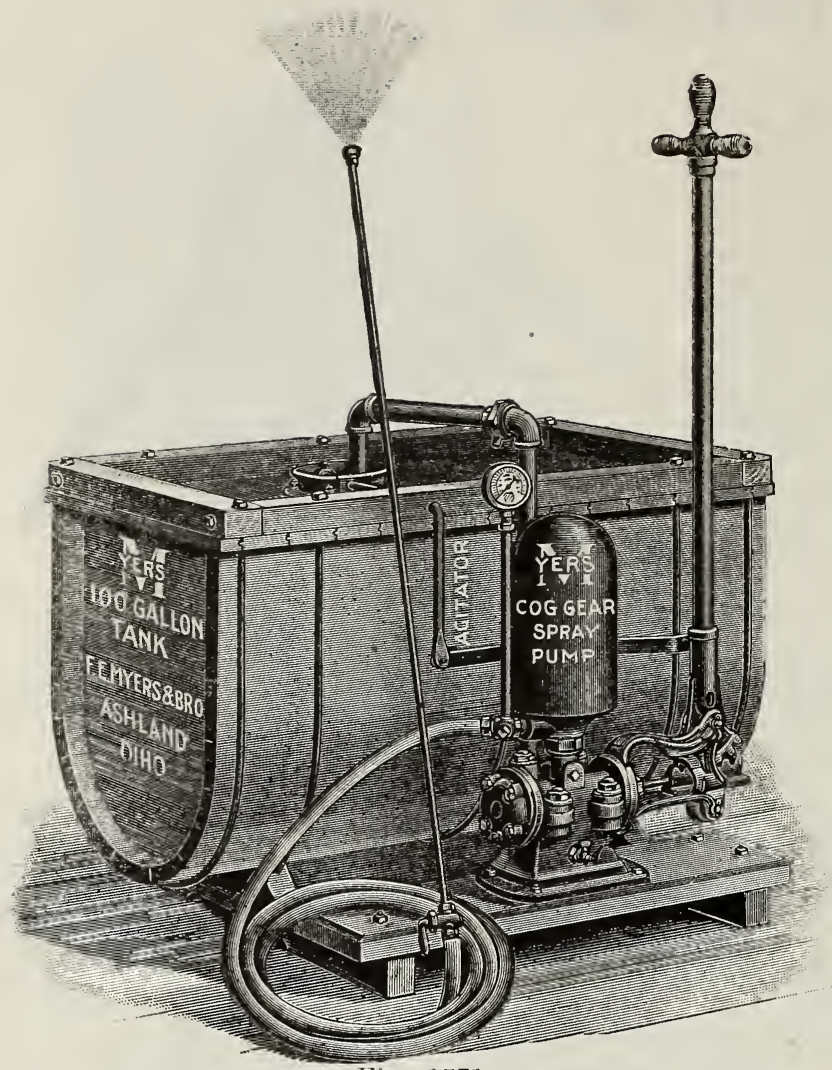

l'ig. J.j]. Large capacity tank holding 100 gailons, with mechanical agitator $\operatorname{cog}$ geared double acting P'unp with large capacity.

The cog gear morement inereases the leverage over 40 ir arapting it for spraying under heary pressure. II ounted complete occupyingr smallest space possible, can be placed in the ordinary wagon box. Can be furnished with one horse gasoline engine instead of hand power at an attractive price.

Fig. 1571

PRICE LIST Represented by Fig. 1571.

No. R31iB. Pump complete with 100 gallon tank and mechanical agitator, mounted on skids, with pressure gauge, one 15 foot lead of $1 / 2$ inch 7 -ply discharge hose, one Fembro Fig. 1290 нozzle, one 8 foot Fig. 1535 pipe extension with lever's shut off. Price, each (Prime) $\$ 55.00$

No. R317C. Pump complete with 100 gallon tank and mechanical agitator, mounted on skids, with pressure gauge, two 15 foot leads of $1 / 2$ inch 7 -ply discharge hose, two Fembro Fig. 1290 nozzles, two 8 foot Fig. 1535 pipe extensions with lever shut off. Price each (Primer)

Above outfit equipped with one-horse power, gasoline engine and pump-jack added to ahove List Prices,

\section{MYERS DOUBLE ACTING COG GEAR SPRAY PUMP, Fig. 1518}

Mounted on skids with 50 Gallon Barrel and Mechanical Agitator. Has Brass Valves and Ground Bevel Brass Seats.

\section{Price List Fig. 1518}

No. R316B Jump complete 50 Gallon Barrel mounted on skids with pressure gauge one $15 \mathrm{ft}$ lead $1 / 2$ in 7 -ply hose, one Fembro Nozzle, one 8 foot pipe extension, one lever shut-off with mechanical agitator.

List, $\$ 40.00$

No. R316C. Same as above but fitted with two leads of hose, two poles, two nozzles, etc.

sist, $\$ 45.00$

Large Discount from Above List Prices.

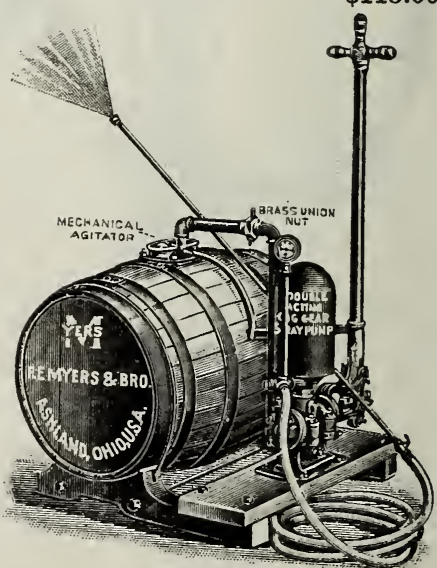

Fig. 1518 


\section{SPRAYING NOZZLES}

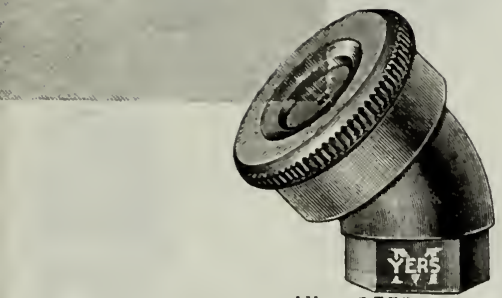

r'ig. 155 !

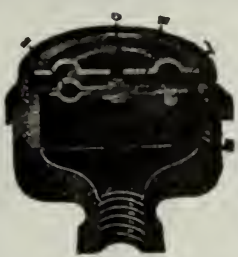

Fig. 100

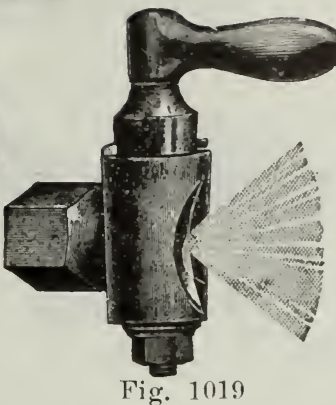

Figme 1.5.9. Represents the populat leblor $45^{\circ}$ Noz\%le. is fitterl with a removahle steol risk in the calp.

Straight Fembro Nozzle.
P'lices Xet. \$. (6.)

(i)

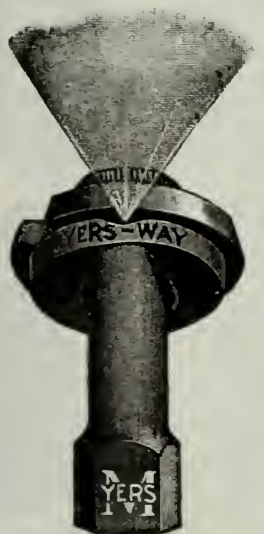

Fig. 1470

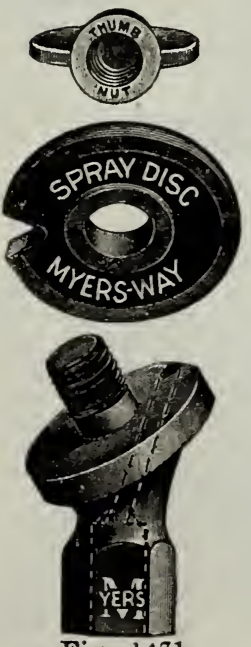

Fig. 1471 lig. 100. Represents the Nour ('loge Automie Forzle, it las the capacity of four ordinary nozzles. It positively can not clog as it is filter! with a removable wire screen through which all solution passes. Adjustable from a fine wide spray to a solid stream by simply moring the disk in the nozzle.

Price, all Brass Net. $\$ 1.00$ Aluminum, $\$ 1.1 .5$

Fig. 1019. Represents regular Bordeaux Nozzle, Net. \$.6:5

Fig 1317. Represents Myers Power Nozzle with self cleaner or Disgorger by pressing the nozzle against a limb on the tree, a pin is thrust in the opening in the disk and the pressure from the pump forces the nozzle open again ready for use.

Price Net, $\$ .90$

Fig. 1:54. Represents Myers Grarluating Vermorel Nozzle. The disgorger is operated by the screw plunger instead of a spring.

Net Price, \$.65

Wig 6it2. Represents Myers Imperial Noz\%le.

Net Price, $\$ .30$

Fig. $1+70$ and 1471 . Represent Myers War Nozzle of large capacity and throws a hroal, fan-like spray at an angle of $45^{\circ}$.

Net Price, $\$ .75$

Fig. 101. Fonld's Majestry Jr. Nozzles.

('all be furnished in stright or angle Brass or . Iluminum.

Net Price, $\$ .60$

All above noz\%les are fitterl to use $1 / 4 \mathrm{in}$. pipe for extensions.
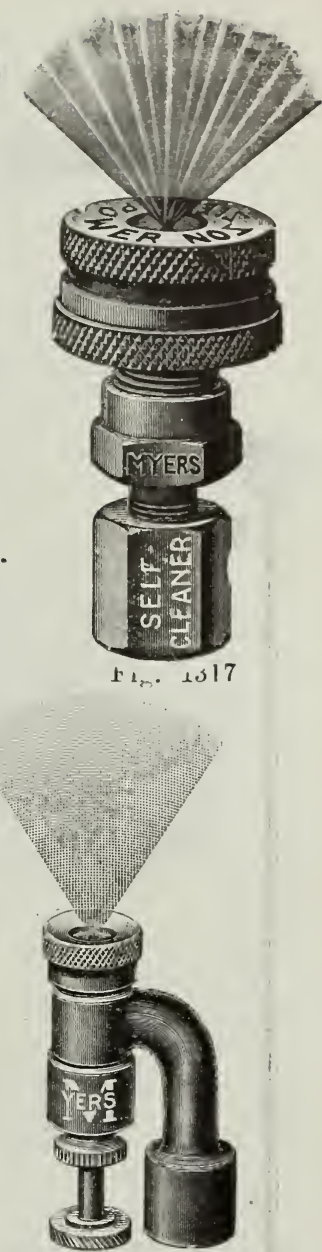

Fig. 1564

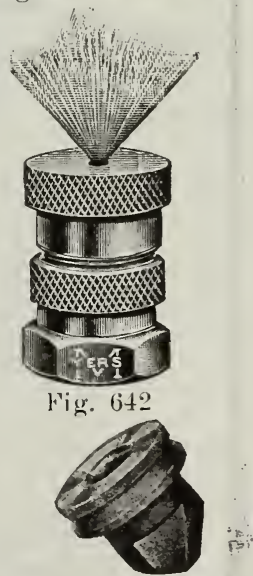

Fig. 101 


\section{SPRAY PUMP FITTINGS}
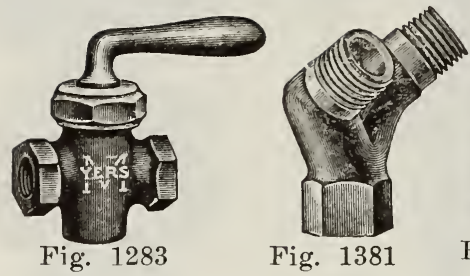

Fig. 1381

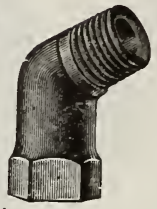

Fig. 1380

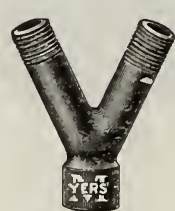

Fig. 1560

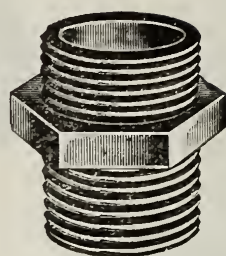

Fig. 540

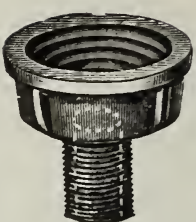

Fig. 772

Fig. 1283. Lever Shut Off Cock no dripping. All Brass, Made for use with pipe extension. Tapped for $1 / 4$ in. pipe.

Net Price, $\$ .60$

Fig. $1380-45^{\circ}$ Bevel Single Brass with $1 / 1$ inch pipe thread.

Net Price, $\$ .30$

Fig. 1381-45० Bevel Double Brass with $1 / 4$ in. pipe thread.

Net Price, $\$ .50$

Fig. 1560. Brass $Y$ for two nozzles with $1 / 1$ inch prpe thread. Net Price, $\$ .50$ $\$ .30$.

Fig. 540. Brass Hose Nipple. Net Prices, $3 / 4$ inch, $\$ .25 ; 1$ inch

Fig. 772. Brass Hose Reducer, 3/4 inch hose, 1/4 inch Pipe.

Net Price, $\$ .20$

Fig. 1091. Female End $1 / 2$ in. hose, $1 / 4$ in. Pipe. Net Price, $\$ .25$

Fig. 549. Male End $1 / 2$ in. hose, 1/4 in. Pipe. Net Price, \$.25

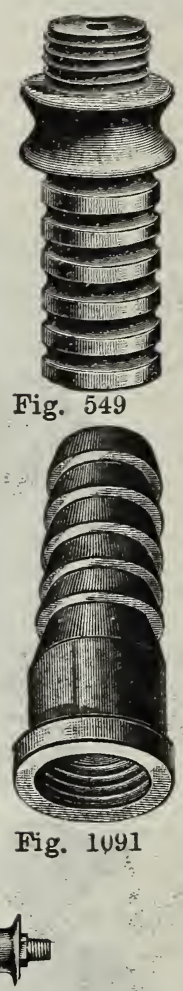

Fig. 1554

Fig. $48 u-8$ foot pipe extension with coupling,

Fig. $480-8$ foot pipe extension with stop cock.

Fig. 480-8 foot pipe extension, with Lever Shut-ofi

Fig. 1554-8 foot bamboo extension with Lever Shut-off eock.

Fig. 1554-10 foot bamboo extension, with Lever Shut-off cock.

Fig. 1554-12 foot bamboo extension with Lever Shut-off cock.

\section{Above Prices do not include Nozzles.}

\section{Spray Hose.}

15 Foot Lengths of 5 ply Hose with couplings.

25 Foot Lengths of 5 ply Hose with couplings.

15 Foot Lengths of 7 ply Hose with couplings.

25 Foot Lengths of 7 ply Hose with couplings.
Net Price, $\$ .40$

Net Price, $\$ .85$

Net Price, $\$ 1.00$

Net Price, $\$ 2.75$

Net Price, $\$ 3.15$

Net Price, $\$ 3.50$
Net Price, $\$ 1.80$

Net Price, $\$ 3.00$

Net Price, $\$ 2.25$

Net Price, $\$ 3.75$ 


\section{THE POWER SPRAY OUTFIT}

Figs 1591 represent the Myers Power Spray Outfit. It is furnished complete, including hose, nozzles, bamboo extemsions, pump, tank, agitator, ete. The entire frame work is made of channel and angle iron, making a very stiff frame with the least possible weight. It is fitted with a wrot steel hed plate on which the engine and pump are mounted, thus making a solid foundation which will not vihrate when under the most extreme pressure. The tank is male of selected eypress, holds 200 gallons has foml hoops. is fitted witl a rotary agitator with wooklen blades. The Agitator is driven by a link chain, which makes a flexible joint and relieves the tank from all strain. The inside measurements of the eab are: Width 4()$^{1} .2$ in., height 36 in., length 48 in. The distance fiom the edge of cog gear ou pump to the rear end of cab is 26 in.; thus aflording room for any size engine up to $21 / 2$ II. P. The cab has sliding doors for protection of the engine and lump. The sills are placed 26 in. apart which pernits a short turn of the wagon. The guarel rails on the top are to protect the operator from falling oft. Fig. 1591 shows the eab open.

\section{Price List Fig. 1591}

No. 1, Tank and Spray Outfit as slown in eut complete with No. 446 1)uplex I'ump with pinion for crank shaft of engine, without engine. List Price, $\$ 200.00$

Above Outfit equipped with 2 II. P. Gasoline Eugine.

List l'riee, $\$ 310.00$

linuipped complete as above or mounted. Truck with steel wheels. List Price, $\$ 360.00$

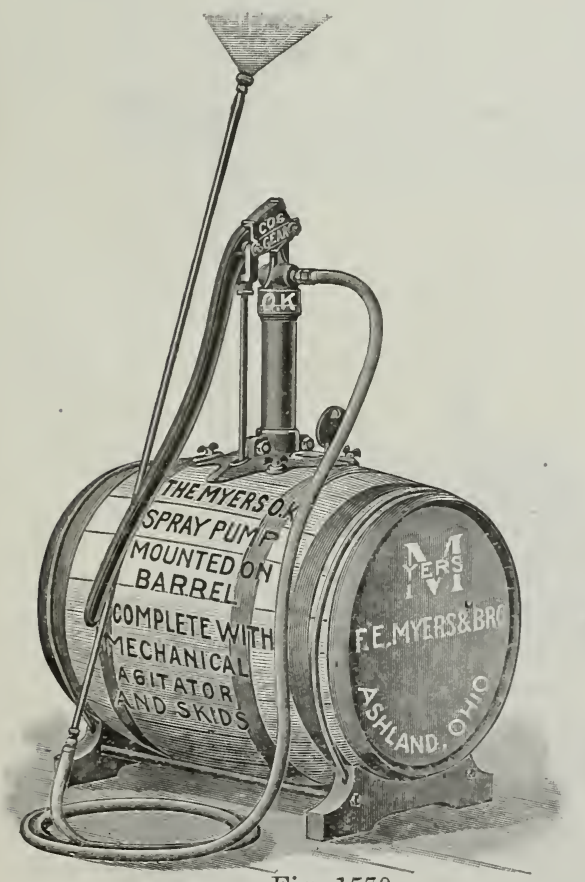

Fig. 1570

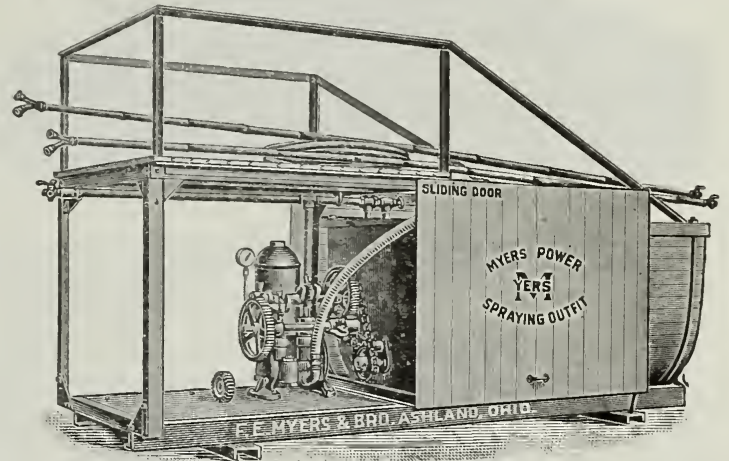

Fig. 1591

Equipment Fig. 1591 includes 50-foot lead of $1 / 2$ inch 7 -ply hose, 110 -foot lead of $1 / 2$ in. i-ply hose, 10 feet wire bound suction hose, 2-10 foot Bamboo Rods complete with lever shut-off, + Fembro uozzles, 2-Fig. $1560 \mathrm{Y}$ 's Rotary Agitutor, cut offs for discharge lines. Relief Valve, Fressure, Gauge and Strainer, all assembled for use.

Fig. 1570. O. K. Cog Gear Spray Pump, mounted complete with 50 Gallon Barrel, has Nechanical Agitatr. solid krass Ram Plung(r: Ground Pevel Valve and Seat.

No. Rogeb Gutfit complete as above with 1-1.) foot lead of $1 / 2$ in. $7-p l y$ lrose and Fembro Nozzle.

List Price, $\$ 30.00$

No. Re!)?(' same as above with 2-15 foot leacls of $1 / 2$ in. T-ply hose and nozzle.

List Price, $\$ 35.00$ 


\section{POWER SPRAYING OUTFITS}

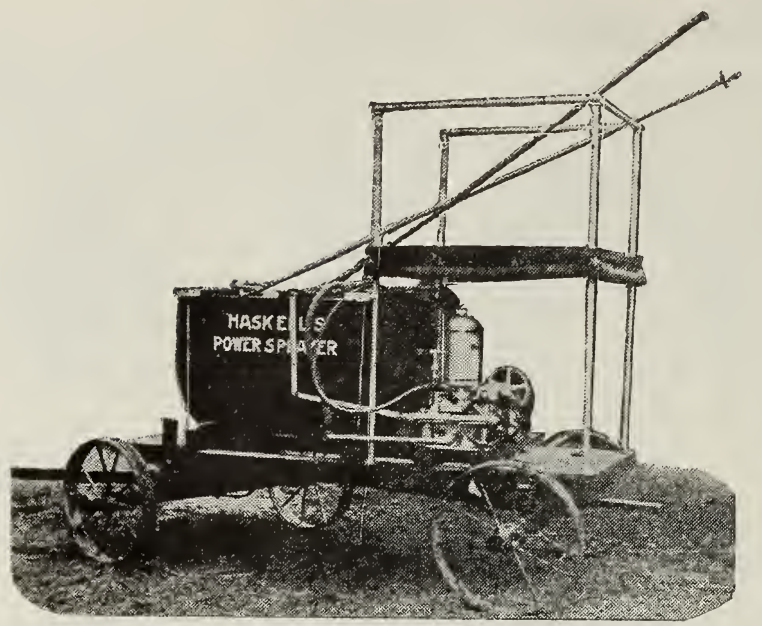

Fig. 103 represents Haskell's Power Sprayer complete with Tank, 200 gallon cajuacity, 2 H. P. Triumph Hopper ('ooled gasoline engine, mounted on truck with steel wheels $28 \times 30$ inch, 4 inch grooved tires. We use Myers No. Hti Duplex Power Spray Pump with relief valve and pressure gauge. Outfit also includes mechanical agitator for tank 2-2.5 ft. lengths of $1 / 2$ " hose, 2 Fembro spray Nozzles-crerything complete

Outfit less Truck,

$\$ 190.00$

SUBURBAN ELECTRIC LIGHTING AND POWER SYSTEMS

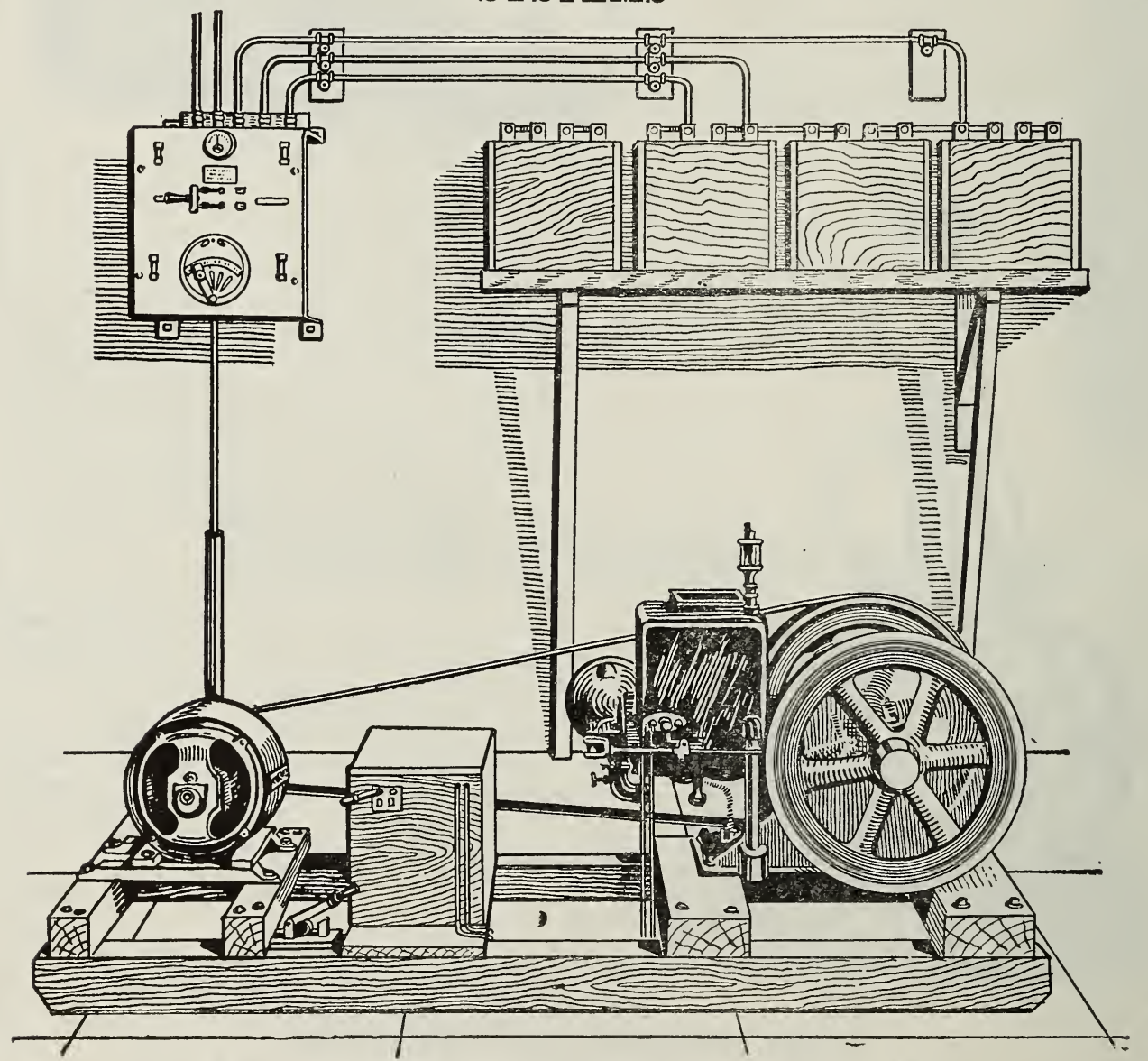

THE DEAN ELECTRIC HOME LIGHTING \& POWER SYSTEM

Not, the completeness and simplicity of the system 


\section{ELECTRIC LIGHTING AND POWER SYSTEMS}

The object of the Dean Homelite Plant is to provide for the isolated home, conveniences that are found in the city home today. Thus, the farmer is now enabled to do his chores by light that is practically as clear as day light and eliminate danger of fire eaused by using lanterns and lamps. The housewife is made happy by the advent of electric lights in her home. No more kerosene lamps to fill and wicks to trim, no more offensive odors and filthy labor to perform, and fire dangers are eliminated and insurance cost reduced.

\section{Rating}

Dean Homelite Plants are rated on the basis of using 30 volt, 20 watt, 16 candle power Tungsten lamps. We have selected the 30 volt system as the safest one for the average home-you being protected from electric shocks.

The Dean Homelite Plants consist of a storage battery, generator and switch board. The generator is mounted on skid with engine and everything is assembled in the most compact form.

If you are interested in a lighting outfit of the above nature we would be pleased to send you a complete catalog or send our representative to call on you, or by giving us the necessary information by answering questions below, we can estimate the cost to you.

Total number of $16 \mathrm{C} \mathrm{P}$ lamps to be used during the day.

Total number of $16 \mathrm{C} \mathrm{P}$ lamps to be used during the evening.

Total number of $16 \mathrm{C}$ P lamps to be used during remainder of night.

Give number and kind of electric devices and hours of service which will be used, such as fans motors, washing machines, flat irons, vacuum house cleaners, coffee percolaters, power motors for pumping, cream separators, etc.

Number of rooms in house which are to be wired.

Number of out buildings to be wired.

Approximate distance in feet from house to each out building.

\section{Warranty}

We guarantee our "Homelite" to develop their actual rating and to work satisfactorily when installed and operated according to our instructions. We will replace or repair, free of charge, at our factory, any part showing inherent defects, for a period of two (2) years from date of purchase, providing that such part or parts showing defects are delivered to our factory prepaid. 


\section{PNEUMATIC WATER SYSTEMS}

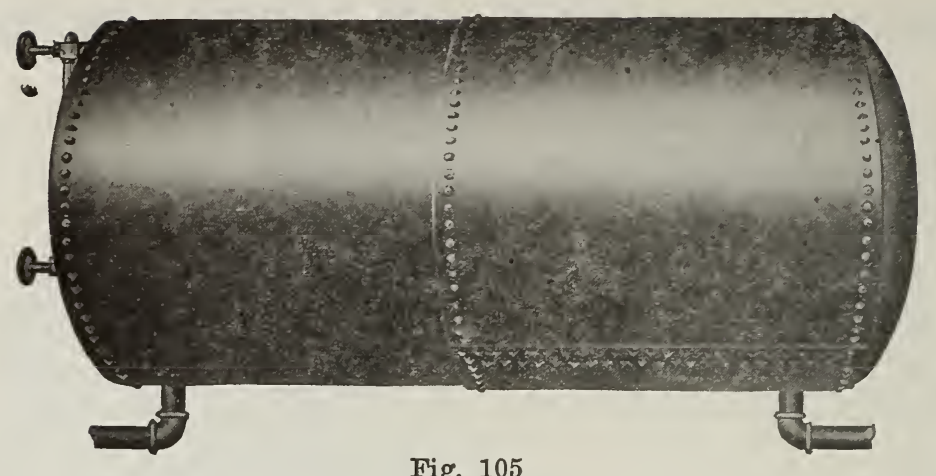

HASKELL

Double Kiveted Air-Tight Pneumatic Water Tanks will give you all the benefits of a city water works with no water rent bills to pay.

Have running water in your kitchen, bathroom, barn and other buildings and secure at the same time, fire protection for your property. It solves the problem for the suburban home, the club-house, the summer cottage, and incidentally other problems.

Pressure Tanks can be operated by pumps using wind mills, gasoline engines or hand power.

Fig. 106 represents a system operated by a hand pump. You can get some idea how cheaply these systems can be installed when you realize that we can furnish you one $30 x 6$ tank, 220 gal. capacity including one Double Acting Air and Water Pump, one Air Pressure Gauge, one Brass Gate Valve, one Water Gauge, one Faucet, one Stop and Waste, one Swing Check Valve, all for around, $\$ 70.00$ FITTINGS

We carry a full line of engines, pumps, galvanized pipe, malleable fittings, brass fittings such as fancets, check valves. etc.
IVe will be pleased to figure on your requirements. Send for catalog and further information.

Price List of Pneumatic Tanks.

\begin{tabular}{|c|c|c|c|c|c|}
\hline$\underset{\Xi}{\overrightarrow{0}}$ & & & & $\Xi$ & \\
\hline.$\beth$ & & & & & $\stackrel{\Xi}{\mathcal{E}}$ \\
\hline$\frac{7}{30}$ & & & & $\omega_{0}$ & $\vec{n}$ \\
\hline चี & Thicl & kness & & & $\vec{n}$ \\
\hline 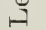 & Shell & Heads & Wts. & ש & 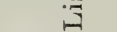 \\
\hline 5 & $3-16$ & $5-16$ & 425 & 120 & $\$ 5500$ \\
\hline 10 & $3-16$ & $5-16$ & 675 & 245 & 74.00 \\
\hline 6 & $3-16$ & $5-16$ & 560 & 220 & 70.00 \\
\hline 10 & $3-16$ & $5-16$ & 870 & 365 & 102.00 \\
\hline 5 & $3-16$ & $5-16$ & 675 & 265 & 85.00 \\
\hline 10 & $3-16$ & $5-16$ & 1050 & 525 & 131.00 \\
\hline 8 & $1 / 4$ & $3 / 8$ & 1450 & 575 & 135.00 \\
\hline 12 & $1 / 4$ & $3 / 8$ & 1900 & 865 & 1.96 .00 \\
\hline 12 & $1 / 4$ & $3 / 8$ & 2200 & 1000 & 219.00 \\
\hline 14 & $1 / 4$ & $3 / 8$ & 2610 & 1300 & 274.00 \\
\hline 16 & $1 / 4$ & $3 / 8$ & 2900 & 1500 & 304.00 \\
\hline 20 & $1 / 4$ & $3 / 8$ & 2950 & 1880 & 393.00 \\
\hline 24 & $1 / 4$ & $3 / 8$ & 4650 & 2260 & 437.00 \\
\hline
\end{tabular}

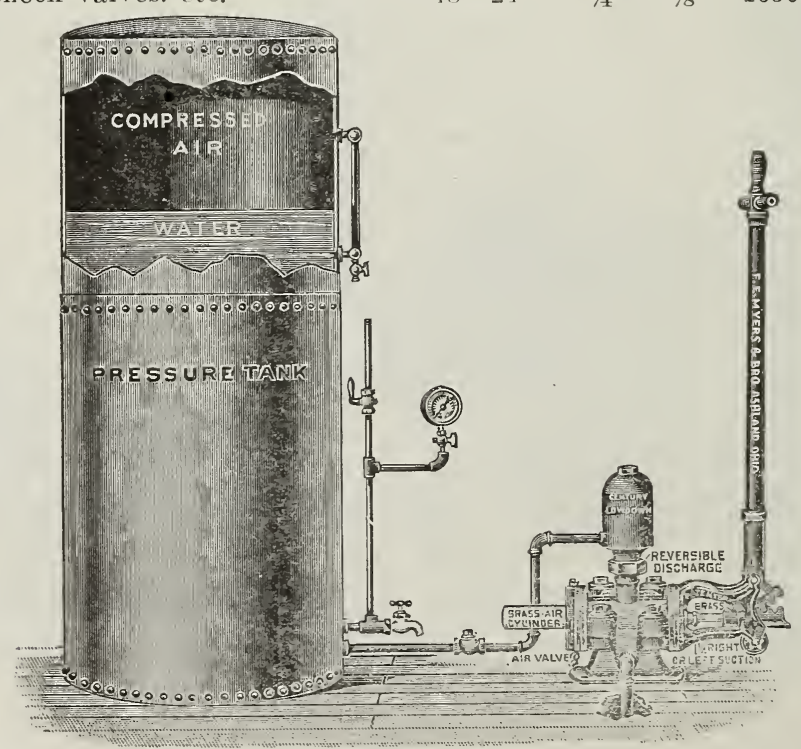

Fig. 106

Liberal Discount from List Prices 


\section{A Few of the Implements for which we are Headquarters in this section of the state}

Porter Litter Carriers

Deere Riding Cultivators

Deere Walking Cultivators

Syracuse Walking Cultivators

Deere Disc Cultivators

Ohio Feed Ensilage Cutters

Deere Potato Diggers

Hoover and Dowden Potato Diggers

R \& V Gasoline Engines

Deere Disc Harrows

Deere Smoothing Harrows

Syracuse \& Perry Spring Tooth Harrows

Acme Harrows

Johnston Mowers and Rakes

Johnston Corn and Grain Binders

Dain Mowers and Rakes

Deere and Dain Hay Loaders

Marseilies Feed Grinders'

Freeman Wind Mills

Deere two row Corn Planters
Eclipse and Eureka Corn Planters

Aspinwall Potato Planters

Deere Sulky Plows

Syracuse Sulky Plows

Deere and Syracuse Walking Plows

Dain Hay Presses

Dain Side Delivery Rakes

Dunham Land and Lawn Rollers

Van Brunt Drills and Seeders

Simpiex Cream Separators

Marseilles Corn Shellers

Aspinwall Sprayers

New John Deere Spreader

Success Manure Spreaders

Campbell Threshers

Davenport Roller Bearing Wagons

Havana Trucks

Eureka and Hallock Weeders

Chatham Cleaning and Separating Mill

Send for Special Circulars and Prices 


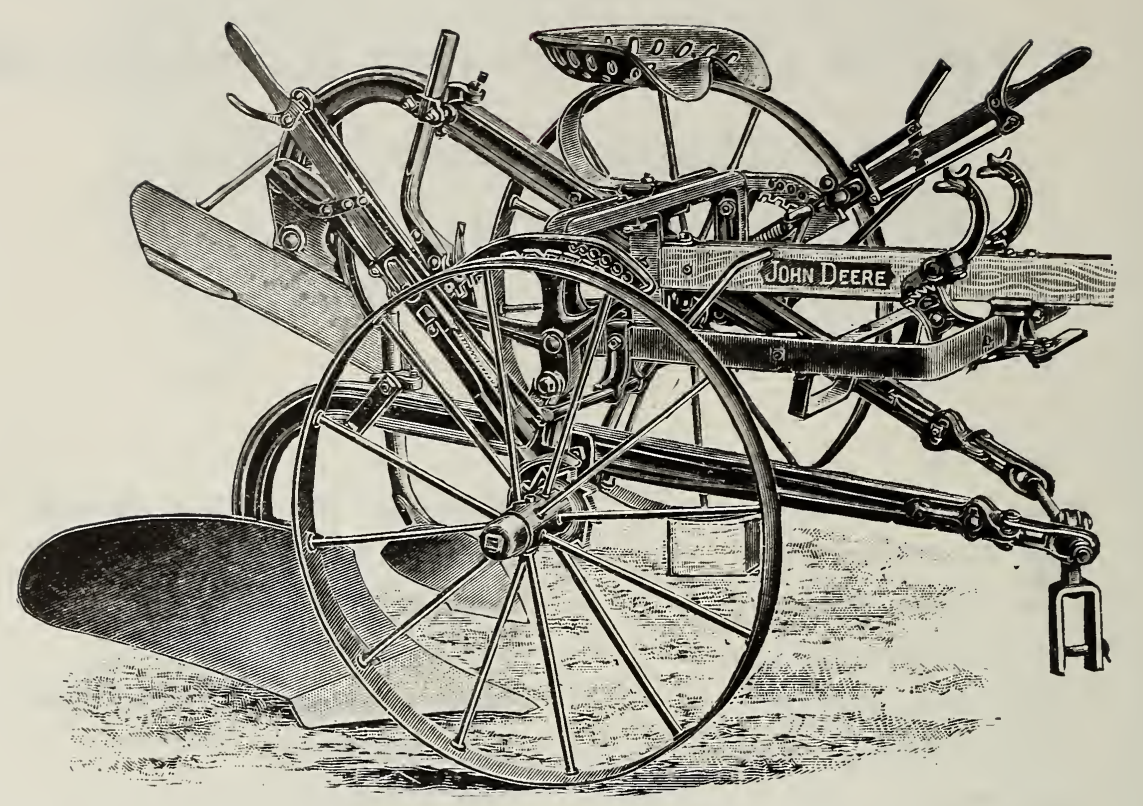

NEW JOHN DEERE TWO-WAY SULKY PLOW

\section{ADVANTAGES OF THE TWO-WAY PLOW}

First-The ground can all be turned one way, leaving no ridges and no dead-furrows in the field. This is true no matter whether working on level ground or on a side-hill.

Second-No time is lost working out irregular "centers" and small patches where the nature of the ground is such that neither square nor rectangular "lands", can be laid out for plowing.

Third-In plowing side-hills the ground can all be worked one-way. Every furrow can be thrown down hill if that method of plowing is desirable.

Fourth-It enables you to plant close up to the plowing, following the plow immediately with harrow and seeder before the ground dries out.

\section{Construction.}

The John Deere Sulky Plow represents the highest type of material and workmanship that is possible to procure. The entire frame and beams are constructed entirely of high carbon steel, hence are very strong and durable.

The new style foot landing device is the most satisfactory ever used and by its use and the horselift operated by foot power the plow can be operated very easily.

\section{Sizes}

$\begin{array}{lr} & \text { Cuts } \\ \text { 1342S-1442S Medium size } & 3 \text { to } 8 \text { in. deep } \\ 12 \text { to } 16 \text { in. wide } \\ \text { 1341S-1441S Large size } \quad 4 \text { to } 9 \text { in. deep } \\ 14 \text { to } 18 \text { in. wide }\end{array}$

Fitted with either Jointers, Hanging Cutters or Fin Cutters. Two or Three-Horse Eveners.

\section{If Interested Send for Special Circulars and Prices}




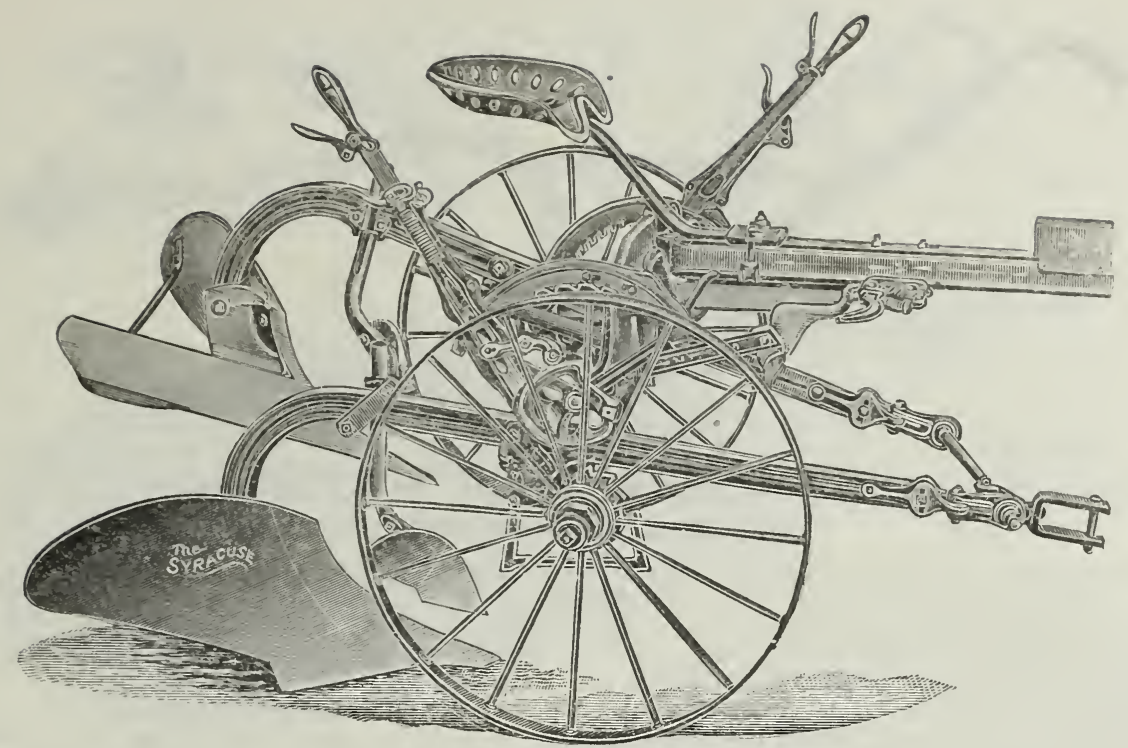

\section{THE SYRACUSE REVERSIBLE SULKY PLOW}

For Hillside or Level Land

For a great many years the Syracuse plows have been among the most popular in New England and their work easily gains them that distinction.

These plows are equipped with Hardened Steel Mouldboard, Steel Landside and Chilled Frog and Share. Furnished with either two or three-horse equipment.

Price and Special Circulars mailed on application.

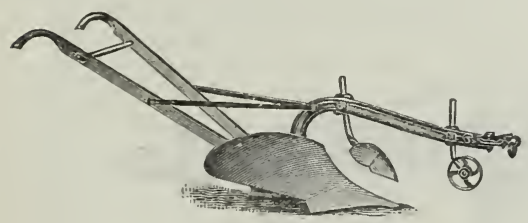

This type has also been very popular in Maine. It has the well-known Syracuse straight style of Beam, which gives ample (learance room. No. 443. Small Two-Horse. No. 442. Large Two-Horse.

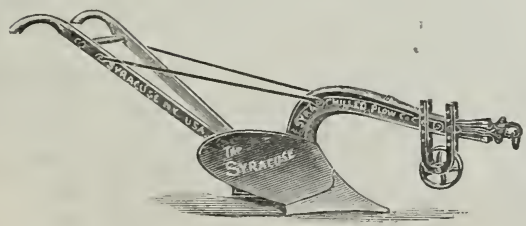

Special Catalog on Syracuse Plows mailed on Request

\section{SYRACUSE COMBINATION WALKING PLOWS}

This particular pattern is one of the best

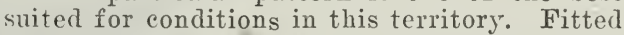
with Hardened Steel Mouldboard, Steel Landslide and Chilled Share. No. 32-Medium Two-Horse. No. 31-Large Two-Horse.

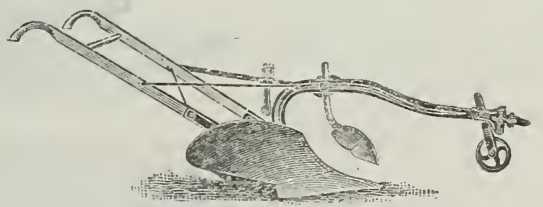

\section{SYRACUSE CONTRACTORS' PLOW}

Hard iron wearing parts. Extra heavy Beam, Share and Strip Steel Wheel Frame. Loop IIandle wear Irons. An excellent Plow for general grading purposes. 


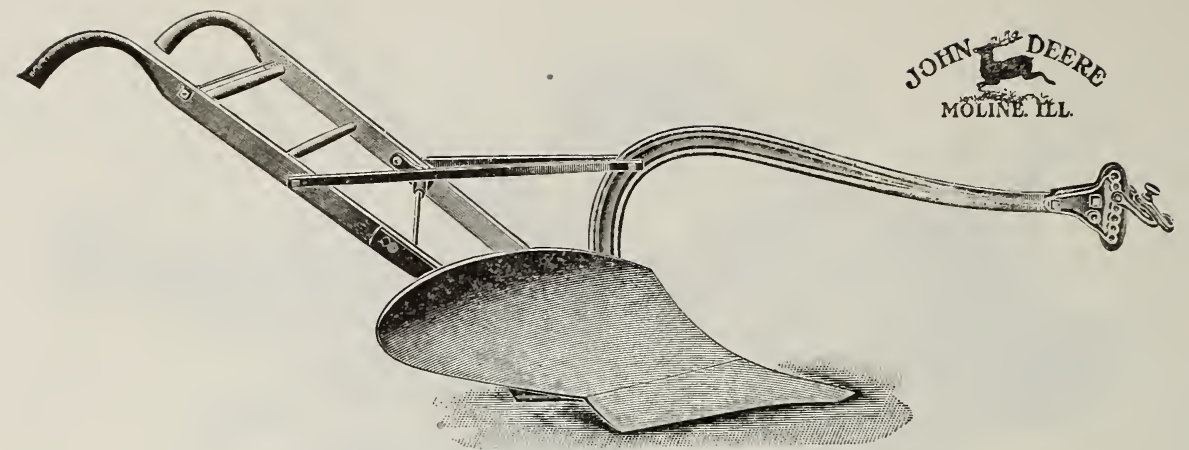

\section{JOHN DEERE WALKING PLOW GENERAL PURPOSE SERIES}

The Share is hardened Soft Centre Steel, which may be drawn out and resharpened when dull. The Moldboard is Soft Centre Steel and Double Shinned by welding a piece of solid steel to the edge where the hardest wear comes. The Landside is thicker by far than is to be found on any other Plow and its fitted with a runner, or slip heel, which takes all wear from the bottom and reduces friction.

The Plows of this series are built to work in old ground, stubble or tame sod.

Having a low, wide throat it leaves a clean furrow for the furrow horse and plowman to walk in. They have a wide, easy turn of the moldboard, which gives them lightness of draft, and are general favorites in all the New England States.

\section{Sizes}

MP 11-Small Two-Horse

MP 13 Medium Two-Horse $\cdot \cdot \cdot \cdot \cdot$

MP 15-Large Two-Horse

We also furnish this same style Plow with a Combination bottom having Chilled Share and Landside at less price than the All Steel Plow.

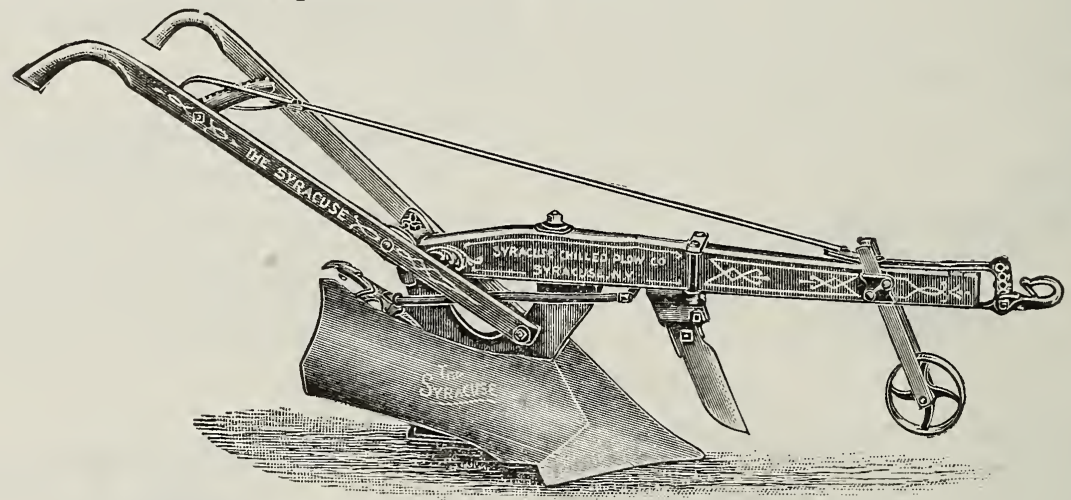

\section{SYRACUSE DIAMOND PLOWS}

Cast or Steel Moldboards. Chilled Shares. The Syracuse Diamond Series of Hillside or Swivel Wood Beam Plows are much used in the New England States, for which section they are splendidly adapted because of their exceeding light weight, strength and good capacity. Their turning qualities are excellent both in sidehill or level land.

Provided with a reliable and quickly adjusted side-shifting Clevis which will be found a great convenience. The two-horse sizes are fitted with an automatic shifting Colter.

The Diamond C2 Plow is furnished with Cast Moldboard only.

No.

Dia. C2 Light One-Horse

Dia. B2 Light Two-Horse

Dia. A2 Medium Two-Horse

Furrow

Complete Syracuse Catalog

3 to 5 in. deep, 7 to 8 in. wide

Weight, Plain

4 to 6 in. deep, 8 to 10 in. wide $85 \mathrm{lbs}$.

5 to $7 \mathrm{in}$. deep, 11 to $14 \mathrm{in}$. wide . . . $130 \mathrm{lbs}$.

and Prices on Application. 


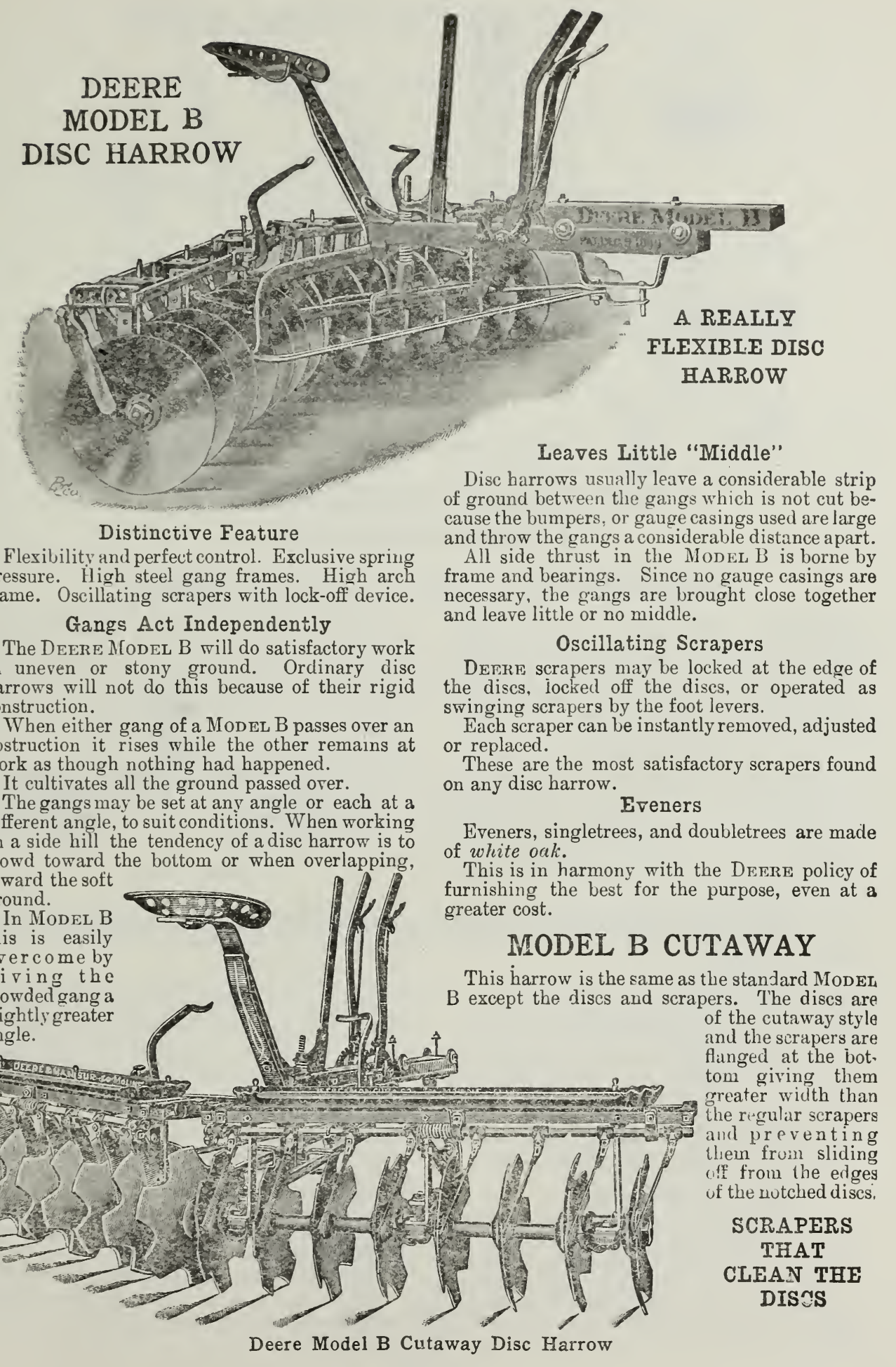




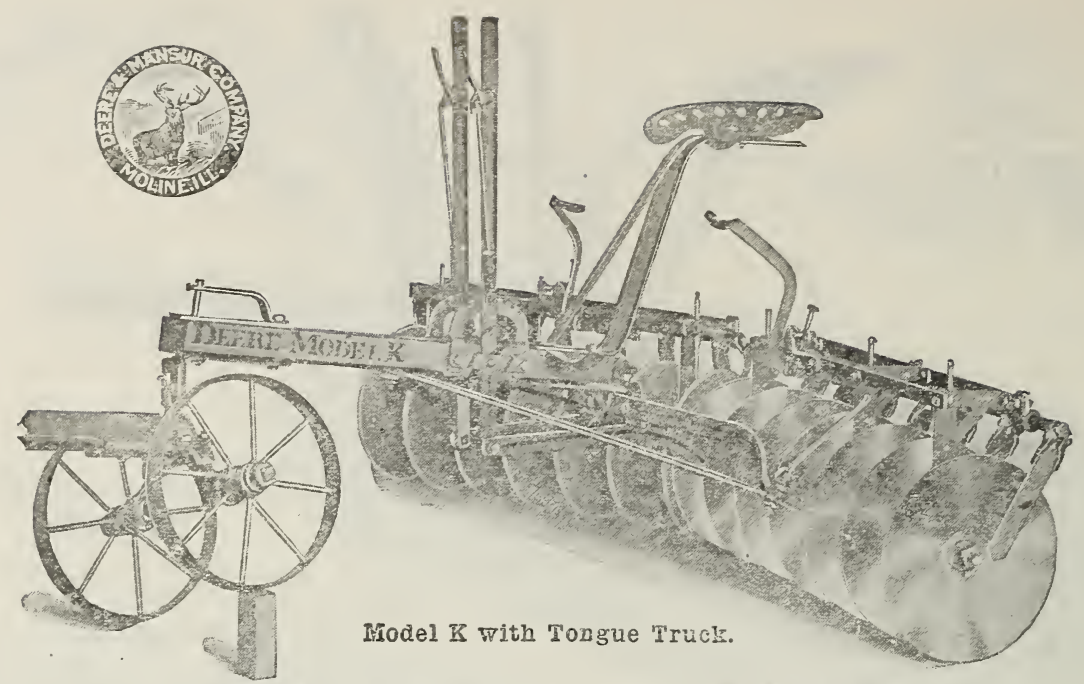

\section{DEERE MODEL $\mathbb{K}$ DISC HARROW}

\section{6, 7 AND 8-FOOT WIDTHS}

\section{A Two-Lever Harrow}

Controlling each gang of a disc harrow independently of the otber is a distinct advantage. You can do this with a Deere Modes K.

Two angling levers make it easy to adjust the harrow for hill-side work, or for overlapping, by giving the gangs different angles.

\section{Steel Frame}

A single piece of heavy steel constitutes the main frame.

Great strength and clearance is obtained by making the frame in the form of an arch.

The gangs are connected directly to the ends of the main frame.

The gang frames are also made of steel and all frame bars. cross ties and braces are securely fastened together.

\section{Disc Blades and Gang Bolts}

Disc blades are made of the very best material. They are thoroughly polished and sharpened.

After a disc harrow has been assembled. it is impossible to tell the size of the gang bolts. This should be investigated before buying. DEERE gang bolts are of heavy steel with forged heads. The nuts are securely held by lock washers which prevent their coming loose.

\section{Bearings}

Hard maple, oil-soaked bearings are used, because experience has proved that they wear longer and are more easily replaced than others.

Extension oil tubes pass through the weight boxes to the bearings. The tops of the tubes are closed by spring cotters to keep out the dirt and dust.

\section{Scrapers}

Every disc harrow user is familiar with the old style troublesome scraper. 'The improved oscillating scrapers used on DeERE harrows are the most simple and satisfactory ever devised. They may be locked off the disc, at the edge of the disc, or operated as swinging scrapers.

When used as swinging scrapers, they are operated by the foot treadle.

Each scraper can be removed, replaced or adjusted independently of all the others.

Further there are no rivets, set screws or other objectionable features.

\section{Stub Poles}

All Deere Disc Harrows are built with stub poles. For this reason they are easily stored and the three-horse hitch and set over tongue may be used on either side.

The stub pole construction also permits the operator to use the harrow with a rigid pole or with a tongue truck without extra equipment.

The poles are securely bolted to the stub with four heary bolts which have large cast washers.

\section{Tongue Truck}

The above illustration shows a Deere Model $\mathrm{K}$ equipped with a tongue truck. One of these trucks can be furnished with any DeERE Disc HARROW at a slight additional cost.

The DeEre Disc Harrows operate without neck weight and for that reason a tongue truck is of no advantage in this respect.

It is sometimes useful as a guide to the harrow.

The Deere Tongue Truck is subjected to no draft strain, the harrow being drawn from the stub pole. 


\section{DEERE DOUBLE ACTION DISC HARROW}

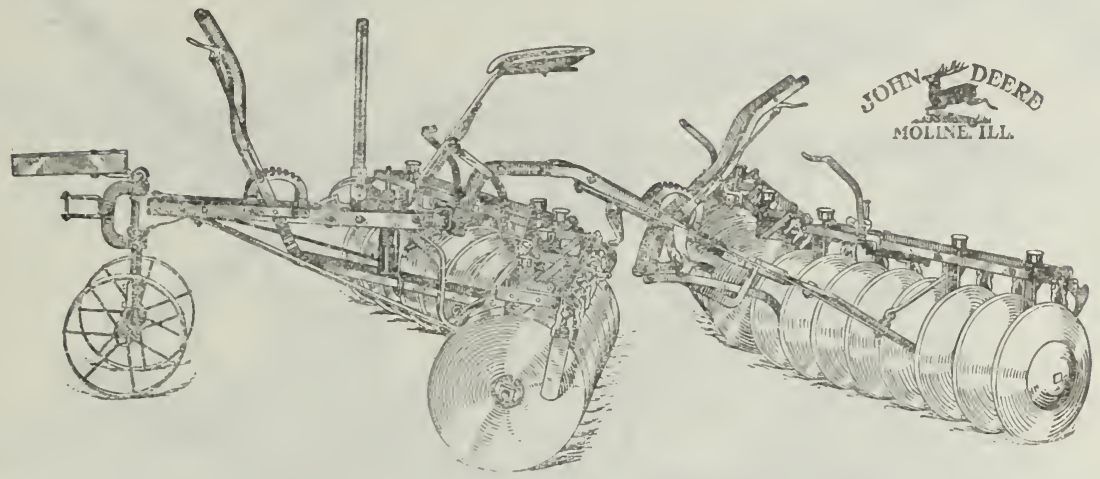

One working of the DEERE DOUBLEACTION HARROIV accomplishes more thorough pulverization of the soil than two separate operations hecause with this harrow the second working takes place immediately after the first, and the partially broken-up soil does not have time to dry out and is, there. fore more finely pulverized by the action of the second section of the harrow. We recommend using plain dises on the front section and cutaway dises on the rear section and by their throwing in opposite directions the greatest efficiency in a harrow will be obtained. The front section can be used alone any time desired.

Special Circulars and prices on application.

\section{DEERE MODEL R ORCHARD HARROW}

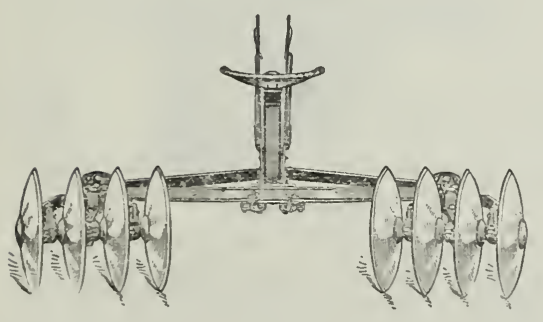

This harrow is constructed to especially meet the requirements of orchard cultivation and it can also be used as an ordinary harrow. The Gangs are reversible for in or out throw and are adjustable in or out on the harrow frame and extension frame.

By use of an extension frame the gangs can be spread to a distance of over ten feet between them. This allows cultivation under overhanging branches. Can be furnished in either 4,5 or $6 \mathrm{ft}$. widths. Unexcelled for orchard work.

Send for full descriptive catalog and prices

\section{DEERE NO. 5 COMBINATION TONGUE TRUCK}

The New Deere Combination Tongue Truck and Fore Carriage illustrated herewith will fully meet the requirements of all dise harrow users. It is simple, strong and conpurt. in construction. The hitch is minde to the vertical standard and the truck therefore turns and is controlled in its movements by the direction of pull on the eveners. The axle is pivoted in the center allowing either wheel to pass an obstruction witlout any strain whatever. The wheels are solid steel with wide oval tires and with closed bearing boxes. By simply changing tongue iron can be changed from two to three horse hitch. Send for special circular givng full description.

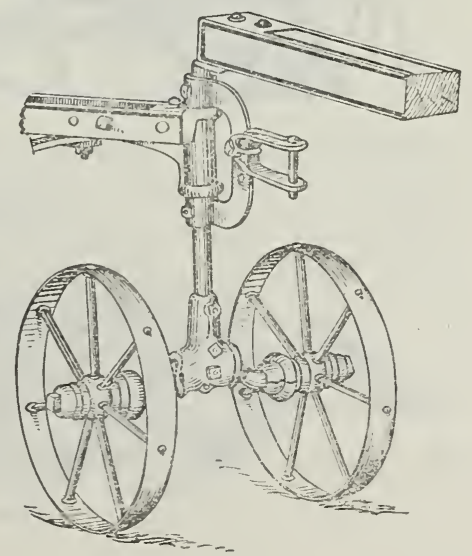




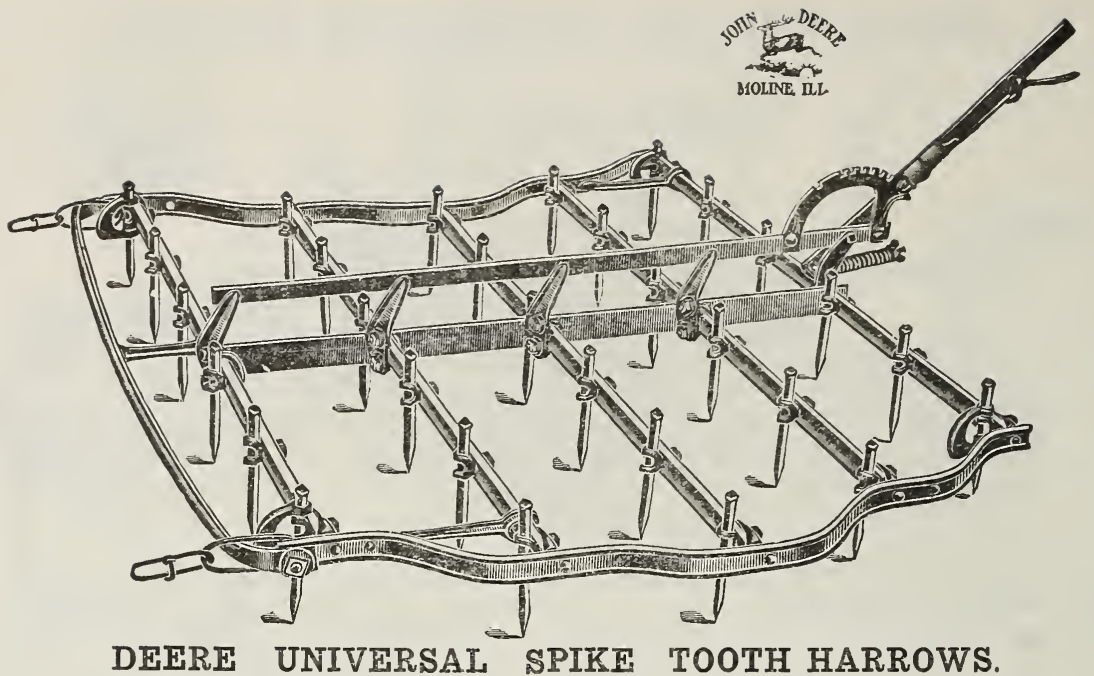

This harrow is made of steel throughout. The tooth bars are made of U-bar steel, which insures strength without useless weight. The teeth are fastened on by our patent tooth fastener, which holds the teeth firmly, yet permits of its being removed to be replaced by new teeth, or to turn the tooth to present a new corner to the work. The side bars are made of I-bar steel, shaped to give even

\section{STZFS}

Universal, 1 section one horse ..........

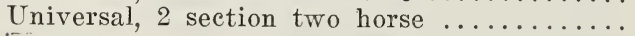
is:

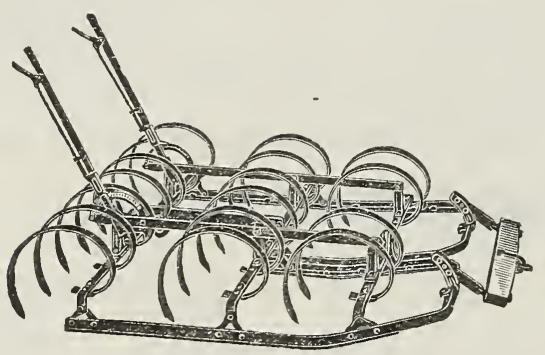

spacing of the teeth. These bars form a guard, which prevents the tooth bars from catching on shrubbery, trees, or in vineyard and orchard work. The lever allows the teeth to be angled to any desired position. The lever is provided with a spring trip, which allows the teeth to give in stony or rooty ground, and saves a large amount of breakage.

\section{Sizes}

$305 / 8$-inch teeth $605 / 8$-inch teeth

Weight,
Pounds
110
220

Price

$\$ 6.75$

$\$ 13.00$

\section{SYRACUSE SPRING TOOTH HARROWS Construction}

Frame bars of angle steel are thoroughly protected by steel shoes, doubling the life of the harrow. Frame bal's are raised at the rear inner ends to give free outlet to trash.

Tooth bars of channel steel journaled in malleable brackets above the frame, whieh give the teeth high and great range of adjustment for depth of cultivation and clearance.

17 Tooth ................. \$16.00

15 Tooth ....................\$15.00

10 Tooth, one horse, top Handles .... \$ \$9.50

10 Tooth, one horse, less Handles ..... \$8.50

\section{ORIGINAI PERRY HARROW}

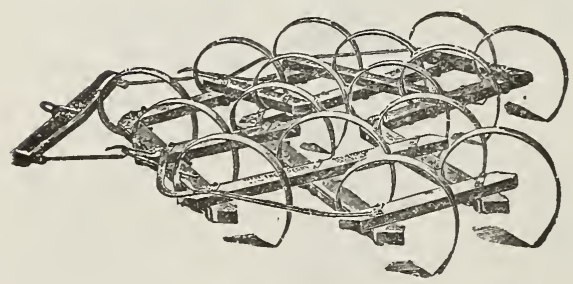

The Wood Frame Perry Harrow is the most durable of the Spring Tooth Harrows. Is simplicity itself. Iron plated on the under side and in front, the entire length. Teeth cannot get loose. No levers or joints to wear and get out of repair. Harrows of this kind have been in constant use for fifteen years.

$\begin{array}{ll}\text { Weight } & \text { Price } \\ \text { Pounds } & \end{array}$

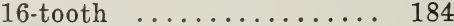

18-tooth $\ldots \ldots \ldots \ldots \ldots \ldots . \ldots \ldots 27$ 


\section{SYRACUSE WING POTATO HOE}

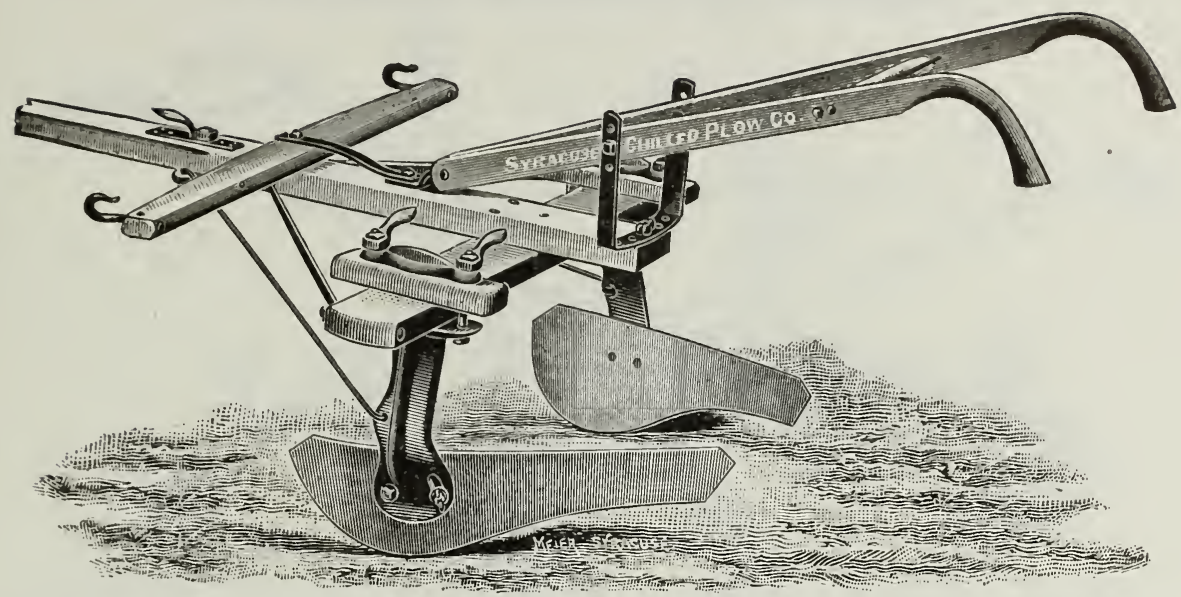

The Potato Hoe has proven to be one of the most raluable tools obtainable for use in covering or hilling potatoes, celery, beets and similar crops.

There is an adjustment for tilting blades 1 p or down to procure proper angle to meet

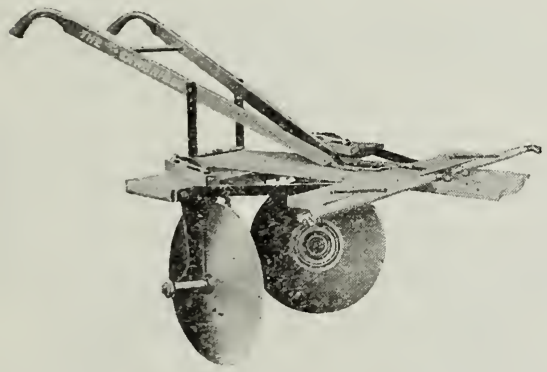

\section{DISC POTATO HOE}

A great many persons prefer the dise type of hoe in preference to the wing. Standards are movable on cross-bar to allow spacing of dises.

('an also furnish this style fitted as a combination with both wings and dises.

\section{Prices}

Dise Hoe with 20 inch dises : . . $\$ 7.50$ Combination Hoe with both wings and dises

\section{HUSSEY WING POTATO HOE}

There has always been a large demand for this well known Hoe. They are always constructed of the best materials and are invariably satisfactory to our eustomers. These are fitted with an adjustable extension on the wings which is a decided advantage.

Price, $\$ 6.50$

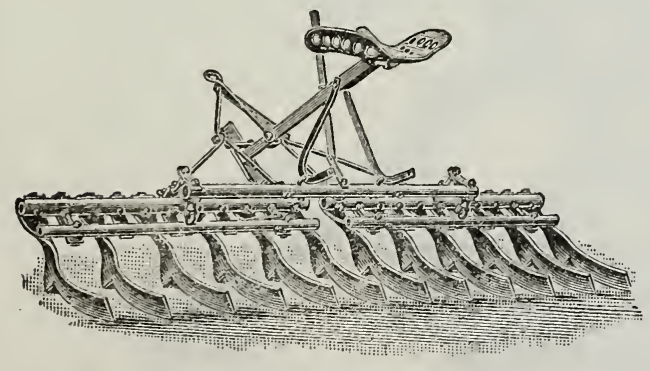

Price, $\$ 6.50$

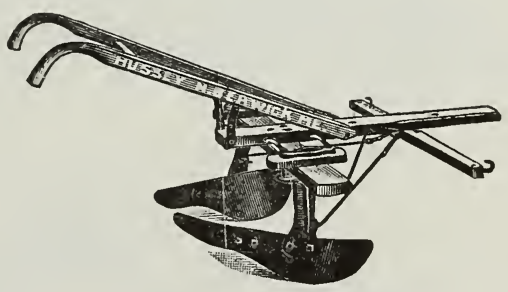

ACME TWO-HORSE RIDING HARROW

The Acme Standard Two-Horse Riding Harrow has two coulter sections and is flexible. The harrow may be made rigid when desired by braces provided for this purpose. Each section has six coulters, making twelve in all. Width of cut is 6 feet 6 inches. Weight, 125 pounds.

Acme harrows are made in various styles and sizes to do the best work in different farming sections of the country.

Send for Full Descriptive Catalog and Prices. 


\section{DEERE WALKING CULTIVATORS}

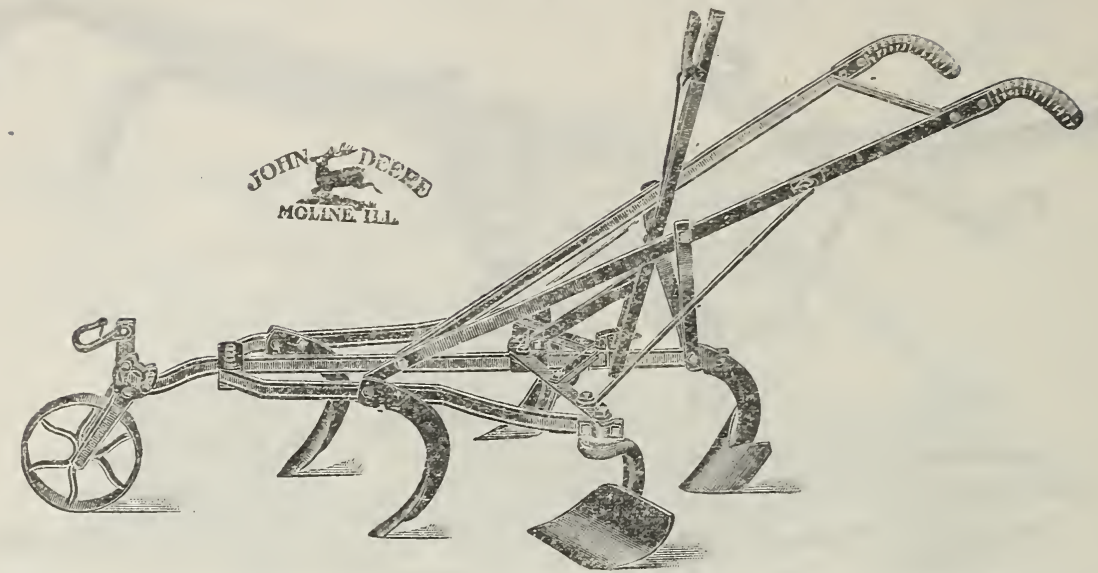

No. 6. 5-Tooth Steel Cultivator with Forse Hoes, Sweep and Gauge Wheel.

It is not often necessary to follow a John Deere Steel Cultivator with a hoe. Most cultivated crops can be entirely worked with it without the laborious hoeing often required to complete the work when an ordinary cultivator of its type is used.

John Deere Steel Cultivators are especially adapted for cultivating any crop planted in rows far enough apart to permit the use of a horse-drawn cultivator. They are also favorites with market gardeners.

The illustration above shows the five-tooth cultivator equipped with horse hoes, sweep, and gauge wheel. The horse hoes are reversible and can be set for throwing soil toward or away from the plants.

The seven-tooth cultivator may be equipped in the same way, but is shown with doublepointed steel shovels.

The expanding lever brings the hoes or shovels close together for narrow rows, or throws them as far apart as is desirable for wide rows.

This lever works easily and saves considerable time usually lost in loosening or tightening set screws, or handling other adjusting devices.

\section{PRICES}

No. 6. 5-Tooth..............

No. 6. 5-Tooth, with horse hoes.....

No. 6. 5-Tooth, with long hillers....

No. 14 7-Tooth................

No. 14. 7-Tooth, with horse hoes.....

No. 14. 7-Tooth, with long hillers.... Attachments as shown on 5 and 7 tooth cultivators on following pages.

For Front Gauge Wheel Lever, add For Rear Gauge Wheel and Foot Lever, add............... 6.00 7.25 5.75 6.75 8.00

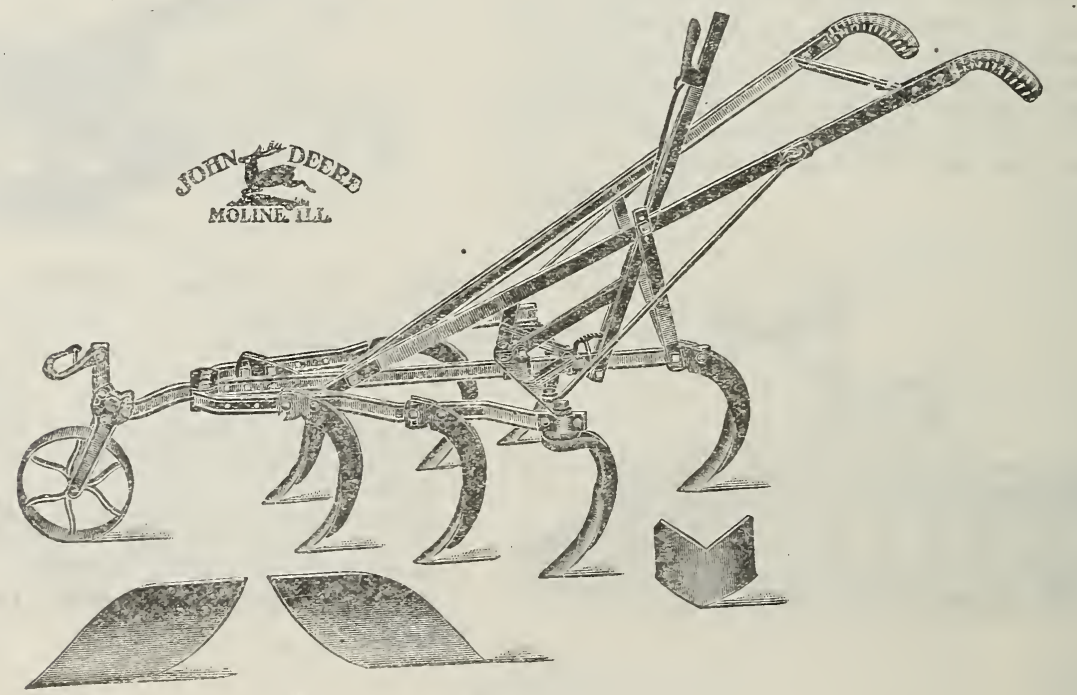

No. 14. 7-Tooth Steel Cultivator. 


\section{DEERE WALKING CULTIVATORS}

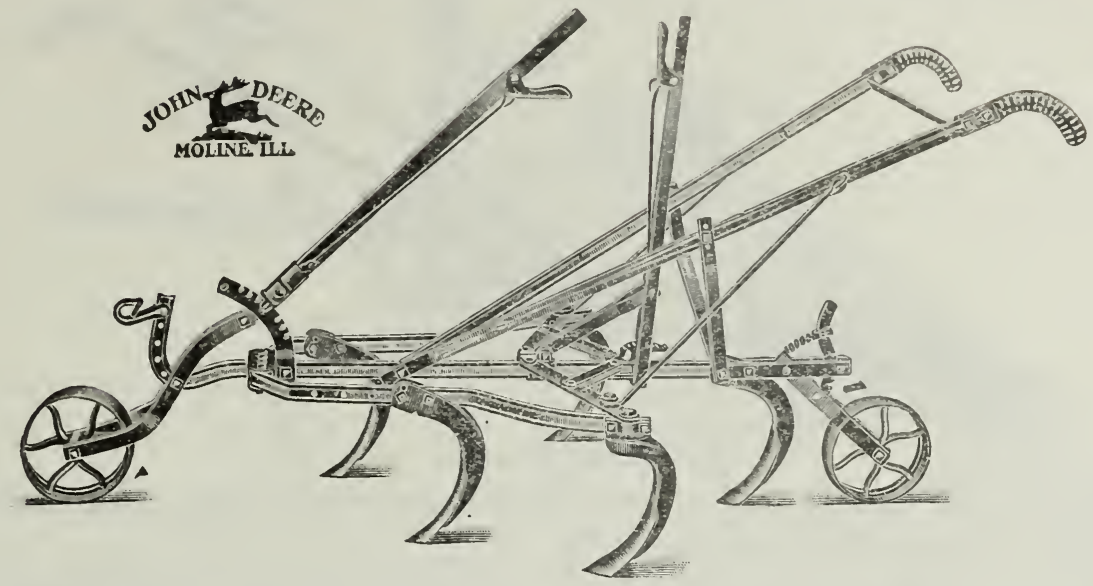

Deere No. 6. 5-Tooth Steel Cultivator with Double Lever Front and rear Gauge Wheel.

When absolutely uniform depth of cultivating is required, two adjustable gauge wheels are necessary.

The John Deere Stee: Cultivators can be so equipped when desired.

The front gauge wheel is adjusted by means of a lever within easy reach of the operator. The depth of cultivation can be readily changed by means of the lever without the use of a wrench, or loosening of any nuts. Furnished at a slight additional cost.

The rear wheel adjustment consists of a ratchet and spring device operated by a foot-trip.
The illustration below shows the long hillers used for hilling up celery, tomatoes and other plants which require a large amount of soil to be moved.

The Celery Hillers can be used on the Deere 5 or 7 Tooth Cultivators.

The front gauge wheel lever and rear gauge wheel, with foot lever, may be used on 5 and 7 tooth cultivators, and are priced as attachments on previous page.

The Long Hillers are Especially Adapted for Work where a Large Amount of Soil Must be Moved.

Prices quoted on previous page.

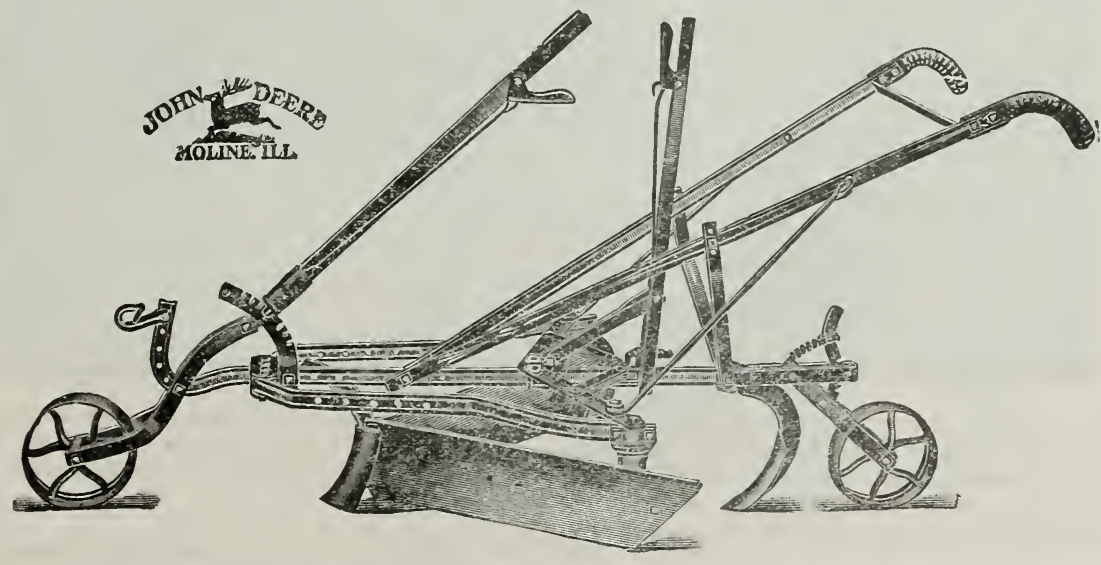




\section{DEERE WALKING CULTIVATORS}

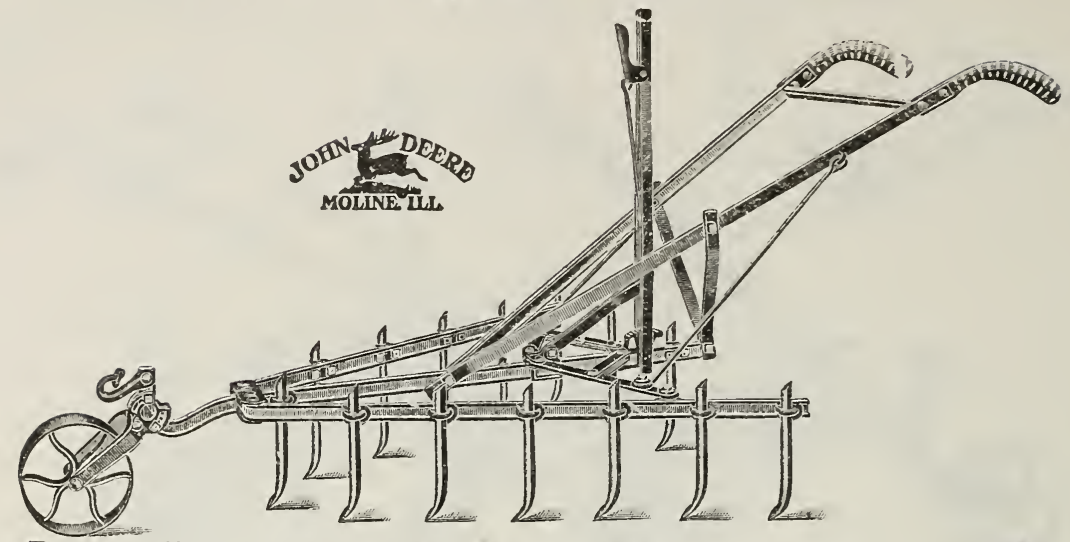

\section{John Deere Combination 14-Tooth Steel Cultivator and Harrow}

The Deere 14-Tooth Steel Combination Cultivator and Harrow shown above is adapted for close work among very small plants. It stirs the soil thoroughly, but does not throw any dirt on the plants. However, it is more than a cultivator, it is an excellent smoothing harrow also. The steel teeth are reversible, each one having a small cultivator tooth forged at one end, and the other being straight and sharp.
This cultivator is often used to break up the baked surface of a planted field so the plants can get through the ground much easier.

The Combination Cultivator and Harrow is regularly equipped with expanding lever, and can be furnished with or without gauge wheel.

Price, $\$ 5.00$

\section{HALIOCK WEEDERS}

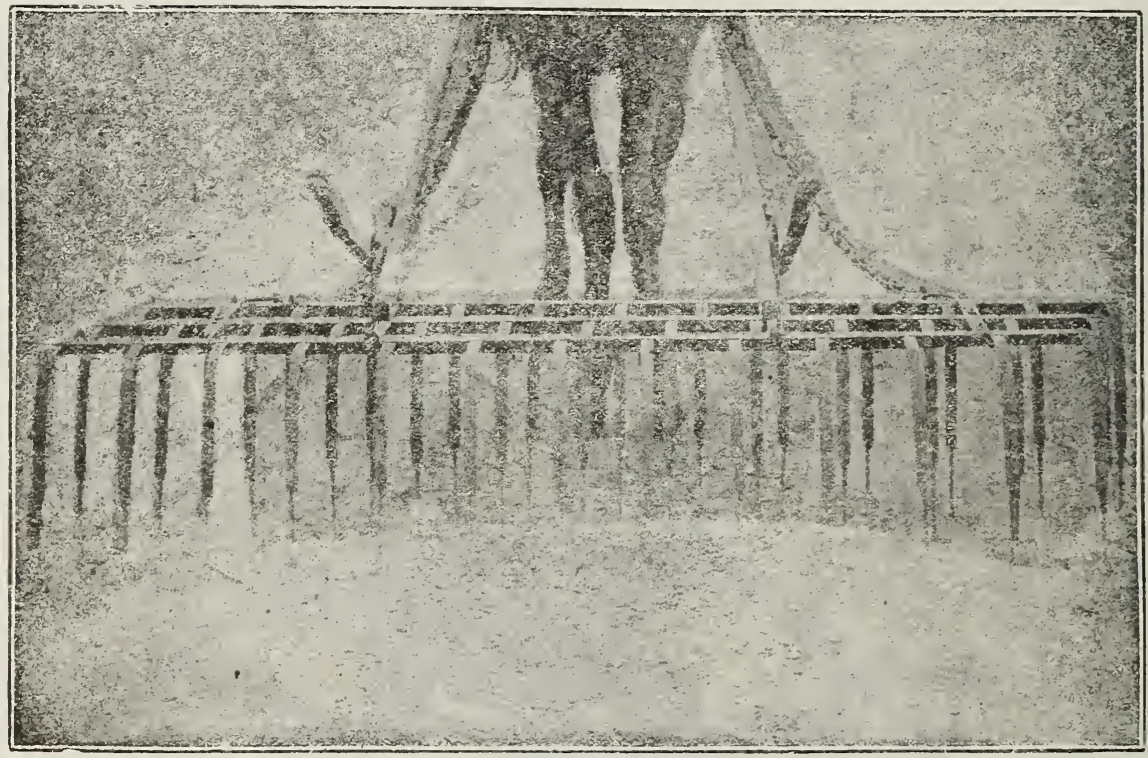

They need no introduction, having had a large trade throughout the New England States. It does most efficient work for all kinds of crop cultivation, such as corn, potatoes, tobacco, etc., and by removing teeth over row, after crop has advanced, will cultivate several rows at once. Used as a walking or riding weeder, and with seeder attachment. 


\section{EUREKA FLAT TOOTH SULKY SMOOTHING CULTIVATOR}

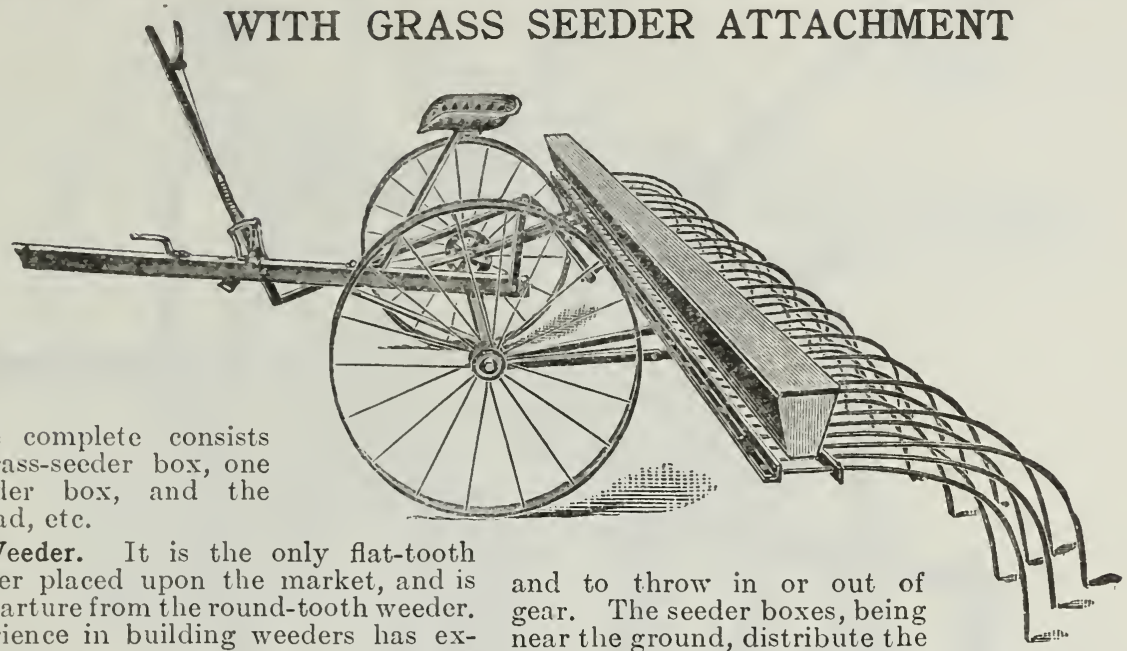

Iachine complete consists of one grass-seeder box, one grain-seeder box, and the weeder head, etc.

As a Weeder. It is the only flat-tooth weeder ever placed upon the market, and is a wide departure from the round-tooth weeder. Our experience in building weeders has extended over many years, our experiments have been thorough, our conclusion is, every farmer who will try the Eureka Flat-Tooth Smoothing Cultivator will say yes to every word we have said in its favor. As a grassseed sower it is a great success.

The seeder boxes are detachably connected, it is correct as to sowing and covering, and is easily changed to sow the required amount (from 2 to 20 quarts) of grass seed and required amount of grain, convenient to handle,

and to throw in or out of near the ground, distribute the seed evenly; windy days make no difference. We have placed a good many with the farmer within the last year, all giving absolute satisfaction.

\section{Eureka Sulky Cultivator} WEIGHT

8 feet with Grass Seeder. . $\quad 216$

10 feet with Grass Seeder.. $\quad 247$

12 feet with Grass Seeder.. 277

\section{THE EUREKA SECTIONAL WEEDER}

Has a solid center section, 2 feet 9 inches long, made of channel steel $1 \frac{1}{2} \times 1 \frac{1}{2}$, with thills adjustable to height of any horse and handles adjustable to man or boy, with two hinger! wings bolted to center section, 2 feet 3 inches long. This gives Weeder three sections, each section working independently and conforming to the inequalities of the ground, doing equally good work over deacl furrows, cradle knolls, hollows, etc. It e claim for the Eureka Weeder that it will do the work of Three Men, Three Cultivators and Three Horses, and do it in much better way than it is possible to do it where the Weeder is not used.

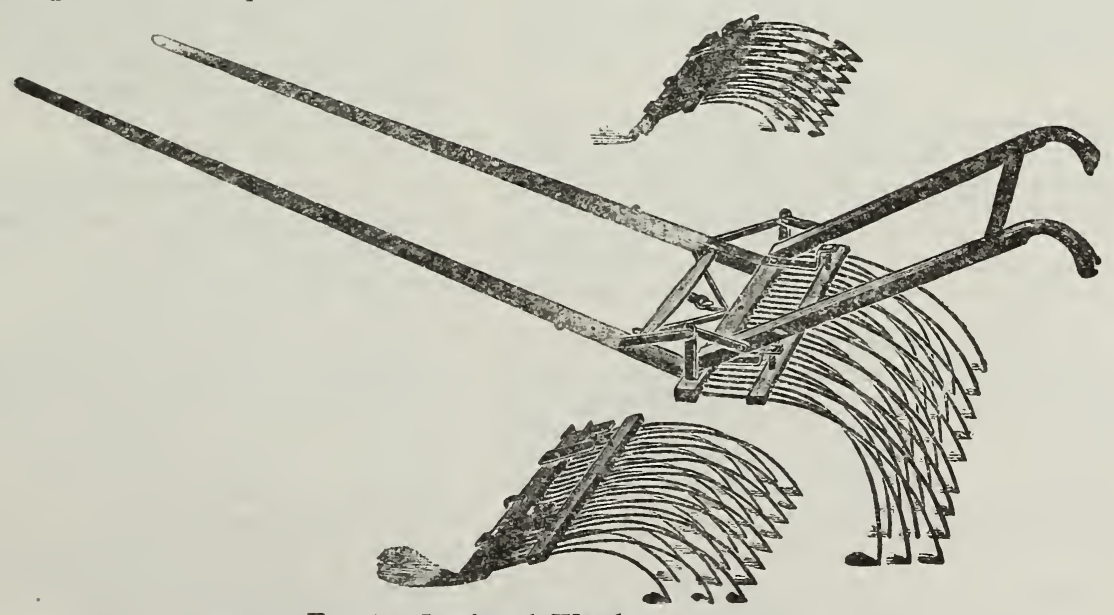

Eureka Sectional Weeder 


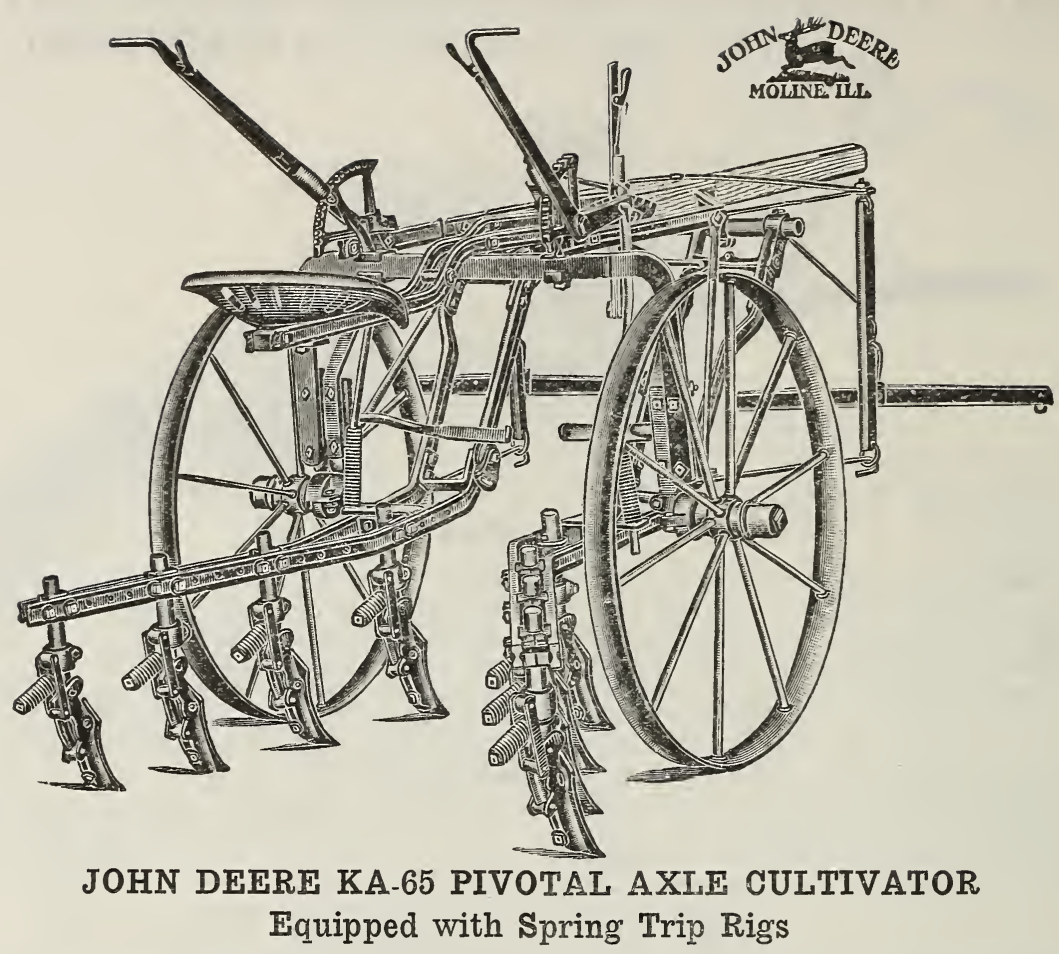

\section{Serviceability}

The John Deere Pivotal Cultivator is adapterl for work in corn, potatoes, beans, in fact, most any crop grown by the general or truck farmer.

\section{Wide or Narrow Tread}

The tread of the wheels can be varied as much as thirteen inches. The Pivotal Cultivator, therefore, can be adapted to any width of row from 24 to 48 inches.

Frame does not overhang the wheels at any adjustment.

\section{Pivot Wheels}

This feature is particularly useful for hillsides or for work in irregular rows, when the wheels, guided by the feet, may be instantly turned to the right or the left as desired. Foot rests are so arranged that they may be easily adjusted to any position necessary for the convenience of the operator in controlling the wheels.

Wheels may be made rigid for level work by a hook rod attached to the frame bar, engaging with the clamp on the adjusting bar. Wheels are 32 inches in diameter, $2 \frac{1}{2}$ inch concave tire, staggered spokes, and are equipped with oil-tight, dust-proof, screwcap, long-distance boxes.

\section{The Pole}

Pole has an up-and-down adjustment at the rear end for the purpose of regulating depth of the front shovel and leveling the machine to suit any height of team.

\section{Rigs}

High carbon channel steel is used in constructing the rigs. The beam of each rig is double and punched with holes at equal distances, enabling the user to have two, three or four shovels on a side at any desired space.

Rigs have a lateral adjustment of nine inches, and can be widened or narrowed while the shovels are in the ground by a small lever within easy reach at the left of the operator. They also extend out beyond the wheel far enough to allow the rear shovel to cut out the rear track.

\section{Close Fitting Couplings}

The couplings have an adjustment for taking up the wear, thus always insuring a close fit on the shifting bar.

\section{The Side Levers}

These serve to raise and lower the rigs and to regulate their depth in the ground. Each is equipped with a compression spring which exerts an even or yielding pressure on all the shovels. By removing the cotter on top of compression spring, they are readily converted into floating rigs.

Also furnished, if desired, with Spring Teeth in place of Spring Trip Hoes. 


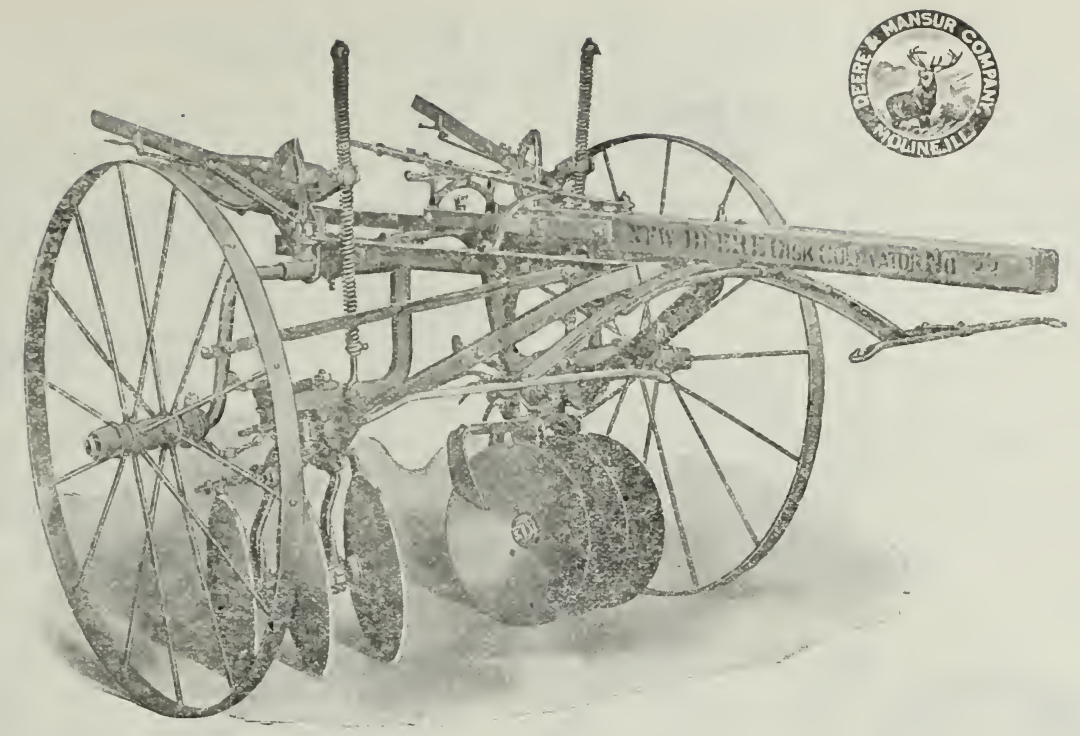

NEW DEERE No. 24 DISC CULTIVATOR

IIGHT, STRONG, CONVENIENT

\section{Made of Malleables and Steel}

A disc cultivator must be strong, but undue weight must be avoided.

For this reason malleable instead of gray iron castings are used in the New Defre.

It is light and so strong that it is not liable to break.

\section{Main Frame}

If a cultivator is to lo good work, its parts must be kept in their proper positions.

This is a part of the wrork of the frame and if it is weak, it is lialle to spring and throw the whole machine ont of line.

The New Desere frame has strength and stiffness to withstand any strain liable to be put upon it.

\section{High Arch}

A higher and heavier arch is used in the N'Ew DEERE DISC than in the ordinary cuitivator of its type. For this reason it is worth more.

Higher corn can be cultivated. hence more cultirations can be given before being laid away.

The effect of the extra cultivations will show up at harvest time The crop will he cleaner and freer from weeds, hence eisier gathering.

\section{Axle Adjustment}

The axles are carried in a tubular cross brace. By loosening a screw, the axles can be adjusted for wide or narrow cultivation without disturbing any other part of the machine.

\section{Special Catalog and}

\section{Gang Adjustments}

A lever and rack device is used for angling the gangs. A similar device is used for tipping them.

It is not necessary to take the gangs off to reverse them, merely loosen a nut, swing them around and tighten the nut.

\section{Pressure Springs}

Extra long and very flexible pressure springs are used.

Any pressure up to the weight of the cultivator can be placed upon the gangs with these springs.

\section{The Doåge}

The New Deere No. 24 has a lever dodge which is operated from the seat.

The cultivator can be made rigid by locking this lever in the center notch of the rack.

For work in a circular row, the lever can be set at the proper angle and locked.

\section{A Boy Can Operate}

The lifting levers are provided with lifting springs, not because they are needed but to make the operation that much easier.

\section{Attachments}

There are several special attachments for this cultivator by means of which it can do any kind of work successfully. 


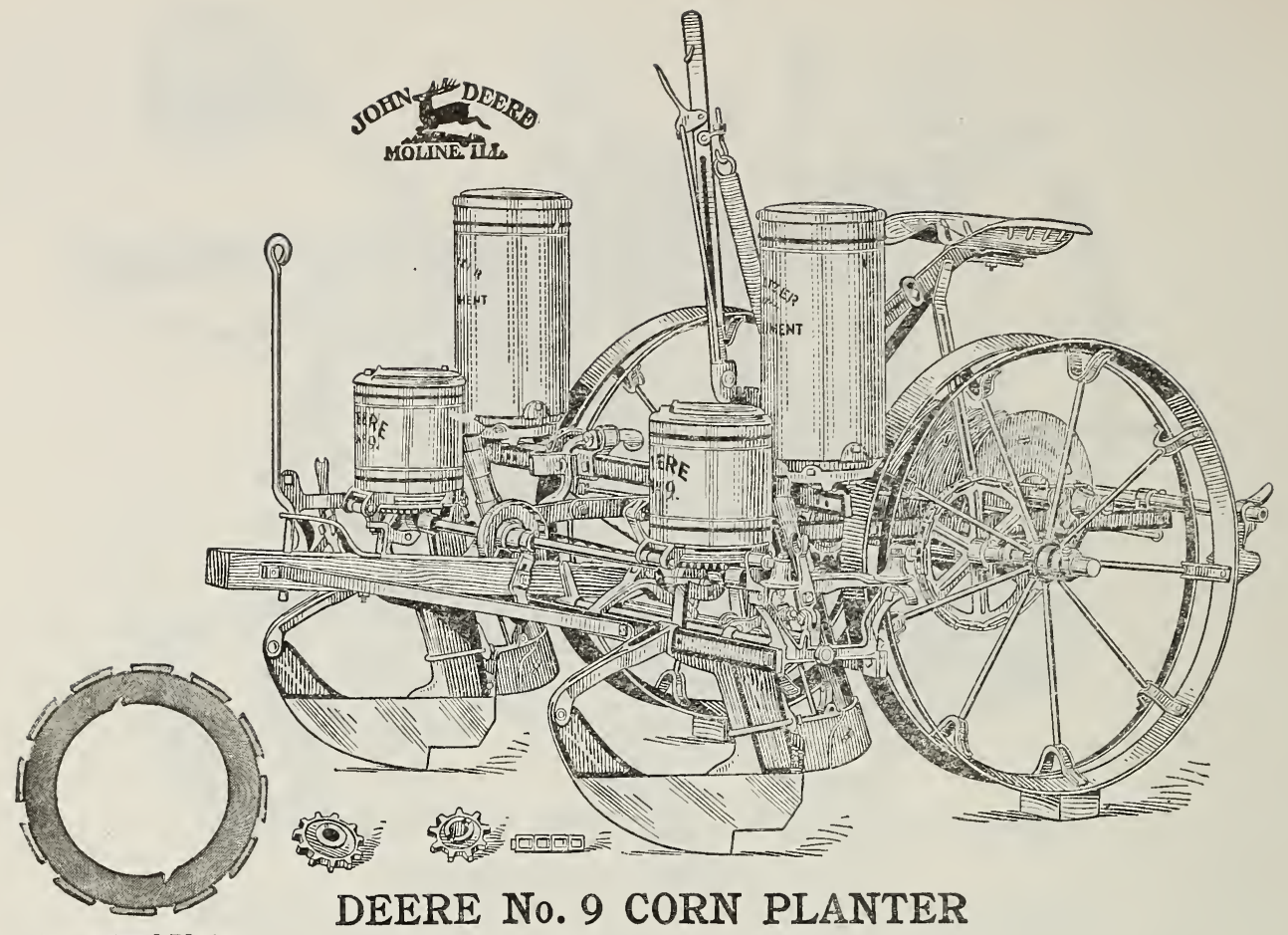

No. 9 Seed Plate.

\section{A Good Corn Planter Pays}

It pays to secure an accurate stand of corn.

Five stalks in one hill and one in another does not pay. In one instance the soil is overtaxed and will not produce good ears-in the other the producing power of the soil is not utilized to its full extent. In both cases there is a loss.

Every farmer knows how many kernels to the hill his land requires and the planter that can be depended upon to drop that number with uniformity, insures the greatest yield.

\section{Why Deere No. 9 is Most Accurate}

There is slight variation in the thickness of corn kernels, but they vary greatly in width. In the construction of the seed plates and hopper bottom lies the reason for DeERe No. 9 accuracy.

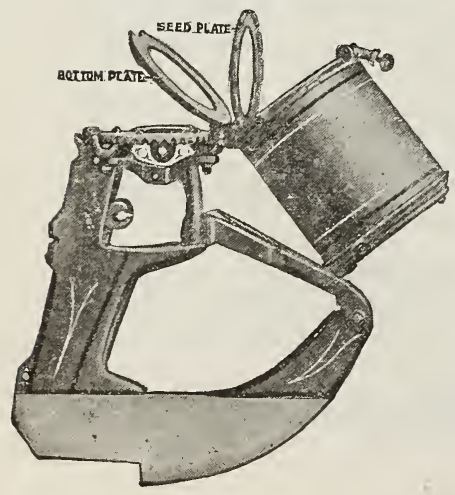

To begin with, every cell must receive a kernel edgewise, but to insure this it must beslightly larger than the kernel. Sometimes, therefore, a second kernel might enter. To overcome this, the DeERe No. 9 seed plates and hopper bottoms are so constructed that the cells diminish in depth and width as they revolve toward the cut-off. The extra kernel that may have partly entered at the point of filling, is excluded and only one is delivered to the valves.

All that is necessary then to plant any number of kernels is to revolve the seed plates far enough to collect and deposit that number in the valves.

The DeERe No. 9 will do this more uniformly than any other planter.

\section{Tilting Hoppers}

In construction and convenience the DEERE tip-over hopper is unequaled.

The gear ring is held stationary and is always in proper time.

Seed plates cannot be put in wrong, they will not fit unless put in correctly.

In changing plates the upper valve is not exposed and there is no danger of brushing the hill of corn off and losing it.

A flat spring at the side of the hopper bottom holds the seed plate and bottom plate in position while returning the hopper to the upright position.

The hinge is wide and holds the hopper securely in position.

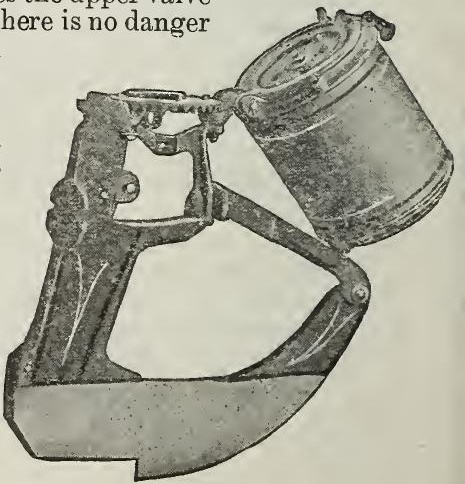




\section{DEERE NO. 9 CORN PLANTER \\ (Continued)}

\section{Hoppers}

One thumb nut instead of two is used to hold the hopper in place.

The cover is a sliding lid, which effectually prevents spilling the corn.

\section{Force Drop}

A positive drop discharges the kernels downward and backward into the furrow, insuring perfect checking under all conditions.

There is no stringing or scattering.

Seed tubes are free from shelves or other obstructions that interfere with perfect dropping.

\section{Hilling or Drilling}

No extra attachments or tools are required to change from hilling to drilling, or back again. There is no switching of the valves, no parts to add or remove.

To adjust for drilling merely hook the foot drop over the small casting on the rock shaft, using notch nearest end, and then press down on the foot drop lever till it locks automatically.

When turning at the end of the rows, a slight pressure on the foot treadle unlocks the lever and stops the drilling.

\section{Sight Drop}

There is a slight opening just above the upper valve which enables the operator to see the kernels as collected.

A glance will show whether the planter is working properly or not.

\section{Open or Concave Tire Wheels}

Thirty-inch concave or open wheels are furnished regularly.

Thirty-eight inch wheels are furnished on special order, and are desirable in stumpy ground or in following the lister.

All wheels have removable bearing boxes which can be readily replaced when worn.

\section{Automatic Reel}

This is a very practical and convenient reel. It is always ready to take up the wire.
The drum is a perfect cylinder of sheet steel upon which the wire is easily wound without kinking or snarling.

A very simple reel drive is provided. A small sprocket with a friction hub and spring enables the operator to reel up or unreel the wire, always keeping it at a unifcrm tension.

One of the anchor pins is used as a reel brake when unreeling the wire, and as a distributor when reeling up the wire.

\section{Buttonless Wire}

Each planter is equipped with eighty rods of annealed steel, buttonless wire.

Either 3 feet 6 -inch, or 3 feet 8 -inch wire is furnished regularly, but other sizes may be had on special order.

Double twist joints make this wire very strong, and prevent its slipping through the forks.

\section{Stub Runners}

When planting in very trashy ground some prefer the stub runners. These can be furnished with the Deere No. 9 when desired. Single disc openers can also be furnished.

\section{Planting}

The Deere No. 9 Planter plants field ensilage, or sweet corn, peas, beans, etc., with an accuracy that is marvelous. Different style seed plates designed for the different seeds are provided with the planter. For different width rows the planter is adjustable from 28 to 44 inches, the distance between buttons on check wire governed according to distance wanted between hills.

\section{Fertilizer Attachment}

The fertilizer attachment on the Deere is perfect. Has large capacity galvanized hopper, wide range of quantity up to 600 pounds per acre. Has an agitator in hopper which keeps fertilizer from bridging, and insures accuracy in the feed. Fertilizer is sown in the hill or continuous in the drill, but does not come in direct contact with the seed, hence will not cause burning of the seed.

Write us for special booklet and prices on this planter. It will certainly pay you to investigate if in need of a planter.

\section{IMPROVED STONE BOAT FRONT}
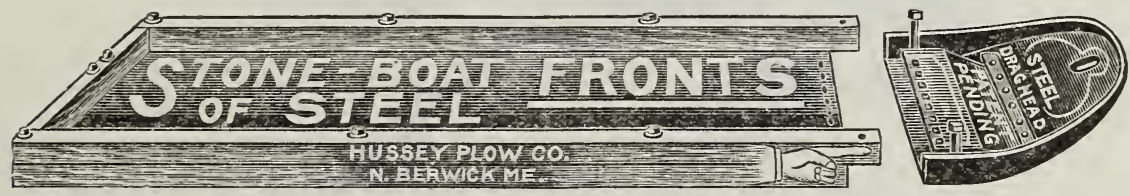

This device enables the farmer to make a good stone boat in one hour's time with ordinary straight plank that he may have on the farm. All tools necessary are saw and bit.

Price, $\$ 2.75$ 


\section{EUREKA No. 2 CORN PLANTER}

Eureka Planters plant corn, beans, peas, beets, onions and turnips.

They drop seed and fertilizer automatically at any desired distance.

They will drill continuous'y both seed and fertilizer.

They have a perfect hand check so that grain may be planted in hills when it is desirable to cultivate the crop both ways. 


\section{EUREKA No. 4 TWO-ROW CORN PLANTER}

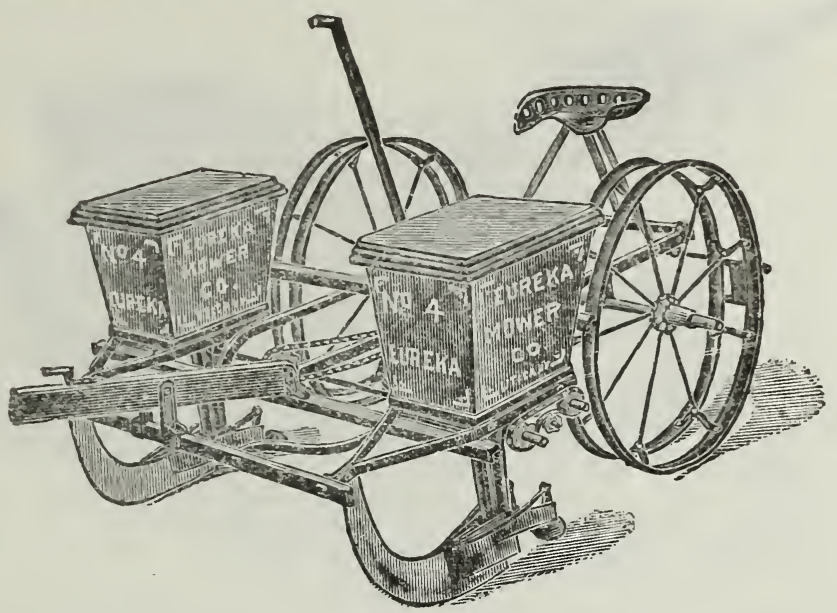

The Eureka Two Row Planter will plant corn, beans, beets, peas, onions and turnips. It plants seed and fertilizer either in the hill or drill. The fertilizer attachment is the best on the market. The fertilizer does not come in direct contact with the seed, but is lropped on both sides, allowing the earth to separate them. The planter is entirely independent of the truck which insures planting in dead furrows, over knolls, and will conform to the irregularities of the ground.

The Eureka Marker is a special feature; it is raised and lowered by the foot.

The planter is most durably built, steel and malleable iron being used in its construction. It handles easy, is very light draft, and of pleasing design.

No. 4. Complete, weight 430 lbs., Price, $\$ 40.00$

\section{ECLIPSE CORN PLANTFR}

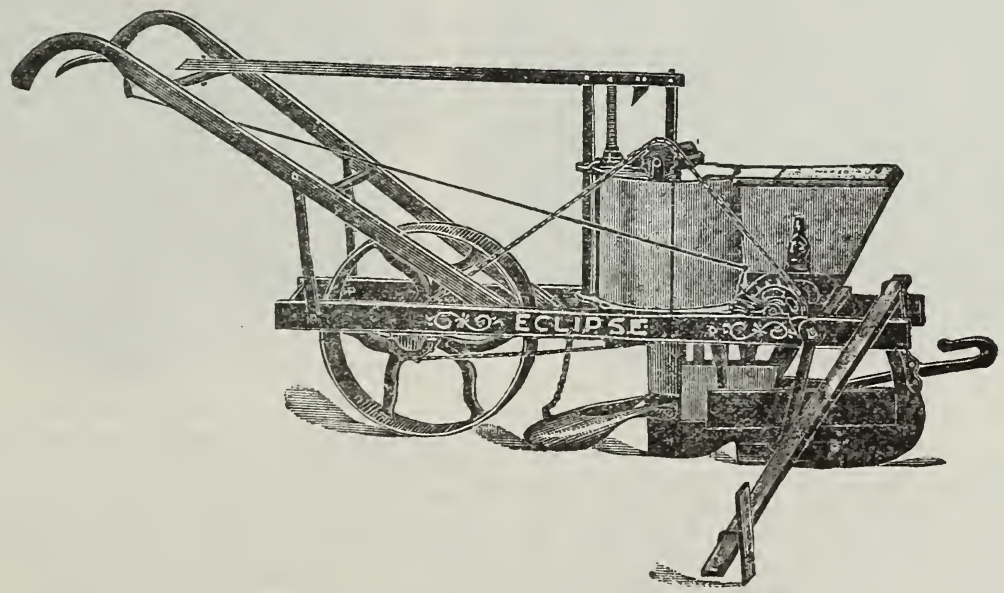

DUPLICATE OF THE ORIGINAL ECLIPSE

This planter has been sold for over twenty that the Eclipse is still on the market without years, thousands of them are in use, and there being changed is guarantee enough of its is great demand for this machine. The fact efficiency and durability. 


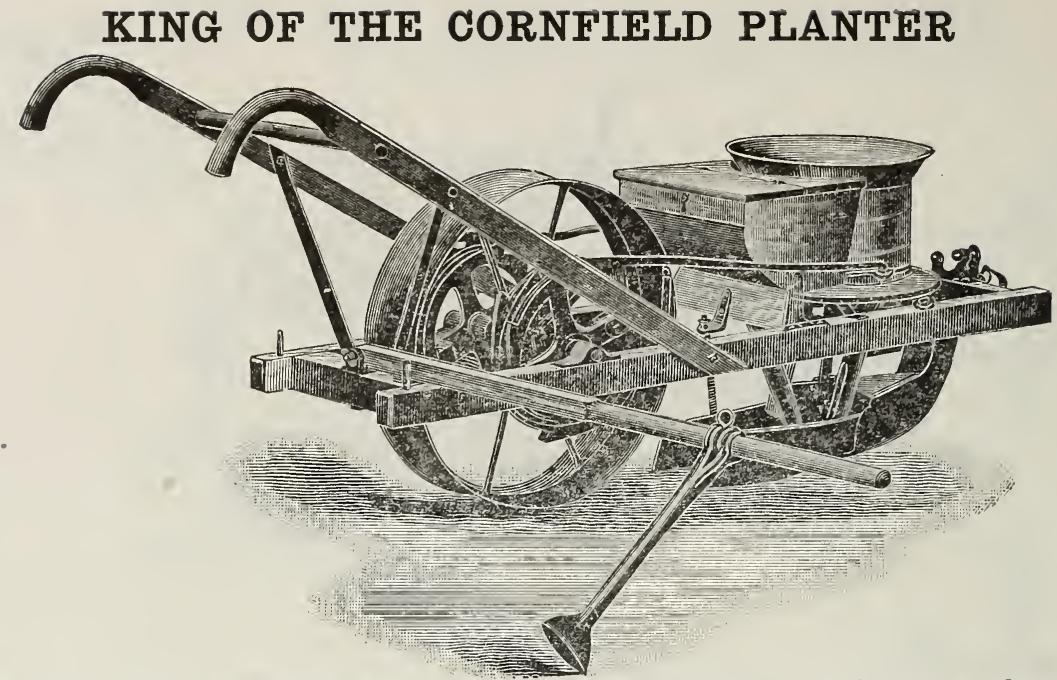

This Corn Planter has been for years one of the leading machines for planting corn, beans, peas, beets and other seeds used throughout this territory. It is equipped with fertilizer distributor, and is perfectly adapted to all requirements of this section. It can be arranged to drop any desired quantity of seed or fertilizer; can also be used for planting corn and beans at the same time, dropping each kind of seed in rotation.

Price.

Descriotive Circular Mailed on Application

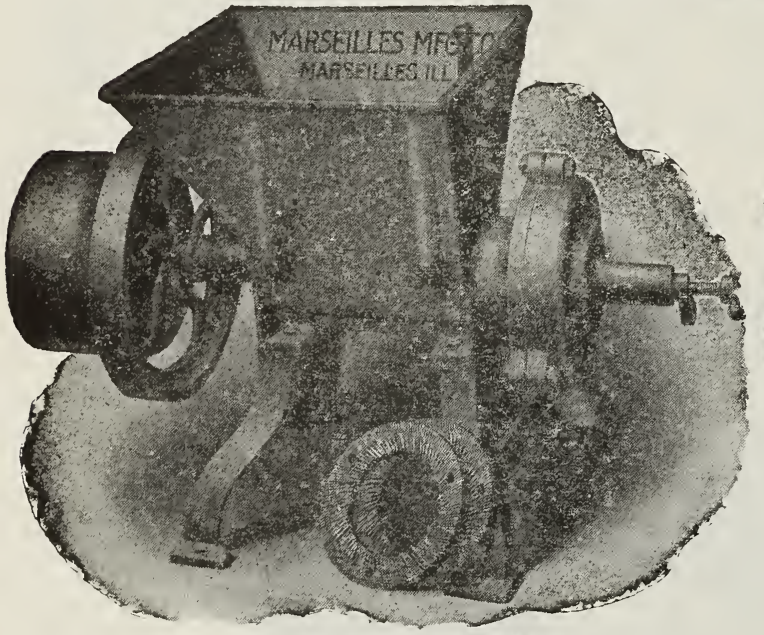

No. 552 Marseilles Grinder.

The above grinder has been one of our most successful machines for small and medium powers. It will grind both small grains and ear corn; it can be used with as small as 4 horse power. The hopper is entirely of metal, making it indestructible. Furnished with two sets of burrs; one fine and one coarse. Capacity for feed purposes under ordinary conditions 15 bushels per hour; meal for table use 10 bushels per hour.

Send for Descriptive Circular and Prices.

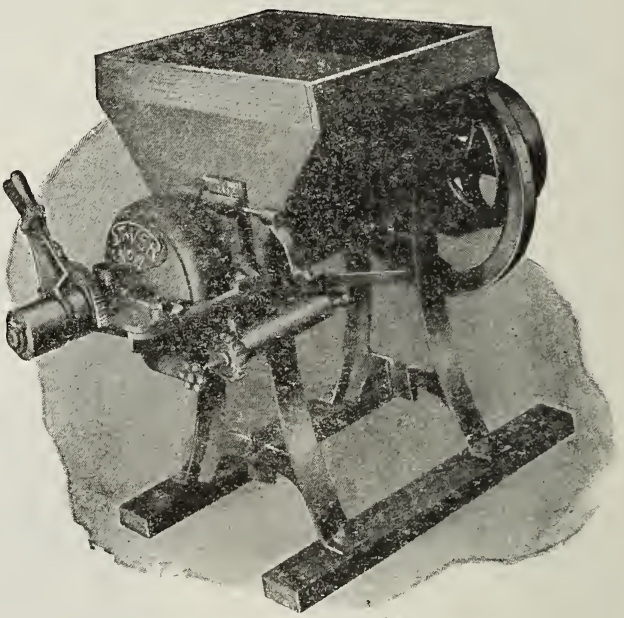

No. 4 Stover Grinder.

The above cut represents one of our celebrated Stover line of grinders which has been very popular especially for farm use. This mill will handle both the small grain and ear corn in a very satisfactory manner, and we can recommend it very strongly to our customers as a mill that will give perfect satisfaction. The grinding burrs are white iron, known to some makers as chilled steel, and the machine is shipped complete with two sets. If anyone desires a still larger mill in this same style, we can furnish the No. 40, full descriptive catalog of which we will gladly mail on application. 


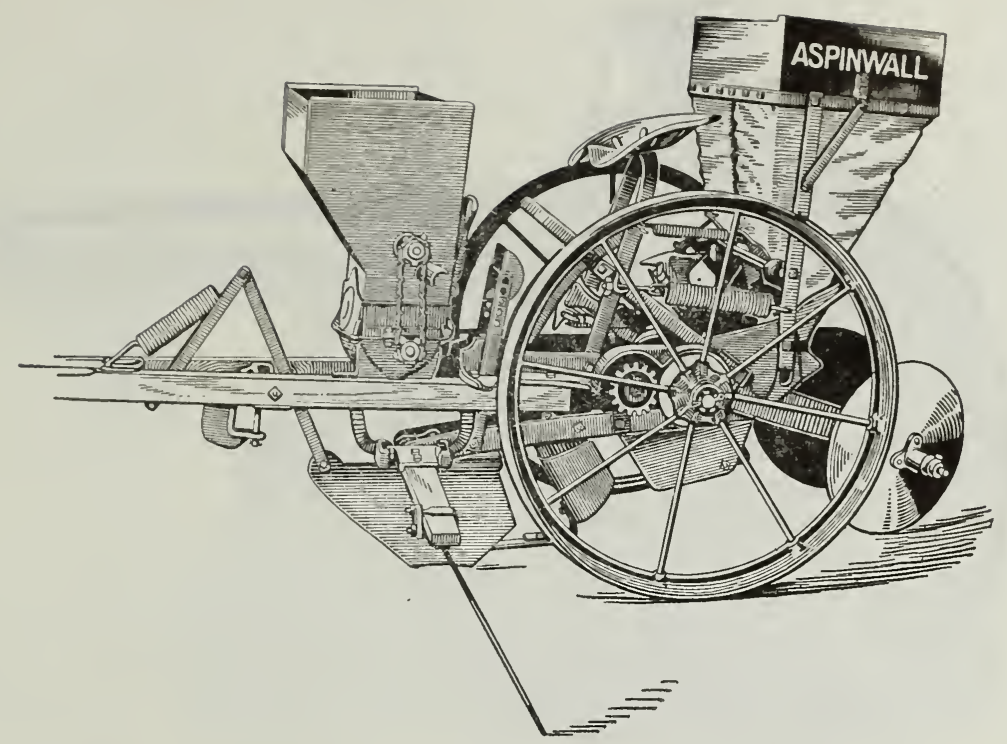

\section{ASPINWALL POTATO PLANTER NO. 3}

\section{The World's Oldest and IIost Widely Used Potato Machinery}

Simplicity in construction characterizes the Aspinwall Planter, and its durability is attested by the fact that many of these machines have been in service from twenty to twenty-five years without a cent expended for repairs. The first Aspinwall Planter demonstrated conclusively and emphatically the correctness of Aspinwall Mechanical principles. They were first in the field and still lead.

In the No. 3 Planter the distance of planting is regulated by gears doing away with the old method of adjusting pickers, which means a great saving in time as the Gears can be changed more quickly than a single picker can be removed, and the Aspinwall Planter is absolutely the only machine that will plant potatoes of any size without adjustments. The manufacturers have also adopted the canvas hopper which reduces to a minimum, clogging or bridging whether the seed be large or small, cut or whole.

The machine in brief guarantees accuracy, the first and greatest essential; Reduction in Cost and Increase of Production; Ease of Operation; Saving in Labor and Worry;
Rapid, Thorough Work; Protection against the Loss of Fingers, because it does the work, and is not fed by human hands; Lightness of Draft and the consequent planting of more acres per day-no additional man to increase the weight and retard the work, for human fingers cannot possibly keep pace with a rapid machine.

Both the Feed and Coverer Tension are Regulated from the Seat. No removal of bolts-simply turning a thumb screw does the work.

The distance of planting is regulated by gears, which can be changed in exceedingly quick time. The distances of dropping are $9,10,11,13,15,17,20,24,26$ and 30 inches. For most localities the 13 and 15 inch gears are the distances generally desired, and we ship all planters, unless other instructions are received with 13-inch gears on the machines and 15-inch set extra. Should other gears be wanted, proper advices should accompany order. We will furnish two sets, any distances desired, with each machine. If more than two sets are required, an additional charge will be made.

\section{Send for Special Circular and Prices.}




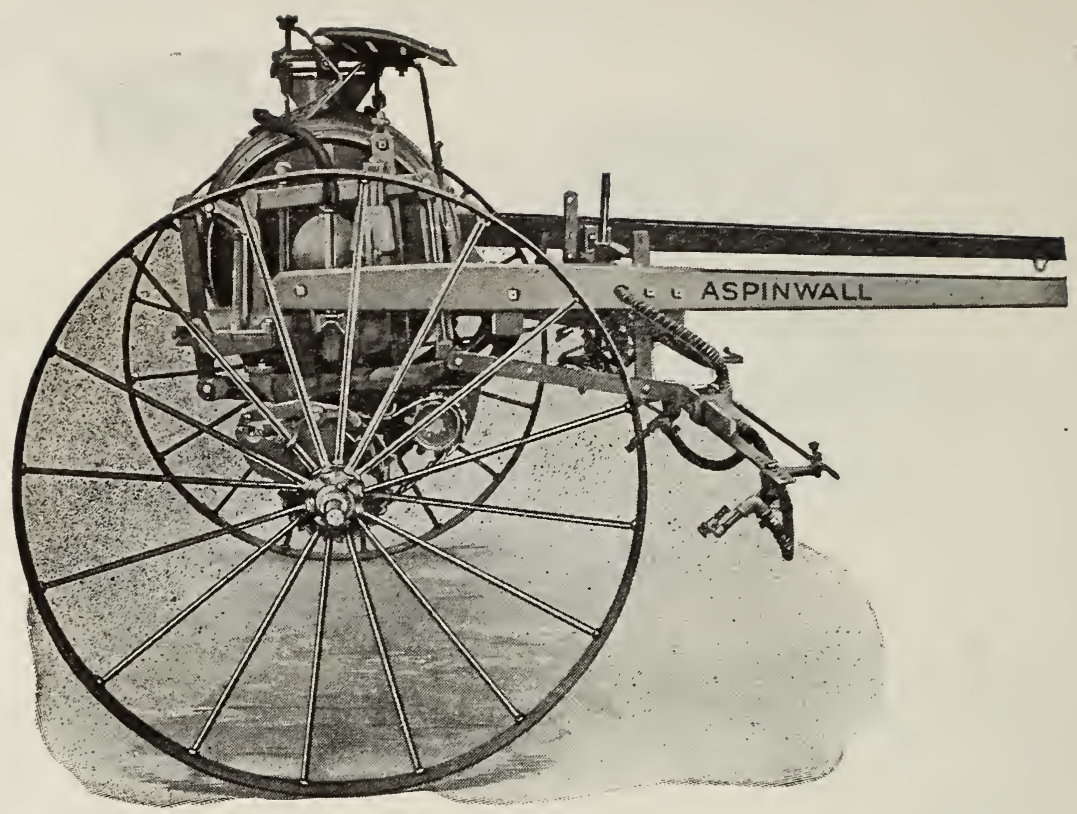

\section{NEW 1913 ASPINWALL POTATO SPRAYER}

\section{FITTED WITH 4 ROW ATTACHMENT EITHER AT FRONT OR IN THE REAR}

The Aspinwall Sprayer, as constructed today, is foremost for the purpose intended, and without equal, placing the machine in a class by itself. It is absolutely different from anything of its kind on the market, more positive, with better results obtained.

The Pump.-First and most important is the pump, which we term a right angle pump. This distributes the intake or power required in suction and pressure in spraying, on quarter points of the crank, making it absolutely free from any back lash, and equivalent to purely rotary motion. The cylinders are open ends, which eliminates any work of removing the piston, such as unscrewing the head as from the ordinary cylinder. The packing is adjustable by set screw at the end of each piston.

An important feature of our 1913 Sprayer is the arrangement of the barrel directly over the axle of the machine, thereby eliminating the weight which would otherwise bear largely upon the team.

The Nozzles are adjustable in every way, laterally, also as to width and inclination of spray, as well as height from the potato rows. The sprayer is also equipped with a foot-bar for deflecting the spray to overcome the effect of side winds.

Perfect Agitation-The next point of excellence is the Syphon Suction Hose, having a screen attached to a paddle which operates through the top side of the hopper on the barrel. This screen is provided with a quantity of buck shot, which with the agitation caused by movement of the paddle, prevents any clogging of the screen. There are no stuffing boxes to keep from leaking, or difficult parts to adjust, tighten, or take apart when removing the paddle.

Aspinwall Relief Valve-The pressure will range as desired from 25 to $150 \mathrm{lbs}$, or more, according to the requirements and mixtures used. The relief valve is located within the barrel, and the pressure is regulated entirely by a spring located above the barrel.

All sprayers are equipped with a combination pole and shafts, so that they may be used with either one or two horses. The barrel is equipped with a special float to show the amount of liquid at all times.

The machine is well balanced and driven from both wheels, thus eliminating all side draft. In construction. the material and workmanship are first class.

\section{Send for Descriptive Folder and Prices}




\section{HOOVER POTATO DIGGER}

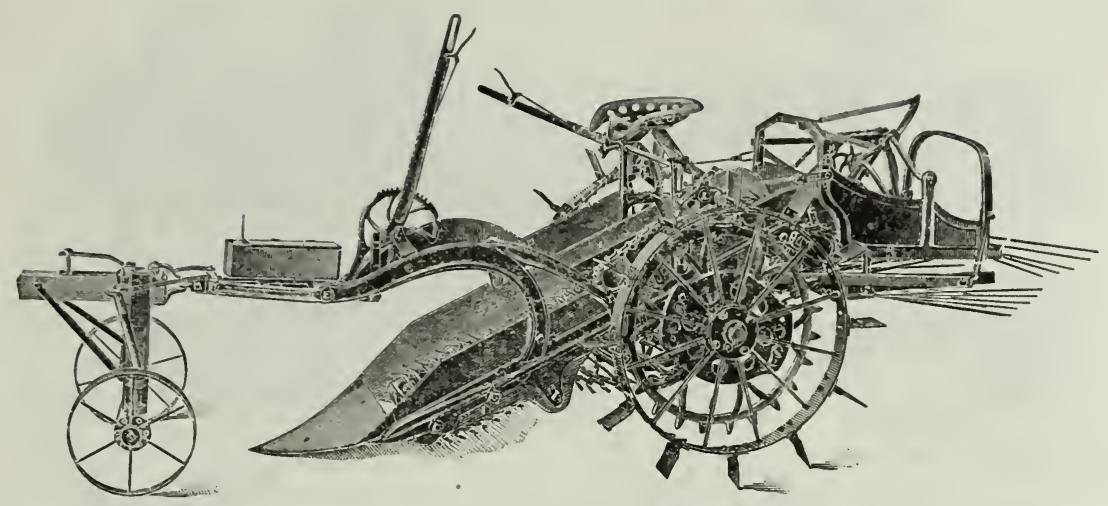

There is probably no implement so well known in potato-growing sections as the Hoover Elevator Potato Digger. In Aroostook County, Maine, where more potatoes are grown than any other section in New England, and where a potato digger gets a severe trial, the Hoover has given perfect satisfaction. Its success can be attributed to the fact that it was built to withstand most trying conditions.

It hardly seems necessary to go into detail regarding its points of merit, for its success is guarantee enough for its superiority in design, construction and efficiency in the field.

We do wish to call particular attention to the vine separator used on the Hoover, which delivers the vine, weeds and trash to one side of the row, leaving the potatoes exposed to view and readily accessible.

Send for descriptive catalogue which contains convincing testimonials from most onthusiastic purchasers.

\section{THE PURCHASE OF A HOOVER IS NEVER REGRETTED}

\section{THE SHAKER POTATO DIGGER}

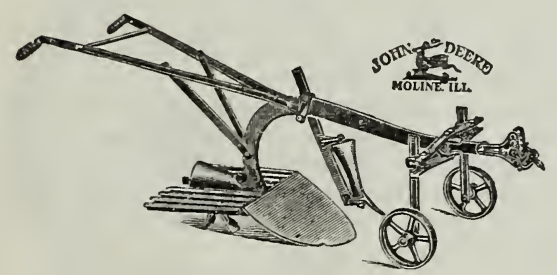

A most excellent working Digger under reasonable conditions. Is equipped with per. fectly flat blade so as not to cut the potatoes. The weed fender clears away the weeds and vines.

Regularly furnished with weed fender, fore carriage and side wings. Price, $\$ 16.50$

\section{DEERE POTATO DIGGER}

The Deere Potato Digger has been in successful use for many years, and is equal to any requirement that may be made on it. It works with very light draft, and throws the potatoes out of the ground without cutting, leaving the ground in good shape.

Price, $\$ 9.00$

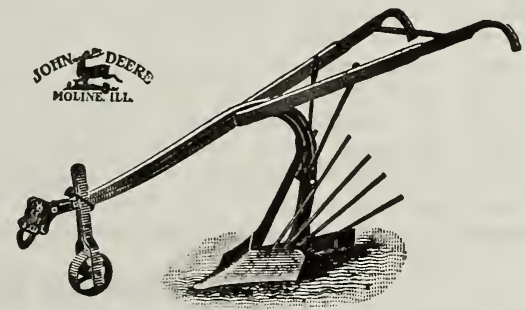




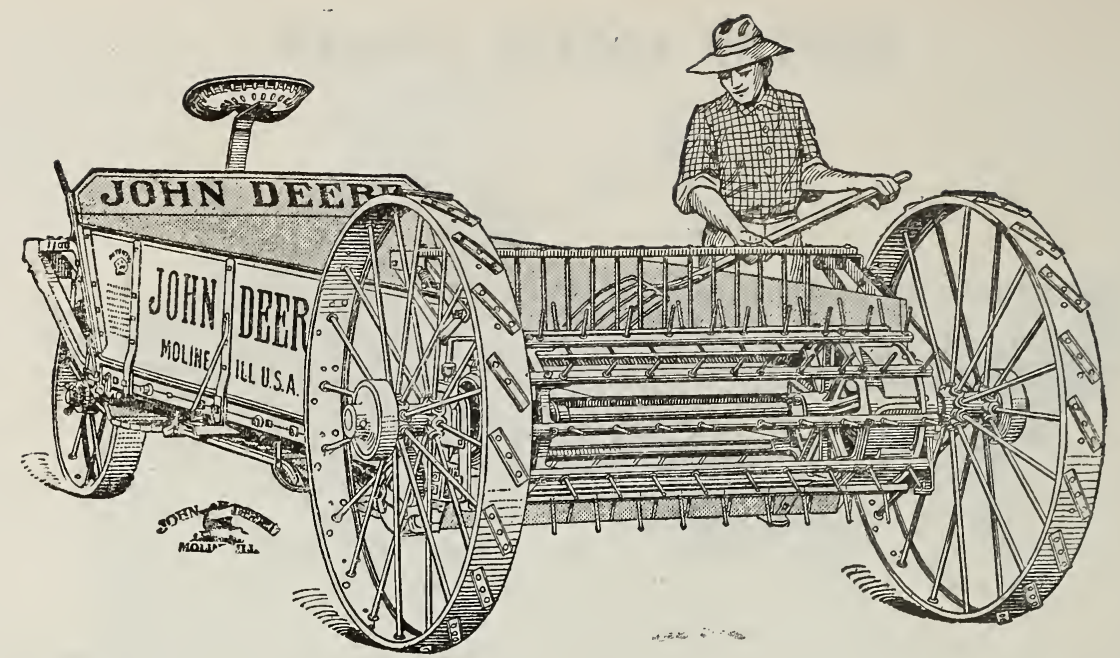

\section{THE NEW JOHN DEERE SPREADER}

$\begin{array}{lcc}\text { No Clutches } & \text { THE SPREADER WITH THE BEATER ON THE AXLE } & \begin{array}{r}\text { Roller Bearings } \\ \text { No Chains Draft }\end{array} \\ \text { No Adjustments } & \text { ALI DRIVING PARTS ON THE REAR AXLE } & \text { Easy to Ioad }\end{array}$

The fact that heretofore it was necessary to mount the beater of a manure spreader on a separate shaft and drive it from the axle, either with chains or sets of gears carried by independent studs or shafts, has been the cause of a great deal of trouble both to the users and manufacturers of manure spreaders. All of these independent studs and shafts on the ordinary spreader necessarily must be mounted on the frame or sides of the spreader, consequently all the strains and stresses of operation are borne by the frame and sides. As the natural tendency is for the strain of operation to pull the gears and shafts out of line, it has always been found difficult to give the gears and shafts a mounting strong enough to take care of their work. In mounting the beater-drive on the main axle, this seemingly necessary evil has been done away with as on the John Deere Spreader all the strains and stresses of spreading manure are borne by the rear axle and are not transmitted to the side of the box or the frame of the spreader.

The John Deere Spreader has no clutches and requires no adjustments. To throw this spreader into gear the driver pulls back the lever at the right of the seat. This moves a dog back until it engages the large stop on the right-hand end of the beater. The operation is simple, easy and effective.

The average point of the load is much nearer the horses than on any other spreader. The front end board slants well upward and forward to permit putting more of the load on the front end of the spreader, and the weight of the load is evenly distributed between the front and rear axles.

By the use of a very simple locking device on the inside of the rachet feed, the apron is positively locked against racing when spreading up-hill or over exceedingly rough ground.

Change of feed is accomplished by a double shoe which is moved from the seat, and which determines the number of teeth the ratchets engage at each stroke. While one ratchet is working the other one is returning for a new hold, consequently, the apron travel is automatic, positive and steady.

There is no chance for the beater on the John Deere spreader to warp, split, twist, get out of shape, or give trouble. It is made entirely of steel. There are ten bars made of high carbon channel steel to which the teeth are fastened.

Four sets of roller bearings, together with the simplicity of the entire machine itself, make the John Deere Spreader the lightest draft spreader on the market. The bearing on the rollers is equal along their whole length. Even after years of use they show no appreciable wear.

The John Deere Spreader is low-down. It is only necessary to lift each fork of manure three feet. Thus, the hard work of loading manure spreaders is eliminated.

The John Deere Spreader is built in three sizes, namely: A, two-horse, 40 Bushel; B, two-horse, 50 bushel; C, three-horse, 70 Bushel.

\section{Send for Special Descriptive Catalog and Prices




\section{SUCCESS MANURE SPREADER}

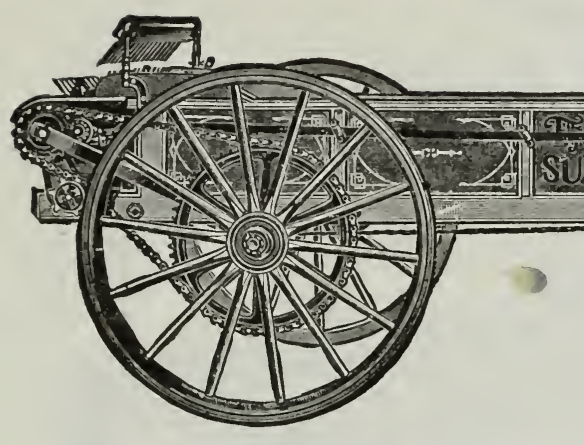

Why Use a Spreader

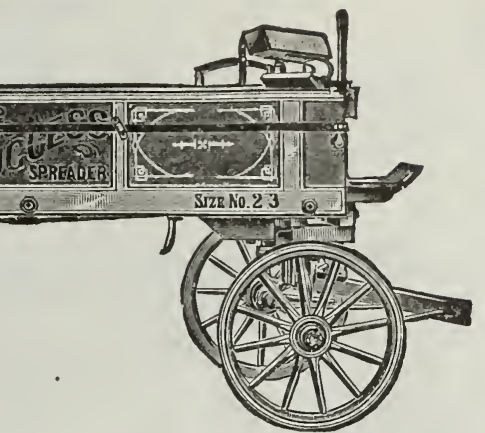

It doubles the value of manure.

It saves labor.

It spreads manure evenly.

It makes meadow top-dressing practical.

\section{Variety of Uses}

Roller Bearings

spreaders should be available for a variety of uses. A Success will spread lime, ashes and commercial fertilizers.

It may also be used as a dump wagon for drawing gravel and many farm products when not used as a spreader.

\section{Capacity to Suit}

There are several sizes of Srccess Spreaders ranging from 40 bushels to 100 bushels in capacity.

\section{Must Be a Staunch Machine}

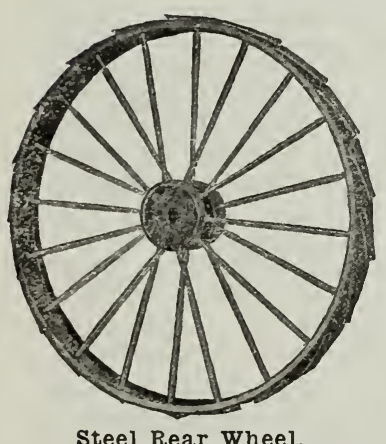

Steel Rear Wheel.

Manure Spreaders are subjected to greater strain than any other farm implement. They carry a heavy load and are used extensively in the spring and fall when the ground is wet and uneven. Strength of construction, therefore, is absolutely essential to insure quality of service and long life.

\section{The Success Is Strong}

Succ ess frames are made of thoroughly seasoned second growth white ash and oak. The center sills are continuous, the cross sills are mortised into the side sills and provided with heavy steel truss rods. All parts are securely bolted together making an exceptionally strong and durable machine.

Remember-That, outside of the New John Deere, there is absolutely no spreader on the market that can compare with the success in lightness of draft. 


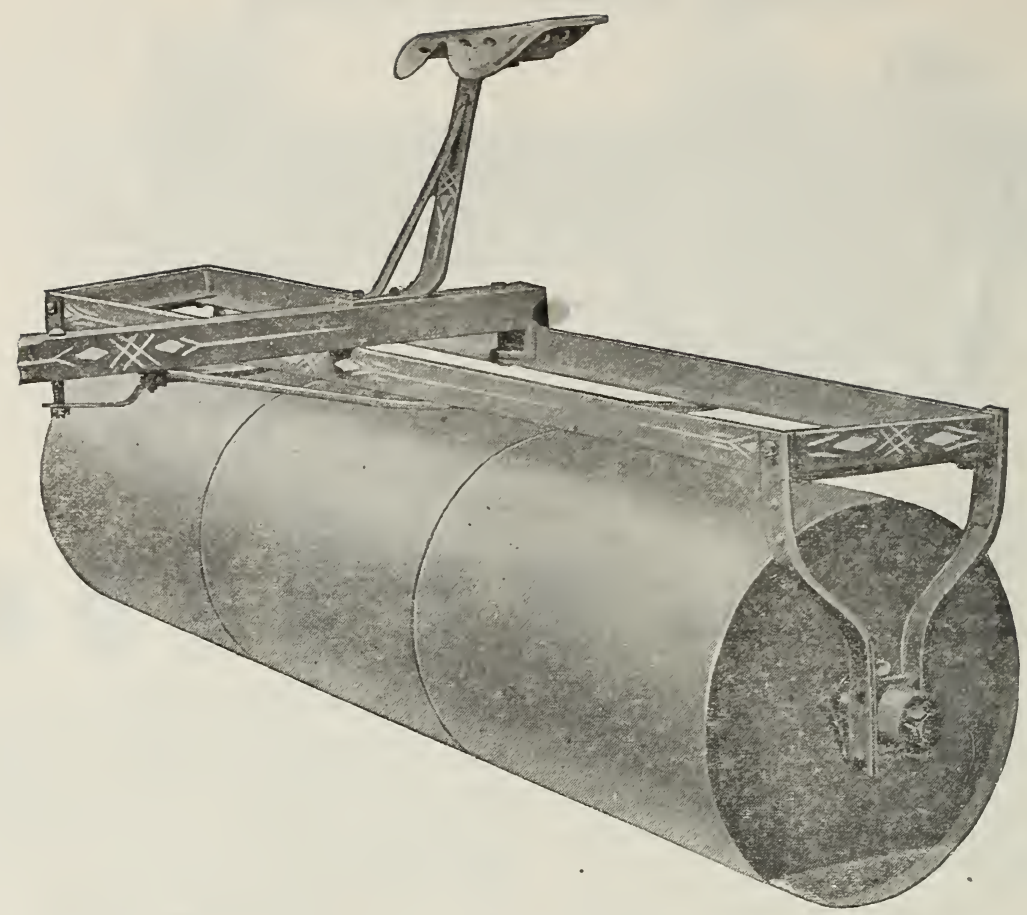

THE DUNHAM ALL-STEEL LAND ROLLERS

SERIES S.

\section{THE ONLY ROLLER-BEARING LAND ROLLER MANUFACTURED}

These Sectional Rollers will turn on their own width without disturbing the top-soil. The sections revolve in opposite directions independent of each other. Each section is a complete drum with a head in each end. This construction prevents the gathering of stones and dirt within the roller when in use or the accumulation of rain water when allowed to stand exposed. The drums are made of high carbon steel and guaranteed not to dent. The seat spring is reinforced and bolted securely to the tongue with two half-inch bolts. The pole is held securely in place by two extra long braces which are bolted to both the front and rear irons of the frame. The end brackets are made of heavy channel iron and built close to the drums to bring the hitch as low down as possible and thus lighten the draft. Hard grease cups are furnished on all Dunham Roller Bearing Machines.

The above cut shows the extra wide end bracket casting which holds the Roller Bearing, but does not show the grease cup or the enclosing cap which fits over this casting covering the end of the axle and preventing the entrance of dirt. The Roller Bearings take up the weight and cut the friction in two.
The one and three-fourths inch round axle is lathe-turned at both ends to give it a slight shoulder and assure it a perfect rolling surface. The first washer is made of heavy felt and is protected by the steel washer which accompanies it. Next is the improved Dunham Roller Bearing. This bearing is made up of twelve $7-16$ inch hardened steel rods that revolve independently. This bearing fits over the lathe turned axle up to the washers and shoulder. The axle revolves in the Roller Bearing.

The flow is regulated by a screwing down the top of this cup so as to force the hard grease into use. The axle protrudes through the end bracket casting and is held in place by a wide slotted washer and cotter pin.

The end bracket is made of two inch high carbon channel steel. The Bearing casting and the heavy top cross pieces are made with lugs which lock into the channel of the side pieces and are held in place by half-inch bolts. This construction assures an indestructible and thoroughly rigid end bracket which positively prevents the frame from working loose.

\begin{tabular}{|c|c|c|c|c|}
\hline 817 & $6 \mathrm{ft}$. & $24 \mathrm{in.}$ & diameter & 3 Section with Shafts \\
\hline 819 & $8 \mathrm{ft}$. & $24 \mathrm{in.}$ & diameter & 3 Section with Pole \\
\hline 2. & $8 \mathrm{ft}$. & 26 in. & diameter & 3 Section with Pole \\
\hline & $8 \mathrm{ft}$. & 30 & ameter & 3 Section \\
\hline
\end{tabular}




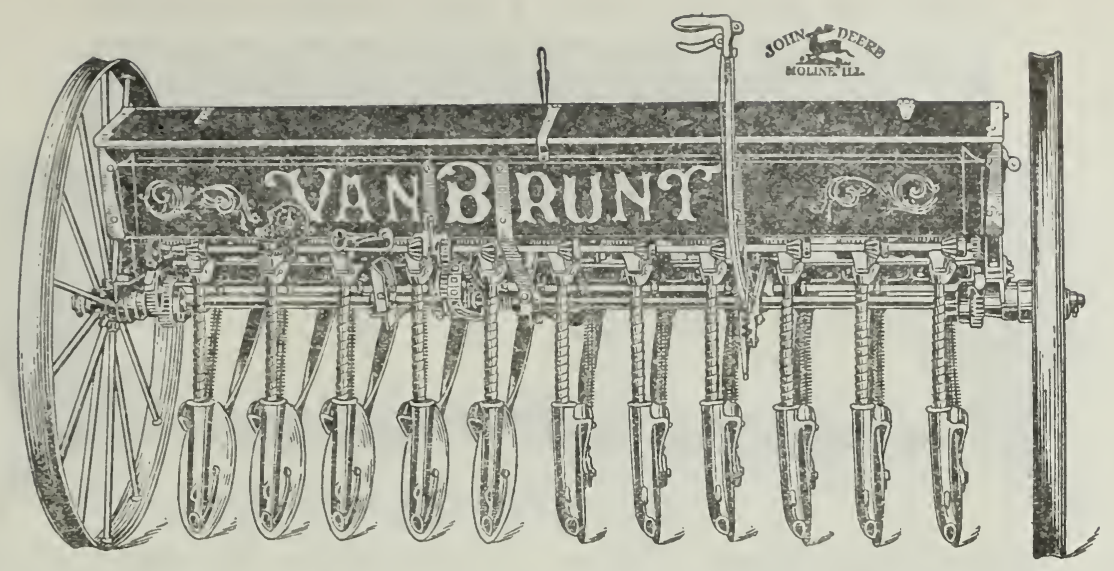

THE VAN BRUNT 11x7 FERTILIZER DISC DRILL

TIIE VAN BRUNT FERTILIZER DRILI, is the up-to-date machine. Its valuable aud exclusive features appeal at once to operators who desire accurate working qualities with all conditions of Soil, Seed and Fertilizer. Neat in design, strong in construction, but light in weight, living strength las replaced clumsy, heary frames. The vital parts of a Grain Drill are the Furrow Openers and the Feeds. Van Brunt construction supplies long life in all parts with small Repair Bills.

This Drill is adjustable to respond accurately to the wants of every operator. It landles all standard brands of Fertilizer in 82 different quantities from 65 to 1070 pounds. The flow of the Fertilizer is always steady and continuous and the discharge is positive. The Van Brunt Feed is the "Star" or "Finger" type with exclusive improvements. It is run with two speeds, the exchange of one sprocket wheel only cuanges from slow to fast drive, very simple and effective. The Gates on the Fertilizer sreeds can be changed instantly to varying quantities by moving the handle at end of Hopper up or down. This can be done while machine is in motion. Thus the amounts of Fertilizer sown can be varied easily as different parts of the field require. Scrapers and Knockers keep the Feeds clean and in constant operation. The seed attachments are all Force Feed with one feed for each Dise and always furnished with Combination tubes 1or drilling and broad-casting.
THE VAN BRUNT SINGLE DISC with Forward Delivery and Closed Boot is rapidly replacing the old style Open Delivery Disc with Shield. The Closed Boot conducts every kernel of seed down into the very bottom of the Furrow. It beats the dirt. The upward turning Dise eannot deflect it. The Disc Bearings are warranted to outlast the Drill. They are case hardened and run in beds of oil. Oil tight and dust proof. One oiling a season is plenty.

The Adjustable Gate Feed is the latest and most accurate of all seeding devices. It is unlike any other Feed you have known. This Feed with the Gate Adjustment compels accurate seeding of all kinds of Grain from Alfalfa and Flax to Corn and Beans. No cracking, no bunching. Permits wide range of quantities and kinds without change of gear. No complicated speed changing of mechanism, no reducing devices required. The Van Brunt is the right feed.

The Wheel Hubs on Van Brunt Drills are 8 inches long and chilled. They do not wear out. The Frame and Machine are supported directly on and over the $\mathrm{Hub}$ and not on the axle. Wheels run on a plumb spoke and never sag in.

Driving Gear. Each wheel is a drive wheel. When the Dises are in the ground the Drill is in gear and raising Dises from the ground automatically throws the machine out of gear. Grain and Fertilizer can be sown separately, if so desired.

\section{Send for Complete Descriptive Circular and Prices}




\section{EMPIRE BROADCAST FERTILIZER SOWER}

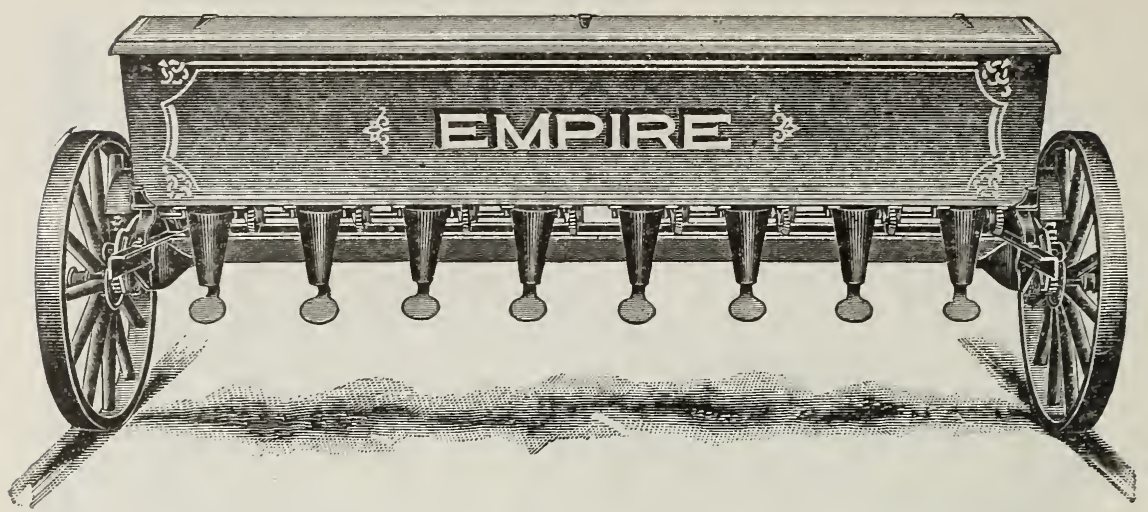

The Empire 8-foot Broadcast Fertilizer Sower is especially designed for sowing a large quantity of lime or fertilizer per acre. 'The hopper is strong, with large carrying capacity, mounted on low, broad-tired wheels.

It has a positive force feed, which insures aceuracy in the quantity sown. The seattering tubes are constructed so as to deliver the furtilizer or lime in an even sheet over the ground. The scattering tubes are low down and $t h \in$ iertilizer is not affected by the wind.
The "capacity of the Empire, as regularly equipped, is $\mathrm{f}$.m 150 to 1,400 quarts of fertilizer; from 375 to 1,500 quarts of lime per acre. We can fu"nish gears that will sow a gres.ter or lesser avantity if desired.

The chippire is well made, neat in design, compact, light-running machine with large range of quantity.

Furnished regularly with pole, double trees and neckyoke.

\section{Send for Special Circulars and Prices}

\section{DEFRE WHEELBARROW SEEDER}

Grass Seeder sows clover, timothy, alfalfa, ete., also all chaffy seeds, such as red top, orchard grass, clean blue grass, etc.

Grain Seeder sows all small grains, such as oats, wheat, rye, barley, etc.

The quantity of seed is accurately governed by the wheel, which moves correspondingly slow or fast, as the machine moves over the ground. The seeder is operated by a cam device attached to the wheel, over which the lever that works the seed chain runs. The feed is instantly ehanged by changing the position of the pin in the index plate. This seeder does not injure or bunch the seed, but distributes it evenly over the ground.

Deere Wheelbarrow Grass Seeder with 14-foot Hopper Deere Grain Seeder Attachment

\section{STROWBRIDGE BROADCAST SEED SOWER}

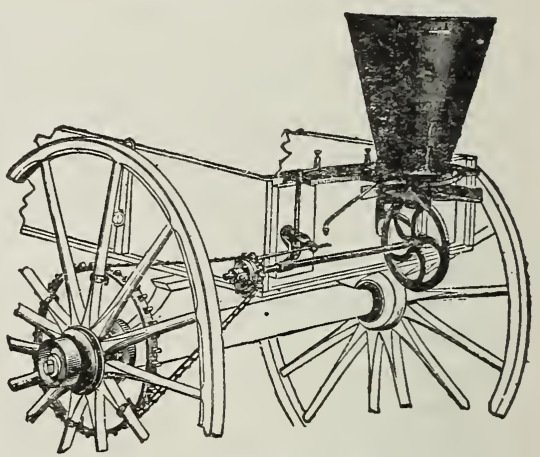

It is a simple, effective seeding apparatus complete in itself which may be attached in a few moments' time to any farm wagon or other vehicle.

Price, $\$ 7.00$

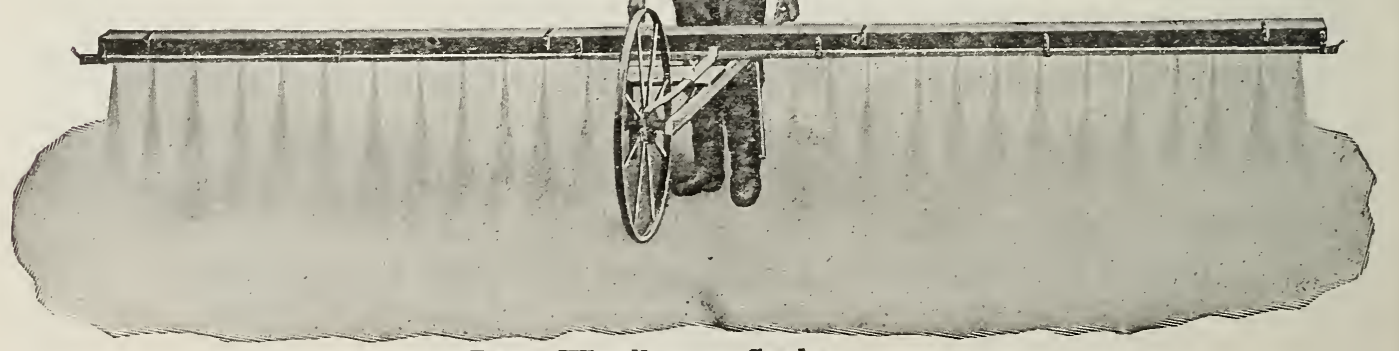




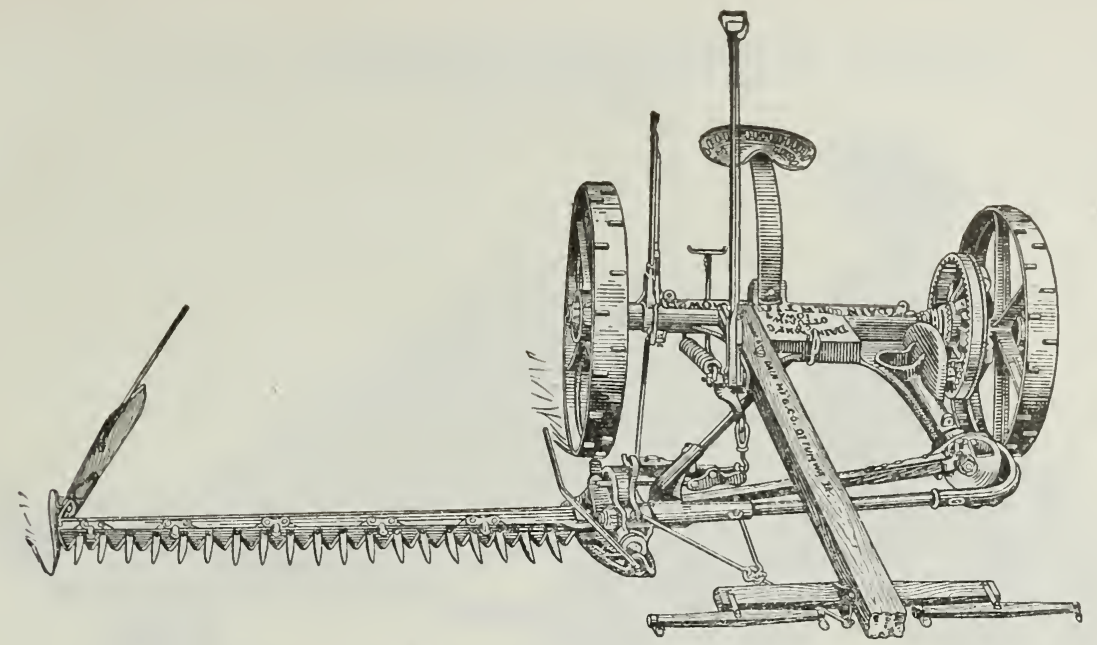

\section{DAIN VERTICAI LIFT MOWER}

\section{Points of Superiority}

\section{4, 5 and 6 Foot Cut}

Qualities which charaterize the Dain Mower are strength, durability, light draft, ease of management, and superior cutting power.

\section{Substantial Frame}

One solid piece of iron constitutes the frame. All parts are held securely in place.

\section{Simple Gears}

There are only three pieces in the gear mechanism.

A large internal gear on the main axle meshes with a spur pinion with which the bevel gear is cast in one piece. The bevel pinion transmits the power to the pitman shaft.

The gears are placed close to the left wheel to counterbalance the weight of the cutter har.

\section{Cuts Clean and Easy}

The wheels have ample traction and produce sufficient power to drive the knives easily in any condition of hay.

The knives are made of soft center steel. The wearing plates are wide, insuring long wear and clean cutting.

\section{Wood Pitman}

Wood will not crystalize by use like iron or steel.

The Dain pitman is long and made of second growth hickory. With proper usage it will last a lifetime.

A hinge joint at the wrist pin end and a socket joint at knife head, allow the cutter bar to be raised, lowered, tilted up or down without causing friction on the pitman bearings.

\section{Easy to Control}

A coil spring working with the lifting mechanism makes the control of the cutter bar either by hand or foot lift very simple.

A small boy can lift the bar for turning corners or passing obstructions and can raise it to a vertical position for transporting, without leaving the seat.

The foot and hand levers are convenient for the operator and may be used independently or together as desired.

\section{Tilting Lever}

The guards can be tilted up or down to suit the condition of any meadow surface.

Reversing the position of the lever latch allows the guards to adjust themselves automatically to the uneveness of the ground.

Features that Characterize the Dain Vertical

\section{Lift Mower}

Compensating Gears-That remove strain form the bearings and transmit instead of consume power.

Long Pitman Shaft-That has all end thrust removed, hence has no need of thrust bearings.

Alignment of Cutter Bar-Seldom necessary, but easily, quickly and positively made.

Centering the Knives-So that they always register perfectly in the guards, insuring perfect work.

Vertical Lift-A lift so easy to operate, an ordinary boy handles it readily.

An Easy Foot Lift-So easy it's surprising, especially after using other kinds.

Adjustable Draft Hitch-Instantly set to remove side draft in the most severe conditions of work.

Material and Workmanship-Of the known Dain standard proven by service reliable and trustworthy.

\section{Special Catalog and Prices on Application




\section{JOHNSTON MOWERS}

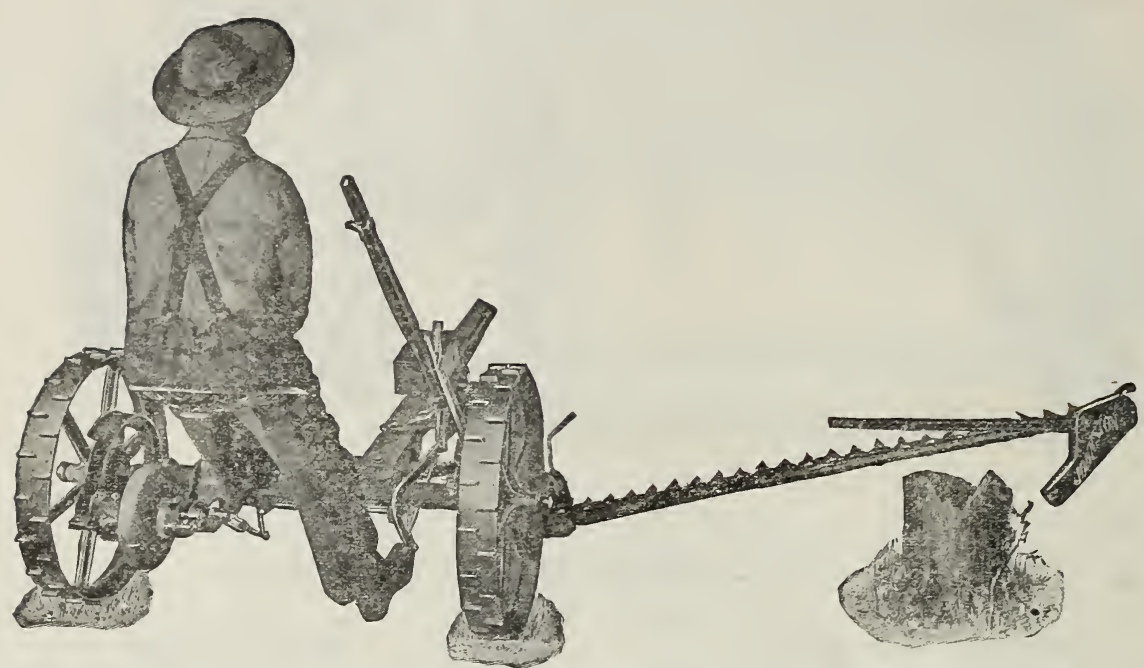

Showing Ease of Handling Johnston No. 10 Lever Fold Mower in Passing Over Obstruction

Features which make up the efficiency, turability, light draft and ease of handling of the Johnston Mowers.

Cast frame, high wheels.

Three pawls in each wheel.

Roller bearings.

Long horizontal crank shaft.

Separate self-aligned crank boxes.

Gearing that meshes properly.

Long wood pitman with ratch adjustment. Babbitted pitman boxes.

Cold-rolled cutter bar finished smooth on top. Serrated guard plates.

Section rivets, headed top and bottom.

Steel wear plates for knife.

Steel subsole for outer shoe.

Even and direct draft.

Special fittings for whiffletrees.

Non-inding solid steel push bar with wide joint.

Convenient levers.

Perfect foot lift.

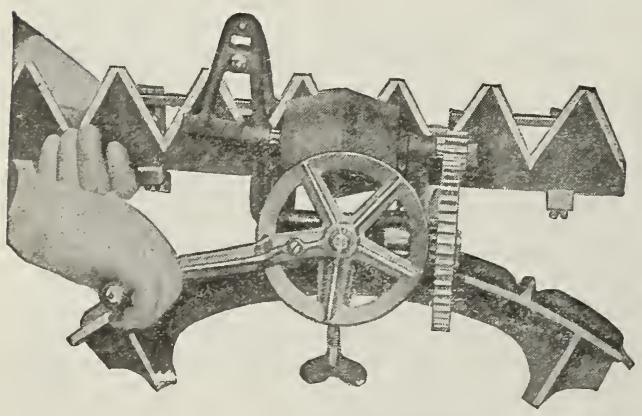

No. IO MOWER WITH LEVER FOLD

Made in 5, 6 and 7 foot sizes.

The lever fold is a decided advantage over the so-called vertical and plain lift.

By use of the hand and foot levers the operator has absolute control of the bar at all times, and enables a wide range of clearance of the bar when passing over an obstruction, in turning corners, or cutting on a hillside. The lifting spring carries the weight of the bar in raising. It drops of its own weight when released.

\section{No. II ONE-HORSE IMOWER}

Made in 4-foot cut.

This machine is especially adapted for small farms, orchards, parks, lawns, etc.

It is constructed along the same general lines as the No. 10. Greatest care is taken in its construction, durability and efficiency in the field.

On account or its light running qualities it is especially to be recommended for a onehorse mower.

Send for full descriptive catalog and net prices.

\section{KNIFE AND TOOL GRINDER}

Grinder is convenient for use in fiela as it can be readily attached to mower wheel by thumb-latch which holds grinder in position. This grinder does its work perfectly, lever gives operator perfect contro? jo that nicks can br ground out and shape if stone insures sections being ground with their original bevel. This grinder can also be furnished on special order as a foot power machine. 


\section{JOHNSTON CONTINENTAL CORN BINDER}

Built for Business

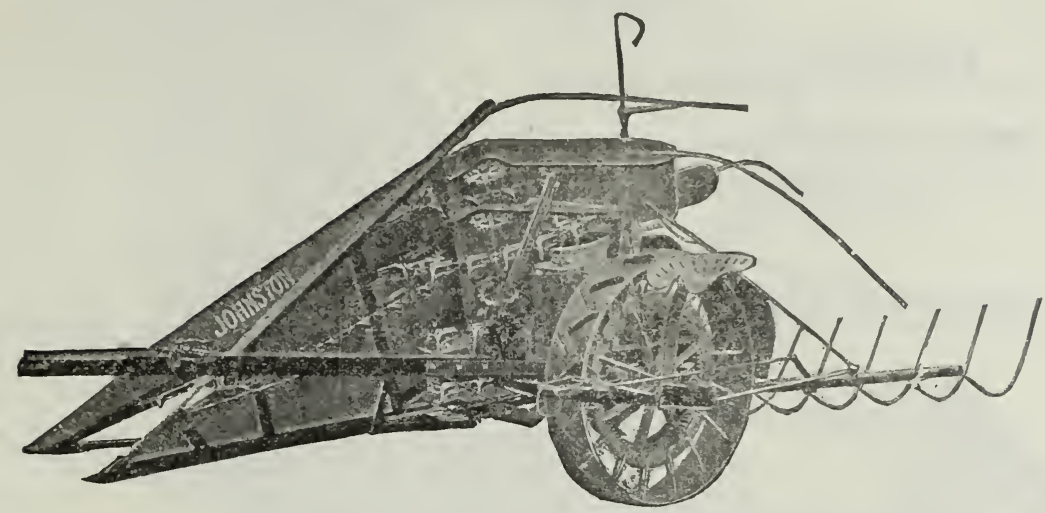

On every important point the Johnston is superior to any corn binder manufactured. This is especially so in regard to power, draft and manner of elevating and binding the corn.

The Johnston elevates and binds corn in an inclined position,- - the natural way. Binding corn in a horizontal position is very wasteful. Binding corn in a vertical position requires more power and does not allow the weight of the corn to be carried back of the line of draft.

This tends to destroy the balance of the machine.

\section{Why the Johnston is Superior}

Light, compact construction.

Steel frame, wheels and supporting bor ms.

Light draft. No side draft. N neck weight.

Two horses handle the machine.

An even balance. Cannot $t^{;}$over on sidehills.

Smoothly running working pe" s.
Roller bearings. Brass bush bearings.

Largest main wheel on any corn binder Gains power.

Natural inclined elevation. Saves power.

Handles perfectly down or tangled corn.

No Packers. Saves corn.

Knocks off fewer ears.

Ties every bundle. Ties tight, shapely bundles.

Ties 18 or 32 inches from the butts.

Automatic conveyor fingers.

Only machine with automatic gates.

Saves crowding the tier.

Special chain adjustment. Adjustable stalk passage.

Perfect cutting apparatus. Three knives and one center plate. Takes care of the weeds and vines.

Right-hand levers.

Steel bundle carrier. Bundles discharged farthest from the machine.

The complete machine is 5 feet 11 inches wide, and will pass through any ordinary farm gateway.

\section{Send for Special Catalog and Prices THE JOHN DEERE STEEL RAKE}

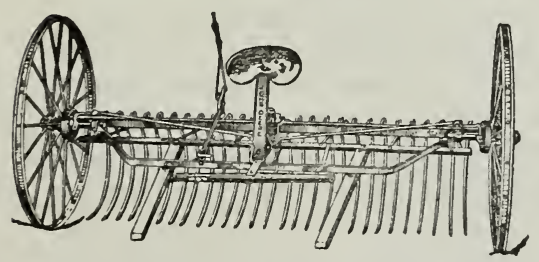

A FEW ESSENTIAL FEATURES.

The axle stubs are one and one-quarter inch in diameter, also reversible and interchangeable, which adds longer life.

The dump rods are three-quarter inch in diameter, and of high carbon steel. These are reversible and interchangeable, making four times the durability of the ordinary type.

The tooth holders are constructed of steel instead of east iron saving much breakage, and they are also made to accommodate a minimum or maximum number of teeth.

You will note by the above reproduction that the front frame angle is connected to end of axle stubs.

The wheels are 54 inches in height, with 20 -16 in. round spokes, staggered hubs, inside ratchets cast integral with boxes, which are replaceable, ratchets will not gather hay as will outside ratchets. Channel tire, with channel out.

Price

8 foot 


\section{JOHNSTON CONTINENTAL GRAIN BINDER}

\section{Strong, Durable, Efficient}

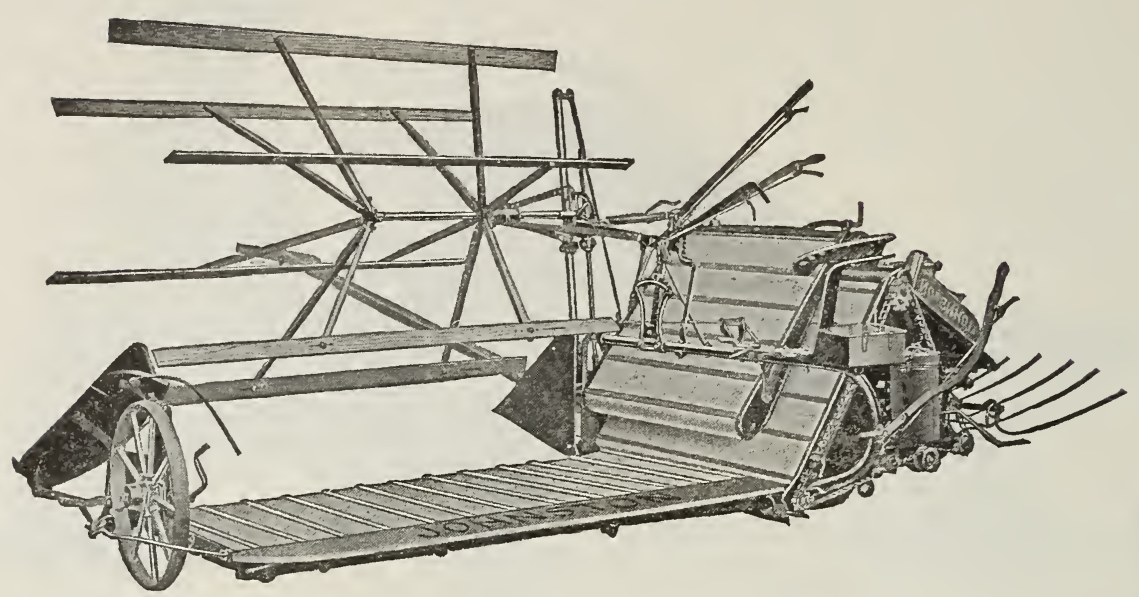

Simple construction, ease of operation, liçht, durable, strong and sure, these are the essentials you want when you purchase a Grain Binder.

You will also desire a binder that will handle a variety of crops with equal satisfaction and dispatch.

You will get all these desirable features in the Johnston "Continental" Binder. You will not have to experiment, as there are twenty-eight years of a successful and an unrivaled record for actual field results behind the Johnston "Continental" Binder, and that counts for something.

Remember you take no chances. Every binder is thoroughly tried out before it leaves the Johnston factory.

\section{Some Construction Features that are the Best Reasons why it Never Fails to do its Work Right}

\section{All-steel frames.}

Sheet-steel platform, with strong connections to frame.

Perfect draft connections.

Steel wheels; main wheel, 36 inch; drives with great power.

Roller bearing in both wheels; drives with least friction.

Perfect mesh of gears throughout.
Brass bushing in crank-box prevents heating.

Angle-steel cutting-bar with stiffener.

Steel Locke belt drive chain.

Both dividers are steel, and both fold out of the way.

All levers on right-hand side.

Gear-drive reel. No lost motion. Handles all kinds of grain.

Largest elevator roller in use. Increases capacity.

Roller boxes are self-aligning, economical.

Seventh roller saves loss at the top.

Canvases made to wear, and each has eccentric tightener.

Gear-drive binder attachment. Has widest shift.

A trip that never repeats.

A knotter that always ties.

Detachable packer boxes.

Steep-slanted decks.

Steel folding bundle carrier, six fingers.

Best three-horse equipment on the market.

Tongue trucks for 7 and 8 foot binders.

Steel transporting truck, the quick-change kind.

You cannot make a mistake if you get a Johnston, and remember each

Johnston Binder is sold under a guarantee.

\section{SEND FOR COMPLETE CATA LOGUE AND PRICES}

\section{BINDER TWINE}

We carry the Standard Binder Twine, which has given such excellent satisfaction to the grain raisers. The fibre is long and runs very even. Write for prices. 


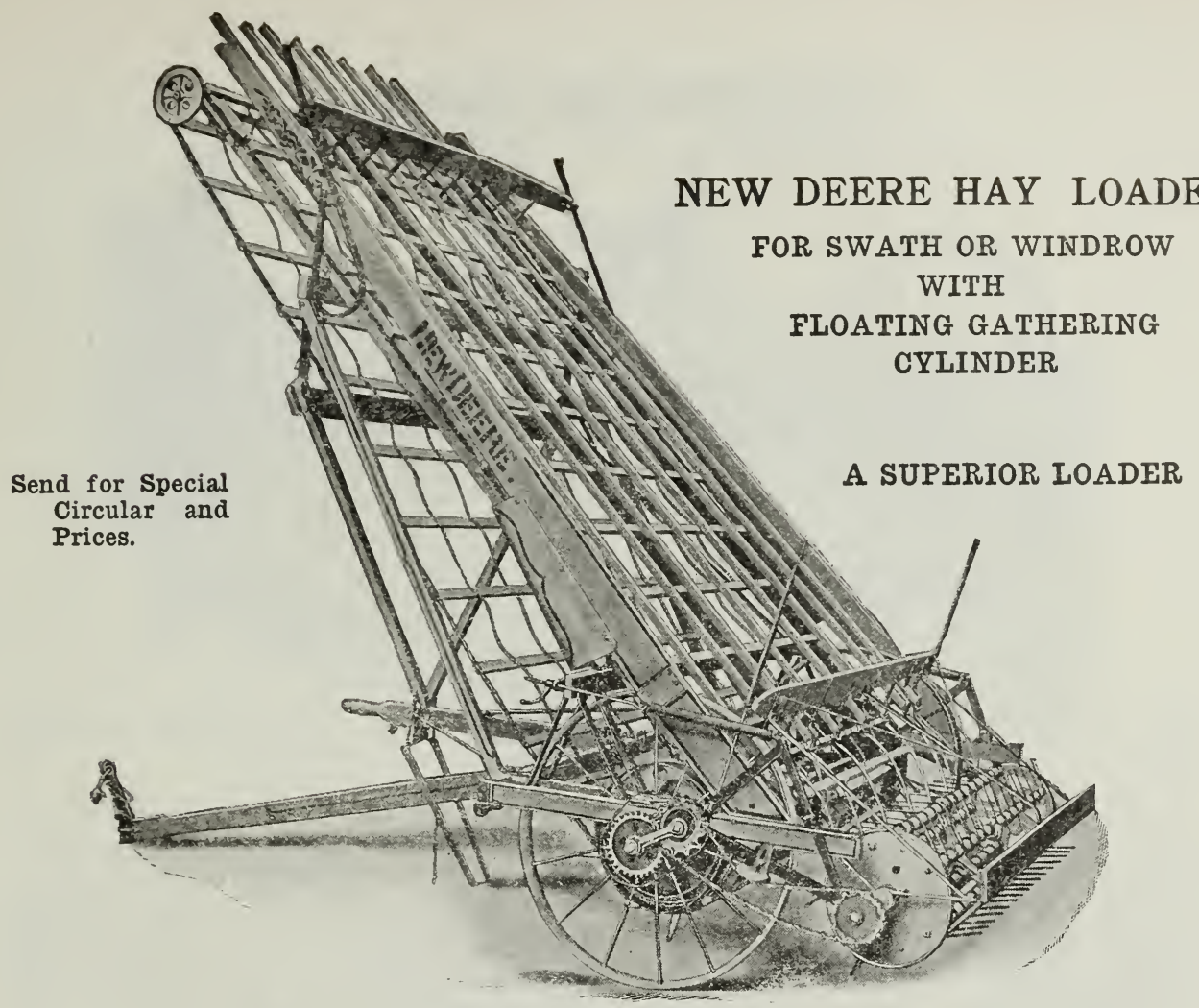

\section{An Economy}

Where hay is grown in any quantity, the saving in time, labor, aind quality of product effected by a hay loader will often wipe out the purchase price the first year used and thereafter become a source of clear profit.

\section{A Desirable Loader}

The most desirable hay loader is the one that combines to the greatest degree durability, capacity. and efficiency. This describes the NEw DEERE LOADER in a nut-shell. It is very durably constructed, ret light in weight, will pick up any quality and condition of hay either from the swath or windrow and do it as clean as any rake.

\section{Any Kind of Work}

The New DeEre Loader has a wide range of capacity and will do any grade of work without changes in adjustment.

\section{Wagon Coupling}

The hitching and unhitching device is very simple and locks and unlocks automatically making it unnecessary for the operator to get under the wagon.

\section{A Light Machine}

Although very durable it is a light machine; light in draft and so simple in construction thac it cannot easily get out fo ordes.

\section{Handles Hay Gently}

The hay is picked up by the gathering cylinder, passed on to the elevator carrier, and elevated to the load in a slow, continuous manner which avoids all threshing or beating and consequently saves all the leaves.

A gathering frame is pivotally attached to the main frame and readily adjusts itself to the irregularities of the surface of the field and passes over obstructions without any damage. The tooth bars of this cylinder are also mounted pivotally and automatically adjust themseives as the cylinder revolves. As each bar reaches the lowest point. the teeth stand straight out from the face and are caught and held in this position until the hay is gently lifted and carried to the elevator, where the teeth are withdrawn from the hay instead of being forced through, consequently carry none after them.

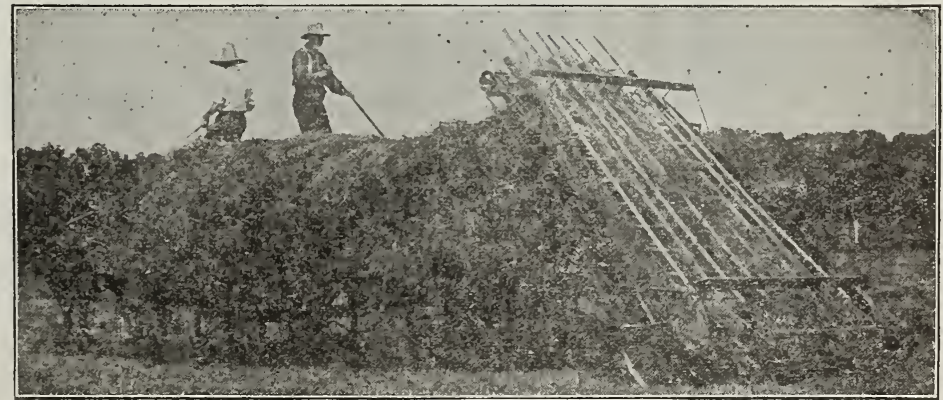

A New Deere Loader at Work. 
JOHNSTON HAY RAKES

All steel construction. Strong, durable. None better.

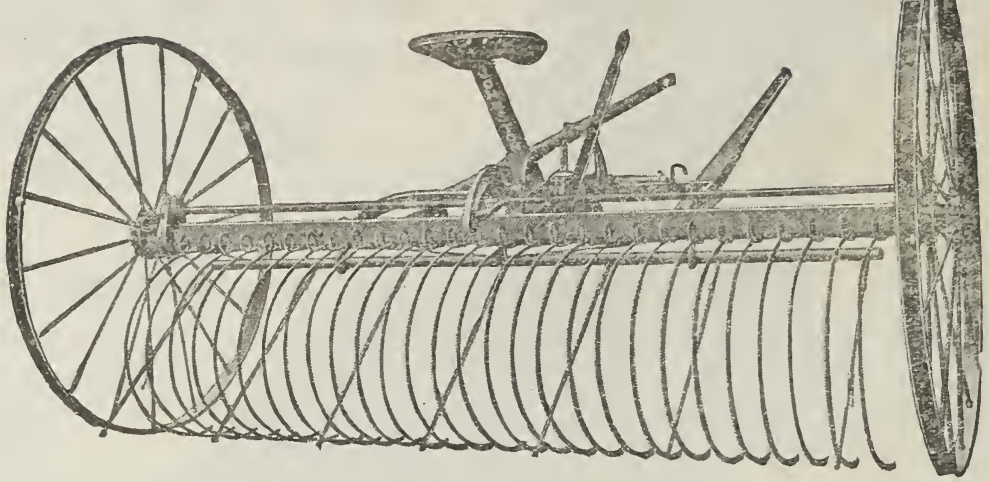

Johnston all steel Rakes are the best.

All steel, but the combination pole and shafts. Double hub steel wheels; angle steel frame, steel trussed.

Long flat-pointed teeth.

Teeth interchangeable.

Steel cleaners bolted, not riveted.

One-piece dump rod.

Levers on right-hand side.

Trip ratchet plate, adjustable for fast or slow walking horses.
Separate holders for the teeth.

Steel seat with steel support.

Comfortable, convenient and easy to handle, does clean work; is light draft.

Economical and durable.

The Johnston Rakes can be furnished in the following sizes:

\section{PRICES}

$8 \mathrm{ft} .24$ teeth ................. $\$ 21.00$

9 ft. 28 teeth ............... 22.50

$10 \mathrm{r} / 2 \mathrm{ft} .32$ teeth $\ldots \ldots \ldots \ldots \ldots \ldots \ldots 25.00$

12 ft. 38 teeth .............. 29.00

\section{JOHNSTON TEDDERS}

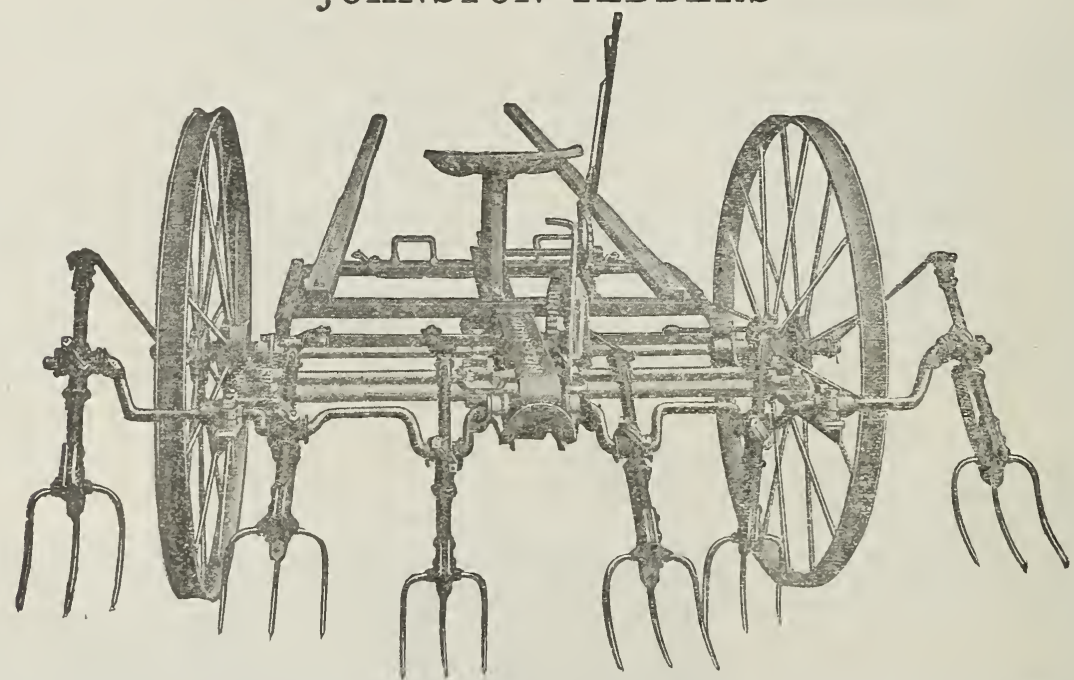

Johnston all-steel Tedders are strong and durable, and work most satisfactorily. The frame is steel, the wheels are steel and double hubbed. Three sets of roller bearings on the main shaft insure its light running. Three tined crucible forks are used; the spring

on the fork is located behind it, and does not come in contact with the hay and get tangled in the rod and spring. Another feature is the spring balance tilt. The Johnston is equipped with combination pole or shafts. Made in two sizes, 6 and 8 iork.

\section{PRICES}

Johnston. 6 Fork Tedder 


\section{DAIN SIDE DELIVERY RAKE}

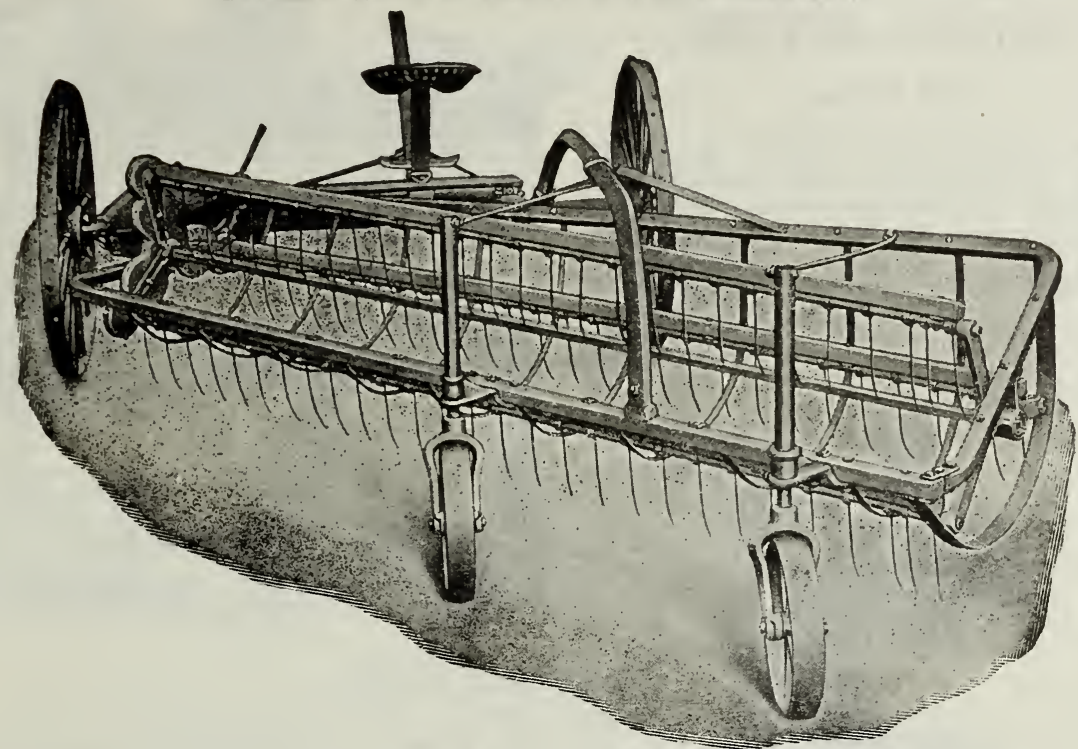

The Dain Side Delivery Rake has a frame of strong steel construction giving great durability. Can be furnished with either one or two castor wheels. Can be adjusted to all conditions of hay crop. Has strong steel raker teeth sufficient to rake and deliver the heaviest crop of hay, also having perfect flexibility when striking an obstruction.
No farmer cutting a quantity of hay can afford to be without one, especially if using a hay loader.

Leaves the hay in a long, continuous windrow in the very best condition for curing. Will shake water from grass in as satisfactory way as a tedder. Let us send you booklet giving full description and prices.

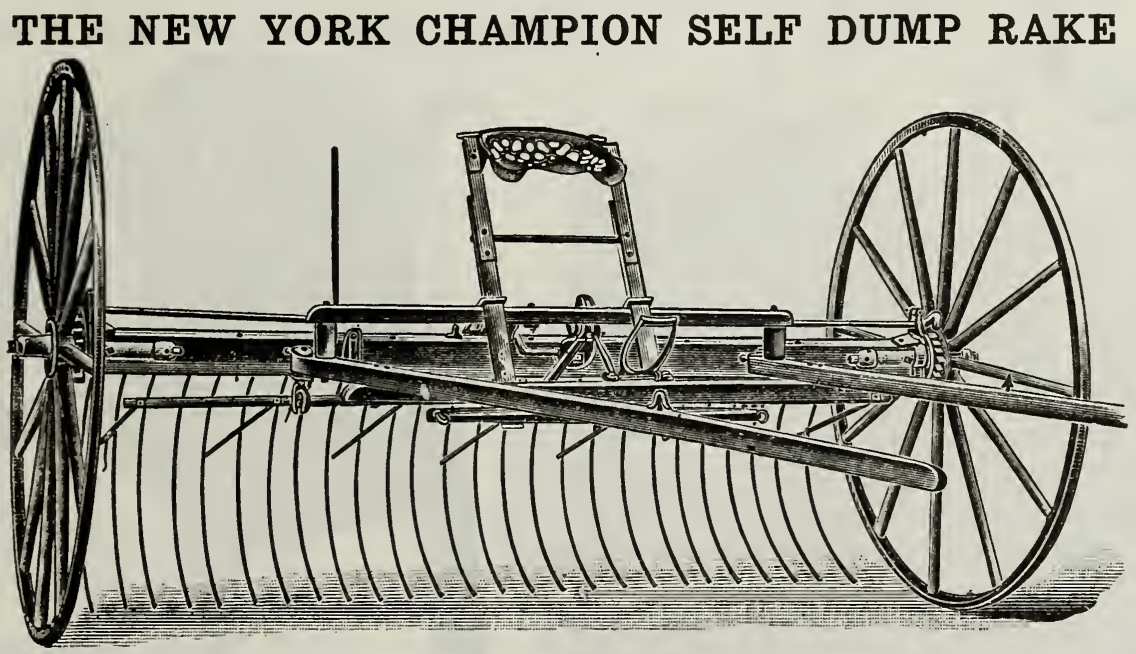

For years the New York Champion Rake has been the best known and most successful rake in use in this locality.

We would certainly recommend the above to our customers who do not desire a steel rake.

8 foot, 26 tooth
It is carefully and substantially built, and nothing but the best of material is used in its construction.

Price $\$ 20.00$ 


\section{"NEW MODEL" CLOVER CUTTER}

\section{For Poultry}

Just the eutter for the poultry raiser. Cuts all kinds of feed, either green or dry. Has remorable steel knives, adjustable eutter bar. It runs easy, cuts fine, and is durable.

$\begin{array}{ccc} & \begin{array}{c}\text { Weight, } \\ \text { Pounds }\end{array} & \text { Price } \\ \text { With four } & \text {-inch knives . } \quad 60 & \$ 8.75\end{array}$
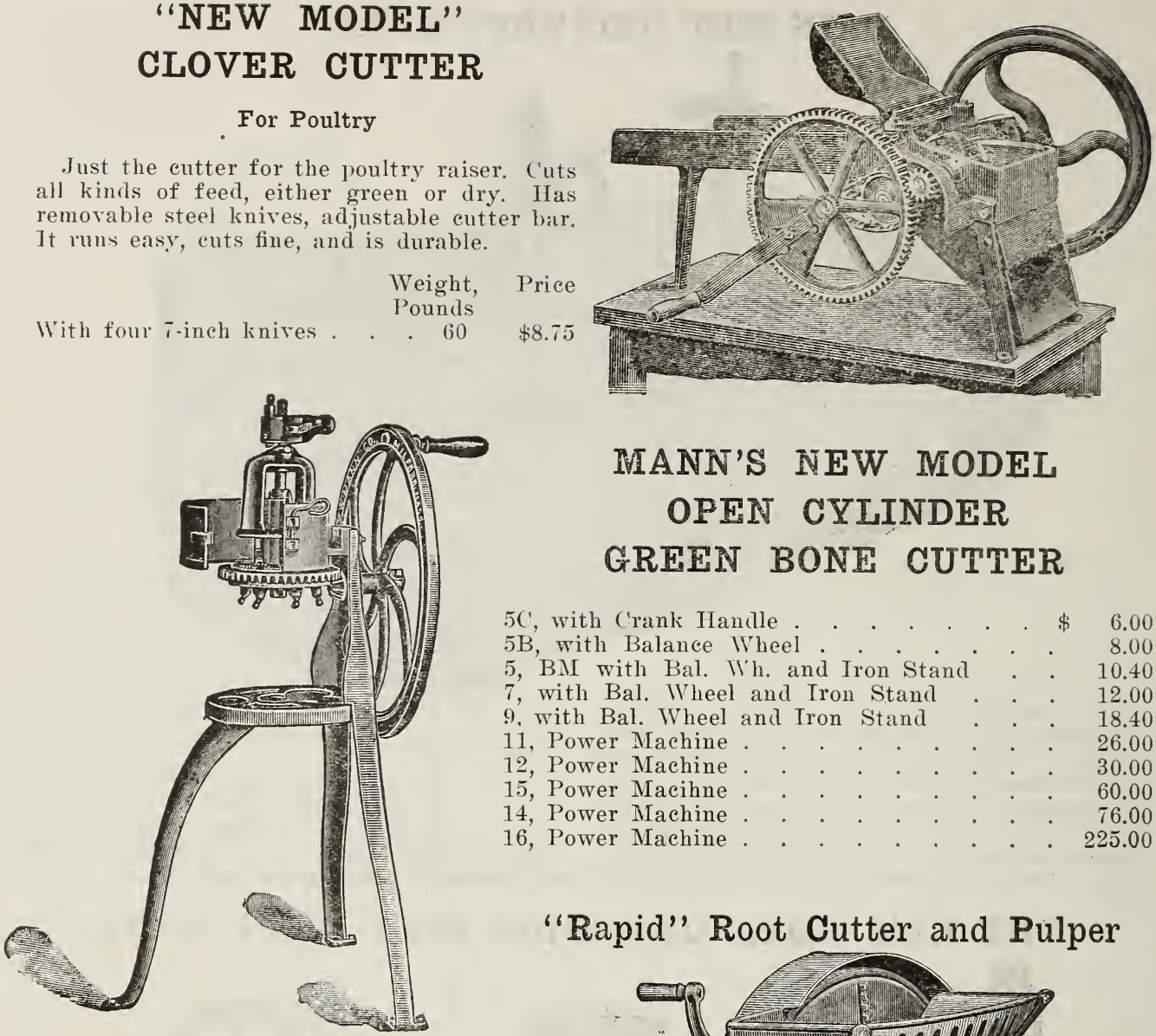

\section{MANN'S NEW MODEL OPEN CYLINDER GREEN BONE CUTTER}

5C, with C'rank Handle . . . . . . . \$ 6.00

$5 \mathrm{~B}$, with Balance Wheel . . . . . . 8.00

5, BM with Bal. Wh. and Iron Stand . . 10.40

7, with Bal. Wheel and Iron Stand . . . 12.00

9. with Bal. Wheel and Iron Stand . . . 18.40

11, Power Machine . . . . . . 26.00

12, Power Machine . . . . . . . . 30.00

15, Power Macihne . . . . . . . . . 60.00

14, Power Machine . . . . . . . 76.00

16, Power Machine . . . . . . . . 225.00

Knives Are Double-Edged and ReversibleThe picture is a good representation of our new Root Pulper and Slicer. The knives are double-edged and reversible, one being straight for slicing, the other edge being grooved, thus dividing it into separate bits for pulping.

Knives Are Adjustable-The knives cut the roots into slices, of uniform thickness, and the bits pulp them so that poultry and young animals eat them freely without danger of choking. The knives are adjustable to the cutting plate, which is to gauge the thickness of the slices and to counteract wear in the knires.

Capacity-Capacity per hour, slicing or pulping, hand, 30 bushels; power, 125 bushels.

Pulley-Size of pulley for power, 10x4 inches. Weight, 215 pounds, with pulley.

\section{Size and Price}

No, 2 Root ('utter and Pulper, 6 knives, for hand . . \$13.50 No. 2 Root Cutter and Pulper, 6 knives, for hand or power . . . . 15.00

\section{"Rapid" Root Cutter and Pulper}

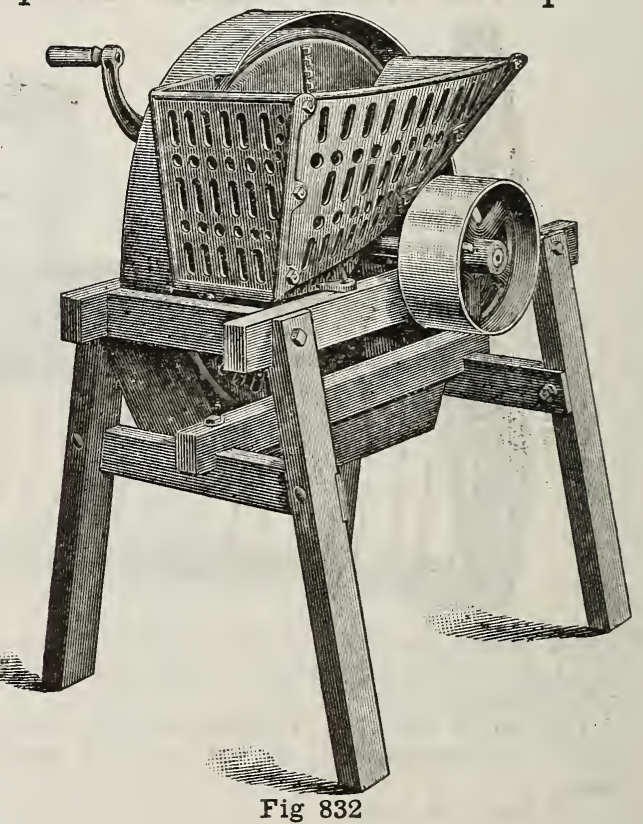




\section{" OHIO" HAND FEED CUTTERS}

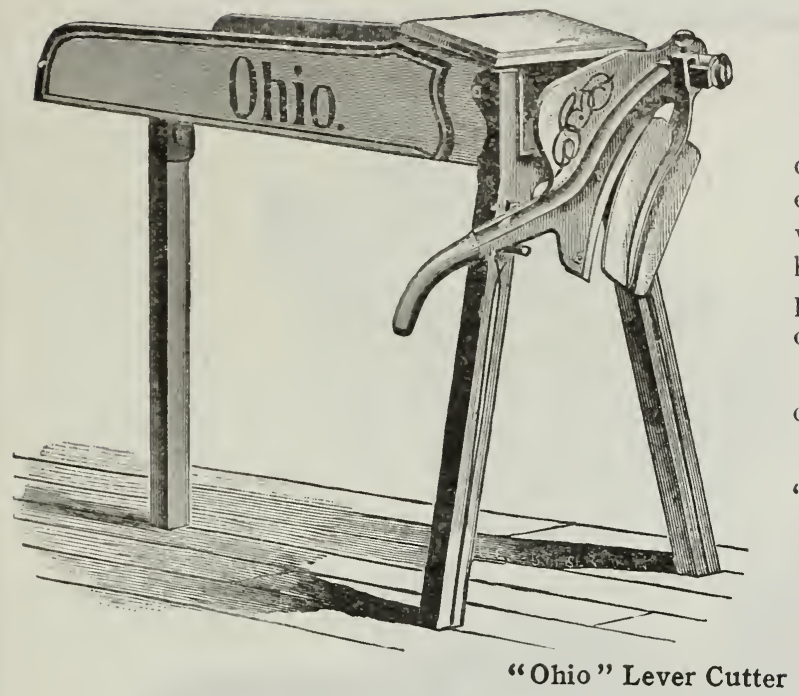

"Ohio" Hand Cutter

The No. $81 / 2$ "Ohio," as illustrated below, is built along the same general lines as the power cutters. It has great capacity, is strongly built, and is a high-class cutter in every way.

No. $81 / 2$. With two $8 x / 2$-inch knives.

Cuts $1 / 2,3 / 4$, or $11 / 2$ inch. Weight $165 \mathrm{lbs}$.

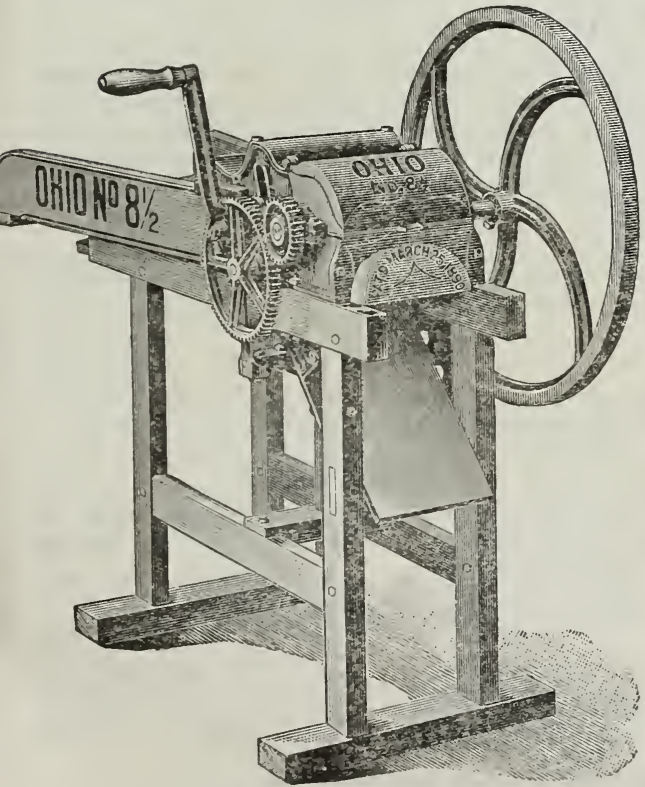

"Ohio" Hand Cutter
Pony Hand Feed Cutter

The "Ohio" Lever Cutter will cut hay, straw, corn stalks and every kind of feed. It is equipped with one 11 -inch oil-tempered knife; also provided with a guard plate, adjustable to vary the lengths of cut.

It is nicely finished, of pleasing design, strong and durable.

\section{"Ohio" Lever Cutter, weight} $55 \mathrm{lbs}$.

The Pony Cutter, as illustıated below, is strictly a hand machine.

A bushel of hay can be cut in thirty-five seconds. Cuts all kinds of feed. Only highgrade material is used, and makes it a strong and efficient cutter.

No. 11 $1 / 4$. One $11 \frac{1}{2}$-inch knife cuts $1 / 2$ to 2 inches, weight $165 \mathrm{lbs} . .$. .

$\$ 10.50$

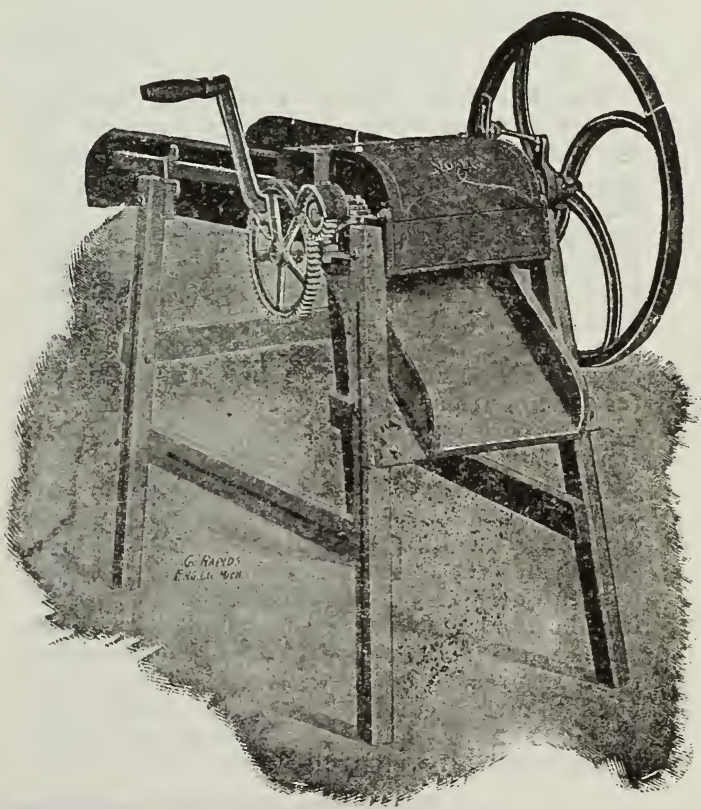

Pony hañu Feed Cutter 


\section{NO. 11 “OHIO" FEED AND ENSILAGE CUTTER}

\section{Equipped with Round Inclosed Steel Carrier for Straightaway Delivery}

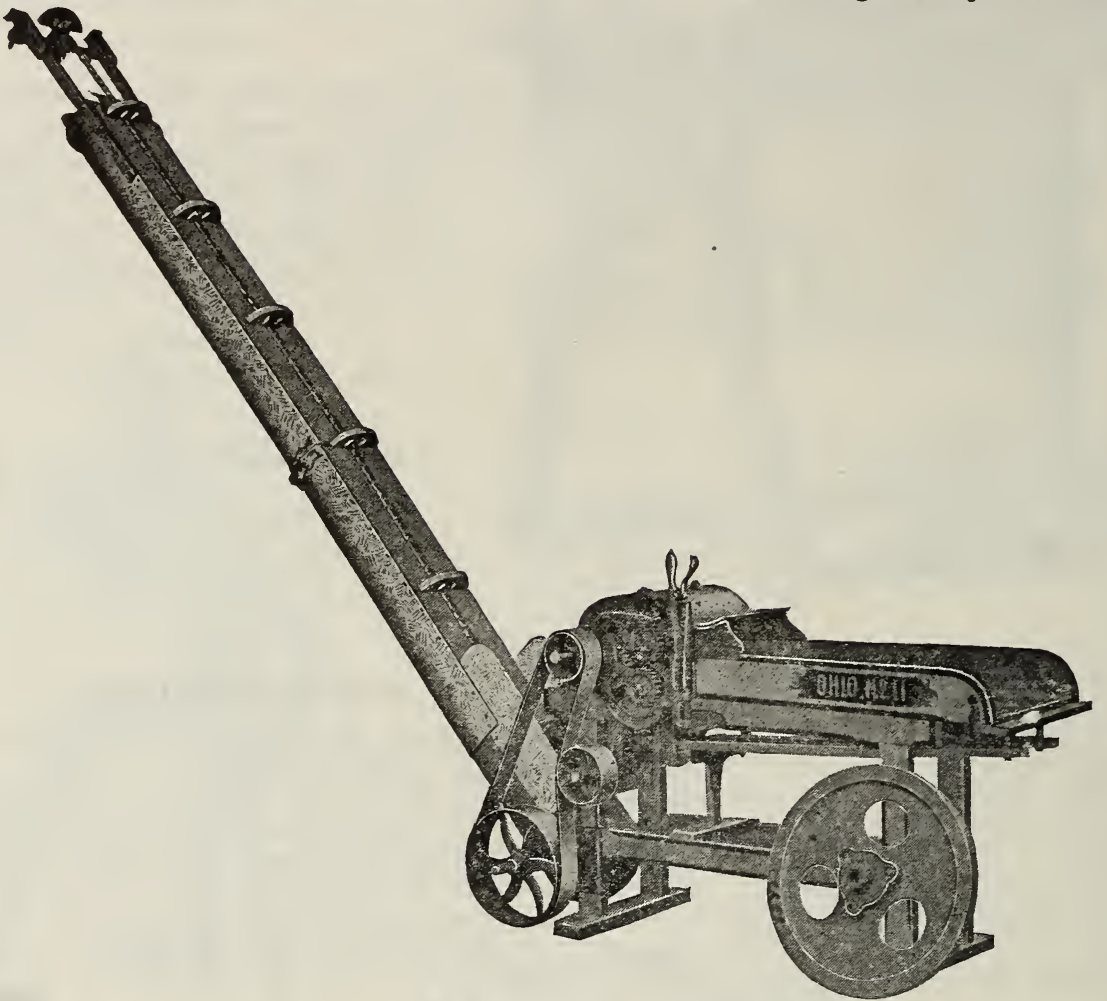

Fig. 784 No. 11.

The No. 11 "Ohio" Feed and Ensilage Cutter has long been our most popular size for general farm use. The strength, durability, beauty and satisfactory operation of this machine are notable features. It is a strong feeder, has large capacity and, supplied with a carrier, is largely used for cutting all kinds of dry feed and for shredding fodder. The knife shaft is steel, $13 / 8$ inches in diameter. The safety Fly Wheel, adjustable homemade knives, hard cutter bar and patented feed gears are special features of the machine. The feed lever gives the operator perfect eontrol of the machines at all times.

Being inclosed, the Carrier is independent of wind conditions, and conveys ALL of the cut material into the silo. It is of ample size to deliver up to full capacity of machine without danger of clogging. The galvanized iron body is round, and has rounded cast base with wide high hopper. The overhead return insures a clear delivery at top. The buckets are securely bolted at center, to a strong single chain, the tension of which is automatically controlled by a long heavy coiled spring on each side. The coiled springs act directly on the sliding bearings of the shaft carrying upper chain sprocket, so that the slightest variation in chain tension is immediately absorbed.

\section{Capacity}

Dry feed, 2500 to 3000 pounds; ensilage 3 to 4 tons per hour.

\section{Speed and Power}

400 to 600 revolutions per minute; 4 to 6 horse power gasoline engine.

\section{IIST PRICES}

No. 11 with four 11 inch knives, euts 1/4, $1 / 2,3 / 4$ and 1 inch

$\$ 45.00$

Straight delivery round inclosed steel carrier $12 \mathrm{ft}$. long or less (270 lbs.)

$\$ 50.00$

Additional length over $12 \mathrm{ft}$. per foot (13 lbs.)

$\$ 1.70$

For Traveling Feed Table Add 


\section{"OHIO" MONARCH SELF-FEED ENSILAGE CUTTER}

\section{Showing New Metal Bucket Swivel Carrier}

Supplied Also With Straightaway Carrier, as Listed.

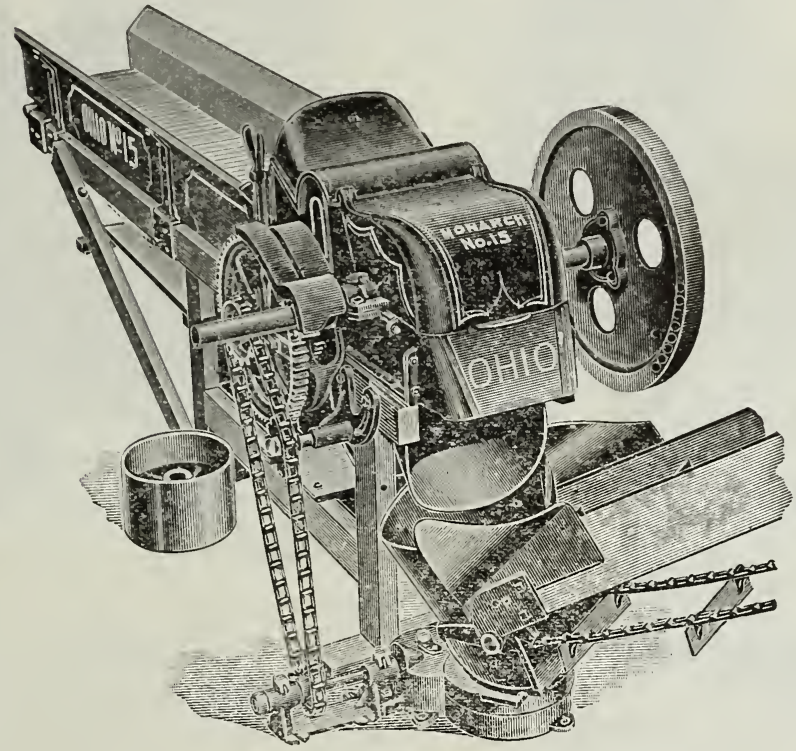

Fig. 794. Nos. 12 and 15.

The illustration above represents our line of "Ohio" Monarch Self-Feed Ensilage Cutters, equipped.with swivel chain carrier. The new Monarchs are stronger and heavier in every part than the old style, and their capacities are greater than the length of knives would indicate, owing to the additional raise of the feed rollers.

ABOUT TRAVELING APRON. The traveling apron of the machine travels on single sprockets (one at each end in the center) and on metal tracks at the sides. Guide wheels are at the front and rear ends to carry the slats safely on to the track. The feed table is 8 feet in length and will readily. receive the corn.

\section{SELF-FEED INCREASES CAPACITY} $331 / 3 \%$, SAVES $75 \%$ OF IABOR FEEDING. The self-feed means that it is only necessary to bring the feed to the box. It also increases the capacity of the machines about one-third, on account of its being so much easier to keep the feed rolls full. The corn may be fed in armfuls or in bundles from the corn harvester.

There are two styles of metal bucket carriers for this line-the Straightaway and the
Swivel. The Straightaway is the simpler and is recommended wherever a straight delivery carrier can be used. Its usefulness, however, is limited to delivery in but one direction. The Swivel Carrier is shown in the illustration above, also how it connects with and is driven by the machine.

CAPACITY, POWER, SPEED, PUIIEY. Capacities based on $1 / 2$ inch cut.

No. 12-Capacity: 8 to 10 tons per hour; power, 5 to 7 horse, gasoline.

No. 15-Capacity: 12 to 15 tons per hour; power, 6 to 8 horse, gasoline.

Speed-450 to 600 revolutions per minute.

\section{IIST PRICES.}

No. 12 Cutter with 4 knives ....... $\$ 95.00$

No. 15 Cutter with 4 knives .......\$120.00

12-foot Straight Carrier for Nos. 12 and 15,

$\$ 33.50$

12-foot Swivel Carrier for Nos. 12 and 15 ,

$\$ 45.00$

Carrier over 12 feet for Nos. 12 and 15, per foot,

$\$ 1.70$

Wood cover with hooks and eyes to fasten, per foot for Nos. 12 and 15, $\mathbf{8 . 2 5}$ 


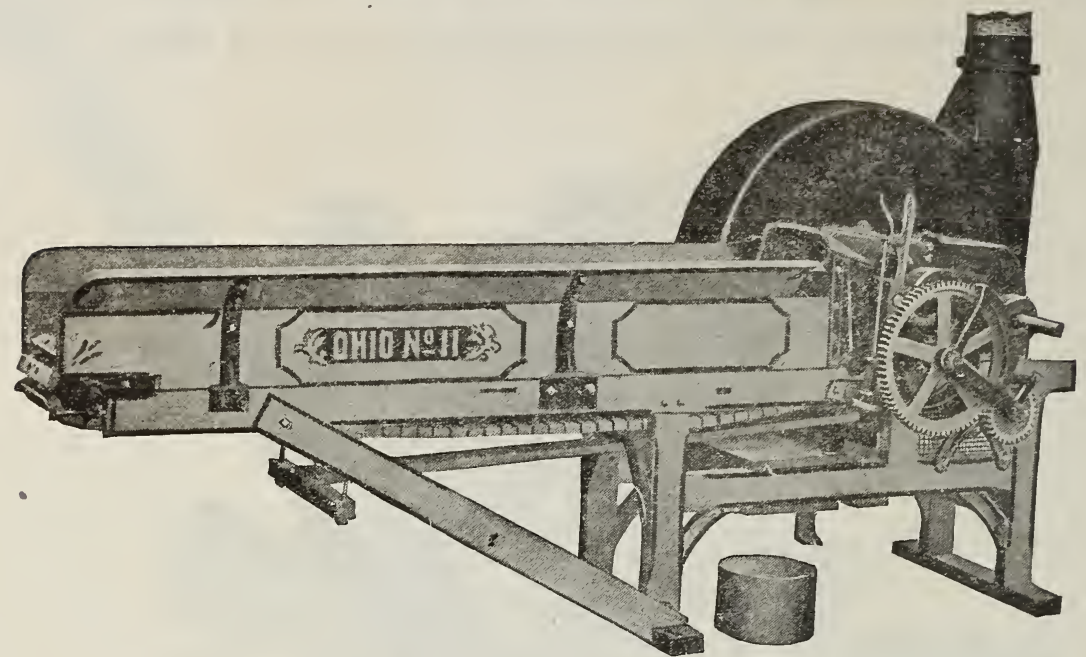

Fig. 803 , No. 11

THE ABOVE ILLUSTRATION shows our No. 11 Feed and Ensilage Cutter, equipped with Blower Elevator, and which can be furnished with either plain or traveling table.

ADAPTABILITY.-This Cutter has long been our most popular size for general farm use. It is adapted to cutting all kinds of dry feed as well as ensilage, is strongly and durably built, has large capacity and requires but moderate power to run.

DIRECT BLAST BLOWER. The fan wheel is heavy, and carries four blades or paddles. The paddles are securely riveted to an L-shaped steel flange, and are fitted over the outer edge of the fan wheel and down both sides in grooves provided, where they are securely bolted. This method makes it quite impossible for the blade to work loose in any direction whatever. The fan case is made of heary steel and is closely riveted.

PIPE AND PIPE CONNECTIONS. The pipe is $\tau$ inches in diameter and is made of galranized steel with standing seam on the outside, running lengthwise, being very rigid.

The No. 12 or Monarch Cutter is built along the same lines as the No. 11 herewith lescribed, with the exception that it is constructed on a much heavier plan and is intended for heavier work. The capacity is much larger and requires greater power to operate. The No. 12 Cutter is furnished with 10 inch pipe to meet the capacity instead of 7 inch as used with the No. 11.

\section{Capacity}

No. 11. Three to five tons of ensilage per hour.

No. 12. Eight to ten tons of ensilage per hour'.

\section{Power}

No. 11. Six to eight horse, gasoline.

No. 12. Eight to ten loise, gasoline.

\section{Speed}

750 to 800 revolutions per minute.

\section{SIZES AND LIST PRICES}

No. 11. Plain Table, with two 11 in. knives, cuts 1/2, 1. 11/2 and 2 inches $\$ 95.00$

No. 11. Self Feed, with two 11 in. knives, cuts $1 / 2,1,1 \frac{1}{2}$ and 2 inches

$\$ 120.00$

No. 12. Self Feed, with four 12 inch knives, euts $1 / 4,1 / 2,3 / 4$ and 1 inch $\$ 160.00$

The above prices are for machines complete with Blower and Distributor, but no pipe.

For No. 11 Blower 7 in. galvanized pipe in 4,6 and 10 foot lengths, per foot $.50 \mathrm{c}$

For No. 12 Blower 10 in. galvanized pipe in 4, 6 and 10 foot lengths, per foot $\quad .75 \mathrm{c}$

\section{Send for Complete Catalog and Special Net Prices.}




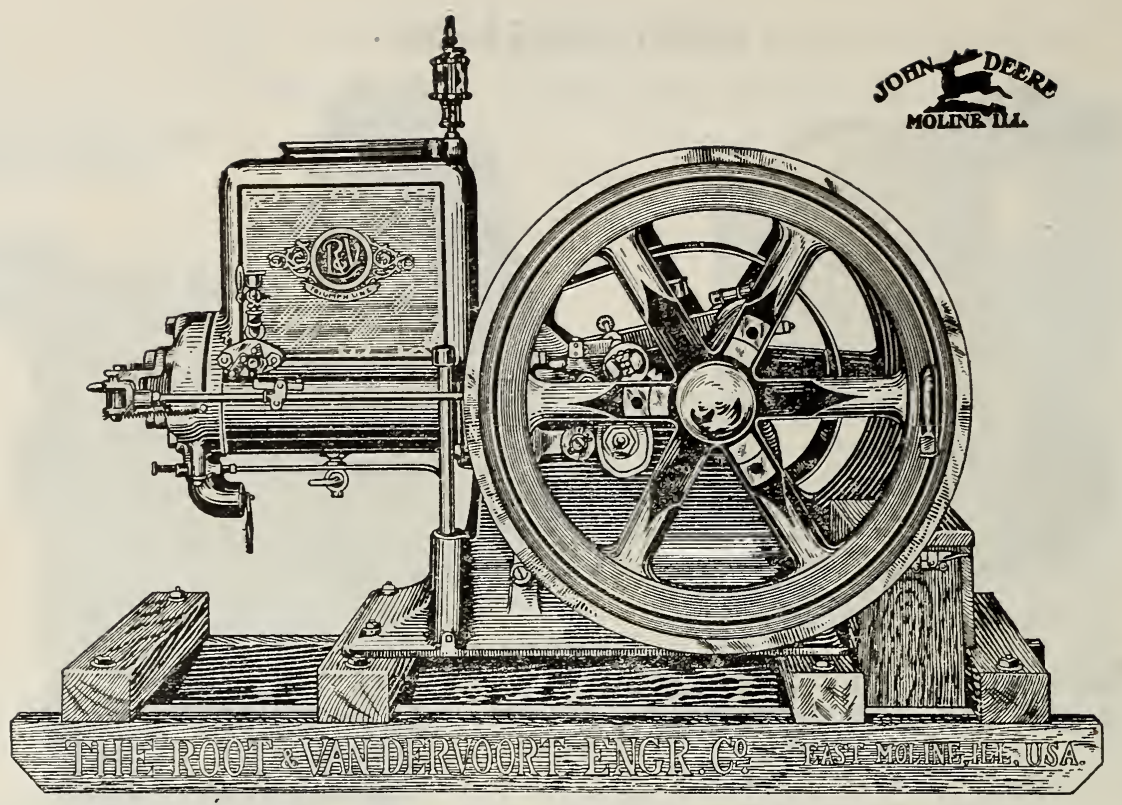

\section{THE R AND V TRIUIMPH GASOLINE ENGINE Hit-and-Miss Governing-Hopper Cooled}

\section{1, 2, 4, 6, 8, 10, 12 Horse Power.}

This type of engine has proven exceedingly practical for farm use. As a light dependable and economical source of power, its advantages and accessibility have made it one of the most popular of all the $R$ \& $V$ line. Some of the leading features are:

DESIGN. This engine is second to none in strength, symmetry and beauty of outline together with durability and smoothness in operation.

HOPPER COOLED. No tank, pump, piping or fittings required. Polar ice machine or artic oil may be used in place of water.

ACCESSORIES. These engines are equipped with the highest grade accessories that the market affords. Each engine has a Solid Cast Iron Gasoline Tank Sub-base, and is mounted on skids with battery box attached, containing five number six dry cells, high-grade spark coil with switch, wire, etc., muffler, sight feed cylinder lubricator, wrenches and oil can; also instruction for starting and taking care of engine.

PISTON. The piston on the 1 and $2 \mathrm{hp}$. is fitted with four, and larger sizes with five accurately-ground compression rings, one of which is placed over the Hardened and Ground Steel Piston Pin, thus avoiding any possibility of scoring the cylinder as a result of the pin becoming loose and working endwise.

CRANK SHAFT AND CONNECTING ROD are of liberal proportions and finished to standard size, the connecting rod being Ibeam in section, which is the strongest form in proportion to weight that can be made.

BEARINGS. Copper-hardened, genuine babbitt bushings die cast (Removable and Adjustable) are used on the crank pin and main bearings and are lubricated by means of hard oil cups. Adjustments to these bearings are made by removing Metal liners of varying thicknesses. An extra long hard bronze bushing is used on the piston end, and works on a Hardened Steel piston pin.

MIXING. The mixing valve or carburetor is of approved suction type and designed to deliver a good mixture under all conditions.

AIR THROTTLE. A damper attached to the mixer assures prompt starting of engine.

IGNITOR. (Make and break.) The same rod that opens and closes exhaust valve also trips the ignitor. This feature is very valuable, not only for its simplicity, but also from the fact that the ignitor is always inoperative when the engine is not taking an explosion, thus saving unnecessary wear on all these parts, and prolonging the life of the battery.

SPEED CONTROL. The speed of the engine can be increased or decreased at will by means of a knurled thumb serew on top of detent casting, permitting a variation of over fifty per cent in speed while engine is running.

\section{Send for Full Descriptive Catalog}




\section{"R. \& V.." VERTICAL AIR COOLED ENGINE}

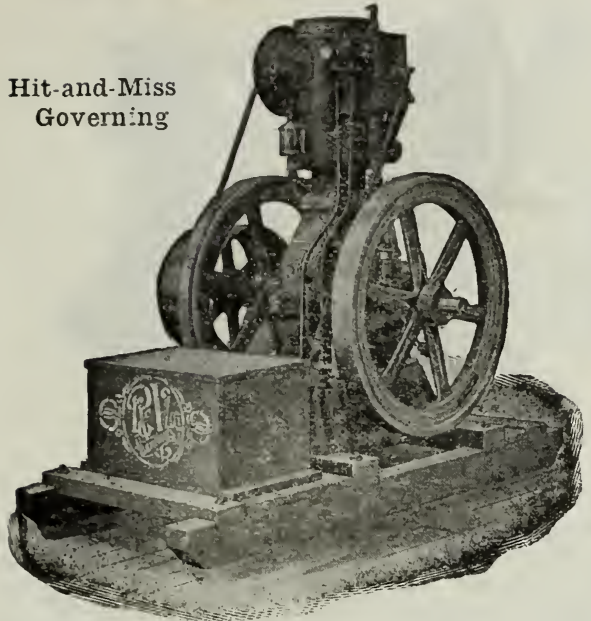

Description. This outfit, though similar in principle and general outline to our Standard Vertical Engines, requires no cooling system whatever. It is strictly air cooled, water tank, pipe connections, hose, etc., being entirely dispensed with.

Features. Compact, cylinder and cylinder head in one casting. No packing to blow out. Hinged crack case. Reducing gear, and all working parts enclosed. All bearings renewable and adjustable. Ball-bearing fan, reducing friction to the minimum, self-contained, gasoline supply in sub-base. Supplementary or double-ported exhaust, thus relieving and preserving the exhaust valve. No cooling tank. Light weight.

Equipment. Engine mounted on skids, with, battery box attached, containing four 31/4-inch $x$ 8-inch dry cells; high tension spark coil with switch and wiring; two spark plugs; monkey wrench; two connecting rod wrenches, spanner wrench; oil can and muffler, besides instruction book for setting up, starting, and general care of engine.

Made in four horse power size.

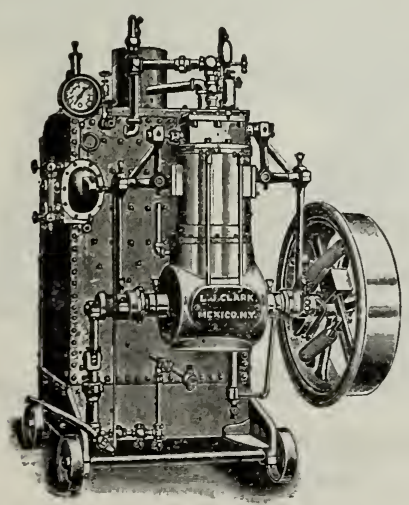

\section{"R. \& V." VERTICAL SCREEN COOLED ENGINE}

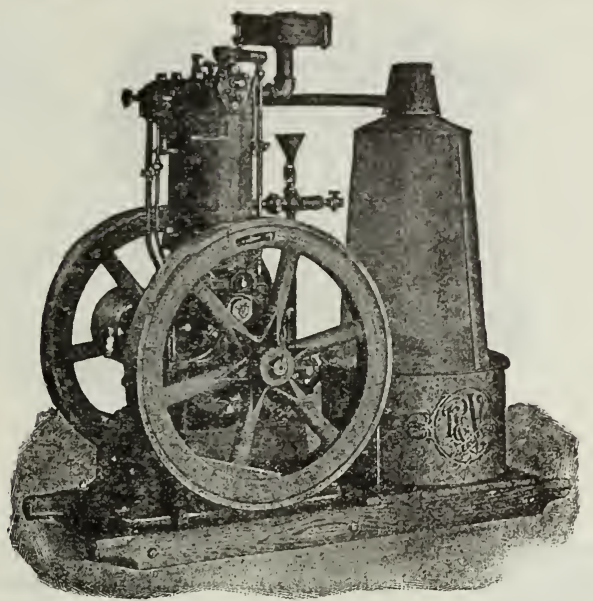

Description.-The $R$ and $V$ Vertical Engine, illustrated above, is hit-and-miss governed, and has make-and-break ignition; is very simple in design, and by being mounted, completely on the same skids, is handy for transportation.

Features. The governor is of the centrifugal type, attached to the balance wheel, forming a very simple adjustment which admits of close regulation; connecting rod of the most approved design with copper-hardened genuine Babbitt bushings in the crank end, and extra long phosphor-bronze bushing on the piston end. The piston is unusually long fitted with accurately ground compression rings, the rear one of which passes over the ends of the wrist pin, thereby preventing the possibility of its working endways and scoring the cylinder. The gasoline is carried in the cast sub-base, providing a perfectly safe receptacle doing away with separate tanks.

Comes fully equipped with batteries, spark coil, and all necessary tools. Made in three horse power size, only.

Write for special circulars and prices.

\section{THE SAFETY BOILER AND ENGINE}

Perfectly safe, automatic governor, automatic water feed, automatic draught. Built on scientific principles of the very best material obtainable; all boilers tested to 240 pounds per square inch; will burn anything from the accumulation of refuse wood about the farm to the finest steam coal. Guaranteed to furnish any given horse power with one-half the fuel required with any other make of boiler.

One small armful of wood will raise 80 pounds steam in ten minutes from cold water. Write for Special Prices 


\section{IMPROVED WOOD AND POLE SAW FRAMES}

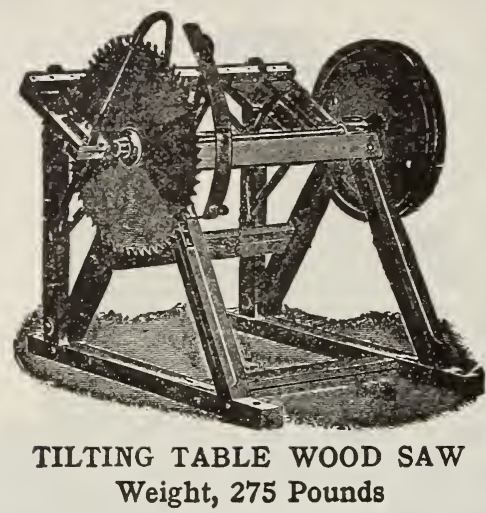

Illustrations show our various styles of Wood and Pole Saw Frames. These are substantial machines, well made and of good materials throughout. Wood saw frames have the balance wheel on the saw arbor, and are intended for sawing cord wood. Pole saw frames have the balance wheel on a separate frame below the table, so that they can be used for sawing long poles as well as cord wood. We make both styles of these machines with either tilting or sliding table.

The tilting table is pivoted so that it balances perfectly and is easy to handle. The sliding table is fitted with grooved rollers. which run on a " $V$ "-shaped track, and is very easy to operate. The arbors are true and heavy. They run in long, babbitted bearings, and are fitted with a 95-pound balance wheel. On pole saw frames the connection between the two arbors is made by running belt over idler pulley.

Note. All our Wood and Pole Saw Frames are made right hand, unless otherwise ordered.

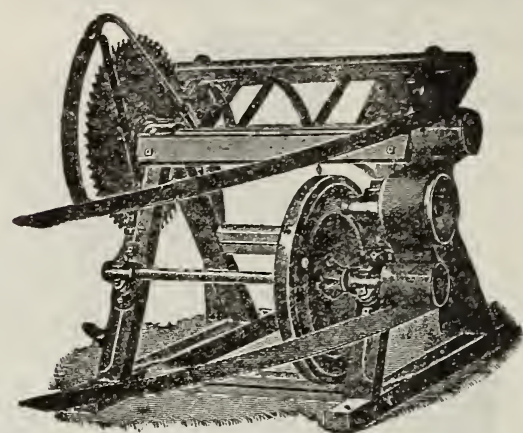

TILTING TABLE POLE SAW Weight, 350 Pounds

Weights shown above are for machines without saw blades. Saw blades weigh about as follows: 20-inch, 8 pounds; 22-inch, 10 pounds; 24-inch, 14 pounds; 26-inch, 17 pounds; 28-inch, 20 pounds; 30-inch, 24 pounds.

Prices of Tables without Saws

Tilting Table Wood Saw.......... Tilting Table Pole Saw.............

Sliding Table Wood Saw...........

Sliding Table Pole Saw.............

7-foot Swing Table Pole Saw Frame. Iron parts only for Tilting Table

Wood Saw Frame............

\section{Simonds' Celebrated Circular Saws}

24-inch, set and sharpened........

PRICE

28-inch, set and sharpened.............

30 -inch, set and sharpened. ........

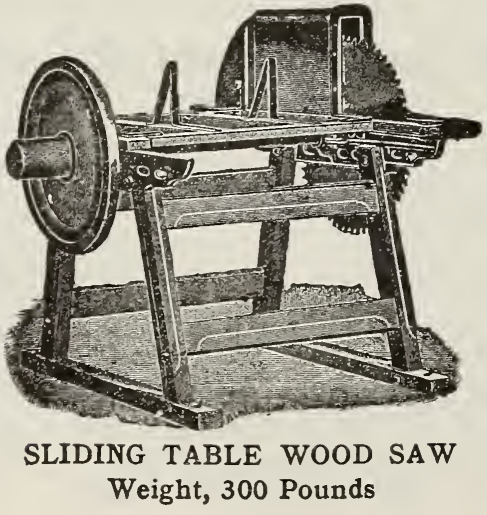

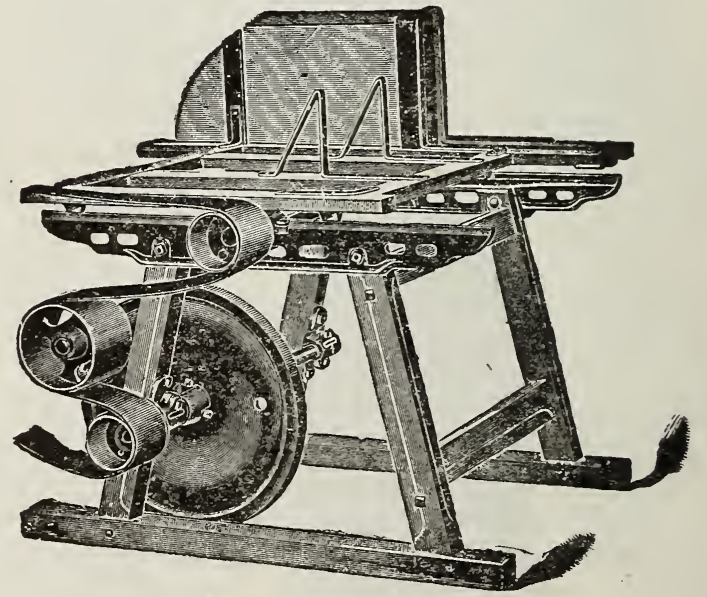

SLIDING TABLE POLE SAW

Weight, 380 Pounds 


\section{THE DAIN PERFECTION MOTOR PRESS}

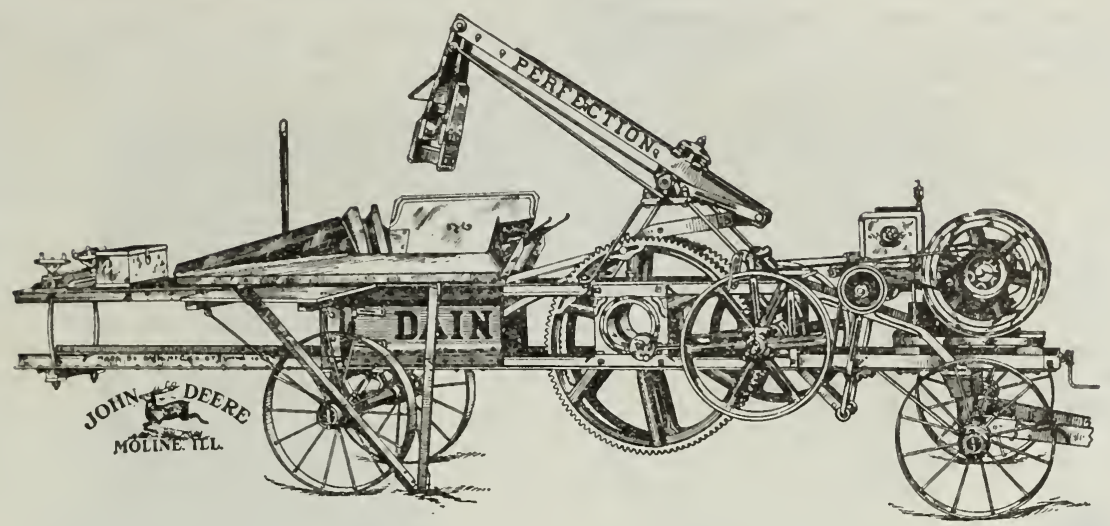

In the new motor press illustrated above, we are able to offer to onr customers a machine that is of greatly simplified construetion, has a large baling eapacity, and can be operated by an engine of moderate power. $B y$ the use of eccentric gears to trive the pinnoer there is obtained nearly 7.5 percent gain in leverage, which enables the same amount of work to be done with this press with a greatly reduced power. Much presstre is also saved for the reason that only alout one-half the gearing that will be fom (m) other presses is msed.

Another valuable feature is that it is driven with a louble belt drive from both sides of the engine; this being an allvantage to the working of the engine as well as transmitting the maximm amomut of power.

This juess is equipled with a positive working self feeder which is so timed that the best results will be obtained.

The frame is made of ligh grade steel angles liberally braced and trussed, furnishing rery sitong construction.

lie furmish these with 1 (ix) 15 or $18 \times 22$ hale chambers and mounted complete witl trucks.

If desired, we will equip the ontfit with $t$ or 6 horse power engine all ready for operation.

This machine is certainly very far steplued in alvance of any other press constructed on the market at the present time.

\section{Special Circulars and Prices Gladly Mailed on Application}

\section{NO. 100 STEEL FARM TRUCK}

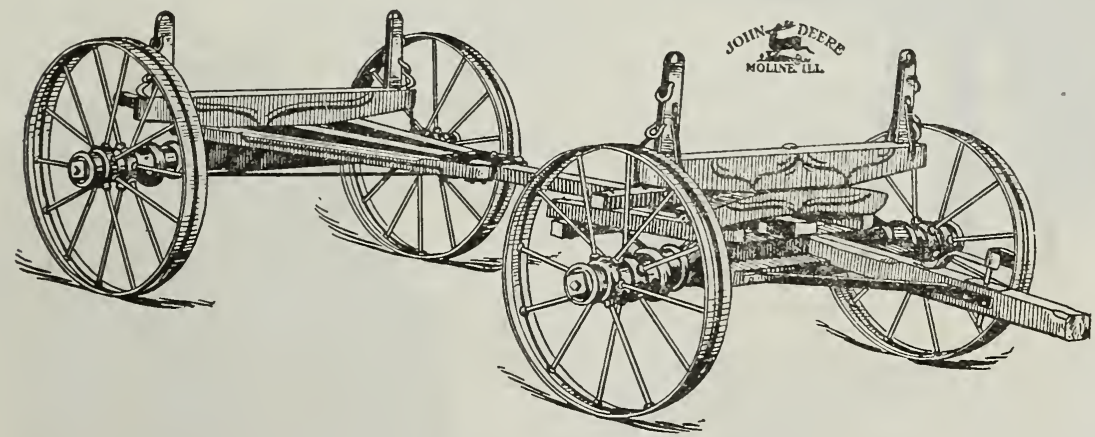

The above cut represents one style in our low-lown farm gear. These are especially desirable where one desires a medium priced truck which is both light and strong, and well fitted for common farm purposes. Un- excelled for use in mounting spraying rigs, saw outfits, engines, etc. We can furnish these fitted with either wood or steel wheels, and they are commonly equiped with $3 \frac{1}{4} \times 10$ inch skeins and 4 inch tires. 


\section{THE FREEMAN STEEL WINDMILL}

Have you ever seen a better windmill? The rreeman, without a doubt, is the strongest and most durable windmill made. Its simplicity of construction commends it to all buyers. Every detail part is made the best the manufacturers know how, making a faultless combination which cannot be equaled. A windmill that will do more work, stand harder service, require less repairs and will give you better satisfaction than any other mill on the market. If it doesn't we will right the wrong. Isn't such a guarantee as this, backed up by $\mathbf{S}$. Freeman \& Sons Manufacturing Company, strong enough to interest you in our windmill?

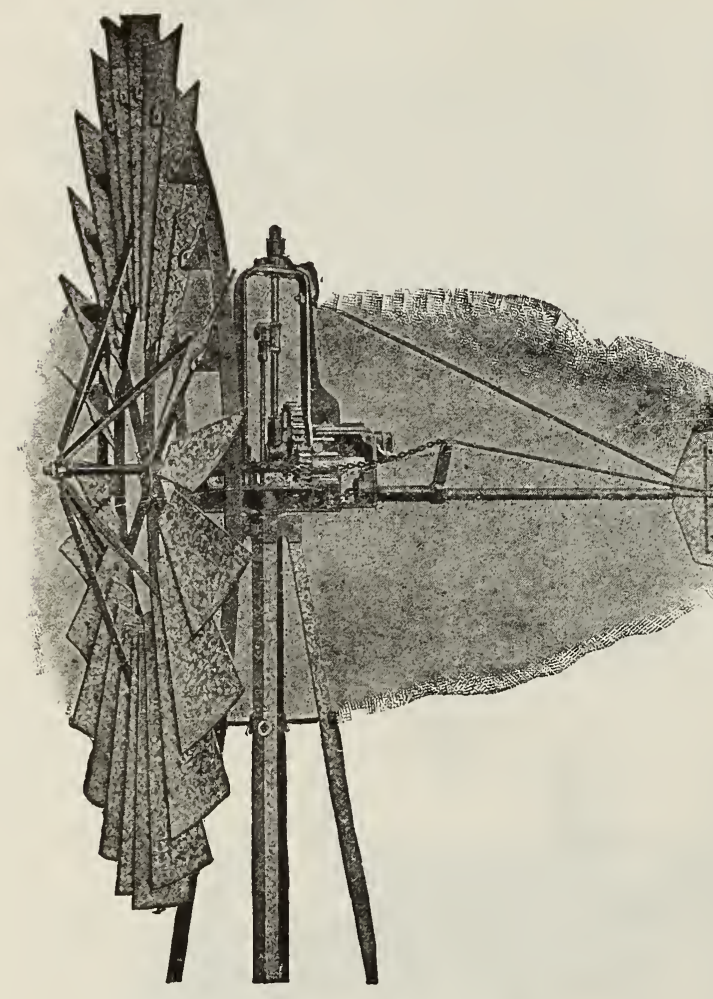

Fig. 6 illustrates the lower ten feet of our 30 -foot, four-post angle steel tower. This illustration shows the thoroughness of the bracing employed in the construction of all our towers.

\section{ESTIMATES}

We will be pleased to estimate cost of water supply where windmills, towers, substructures, pumps and wood or pneumatic tanks are used.

Write for special catalogues and prices.
The illustration, Fig. 5, shows the engine head of our 8-foot pumping windmill. 11 a call particular attention to the distance fruil out to out of the main shaft bearings. This serves a double purpose of making the mill run easier, and because properly balanced, it will turn more promptly in shifting winds.

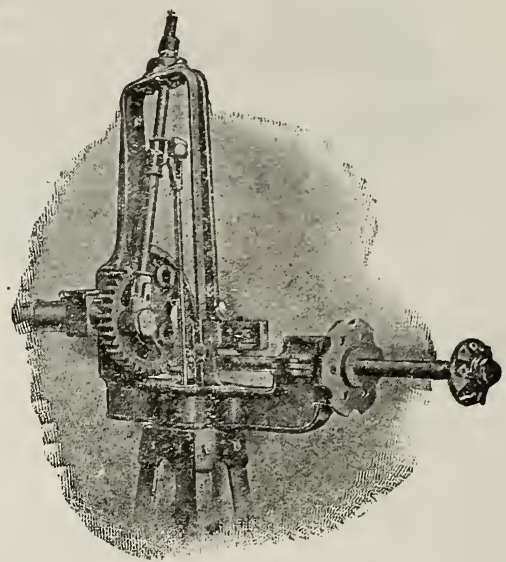

Fig. 5

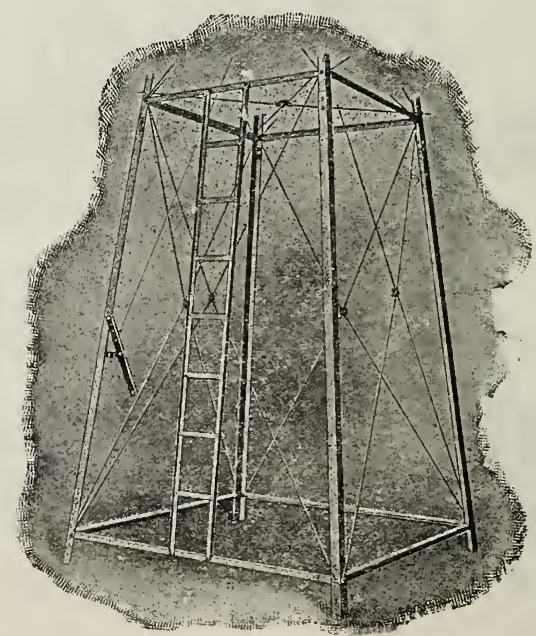

Fig. 6 


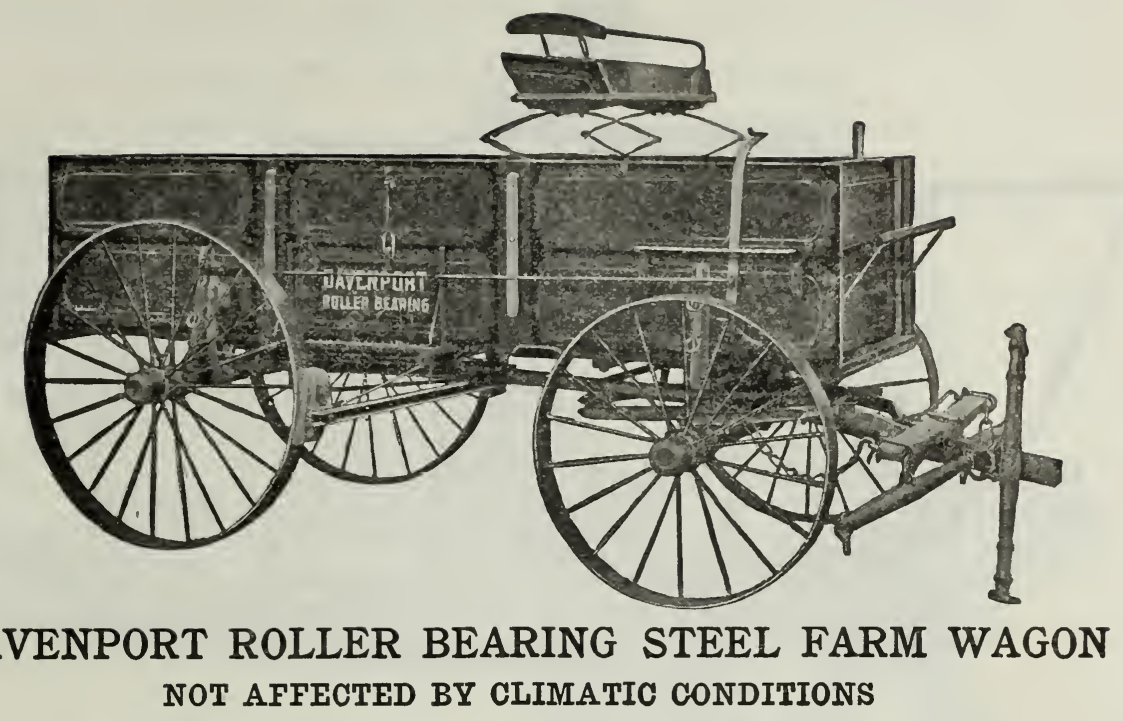

\section{Roller Bearings}

Reduce draft thirty to fifty per cent. This means a farmer can do more work in a given time and keep his horses in better condition than is possible with a wagon that pulls harder.

\section{Steel Gears}

Built like a bridge. Made of I-beams, angles and channels. Strongest forms into which steel is rolled. No sheet metal used in this construction. All parts hot riveted, which means rivets completely fill holes, making absolutely solid joints. Nothing to shake loose, rattle, dry out or rot.

\section{Steel Wheels}

Stand straight, run with tire flat on the ground. No dish to wheel. No pitch or gather to axle. This means no side strain on wheel or uneven binding on spindle. These wheels are guaranteed to give absolute satisfaction under all the varying conditions a wheel meets with in service.

\section{Enclosed and Protected Bearings}

The Roller Bearing is effectively enclosed like the high-grade automobile bearing. Mud, sand and water proof. The only enclosed and protected bearing on the market.

\section{Automatically Closing Oil Cup}

You only oil every three or four weeks-using ordinary machine oil in small quantity. Do not have to take wheel off. Makes no difference whether wagon is empty or loaded you can oil just the same.

\section{Linch Pin}

The Davenport wheel is held on with a linch pin. No nut to run off and let you down.

\section{Life and Durability}

The DAVENPORT being almost entirely a steel wagon, solidly riveted together-not bolted means that it is not affected by hot, cold, dry or wet weather. No trouble from drying out or rotting.

\section{Distinctive Features of Merit}

The above are only a few of the important features to be found on the DAVENPORT - many other points of distinction are described in the DAVENPORT catalogue.

\section{Guarantee}

The DAVENPORT is strongly guaranteed regarding all the claims made for it.

\section{Capacity and Weights}

Narrow Track, with Regular Wheels, 40-inch, 48-inch in Diameter

\begin{tabular}{|c|c|c|c|}
\hline $\begin{array}{c}\text { All Wagons 5,000 Pounds } \\
\text { Capacity }\end{array}$ & $\begin{array}{c}\text { Tire 13/4" } \\
\text { Heavy } \\
\text { Channel } \\
\end{array}$ & $\begin{array}{c}\text { Tire } \\
3 \times 9 / 16 \\
\end{array}$ & $\begin{array}{l}\text { Tire } \\
4 \times 1 / 2 "\end{array}$ \\
\hline $\begin{array}{l}\text { Wagon Complete, 26-in. Double } \\
\text { Box, Seat, Doubletree, Sin- } \\
\text { gletrees, Neckyoke............ }\end{array}$ & $\begin{array}{l}\text { Lbs. } \\
1140\end{array}$ & $\begin{array}{l}\text { Lbs. } \\
1210\end{array}$ & $\begin{array}{l}\text { Lbs. } \\
1260\end{array}$ \\
\hline $\begin{array}{l}\text { Running Gear Complete, with- } \\
\text { out Brake. }\end{array}$ & 770 & 810 & 890 \\
\hline
\end{tabular}

Brake Parts Complete, 65 lbs.; 10 " Tiptops, 75 lbs.

Wide Track Wagons, 20 lbs. more; Wide Track Gears, 10 lbs. more.

With Low Wheels, 36 in.-44 in. Diameter, $3 \times 9 / 1 \beta^{\prime \prime}$ or $4 \times 36$ " Tires, $40 \mathrm{lbs}$. less.

Semi-stiff or Slip Tongues furnished when ordered.

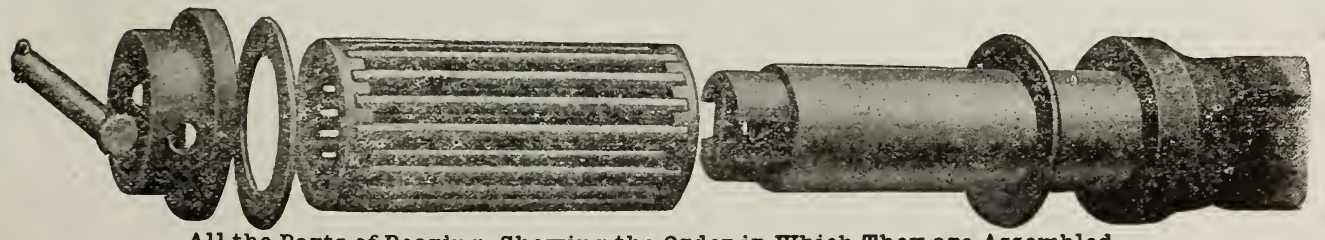

All the Parts of Bearing, Showing the Order in Which They are Assembled. 


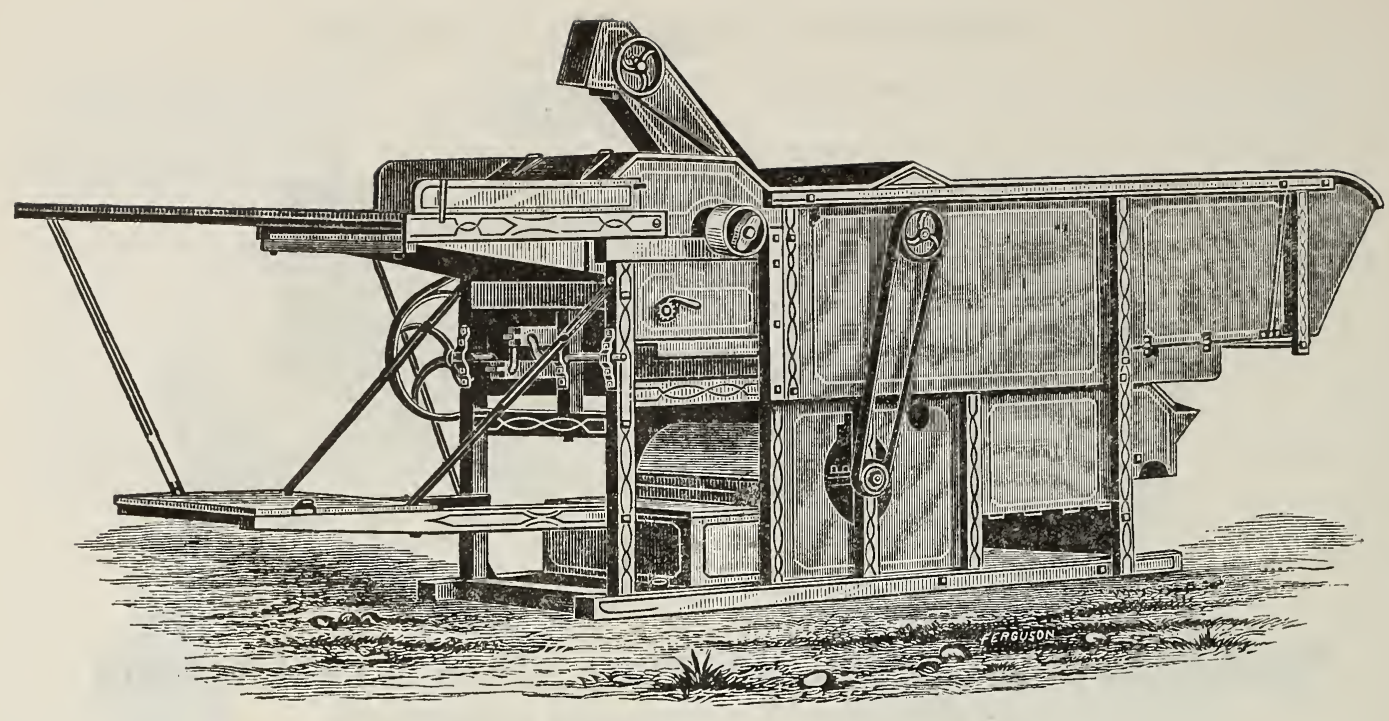

\section{CAMPBELL THRESHERS}

Campbell Threshers have been on the narket for forty years and are no experiment.

The frames are made of maple and ash, well proportioned, securely bolted and braced.

The cylinder is a bar or open cylinder, with shaft, made of cold rolled steel running in good wide boxes, babbitted top and bottom. These boxes are supplied with compression grease cups which keep out the dirt, in fact all of the principal bearings are supplied with these cups.

The construction of the Tooth Bars is hridge angle steel backed up by wood bars, which make a cushion for the teeth when coming in contact with stones or other hard substances and prevents them from breaking, also keeps the nuts from jarring off.

Furnished with stackers, elevators and baggers at extra cost.
Can furnish these machines with 26-30 or 36-in. cylinder and guarantee them to equal or exceed capacity of any machine made of the same size cylinder.

Our small Thresher No. $1 \frac{1}{2}$ has a cylinder 26 inches long, 14 inches diameter, with cylinder shaft $1 \frac{1 / s}{\mathrm{inches}}$

Length of Separator, 81/2 feet.

Width of Separator 36 inches.

Length of chaffing sieves, 48 inches.

Length of recleaning sieves, 36 inches.

Wiath of sieves, 32 inches.

Number of sieres, 8 .

Power required, 4 to 6 Ilorse Power.

(apacity guaranteed one bushel per minute under favorable conditions.

Furnished Mounted or Unmounted.

Larger sizes built in proportion.

\section{Write for Catalog and Prices}




\section{THE NEW MODEL SIMPLEX CREAM SEPARATOR Self-balancing Bowl, Link Blade Device}

\section{A DAIRY NECESSITY}

The most suceessful dairyman is the one who produces the greatest amount of dairy prodncts in proportion to the cost. This cannot be done withont the use of a good cream separator. Every farmer, who keeps even a few cows should have one, because it will save him money and relieve him of much drudgery.

\section{OLD METHODS WASTEFUL}

The old methods of handling milk are wasteful in that much of the butter fat is lost. A separator saves this loss because it skims the milk clean, getting all the butter fat which can be made into butter at home, or delivered to the creamery much more easi. Ir than the whole milk.

The Improved Simplex Separator should appeal to every intelligent and discriminating dairyman or farmer for the following reasons:

1. It is the most efficient and gets all of the fat that can be obtained from the milk by any process.

2. It is self-balancing, and will not give trouble as other machines do.

3. It is the lightest running, and can be operated by any member of the family

4. It is the simplest machine, having the fewest parts.

5. It can skim cold or warm milk, and will not clog up.
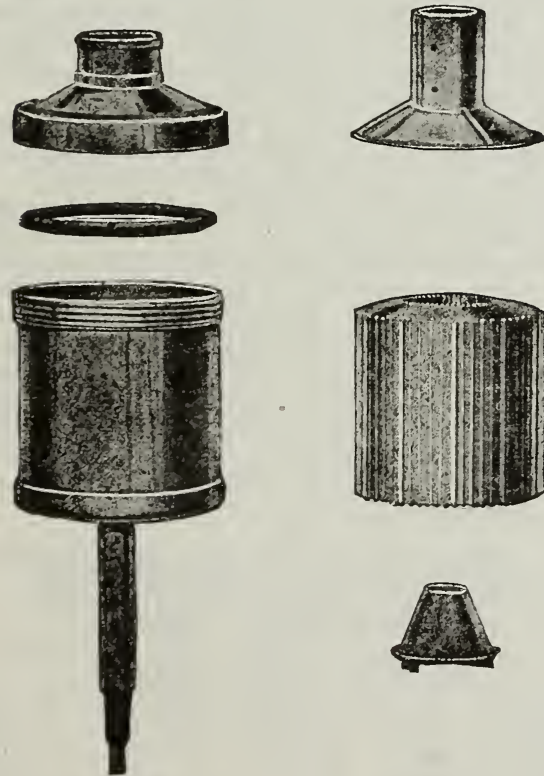

The LINK-BLADE Bowl complete. This bowl, 900 lbs. capacity, is only $4 \frac{1}{2}$ " diameter, 5" deep, and runs at only 7700 R. P. M.

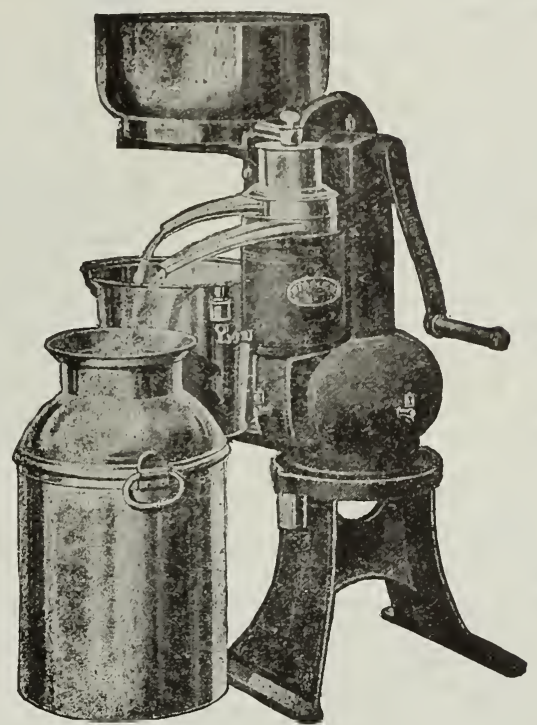

Note the heary, compact construction and convenient height of supply-can and discharge spouts. The top of the supply-can is only $3 \frac{1}{2} \mathrm{ft}$. from the floor.

Some advantages of the Link Blades are as follows:

1. Increased capacity of from 30 to 50 per cent over the most efficient of previous devices, combined with very clean skimming under a wide range of conditions as to milk, temperature, etc.

2. Great convenience in cleaning and handling, because the blades do not come apart, and do not have to be reassembled in any particular order.

3. The device being expansible and fitting the bowl snugly, it can never become loose, or shift in the bowl, and throw the same out of balance.

4. The pressure being transmitted through a series of brass rivets, there is no sirain on the blades themselves, and there is no rusting formed by the points of contact of the rivets.

5. The device being much more efficient is a great deal lighter and smaller in order to do the same amount of work, making it still easier to handle, and requires less power to run than ther devices of same capacity.

5. Th jear and tear on the bearings, gearing, eve., is, in the long run, much less with the Self-Balancing "Simplex', because most of the wear in the other machines comes from the rough running of the bowl, which multiplies the friction and causes the machines to run harder and bring increased wear on every running part. 


\section{NEW IMPROVED SIMPLEX}

A Few of the Special Features on the Simplex.

The most striking feature of the new "Simplex" is its light running. The 1100lb size, when at speed and skimming milk, take no more power than the ordinary $500-1 b$. Hand Separator of other makes. It opens up a distinctively new field for the large Hand Separator.

To obtain these remarkably light running qualities, a higher grade and type of bearings than has ever been used before in the Cream Separators, as well as a higher and more improved types of gearings had to be adopted. The principal bearings used in the new "Simplex," those carrying the weight of the bowl and gearing, are imported annular ball bearings of exactly the same kind that are used in the highest class of Automobiles-the most accurate, the lightest running and the most durable ball bearings known. In the "Simplex' these bearings carry less than onetenth of the load they are intended to carry, so that their life, with proper care, is practically unlimited.

The gearing contains as few parts as it is possible to use in a Separator. The bevel driving gears have planed teeth, three times more expensive but far more satisfactory than cut teeth used in cheap-grade machines. The bevel pinion is of steel. The spur pinion at the end of the bowl-spindle is made of Vanadium or Nickel steel, the first time that these wonderful alloy steels have been used in Cream Separator work.

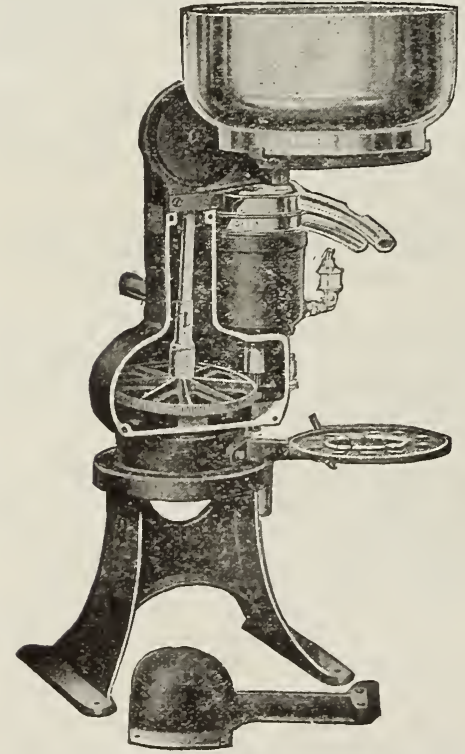

Showing accessibility of gearing. lower bearings.

\section{SEPARATOR-(Continued)}

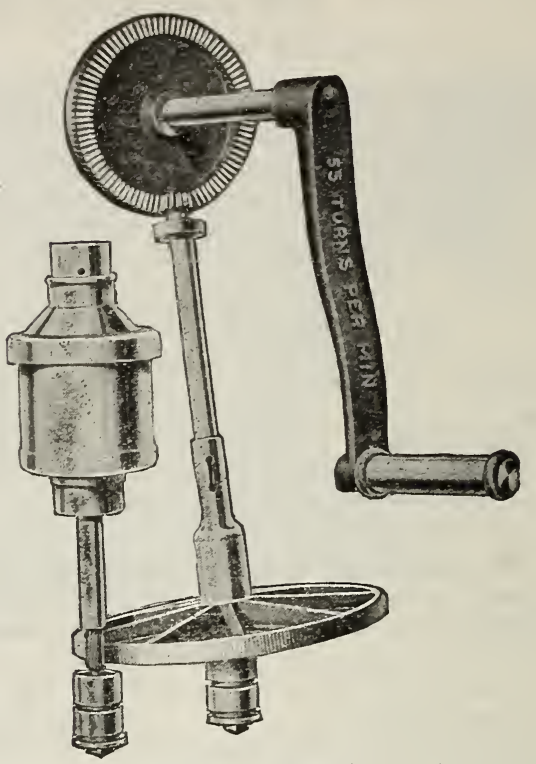

Showing extreme simplicity of driving gears-one pair bevel gears, one pair spur gears. Showing also the inclinded intermediate shaft, a new and exclusive "Simplex" feature.

All shafts, even to the crank-shaft, are ground to size, and the crank-shaft runs in bronze bushings. The whole design and construction of the "Simplex" is of a higher and more expensive type than has ever been attempted either here or abroad.

The clutch is the one-piece automatic safety clutch that has been so successfully used on the previous "Simplex" Models.

The vast sum spent in advertising other machines has been put into the construction of the "Simplex," producing a new and higher type of machine and setting an entirely new standard in the Cream Separator construction. The "Simplex" is a machine that the dairyman can buy as his last Separator. It will appeal especially to those who have been users of other makes. It will last for years and, owing to its improved system of bearings, stay in balance and always run at maximum efficiency.

Specifications of "SIMPLEX" LINKBLADE CREAM SEPARATORS.

\begin{tabular}{|c|c|c|c|c|c|}
\hline No & $\begin{array}{c}\text { Dairy Sizes } \\
\text { Style }\end{array}$ & $\begin{array}{c}\text { Guaranteed } \\
\text { Capacity } \\
\text { Per Hour }\end{array}$ & $\begin{array}{c}\text { Diam. } \\
\text { of } \\
\text { Bowl }\end{array}$ & $\begin{array}{l}\text { Depth } \\
\text { of } \\
\text { Bowl }\end{array}$ & Price \\
\hline & Hand Po & 500 & 4 in. & $33 / 4$ in. & 5.00 \\
\hline & Hand Por & -00 & $41 / 2$ in & $41 / 2$ in. & 80.00 \\
\hline & Hand Pov & 900 & $41 / 2$ in. & in. & 90.00 \\
\hline & Hand Power & 1100 & in. & $51 / 2$ in. & 100.00 \\
\hline
\end{tabular}

Send for handsome booklet. 


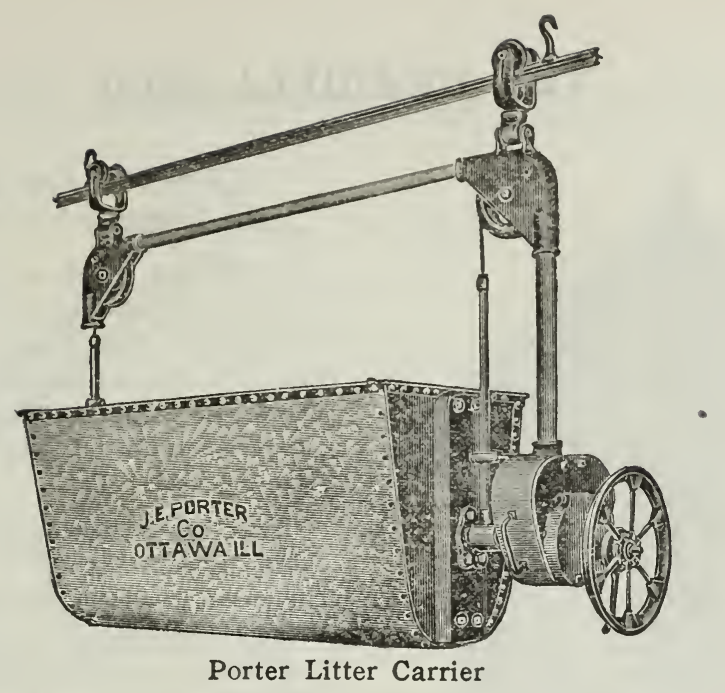

\section{PORTER LITTER CARRIER A HIGH GRADE MACHINE}

The Porter Litter Carrier shown above is a high-class machine, built for heavy service. The tub is four feet long and two feet wide, with a capacity of $12 \mathrm{r} / 2$ cubic feet, or 800 pounds of wet manure. It is built of heavy, galvanized steel, reinforced with rolled steel angle one inch wide all around the top and along the end seams. Rivets are spaced only two inches apart, and all joints are soldered inside, giving a construction far superior to any other. The ends are stiffened with heavy hardwood battens, which carry the trunnions by which the tub is hung.

The hoisting device is of simple construction, consisting of spur gears and pinions, which multiply the power eighteen times. The wire cables run entirely within the pipe frame, and each winds on its own drum in the gear box. The hand wheel is fifteen inches in diameter. The brake, consisting of one piece, locks the hand wheel, and holds the tub at any desired height. An exclusive feature of the Porter carrier is that the tub is kept from swinging, either in raised or lowered position.

The tub capsizes of its own accord by the tripping of a latch. The trunnions by which the tub is hung are below the center, so that when the latch is tripped the tub is turned completely over.

The frame is rigidly constructed of pipe and malleable iron. It hangs from two pairs of roller-bearing wheels with swiveling trucks, which enable it to go around the sharpest curve. The trucks are pivoted to permit lateral swing, a feature which promotes easy running. The pipe frame encloses and protects the hoisting cables from moisture and dirt.

\section{PORTER ADJUSTABLE}

\section{BARN DOOR HANGER}

This is something decidedly new in ths way of an adjustable door hanger. It possesses a number of very excellent points of construction, which are worthy of notice if you desire to have the best.

Price per pair, $\$ 1.00$

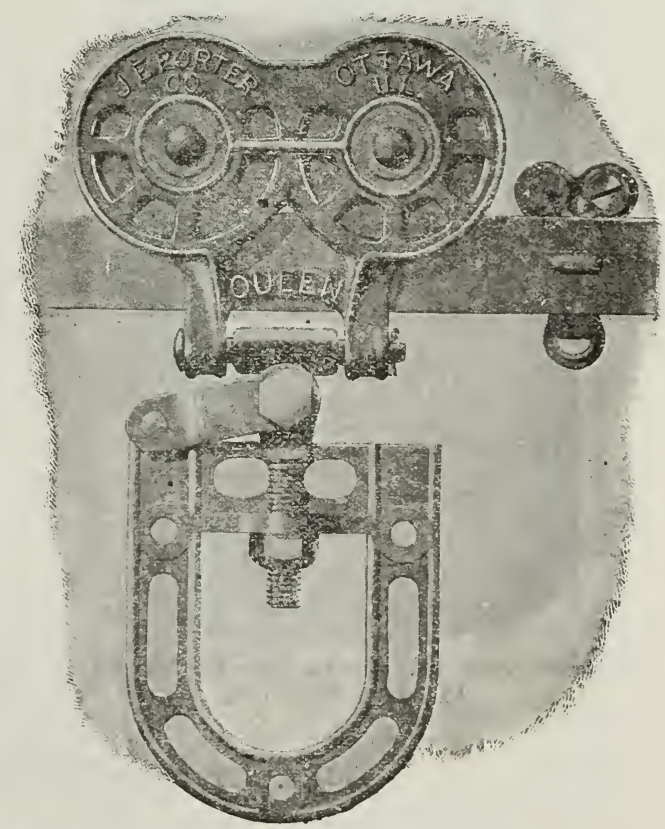




\section{THE UNADILLA SILO}

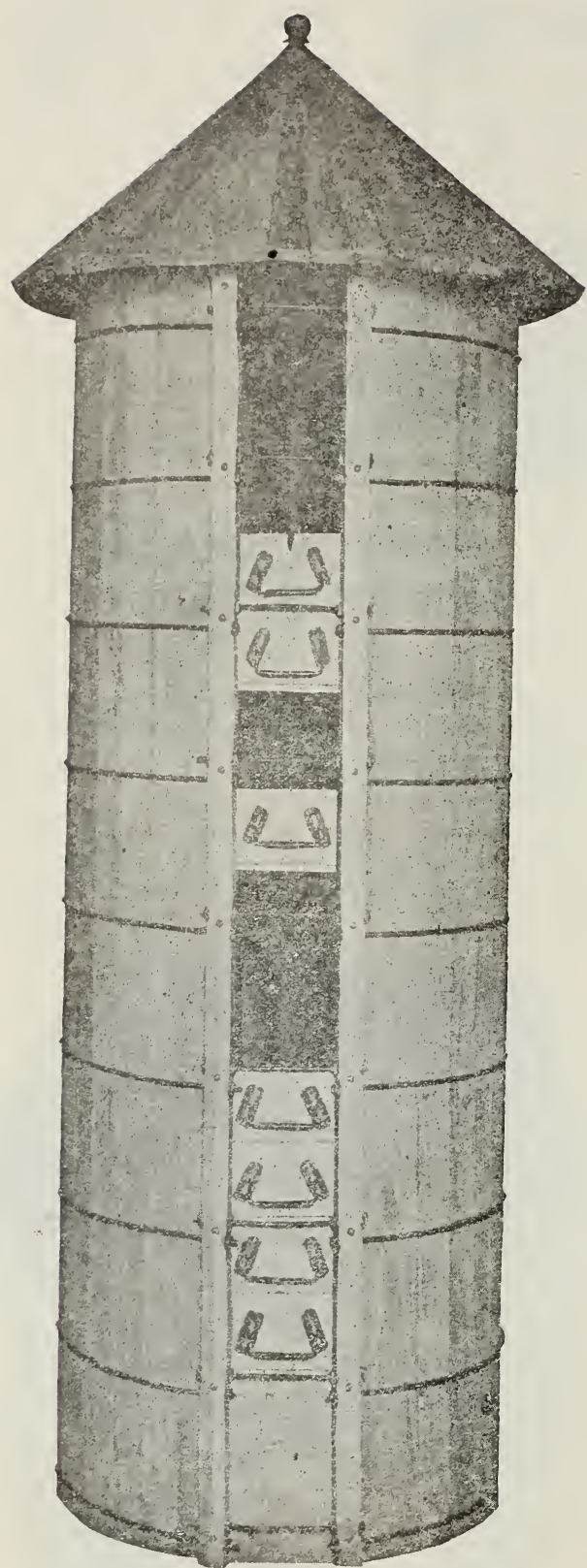

Note that the Doors Can Be Placed in Any Position.

\section{A Few of the Reasons Why This Silo Is Superior to Other Makes}

It has an unobstructed continuous door front, which allows you to shove the ensilage out instead of pitching it up three to six feet and over across bars separating doors. When doors are placed at intervals one is not able to slide the door up, but has to push it back into the silo.

The sides of the door opening being adjustable, on account of the short hoops across the front, gives the owner of the UNADILLA SILO the advantage of merely tightening or loosening a few nuts to adjust the front, rather than being obliged to re-fit the doors.

The UNADILLA SILO doors can be shoved up and left in the opening, thereby keeping out the snow, rain, wind and sun, which would be injurious to the ensilage, as well as shrinking and decaying the lumber in the silo.

The doors, as well as the frame, are put over a jointer after being built, thus assuring a tight fitting joint.

Our doors do not warp out of shape for they are made of two thicknesses of matched lumber laid cross-wise and nailed firmly together, with the grain in opposite directions.

To put our doors in place and fasten or remove them engages but one hand, while the other is used to hold onto the ladder formed by the fastener. Our lugs and door fasteners are made of malleable iron, not the ordinary grey iron that is commonly used. The malleable iron will bend instead of break, and when it receives a sudden blow, does not crack and break as the grey iron.

On account of the peculiar construction and combination of our door front with the short bar across the door, combined with the patent lug at the side of the doorway, we are enabled to tighten every hoop on the silo twelve inches while standing on the ladder formed by our fastener.

Made of Spruce, Yellow Pine, White Pine and Cypress.

\section{Send for Special Booklet and Prices}




\title{
GARDEN CULTIVATORS AND SEEDERS
}

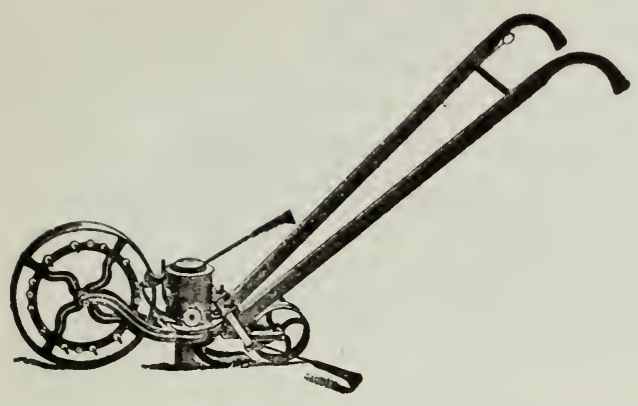

\author{
MATTHEWS NEW UNIVERSAL \\ GARDEN DRHL
}

No. 17

This drill is ackmowledged hy all seedsmen and gardeners to lie one of the leading and most reliable seeders made. Will plant accurately all kiuds of garden seeds. ilas patent Indicator for regulating the dropleng of the seed. Net Price. . . . . $\$ 7.50$

\section{MATTHEWS NEW UNIVERSAL HILL AND DRILL SEEDER}

No. 16

This Seeder is identical with tise iio. I Drill with the exception that it has pins ou the wheel which converts it at will into a
Hill Seeter dropping distances of $4,6,8,12$, 16,24 and $\frac{1}{4} 8$ inches apart. Net Price $\$ 8.25$

\section{MATTHEWS NEW UNIVERSAL COMBINATION HILL AND DRILL SEEDER, CULTIVATOR PLOW, RAKE AND MARKER}

No. 22

In this Implement we present a combination of the No. $16 \mathrm{Hill}$ and Drill Seeder illustrated above and No. 26 High Arch Expansion Double Wheel IIoe illustrated on the follow. ing page. This combination gives the user a One Wheel Seeder and a Singe or Double Wheel Cultivator. Very easily changed from
Seeder to Cultivator by removal of two bolts. We furnish with this the following attachments: 1 Pair s-inch Hoes, 1 pair Narrow ('ultivator Teeth, 1 pair Wide Cultivator Teeth, 1 ('enter Cultivator Tooth, 1 pair Plows, 1 pair Rakes and 1 pair Vine Guards. Net Price

\section{MATTHEWS NEW UNIVERSAL CONSTELLATION SEEDER, HOE, CULTIVATOR, PLOW, RAKE MIARKER}

No. 119

The illustration shows the complete implement with all attachments furnished. In the Constellation is represented a brilliant assemblage of the New Universal Garden Drill and the New Universal Wheel Hoe, Cultivator, Rake and Plow, for use either as a one-wheel or two-wheel Seeder, Hoc. Rake, Cultivator, Plow, Marker. Six implements in one. Each implement is entirely separate from the other and the only parts used in each, the wheels and handles, are changed from one frame to the other by only two bolts. Cultivating attachments are shown detached. They consist of 1 Cultivator Frame, 1 pair Hoes, 1 Pair Plows, 1 Pair Rakes, 1 Pair Narrow Cultivatur Teeth, 1 Pair Wide Cultivator Teeth, 1 Center Cutlivator Tooth, 1 Pair Markers.

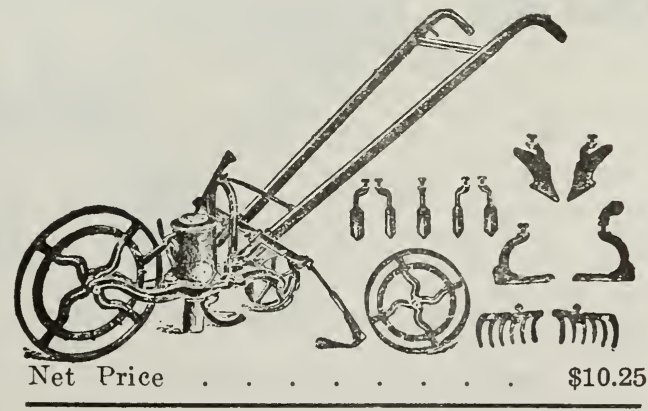

Our High grade garden Seeds should be used with the above seeders. 


\section{GARDEN CULTIVATORS AND SEEDERS \\ NEW UNIVERSAL DOUBLE WHEEL HOE, CULTIVATOR, PLOW AND RAKE \\ No. 14}

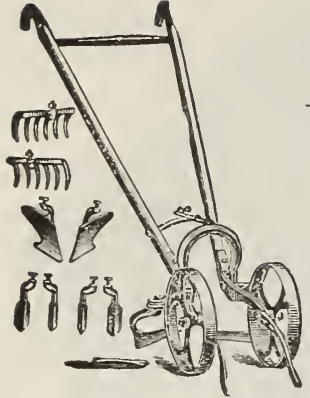

NEW UNIVERSAL HIGH
The special design of a Donble Wheel Hoe is the working of both sides of the row at one passing, but it may also be used as a between rows eultivator.
The Adjustable Arch not only forms a means of gauging the depth of the work to be performed, but by an ingenious derice enables the teeth to be pitched at any angle desired. Attachments furnished with No. 14 are one pair each of Hoes, Plows, Rakes, Narrow Cultivators, Wide ('ultivator's, Vine Guards.

Net Price, $\$ 6.00$

\section{ARCH EXPANSION WHEEL HOE, CULTIVATOR, RAKE AND PLOW}

No. 26

The wheels are $12 \mathrm{in.}$ in diameter, and the Arch high enough to cultivate over plants 20 inches or more in height. Our Double Wheel Hoe already meets all requirements but we present here, if possible, a more complete implement of larger size. Attachments with this Hoe as follows: One pair each, Long Bladed Hoes, Short Bladed Hoes, Narrow Cultivators, Wide Cultivators, Plows, Rakes, Vine Guards, one only Center Cultivator and one ('enter Tooth Holder. Net Price \$8.75

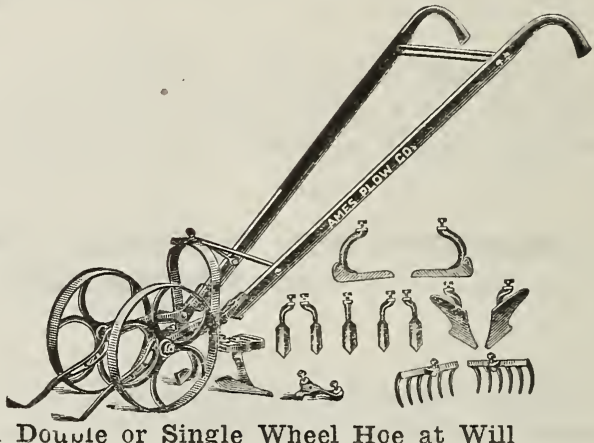

NEW UNIVERSAI SINGLE WHEEL HOE, CULTIVATOR, PLOW AND RAKE No. 11

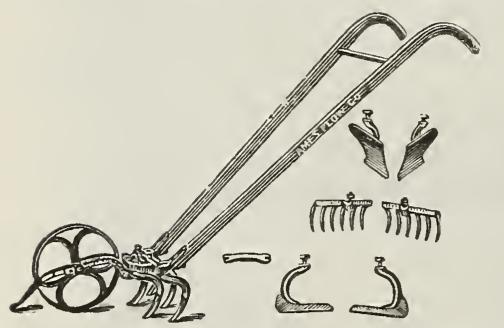

NEW UNIVERSA
This Single Wheel Hoe can be used in stradi.le cultivation by setting the wheel on one side and bringing the rows of plants under center of frame. Later cultivation to be done between rows. Attachments are: One pair each Narrow ('ultivators, Wide Cultivators, líoes, Plows, Rakes, one ('enter Cultivator and one Vine Guard. Net Price

$\$ 5.25$

\section{GARDEN PLOW AND ATTACHMENTS With Rear Wheel}

No. 116

The Front Wheel is adjustable and is $151 / 2$ in. in diameter. The Handles are also adjustable. A first-class garden plow and one which will give perfect satisfaction. The attachments are: 1 Landside Plow, 1 Sweep or Scuffle, 1 Rake and 1 Double Tongued Cultivator. Net Price . . . . $\$ 3.50$

\section{Send for Complete Catalog}

Samples and prices on our Purity grain and Grass Seeds on request.

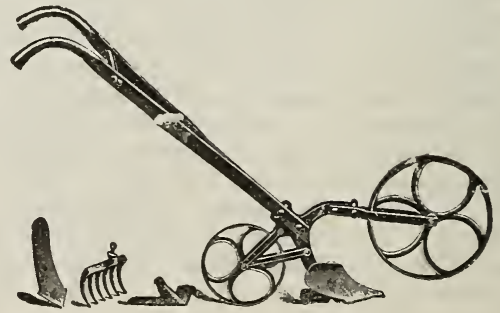




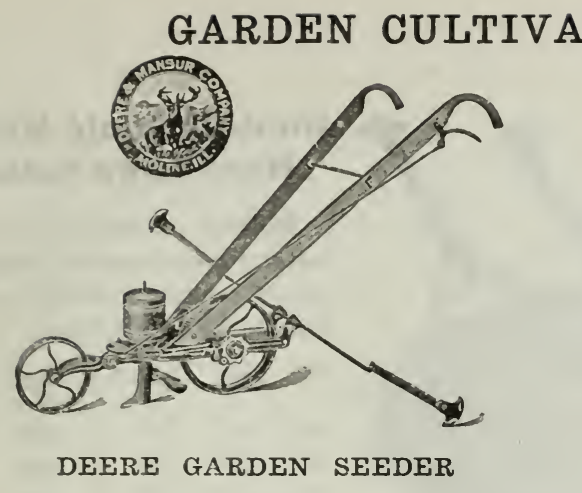

It has a covering wheel in rear, a gauge wheel in front, and between them a furrow opener and seed hopper. A steel pitman driven by a cam wheel on the covering-wheel shaft gives the seed plate a sharp, oscillating motion, which insures a steady, even flow of seed. In the seed plate is a series of holes for different kinds and quantities of seed, and changes in feed can be made without cinptying the hopper.

The depth of planting is quickiy regulated. The furrow opener makes a clean, regular seed bed, and attached to the opener are wing serapers, which bring the earth back into the furrow, and the wheel following presses it lown, leaving it in the best possible condition for quick and sure germination.

Price

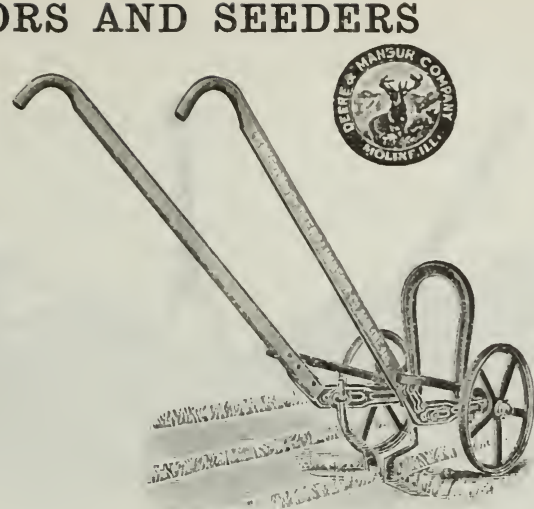

\section{MCGEE GARDEN SEED CULTIVATOR}

It has an arch frame and two wheels, like a tougueless cultivator. Two laterally swinging beams are attached to the areh and operated by two handles. Springs between the beams, or handles, and arch enable the operator to control easily, accurately and instantly the side movement of the knives or cultivators and to keep any kind of a crop well enltivated and thoroughly clean, with little or no hand weeding. The Mecree is furnished with a set of reeding knives and a set of cultivators.

Other attachments extra. Price

IrGee Garden ('nltivator with weeding

knives and wrench

\section{THE NEW COLUMBIA GARDEN SEEDER}

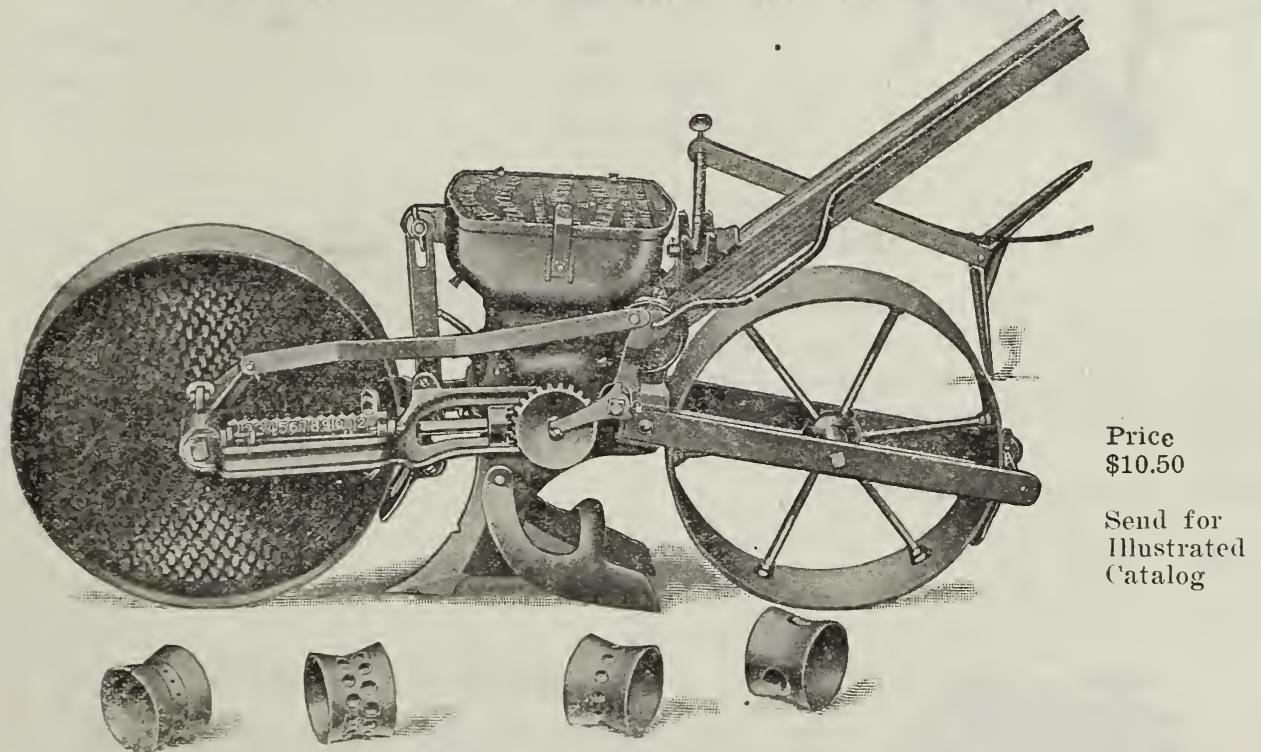

For two seasons this new Seeder has created a sensation in the garden tool line and proved to be the most successful and accurate planter on the market. With the Columbia you can plant a greater variety of seed and more accurately than any other machine manufactured and also bear in mind that it has positively a force feed. Seed can be drilled or planted in hills at various distances. Comes equipped with seven seed cylinders and can furnish extra ones for any special seed you might have.

Regular equipment will plant all common vegetable seeds from the smallest up to Beans and Peas.

We most heartily recommend this Seeder. 


\section{PARCEL POST INFORMATION}

The act of Congress authorizing the establishment of a parcel post system provides that on and after January 1, 1913, fourth class mail matter shall embrace all other matter, including farm and factory products, not now embraced by law in either the first, second, or third class, not exceeding 11 pounds in weight nor greater in size than 72 inches in length and girth combined, nor in form or kind likely to injure the person of any postal employee or damage the mail equipment or other mail matter, and not of a character perishable within a period reasonably required for transportation and delivery.

\section{Table of Rates.}

\begin{tabular}{|c|c|c|c|c|c|c|c|c|c|}
\hline \multirow[b]{2}{*}{ Weight. } & \multicolumn{2}{|c|}{ First zone. } & \multirow{2}{*}{$\begin{array}{c}\text { Second } \\
\text { zone, } \\
50 \text { to } \\
150 \\
\text { miles. }\end{array}$} & \multirow{2}{*}{$\begin{array}{l}\text { Third } \\
\text { zone, } \\
150 \text { to } \\
300 \\
\text { mlles. }\end{array}$} & \multirow{2}{*}{$\begin{array}{c}\text { Fourth } \\
\text { zone, } \\
300 \text { to } \\
600 \\
\text { miles. }\end{array}$} & \multirow{2}{*}{$\begin{array}{c}\text { Fif th } \\
\text { zone, } \\
600 \text { to } \\
1,000 \\
\text { miles. }\end{array}$} & \multirow{2}{*}{$\begin{array}{l}\text { Sixth } \\
\text { zone, } \\
\text { I,0no to } \\
1.400 \\
\text { miles. }\end{array}$} & \multirow{2}{*}{$\begin{array}{c}\text { Seventli } \\
\text { zone, } \\
1,400 \text { to } \\
1,800 \\
\text { miles. }\end{array}$} & \multirow{2}{*}{$\begin{array}{c}\text { Eiglith } \\
\text { zone, } \\
\text { all } \\
\text { over } \\
1,800 \\
\text { miles. }\end{array}$} \\
\hline & $\begin{array}{l}\text { Local } \\
\text { rate. }\end{array}$ & $\begin{array}{c}\text { Zone } \\
\text { rate, } 50 \\
\text { miles. }\end{array}$ & & & & & & & \\
\hline 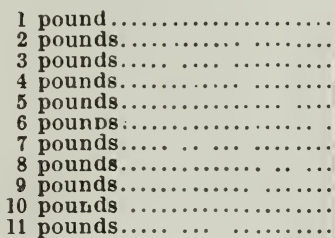 & $\begin{array}{r}\$ 0.05 \\
.06 \\
.07 \\
.08 \\
.09 \\
.10 \\
.11 \\
.12 \\
.13 \\
.14 \\
.15\end{array}$ & $\begin{array}{r}\$ 0.05 \\
.08 \\
.11 \\
.14 \\
.17 \\
.20 \\
.23 \\
.26 \\
.29 \\
.32 \\
.35\end{array}$ & $\begin{array}{r}\$ 0.06 \\
.10 \\
.14 \\
.18 \\
.22 \\
.26 \\
.30 \\
.34 \\
.38 \\
.42 \\
.46\end{array}$ & $\begin{array}{r}\$ 0.07 \\
.12 \\
.17 \\
.22 \\
.27 \\
.32 \\
.37 \\
.42 \\
.47 \\
.52 \\
.57\end{array}$ & $\begin{array}{r}\$ 0.08 \\
.14 \\
.20 \\
.26 \\
.32 \\
.38 \\
.44 \\
.50 \\
.56 \\
.62 \\
.68\end{array}$ & $\begin{array}{l}\$ 0.09 \\
.16 \\
.23 \\
.30 \\
.37 \\
.44 \\
.51 \\
.58 \\
.65 \\
.72 \\
.79\end{array}$ & $\begin{array}{r}\$ 0.10 \\
.19 \\
.28 \\
.37 \\
.46 \\
.55 \\
.64 \\
.73 \\
.82 \\
.91 \\
1.00\end{array}$ & $\begin{array}{r}\$ 0.11 \\
.21 \\
.31 \\
.41 \\
.51 \\
.61 \\
.71 \\
.81 \\
.91 \\
1.01 \\
1.11\end{array}$ & $\begin{array}{r}80.12 \\
.24 \\
.36 \\
.48 \\
.60 \\
.72 \\
.84 \\
.96 \\
1.08 \\
120 \\
1.32\end{array}$ \\
\hline
\end{tabular}

The local rate is applicable to parcels intended for delivery at the office of mailing or on a rural route starting therefrom.

\section{N D E X}

\section{A.}

Alfalfa, Cut Axes, Chopping Axes, Ice

\section{B}

Bag Balm

Bags, Feed

Balls, ox

Bands, Leg

Barrows, Wheel

Bars, Ice

Baskets, Galvanized

Baskets, Splint

Beaters, Egg

Bells, Cow

Belting, Rubber

Benches, IVash

Binders, Corn

Binders, Grain

Boards, Bread \& Pastry 14

Boards, Skirt

Boards, Wash

Bollers, Farmers'

Boilers, Wash

Bordeaux, Dry

Bordeaux, Liquld

Bottles, Test

Boxes, Butter

Boxes, Egg

Boxes, Grit \& shell

Bowls, Wooden Butter

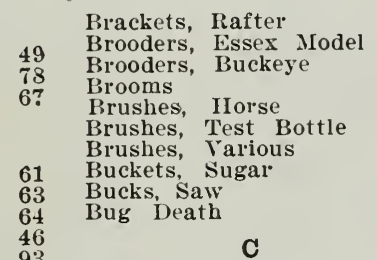

Candles, Sulphur

Cans, Cream

Cans, Garbage

('ans, Milk

Cans, Oil

Caps, Bottle

C'aponizing Sets

Carbonol

Cards, Cattle

Carriers, Bottle

C'arrier, Butter

('arrier's, Hay

Carriers, Litter

Carts, Children's

Cases, Egg

Chains, Cow \& Halter

Chains, Girting

Chains, Stake \& Trace

Charcoal

Chemicals

Chimneys, Lamp
Chippers, Ice

Chisels, Ice

Choppers, Food

Churns, Barrel

Churns, Cylinder

Churns, Dash

Churns, Elmer

Color, Butter

Combs, Curry

Compound, Lawn

Compound, Sweeping

Coolers, Milk

Cordial, Calves

Covers, Barre

Cows' Relief

('reamers, Cooley

Crenoid

Creolusol

Crowbars

Cultivators

24 Disc

Garden

KA Riding

Walking

Cure, Garget

Cure, Scr

Cutters, Bone 146

Cutters, Clover

Cutters, Ensil-$$
\text { age }
$$

$\begin{array}{cr}\text { age } & 148-149-150 \\ \text { Cutters, Hand Feed } 147\end{array}$

48-149-150

Cutters, Root $\quad 146$

\section{D}

Digger's, I'otato

1)ilators, 'Teat

Dip, Sheep

Drag Head

Dressing, Harness

Drills, Disc

Dryers, Outdoor

Dryers, Wall

Dustbane

Dusters, Ostrich

Dusters, Powder

\section{E}

Eggs, China Nest

Eggs, Ovinaphthol

Electric Lighting tems

mulsion, Kerosene

Extras, Repairs \& Parts 86

\section{$\mathbf{F}$}

Faucets, Wood

Feeders, Calf

Feeders, Chicken

Feeders, Norwich

Feeder's, I'oultry

Fence, Field and Poul-

try

Fertilizers

Fillers, Bottle 
Fittings, Brass Pipe 92 Fittings, Brass spray 106 Food, Plant Food, Poultry

Food, Stock Hay Formaldehyde, Iiquid $4:$ Fountains, Drinking 46-48 Frames, Saw

Freezers, Peerless $7:$ Freezers, White Mountain Front, Stone Boat $\quad 127$

\section{G}

(ilassware, 'Tester

ilobes,

(rapples, Steel Rafter 90

Grease, Axle 78

Grinders, Feed 130

Grinders, Knife \& T'ool 140

Grindstones 166

Grit, Poultry
Guards, Tree \& Flower 79

\section{H}

Halters

Hampers, Clothes

II andles, Ice Hook

I andles, Saw

ranger's, Barn Door 87-161

I Ianger's, IIay 'Track 90

llarlows, Disc 155-117

II arrows, Orchard 117

Harrows, Spike Tooth 118

Harrows, Spring Tooth 118

Harvesters, Corn $1 \pm 1$

$\begin{array}{lr}\text { Harvester's, Grain } & 142 \\ \text { Headers, Barlel } & 78\end{array}$

IIellebore

Hitch, Swivel Rope

Hods, Coal 70

Hoes, Hand Cultivator 83

Hoes, Hor'se 119

Hooks, Bush \& Corn 81

Hooks, Floor 90

Hooks, Grass

Hooks, IIanger

Hooks, Ice

Hooks, Weeding

II ooks, IVood

Hoppers, Food

Horses, CIothes

Hose, Garden

Hovers, Adaptable

IIover's International

\section{I}

Ice Tools 67-68

Implements, List of 111

Incubators, Buckeye 53

Incubators, Essex Model 99

Jacks, Pump

Jars, Stone Butter

7.

Jugs, Ston

\section{K}

Krelers, Fibre

Killer, Louse

Killer, San Jose Scale

Killer, IVeed

Knives, Asparagus

Knives, Killing

Kow Kure

\section{I}

Lacing, Belt

Ladders, All Kinds
Lamps, I) riving

Lamps, Incubator

I anterns

Latches, Barn Door

Lead, Arsenate of

Lead, Pyro-Bordeaux

Leads, cattle

64

Lime, Bordeaux $\quad 38$

lime, Fertilizer

lime \& Sulpliur.

loalders, IIay

\section{M}

Machines, Washing

Iakers, Bread

Markers, Line

Markers, I'oultry

Iattocks, I'icks

Irauls, ('hopper's' 78

Measures, Galv. \& Wood 79

Measures, Fibre 73

Milk Fever Outlit 62

Mills, Cider

IIills, Coffee

Irills, Feed

Mills, IVind

Mops, O-Cedlar

Moulds, Butter

Mowers

Mowers, lawn

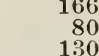

80
130
156

$8-1$

139-140

$65-66$

Nests, Hen

Netting, I'oultry

Nozzles, Hose

Nozzles, Spray

Oil, Fly

Oil, Hal'ness

O

Openers, Can \& Jar

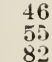

Pails, Chamber

Pails, Dairy

Pails, Dinnel

Pails, Fibre

Paint, Lice

Paint, Roofing

Panacea, Dr. IIess

Pans, Bulb

Pans, Dust

Paper, Butter

Paper, Sheathing

Paper, 'Tarred

Pairers, Apple

Paris Green

Pickers, Fruit

Picks

Pipe, Galv.

Planter's, Deere$$
\text { Corn }
$$

126-12

Planter's, Eureka Corn

Planters, King of the Cornfield

Planters, Potato

Plants

Plaster, Land

Plows, I ce

Plows, Sulky

Plows, IValiking

Pliers, Staple

Polish, O-Ceda

Polish, O-Cedar
Poppers, Corn

Pots, Bean

Pots, Flower

Pots, Watering

79 Powder, Lice

76 Press, ilay

130

$112-113$

72

155
Presses, rider

Pruners, All Kinds

Pullers, Staple

l'ulleys, Hay Fork

Pumps

Cucumber Wood

Iouglass House

Globe Chain

Junior Spray

Myers Bucket

Myers Itouse

Myers Power

Myers Power

Spray

Myer's Outdoor

Iyer's Spray

Myer's Tank

Iyers Windmill

Standard spray

Whitewash

Punches, Drive

\section{$\mathbf{R}$}

Rakes, Side Delivery 145

Rakes, Sulky 141-145

Refrigerators

liemedir's

Bag Balm

Calves' Cordial

'ows' Relief

Garget Cure

Irealing Powder

Kow Fure

Poultry

Roup Cure

Seratch \& rall c'ure

Rings, Bull

Rods, Bamboo

Rollers, Land

Rollers, Lawn

Roofing

\section{$\mathbf{S}$}

Salts, Nutrine Chick

Saw Tables

Saws, c'ircular

Saws, Cross-Cut

Saws, I ce

Saws, One Man

Scalecide

Scales, Counter

Scales, Milk

Scales, Parcel Post

Scales, Platform

Scrapers, Road

Screws, Drive

Seeders,

Seeders, Garden

137-138

Seeds, Bird

Seeds, Flower

Seeds, Grain

Seeds, Grass

Seeds, Ilerbs

Seeds, Table of

Seeds, Vegetable

Separators, Cream 159-160

Shavers, Ice

Shears, Grass

Shears, Pruning

Shellers, Corn

Shells, Oyster

Sifters, Ash

Sinks, Cast Iron

Silos

Skis

Sleds, Children

Snaps, Bull

soap, whale oil

Soda, Silicate of

Sowers, Fertilizers

Spittoons, Fibre

Spray Calendar

166

$5-108$

95

95

101

102
96

102-107

102-107

100

98
101

101

84

45

85

\section{1}

61
61
61

61

63

41

43
44

61

64
106

106

166
94

44

154

69

69

69 

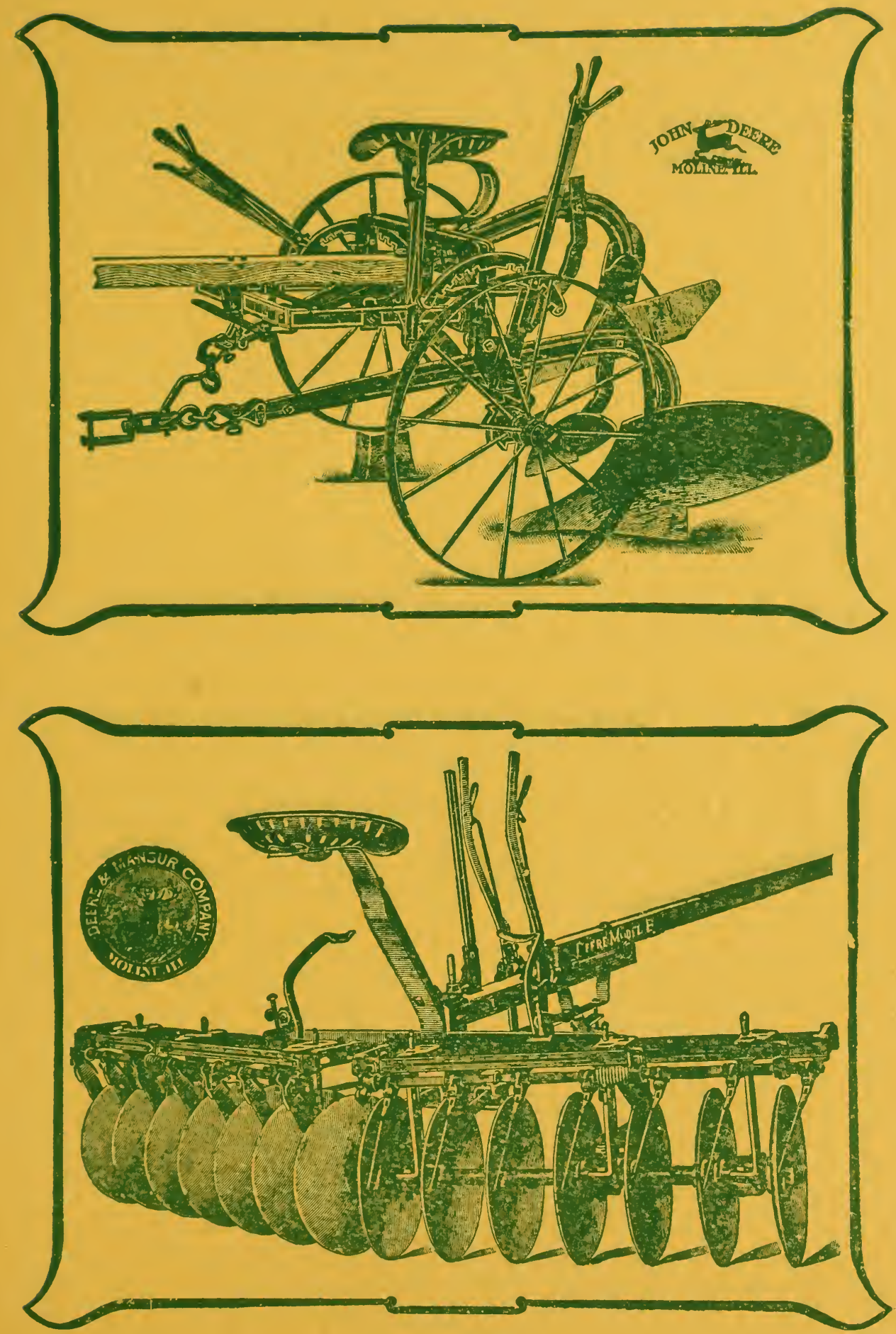



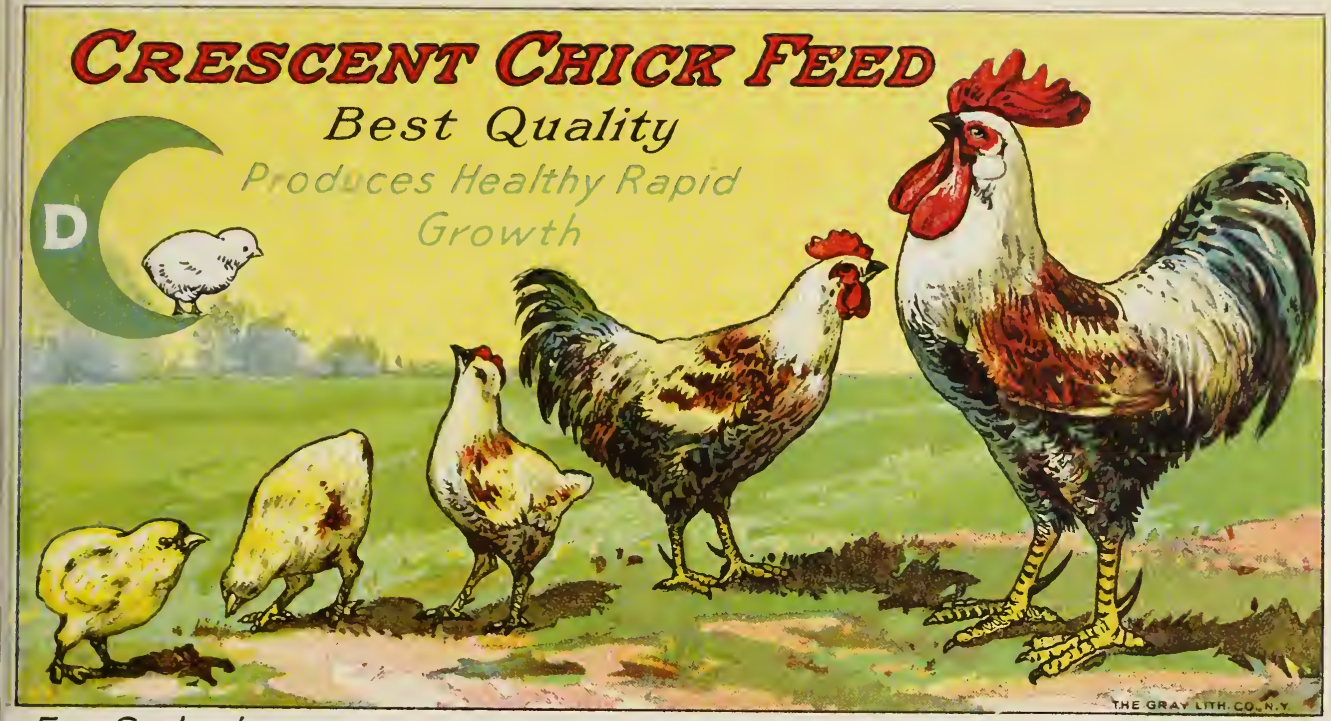

For Sale by

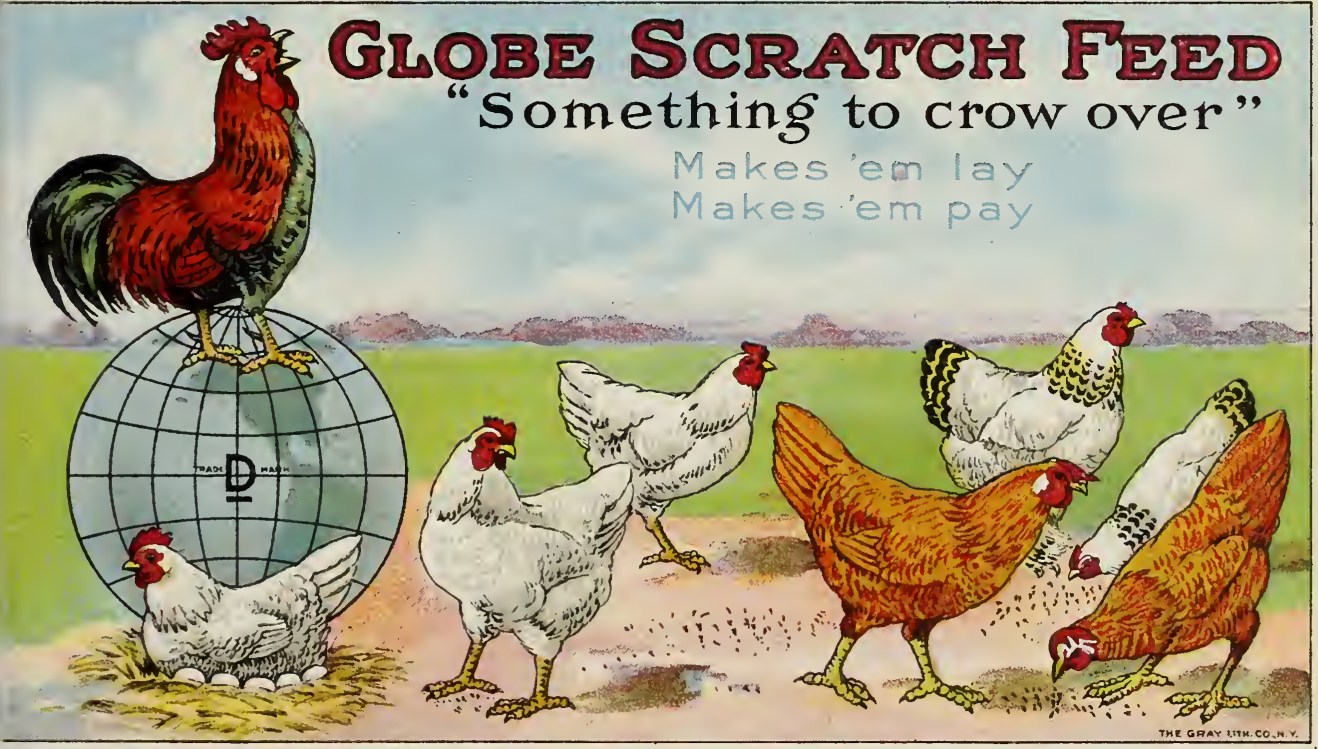

For Sale by 

FROM

Name

Town

State

Be sure and fill out above

\section{Haskell Implement \& Seed Co.}

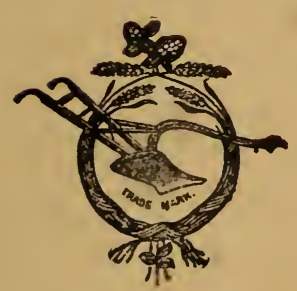

REQ. U. 8, PAT. OFF.
194-200 Main Street,

\author{
LEWISTON,
}

MAINE. 





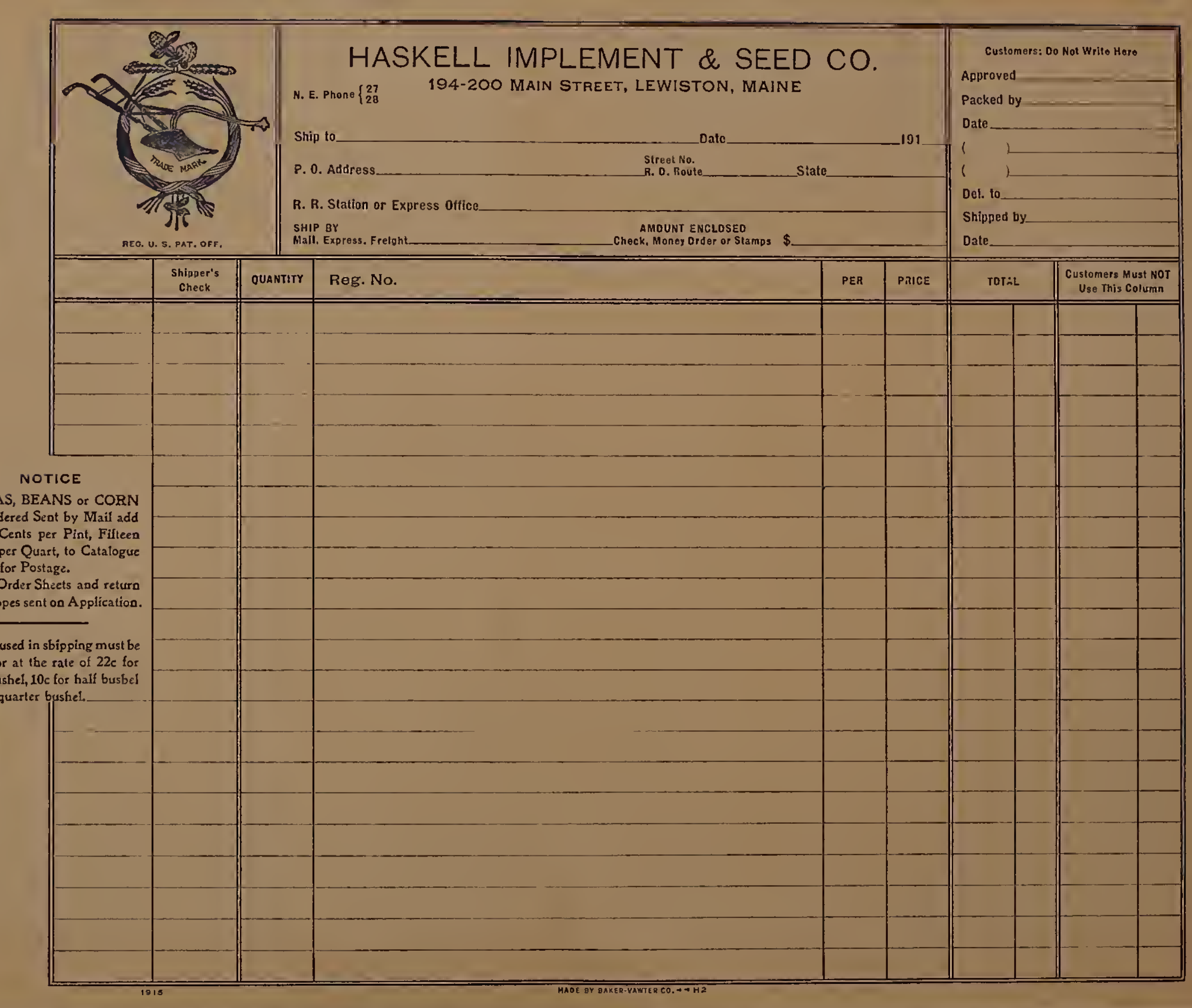




\title{
HASKELL IMPLEMENT \& SEED CO.
}

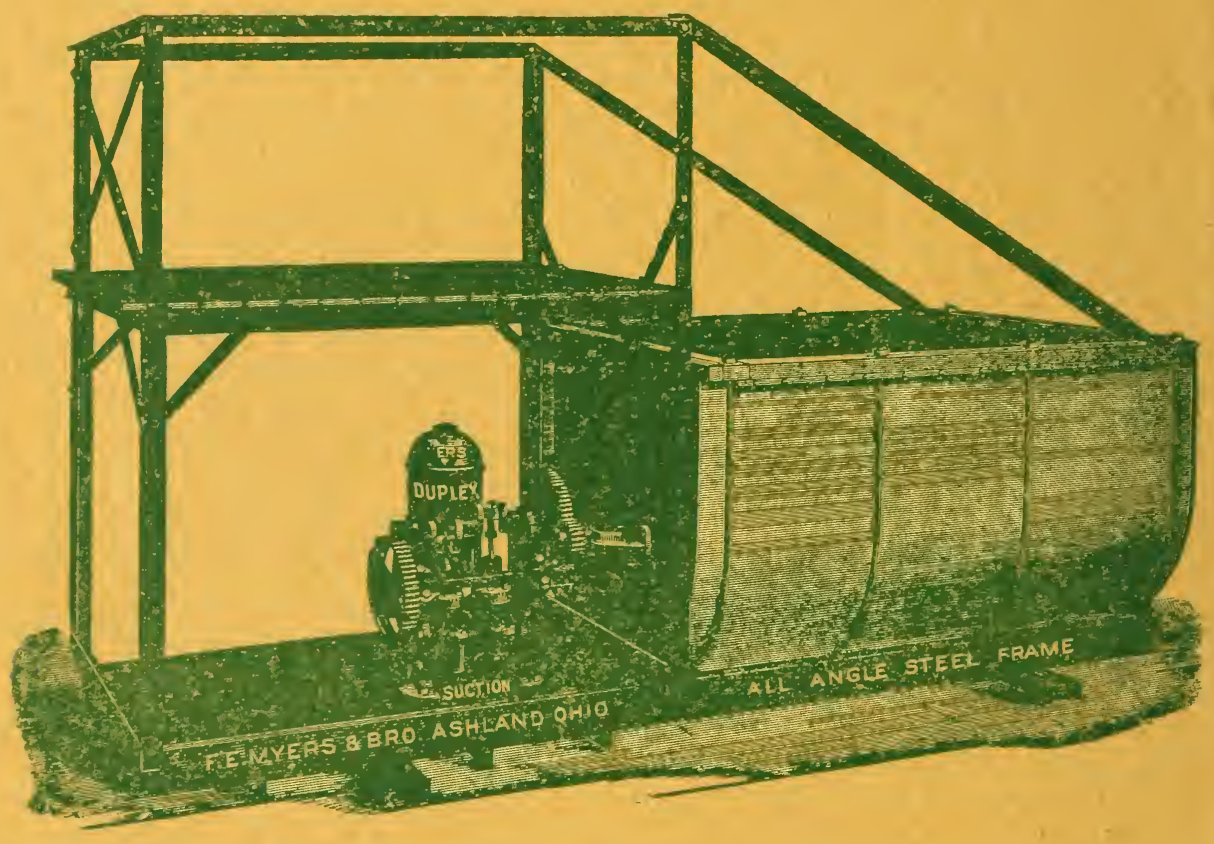

\section{4-200 Main Street LEWISTON, ME.}

\author{
EOTABLISHED $\mid 878$
}

